\title{
BIBLIOGRAPHY OF MARINE GEOLOGY AND OCEANOGRAPHY, CALIFORNIA COAST
}

SPECIAL REPORT 44

1955

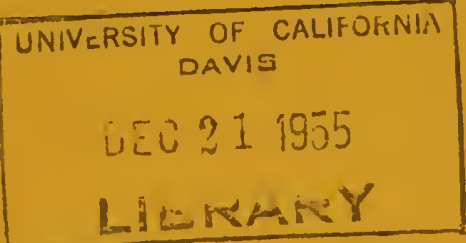

\section{DIVISION OF MINES}




\section{SPECIAL REPORTS ISSUED BY THE DIVISION OF MINES}

1-A. Sierra Blanca limestone in Santa Barbara County, California, by George W. Walker. 1950.5 p ., 1 pl. Price 25 e.

1-B. The Calera limestone, Sun Mateo and Santa Clara Counties, California, by George W. Walker. 1950. 8 pp., 1 pl., 6 figs. Price 25 4 .

2. Geology of part of the Delta-Mendotn Canal nenr Tracy, California, by Parry Reiche. 1950. 12 pp., 5 figs. Price $25 \phi$.

3. Commercial "black granite" of San Diego Counts, California, by Richard A. Hoppin and L. A. Normau, Jr. 1950.19 pp., 18 figs. Price $25 \%$.

4. Geology of the San Dieguito pyrophyllite arca, San Diego County, California, by Richard H. Jahns and John F. Lance. 1950. 32 pp., 2 pls., 21 figs. Price $50 \phi$.

5. Geology of the Jurupa Mountains, San Bernardino and Rircrside Counties, California, by Edward M. MacKevett. 1951. 14 pp., 1 pl., 14 figs. Price $25 \%$.

6. Geology of Bitterwater Creek area, Kern County, California, by Henry H. Heikila and George M. MacLeod. 1951. 21 pp., 2 pls., 15 figs. Price 354 .

7-A. Gem-and lithium-bearing pegmatites of the Pala district, San Diego County, California, by Richard H. Jahns and Lauren A. Wright. 1951. 72 pp., 13 pls., 35 figs. Price $\$ 2.50$.

7-B. Economic geology of the Rincon pegmatites, San Diego County, California, by John B. Hanley. 1951. 24 pp., 1 pl., 5 figs. Price $35 \%$.

8. Talc deposits of steatite grade, Inyo County, California, b5 Ben M. Page. 1951. 35 pp., 11 pls., 25 figs. Price $85 \phi$.

9. Type Moreno formation and overlying Eocene strata on the west side of the San Joaquin Valley, Fresno and Merced Counties, California, by Max B. Payne. 1951. 29 pp., 5 pls., 11 figs. Price 60 .

10.A. Nephrite jude and associated rocks of the Cape San Martin region, Monterey County, California, by Richard A. Crippen, Jr. 2d printing. 1951.14 pp., 14 figs. Price $25 \%$.

10-B. Nephrite in Marin County, California, by Charles W. Chesterman. 1951. 11 pp., 16 figs. Price 254 .

10-C. Jadeite of San Benito County, California, by H. S. Yoder and C. W. Chesterman. 1951.8 pp., 6 figs. Price 25 .

11. Guide to the geology of Pfeiffer-Big Sur State Park, Monterey County, California, by Gordon B. Oakeshott. $1951.16 \mathrm{pp}$. 1 pl., 28 figs. Price $25 \$$.

12. Hydraulic filling in metal mines, by William E. Lightfoot. 1951. 28 pp., 15 figs. Price 50 .

13. Geology of the saline deposits of Bristol Dry Lake, San Bernardino County, California, by Hoyt S. Gale. 1951. 24 pp. 1 pl., 2 figs. Price 35 .

14. Geology of the massive sulfide deposits at Iron Mountain, Shasta County, California, by A. R. Kinkel, Jr., and J. P. Albers. 1951. 19 pp., 6 pls., 6 fgs. Price $75 \%$.

15. Photogeologic interpretation using photogrammetric dip calculations, by D. H. Elliott. 1952.21 pp., 9 figs. Price 50 .

16. Geology of the Shasta King mine, Shasta County, California, by $\mathbf{A}$. R. Kinkel, Jr., and Wayne E. Hall. 1951. 11 pp., 3 pls., 4 figs. Price 504 .

17. Suggestions for exploration at New Almaden quicksilver mine, California, by Edgar H. Bailey. 1952.4 p p., 1 pl. Price 254 .

18. Geology of the Whittier-La Habra area, Los Angeles County, California, by Charles J. Kundert. 1952.22 pp., 3 pls., 19 figs. Price 506 .

19. Geology and ceramic properties of the Ione formation, Buena Vista a rea, Amador County, California, by Joseph A. Pask and Mort D. Turner. 1952. 39 pp., 4 pls., 24 figs. Price 754 .

20. Genlogy of the Superior talc area, Death Valley, California, hy Lauren A. Wright. 1952. 22 pp., 1 pl., 15 fig8. Price $50 \%$.

21. Geology of Burruel Ridge, northwestern Santa Ana Moun. tains, California, by James F. Richmond. 1952.1 pl., 11 figs. Price 50 4 .
22. Geology of Las Trampas Ridge, Berkeley Hills, Californir by Cornelius K. Ham. 1952.26 pp., 2 pls., 20 figs. Price 754.

23. Exploratory wells drilled outside of vil and gas fields in Cali fornia to December 31, 1950, by Gordon B. Oakeshott, Lewis T. Braun, Charles W. Jennings, and Ruth Wells. $1952.77 \mathrm{pp}$ 1 pl., map. Price, map and report, $\$ 1.25$; map alone, $\$ 1$.

24. Geology of the Lebec quadrangle, California, by John Crowell. 1952. 23 pp., 2 pls., 10 fgs. Price 754 .

25. Rocks and structure of the Quartz Spring area, northern Panamint Range, California, by James F. MlcAllister. 1952 38 pp., 3 pls., 13 fgs. Price 754 .

26. Geology of the southern Ridge Basin, Los Angeles County, California, by Peter Dehlinger. 1952. 11 pp., 1 pl., 7 figs. Price $50 \%$.

27. Alkali-aggregate reaction in California concrete aggregates, by Richard Merriam. 1953. 10 pp., 12 fgs. Price $35 \%$.

28. Geology of the Mammoth mine, Shasta County, California, by A. R. Kinkel, Jr., and Wayne E. Hall. 1952, 15 pp., 9 pls., figs. Price 754 .

29. Geology and ore deposits of the Afterthought mine, Shasta County, California, by John P. Albers. 1953. 18 pp., 6 pls., 9 figs. Price 75 .

30. Geology of the southern part of the Quail quadrangle, California, by Charles W. Jennings. 1953.18 pp., 2 pls., 16 figs. Price 754.

31. Geology of the Johnston Grade area, San Bernardino County California, by Robert Barton Guillou. 1953.18 pp., 1 pl., 1 figs. Price $75 \%$.

32. Geological investigations of strontium deposits in southern California, by Cordell Durrell. 1953. 48 pp., 9 pls., 12 figs. Price $\$ 1.25$.

33. Geology of the Griffith Park area, Los Angeles County, Cali fornia, by George J. Neuerberg. 1953. 29 pp., 1 pl., 15 figs. Price 504 .

34. Geology of the Santa Rosa lead mine, Inyo County, Califor nia, by Edward M. Mackevett. 1953. 9 pp., 2 pls., 3 figs. Price $50 \%$.

35. Tungsten deposits of Madera, Fresno, and Tulare Counties, California, by Konrad B. Krauskopf. 1953.83 pp., 4 pls., 52 figs. Price $\$ 1.25$.

36. Geology of the Palen Mountains gypsum deposit, Riverside County, California, by Richard A. Hoppin. 1954, 25 pp., 1 pl., 32 figs., frontis. Price 75

37. Rosamond uranium prospect, Kern County, California, by George W. Walker. 1953. 8 pp., 5 figs. Price 25

38. Geology of the Silver Lake talc deposits, San Bernardino County, California, by Lauren A. Wright. $1954.30 \mathrm{pp}$. 4 pls., 18 figs. Price $\$ 1.00$.

39. Barite deposits near Barstow, San Bernardino County, California, by Cordell Durrell. 1954. 8 pp., 4 pls., 1 fig. Price 504 .

40. Geology and mineral deposits of the Calaveritas quadrangle, Calaveras County, California, by Lorin D. Clark. 1954. 23 pp., 2 pls., 6 figs. Price $\$ 1.75$.

41. Geology of the Angels Camp and Sonora quadrangles, Calaveras and Tuolumne Counties, California, by John H. Eric, Arvid A. Stromquist, and C. Melvin Swinney. 1954. $55 \mathrm{pp}$., 4 pls., 21 figs. Price $\$ 3.75$.

42. Geology and mineral deposits in the Ubehebe Peak quadrangle, Inyo County, California, by James F. McAllister. 1955. 64 pp., 3 pls., 26 figs. Price $\$ 2.00$.

43. Geology of a portion of the Elsinore fault zone, California, by John F. Mann Jr. -_._ pp., 2 pls., 5 figs. Price $75 \phi$.

44. Bibliography of marine geology and oceanography, California Coast, by Richard D. Terry. 146 pp., 2 figs. Price $75 \phi$. 


\author{
STATE OF CALIFORNIA \\ GOODWIN J. KNIGHT, Governor \\ DEPARTMENT OF NATURAL RESOURCES \\ DeWITT NELSON, Director \\ DIVISION OF MINES \\ FERRY BUILDING, SAN FRANCISCO 11 \\ OLAF P. JENRINS, Chief
}

\title{
BIBLIOGRAPHY OF MARINE GEOLOGY AND OCEANOGRAPHY, CALIFORNIA COAST
}

\author{
BY RICHARD D. TERRY
}

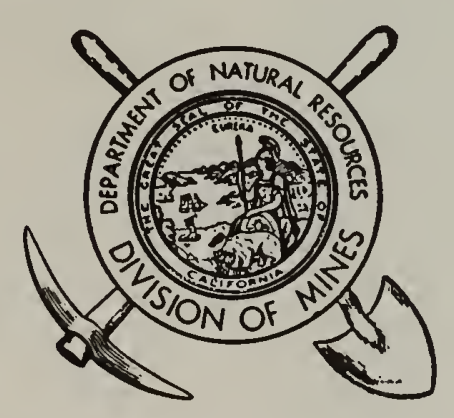

Price 75 cents 



\title{
BIBLIOGRAPHY OF MARINE GEOLOGY AND OCEANOGRAPHY, CALIFORNIA COAST *
}

\author{
BY RICHARD D. TERRY
}

\section{OUTLINE OF REPORT}

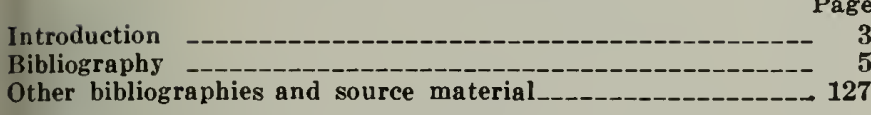

\section{Illustrations}

Figure 1. Chart showing distribution of references concerning major environments

Figure 2. Chart showing distribution of references for each year

INTRODUCTION

The general fields covered by this bibliography include : sedimentation, submarine topography, beach erosion and its control, marine engineering problems, coastal sand dunes, tideland petroleum developments, marine geophysics (including seismology and tsunamis), salt water intrusion, physical and chemical oceanography. References on marine biology and meteorology have been restricted to those which mention biology and meteorology in a discussion of other oceanographic problems. For example, plankton have a profound effect upon the chemistry of sea water and to some extent upon the physical characteristics (i.e. transparency). In addition, plankton contribute to bottom sediments and of ten make major physical-chemical changes in sediments after deposition. Burrowing, boring, and fouling organisms likewise are of interest, so a few selected references on these have been included. Marine terraces are a marine geological problem and, therefore, have been included; however, no general references on coastal geology have been cited. Geology and paleontology of the various offshore islands of California and Mexico are included as they are frequently used in submarine geological interpretations.

In addition to the restriction of certain topics discussed above, references to other branches of science closely allied to marine geology and oceanography which are covered incompletely include: terrestrial magnetism, coastal engineering, and tideland petroleum developments. Perhaps hundreds of references exist in numerous engineering and petroleum periodicals, but are not included because only a few important articles occur amidst hundreds of pages of notes, news stories, popular accounts, and advertising.

- University of Southern Callfornia, Allan Hancock Contribution. No. 154. Manuscript submitted for publication January, 1955.

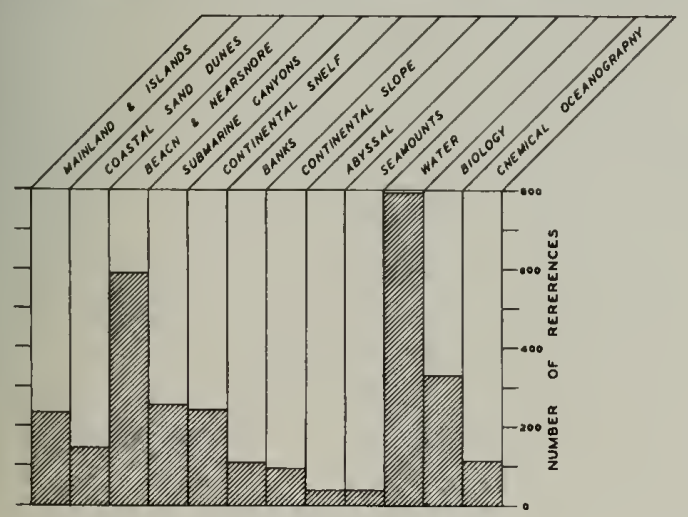

FIGURE 1.
Figure 1 shows the distribution of references concerning major environments. In general, the number of references decreases as the depth of water in the environments increases. The number of references on chemical oceanography comprise only a small percentage of the bibliography and there is reason to believe that the lack of references is due to the relatively small amount of research in this field. Figure 2 shows the distribution of references for each year. It is apparent that a slightly increasing number of articles was published each year up to about 1920, after which the number of references increased rapidly, excepting during World War II. The sharp rise can be attributed partly to the development of sonic sounding equipment in the early 1920 's.

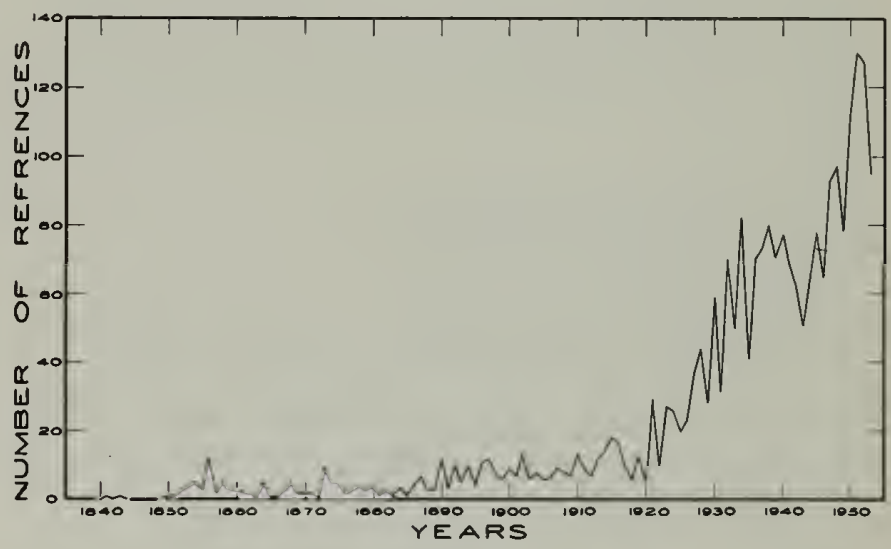

Figure 2.

If the titles of references are the only basis for inclusion or exclusion in a bibliography, a large number of references will probably be overlooked. In order to get an indication of the number of references that would be missed by using titles as the criteria for inclusion in this bibliography, 648 references from nine journals were systematically scanned and placed in three categories as follows: (1) Approximately 37.3 percent of the references had titles containing information that related directly to the region covered by the bibliography, i.e., from the Oregon-Washington border to Central America and midway to the Hawaiian Islands; (2) more than half, or 53.6 percent, of the references had general titles that gave a hint of subjects which might apply to the region; however, each reference in this category had to be read or scanned in order to determine if the reference should be included; and (3) approximately 9.1 percent of the titles gave no indication whatsoever of the region covered and would have been missed. An evaluation of these titles could have been attained only through checking reference citation, through accidental re-discovery, or through a systematic search of the literature.

This bibliography was compiled by a systematic check of a few selected key journals. In addition, countless other books, indexes, bibliographies, theses, reprints, library card files, and unpublished data were checked. 
The following is a list of serials that were systematically checked; that is, each page was scanned, regardless of the titles of articles. The list does not include hundreds of volumes of other periodicals, ete., that were only partially scanned.

American Association of Petroleum Geologists Bulletin

Allan Hancock Foundation, University of Southern California, publications and contributions.

American Journal of Science (1900-1954)

Association d'Océanographie Physique, Union Géodésique et Geophysique Internationale, Proces-Verbaux

California Academy of Sciences, Proceedings and Transactions.

Deep-Sea Research

Ecological Monographs

Geological Society of America, Bulletins and Proceedings

Journal du Conseil pour l 'Exploration de la Mer

Journal of Geology

Journal of Geomorphology

Journal of Marine Research

Journal of Sedimentary Petrology

National Research Council Bulletins

National Research Council Treatise on Marine Ecology as Related to Paleontology

National Research Council Treatise on Sedimentation

Pacific Discovery

Pacific Science Congress Proceedings (1st to 6th conference)

Proceedings on Coastal Engineering (1st to 3rd conference)

Scripps Institution of Oceanography, Bulletins, Reports, and contributions

Shore and Beach

Theses:

California Institute of Technology

Scripps Institution of Oceanography

Stanford University

University of California, Berkeley

University of California, Los Angeles

University of Southern California

University of California, Berkeley, Fluid Mechanics Laboratory

University of California Publications in Geography

University of California Publications in Geology

U. S. Army, Corps of Engineers, Beach Erosion Board Bulletin and Technical Memoranda.

U. S. Navy, Office of Naval Research, Pasadena, reports

While it is difficult to determine the degree of completeness of a bibliography, it is believed that the approximately 2500 references listed in the bibliography probably comprise more than 95 percent of the most important published references on marine geology, and physical and chemical oceanography.

The style used for reference citation in this volume is that recommended by the U. S. Geological Survey. When the same reference has been published more than once, the references have been combined and listed under the earliest citation. All subjects in the cross-index are then cited under the earliest date. Foreign abstracts or reviews of American articles previously published in the United States have not, as a rule, been cited in the bibliography.

An asterisk (*) following references indicates that the reference was not indexed or was only partially indexed, generally because the references were not located, were too long, or were added just before press time. No attempt was made to index books as they have such a large amount of general information. A total of many weeks was spent away from the Los Angeles region in an endeavor to locate references not in this area; however, even this was not sufficient to check all references.

In the accompanying index, marine geological subjects have been placed under one or more geographical locations, such as: Abyssal, Bank, Basin, Beach and Nearshore, Coastal Sand Dunes etc. Thus, if an article dis- cussed "Banks", various sediment and rock types were listed under "Bank". Obviously, many of the references were extremely long and discussed a great number of subjects, some geographically, some in a general manner, while others gave locations by latitude and longitude. In such cases the topics were listed directly after the general subject or under the primary location. As a general rule, various sediment and rock types listed in the "CrossIndex" refer only to bottom material existing on the sea floor within the region covered by the bibliography. Thus, sediments and rocks of the inland or islands are not indexed; however, mineralogy and various sediment types are included for coastal sand dunes and beaches.

As a whole, the index obviously is not completely detailed, however, in some cases it probably is too complete. For example, sometimes Currents, Waves, and various sediment types have been listed when these subjects were only casually mentioned in the article.

Because bibliographies on marine geology and oceanography have been compiled for several other regions of the world, this bibliography has been restricted to the California Coast and adjacent regions. Every bibliography and major source of marine geologic and oceanographic information examined during the compilation of this bibliography has been listed in the section on "Other Bibliographies and Source Material". Several of the most important books on marine geology and oceanography also are listed in this section. In addition, as an aid toward locating unpublished or only sparsely distributed reports and data, a list of suggested sources of information has been included in this section. Additional information may be located by contacting individuals or organizations carrying out marine research or work having to do with the ocean and adjacent inland waters. It is suggested that where specific information is sought for a local region, local sources will have more information than will more distant ones.

Acknowledgments. This bibliography is made possible largely through the aid given by the Allan Hancock Foundation of the University of Southern California and Professor K. O. Emery. The Allan Hancock Foundation gave financial assistance and time from other duties in order to work on the bibliography on a more or less full-time basis. Dr. Emery not only suggested the bibliography and guided the compiler throughout, but also gave access to his own personal library and contributed scores of obscure references.

Special thanks must go to Drs. T. Clements and O. L. Bandy for their assistance. Mrs. Dorothy M. Halmos, Miss Mary E. Pippin and Mr. Morris Polan, Librarians of the Allan Hancock Foundation Library of Marine Biology and Oceanography, made every effort to aid in the location of references and helped in many ways in the development of this bibliography. Mr. H. C. Stone of Doheny Library of the University of Southern California, and the Librarians of Stanford University and Scripps Institute of Oceanography also helped locate many references. Appreciation is also expressed to $\mathrm{Mr}$. W. J. Herron, Jr., U. S. Army Corps of Engineers, Los Angeles District; Dr. J. W. Johnson of the University of California at Berkeley; and Dr. J. B. Loefer of the Office of Naval Research in Pasadena, for making unpublished material available.

My wife, Mary, aided me in many ways during the long period required to compile this volume. 
Anonymous, 1859, currents of the Pacific ocean: Nautical Mag., London, v. 28 , p. $287-293,369-376,425-428$. * onymous, 1882a, Shore scenes at Santa Cruz: Min. and Sci. Press, v. 45 , p. 425.

nymous, $1882 \mathrm{~b}$, Diatoms and diatomaceous earths: Calif. Div. Mines, 2nd Rept. State Mineralogist, p. 266-270. nymous, 1882c, Iron ores and iron industries of California: Black sand: Calif. Div. Mines, 2nd Rept. State Mineralogist, p. 196.

nymous, 1883 , The Java upheaval: Nature, v. 28 , p. 443444; Science, v. 2, p. 469-470.

nonymous, 1884, Gold sands of California: Science, v. 3 , p. 797 .

nonymous, 1887, Santa Cruz Island: West Am. Scientist, v. 3, p. 77 .

onymous, 1891, Diatomaceous earth found on beach: West Am. Scientist, v. 7 , p. 136.

nonymous, 1894a, our auriferous beach sands: Min. and Sci. Press, v. 69, p. 258.

nonymous, 1894b, Black sand mining: Min. and Sci. Press, v. 69 , oct. 27, p. 263.

onymous, 1904, Informe acerca de la fisiografia, geologia y hidrologia de los alrededores de la Paz, Baja, California: Inst. Geologia de Mexico, Parergones, v. 1, no. 2, p. 3- ; Bol. Sec. Fom., v. 3, no. 1l, p. $216-\ldots$

nymous, $1906 \mathrm{a}$, Harbor Improvement at San Pedro and Wilmington, California: Eng. News, v. 56 , no. 7 , p. $155-158$.

onymous, 1906b, Black sand: Min. and Sci. Press, v. 93, Sept. 1, p. 242.

Anonymous, 1915, Storm damage to sea walls on California cosst: Eng. News, v. 73 , no. 15, p. $720-721$.

Anonymous, 1916a, Shore at Venice, California, best protected by permanent sea wall and low groins: Eng. Record, v. 73 , no. 2 , p. $36,51-54$ (rept. of Leeds and Barnard, engineers).

onymous, 1916b, Protecting a beach highway from the sea: Eng. Record, v. 74 , no. 7, p. 208.

Anonymous, 1916c, The Brasher Air Breakwater: The Engineer, v. 121, p. 414-415.

Anonymous, 1916d, The Air Breakwater put to severe test: Sci. Am., v. 114, p. 403.

nonymous, '1916e, San Francisco shore protection near completion: Eng. News, v. 76 , no. 12, p. 543-544.

nonymous, 1917, Experiment with groins at Santa Monica Beach successful. Wood and concrete structures are effectively building up sand deposits: Eng. Record, v. 75 , no. 13, p. 501-502.

Anonymous, 1925a, No "lost continent" in Pacific Ocean: Science, v. 62 , no. 1613 , p. xiv.

nonymous, 1925b, Long Beach Harbor improvements: Eng. and Contracting, v. 63 , no. 6 , p. 1347-1349.

Anonymous, 1927, Ocean canyons: Science, v. 66 , no. 1715 , p. $x$.

Anonyous, 1928, The Mexican earthquake: Science, v. 67, no. 1748 , p. xi1.

nonymous, $1929 a$, Lower California drift bottle recovered in Philippines after 17 month trip: Science, v. 69, no. 1797, p. xiv.

nonymous, 1929b, Salt water advances up San Francisco Bay: Eng. News-Record, v. 103, p. 621.

Anonymous, 1932a, Rincon ocean test finds formation running high: 0il Weekly, v. 67 , no. 13, Dec. 12, p. 45.

Anonymous, 1932b, Ocean test plugged back for production test: 011 Weekly, v. 68 , no. 2 , Dec. 26, p. 37.

Anonymous, 1932c, Standard ready to test Santa Rosa Island: Petroleum World, v. 29, p. 15-17, 37.

nonymous, 1932d, Standard to drill of fanta Barbara Coast: $0 i l$ Weekly, v. 65 , no. 5, April 18, p. 49.

Anonymous, 1932e, Santa Rosa geology compares with mainland oil areas: 0il Weekly, v. 65 , no. 7 , May 2, p. $45-46$.

Anonymous, 1933a, Book review: Salinity in Sacramento River: Eng. News-Record, v. 110, p. 385.

nonymous, 1933b, Salinity in Sacramento River Delta area reviewed: Eng. News-Record, v. 110, p. 460.

Anonymous, 1933c, LOs Angeles beach acquisition: Shore and Beach, v. 1, p. 63.

Anonymous, 1933d, Santa Monica Breakwater: Shore and Beach, v. 1, p. 64 .

Anonymous, 1933e, Beach erosion studies by Federal Board:
Fing. News-Record, v. 111, p. 281-283.

Anonymous, 1935, Beach-protection work on California cosst roads. Fing. News-Record, v. 114, p. 253-254.

Anonymous, 1936, Program of initial works on Central Valley Project in California: Western Construction News, v. 11 , no. 3 , p. 68-72.

Anonymous, 1938a, The beach erosion study at Santa Barbara, California: Shore and Beach, v. 6, p. 27-34, pls. I and II on inside front cover (Pub. in Congressional Documents, 1938a).

Anonymous, 1938b, Santa Barbara dredging operations: Shore and Beach, v. 6, p. 143.

Anonymous, 1938c, Submarine Pacific cosst petroleum: Rev. Petrolif., no. 767 , Jan. 7 , p. 17 . *

Anonymous, 1939, New sea-floor coring method: Shore and Beach, v. 7, p. 88.

Anonymous, 1940a, Recent ocean wave observations: Shore and Beach, v. 8, p. 7 .

Anonymous, 1940b, Report completed. Study of orange County, California shore approved for publication: Shore and Beach, v. 8, p. 63. (pub. in Congressional Documents, 1940a).

Anonymous, 1940c, Burning of the Minnie A. Caine. Grounded vessel fired to end erosion threatening California shorefront highway: Shore and Beach, v. 8, p. 93, 71; Calif. Highways and Public Works, April 1940.

Anonymous, 1940d, Report on studies in orange County, California. Investigation by Beach Erosion Board discloses beach material shortage caused by flood control: Shore and Beach, v. 8, p. 110-113, 126-130. (Complete report pub. in Congressional Documents, 1940a).

Anonymous, 194la, Ocean studies at the University of California: Science, v. 94 , no. 2431 , p. 11.

Anonymous, 1941b, Los Angeles County Master Shore Plan. Supervisors adopt nine-point plan to acquire and develop almost entire county shoreline for public use: Shore and Beach, v. 9, p. 3-8, 32 .

Anonymous, 1942, Current activities: Natl. Research Council, Div. Geology and Geography, Rept. Comm. Marine Ecology as Related to Paleontology, no. 2, p. 13-21.

Anonymous, 1943, Occurrence of "red water" near San Diego: Shore and Beach, V. 11, p. 4.

Anonymous, 1944a, Public's interest supersede individual's, california court decides: Shore and Beach, v. 12, p. 14

Anonymous, 1944b, Current activities: Western United States: Natl. Research Council, Div. Geology and Geography, Rept. Conm. Marine Ecology as Related to Paleontology, $1943-1944$, no. 4 , p. 11-13.

Anonymous, 1945, Index for ground photographs for various Pacific Coast beaches: Univ. Calif., Berkeley, Fluid mechanics lab., tech. rept. HE-116-172, sept. 29, 3 p.

Anonymous, 1946a, Continental shelf oil possibilities: 0il Weekly, v. 123, no. 7 , oct. 14, p. 37.

Anonymous, $1946 \mathrm{~b}$, The earthquake and seismic sea wave of April 1, 1946, Seismol. Soc. Am., Bull., v. 18, p. 10-11.

Anonymous, $1946 \mathrm{c}$, Seiamic sea wave of April 1, 1946: Am. Geophys. Union Trans., v. 27, p. 453.

Anonymous, 1948 , Sea-borne seismic work under way off California coast: Petroleum world, v. 45 , no. 8 , p. $15-17$.

Anonymous, 1949a, Engineering problems of Santa Rosa Island. Exploratory drilling solved: Petroleum World, v. 46, no. 1, p. 15-17.

Anonymous, $1949 \mathrm{~b}$, Settling at Wilmington: Petroleum World, v. 46 , no. 7, p. $10-11,13$.

Anonymous, 1949c, Chromium: Mineral Information Service, Calif. Div. Mines, v. 2, no. 11, p. 4-5.

Anonymous, 1950a, Monazite and the rare-earth elements: Mineral Information Service, Calif. Div. Mines, v. 3, no. 3, p. 3-4.

Anonymous, 1950b, Zirconium: Mineral Information Service, Calif. Div. Mines, v. 3, no. 3, p. 7-9.

Anonymous, 1950c, A survey of San Diego Bay: U. S. Navy Volunteer Research Reserve Unit 11-5, progress rept. 1,31 Dec., 21 p. Abs. in San Diego Regional water Pollution Control Board, 1952, Report upon the extent, effects and limitations of waste disposal into San Diego Bay, app. IV, p. 95.

Anonymous, 1950d, California sandblasting materials: Mineral Information Service. Calif. Div. Mines, v. 3, no. 5, p. 9-11. 
Anonymous, 1950e, Abrasives: sand, sandstone and crushed rock: Mineral Information Service, Calif. Div. Mines, v. 3 , no. 7 , p. 8-9.

Anonymous, 1950f, East Bay Municipal Utility District, construction of concrete outfall sewer, land and underwater sections: Western Construction Monthly, July, p. 59. *

Anonymous, 1951a, Scripps oceanographers on second expedition: U. S. Coast and Geod. Survey Jour., no. 4, p. 105.

Anonymous, 1951b, San Diego builds playground: Eng. NewsRecord, v. 146, Jan. 18, p. 45-46.

Anonymous, 1951c, Laboratory research - sea-water intrusion into groundwater sources and methods of its prevention: Univ. Calif., Berkeley, Inst. eng. research, 5 p. *

Anonymous, 1951d, Black sands: Mineral Information Service, Calif. Div. Mines, v. 4, no. 8, p. 1-2.

Anonymous, 1952a, Arvin-Tehachap1 earthquake: Mineral Information Service, Calif. Div. Mines, v. 5, no. 9, p. $1-4$.

Anonymous, 1952b, Washington highlights: Calif. Oil World, v. 45 , no. 1, p. 1 .

Anonymous, 1952c, Drilling halted - Long Beach's 30 day ban due to quake damage costs: 0 il and Gas Jour., v. 50, no. 43, March 3, p. 60.

Anonymous, 1952d, Man-made island to be drilling site: Mineral Information Service, Calif. Div. Mines, v. 5, no. $8, \mathrm{p} .3$.

Anonymous, 1952e, Arvin-Tehachapi earthquake: Mineral Information Service, Calif. Div. Mines, v. 5, no. 9, p. $1-4$.

Anonymous, 1952f, Steel piling calms the high seas: Western Metals, Sept., p. 57.

Anonymous, 1952g, Longest submarine line on west coast: 0 il Forum, April, p. 128; Pipeline News, Jan., p. 32.

Anonymous, $1952 \mathrm{~h}$, Offshore survey started: 011 and Gas Jour., v. 50, no. 44, March 10, p. 68 .

Anonymous, 1952i, Subsidence attacked anew: 011 and Gas Jour., ${ }^{\circ}$. 50, May 5, p. 162.

Anonymous, 1952 J, Harbor drilling eyed: 011 and Gas Jour., v. 51 , no. 3 , May 26, p. 66 .

Anonymous, 1952k, Long Beach oil vote set: $0 i l$ and Gas Jour., v. 51, no. 14, Aug. 11, p. 78 .

Anonymous, 1952L, Drilling island started: 011 and Gas Jour., v. 51, no. 14, Aug. 11, p. 78 .

Anonymous, 1952m, California - Work underway at Seal Beach steel-rimmed island: 0 il and Gas Jour., v. 51, no. 14, Aug. 11, p. 176 .

Anonymous, 1952n, Island drilling threatened: 011 and Gas Jour., v. 51, no. 15 , Aug. 18 , p. 80.

Anonymous, 19520, Suit f1led over island: $0 i 1$ and Gas Jour., v. 51 , no. 19 , Sept. 15, p. 74 .

Anonymous, 1952p, More tidelands funds frozen: 011 and Gas Jour., v. 51, no. 27 , Nov. 10, p. 80.

Anonymous, 1952q, West Cosst - Well No. 100 completed: Oil and Gas Jour., v. 51, no. 33, Dec. 22, p. 148.

Anonymous, 1953a, More progress made toward offshore oil developments: World 011, v. 137, no. 1, p. 79.

Anonymous, 1953b, Judge rules against Monterey: Petroleum World and 011 , v. 50, no. 2, Jan. 8, p. 1 .

Anonymous, 1953c, Redondo Beach wonders: To drill or not to drill? Petroleum World and 0il, v. 50, no. 32 , Aug. 6, p. 1 .

Anonymous, 1953d, Call for harbor land bids: Petroleum World and 011, v. 50, no. 34, p. 1 .

Anonymous, $1953 \mathrm{e}$, Seal Beach drilling case mulled by Appellate Court: Petroleum World and 0il, v. 50, no. 34 , Aug. 20, p. 3.

Anonymous, 1953f, Hint Seal Beach may appeal latest ruling on island drillsite: Petroleum World and 011, v. 50, no. 36 , Sept. 3 , p. 1 .

Anonymous, 1953g, New Marine Loading line at Ventura: Petroleum World and 011, v. 50, no. 39, Sept. 24, p. 51.

Anonymous, 1954a, Tidelands development active despite row over law: World 011, v. 138 , no. 1, p. 70.

Anonymous, 1954b, Santa Barbara is fearful. Urge "human refuge" if California allows new offshore drilling: Petroleum World, v. 51 , no. 3 , Jan. 21, p. 3 .

Anonymous, 1954c, Brown Drilling gets contract for island wells of seal Beach: Petroleum World and 0il, v. 51, no. 9, March 4, p. 1 .

Anonymous, 1954d, Will tunneling under the ocean be a cheaper way to drill offshore: Petroleum World and 011, v. 51, no. 12, p. 24-25.

Anonymous, 1954e, Richfield "shooting" offshore: Petroleum World and $011, \mathrm{v} .51$, no. 20 , May 20 , p. 1 .

Anonymous, 1954f, Monterey completes second Newport of fshore well: 011 and Gas Jour., v. 52, no. 48, April 5, p. 172.
Anonymous, 1954g, Monterey readies rig: 011 and Gas Jour., v. 52, no. 50, April 19, p. 102 .

Anonymous, 1954h, California offers leases: 011 and Gas Jour. v. 52, no. 50, April 19, p. 102.

Anonymous, 1954i, Island test begun. Monterey starts first of three Seal Beach wildcats: 011 and Gas Jour., v. 53, no. 4, May 31, p. 45.

Anonymous, 1954j, Zirconium: Mineral Information Service, Calif. Div. Mines, v. 7, no. 9, p. 1-3

Anonymous, $1954 \mathrm{k}$, Man-made island oil drilling project: Mineral Information Service, Calif. Div. Mines, v. 7, no. 9, p. 7 .

Anonymous, $1954 \mathrm{~m}$, Glass sand in California: Mineral Information Service, Calif. Div. Mines, v. 7 , no. 6 , p. 1-4.

Agassiz, A., 1905, On the progress of the Albatross Expedition to the eastern Pacific: Am. Jour. Sc1., 4th ser., v. 19, p. 143-148, 367-376.

Agassiz, A., and Murray, J., 1902, Reports on the scientific results of the expedition to the tropical Pacific, in charge of A. Agassiz, by the U. S. Fish Comission steamer Albatross, from August, 1899, to March 1900, Commander J. F. Moser, U. S. N., commanding. I. Preliminary report and list of stations by A. Agassiz with remarks on the deep-sea deposits by J. Murray: Mus. Comp. Zoology Mem., v. 26, no. 1, 114 p., 21 charts. *

Ahlatrom, E. H., 1950, The sardine in 1ts environment. A popular account of the objectives of the Pacific coast Sardine Research Program: Pan-Am. Fisherman, v. 5, no. $6, \mathrm{p} .15,16,32-47$.

Alden, J., 1852, Extracts from a letter to A. D. Bache, Superintendent, relating to Humboldt Harbor and Trinidad Bay, California: Ann. Rept. U. S. Cosst Survey 1851, app. 4, p. 520-522.

Alden, J., 1853, Report on a reconnaissance of the western cosst from San Francisco, south, to San Diego, including the Santa Barbara Islands and Channel: Ann. Rept. U. S. Coast Survey 1852, app. 18, p. 104-107.

Alden, J., 1854a, Extracts from a letter on the results of an examination of the coast and several harbors and anchorages between San Francisco and the Columbia River: Ann. Rept. U. S. Coast Survey 1853, app. 23, p. 55.

Alden, J., 1854b, Extracts of report on the determination of the position of a bank in the Pacific, lying in the tract of the Panama steamers: Ann. Rept. U. S. Coast Survey 1853, app. 24, p. 55-56.

Alden, J., 1856, Deposit of red sand inside of the bar of San Francisco Bay, California: Ann. Rept. U. S. Coast Survey 1855 , app. 20, p. 162 .

Aldrich, L., and Smith, H. G., 1948, Los Angeles' $\$ 41,000,000$ Hyperion Project ends beach contamination: Civil Eng., v. 18 , no. 7, p. $418-423,480$.

Alexander, A. H., 1936, Beach considerations of the California Division of State Lands: Shore and Beach, v. 4, p. 169-17

Alexander, C. S., 1950, The marine and stream terraces of the Capitola-Watsonville area, California: M. A. thesis, Univ. Calif., Berkeley; Univ. Calif. Pubs. Geography, v. $10,(1953)$, p. $1-44$, pls. $1-3,10$ figs.

Allen, E. C., 1933, The carbon dioxide content of sea water: M. S. thesis, Univ. Calif., Berkeley. *

Allen, W. B., 1932, Breakwaters for the protection of harbors: World Ports, v. 20, no. 3, p. 193-203 1ncl. discussion. *

Allen, W. E., 1920, A quantitative and statistical study of the plankton of the San Joaquin River and Its tributaries in and near Stockton, California, in 1913: Univ. Calif. Pub. Zoology, v. 22, p. 1-292, pls. 1-12.

Allen, W. E., 192la, Problems of floral dominance in the open sea: Ecology, v. 2, p. 26-31.

Allen, W. E., 1921b, The investigation of ocean pasturage: Ecology, v. 2, p. 215-219.

Allen, W. E., 192lc, Ocean pasturage and ocean fisheries: First Pan-Pacific Sc1. Conf. Proc., v. 1, p. 213-221 incl. discussion.

Allen, W. E., 1921d, Preliminary statistical studies of marine phytoplankton of the San Diego region, California: First Pan-Pacific Sc1. Conf. Proc,, pt. 2, p. 537-554.

Allen, W. E., 192le, some work on marine phytoplankton in 1919: Am. Micros. Soc. Trans., v. 40, p. 177-181. 
Allen, W. E., 1922a, Quantitative studies on marine phytoplankton at La Jolla in 1919: Univ. Calif. Pub. Zoology, v. 22, p. $329-347$.

Allen, W. E., 1922b, Quantitative studies on inshore marine diatoms and dinoflagellates of southern california in 1920: Univ. Calif. Pub. Zoology, v. 22, p. 369-378.

Allen, W. E., 1922c, Observations on the distribution of marine diatoms between San Diego and Seattle: Ecology, v. 3, p. 140-145.

Allen, W. E., 1923a, Studies on catches of marine phytoplankton made by aid of Kofoid bucket in 1921: Ecology, v. 4, p. $74-80$.

Allen, W. E., 1923b, Some tide-water collections of marine diatoms taken athalf-hour intervals near San Diego, California: Univ. Calif. Pub. Zoology, v. 22, p. 413-416.

Allen, W. E., 1923c, Studies on marine diatoms and dinoflagellates caught by the aid of the Kofold bucket in 1922: Univ. Calif. Pub. Zoology, v. 22, p. 435-445.

Allen, W. E., 1923d, Statistical studies of marine diatoms of the San Diego region collected by U. S. S. Pioneer in midwinter, 1923: Univ. Calif. Pub. Zoology, v. 22, p. $445-448$.

Allen, w. E., 1923e, Observations on surface distribution of marine diatoms of Lower California in 1921: Calif Acad. Sc1. Proc., v. 12, p. $437-442$.

Allen, W. E., 1923f, Recent work on marine micro-plankton at the La Jolla Biological Station: Am. Micros. Soc. Trans., v. 42 , p. $180-183$.

Allen, W. E., 1924a, Surface catches of marine diatoms and dinoflagellates made by U.S. S. Ploneer between San Diego and Seattle in 1923: Univ. Calif. Pub. Zoology, v. 26, p. 243-248.

Allen, W. E., 1924b, Observations on surface distribution of marine diatoms of Lower California in 1922: Ecology, v. 5 , p. 389-392.

4llen, W. E., 1925, Statistical studies of surface catches of marine diatoms and dinoflagellates made by the yacht ohio in tropical waters in 1924: Am. Micros. Soc. Trans., v. 44, p. 24-30.

4llen, W. E., 1926, Remarks on surface distribution of marine plankton diatoms in the east Pacific: Science, v. 63 , no. 162 , p. 96-97.

qlien, W. E., 1927a, Quantitative studies on inshore marine diatoms and dinoflagellates of southern California in 1921: Scripps Inst. Oceanography Bull., tech. ser., v. 1, p. 19-29.

Allen, W. E., 1927b, Quantitative studies on inshore marine diatoms and dinoflagellates of southern California, 1922: Scripps Inst. Oceanography Bull,, tech. ser. v. 1, p. $31-38$.

Allen, W. E., 1927c, Why we study the ocean's plankton: Calif. Monthly, v. 21, p. 2,98

Allen, W. E., 1927d, Surface catches of marine diatoms and dinoflagellates from the Pacific high seas in 1925 and 1926: Scripps Inst. Oceanography Bull., tech. ser., v. 1 , p. $197-200$.

Allen, W. E., 1928a, Catches of marine diatoms and dinoflagellates taken by boat in southern California waters in 1926: Scripps Inst. Oceanography Bull., tech. ser., v. 1, p. $201-246$.

Ilen, W. E., 1928b, Quantitative studies on inshore marine diatoms and dinoflagellates collected in southern california in 1924: Scripps Inst. Oceanography Bull., tech. ser., v. 1, p. 347-356.

Allen,W. E., 1928c, Review of five years of studies on phytoplankton at southern California piers, 1920-1924, inclusive: Scripps Inst. Oceanography Bull., tech ser., v. I p. 357-401.

lllen, W. E., 1928d, investigations on phyto-plankton in the Pacific Ocean: Third Pan-Pacific Sc1. Cong. Proc., v. 1 p. $250-263$.

Ilen, W. E., 1929, ten years of statistical studies of marine phytoplankton at the Scripps Institution of Oceanography: Sclence, v. 70 , no. 1818 , p. $416-419$.

Allen, W. E., 1930 a, Methods in quantitative research on marine microplaniton: Scripps Inst. Oceanography Bull., tech. ser., v. 2, p. 319-329.

llen, W. E., 1930b, Quantitative studies on marine diatoms and dinoflagellates at the Scripps Institution of oceanography: Fourth Pacific Sci. Cong. Proc., v. 3, p. 545 546 (abs.)

Allen, W. E., 1933a, Surface phytoplankton obtained by the Templeton Crocker Expedition of the California Academ of Sciences of 1932: Am. Micros. Soc. Trans., v. 52, p. 101-102.
Allen, W. E., 1933b, "Red water" in La Jolla Bay in 1933: Sclence, v. 78 , no. 2010 , p. 12-13.

Allen, W. E., 1934a, Marine plankton diatoms of Lower California in 1931: Bot. Gaz., v. 95, p. 485-492.

Allen, W. E., 1934b, The importance of continulty in marine plankton investigations: Fifth Pacific Sci. Cong. Proc., v. 3, p. 2051-2055.

Allen, W. E., 1934, "Yellow water" in La Jolla Bay in 1935 Science, v. 82, no. 2127, p. 325-326.

Allen, W. E., 1936, Occurrence of marine plankton diatoms in a ten year series of dally catches in southern California: Am. Jour. Botany, v. 23, p. 60-63.

Allen, W. E., 1937a, A large catch of Noctiluca: Science, v. 86 , no. 2226 , p. 197-198.

Allen, W. E., 19370, Plankton diatoms of the Gulf of California obtained by the G. Allan Hancock Expedition of 1936: Univ. Southern Calif., The Hancock Expeditions Pub. v. 3, no. 4, p. 47-59.

Allen, W. E., 1938a, The Templeton Crocker Expedition to the Gulf of California in 1935 - the phytoplankton: Am. Micros. Soc. Trans., v. 57, p. 328-335.

Allen, W. E., 1938b, Quantity collecting of planktonic diatoms: Science, v. 87, no. 2251 , p. 171 .

Allen, W. E., 1938c, "Red water" along the west cosst of the United States in 1938: Science, v. 88, no. 2272, p. $55-56$.

Allen, W. E., 1939, "Phosphorescence" in the sea: Nautical Gaz., Aug. 26, 2 p.

Allen, W. E., 1940a, Methods of fleld and laboratory procedure in phytoplankton research at the Scripps Institution of Oceanography of the University of California: Sixth Pacific Sci. Cong. Proc., v. 3, p. 525-528.

Allen, W. E., 1940b, Discolored sea water: U. S. Hydrog. Bull, 2662, Sept. 11, 3 p.

Allen, W. E., 1940c, Indicator value of phytoplankton: Sixth Pacific Sci. Cong. Proc., v. 3, p. 529-531.

Allen, W. E., 1940d, Summary of results of twenty years of researches on marine phytoplnakton: Sixtb Pacific Sc1. Cong. Proc., v. 3, p. 577-583.

Allen, W. E., 194la, Twenty years' statistical studies of marine plankton dinoflagellates of southern California: Am. Midland Naturalist, v. 26, no. 3, p. 603-635.

Allen, W. E., 194lb, Frustles of marine plankton diatoms: Chronica Botanica, v. 6, p. 365-367.

Allen, W. E., 194lc, Ocean pasturage in California waters: Sci. Montbly, v. 52 , p. 261-264.

Allen, W. E., 194ld, Depth relationships of plankton diatoms in sea water: Jour. Marine Research, v. 4, p. 107-111.

Allen, W. E., 1942a, Diatoms, in Scripps Inst. Oceanography, Records of observations, oceanographic observations of the E. W. Scripps crulses of $1938, \mathrm{v} .1$, no. 1, p. 25-26.

Allen, W. E., 1942b, Occurrence of "red water" near San Diego: Science, v. 96, no. 2499, p. 471.

Allen, W. E., 1943, "Red water" in La Jolla Bay in 1942 Am. Micros. Soc. Trans., v. 62 , no. 2 , p. 262-264.

Allen, W. E., 1945, Occurrence and abundance of marine plankton diatoms offshore in southern California: Am. Micros. Soc. Trans., v. 64, p. 21-24.

Allen, W. E., 1946a, "Red water" in La Jolla Bay in 1945: Am. Micros. Soc. Trans., v. 65, p. 149-153.

Allen, W. E., 1946b, Significance of "red water" in the sea: Turtox News, v. 24, no. 2, p. 49-50.

Allen, W. E. and Lewis, R., 1927, Surface catches of marine diatoms and dinoflagellates from Pacific high sees in 1925 and 1926: Scripps Inst. Oceanography Bull., tech. ser., v. 1, p. 197-200.

Alliott, H., 1917, Pre-historic use of bitumen in southern California: Southern Calif. Acad. Sc1. Bull., v. 16, pt. II, p. $41-44$.

Allison, J. M., 1940, Origin, path of travel and characteristics of storms causing major floods in the north and south pacific division, in U. S. Engineering Dept., Corps oi Engineers, Proc. of the Engineering Conf., South Pacific Div. and North Pacific Div., San Francisco, p. 40-46, 5 pls. and discussion. '(See other repts. In this volume for meteorology, floods etc.).

Alpert, L., 1946a, Contributions to the weather and climate of the tropical eastern Pacific Ocean: $\mathrm{Ph}$. D. thesis, Clark Univ., Worchester, Mass.

Alpert, L., 1946b, Atmospheric cross-sections of the stratus zone of the tropical eastern Pacific ocean: Am. Geophys. Union Trans., v. 27 , p. 800-813. 
Anderson, C. A., 1941, Geology of the Gulf of California: Geol. Soc. America Bull., v. 52, p. 1888 (abs.).

Anderson, C. A., 1950,1940 E. W. Scripps crulse to the Gulf of California. Part I. Geology of the 1slands and nelghboring land areas: Geol. Soc. America Mem. 43, p. 1-53.

Anderson, E. R., 1950, Distribution of sound velocity in a section of the eastern North Pacific: Am. Geophys. Union Trans., v. 31, p. 221-228.

Anderson, F. M., 1896-1902, The geology of Point Reyes Peninsula: M. S. thesis (1897), Univ. Calif., Berkeley; Univ. Callf. Pub. Geol. Bull., v. 2, p. 119-153, pl. 4.

Anderson, F. M., 1926, Origin of California petroleum: Geol. Soc. America Bull., v. 37, p. 585-614.

Anderson, F. M., and Hanna, G. D., 1935, Cretaceous geology of Lower Calffornia: Calif. Acad. Sc1. Proc., v. 23, p. $1-34$.

Anderson, G. E., 1926, Experiments on the rate of wear of sand grains: Jour. Geology, v. 34, p. 144-158.

Anderson, J. B., 1931, Observations from afrplanes of cloud and $f \circ g$ conditions along the southern California cosst: Monthly Weather Rev., v. 59, p. 264-270.

Anderson, R., 1927, Origin of oil from martne plankton shales in Calffornia: Geol. Soc. America Bull., proc. for 1926, v. 38, p. 199-200 (abs.).

Anderson, R. E., Redwine, L. E., and McGovney, P. E., 1949, Geology of northern Santa Rosa Island: Am. Assoc. Petroleum Geologists Bull. v. 33, p. 2062 (abs.); 011 and Gas Jour., v. 48, no. 29, Nov. 24, p. 140 (abs.).

Anderson, W., 1939, Quaternary sea-levels in the northern hemisphere: Geol. Mag., v. 76, p. 489-493.

Andrews, H. L., 1945, The kelp beds of the Monterey region: Ecology, v. 26, p. 24-37.

Aplin, J. A., 1947, The effect of explosives on marine life: Calif. Fish and Game, v. 33, p. 23-30 incl. figs and tables.

Archer, W. E., 1934, El Segundo marine loading line la1d in half mile sections: 011 Weekly, v, 73 , no. 1, March 19 , p. 33-34.

Armstrong, T. A., 1954, Sclentists in rubber sufts and aqualungs are diving for oil off Calffornia: 0 il and Gas Jour., v. 53, no. 9, July 5, p. 104-105.

Army Air Forces, weather Information Branch, 1943, Hurricanes affecting the Atlantic coast, the Gulf coast, and the southern California Coast of the United States: Rept. no. 636 .*

Arnestad, K. H., 1950, The geology of a portion of the Lompoc quadrangle, Santa Barbara County, Calffornia: M. A. thesis, Univ. Calif., Los Angeles, 62 p., 2 figs.

Arnold, A. F., 1916, The sea beach at ebb-tide; a guide to the study of the sea-weeds and the lower animals found between tide-marks: New York, Century. x, 490 p., $85 \mathrm{pls}$. *

Arnold, C. E., Hedger, H. E., Rawn, A. M., 1949, Report upon the reclamation of water from sewage and industrial wastes in Los Angeles County, California: Rept. to Board of Supervisors, Los Angeles County, April. *

Arnold, D., 1896, An interrogation regarding the fossil shells of San Pedro Bay: Naut1lus, v. 10, p. 33-34.

Arnold, D., 1897, Foss1ls of Dead Man's Is land: Nautilus, v. 10, p. $140-142$

Arnold, D., and Arnold, R., 1902, The marine Pllocene and Pleistocene stratigraphy of the coast of southern Californta: Jour. Geology, v. 10, p. 117-138.

Arnold, J. L., 1928, A study of the mollusca of Anahelm Slough: their distribution, and classification with notes on the crystalline style: M. A. thesis, Univ. Southern Calif., 124 p., 13 pls., 2 flgs. 1 map.
Arnold, R., 1900, The geology of San Pedro Bay: M. A. thes 18 , Stanford Un1v., 32 p., 3 figs.

Arnold, R., 1903, The paleontology and statigraphy of the marlne Pliocene and Plelatocene of San Pedro, California: Calif. Acad. Sc1. Mem. 3, 420 p., 37 pls.

Arnold,.R., 1909, Environment of the Tertiary faunas of the Pacific Coast of United States: Jour. Geology, v. 17, p. 509-533, $1 \mathrm{pl}$.

Arnold, R., and Hannibal, H., 1913, The marine Tertiary statigraphy of the North Pacific Coast of America: Am. Ph1los. Soc. Proc., v. 52, p. 559-605.

Arthur, R. S., 1948, Revised wave forecasting graphs and procedure: Scripps Inst. Oceanography, Wave Rept. 73, 14 p., 9 pls. *

Arthur, R. S., 1949, Varlability in direction of wave travel: New York Acad. Sc1. Annals, v. 51, p. 511-522; Scripps Inst. Oceanography, Wave Rept. 80,12 p. Incl. 1llus.

Arthur, R. S., 1950, Refraction of shallow water waves; the combined effect of currents and underwater topography: Am. Geophys. Union Trans., v. 31, p. 549-552.

Arthur, R. S., 1951, wave forecasting and hindcasting: Scripps Inst. Oceanography, SIO ref. 51-56, Wave Rept. 98; First Conf. on Coastal Eng. Proc., Berkeley, p. 82-87

Ashauer, H., Hollister, J. S., and Reed, R. D., 1936, Sedimentation und Faltung im sudlichen Kalffornien: Festschrift zum 60 Geoburstag von Hans Stille, Stuttgart, Ferdinand Enke, p. 232-258, 4 11g8. + maps.*

Ashley, G. H., 1895, Studies in the Neocene of California: Jour. Geology, v. 3, p. 434-454.

Ashley, G. H., 1896, The Neocene statigraphy of the Santa Cruz Mountains of California: Calif. Acad. Sc1. Proc., ser 2, v. 5 (1895), p. 273-367.

Ashley, G. H., 1931, our youthful scenery: Geol. Soc. America Bull., v. 42, p. 216 (abs.), p. 537-546; Pan-Am Geologist v. 55, p. 74 (abs.).

Atwill, E. R., 1942, Progress of stratigraphic studies in Calffornia: Am. Assoc. Petroleum Geologist Bull., v. 26, p. 153-161.

Atwood, W. G., and Johnson, A. A., 1924, Marine structures, their deterioration and preservation: Rept. of the Comm. on Marine Plling Inv. of the Div. of Eng. and Indus. Research of the National Research Council, Wash., D. C., $534 \mathrm{p}$.

Averill, C. V., 1941, Mineral resources of Humboldt County: Calif. Jour. Mines and Geology, chap. 4, oct., p. 499-528 Averi11, C. V. and others, 1946, Placer mining for gold in California: Calte. Div. Mines Bull. 135, $357 \mathrm{p}$.

Avers, H. G., 1927, A study of the varfation of mean sea-level from a level surface: Am. Geophys. Union Trans., 8th ann. meet., in Natl. Research Council Bull. 61, p. 56-58.

Axelrod, D. I., 1939, Late Tertiary vegetation and climate of the Great Basin and border areas: Geol. Soc. America Bull., v. 50, p. 1945-1946 (abs.).

Bache, A. D., 1852, Letter to the Secretary of the Treasury, communicating information relating to Trinidad, Humboldt, and San Diego Bays: Ann. Rept. U. S. Cosst Survey 1851, app. 50, p. $528-530$.

Bache, A. D., 1854a, on the tides of the western coast of the United States. Tides of San Francisco Bay, California: Ann. Rept. U. S. Cosst Survey 1853, app. 28, p. 77-81.

Bache, A. D., 1854b, Notes on the tides at San Francisco, California: Ann. Rept. U. S. Coast Survey 1853, app. 29 , p. $81-82$.

Bache, A. D., 1856a, Letter from the superintendent to the Secretary of the Treasury, with copy of a communication from Captain W. L. Dall, P. M. S. S. Columbia, and extrac from a letter of Captain James Witking, P. M. S. S. Golden Age, relative to facilities for navigation afforde by the development of a deposit of reddish sand detected by Commander Alden inside of the bar at the entrance to San Francisco Harbor, California? Ann. Rept. U. S. Coast Survey 1856, app. 16, p. 119-120.

Bache, A. D., 1856b, Position of a dangerous rock on Cortez Bank, coast of California, determined by A. MacRae: Ann, Rept. U. S. Coast Survey 1855, app. 18, p. 160-161. 
ache, A. D., 1856c, Extracts of a report of Lt. Comdr. A. MacRae, U. S. N., relative to the position of a rock on which the steamer Uncle Sam struck, May 7, 1855: Ann. Rept. U. S. Coast Survey 1855, app. 19, p. 161-162. e, A. D., 1856d, Approximate cotidal lines of the Pacific Coast of the United States, from observations in the United States Coast Survey: Ann. Rept. U. S. Coast Survey 1855, app. 50, p. 338-342, pl. 49 .

che, A. D., 1856e, Notice of earthquake waves on the western casst of the United States, on the 23d and 25th December, 1854: Am. Jour. Sci. and Arts, v. 21, 2nd ser., p. 37-43; Ann. Rept. U. S. Coast Survey 1855, app. 51, p. 342-346, pl. 50 (no. 3A); Also again in Ann. Rept. U. S. Casst Survey 1862 , app. 24 , p. 238-241 with slight alterations.

ache, A. D., 1858, on the winds of the western cast of the United States, from observations in connection with the U. S. Coast Survey: Ann. Rept. U. S. Cosst Survey 1857, app. 36, p. 354-358, p1. 66 .

he, A. D., 1859, Letter to the Secretary of the Treasury, comunicating the development of dangers to navigation in San Francisco Bay, California: Ann. Rept. U. S. Coast Survey 1858, app. 18, p. 154-155.

che, A. D., 1862, Report of the Superintendent, section X, from San Diego, or the southern boundary on the Pacific ocean, to the forty-second parallel, including the coust of California: Ann. Rept. U. S. Cosst Survey 1861, p. 66-69, sketches $\mathrm{J}$, nos. 20, 21.

e, A. D., 1864a, Report of the Superintendent, section $\mathrm{X}$, the southern boundary on the Pacific, to the forty-second parallel, including the coast of California: Ann. Rept. U. S. Cosst Survey 1862 , p. 58-61, sketches J. nos. 37 , 38.

he, A. D., 1864b, Report of the Superintendent, section X, from San Diego, on the Pacific northward to the fortysecond parallel, including the coast of California: Ann. Rept. U. S. Coast Survey 1863, p. 55-57, sketch 24.

agg, R. M. Jr., 1912, Pliocene and Pleistocene Foraminifera from southern California: U. S. Geol. Survey Bull. 513 , 153 p., pls. 1-28.

iley, E. H., 1940, Pledmontite and kyanite from the Franciscan of Santa Catalina Island: Geol. Soc. America Bull., v. 51, p. 1955 (abs.).

1ley, E. H., 1941, Mineralogy, petrology, and geology of Santa Catalina Island, California: Ph. D. thesis, Stanford Univ. *

alley, T. L., 1921, The petrography and origin of the Recent sediments along the east side of the San Francisco Peninsula, California: M. A. thesis, Univ. Calif., Berkeley, 175 p., map. *

ailey, T. L., 1935, Lateral change of fauna in the Lower Pleistocene: Geol. Soc. America Bull., v. 46, p. 489-502.

ailey, T. L., 1943, Late Pleistocene Cosst Range orogenesis in southern California: Geol. Soc. America Bull., v. 54 , p. 1549-1568.

ailey, T. L., 1947, origin and migration of oil into sespe redbeds, California: Am. Assoc. Petroleum Geologists Bul1., v. 31, p. 1913-1935.

aldwin, E. M., 1945, Some revisions of the late Cenozoic stratigraphy of the southern Oregon coast: Jour. Geology, v. 53, p. 35-46.

andy, 0. L., 1952, The frequency distribution of Recent Foraminifera off California: $0 i l$ and Gas Jour., March 24, p. 212 (abs.).

andy, O. L., 1953a, Ecology and paleoecology of some California Foraminifera. Part I. The frequency distribution of Recent Foraminifera off California: Jour. Paleontology, v. 27, p. 161-182, pls. 21-25.

andy, O. L., 1953b, Ecology and paleoecology of some California Foraminifera. Part II. Foraminiferal evidence of subsidence rates in the Ventura Basin: Jour. Paleontology, v. 27, p. 200-203.

andy, O. L., 1954, Aragonite tests among Foraminifera: Jour. Sed. Petrology, v. 24, p. 60-61.

dy, 0. L., 195 , Evidence of displaced Foraminifera in the Purisima Formation of the Halfmoon Bay area, California: Contr. Cushman Foundation for Foram. Research (in press).

anks, H. O., and Bookman, M., 1951, Proposed investigational work for control and prevention of sea-water intrusion into ground water basins: Calif. Div. Water Res., Rept. to State water Res. Board, 33 p. *
Banks, H. O., Gleason, G. B., and Richter, R. C., 1950, Seawater intrusion into ground-water besins bordering the California coast and inland bays: Calif. Div. Water Res., Water Pollution Inv., Rept. no. 1, 23 p. *

Banks, H. O., and Lawrence, J. H., 1953, Water quality problems in California: Am. Geophs. Union Trans., v. 34, p. 58-66.

Banks, H. O., and Richter, R. C., 1953, Sea-water intrusion into ground-water basins bordering the california coast and inlend bays: Am. Geophys. Union Trans., v. 34, p. 575-582. (Extensive bibliography on Calif. salt water intrusion).

Barlow, C. and Taylor, H. R., 1897, The story of the Farallones: Alameda, Calif., privately printed, 32 p., illus. *

Barnard, J. L., 1952, The gammaridean family cheluridae (crustacea, amphipoda): A study in morphology, anatomy, and ecology, with special reference to Chelura terebrans: Ph. D. thesis, Univ. Southern Calif., 589 p. Including 25 tables, 50 figs., 52 pls.

Barnes, A. J., 1937, A new deal needed for our ocean beaches relative to Spanish and Mexican Land Grants: Shore and Beach, v. 5, p. 35-37.

Barnes, K. B., 1945, Wells slanted out 3,700 feet tap under ocean pool: Oil and Gas Jour., v. 44, no. 26, Nov. 3 , p. $82-85,89,93,119$.

Barrows, A. L., 1913, Preliminary inquiry into the geological significance of rock boring shells: Geol. Soc. Americe Bull., proc. 13th ann. meet., v. 24, p. 130-131.

Barrows, A. L., 1917, An unusual extension of the distribution of the shipworm in San Francisco Bay, California: Univ. Calif. Pub. Zoology, v. 18, p. 24-43.

Barrows, A. L., 1919, The occurrence of a rock-boring isopod along the shore of San Francisco Bay, California: Univ. Calif. Pub. Zoology, v. 19, p. 299-316.

Bartholomew, J. W., and Rittenberg, S. C., 1949, Thermophilic bacteria from deep ocean bottom cores: Jour. Bacteriology, v. 57, p. 658 .

Bartlett, W. A., 1852, Report ... on the general character of the cosst of California: Ann. Rept. U. S. Coast Survey 1851, app. 48, p. 525-526.

Bartsch, P., 1912, A zoogeographic study based on the pyramidellid mollusks of the west coast of America: U. S. Natl. Mus. Proc., v. 42, p. 297-349.

Bartsch, P., 192la, Discussion on mapping the Pacific by members of the conference: First Pan-Pacific Sci. Conf., pt. 2 , p. $483-484$.

Bartsch, P., 1921b, Ocean currents, the prime factor in the distribution of marine mollusks on the west cosst of America: First Pan-Pacific Sc1. Conf. Proc., pt. 2, p. 505-526.

Bascom, W. N., 1946a, Effect on seismic sea wave on California coast: Univ. Calif., Berkeley, fluid mechanics lab., tech. rept. HE-116-204, April 16, 11 p., table, photos, graph.

Bascom, W. N., 1946b, Field studies at Monterey, April-August 1946: Univ. Calif., Berkeley, fluid mechanics lab., tech. rept. HE-116-224, oct., 27 p., photos, maps, graphs.

Bascom, W. N., 1947a, LST's on Fort Ord Beach: Univ. Calif. Berkeley, fluid mechanics lab., tech. rept. HE-116-237, Feb. 19, 3 p., photos, graphs.

Bascom, W. N., 1947b, Installation of a wave recorder at point Sur: Univ. Calif., Berkeley, fluid mechanics lab., tech. rept. HE-116-242, April 15, 6 p., sketches, photos, chart.

Bascom, W. N., 1947c, Beach surveys at Moss Landing, California, June 6, 1946 to March 31, 1947: Univ. Calif., Berkeley, fluid mechanics lab., tech. rept. HE-116-243, April 25, 4 p., photos, sketches, graphs.

Bascom, W. N., 1947d, Beach and surf conditions on beaches of the Oregon and Washington coast between october 9, 1946 and November 18, 1946: Univ. Calif., Berkeley, fluid mechanics lab., tech. rept. HE-116-247, April 16, 15 p., tables, photos, graphs.

Bascom, W. N., 1947e, Installation of a wave recorder at Heceta Head, Oregon: Univ. Calif., Berkeley, fluid mechanics lab., tech. rept. HE-116-259, May 19, 3 p. photos.

Bascom, W. N., 1948a, A memorandum on the feasibility of Pigeon Point as a location for instruments: Univ. Calif., 
Berkeley, fluid mechanics lab., tech. rept. HE-116-278, Feb. 5, I p., sketches, photos.

Bascom, W. N., 1948b, Installation of wave recorders at Point Arguello, Callfornia: Univ. Calif., Berkeley, fluid mechanica lab., tech. rept. HE-116-29l, July, 8 p., photos, sketches.

Bascom, W. N., 1950a, Inftial surveys and instrumentation; sand transport study, Santa Barbara, California: Univ. Calif., Beriseley, Inst. eng. research, ser. 14, 1ssue 3,4 p., 58 pls.

Bascom, w. N., 1950b, Surging in Depoe Bay, oregon: U. S. Army, Corps of Engineers, Beach Erosion Board Bull., v. 4 , no. 4 , p. $32-39$.

Bascom, W. N., 1950c, The relationsh1p between sand size and beach-face slope: Untv. Calif., Berkeley, Inst. eng. research, ser. 14, issue 3, 7 p., 7 pls.; Am. Geophys. Union Trans., v. 32 (1951), p. 866-874.

Bascom, W. N., 1951, Investigation of cosstal sand movements near Santa Barbara, California: Univ. Calif., Berkeley, Inst. eng. research ser. 14 , 18sue 8 , pt. I, 38 p., pt. II, 78 pls.

Bascom, W. N., Wiegel, R. I., and Chinn, A. J., 1948, Oceanside Amphibious Operation, November 13 and 14, 1947: Univ. Calif., Berkeley, fluid mechanics lab., tech. rept. HE-116-293, Nov., 13 p., photos, graphs.

Bates, C. C. and Glenn, A. H., 1948, Oceanography in the offshore drilling campaign: World 011, Apr11, p. 114, $116,119,120,123,124,126$.

Bath, M., 1952, Initial motion of the first longitudinal earthquake wave recorded at Pasadena and Huancayo: Seismol. Soc. Amer1ca Bull., v. 42, p. 175-195.

Bathgate, V. M., 1913, The Dinoflagellata of San Franc1sco Bay: M. S. thes18, Univ. Calif., Berkeley. *

Baucher, J. W., 1947, Osc1llatory waves in shallow water: M. S. thesis, Univ. Calif., Berkeley.*

Bauer, F. H., 1952, Marine terraces between Salmon Creek and Stewarts Point, Sonoma county, California: M. A. thesis, Un1v. Calif., Berkeley, 273 p., 16 pls., 74 figs. *

Bauer, L. A., 1911, on gravity determinations at sea: Am. Jour. Sc1., 4th ser., v. 31, p. 1-18.

Beach Erosion Board Varlously listed. In Library catalogues generally listed as U. S. Engineering Department, Beach Erosion Board.

Beach Erosion Board, 1938, Beach erosion atudy at Ballone Creek and San Gabriel River, California: Cooperating agency State of California acting through the Los Angeles Flood Control District. *

Beach Erosion Board, 1939, Manual of procedure in beach erosion studies: U. S. Eng. Dept., Wash., 77p. Incl. 18 pls. (Paper no. 2 of the Beach Erosion Board).

Beach Erosion Board, 1942a, Beach erosion study at Coronado, California. Investigation by Beach Erosion Board in connection with San Diego Harbor improvement program: Shore and Beach, v. 10, p. 8-11.

Beach Erosion Board, $1942 \mathrm{~b}$, Beach er osion study of Mission Beach, completed on November 4, 1942; Cooperating agency, C1ty of San Diego, acting through Council of C1ty of San Diego. *

Beach Erosion Board, 1942c, Beach erosion study of Long Beach, completed April 3, 1942, Cooperating agency, City of Long Beach, California. *

Beach Erosion Board, 1946, Report on cooperative beach erosion study at Santa Barbara, California: U. S. Army, Corps of Engineers, Los Angeles district. *

Beach Erosion Board, 1947-50, Shoreline effects; appendices on survey reports, Los Angeles - Long Beach Harbor, Redondo Harbor and Playa del Rey Harbor; U. S. Army, Corps of Engineers, LOs Angeles district. *

Beach Erosion Board, 1948a, Littoral drift study, Los Angeles, California: U. S. Army, Corps of Engineers, Beach Erosion Board Bull. v. 2, no. 3, p. 1-4.

Beach Erosion Board, 1948b, An elementary discussion of tides, currents, and wave action in beach erosion: U. S. Army, Corps of Engineers, Beach Erosion Board Bull., v. 2, no. 4 , p. 8-12.

Beach Erosion Board, 1948c, Review of reports on Redondo Beach Harbor, appendix 6, shore-line effects: U. S. Army, Corps of Engineers, Los Angeles district. *
Beach Erosion Board, 1948d, Effect of proposed breakwater extension on adjacent shore lines, Lo Angeles and Long Beach Harbors, California. Appendix 8, July: U. S. Army, Corps of Engineers, Los Angeles district. *

Beach Erosion Board, $1948 \mathrm{e}$, Report on survey of navigation harbor at Playa del Rey, California: U. S. Army, Corps of Engineers, Los Angeles district. *

Beach Erosion Board, 1948f, Shoreline effects, harbor at Playr del Rey, California. Enclosure 20 of report of survey of harbor at Playa del Rey, California: U. S. Army, Corps of Engineers, Los Angeles district, i1, 51 p., pl., maps, diagram.

Beach Erosion Board, $1948 \mathrm{~g}$, Harbor and shore protection in the vicinity of Port Hueneme, California: U. S. Army, Corps of Engineers, Los Angeles district, South Pacific Div. *

Beach Erosion Board, $1948 \mathrm{~h}$, Shore-line effects, harbor at Playa del Rey, California; U. S. Army, Corps of Engineers, LOs Angeles district. Enclosure 20 accompanying report on harbor at Playa del Rey, California, dated Aug. 16, 1948, 51 p., 29 pls.

Beach Erosion Board, 19481 , Shore protection report on survey of harbor at Port Hueneme, California: U. S. Army, Corpa of Engineers, Los Angeles district. 75 p., pls. + 7 app.

Beach Erosion Board, $1948 \mathrm{j}$, Effect of proposed breakwater extension on adjacent shoreline, LOs Angeles and Lons Beach Harbors, Californ1a: U. S. Army, Corps of Engineer Los Angeles district. App. 8 accompanying reviews of reports, navigation, Los Angeles and Long Beach Harbors, California, with a view of extending the existing breakwater and to improving Blxby Slough and Laguna Dominguez, dated July 1, 1948, 52 p., 35 pls.

Beach Erosion Board, 1949a, Summaries of reports transmitted to congress Santa Barbara, California: U. S. Army, Corps of Engineers, Beach Erosion Board Bull., v. 3 no. 1, p. 24-29.

Beach Erosion Board, 1949b, Surveying in haze and fog: U. S. Army, Corps of Engineers, Beach Erosion Board Bull., v. 3 , no. 2 , p. 6-7.

Beach Erosion Board, 1949c, Combining leadline and echo-sounding methods in surveys of submarine canyons: U. S. Army, Corps of Engineers, Beach Erosion Board Bull., v. 3 no. 4, p. 20-22.

Beach Erosion Board, 1950a, Beach erosion control report of cooperative study of the Pacific coast line of the state of Calffornia, Point Mugu to San Pedro Breakwater: U. S. Army, Corps of Englneers, Los Angeles district, Sept. 1. *

Beach Erosion Board, 1950b, Appendixes 1 to 6, inclusive to accompany beach-erosion control report on cooperative study of Pacific Cosst line of the state of california, Point Mugu to San Pedro Breakwater: U. S. Army, Corps of Engineers, Los Angeles district, Sept. 1, app. 1, prior repts., 35 p.; app. 2, description of the area, 36 p. 1 pl; app. 3, geology, 52 p., 2 tables, 6 pls.; app. 4, winds and waves, 13 p. Including 3 tables, 3 pls.; app. 5, destructive waves along the southern California coast, 22 p. incl. photos; app. 6, hydrographt surveys, 16 p. including photos, 20 pls. *

Beach Erosion Board, 1951, By-passing littoral drift at a harbor entrance: U. S. Army, Corps of Engineers, Beach Erosion Board Bull., v. 5, no. 3, p. 1-14.

Beach Erosion Board, 1952a, Surmary report on studies on sand transportation by wave action: U. S. Army, Corps of Engineers, Beach Erosion Board Bull., v. 6; no. 1, p. 1-17.

Beach Erosion Board, 1952b, Scripps Inatitution of Oceanograpk quarterly progress report number 10, Oct. - Dec. 1951: U. S. Army, Corps of Engineers, Beach Erosion Board Bull v. 6 , no. 2 , p. $32-41$.

Beach Erosion Board, 1953a, Summarles of reports transmitted to Congress: California, Carpinteria to Point Mugu: U. S. Army, Corps of Engineers, Beach Erosion Board Bull. v. 7 , no. 1 , p. 47-50.

Beach Erosion Board, 1953b, Scripps Institution of Oceanograpl quarterly progress report number 14, Oct. - Dec. 1952: U. S. Army, Corps of Engineers, Beach Erosion Board Bul v. 7 , no. 2 , p. $11-12$.

Beach Erosion Board, 1953c, Shore protection planning and design: U. S. Army, Corp of Engineers, Beach Erosion Board Special Isaue no. 2, 230 p., app. 125 p.

Beach Erosion Board, 1954a, Beach erosion studies - state of California: U. S. Army, Corps of Engineers, Beach Erosion Board Bull., v. 8 , no. 1, p. 31-34. 
ach Erosion Board, 1954b, Progress reports on research sponsored by the Beach Erosion Board: U. S. Army, Corps of Engineers, Beach Erosion Board Bull., v. 8, no. 2, p. $10-11$.

ch Erosion Board, 1954c, Beach erosion studies: Anaheim Bay Harbor, California: U. S. Army, Corps of Englneers, Beach Erosion Board Bull., v. 8, no. 2, p. 23.

al, C. H., 1915, The geology of the Monterey quadrangle, California: M. A. thesis, Stanford Univ., 88 p. Incl. 4 figs., 12 pls.

al, c. H., 1945, Reconnaissance of the geology and oil possibilities of Lower California, Mexico: Geol. Soc. America Bull., v. 56, p. 1147 (abs.).

als, E. A., 1919, Barometric pressure, winds, and storms of the Pacific Ocean: Scripps Inst. of Biol. Research, Univ. Calif., Bull. 9, p. 65-74, 3 charts.

ard, C. N., 1941, Drainage development in the vicinity of Monterey Bay, California: Ph. D. thesis, Univ. Illinois, Urbana, IIl. *

ardslee, C. G., 1942a, Salt water barrier at cooke: Weatern Construction News, v. 17, no. 2, p. 53-55.

ardslee, C. G., 1942b, Underground storage for floods assures army camp water supply: Eng. News-Record, v. 128, no. 11 , p. 406-407.

ck, A. I., 1922, An application of the principles of Bjerknes ' dynamic meteorology in a study of synoptic weather maps for the United States: M. A. thesis, Univ. Calif., Berksley.*

cker, G. F., 1888, Geology of the quicksilver deposits of the Pacific slope: U. S. Geol. Survey Mon. 13, 486 p., 7 pls., 20 figs. *

, C. G. P., and Leopold, L. B., 1947, Meteorological factors influencing air pollution in the Los Angeles area: Am. Geophys. Union Trans., v. 28, p. 173-192.

lcher, E., 1843, Narrative of a voyage round the world, performed in Her Majesty's Ship Sulphur, during the years 1836-1842. Including deta11s of the Naval operations in China, from December 1840, to November 1841: London, Henry Colburn, 2 v. in 1, illus.

Iknap, G. E., 1874a, Deep-sea soundings in the North Pac1fic ocean, obtained in the United States steamer Tuscorora: Wash., U. S. Hydrog. Office, no. 54,51 p., 12 pls., 9 profiles, 1 chart, tables of bottom material.

knap, G. E., 1874b, Concerning deep-sea sounding: Aslatic Soc. Japan Trans., v. 2, p. 159-170, discussion, p. 171173 , table.

11, G. K., 1948, Explosives and petroleum: Explosives Eng., v. 26 , no. 2 , p. $39-43$, no. 3 , p. $76-78$.

11, H. S., 1942, Density currents as agents for transporting sediments: Jour. Geology, v. 50, p. 512-547.

11, W. E., Bassler, F. F., Buek, F. E., Murphy, D. E., Writt, J. J., and Beauchamp, E. E., 1944, Use of cosstal radiosonde data in calling the approch of storms along the west cosst: M. S. thesis, Calif. Inst. Technology, $65 \mathrm{p.}, 20 \mathrm{pls}$.

nest, H., 1899, Submarine gullies, river outlets, and freshwater escapes beneath the sea-level: Geog. Jour., v. 14, p. 394-413, charts.

nioff, $\mathrm{H} ., 1938$, The determination of the extent of faulting with application to the Long Beach earthquake: Seismol. Soc. America Bull., v. 28 , p. 77-84.

rghaus, H., 1891, Atlas der Hydrographie: Gotha, Justus Perthes, 11 kolorierte karten in Kupferstich mit 173 darstellungen.

gelow, H. B., and Leslie, M., 1930, Reconnalssance of the waters and plankton of Monterey Bay, July 1928: Mus. Comp. Zoology Bull., v. 70, no. 5, p. 427-581.
Pacific Coast fisheries: Stanford Univ. Press, $75 \mathrm{p}$; Rev. by G. H. Clark, Calif. Fish and Game, v.'25 (1939), p. $256-257$.

Bishop, S. E., 1904, The cold-current system of the Pacific, and the source of the Pacific Coast Current: Science, v. 20 , no. 506, p. 338-341.

Bittinger, C., 1933, Experiences over a submarine epicenter: Am. Geophys. Union Trans., 14th ann. meet., p. 260.

Black, G. L., 1954, The case of the "tied" island: Westways, June, p. 8-9 (Palos Verdes Hills).

Blackman, E. O., 1935, Submarine geology from the air: Petroleum World, Ann. Rev., Los Angeles, p. 187-188.

Blackman, J. W. B., 1936, Conditions at Long Beach, California: Shore and Beach, v. 4, p. 159.

Blake, D., 1926, Forecasting fog on the California Coast: Scripps Inst. Oceanography Bull., no. 12, p. 28-33.

Blake, D., 1935, Mexican west cosst cyclones: Monthly Weather Rev., v. 63, p. 344-348.

Blake, E. W. Jr., 1887, The coast fox: West Am. Scientist, v. 3, p. 49-52.

Blake, J., 1868a, Infusoria from the moving sands in the nieghborhood of San Francisco: Calif. Acad. Nat. Sci. Proc., v. 3 (1863-1867), p. -35-36.

Blake, J., $1868 \mathrm{~b}$, on the gradual elevation of the land in the environs of San Francisco: Calif. Acad. Nat. Sci. Proc., v. 3 (1863-1867), p. $45-46$.

Blake, J., 1873, Remarks on the climate of California: Calif. Acad. Nat. Sc1. Proc., v. 4 (1868-1872), p. 110-116.

Blake, W. P., 1853, Preliminary geological report, in U. S. Pacific Railroad aurvey, (partial route in California) under command of Lt. R. S. Williamson, Corps of Topographical Engineers: House Doc. 129, 80 p.

Blake, W. P., 1854, Gold and platinum of Cape Blanco: Am. Jour. Sc1., 2nd ser., v. 18, p. 156.*

Blake, W. P., 1855, Preliminary geological report of the U. S. Pacific Railroad Survey, under the command of Lieut. R. S. Williamson, Corps of Topographic Engineers, 1853: Am. Jour. Sci. and Arts, 2nd ser., v. 19, p. 433-434.

Blake, W. P., 1856, Observations on the physical geography and geology of the cosst of California, from Bodega Bay to San Diego: Ann. Rept. U. S. Coast Survey 1855, app. 65, p. 376-398, pls. 57-60.

Blake, W. P., 1868, Note on the fossil remains of the horse and elephant, mingled, at Mare Island, San Francisco Bay: Calif. Acad. Nat. Sci. Proc., v. 3 (1863-1867), p. 166.

Blake, W. P., 1898, Oscillations of level of the Pacific Coast of the United States: Am. Geologist, v. 21, p. 164-165.

Blankinship, J. W., and Keeler, C. A., 1892, on the natural history of the Farallon Islands: Zoe, v. 3, p. 144-165.

Blinn, F. S., 1928, Jetty design, location and construction: M. S. thesis, Univ. Calif., Berkeley, 32 p., 22 pls.

Blochman, L. F., 1923, A study in the forecasting of seasonal rainfall for California: M. A. theais, Univ. Calif. Berkeley. *

Blodget, R. M., 1949, Does the tidelands dispute affect the San Joaquin Valley? Petroleum World, v. 46, no. 1 , p. $18-20$.

Boase, A. J., 1938, Essential requirements of concrete for sea-water exposure: Shore and Beach, v. 6, p. 121-122.

Boden, B. P., 1950, Plankton organisms in the deep scattering layer: U. S. Naval Electronics Lab., San Diego, rept. 186,29 p. incl. 13 figs.

Bodle, R. R., 1941, U. S. earthquakes 1939: U. S. Goast and Geod. Survey, serial 637, $69 \mathrm{p}$.

Bodle, R. R., 1944, U. S. earthquakes 1942: U. S. Coast and Geod. Survey, serial $662,38 \mathrm{p}$.

Bodle, R. R., 1945, U. S. earthquakes 1943: U. S. Coast and Geod. Survey, serial $672,47 \mathrm{p}$. 
Bodle, R. R., 1946a, Note on the earthquake and seismic sea wave of April 1, 1946: Am. Geophs. Union Trans., v. 27, p. $464-465$.

Bodle, R. R., 1946b, U. S. earthquakes 1944: U. S. Casst and Geod. Survey, serial $682,43 \mathrm{p}$.

Bodle, R. R., and Murphy, L. M., 1947, U. S. earthquakes 1945: U. S. Coast and Geod. Survey, serial 699, 38 p.

Bodle, 1948, U. S. earthquakes 1946: U. S. Coast and Geod. Survey, serial 714,47 p.

Bond, A. H., 1927, Meteorological studies at Humboldt Bay: Military Engineer, v. 19, p. 507-509.

Bonnot, P., and Phillips, J. B., 1938, Red water, its cause and occurrences: Calif. Fish and Game, v. 24 , no. 1 , p. 55-59.

Boos, M. F., 1940, Black beach sands of Guatemala, Central America: Geol. Soc. America Bull., v. 51, p. 1921 (abs.).

Böse, E. and Wittich, E., 1913, Informe relativo a la exploración de la region norte de la costa occidental de la Baja California: Parergones del Inst. Geologia México, v. 4, p. 307-529.

Boutelle, C. 0., 1884, Water-waves from Krakatoa: Science, v. 3, p. 777 .

Bowers, S., 1878, Geology of Santa Rosa Island: Smithsonian Inst. Ann. Rept. for 1877 , p. 316-320.

Bowers, S., 1890, San Nicolas Island: Calif. State Min. Bur., 9th Rept. State Mineralogist, p. 57-61.

Bowie, W., 1924a, Earth movements in California as disclosed by triangulation: Geol. Soc. America Bull., proc. for 1923 , v. 35 , p. 60-61 (abs.).

Bowie, W., 1924b, Isostatic Investigations and data for gravity stations in the United States established since 1915: U. S. Coast and Geod. Survey special pub. 99, $91 \mathrm{p}$.

Bowie, W., 1936, The place of geodesy in geophysical research: Am. Geophys. Union Trans., 17th ann. meet., p. 15-20.

Bowlus, F. D., 1943, Elevation changes along the line of the outfall sewer from the Joint Disposal Plant to white Point: Unpub. rept. addresed to A. M. Rawn, chief eng., Los Angeles County Sanitation districts. *

Bowman, A., 1873, on coast surface and scenic geology: Calif. Acad. Nat. Sci. Proc., v. $4(1868-1872)$, p. 244-245, 1 pl.

Branner, J. C., 1900, The origin of beach cusps: Jour. Geology, v. 8 , p. $481-484$.

Branner, J. C., 1913, Influence of wind on the accumulation of oll-bearing rocks: Geol. Soc. America Bull., proc. 13th ann. meet., 1912, v. 24, p. 94-95 (abs.).

Brant, I., 1925, The "undertow": Science, v. 62, no. 1593, p. 30-31.

Bremner, C. St. J., 1890, Geology of Santa Catalina Island: Calif. State Min. Bur., loth Rept. State Mineralogiat, p. 277-281, map.

Bremner, C. St. J., 1932, Geology of Santa Cruz Island, Santa Barbara County, California: Santa Barbara Mus. Nat. History, occasional papers, no. 1, $33 \mathrm{p}, 2$ maps, 3 pls.

Bremner, C. St. J., 1933, Geology of San Miguel Island, Santa Barbara County, California: Santa Barbara Mus. Nat. History, occasional papers, no. 2, 23 p., illus., 3 pls., map.

Briggs, L. J., 1916, A new method of measuring the acceleration of gravity at sea: Natl. Acad. Sc1. Proc., v. 2, p. 399407.

Brongersma-Sanders, M., 1948, The importance of upwelling water to vertebrate paleontology and oil geology: Verh. konkl. Nederlandsche Aksd. v. Wetensch. afd. Naturkunde, v. 45 , no. 4, p. 1-112; Rev. by C. O. Dunbar, Am. Jour. Sc1., v. 248 (1950), p. 78-79.

Brooks, C. W., 1875, Japanese wrecks stranded and picked up adrift in the North Pacific ocean, ethnologically considered as furnishing evidence of a constant infusion of Japanese blood among the Coast Tribes of Northwestern Indians: Calif. Acad. Sci. Proc., v. 4, p. 50-66, chart.
Broshous, C. R., 1938, Surging in harbors: M. S. thesis, Uni, Calif., Berkeley, 74 p., incl. photos, tables, diagrams

Brown, C. B., 1942, Discussion of "The hydrologic aspects of beach-material supply, with special reference to the shoreline at Long Beach, California" by W. E. Darrow: Am. Geophys. Union Trans., v. 23, p. 649-650.

Brown, E. I., 1939, Beach erosion studies: Shore and Beach, v. 7, p. 3-13, discussion p. 13-23.

Bruff, S. C., 1940, The Pleistocene history of the Newport Bay area, Bouthern California: M. A. thesis, Univ. Calif., Berkeley *; Geol. Soc. America Bull., v. 51 (1940), p. 1981 (abs.).

Bruff, S. C., 1946, The paleontology of the Pleistocene molluscan fauna of the Newport Bay area, California: Univ. Calif. Pub. Geology, v. 27, p. 213-240.

Bucher, W. H., 1939, Deformation of the earth's crust: Geol. Soc. America Bull., v. 50, p. 421-432.

Bucher, W. H., 1940, Submarine valleys and related geologic problems of the North Atlantic: Geol. Soc. America Bull v. 51, p. 489-512.

Buck, C. D., 1928, A study of the fish of Anaheim Slough witl reference to classification and nature of their food: M. A. thesis, Univ. Southern Calif., 47 p., 14 pls., $1 \mathrm{map}$.

Buffington, E. C., 1951, Gullied submarine slopes off southes California: Geol. Soc. America Bull., v. 62, p. 1497 (al

Buffington, E. C., 1952, Submarine "natural levees:" Jour. Geology, v. 60 , p. 473-479, 1 pl.

Buley, H. M., 1929, Quantitative studies on inshore diatoms and dinoflagellates of the California coast in 1925: Scripps Inst. Oceanography Bull., tech. ser., v. 2, p. $181-187$

Bullard, E. C., 1940, Reply to Submarine geology and geophys by F. P. Shepard: Nature, v. 146 , no. 3700 , p. 432.

Bullard, F. M., and Mills, R. A., 1951, Beach sand at Los $0 j 08$ de Agua de San Telmo, Michoácan, Mexico: Jour. Sed Petrology, v. 21, p. 195-199.

Bullington, J. P., 1940, Who owns petroleum beneath bed of sea? 011 Weekly, v. 98, no. 7 , July 22, p. 18-20.

Bullock, F. W., 1933, A study of physiological conditions relating to the distribution of marine phytoplankton at Los Angeles Harbor using an especially designed plankto and water sampling apparatus: M. A. thesis, Univ. Southern California, 93 p., incl. 11 pls., 4 photos, chart, graphs, tables.

Burch, B. L., 1947, Comparison of the mollusks of three Pleistocene beds with the Recent fauns of LOs Angeles County, California: Conchological club of Southern Calif. Minutes, no. 73 , p. 1-18.*

Burch, J. Q., 1945, Diatributional liat of the west American marine mollusks from San Diego, California to the Polar Sea: Conchological club of Southern Calif. Proc., pt. 1 Pelecypoda.*

Burt, W., 1952, Scattering of light in turbid water: Ph. D thesis, Univ. Calif.*

Burt, W. V., and Bush, V., 1949, Distribution of bathythermo. graphy observations: North Pacific Ocean 1941-1947: Scripps Inst. Oceanography, Oceanographic Rept. 16 3 p., graph.

Burt, W. V., and Saur, J. F. T., Jr., 1948, Hindcasting technique provides statistical wave data: Civil Eng. Dec., p. 47-49.

Bush, J. B., 1930, Foraminifera of Tomales Bay, California: Micropaleontology Bull., Stanford Univ., v. 2, p. 38-42.

Butcher, W. S., 195la, Lithology of the offshore San Diego ar Scripps Inst. Oceanography, Submarine Geol. Rept. 20, re 51-22, 8 p., 5 figs., charts; Ph. D. thesis, Univ. Calif Los Angeles, 98 p. incl. 2 app. of tables, 9 figs., 2 pl 
cher, W. S., 1951b, Foraminifera, Coranado Bank and vicinity, California, pt. II: Scripps Inst. Oceanography, Submarine Geol. Rept. 19, ref. 51-21, 9 p. tables, diagrams.

tler, M. M., 1936, Shore development program at Los Angeles: Shore and Beach, v. 4, p. 159-162.

walda, J. P., 1927, Pleistocene and Recent topographic changes in the Pacific Coast states: Am. Geophys. Union Trans., 8th ann. meet., in Natl. Research Council Bull. 61, p. 39-43.

walda, J. P., 1933, The Long Beach earthquake - what happened geologically: Science, v. 78 , no. 2016 , p. $148-149$.

walda, J. P., 1936, The geologic history of the California Coast: Shore and Beach, v. 4, p. 153-157.

walda, J. P., 1948, Geologic faulting in southern California. The proces's, its effects, and its consequences: Eng. and Sci. Monthly, v. 11 , no. 2, p. 15-18

erly, P., 1927, The Eureka (California) earthquake of August 20, 1927: Seismol. Soc. America Bull., v. 17, p. 213-217.

erly, P., 1930, The California earthquake of November 4, 1927: Seismol. Soc. America Bull., v. 20, p. 53-66.

erly, P., 1931, Dispersion of seismic wave of the Love type and the thickness of the surface layer of the earth under the Pacific: Geol. Soc. America Bull., proc. for 1930, v. 42 , p. 312 (abs.).

erly, P., 1937, Earthquakes off the coast of northern California: Seismol. Soc. America Bull., v. 27, p. 73-96. rly, P., 1938a, The earthquake of July 6, 1934: Amplitudes and first motion: Seismol. Soc. America Bull., v. 28, p. $1-13$.

exly, P., 1938b, Determination of deep-seated crustal structure in California: Geol. Soc. America Bull., v. 49, p. $1946-1947$ (abs.).

erly, P., 1940a, Earthquake epicenters and structure of the Pacific region of North America (northern part): Sixth Pacific Sci. Cong. Proc., v. 1, p. 1l1-112.

erly, P., 1940b, Seismicity of the northern Pacific Coast of the United States: Geol. Soc. America Bull., v. 51, p. $255-260$.

rly, P., 1942, Microseisms at Berkeley and surf on near-by coasts: Seismol. Soc. America Bull., v. 32, p. 277-282.

rly, P., 1952, Pacific cosst earthquakes: Condon Lectures, Oregon State System of Higher Education, Eugene, Oregon, $38 \mathrm{p}$.

erly, P., and Evernden, J. F., 1950a, First motion in earthquakes recorded at Berkeley: Seismol. Soc. America Bull., v. 40, p. $291-298$.

erly, P., and Evernden, J. F., 1950b, False S: Geol. Soc. America Bull., v. 61, p. 1544 (abs.).

erly, P. and Wilson, J. T., 1936, Northern California earthquakes, April 1, 1934, to December 31, 1935: Seismol. Soc. America Bull., v. 26, p. 207-213.

erly, P. and Wilson, J. T., 1937, Northern California earthquakes, January 1 to December 31, 1936: Seismol. Soc. America Bull., v. 27, p. 225-229.

rly, P. and Wilson, J. T., 1938, Northern California earthquakes, January 1 to December 31, 1937: Seismol. Soc. America Bull., v. 28, p. 263-268.

rs, H. R., 1930, Sumner sea fogs of the central California Coast: Univ. Calif. Pub. Geography, v. 3, no. 5, p. 291-338. s, H. R., 1931, Characteristic weather phenomena of California: Mass. Inst. Tech. Meteorol. Papers, v. 1, no. 2, 54 p., 22 pls.

ers, H. R., 1934, The air masses of the North Pacific: Scrippe Inst. Oceanography Bull., tech. ser., v. 3, p. $311-354$.

Ldwell, J. M., 1950, Sedimentation in harbors, in Trask, P. D., and others, applied sedimentation, a symposium: New York, John Wiley and Sons, Inc., p. 291-299.

Lifornia Academy of Sciences, California Division of Fish and Game, Scripps Institution of oceanography, U. S. Fish and Wildlife Service, 1950, California cooperative sardine research program, progress report 1950: Calif. Dept. Nat. Res., Marine Research Comm., 54 p. including. 37 figs., 2 app.

Lifornia Academy of Sciences, California Division of Fish and Game, Scripps Institution of oceanography of the University of California, and U. S. Fish and Wildlife Service, 195la, California Cooperative Sardine Research
Program, interim progress report for the period 1 January, 1951 to 30 April, 1951 to the Marine Research Committee, 13 p.

California Academy of Sciences, California Division of Fish and Game, Scripps Institution of Oceanography of the University of California, and U. S. Fish and Wildlife Service, 1951b, California Cooperative Sardine Research Program, interim progress report for the period l May to 31 August 1951 to the Marine Research Committee, $16 \mathrm{p}$.

California Academy of Sciences, California Division of Fish and Game, Scripps Institution of Oceanography of the University of California, U. S. Fish and wildlife Service, and Hopkins Marine Station, Stanford University, 1951, California Cooperative Sardine Research Program, interim progress report for the period 1 september to 31 December 1951 to Marine Research Committee, 33 p.

California Academy of Sciences, California Division of Fish and Game, Stanford University, Hopkins Marine Station, U. S. Fish and Wildife Service, South Pacific Fishery Investigation, University of California, Scripps Institution of Oceanography, 1952, California cooperative sardine research program; Progress report 1 January 1951 to 30 June 1952: Calif. Dept. Fish and Game, Marine Research Comm., 51 p. incl. 51 figs.

California Academy of Sciences, California Division of Fish and Game, Stanford University, Hopkins Marine Station, U. S. Fish and Wildlife Service, South Pacific Fishery Investigation, University of California, Scripps Institution of Oceanography, 1953, California cooperative oceanic fisheries investigations: Progress report, 1 July 1952 to 30 June 1953: Calif. Dept. Fish and Game, Marine Research Comm., 44 p. incl. 31 figs.

California Bureau of Sanitary Engineering, 1943, Report on a pollution survey of Santa Monica Bay Beaches in 1942: June 26, Calif. State Printing office, 69 p. *

California Bureau of Sanitary Engineering, 1952, A survey of pollution and nuisance problems in San Diego Bay, in San Diego Regional Water Pollution Control Board, report upon the extent, effects and limitations of waste disposal into San Diego Bay, app. 1, p. 29-65 (abs.); Full rept. with title of: San Diego Bay water pollution survey, 1951, conducted in part by the Bureau of Sanitary Engineering, California Department of Public Health for the San Diego Regional water Pollution Control Board, on file at the San Diego Regional Water Pollution Control Board, 3441 Univ. Ave., San Diego; Gov't. Reference Library, Civic Center, San Diego; and at the Library of the Scripps Institution of oceanography, La Jolla, Calif.

California Department of Fish and Game, 1951, San Diego Bay water pollution survey: Conducted in part by the Calif. Dept. Fish and Game for the San Diego Regional Water Pollution control Board. Full rept. on file in locations cited in preceding reference. Abs. in San Diego Regional Water Pollution Control Board, 1952, app. II, p. 67-80, incl. 9 figs.

California Department of Public Health, 1951, Los AngelesLong Beach Harbor pollution survey. Prepared for the Los Angeles Regional water Pollution control Board Number 4, California Department of Public Health, Bureau of Sanitary Engineering, 30 p., 9 pls. App. A, Bottom conditions in Los Angeles-Long Beach Harbors, prepared by the Calif. Dept. Fish and Game, p. 31-43, incl. tables and figs.

California Department of Public Works, 1932a, Varlation and control of salinity in Sacramento - San Joaquin Delta and upper San Francisco Bay, 1931: Div. Water Res. Bull. $27,438 \mathrm{p.} *$

California Department of Public Works, 1932b, Economic aspects of a salt water barrier below confluence of Sacramento and San Joaquin Rivers, 1931: Div. Water Res. Bull. 28, 445 p. *

California Department of Public Works, 1933, Ventura County investigation: Div. Water Res. Bull. 46, 239 p., 49 pls., 94 tables. *

California Department of Public Works, 1947, Preliminary studies for an additional bridge across San Francisco Bay: Sacramento, 179 p. * 
California Department of Public Works, 1950, Sea-water intrusion into ground-water basins bordering the California Coast and inland bays: Div. Water Res., Water Quality Inv. Rept. 1, Dec.*

California Department of Public Works, 1951, Proposed investigational work for control and prevention of sea-water intrusion into ground-water basins: Div. Water Res., August. *

California Department of Public Works, 195la, Report to San Francisco Bay Regional Water Pollution Control Board, quality determination and flow measurements in tributary creeks and sloughs, south end of San Francisco Bay: Div. Water Res. *

California Department of Public Work8, 1951-1952, Progress report on experimental investigations for prevention of sea-water intrusion under Chapter 1500, statutes of September 25, 1951; August 29, July 10, May 26, April 25, March 28, and Pebruary 29, 1952 .

California Department of Public Works, 1952a, Open files, coastal ground-water basins between the Mexican border and California-oregon State line: Div. Water Res.

California Department of Public Works, 1952b, Draft of report of referee, west Coast Basin reference: Div. Water Res., Feb. *

California Department of Public Works, 1952c, Progress report, experimental pressure mound project at Manhattan Beach: Div. Water Res., memo rept., Feb. 28 and March 21: *

California Department of Public Works, 1952d, Progress report of investigation of use of earthen cutoff walls for prevention of sea-water intrusion: Div. Water Res., memo. rept., Feb. 29.*

California Department of Public Works, 1952e, Progress report on use of subsurface barriers to prevent sea-water intrusion and an earthen cutoff wall experimental project in San Luis Rey River Narrows: Div. Water Res., memo rept., oct. 31.*

California Department of Public Works, 1952f, A pollution study of the Richmond - San Pablo shoreline; water quality investigations: Div. Water Res., project no. 52-2-10.* *

California Division San Francisco Bay Toll Crossings, 1948, A report to the Department of Public Works on additional crossings of San Francisco Bay: Berkeley. *

California Division San Francisco Bay Toll Crossings, 1951, A report to Department of Public Works on proposed highway toll crossing, Richmond - San Rafael Bridge: Berkeley, 233 p. *

California Legislature, 1874, Reports of the Joint Committees on Swamp and Overflow Lands and Land Monopoly, presented at the 20th sess. of the Legislature of Calif., Sacramento, $354 \mathrm{p}$.

California Legislature, 1931a, Report of the Joint Committee of the Senate and Assembly dealing with the water problems of the state submitted to the Legislature of the State of California: Calif. Legislature, app. to Senate Jour. of March 23, p. 1-37.

California Legislature, 1931b, Review of California seacoast conditions with Legislative recommendations by the State Seacosst Committee: 48th sess., 17 p., incl. Assembly Bills 425-428.

California Legislature, 1947, Report to Legislature (57th sess.) on water problems of the State of California by Joint Committee on Water Problems ...... Senator B. S. Crittenden, chairman, 102 p. illus., pls.

California Legislature, 1949, Report of the Interim FactFinding Committee on water Pollution: Calif. Assembly, 172 p. illus.

California Legislature, 195la, Final summary report of Assembly Interim Committee on Air and water Pollution: Calif. Assembly, 111 p., illus.

California Legislature, $1951 \mathrm{~b}$, Report on the Senate Interim Committee on Tidelands: Pub. by Calif. State Senate, $52 \mathrm{p}$. incl. illus.

California Miners' Association, 1899, California mines and minerals: San Francisco, Pub. by the Assoc. under direction of E. H. Benjamin, secretary for the Calif. meet. of the Am. Inst. Min. Eng., Louis Roesch Co. $450 \mathrm{p}$. illus.

California, University of, 1942, Reverberation studies of $24 \mathrm{kc}$ : Div. War Research, UCDWR no. U7. *

California, University of, 1943 , Volume reverberation; scattering and attenuation versus frequency: Div. War
Research, UCDWR no. U50. *

California, University of, 1945 , Final report on wave investigations (contract Nobs 16290): Berkeley, fluid mechanics lab., tech. rept. HE-116-165, 40 p., photos, graphs, maps, tables, charts, sketches, refraction alagrams (92 p.).

California, University of, 1946a, Stratification of sound scatterers in the ocean: Div. War Research, UCDWR no. M397, 13 p. (ozilid), 18 figs. (photostat), Feb. 16. (Copies available as PB 60290 from the U. S. Dept. of Commerce, office of Tech. Service, wash. 25, D. C.).

California, University of, 1946b, Forward scattering from the deep scattering layer: Div. War Res., UCDWR no. M398. *

California, University of, 1946c, Studies of the deep scattering layer: UCDWR no. M445. *

California, University of, 1949, Forecasting breakers and surf on a straight beach of infinite length: Berkeley, fluid mechanics lab., tech. rept. He-116-13 and HE-116-67; U. S. Army, Eorps of Engineers, Beach Erosion Board Bull., v. 3, no. 4, p. 23-32.

California, University of, 195la, Investigation of travel of pollution: Sanitary Eng. research project 12C-3, progress rept. 2, June 30 .*

California, University of, $195 \mathrm{lb}$, Present economic and technical status of water reclamation form sewage and industrial wastes: Sanitary eng. research project, tech. bull. 4, March.*

California, University of, $195 \mathrm{lc}$, Final report on sand transportation by wave action: Berkeley, Inst. eng. research, ser. 14, issue $9,14 \mathrm{p}$.

California, University of, 1952a, Summary report on studies of sand transportation by wave action: U. S. Army, Corps of Engineers, Beach Erosion Board Bull., v. 6, no. 1, p. $1-17$.

California, University of, 1952b, Status report no. 4, 1 December 1951 through 31 January 1952: U. S. Army, Corps of Engineers, Beach Erosion Board Bull., v. 6 , no. 2, p. 23-24.

Californie, University of, 1952c, Status report no. 6, 1 April through 31 May 1952: U. S. Army, Corps of Engineere Beach Erosion Board Bull., v. 6 , no. 4, p. 13.

California, University of, 1952d, Status report no. 7, 1 June through 31 July 1952: U. S. Army, Corps of Engineers Beach Erosion Board Bull., v. 6, no. 4, p. 13-14.

California, University of, 1953a, Status report no. 8, 1 February through 31 March 1953: U. S. Army, Corps of Engineers, Beach Erosion Board Bull., v. 7, no. 3, p. 13

California, University of, 1953b, Status report no. 9, 1 April through 31 May 1953: U. S. Army, Corps of Engineers, Beach Erosion Board Bull., v. 7, no. 3, p. $13-14$.

California, University of, 1954a, Progress reports on research sponsored by the Beach Erosion Board: U. S. Army, Corps of Engineers, Beach Erosion Board Bull., v. 8, no. 2, p. 9-10.

California, University of, 1954b, Progress reports on research sponsored by the Beach Erosion Board: U. S. Army, Corps of Engineers, Beach Erosion Board Bull., v. 8, no. 1, p. $21-23$.

California Water Pollution Control Board, 1952, water quality criteria: Sacramento, SWPCB No. 3, 512 p. incl. app., tables, figs. (see p. 459-512 for extensive bibllography on pollution).

Campbell, M. R., 1915, Movement of Sand-dunes on the California Coast: Wash. Acad. Sci. Jour., v. 5, p. 328 (abs.)

Carder, D. S., 1934, Seismic surface waves and the crustal structure of the Pacific region: Seismol. Soc. America Bull., v. 24, p. 231-302.

Carpenter, E. J., and Storie, R. E., 1929, Soil survey of the Capistrano area, California: U. S. Dept. Agriculture, Bur. of Chemistry and Soils, ser. 1929, no. 19, 48 p., map.

Carpenter, F. A., 1924, Notes on the irregularities of ocean currents: Southern Callf. Acad. Sci. Bull., v. 23, p. 100-101, incl. pl. 13 .

Carpenter, P. P., 1857, Report on the present state of our knowedge with regard to Mollusca of the west coast of North America: British Assoc. Adv. Sci. Rept. for 1856 , p. $159-368$. 
arsola, A. J., 1947, Depth distribution of Recent Ostracoda collected off Baja California: M. S. thesis, Univ. Southern Calif., 53 p., 2 figs., 1 pl., 3 charts.

sola, A. J., and Dietz, R. S., 1952, Submarine geology of two-flat-topped northeast Pacific sea mounts: Am. Jour. Sci., v. 250, p. 481-497.

rsola, A. J., Dietz, R. S., and Russell, R. D., 1949, Submarine geology of two northeast Pacific sea mounts: Geol. Soc. America Bull., v. 60, p. 1878 (abs.).

arter, G. F., 1948, Evidence for Pleistocene man in an alluvial fan at La Jolla, California: Geol. Soc. America Bull., v. 59, p. 1315 (abs.); Also with slightly changed title in New York Acad. Sc1. Trans., ser. 2, v. 11 (1949), p. 254-257; Geog. Rev., v. 40 (1950), p. 84-102.

artwright, L. D., Jr., 1928, Loss of color of red sandstone upon deposition: Am. Assoc. Petroleum Geologist Bull., v. 12 , p. $85-87$.

Thace, B. W., 1953, Los Angeles County beach development: California - Mag. of the Pacific, Sept., p. 13, 33, 34.

Chace, E. P., and Chace, E. M., 1919, An unreported exposure of the San Pedro Pleistocene: Lorquinia, v. 2 , no. 6 , p. $41-43$.

Shadwick, W. I., Clark, F. S., and Fox, D. L., 1950, Thermal control of marine fouling at Redondo station of the Southern California Edison Company: Am. Soc. Mechanical Eng. Trans., Feb., p. 127-131.

Chamberlin, R. T., 1944, Plelatocene Coast Range orugenesis in southern California: a discussion: Jour. Geology, v. 52, p. 357-358.

Chambers, S. W., 1930, Vertical sections of one thousand meters and over in the northeast Pacific ocean: Fourth Pacific Sci. Cong. Proc., v. 2B, p. 953-978.

Chaney, R. W., 1928, Recent additions to the Pleistocene history of western California: Geol. Soc. America Bull., proc. for 1927, v. 39, p. 221 (abs.).

thaney, R. W., 1936a, The succession and distribution of Cenozoic floras around the northern Pacific Basin: Essays in geobotany in honor of William Albert Setchell, Univ. Calif., Berkeley, p. 55-85.

aney, R. W., 1936b, Factor of distribution in the interpretation of Tertlary floras: Geol. Soc. America Bull., proc. for 1935, v. 47, p. 382-383 (abs.).

ney, R. W., 1940, Tertiary forests and continental bistory: Geol. Soc. America Bull., v. 51, p. 469-488.

aney, R. W., and Dorf, E., 1934, Ecology of the Tertiary forests of western North America: Geol. Soc. America Bull., proc. for 1933, v. 45 , p. 357 (abs.).

Thaney, R. W., and Mason, B. L., 1934, A Plelstocene Plora from Santa Cruz Island, California: Carnegie Inst. Wash. Pub. 415, p. 1-24, 7 pls.

ase, A. W., 1875, Remarks on the auriferous sands of Gold Bluff: Calif. Acad. Sc1. Proc., v. 5 (1873-1874), p. $246-247$.

Shase, J. L., 1948, Surface geology beneath the sea: Petroleum Engineer, v. 19, no. 12, Aug., p. 102, 104, $106,108,110,112$.

Chesterman, C. W., 1952, Deccriptive petrography of rocke dredged off the coast of central California: Calif. Acad. Sc1. Proc., v. 27, p. 359-374, pls. 15-19.

Ihinn, A. J., 1949, Summary report on Shore Wave Recorder Mark III: Univ. Calif., Berkeley, fluid mechanics lab. tech rept., HE-116-303; ser. 3, 1ssue 303, 25 p., 28 pls.

Church, C. C., 1929, Some Recent shallow water Foraminifera dredged near Santa Catalina Island, California: Jour. Paleontology, v. 3, p. 302-305.

clark, A., 1933, Environment of marine Mollusca living off Long Beach, California, and its bearing on Pleistocene correlations: Pan Am. Geologist, v. 59, p. 379 (abs.); Geol. Soc. America Bull., proc. for 1933, v. 41 (1934), p. 393-394 (abs.).
Clark, A. H., 1914, The circulation of the abyssal waters of the oceans, as indicated by the geographical and bathymetrical distribution of the Recent crinoids: Monaco oceanographic Inst. Bull. 285, p. 1-16.

Clark, B. L., 1921, The marine Tertiary of the west coast of the United States: Its sequence, paleogeography, and the problems of correlation: Jour. Geology, v. 29, p. 583-614.

Clark, B. L., 1930, Tectonics of the Coast Ranges of middle California: Geol. Soc. America Bull., v. 41, p. 747-828.

Clark, B. L., 1931, Fault trough redimentation: Pan Am. Geologist, v. 55, p. 371-372 (abs.); Geol. Soc. America Bull., proc. for 1931, v. 43 (1932), p. 230 (abs.).

clark, B. L., 1933?, Statigraphy and faunal horizons of the Coast Ranges of California: San Francisco? 30 p., 50 pls.

Clark, F. N., 1938, Grunion in southern California: Calif. Fish and Game, v. 24, p. 49-54.

Clark, J. T., 1944, Index to descriptive catalog of earthquakes of the Pacific Coast of the United States, 17691928: Seismol. Soc. America Bull., v. 34, p. 35-62. This is the index to the catalog by S. D. Townley and M. W. Allen, published as v. 29 (1939), no. 1, p. 1-298, of the Seismol. Soc. America Bull.

Clark, w. 0., 1915, Ground-water resource of the Niles cone and adjacent areas, California: U. S. Geol. Survey Water-Supply Paper 345-H, p. 127-168, pls. 9-17, figs. 9-24.

Clarke, K. B., 1934, Meteorological results during Cruise VII of the Carnegie, 1928-1929: Fifth Pacific Sc1. Cong. Proc., v. 3, p. 1969-1976.

Clary, W. W., 1949, Legal aspect of tideland controversy: Am. Assoc. Petroleum Geologists Bull., v. 33, p. 2060 (abs.).

Cleland, H. F., 1910, North America natural bridges, with a discussion of their origin: Geol. Soc. America Bull., v. 21, p. 313-338.

Clements, T., 1946, Some stages in the geologic history of the Channel Island region, southern California: Geol. Soc. America Bull., v. 57, p. 1250-1251 (abs.).

Clements, T., 1948, Terrace on Santa Catalina Island, California: Geol. Soc. America. Bull., v. 59, p. 1368 (abs.).

Clements, T., and Dana, S. W., 1944, Geologic significance of a coarse marine sediment from near Santa catalina I\&land, California: Jour. Geology, v. 52, p. 351-354.

Clements, T., and Emery, K. 0., 1947, Selsmic activity and topography of the sea floor off southern California: Selomol. Soc. America Bull., v. 37, p. 307-313.

Cochrane, J. D., and Arthur, R. S., 1948, Reflection of tsunamis: Jour. Marine Research, v. 7, p. 239-251.

Cockerell, T. D. A., 1937, Belminthoglypta ayresiana on San Miguel Island, Callfornia: Nautilus, v. 51, p. 71-72.

Cockerell, T. D. A., 1938a, San Miguel Island, California: Sc1. Monthly, v. 46, p. 180-187.

Cockerell, T. D. A., 1938b, Studies of 18land life: Colorado Univ. Studies, v. 26, no. 1, p. 3-20 (Univ. Colorado Bull., v. 38, no. 19, general er. no. 423).

Cockerell, T. D. A., 1938c, A Plelstocene snail from Son Miguel Is land, California: Nautilus, v. 52, p. 24-25.

Cockerell, T. D. A., 1939, Pleistocene shells from San clemente Island, California: Nautilus, v. 53, p. 22-23.

Cockerell, T. D. A., 1940, The marine invertebrate fauna of the Californian Ir lands: Sixth Pacific Sc1. Cong. Proc., v. 3 , p. 501-504.

Coe, W. R., 1932, Season of attachment and rate of growth of sedentary marine organisms at the pier of the Scripps Institution of oceanography, La Jolla, California: Scripps Inst. Oceanography Bull., tech. ser., v. 3 , p. $37-86$.

Coe, W. R., 1945, Nutrition and growth of the California baymussel (Mytilus edulis diegensis): Jour. Experimental Zoology, v. 99, p. 1-14

Coe, W. R., 1947, Nutrition, growth and sexuality of the Pismo clam (Tivela stultorum): Jour. Experimental Zoology, v. 104, p. 1-24. 
Coe, W. R., 1948, Nutrition, environmental conditions, and growth of marine bivalve mollusks: Jour. Marine Rezearch, v. 7, p. $586-601$.

Coe, W. R., 1953, Resurgent populations of littoral marine invertebrates and thier dependence on ocean currents and tidal currents: Ecology, v. 34, p. 225-229.

Coe, W. R., and Allen, W. E., 1937, Growth of sedentary marine organisms on experimental blocks and plates for nine successive years at the pier of the Scripps Inatitution of Oceanography: Scripps Inst. Oceanography Bull., tech. ser., v. 4, p. 101-136.

Coe, W. R., and Fox, D. L., 1942, Biology of the California sea mussel (Mytilus californianus). I influence of temperature, food supply, sex and age on the rate of growth: Jour. Experimental Zoology, v. 90, p. 1-30.

Coe, W. R., and Fox, D. L., 1944, Biology of the California sea-muasel (Mytilus californianus). III Environmental conditions and rate of growth: Biol. Bull., v. 87, p. 59-72.

Cohee, G. V., 1938, Sediments of the submarine canyons of $f$ the California coast: Jour. Sed. Petrology, v. 8, p. 19-32.

Colbert, L. 0., 1939, Charting geomorphic features of the sea bottom: Jour. Geomorphology, v. 2, p. 335-338, 3 charts.

Colbert, L. 0., 1940, Oceanographic activities of the United States Coast and Geodetic Survey: Am. Geophys. Union Trans., 21at ann. meet., p. 340-343.

Colden, C. J., 1926, The port and harbour of Los Angeles, California: Dock and Harbour Authority, London, v. 6 , no. 62, p. $35-41$. *

Collins, L. B., 1931, Drilling in Pacific requires substantial foundations: 011 Weekly, v. 60 , no. 8 , Feb. 6, p. 24-26.

Collins, L. B., Gilbert, J. C., and simon, J. H., 1933, A review of marine oil drilling in California: Am. Petroleum Inst. Production Bul1. 212. *

Comstock, T. B., 1902, Geological notes: Southern Calif. Acad. Sci. Bull., v. 1, p. 74-77.

Congressional Documents, 1880a, 46th Cong., $2 d$ sess., Ex. Doc. $31,2 \mathrm{p} .1 \mathrm{pl}$. Sand bars and deposits near Mare Is land.

Congressional Documents, 1880b, 46th Cong., $2 \mathrm{~d}$ sess., S. Ex. Doc. 175,4 p. chart, Trinidad Harbor, California.

Congressional Documents, 1880c, 46th Cong., $2 \mathrm{~d}$ sess., S. Ex. Doc. 188,183 p. chart, Proposed harbor of refuge for the Pacific Coast. Ex. Doc. 188, pt. 2, 12 p.

Congressional Documents, 1881, 46th Cong., 3d sess., H. Ex. Doc. 39, 27 p., chart, Yerba Buena Island.

Congressional Documents, 1892, 52d Cong., lst sess., S. Doc. 153, 26 p., 4 photos, 9 charts, Report on the results of the survey for the purpose of determining the practicability of laying a telegraphic cable between the United States and the Hawilan Islands.*

Congressional Documents, 1897, 55th Cong., lst sess., s. Doc. 18,330 p., charts, pls., Deep-water harbor at Port Los Angeles or at San Pedro, California. (Also see: U. s. Board ...., 1897).

Congressional Documents, 1907, 60th Cong., lst sess., H. Doc. 77,5 p., Islaia Creek, or River, California (Sen Francisco Bay).

Congressional Documents, 1908a, 60th Cong., 2d sess., H. Doc. $1103,17 \mathrm{p} ., 3$ pls., Hydraulics of Mare Irland Straits and approaches.

Congressional Documents, 1908b, 60th Cong., $2 \mathrm{~d}$ sess., H. Doc. 1114,23 p., Wilmington Harbor, California.

Congressional Documents, 1908c, 60th Cong., 2d sess., H. Doc. 1119,13 p., 1 pl., Rocks in Sen Franciaco Harbor, California.

Congressional Documents, 1908e, 60th Cong., lst sess., H. Doc. 950, 12 p., Entrance to Humboldt Harbor, California.

Congressional Documents, 1908f, 60th Cong., 2d sess., H. Doc. 1123, 19 p., 26 charts, Reports of examination and aurvey of Sacramento River, California, from its mouth to Feather River.

Congressionsl Documents, 1908g, 60th Cong., 2d sess., H. Doc. 1124, 18p., 18 pls., San Joaquin River, Stockton Channel, etc., from San Francisco Bay to Stockton, California.

Congressional Documents, 1908h, 60th Cong., lst sess., H. Doc. 969,10 p., 1 pl. Breakwater at San Pedro Bay, California.
Congressional Documenta, 1909, 6lst Cong., $2 \mathrm{~d}$ se日s., H. Doc. 326,5 p. chart, Humboldt Bay, California.

Congressional Documents, 1910, 6lat Cong., 2d sess., H. Doc. 647, 11 p., Oakland Harbor, California.

Congressional Documents, 1926, 69th Cong., lat sess., H. Doc. 407, 61 p., chart, Oakland Harbor, California.

Congressional Documents, 1934a, 73d Cong., 2d sess., H. Doc. 191, 107 p., 9 pls., Sacramento, San Joaquin, and Kern Rivers, California.

Congressional Documents, 1934b, 73d Cong., 2d sess., H. Doc. 223, 29 p. 1 pl., San Diego Harbor, California.

Congressional Documents, 1936, 74th Cong., 2d sess., H. Doc. 495,87 p., Stream pollution by federal agencles, with recommendations.

Congressional Documents, 1938a, 75th Cong., 3d sess., H. Doc. 552, 51 p. incl. 17 pls., Beach Erosion at Santa Barbara, California.

Congressional Documents, 1938b, 75th Cong., 3d sess., H. Doc. 598,18 p., 1 chart, Richmond Harbor, California.

Congressional Documents, 1938c, 75th Cong., 3d sess., H. Doc. 619,24 p., 1 chart, Bodega Bay, California.

Congressional Documents, 1938d, 75th Cong., 3d sess., H. Doc. 644, 11 p., I chart, Pinole Shool and Mare Island Channel and Turning Basin, California.

Congressional Documents, 1940a, 76th Cong., 3d sess., H. Doc. 637, 26 p., 14 pls., Beach erosion study, orange County, California.

Congressional Documents, 1940b, 76th Cong., 3d sess., H. Doc. 682, 17 p., I chart, Noyo River and Harbor, California.

Congressional Documents, 1940c, 76th Cong., 3d sess., H. Doc. 688,16 p., 2 charts, Crescent City Harbor, California.

Congressional Documents, 1940d, 76th Cong., 3d sess., H. Doc. 715,12 p., 2 charts, Richmond Harbor, California.

Congressional Documents, $1940 \mathrm{e}, 76$ th Cong., 3d sess., H. Doc. 843, 19 p., 1 chart, Los Angeles and Long Beach Harbors, California.

Congressional Documents, 1940f, 76th Cong., 3d sess., H. Doc. 844,4 p., 1 chart, San Diego Harbor, California.

Congressional Documents, 1941, 77th Cong., lst sess., H. Doc. 283, 19 p., 1 pl., Morro Bay, California.

Congressional Documents, 1942a, 77 th Cong., $2 \mathrm{~d}$ sess., H. Doc. 635,4 p., I chart, San Diego River, California.

Congressional Documents, 1942b, 77th Cong., 2d sess., H. Doc. 636,14 p., 11 pls., Beach erosion study, Coronado, California.

Congressional Documents, 1942c, 77th Cong., 2d sess., H. Doc. 817,15 p., 1 chart, Chetco River, oregon.

Congressional Documents, 1943, 78th Cong., lst sess., S. Doc. 138,21 p., I chart, Newport Bay Harbor, California

Congressional Documents, 1949a, 80th Cong., 2d sess., H. Doc. 586,24 p., 1 pl., Noyo River and Harbor, Californ

Congressional Documents, $1949 \mathrm{~b}, 80$ th Cong., $2 \mathrm{~d}$ sess., H. Doc. 644,30 p., 2 charts, Halfmoon Bay, San Mateo County, California.

Congressional Documents, 1949c, 80th Cong., $2 \mathrm{~d}$ sess., H. Doc. 646,20 p., I chart, Coos Bay at Charleston, South Slough, oregon.

Congressional Documents, 1949d, 80th Cong., 2d sess., H. Doc. 650,35 p., 1 pl., Tillamook Bay and Bar, Oregon.

Congressional Documents, 1949e, 80th Cong., $2 \mathrm{~d}$ sess., H. Doc. 752,38 p., I pl., San Joaquin River and Stockton Channel, California.

Congressional Documents, 1949f, 80th Cong., 2d sess., H. Doc. 761,35 p. Incl. 5 tables, 13 pls., Santa Barbara, California beach erosion control study (final report).

Congressional Documents, 1949-50a, 8lat Cong., lst sess., H. Doc. 286, 20 p., 1 pl., San Franclaco Harbor and Bay, California.

Congressional Documents, 1949-50b, 8lst Cong., lst sess., H. Doc. 303,37 p., 2 charts, Redondo Beach Harbor, California.

Congressional Documents, 1950a, 8lst Cong., lst sess., H. Doc. 367, 153 p., 2 pls., tables, Sacramento - San Joaquin Basin atreams, California.

Congreasional Documents, 1953a, 83d Cong., lat sess., $\mathrm{K}$. Doc. 161,58 p., 3 pls., Los Angeles and Long Beach Harbors, California.

Congressional Documents, 1953b, 83d Cong., lst sess., H. Doc. 29, 92 p. + pls., charts. Appendix 1, Cosst of California, Carpinteria to Point Mugu, beach erosion control study. 
Connell, C. H., and Cross, J. B., 1950, Mass mortality of fish associated with the protozoan Gonyaulax in the Gulf of Mexico: Science, v. 112, no. 2909, p. 359-363.

Cook, E. H., 1908, The saline deposits of Carmen Island: Eng. and Min. Jour., v. 85, p. 545-546.

Cooper, W. S., 1927, Sand dunes and sand dune vegetation: Activities of the department of botany, Univ. Minnesota. *

Cooper, W. S., 1934, Types of Pacific Cosst dunes: Am. Assoc. Geog. Annals, v. 24, no. 1, p. 46 (abs.).

copeland, C. A., 1933, A study in evaporation as affecting the runoff of Owens River, California: Am. Geophys. Union Trans., l4th ann. meet., p. 461-465.

Corey, W. H., 1951, Southern California cosatal paleogeography: Geol. Soc. America Bull., v. 62, p. 1500 (abs.).

corey, W. H., 1952, Tertiary basins of southern California and offshore area: Am. Assoc. Petroleum Geologist Bull., v. 36, p. 924 (авв.).

Corning, L. H., 1944, Concrete shore protection structures: Shore and Beach, v. 12, p. 45-48.

Cotton, C. A., 1942, Shorelines of transverse deformation: Jour. Geomorphology, v. 5, p. 45-58.

Cotton, C. A., 1944, Glacial epochs of the Santa Monica Mountains: a discuseion: Jour. Geology, v. 52, p. 355-356.

Couch, E. B., 1915, A study of the ecology of the marine algae at Point Fermin, California: M. A. thesis, Univ. Southern Calif., 67 p., 48 fige.

Coulter, J. W., 1922, The geography of the Santa Lucia Mountains with special consideration of the isolated cosst region: M. A. thesis, Univ. Calif., Berkeley.*

Coxe, L. C., 1949, Failure of quay wall at Mare Island, California: Am. Soc. Civil Eng. Trans., v. 114, p. 499506.

Coy, 0. C., 1923, California county boundaries: Berkeley, Hist. Survey Conm. *

Cram, C. M., 1931, An unuaual sea wall achievement: Civil Eng., v. 1, p. 409-412.

Crandall, H., 1915, Geology of the La Jolla quadrangle, San Diego County, California: M. A. thesis, Stanford Univ., $77 \mathrm{p} ., 12 \mathrm{pls}$, maps.

Crickmay, C. H., 1929a, The anamalous stratigraphy of Deadman's Island, California: Jour. Geology, v. 37, p. 617638.

Crickmay, C. H., 1929b, Revision of the geology of Dead Man Island, California: Geol. Soc. America Bull., proc for 1928 , v. 40 , p. 164 (abs).

Crooke, R. C., Elvitsky, A. W., Fowler, L. C., Granthem, K. N , Johnson, J. W., Morgan, M. E., Morrison, J. R. and Trask, P. D., 1953, Inshore survey, San Francisco Bay: Literature survey: University of Calif., Berkeley, Inst. eng. research, wave reselrch lab., tech. rept. ser. 57, issue 1, approx. 370 p. incl. illus.

Crosley, W. S., 1927, The Hydrographic Office of the Navy: Military Engineer, v. 19, p. 278-293.

Crouch, R. W., 1951, Significance of temperature upon the Foraminifer from the deep basins off the southern California Coast: Geol. Soc. America Bull., v. 62, p. 1521 (abs.)

Crouch, R. W., 1952, Significance of temperature on Foraminifera from deep basins off southern California Coast: Am. Assoc. Petroleum Geologists Bull., v. 36, p. $807-$ 843.

Crouch, R. W., 1954, Paleontology and paleoecology of the San Pedro ohelf and vicinity: Jour. Sed. Petrology, v. 24, p. 182-190.

Crowell, J. C., 1947, Transportation of sediments in the sea by currents: Geol. Soc. America Bull., v. 58, p. 12491250 (abs.).
Crowell, J. C., 1950, Submarine canyons bordering southern California: Geol. Soc. America Bull., v. 61, p. 14531454 (abs.).

Crowell, J. C., 1952, Submarine canyons bordering central and southern California: Jour. Geology, v. 60 , p. 58-83.

Cummings, N. W., 1921, Evaporation from water surfaces: Electricity and Western Industry Jour., v. 46, p. 491496.

Cummings, N. W., 1950, Minimum evaporation from water aurfaces: Am. Geophys. Union Trans., v. 31, p. 757-762.

Cupp, E. E., 1930, Quantitative studies of miscellaneous serles of surface catches of marine diatoms and dinoflagellates taken between Seattle and the canal Zone from 1924 to 1928: Am. Micros. Soc. Trans., v. 49, p. $238-245$.

Cupp, E. E., 1934a, Analysis of marine plankton diatom collections taken from the Canal zone to California during March, 1933: Am. Micros. Soc. Trans., v. 53, p. $22-29$.

Cupp, E. E., 1934b, A critical study of certain distinguishing characters in three closely allied plankton species of the diatom genus Nitzschia and their relationships to certain environmental conditions: $\mathrm{Ph}$. D. thesis, Univ. Calif., 96 p., 5 pls., graphs, figs. *

Cupp, E. E., 1943, Marine plankton diatoms of the west coast of North America: Scripps Inst. Oceanography Bull., tech. ser., v. 5, p. $1-238$.

Cupp, E. E. and Allen, W. E., 1938, Plankton diatoms of the Gulf of California obtained by Allan Hancock Pacific Expeditions of 1937: Univ. Southern Calif., The Hancock Pacific Expeditions, pub. 3, p. 61-74, map, pls. 4-15.

Cushman, J. A., 1925, Recent Foraminifera from British Columbia: Contr. Cushman Lab. Foram. Research, v. I, p. $38-47$, pls. 6,7 .

Cushman, J. A., and Valentine, W. W., 1930, Shallow-water Foraminifera from the Channel Islands of southern California: Contr. Dept. Geology, Stanford Univ., v. 1, no. 1 , p. 5-51, incl. $10 \mathrm{pls}$.

Dall, W. H., 1878, Postpliocene fossils in the Coast Range of California: U. S. Natl. Mus. Proc., v. 1, p. 3 .

Dall, W. H., 1904, Current of the North Pacific: Science, v. 20 , no. 509 , p. $436-437$.

Dall, W. H., 19ll, Nature of Tertiary and modern marine faunal barriers and currents: Geol. Soc. America Bull., v. 22 , p. $218-220$.

Dall, W. H., and Harria, G. D., 1892, Correlation papers: Neocene: U. S. Geol. Survey Bull. 84,349 p., 3 pls., 43 figs.

Dall, W. H., 1921, Summary of the marine shell bearing mollusks of the northwest coast of America, from San Diego, California to the Polar Sea: U. S. Natl. Mus. Bull., v. 112, p. 1-217. *

Daly, R. A., 1934, The sub-Pacific crust: Fifth Pacific Sc1. Cong. Proc. v. 3, p. 2503-2510.

Daly, R. A., 1939, Regional departure from ideal isostasy: Geol. Soc. America Bull., v. 50, p. 387-420.

Daly, R. A., 1942, The floor of the ocean: oxford Univ. Press, Univ. North Caroline Press, 177 p.

Dana, S. W., 1942, A sedimentary study of bottom mud amplea dredged by the Velero III: M. S. thesis, Univ. Southern Calif., 47 p., graphs, charts.

Dapples, E. C., 1942, The effect of macro-organisms upon near-shore marine sediments: Jour. Sed. Petrology, v. 12 , p. $118-126$.

Darrow, W. E., 1942, The hydrologic aspects of beach-material supply, with specific reference to the shoreline at Long Beach, California: Am. Geophya. Union Trans., 23rd ann. meet., p. 644-649, discussion p. 649-652.

Darton, N. H., 1921, Geologic reconnaisance in Baja California: Jour. Geology, v. 29, p. 720-748.

Dasher, J., Fras, F., and Gabriel, A., 1942, Mineral dressing of Oregon beach sands: U. S. Bur. Mines, Rept. Inv. 3668 , $19 \mathrm{p}$.

Datz, M., and others, 1953, Comparison of deep water wave by the Darbyshire and Bretachneider methods and recorded 
wave for Point Arguello, California, 26-29 october 1950: U. S. Army, Corps of Engineers, Beach Erosion Board Bull., v. 7, no. 4, p. 1-3.

David, L. R., 1946, Fish remains in recent deposits off the southern California Coast: Natl. Research Council, Div. Geology and Geography, Rept. Comm. Marine Ecology as Related to Paleontology, 1945-46, no. 6, p. 81-83.

Devid, L. R., 1947, Significance of fish remain in recent deposits off cost of southern California: Am. Assoc. Petroleum Geologist Bull., v. 31, p. 367-370.

Davida on, G., 1856, Extracts from a descriptive report to the Superintendent, upon localities on the western coast of the United State from the north entrance cf Rosario Strait, Washington Territory, to the southern boundary of California: Ann. Rept. U. S. Coast Survey 1855, app. 26 , p. $176-185$.

Devidson, G., 1859, Directory for the Pacific coast of the United States: Ann. Rept. U. S. Coast Survey 1858 , app. 44, p. 297-458.

Davidson, G., 1864, Directory for the Pacific Cosst of the United Statea, reported to the Superintendent of the United States Corst Survey: Ann. Rept. U. S. Cosst Survey 1862 , app. 39, p. 268-430.

Davidson, G., 1869, Pacific Coast, coast pilot of California, oregon and Washington Territory: U. S. Coast Survey, Wash., 262 p., pls.

Davidson, G., 1873a, Remarks on wrecks of Japanese vessels on the cosst of California: Cal1f. Acad. Sc1. Proc., v. $4(1868-1872)$, p. 84 .

Davidson, G., 1873b, Remarks on recent earthquake waves: Calif. Acrd. Sci. Proc., v. 4 (1868-1872), p. 268-269.

Davidson, G., 1873c, Remarks on the bars and entrances to the bays of the Pacific Coast: Calif. Acad. Sc1. Proc., v. $4(1868-1872$, p. $149-150$.

Davidson, G., 1873d, Remarks on surface geology as affected by upheavals: Cal1f. Acad. Sc1. Proc., v. 4 (1868-1872), p. 179.

Davidson, G., 1875a, The abrasions of the continental shores of $\mathrm{N}$. W. America, and the supposed ancient sea levels: Calif. Acad. Sc1. Proc., v. 5 (1873-1874), p. 90-97, profiles.

Davidson, G., 1875b, Remarks on the results of the deep sea soundings made by Commander George $\mathrm{E}$. Belknap, of the U. S. steamer Tuscarora, in 1873: Calif. Acad. Sci. Proc., v. 5 (1873-1874), p. 267-268, 343-344.

Davidson, G., 1884, The shoaling of the bar at the entrance to San Francisco Farbor: Geog. Soc. Pacific Proc., v. 1, ser. 1 , pt. 4, p. $1-23$.

Davidson, G., 1886, The temperature of the water of the Golden Gate: Cal1f. Acad. Sc1. Bull., v. 1, p. 354-357.

Davidson, G., 1887, Submarine valleys on the Pacific Coast of the United States: Calif. Acad. Sci. Bull., v. 2, p. 265-268.

Davidson, G., 1897, The submerged valleys of the cosst of California, U. S. A., and of Lower California, Mexico: Calif. Acad. Sci. Proc., 3rd ser., geology, v. 1, p. $73-103,9$ pls; Rev. by W. S. T. Smith, Jour. Geology, v. 5 (1897), p. 533-534.

Davidson, W. S., and Swanson; R. B., 1947, Submarine pipe lines at Ventura: Petroleum Engineer, v. 18, March, p. $216,218,220,224$.

Davis, H., 1872, on the likelihood of an admixture of Japanese blood on our northwest cost: Am. Antiquarian Soc. Proc., no. 58, p. 64-82, 1 pl.

Davis, W. M , 1925, The "undertow:" Sclence, v. 62, no. 1593 , p. 33.

Davis, W. M., 1931, Shorelines of the Santa Monica Mountaina, California: Pan Am. Geologist, v. 55, p. 362-363 (abs.); Geol. Soc. America Buli., Proc. for 1931, v. 43 (1932), p. 227 (abs.).

Dav1s, W. M., 1932, Glacial epochs of the Santa Monica Mountains, California: Natl. Acad. Sc1. Proc., v. 18, p. 659-665; Geol. Soc. America Bull., v. 44 (1933), p. 1041-1133, 16 pls.; Pan Am. Geologist, v. 59 (1933), p. 306-307 (abs.); Nature, v: 131 (1933), p. 288 (abs.) Geol. Soc. Amer1ca Bull., proc. for 1933, v. 45 (1934), p. 304-305; Rev. in Geographical Rev., v. 24 (1934), p. 139.

Davis, W. M., 1933, Submarine mock valleys: Am: Geophys. Union Trans., 14th ann. meet., p. 231-234; Pan Am. Geologist, v. 59, p. 307-308 (abs.); Geol. Soc. America
Bull., proc. for 1933, v. 45, (1934), p. 306 (abs.); Geographical Rev., v. 24 (1934), p. 297-308.

Davis, W. M., Putnam, W. C., and Richards, G. L., Jr., 1930 Elevated shorelines of the Santa Monica Mountains, California: Pan Am. Geologists, v. 54, p. 154 (abs.); Geol. Soc. America Bull., proc. for 1930, v. 42 (1931), p. 309-310 (abs.).

Davison, C., 1900, on the sea waves connected with the Japanese earthquake of June 15, 1896: Philos. Mag., London, v. 50, p. 579-583.

Davison, C., 1933, The recent Japanese earthquake: Nature, v. 131, p. $351-352$.

Davison, C., 1937, The distribution of deep-focus earthquakes: Geol. Mag., v. 74, p. 316-324.

Dawson, E. Y., 1946, Marine algae associated with upwelling along the northwestern coast of Baja California, Mexico: Southern Calif. Acad. Sci. Bull., v. 44, p. 57-71 incl. plo. 20-22.

Dawson, E. Y., 1950, A note on the vegetation of a new coartal upwelling area of Baja California: Jour. Marine Research, v. 9, p. 65-68.

Dawson, E. Y., 1951, A further study of upwelling and associated vegetation along Pacific Baja California, Mexico: Jour. Marine Research, v. 10, p. 39-58.

Daws on, E. Y., 1952, Clrculation within Bahia Vizcaino, Baja California, and 1 ts effects on marine vegetation: Jour. Botany, v. 39, p. 425-432.

Day, D. T., 1899, Platinum: Min. and Sc1. Press, v. 78, Jan $28, \mathrm{p} .88$.

Day, D. T., 1900 , Notes on the occurrence of platinum in North America: Am. Inst. Min. and Metall. Eng., v. 30 , p. $702-708$.

Day, D. T., 1907a, Black sands of the Pacific Coast: Franklin Inst. Jour., v. 164, p. 141-153.

Day, D. T., 1907b, The auriferous black sands of calffornia The scope and results of the investigation by the $U . S$. Geological Survey: Mines and Minerals, v. 27, p. 564-565.

Day, D. T., and Richards, R. H., 1906, Useful minerals in the black sand of the Pacific Slope: U. S. Geol. Survey, Min. Res. U. S., 1905, p. 1175-1258.

Deacon, G. E. R., 1949, wave and swell: Royal Meteorol. Soc., Quart. Jour., v. 75, p. 227-238.

De Ballore, M., 1912a, Terremoto y maremoto del 13 agosto de 1868: Historia siemica de los Andes Meridionales, Santiago de Chile, v. 2, p. 77-158.

De Ballore, M., 1912b, Terremoto y maremoto del 9 de mayo de 1877 en Chile septentrianal y Peru meridional: Historia Sismica de los Andes Meridionales, Santiago de Chile, v. 2 , p. $162-223$. *

Defant, A., 1950a, on the origin of internal tide wave in the open sea: Jour. Marine Reearch. v. 9, p. 11l-119.

Defant, A., 1950b, Reality and 1llueion in oceanographic aurveys: Jour. Marine Research, v. 9, p. 120-138.

De Groot, H., 1890, The San Franc18co ocean placer - the auriferous beach sands: Cal1f. State Min. Bur., 10th Ann. Rept. State Mineralogist, p. 545-547.

Deltch, S., 1937, A table of monthly mean sea-water temperatures for 30 stations of the United States and Alaska: Am. Meteorol. Soc. Bull., v. 18, p. 390.

Devaputra, D., Thompson, T. G., and Utterback, C. L., 1932, The radioactivity of sea water: Extrait du Jour. du Conseil Internat. pour I'Exploration de la mer, v. 7, p. $358-366$.

Dewey, G., 1874, Remarks on the coast of Lower California and Mexico: U. S. Hydrog, office pub. 56,60 p. *

Dibblee, T. W., Jr., 1951, Geology of southwestern Santa Barbara County, California: Calif. Div. Minea Bull. 150 $95 \mathrm{p}$.

Dickerson, R. E., 1910, Some variations in stream development on the Pescadero marine terraces: M. S. thesis, Univ. Calif., Berkeley. *

Dickerson, R. E., 1922, Tertiary and Quaternary history of the Petaluma, Point Reyes and Santa Rosa quadrangles: Cal1f. Acad. Sc1. Proc., v. 11, p. 527-601, pls. 17-41. 
Dickey, L. K., 1936, Invitation from California: Shore and Beach, v. 4, p. 52-53.

Dietz, R. S., 1938, Basins of the sea floor off southern Callfornia: Geol. Soc. America Bull., proc. for 1937, v. 49, p. 237 (abs.).

Dietz, R. S., 1941, Clay minerals in Recent marine sediments: Ph. D. thesis, Univ. Ill., 68 p., 3 pls; Am. Mineralogist, v. 37 , no. 3 , p. $219-220$ (abs.).

Dletz, R. S., 1947a, Some Pactific sea floor features: Geol. Soc. America Bull., v. 58, p. 1174-1175 (abs.).

Dietz, R. S., 1947b, Aerial photograph in the geological study of shore features and processes: Photogrametric Engineering, v. 13, p. 537-545.

Dietz, R. S., 1948, Deep scattering layer in the Pacific and Antarctic Oceans: Jour. Marine Research, v. 7, p. $430-442$.

Dietz, R. S., 1951, Proposed geomorphic evolution of continental terraces: Geol. Soc. America Bull., v. 62, p. 1501 (abs.).

Dietz, R. S., 1952a, The Pactfic floor: Sci. Am., v. 186, no. 4 , p. 19-23.

Dietz, R. S., 1952b, Geomorphic evolution of continental terrace (continental shelf and slope): Am. Assoc. Petroleum Geologists Bull., v. 36, p. 1802-1819.

Dietz, R. S., 1953, Possible deep-sea turbidity-current channels in the Indian Ocean: Geol. Soc. America Bull., v. 64, p. $375-378$.

Dletz, R. S., 1954, Methods of exploring the ocean floor, in oceanographic Instrumentation, Isaacs, J. D. and Iselin, C. O'D., editors, pub. 309 Natl. Acad. Sci., Natl. Research Counc1l, p. 194-209 incl. discussion. (also see other papers in this publications for instrumentation).

Dietz, R. S., and Emery, K. O., 1938a, Phosphorite on the sea floor off southern California: Am. Assoc. Petroleum Geologists Bull., v. 22, p. 1717 (abs.).

Dietz, R. S., 1938b, Marine phosphate deposits off the coast of California: Geol. Soc. America Bull., v. 49, p. 1878 (abs.); Am. Assoc. Petroleum Geologists Bull., v. 22, p. 1717 (abs.).

Dietz, R. S., Emery, K. O., and Shepard, F. P., 1942 , Phosphorite deposits on the sea floor off southern California: Geol. Soc. America Bull., v. 53, p. 815-848.

Dietz, R. S., and LaFond, E. C., 1950, Natural slicks on the ocean: Jour. Marine Research, v. 9, p. 69-76.

Dietz, R. S., and Menard, H. W., 195la, origin on the shelfbreak: Geol. Soc. America Bull., v. 62, p. 1501 (abs.).

Dietz, R. S., 1951b, origin of abrupt change in slope at continental shelf margin: Am. Assoc. Petroleum Geologiat. Bu1l., v. 35, p. 1994-2016.

Dietz, R. S., Menard, H. W., and Hamilton, E. L., 1952, Bathygrams of the 1950 Scripps-Navy Mid-Pacific Expedition: Geol. Soc. America Bull., v. 63, p. 1325 (abs.).

Dietz, R. S., Menard, H. W., and Hamilton, E. L., 1954, Echograms of the Mid-Pacific Expedition: Deep-Sea Research, v. 1, p. 258-272.

Dill, R. F., 1949, Sea slicks: The Compass of Sigma Gamma Epsilon, v. 26, no. 4, p. 344-348.

Dill, R. F., 1952, Environmental analys1s of sediment from the sea floor off Point Arguello, California: M. S. thes 1s, Univ. Southern Calif., 64 p., 5 tables, 10 figs, 4 pls.

Dill, R. F., Dietz, R. S., and Stewart, H., 1952, Deep-sea channel of the Monterey Canyon: Geol. Soc. America Bull., v. 63, p. $1325-1326$ (abs.).

Dill, R. F., Dietz, R. S. and Stewart, H., 1954, Deep-8ea channels and delta of the Monterey aubmarine canyon: Geol. Soc. America Bull., v. 65, p. 191-194, chart.

Diller, J. S., 1896, A geological reconnaissance in northwestern Oregon: U. S. Geol. Survey, 17th ann. rept., pt. 1, p. 441-520, pls. IV-XVI, fige. 4-17.

Diller, J. S., 1898, The educational series of rock specimens collected and distributed by the U, S. Geological Survey: U. S. Geol. Survey Bull. 150, 400 p., 47 pls., 18 pigs.

Diller, J. S., 1901, Coos Bay, Oregon: U. S. Geol. Survey Geol. Atlas, follo 73.

Diller, J. S., 1902, Topographic development of the Klamath Mountains: U. S. Geol. Survey Bull. 196, 69 p., 13 pls., 7 fige.

Diller, J. S., 1903, Port orford: U. S. Geol. Survey Geol. Atlas, follo 89.
Diller, J. S., 1915, The relief of our Pacific Coast: Science, v. 41, p. 48-57, 513; Geol. Soc. America Bull., v. 26 , p. 111 (abs.).

Disney, L. P., and Overshiner, W. H., 1925, Tides and currents in San Francisco Bay: U. S. Coast and Geod. Survey, special pub. 115, serial 311, 125 p. incl. P1gø.

Donn, W. L., 1954, Direction studies using microseism groundparticle motion: Am Geophys. Union Trans., v. 35, p. 821-832.

Donnelly, M., 1943, Monthly rainfall-distribution in southern California, with special reference to soll-erosion problems: Am. Geophys. Union Trans., 24th ann. meet., p. 144-148.

Dorman, H. P., 1927a, Studies on marine diatoms and dinoflagellate caught with the Kofold bucket in 1923: Scripps Inst. Oceanography Bull., tech. eries, v. l, p. 49-61.

Dorman, H. P., 1927b, Quantitative studies on marine diatoms and dinoflagellates at four inshore stations on the cosst of California in 1923: Scripps Inst. Oceanography Bull., tech. ser., v. 1, p. 73-89.

Drake, N. F., 1897, The topography of California: Jour. Geology, v. 5, p. 563-578.

Dr1ver, H. L., 1948, Genes 18 and evolution of Los Angeles Besin, California: Am. Assoc. Petroleum Geologists Bull., v. 32 , p. 109-125.

Drury, N. B., 1936, California's part in preserving shore and beach: Shore and Beach, v. 4, p. 80-82.

Drury, N. B., 1938, Point Lobos Reserve: Am. Forests, v. 44, p. $300-309,336$.

Dunham, J. W., 1951, Refraction and diffraction diagrams: First Conf. on Cosstal Eng. Proc., Berkeley, p. 33-49.

Dunkle, M. B., 1944, An investigation of the plant ecology of the Channel Islands of California with special reference to Santa Barbara Island: Ph. D. thesis, Univ. Southern Calif., 264 p., 12 figs., 19 pls., 10 tables.

Dunkle, M. B., 1950, Plant ecology of the Channel Islands of California: Univ. Southern Calif., Allan Hancock Pacific Expeditions Pubs., v. 13, no. 3, p. 247-386.

Durham, J. W., 1942, Recent Pacific Coast coral faunas: Geol. Soc. America Bull., v. 53, p. 1835 (abs.).

Durham, J. W., 1949, Pacific Coast Tertiary marine climates: Geol. Soc. America Bull., v. 60, p. 1884 (abs.).

Durham, J. W., 1950a, Pacific basin and continental drift: Geol. Soc. America Bull., v. 61, p. 1522 (abs.).

Durham, J. W., 1950b, Cenozolc marine climates of the Pacific Coast: Geol. Soc. America Bull., v. 61, p. 1243-1264, p. 1537 (abs.).

Durham, J. W., 1950c, 1940 E. W. Scripps cruise to the Gulf of California. Part II Megascopic paleontology and marine statigraphy: Geol. Soc. America Mem. 43, p. 1-al6.

Durham, J. W., 1952, Early Tertiary marine faunas and continental drift: Am. Jour. Sc1., v. 250, p. 321-343.

Durst, F. M., 1915, The 1dentification and correlation of the marine terraces of the California coast between Santa Cruz and Bolinas: M. A. thes1s, Univ. Calif., Berkeley.*

Dyk, K., and Swalnson, O. W., 1953, The veloc1ty and ray paths of sound waves in deep sea water: Geophys1cs, v. 18, no. 1, p. 75-103.

Eardley, A. J., 1954, Tectonic relations of North and South America: Am. Assoc. Petroleum Geologist Bull., v. 38, p. 707-773.

Eaton, J. E., 1928, Divisions and duration of the Plelstocene In southern California: Am. Assoc. Petroleum Geologists Bull., v. 12, p. 111-141; Rev. by E. Antevs, Am. Jour. Sc1., 5th series, v. 15, p. 447-448.

Eaton, J. E., 1932, Decline of Great Basin, southwestern United States: Am. Assoc. Petroleum Geologists Bull., v. 16, p. $1-49$.

Eaton, J. E., 1933, Long Beach, Cal1fornia, earthquake of March 10, 1933: Am. Assoc. Petroleum Geologists Bull., v. 17, p. $732-738$. 
Eaton, J. E., 1939, Tie-ins between the marine and continental records in California: Am. Jour. Sci., v. 237, p. 899-919.

Eaton, J. E., 1943, The Pleistocene in California: Calif. Div. Mines Bull. 118, p. 203-206.

Eaton, R. O., 1951, Littoral processes on sandy coasts: F1rst Conf. on Coastal Eng. Proc., Berkeley, p. 140-154.

Eckis, R., 1934, South coastal basin investigation; geology and ground water atorage capacity of valley fill: Calif. Div. Water Res. Bull. 45, 273 p., 5 maps.

Eckis, R., 1936, Later Quaternary geology of the Los Angeles Basin area: Geol. Soc. America Bull., proc. for 1935, v. 47, p. 350 (abs.).

Eddy, H. P., Hyde, C. G., Kennedy, C. C., and Reynolds, L. B., 1936, Report on the treatment and disposal of the sewage of the city and county of San Francisco, California: *

Edman, J. A., 1894, Notes on the gold-bearing black sands of California; Min. and Sci. Press., v. 69, Nov. 10, p. 294.

Edman, J. A., 1906, Black sand: Min. and Sci. Press, v. 93, Sept. 29, p. 380 .

Edmondson, C. H., 1949, Seashore treasures: Palo Alto Calif., Pacific Books, 144 p.*

Einstein, H. A., 1951, Estimating quantities of sediment supplied by streams to a coast: First Conf. on Coastal Eng. Proc., Berkeley, p. 137-139.

Eldridge, G. H., 1901, The asphalt and bituminous rock deposits of the United States: U. S. Geol. Survey, 22nd ann. rept., pt. 1, p. 209-452.

Eldredge, Z. S., and Molera, E. J., 1909, The march of Portola and the discovery of the bay of San Francisco by Z. S. Eldredge; The log of the San Carlos and original documents translated and annotated by $\bar{E}$. J. Molera: San Francisco, The Calif. Promotion Comm., 71 p., illus. incl. first chart of San Francisco Bay. (Probably the first reference on salt water encroachment in San Francisco Bay).

Elliott, F. E., Tressler, W. L., and Myers, W. H., 1953, Environmental aspects of the ebb side and flood side of tidal estuaries as a factor in harbor locations: Third Conf. on Coastal Eng. Proc., Berkeley, p. 48-53.

Ellis, A. J., and Lee, E. H., 1919, Geology and ground waters of the western part of San Dlego County, California: U. S. Geol. Survey Water-Supply Paper 446, 321 p.

Emerson, W. C., 1904, The Farllone Islands revisited, 18871903: Condor, v. 6 , no. 3 , p. 61-68, map, 8 photos. *

Emery, K. O., 194la, Lithology of the sea-floor off southern California: $\mathrm{Ph}$. D. thesis, Univ. Ill., Abs. thesis $3 \mathrm{p}$.*

Emery, K. O., 1941b, Rate of surface retreat of sea cliffs based on dated inscriptions: Science, v. 93, p. 617-618.

Emery, K. 0., 1941c, Transportation of rock particles by seamammals: Jour. Sed. Petrology, v. 11, p. 92-93.

Emery, K. 0., 1944, Beach markings made by sand hoppers: Jour. Sed. Petrology, v. 14, p. 26-28.

Emery, K. 0., 1945a, Entrapment of air in beach sand: Jour. Sed. Petrology, v. 15, p. 39-49.

Emery, K. 0., 1945b, Transportation of marine beach sand by flotation: Jour. Sed. Petrology, v. 15, p. 84-87.

Emery, K. 0., 1946a, Study of bottom materials: Univ. Calif., Div. War Research Rept. M404, Sonar Data Div., 16 p.*

Emery, K. 0., 1946b, Marine solution basins: Jour. Geology, v. 54, p. 209-228.

Emery, K. O., 1947a, Phosphorite from the sea floor: Rocks and Minerals, v. 22, p. 8-9.

Emery, K. O., 1947b, Ranger Bank, Mexico: Geol. Soc. America Bull., v. 58, p. 1177 (abs.).

Emery, K. O., 1947c, Submarine geology off southern California: 0il and Gas Jour., v. 45, no. 47, March 29, p. 113 (abs).

Emery, K. 0., 1948, Submarine geology of Ranger Bank, Mexico: Am. Assoc. Petroleum Geologists Bull., v. 32, p. 790-805.

Emery, K. 0., 1950a, Ironstone concretions and beach ridges of San Diego County, California: Calif. Jour. Mines and Geology, v. 46, no. 2, p. 213-221, pls. 30-33.

Emery, K. 0., 1950b, of shore southern California, in Symposium on possible future oil provinces of the Pacific Coast region: Am. Assoc. Petroleum Geologists Bull., v. 34, p. 2384 (abs.).

Emery, K. 0., 1950c, A suggested origin of continental slopes and of submarine canyons: Geol. Mag., v. 87, p. 102-104.

Emery, K. O., 1950d, Contorted Pleistocene strata at Newport Beach, California: Jour. Sed. Petrology, v. 20, p. 1ll115.

Emery, K. O., 1950e, Compaction of marine sediments: Geol. Soc. America Bull., v. 61, p. 1522-1523 (abs.).

Emery, K. 0., 1951, Continental shelf - southern California, in Symposium on possible future petroleum provinces of North America: Am. Assoc. Petroleum Geologists Bull., v. 35, p. $249-252$.

Emery, K. O., 1952a, Continental shelf sediments of southern California: Geol. Soc. America Bull., v. 63, p. 1105-1108.

Emery, K. 0., 1952b, Submarine photography with the benthograph: Sc1. Monthly, v. 75, p. 3-11; Popular Mechanics, Jan 1953, p. 105 (abs.). with title "Deep-sea photographs; "Also translated into French with title "l'exploration des grands fonds sous-marins: le Benthographie realise des photographies a $5,000 \mathrm{~m}$. de profondeur:" Sc1. et Avenir, no. 72 (1953), p. 52-56, 94 and cover.

Emery, K. 0., 1953a, A newly surveyed submarine basin off Mexico: Am. Jour. Sci., v. 251, p. 656-660, chart.

Emery, K. 0., 1953b, Some surface features of marine sediments made by animals: Jour. Sed. Petrology, v. 23, p. 202-204.

Emery, K. O., 1954a, Transparency of water off southern California: Am. Geophys. Union Trans., v. 35, p. 217-220.

Emery, K. O., 1954b, Some characteristics of southern California sediments: Jour. Sedimentary Petrology, v. 24, p. 50-59.

Emery, K. 0., 1954c, Size distribution of gravels: Jour. Sed. Petrology, v. 24, p. 144 (abs.). Jour. Geol., v. 63 (1955), p. 39-49, title - Grain size of Marine beach grav

Emery, K. O., 2954d, Sources of water in basins off southern California: Jour. Marine Research, v. 13, p. 1-21.

Emery, K. O., 1954e, The Painted Cave, Santa Cruz Island Sea and Pacific Motorboat, v. 46, p. 37-39, 91, 92.

Emery, K. 0., Butcher, W. S., Gould, H. R., and Shepard, F. P., 1952, Submarine geology of San Diego, California: Jour. Geology, v. 60 , p. 511-548.

Emery, K. O., and Dietz, R. S., 1939, Telescoping in marine cores: Geol. Soc. America Bull., v. 50, p. 1908 (abs.).

Emery, K. O., and Dietz, R. S., 1941, Gravity coring instrument and mechanics of sediment coring: Geol. Soc. America Bull., v. 52, p. 1685-1714.

Emery, K. O. and Díetz, R. S., 1950, Submarine phosphorite deposits off California and Mexico: Calif. Jour. Mines and Geology, v. 46, p. 7-15, 5 pls.

Emery, K. O., and Foster, J. F., 1948, water-tables in marine beaches: Jour. Marine Research, v. 7, p. 644-654.

Emery, K. O., and Gale, J. F., 1951, Swash and swash mark: Am. Geophys. Union Trans., v. 32, p. 31-36.

Emery, K. O., and Gould, H., 1948, A code for expressing grain size distribution: Jour. Sed. Petrology, v. 18, p. 14-23.

Emery, K. O., and Natland, M. L., 1952, Our shrinking globe a discussion: Geol. Soc. America Bull., v. 63 , p. $1069-$ 1072.

Emery, K. O., and Rittenberg, S. C., 1951, Basin sediments off southern California: Geol. Soc. America Bull., v. 62 , p. 1501-1502 (abs.).

Emery, K. O., and Rittenberg, S. C., 1952, Early diagenes1s of California basin sediments in relation to origin of oil: Am. Assoc. Petroleum Geologists Bull., v. 36, p. $735-806$.

Emery, K. O., and Shepard, F. P., 1941, Lithology of the sea floor off southern California: Geol. Soc. America Bull., v. 52, p. 1899-1900 (abs.).

Emery, K. O., and Shepard, F. P., 1945, Lithology of the see floor off southern Californta: Geol. Soc. America Bull., v. 56, p. $431-478$.

Emery, K. O., and Stevenson, R. E., 1950, Laminated beach sand: Jour. Sed. Petrology, v. 20, p. 220-223.

Emery, K. O., and Trchudy, R. H., 1941, Transportation of rock by kelp: Geol. Soc. America Bull., v. 52, p. 855862.

Emiliani, C., 1954, Temperature of Pacific bottom waters an polar superficial waters during the Tertiary: Science, v. 119, p. 853-855.

Emiliani, C., and Epstein, S., 2953, Temperature variations in the lower Ple1stocene of southern Callfornia: Jour. Geology, v. 61, p. 171-181. 
Emmonds, S. F., and Merrill, G. P., 1894, Geological sketch of Lower California: Geol. Soc. America Bull., v. 5, p. 489-514.

Ennis, C. C., 1934, Use of regional constant correction factors for deduction of echo soundings: Fifth Pacific Sc1. Cong. Proc., v. 3, p. 2075-2082.

Epstein, S. and Mayeda, T., 1953, Variation of 018 content of waters from natural sources: Geochimica et Cosmochimica Acta, v. 4, p. 213-224.

Erickson, C. E., 1952, Sunset sportsman atlas - San Francisco Bay and Delta area: Menlo Park, Calif., Lane Pub. Co., 32 p. incl. maps.

Erickson, C. E., 1953, Sunset sportsman atlas - southern California coast: Menlo Park, Calif., Lane Pub. Co., 32 p. incl. maps.

Eaterly, C. 0., 1911, Diurnal migration of Calanus fimmarchicus in the San Diego region during 1909: Internat. Rev. der Gesell. Hydrobiologie und Hydrographie, band 4, p. 140-151 (in English with German abs.).

Esterly, C. 0., 1912, The occurrence and vertical distribution of the Copepoda of the San Diego region, with particular reference to nineteen species: Univ. Calif. Pubs. Zoology, v. 9, p. 253-340.

Esterly, c. 0., 1923, Preliminary statistical report on the occurrence of marine copepoda in the plankton at La Jolla, California: Univ. Calif. Pubs. Zoology, v. 22 , p. 417-433.

Esterly, C. 0., 1928a, Investigations of zooplankton at the Scripps Institution of Oceanography: Third Pan-Pacific Sci. Cong. Proc., v. 1, p. 264-282.

Esterly, C. 0., 1928b, The periodic occurrence of copepoda in the marine plankton of two successive years at La Jolla, California: Scripps Inst. Oceanography Bull., tech. ser., v. 1, p. 247-345.

Evans, F. J., and Wharton, W. L., 1888, on the seismic sea wave caused by the eruptions of Krakatos, August 26th and 27th, 1883: pt. III of The eruption of krakato and subsequent phenomena, pub. by the Royal Soc. London, p. $89-151$. *

Evans, O. F., 1941, Shore line formation by currents: Shore and Beach, v. 9, p. 46-47.

Evans, 0. F., 1945, Scientific beachcombing: Sci. Monthly, v. 61, p. $245-248$.

Evans, R. D., 1934, Improved technique for determination of radon and radium in liquids: Physical Rev., v. 46, p. 328.

Evans, R. D., Kip, A. F., and Moberg, E. G., 1938, The radium and radon content of Pacific ocean water, life and sediments: Am. Jour. Sc1., 5th ser., v. 36, p. 241-259.

Everest, F. A., Young, R. W., and Johnson, M. W., 1948, Acoustical characteristics of nolse produced by snapping shrimps: Acoustical Soc. America Jour., v. 20, p. 137142.

Ewing, G. C., 1950a, Slicks, surface films and internal waves: Ph. D., thesis, Univ. Calif., Los Angeles, 56 p., 16 figs., I table.

Ewing, G. C., 1950b, Relation between band slicks at the surface and internal waves in the sea: Science, v. Ill, p. 91-94.

Ewing, G. C., 1950c, Slicks, surface films and internal waves: Jour. Marine Research, v. 9, p. 161-187.

Fairbanks, H. W., 1893, Geology of San Diego County; also portions of Orange and San Bernardino Counties: Calif. State Min. Bur., llth Ann. Rept. State Mineralogist, p. $76-120$.

Fairbanks, H. W., 1896-1902, The geology of Point Sal: Univ. Calif. Pub. Geology, v. 2, p. 1-100, 30 pls.

Fairbanks, H. W., 1897, Oscillations of the coast of California during the Pliocene and Pleistocene: Am. Geologist, v. 20, p. $213-245,1$ pl.

Fairbanks, H. W., 1898, Geology of a portion of the southern Coast Ranges: Jour. Geology, v. 6, p. 551-576.

Fairbanks, H. W., 1904, San Luis Obispo: U. S. Geol. Survey Atlas, folío 101.

Farrand, W. H., 1929, The relation of a fossil Foraminifera fauna from Timms Point, San Pedro, California, to a Recent Foraminifera fauna from off the coast of San Pedro, California: M. S. thesis, Univ. Southern Calif., $26 \mathrm{p}$.

Fenton, M. A., and Fenton, C. L., 1934, Scolithus as a fossil Phoronid: Pan Am. Geologist, v. 61, p. 341-348, pl xx.

Fewkes, J. W., 1889, Across the Santa Barbara Channel: Am. Naturalist, v. 23, p. 21l-217, 387-394, pl. xiv.

Findlay, A. G., 1851, A directory for the navigation of the Pacific ocean; with descriptions of its cossts, 1slands etc., from the Strait of Magelhaens (Magellan) to the Artic Sea, and those of Asia and Australia; its winds, currents, and other phenomena....; London, R. H. Laurie,

Findlay, A. G., 1898, A directory for the navigation of the North Pacific Ocean; with descriptions of its coasts, islands, etc. from Panama to Behring Strait and Japan; its winds, currents and passages: London, $3 \mathrm{rd}$ ed. *

Fish, M. P., 1949, Marine mammals of the Pacific with particular reference to the production of underwater sound: Woods Hole Oceanographic Inst., tech. rept. 8, July, ref. 49-30, 69 p. incl. charts.

Fisher, E. M., 1930, The early fauna of Santa Cruz Island, California: Jour. Mammalogy, v. 11, p. 75-76.

Fisher, R. L., and Mills, R., 1952, Sediment trap studies of sand movement in La Jolla Bay: Geol. Soc. America Bull., v. 63 , p. 1328 (abs.).

Fitzgerald, J. N. J., 1952, Supreme court ruling on U. S. offshore oil rights aids Mexican claim to isles: The oil Foram, Oct., p. 337-339, 352-353. (Farollone Islands).

Fleming, J. A., 1930, The seventh cruise of the Carnegie: Am. Geophys. Union Trans., 1lth ann. meet., p. 251-257.

Fleming, J. A., Sverdrup, H. U., Ennis, C. C., Seaton, S. L. and Hendrix, W. C., 1945, Observations and results in physical oceanography. Graphical and tabular summaries, in Scientific results of Cruise VII of the Carnegie, 1928-1929 oceanography I-B. Carnegie Inst. Wash., Dept. Terrestrial Magnetism and Electricity Pub. 545 , 315 p., incl. 254 figs., 5 tables.

Fleming, R. H., 1935, Oceanographic studies in the Central American Pacific: Ph. D. thesis, Univ. Calif. *

Fleming, R. H., 1937-38, Tides and tidal currents in the Gulf of Panama: Jour. Marine Research, v. 1, p. 192-206.

Fleming, R. H., 1939a, The control of diatom populations by grazing: Extrait du Jour. du Conseil Internat. pour 1 'Exploration de la Mer, v. 14, no. 2, p. 3-20.

Fleming, R. H., 1939b, Character of the currents off southern California: Sixth Pacific Sci. Cong. Proc., v. 3, p. $149-160$.

Fleming, R. H., 1940a, The equatorial water masse of the Pacific: Assoc. d'océanographie Physique, Union Géodesique et Géophysique Internat., Procès-Verbaus no. 3 , p. 166-167.

Fleming, R. H., 1940b, The California Current in 1937, 1938, and 1939: Assoc. d'oceanographie Physique, Union Geodesique et Geophysique Internat., Proces-Verbaux no. 3, p. $168-169$.

Fleming, R. H., 1942, Results in physical oceanography; Preliminary discussions, in Scripps Inst. Oceanography, Records of Observations, v. 1, no. 1, p. 13-24.

Fleming, R. H., Moberg, E. G., Revelle, R. R. D., 1937a, The origin and characteristics of the waters off the coast of southern California: Assoc. d'Océanographie Physique, Union Géodésique et Géophysique Internat., Procès-Verbaux no. 2, p. 108.

Fleming, R. H., Moberg, E. G., Revelle, R. R. D., 1937b, The water masses of the North Pacific: Assoc. d'Océanographie Physique, Union Géodésique et GEophysique Internat., Procès-Verbaux no. 2, p. 106-107.

Fleming, R. H., and Revelle, R., 1939, Physical processes in the oceans, in Trask, P. D., Recent marine sediments, Symposium pub. by Am. Assoc. Petroleum Geologists, Tulsa, Okla., p. 48-141. 
Flores, T., 1931, Carta geológica de la Baja California: Inst. Geol. Mexico Cartas geol. y min., v. 1, 22 p., 1 pl. and map.

Folsom, R. G., 19.44a, Memorandum on wave refraction at Standard oil Pier at Eatero Bay: Univ. Calif., Berkeley, fluid mechanics lab., tech. rept. HE-116-22, Nov. 11 , 7 p., tables, graphs.

Folsom, R. G. , 1944b, Teat with an anchored float with graduated mast: Univ. Calif., Berkeley, fluid mechanics lab., tech. rept. $\mathrm{HE}-116-24$, Nov. 11,2 p., table, graphs.

Folsom, R. G., 1944c, Damping disc teats in San Francisco Bay: Univ. Calif., Berkeley, fluid mechanics lab., tech. rept. HE-116-38, Dec. 8,5 p. table.

Folsom, R. G., 1944d, Memorandum on wave forecasting: Univ. Calif., Berkeley, fluid mechanics lab., tech. rept. HE-116-55, Feb. 12, 4 p.

Folsom, R. G:, 1945a, Wave measurement in deep water with recording instruments: Univ. Calif., Berkeley, fluid mechanics lab., tech. rept. gE-116-49, Feb. 16, 28 p., tablea, graphs, sketch.

Folsom, R. G., 1945b, Observations and measurements of waves at sea - I: Univ. Calif., Berkeley, fluid mechanics lab., tech. rept. HE-116-50, Jan. 27, 16 p., tables, graph , photos.

Folsom, R. G., 1945c, Field test of shore wave recorders: Univ. Calif., Berkeley, fluid mechanics lab., tech. rept. He-116-180, Nov. 23, 28 p., tablea, charts, graph, mapa, sketches.

Folsom, R. G., 1948a, Measurement of ocean waves: Univ. Calif., Berkeley, fluid mechanics lab., tech. rept. He-116-282, May 15, 9 p., sketches, photos, charts; Ar. Geophys. Union Trans., v. 30 (1949), p. 691-699.

Folsom, R. G., $1948 \mathrm{~b}$, Discussion of "Inveatigation of underwater pressure records and simultaneous sea surface patterns" by H. R. Seiwell: Am. Geophys. Union Trans., v. 29 , p. 588 .

Fonck, F., 1871, Los agitaciones oceanicas causadas en las costa del Pacifico por el terremoto del 13 agosto, 1868: Anales de la Univ. de Chile, Santiago, v. 39, p. $283-305$. *

Foote, F. J., 1932, Determination of boron in waters: Indus. Eng. Chemistry, Analytical Ed., v. 4, p. 39-42.

Forbush, S. E., 1934, Gravity determinations on the Carnegie: Fifth Pacific Sci. Cong. Proc., v. 2, p. 887-893.

Ford, J. L. C., 1942, Seven scientiats at sea. How a group of scientists made a laboratory of Gulf of California: Calif. Monthly, March, pt. I, p. 19-22, 38; April, pt. II, p. $20-23,36$.

Forreat, D. R., 1950, A method of estimating wave direction: U. S. Army Corps of Engineers, Beach Erosion Board Bull., v. 4 , no. $2, \mathrm{p} .31-35$.

Forrest, D. R., 195la, Comparison of observed wave direction with a refraction diagram: U. S. Army, Corps of Engineers, Beach Erosion Board Bull., v. 5, no. 2, p. 24-25.

Forreat, D. R., 1951b, Wave budget for Mission Beach, San Diego, California for 1950: U. S. Army, Corps of Engineers, Los Angeles dist.*

Fox, C. K., 1936, The Colorado Delta: A discussion of the Spanish explorations and maps, the Colorado River silt load, and its seismic effect on the southwest: Los Angeles, privately pub., 75 p., 18 pls., incl. maps. *

Fox, D. B., 1929, Quantitative studies on inshore marine diatoms and dinoflagellates taken at five atations on the east Pacific coast in 1926: Scripps Inst. Oceanography Bull., tech. ser., v. 2, p. 189-196.

Fox, D. B., 1930, A quantitative study of the marine diatoms and tintinnoids found in the regions of Anaheim Slough, San Pedro, and Catalina Island: M. A. thesis, Univ. Southern Calif., 67 p. incl. 22 pls.

Fox, D. L., 1937, Carotenoids and other lipoid-solusble pigments in the sea and in deep marine mud: Natl. Acad. Sci. Proc., v. 23, p. 295-301.

Fox, D. L., 1944a, Biochemical foseila: Science, v. 100, no. 2589, p. 111-113.

Fox, D. L., 1944b, Fossil pigments: Sci. Monthly, v. 59, p. 394-396.

Fox, D. L., 1950, Comparative metabolism of organic detritua by inahore animals: Ecology, v. 31, p. 100-108.

Fox, D. L., and Anderson, L. J., 1941, Pigments from marine muds: Natl. Acad. Sci. Proc., v. 27, p. 333-336.

Fox, D. L., and Coe, W. R., 1943, Biology of the California sea-musel (Mytilus californianus). II Nutrition, metabolism, growth and calcium deposition: Jour. Experimental Zoology, v. 93, p. 205-249.

Fox, D. L., Crane, S. C., and McConnaughey, B. H., 1948, A biochemical study of the marine annelid worm Thoracophella mucronata. Its food, biochromes and carotenoid metabolism: Jour. Marine Research, v: 7, p. 567-585.

Fox, D. L., Iraacs, J. D., and Corcoran, E. F., 1952, Marine leptopel, its recovery, measurement and distribution: Jour. Marine Research, v. 11, p. 29-46.

Fox, D. L., Updegraff, D. M., and Novelli, G. D., 1944, Carotenoid pigments in the ocean floor: Archives of Biochemistry, v. 5, p. 1-23.

Fox, L. S., 1930, Some methods employed in obtaining submarine geological data: Am. Assoc. Petroleum Geologiats Bull., v. 14, p. 98-101.

Fraser, C., 1928, Marine wood borers on the Pacific coast of North America: Third Pan-Pacific Sci. Cong. Proc. v. 2, p. 2270-2275.

Fraser, C. McL., 1943, General account of the sclentific work of the Velero III in the eastern Pacific, 1931-41; Part III. A ten-year liat of the Velero III collecting tations including an appendix of collecting stations of the Allan Hancock Foundation for the year 1942: Los Angeles, Univ. Southern Calif. Press, Allan Hancock Pacific Expeditions, v. 1, no. 3, p. 259-431, incl. 15 charts.

Freeman, J. R., 1912, on the proposed use of a portion of the Hetch Hetchy, Eleanor and Cherry Valleys within and near to the boundaries of the Stanislaus U. S. National Forest Reserve and the Yosemite National Park as reservoirs for impounding Tuolumne River flood waters and appurtenant works for the water supply of San Francisco, California, and neighboring sites: San Francisco, Rincon Pub. Co., 401 p., lxv, illus.*

Friedman, S. L., 1949, Beaches - California's golden treasure: Pacific Didcovery, v. 2, no. 3, p. 20-29.

Fries, A. A., 1912, Ln Angeles Harbor: Prof. Mem., v. 4, p. $1-35$.

Gaillard, D. D., 1904, Wave action in relation to engineering structures: U. S. Army, Corps of Engineers, Prof. Paper 31, 232 p., illus.

Gale, H. S., 1933, Hopeful view of Huntington Beach tide lands: Calif. Oil World, v. 26, no. 21, Dec. 14, p. 11-12.

Gale, H. S., 1934a, Geology of Huntington Beach oil Field, California: Am. Assoc. Petroleum Geologists Bull., v. 18, p. 327-342.

Gale, H. S., 1934b, Real field lies in the sea at Huntington: Petroleum World, v. 31, June, p. $16,18$.

Gale, H. S. and Others, 1932, Southern California: Internat. Geol. Cong., XVI session, U. S., 1933, guidebook 15, excursion $\mathrm{C}-1,68 \mathrm{p} ., 14 \mathrm{pl}$.

Galliher, E. W., 1932a, Sediments of Monterey Bay, California: Ph. D. thesis, Stanford Univ., 142 p., 1 pl., 23 figs.; Calif. State Min. Bur., 28th Ann. Rept. State Mineralogist, p. 42-79.*

Galliher, E. W., 1932b, Organic structures in sediments: Jour. Sed. Petrology, v. 2, p. 46-47.

Gelliher, E. W., 1933, The sulfur cycle in sediments: Jour. Sed. Petrology, v. 3, p. 51-63; Pan-Am. Geologiat, v. 59, p. 307 (abs.); Geol. Soc. Am. proc. 1933 (1934), p. 305 (abs.).

Galliher, E. W., 1935a, Glauconite genesis: Geol. Soc. America Bull., v. 46, p. $1351-1366,2$ pls.

Galliher, E. W., 1935b, Interstitial sedimentation: Pan Ar. Geologist, v. 63 , p. 303 (abs.); Geol. Soc. America Bull., proc for 1935, v. 47 (1936), p. 326-327 (abs.).

Galliher, E. W., 1935c, Geology of glauconite: Am. Assoc. Petroleum Geologiats Bull., v. 19, p. 1569-1601.

Galliher, E. W., 1937, Regional petrology of glauconite: Geol. Soc. America Bull., proc. for 1936, v. 48 , p. 345 (abs.). 


\section{Bibliography of Marine Geology and Oceanography, California Coast}

Galliher, E. W., 1939, Biotite-glauconite transformation and associated minerals, in Trask, P. D., Recent marine sediments, symposium $\overline{\mathrm{pub}}$. by Am. Assoc. Petroleum Geologists, Tulsa, Okla., p. 513-515.

Garrett, A. A., 1948-49, Status of salt-water contamination in the coastal part of Orange County, California: U. s. Geol. Survey, Ground-Water Branch, mimeo. rept.*

Garrett, A. A., 1951, Status of salt-water contamination in the coastal part of orange County, California, as of 1950: U. S. Geol. Survey Ground-Water branch, mimeo. rept., Apr11.*

Garrison, L. E., and Takasaki, K. L., 1950, Bottom samples off the coast of southern California: Scripps Inat. oceanography, Submarine Geol. Rept. 12, 6 p., map, charts.

Garth, J. S., 1946, Distribution studie of Galapago Brachyura: Univ. Southern Calif. Press, Allan Hancock Pacific Expeditions, v. 5, no. 11, p. 603-638. incl. 10 charta.

Gaylord, E. G., and Hanna, G. D., 1925, Correlationa of organic shales in the southern end of the San Joaquin Valley, California: Am. Assoc. Petroleum Geologists Bull., v. 9, p. 228-234, ple. 4, 5.

Gee. H., 1932, Inorganic marine limestone: Jour. Sed. Petrology, v. 2, p. 162-166.

Gee, H., Greenberg, D. M., and Moberg, E. G., 1932, Calcium equilibrium in sea water: II. Sealed bottles shaken at constant temperature: Scripps Inst. Oceanography Bull., tech. ser., v. 3, p. 158-164.

Gee, H. C., 1938, A model study of Cabrillo Beach Los Angeles, Californ1a: M. S. thesis, Univ. Calif., Berkeley, 54 p. incl. 12 pls., photos., flgs.

Gerhardt, J. R. and John, K. H., 1954, A comparison of atep, pressure, and continuous wire gage wave recording in the Golden Gate Channel: Am. Geophys. Union Trans., v. 35, p. 376-376 (abs.).

Gester, G. C., 1927, Origin and accumulation of oil in California: Geol. Soc. America Bull., proc. for 1926, v. 38 ; p. 200-202 (abs.).

Glbbs, R. E., 1900, Phyllospadix as a beach-builder; M. S. thesis, Univ. Calif., Berkeley.*

Gibson, W. M., 1951, Sand wave in San Francieco Bay: U. S. Coast and Geod. Survey Jour., no. 4, p. 54-58.

Gilbert, G. K., 1917, Hydraulic-mining debris in the Sierra Nevada: U. S. Geol. Survey Prof Paper 105, 154 p., 34 ple., 33 fige., 46 tables. *

Gilbert, J. C., and Simon, J. H., 1933, Marine oll drilling in California: Petroleum World (London), v. 30, p. 327329; Petroleum World, p. 15-18.

Gilbert, J. Y., and Allen, W. E., 1943, The phytoplankton of the Gulf of California obtained by the E. W. Scrippe in 1939 and 1940: Jour. Marine Research, v. 5, p. 89-110.

Gillespie, C. G., 1936, Protection of beacher from sewage pollution: Shore and Beach, v. 4, p. 125-127, discusaion 127-128.

Gillette, C. E., 1905, seacoast harbors in the United States: Internat. Eng. Cong., paper no. 14; Am. Soc. Civil Eng. Trans., v. 54, A., p. 297-324, 2 pls.

Gilluly, J., 1949, Diatribution of mountain building in geologic time: Geol. Soc. America Bull., v. 60 , p. 561590.

Gilluly, J., and Grant, U. S., 1947, Subsidence in the Long Beach Harbor area, California: Geol. Soc. America Bull., v. 58, p. 1251 (abs.); v. 60 (1949), p. 461-530.

Gislën, T., 1943, Phyriographical and ecological inveatigations concerning the littoral of the North Pacific, section 1 , A comparison between the life-conditions in the littoral of central Japan and California: Kungl. Fysiogrefiaka
Sãllskapets Handlingar N. F., band $54, \mathrm{nr} .5, \mathrm{p} .1-64$, 4 plo.

Giblén, T., 1944, Phyriographical and ecological investigations concerning the littoral of the North Pacific, sections 2-4, Regional conditions of the Pacific coset of America and their significance for the development of marine life: Kungl. Fyaiografiska Sillakapets Handlingar $N_{\text {. F. }}$, band 55, nr. 8, p. 1-91, $1 \mathrm{pl}$.

Gleason, D., 1951, Islands of California: Los Angeles, Sea Pub. Co., Inc., 104 p. *

Göes, A., 1896, The Foraminifera, in Reports on the dredging operations off the west coast of Central America to the Galapagos, to the west coast of Mexico, and in the Gulf of California, in charge of Alexander Agassiz, carrled on by the U. S. Fish Commission steamer Albatross, during 1891, Lt. Comdr. Z. L. Tanner, U. S. N., Comanding. Part XX: Mus. Comp. Zoology Bull., v. 29, no. 1, p. 1-103, 10 pls. incl. chart.

Goldberg, E. D., 1952, Iron assimilation by marine diatoma: Biol. Bull., v. 102, p. 243-248.

Goldberg, E. D., Baker, M., and Fox, D. L., 1952, Microfiltration in oceanographic research. I. Marine sampling with molecular filter: Jour. Marine Research, v. 11, p. 194204.

Goldberg, E. D., Walker, T. J., and Whisenand, A., 1951, Phosphate utilization by diatoms: Biol. Bull., v. 101, p. 274-284; Scripps Inst. Oceanography, SIO ref. 52-16, $10 \mathrm{p}$. incl. tables, diagrams.

Goldberg, E. D., 1954, Marine geochemistry I. Chemical scavangers of the sea: Jour. Geology, v. 62, p. 249-265.

Goldberg, J., 1940, The geological aignificance of the coartal terraces of the Santa Monica Mountains: M. A. thesis, Univ. Calif., Loa Angelea, 133 p., 18 pls., 3 figr., table.

Goodwin, J. C., and Thomson, J. N., 1954, Purlaima Pliocene Foraminifera of the Halfmoon Bay area, San Mateo County, California: Contr. Cushman Foundation for Foram. Research, v. 4, pt. 4, p. 170-178. (Also see Bandy, $0 . \mathrm{L}$. , in press).

Goodyear, W. A., 1873, Notes on the geology of the coast of Oregon: Calif. Acad. Sc1. Proc., v. 4 (1868-1872), p. 295-298.

Goodyear, W. A., 1889, San Diego Coungy: Calif. State Min. Bur., 8th Ann. Rept. State Mineralogiat, p. 516-528. Goodyear, W. A., 1890, Santa Cruz Irland: Calif. State Min. Bur., 9th Ann. Rept. State Mineralogist, p. 139-170.

Gordon, J. H., 1923, Tidal bore at mouth of Colorado River, December 8 to 10, 1923: Monthly Weather Rev., v. 52, p. $98-99$. *

Gorgy, S., Rakestraw, N. W., and Fox, D. L., 1948, Arbenic in the sea: Jour. Marine Research, v. 7, p. 22-32.

Gorsline, D. S., 1954, Sedimentation in Sebatian Vircaino Bay and vicinity, Baja California, Mexico: M. S. thesis, Univ. Southern Calif., 83 p. incl. 25 figs., 2 tables.

Gorton, A. F., 1930a, Long-range weather forecasting: Electrical West, v. 65 , p. 112-115.

Gorton, A. F., 1930b, Forecasting seasonal precipitation. Its relation to electrical power production: Am. Inst. Electrical Engineera Jour., v. 49, p. 996-1001.

Gorton, A. F., 1930c, The problem of seasonal weather forecarting in California: Fourth Pacific Sc1. Cong. Proc., v. 2B, p. 1029-1030 (abs.).

Gorton, A. F., 1931a, La Jolla ocean temperature and their value as indicies of atmospheric temperature and domestic gas consumption during the winter season: Am. Meteorol. Soc. Bull., v. 12, p. 163 (abr.).

Gorton, A. F., 1931b, Deficiency in rainfall forecast based on ocean temperature readings: Calif. C1trograph, p. 6 .

Gorton, A. F., 1932, A study of the interrelation between air-temperature in California and ocean-temperatures in the north-east Pacific and its influence on long-range forecasting: Am. Geophys. Union Trans., 13th ann. meet., p. 128-131.

Gorton, A. F., 1933, Revised temperature-formulae for predicting 
seasonal precipitation and runoff in California: Am. Geophys. Union Trans., 14th ann. meet., p. 461.

Gorton, A. F., 1934, Pacific ocean indicators of California's seasonal precipitation: Fifth Pacific Sci. Cong. Proc., v. 3, p. 1767-1773.

Gorton, A. F., and Partridge, A. G., 1930, Note on progres of seasonal weather forecasting in California: Am. Meteorol. Soc. Bull., v. 1l, p. 149-150.

Graham, H. W., 1934, The distribution of the plankton of the Pacific as related to some physical and chemical conditions of the water: Fifth Pacific Sci. Cong. Proc., v. 3, p. 2035-2043.

Graham, H. W., 194la, Plankton production in relation to character of water in the open Pacific: Jour. Marine Research, v. 4, p. 189-197.

Graham, H. W., 1941b, An oceanographic consideration of the dinoflagellate genus Ceratium: Ecol. Mon., v. ll, p. 99-116.

Graham, H. W., 1943, Cblorophyll-content of marine plankton: Jour. Marine Research, v. 5, p. 153-160.

Graham, H. W., and Gay, H., 1945, Season of attachment and growth of sedentary marine organisms at oakland, California: Ecology, v. 26, p. 376-386.

Graham, H. W., and Moberg, E. G., 1944, Chemical results of the last cruise of the Carnegie, Chemistry - I, in Scientific results of cruise VII of the Carnegie during 1928-1929 under command of Captain J. P. Ault: Carnegie Inst. Wash., Dept. Terrestrial Magnetism, pub. 562, 58 p. incl. 23 figs.

Grant, U. S., 1936, Summary of the marine Pleistocene of California: Geol. Soc. America Bull., proc. for 1935, v. 47, p. 349-350 (abs.).

Grant, U. S., 1938, Geological problems involved in the conservation of beaches: Pacific Southwest Acad. pub. 16 , p. 27-28.

Grant, U. S., 1939, Preliminary report on a geological investigation of Long Beach tidelands: Rept. to the Long Beach Harbor Dept. *

Grant, U. S., 1940, Barrier beach formation at Long Beach, California: Geol. Soc. America Bull, v. 5l, p. 19571958 (abs.).

Grant, U. S., 1941, Preliminary report on differential areal subsidence of the eastern part of Terminal Island, Long Beach, California: Rept. to the Board of Harbor Commissioners, City of Long Beach, dated Aug. 14, 1941. Also supplementary report on areal subsidence of Terminal Island, Long Beach, California, during July, August, and September 1941. *

Grant, U. S., 1943, Waves as a sand-transporting agent: Am. Jour. Sci., v. 241, p. 117-123; Shore and Beach, v. 11, p. $46-48,52$

Grant, U. S., 1944, Subsidence and elevation in the Los Angeles region, in Sci. in the Univ., Berkeley and Los Angeles, Univ. Calif. Press, p. 129-158.

Grant, U. S., 1946, Effect of ground-water table on beach erosion: Geol. Soc. America Bull., v. 57, p. 1252 (abs.).

Grant, U. S., 1948, Influence of the water table on beach aggradation and degradation: Jour. Marine Research, v. 7 , p. $655-660$.

Grant, U. S., and Gale, H. R., 1931, Catalogue of the marine Pliocene and Pleistocene Molluaca of California: San Diego Soc. Nat. History Mem. 1, 1036 p., 32 pls., 15 figs.

Grant, U. S., and Shepard, F. P., 1937, Changes along the California coat: Geol. Soc. America Bull., proc. for 1936, v. 48, p. 75-76 (abs.).

Grant, U. S. and Shepard, F. P., 1938a, Short-period oscillations of southern California beaches and adjacent sea floor: Geol. Soc. America Bull., proc. for 1937, v. 49, p. $84-85$ (abs.).

Grant, U. S., and Shepard, F. P., 1938b, Magnitude of some shore processes in southern California: Geol. Soc. America Bull., proc. for 1937, v. 49, p. 239-240 (abs.).

Grant, U. S., and Shepard, F. P., 1940, Shallow-water sedimentshifting processes along the southern California coast: Sixth Pacific Sc1. Cong. Proc., v. 2, p. 801-805.

Grant, U. S., and Shepard, F. P., 1946, Effect of type of wave breaking on shore proceses: Geol. Soc. America Bull., v. 57, p. 1252 (abs.).

Grant, U. S., and Sheppard, W. E., 1939, Some recent changes of elevation in the Los Angeles Basin of southern California, and their posaible significance: Seismol. Soc. America Bull., v. 29, p. 299-326.
Granthem, K. N., 1952, Ellwood field pile studies: Experimental determination of the coefficient of mass: Univ. Calif., Berkeley, Inst. eng. research, ser. 35 , issue $8,6 \mathrm{p}$.

Granthem, K. N., 1953, Run-up of ocean waves on breakwaters: M. S. thesis, Univ. Calif., Berkeley, 51 p. incl. photos, figs. (App. "Design of rubble-mound breakwater for Hunters Point Naval Shipyard, San Francisco, California").

Great Britain Hydrographic office, 1866, Wind and current charts for Pacific, Atlantic and Indian Oceans: London, 6 folded maps. Similar maps exist for later years.

Great Britain Meteorological office, 1950, Monthly meteorological charts of the eastern Pacific Ocean: London, H. M. Stationary office, 122 p., 320 charts. At head of title: M. 0. 518 (formerly M. 0. M. 446).

Greater Los Angeles Citizens Committee, Incorporated, 1944, Shoreline development study, Los Angeles County, California. April.*

Green, C. K., 1946, Seismic sea wave of April 1, 1946, as recorded on tide gages: Am. Geophys. Union Trans., v. 27 , p. $490-500$.

Green, J. L., and Smyser, R. E., Jr., 1932, River and tides and applications of Airy's theory to the Sacramento River, California: B. S. thesis, Univ. Calif., Berkeley.

Greenberg, D. M., Moberg, E. G., and Allen, E. C., 1932, Determination of carbon dioxide and titratable base in sea water: Indus. and Eng. Chemistry, Analytical Ed., v. 4, p. 309 .

Greene, C. S., 1892, Lo Farrallones de los Frayles: Overland Monthly, ser. 2, v. 20, no. 117, p. 226-246. *

Greene, E. L., 1886, Santa Cruz Island: West Am. Scientiat, v. 3, p. $1-4$

Greene, E. L., 1887, Studies in the botany of California and parts adjacent: Calif. Acad. Sci. Bull., v. 2 (1886-1887), p. $377-448$.

Greenwell, W. E., 1858, Report on the survey, character, and recource of the island and mainland adjacent to Santa Barbara Channel, California: Rept. U. S. Coast Survey 1857, app. 44, p. 392-395, sketch 56.

Gregor, H. F., 1952, The southern California water problem in the oxnard area: Geog. Rev., v. 42, p. 16-36.

Gregory, H. E., 1915, The formation and distribution of fluviatile and marine gravels: Am. Jour. Sc1., 4th ser., v. 39 , p. 487-508.

Griezbach, J. 0., 1947, Fulguite and physiographical memoranda of San Clemente Island, California: Rocks and Minerals, v. 22, no. 12, p. 1119-1121.

Griffin, D. F., 1944, Cosstline plans and action for the development of the Los Angeles metropolitan coastline: Los Angeles, Haynes Foundation, $38 \mathrm{p}$. incl. 1llus.

Griggs, A. B., 1945, chromite-bearing sands of the southern part of the coast of oregon: U. S. Geol. Survey Bull. 945-E, v. p., 113-150, 11 pls., 3 figs., maps, 4 tables.

Griggs, A. B., and Wells, F. G., 1942, origin of some chromiferous sands along the southwestern oregon Coast: Geol. Soc. America Bull., v. 53, p. 1802 (abs.).

Grim, R. E., Dietz, R. S., and Bradley, W. F., 1949, Clay mineral composition of some sediments from the Pacific ocean off the California coast and the Gulf of California: Geol. Soc. America Bull., v. 60, p. 1785-1808.

Gross, В. E., 1945, Marine petroleum possibilities: Petroleum Eng., July 1 , p. $76,78-82$.

Grunsky, C. E., 1907, The problem of the lower Colorado River: Typed manuscript in form of a report to the Secretary of the Interior, dated June 30. Copy at general library of the Univ. Callf., Berkeley. * 
Grunsky, C. E., 1921, Report of the sub-committee on hydrography of San Francisco Bay, in Report on San Francisco Bay Marine Piling Survey, v. I, p. 12-23. *

Gulliver, F. P., 1896, Cuspate forelands: Geol. Soc. America Bull., v. 7, p. 399-422.

Gunn, R., 1947, Quantitative aspects of juxtaposed ocean deeps, mountain chains, and volcanic rangea: Geophysics, v. 12, p. 238-255. *

Uutenberg, B., 1933, Is present tilting in North America due to glacial melting? Geol. Soc. America Bull., proc for 1932, v. 44, p. 152-153 (abs.).

tenberg, B., 1934, The tructure of the earth's crust as indicated by seismological data: Fifth Pacific Sci. cong. Proc., v. 3, p. 2511-2521, discussion p. 2533.

enberg, B., 1936a, on microseisms: Seismol. Soc. America Bull., v. 26, p. 111-117.

atenberg, B., 1936b, Structure of the earth's crust and the spreading of the continents: Geol. Soc. America Bull., v. 47, p. 1587-1610; Geol. Soc. America, proc. for 1936, p. 306-307 (abs.).

tenberg, B., 1939, Tsunamis and earthquakes: Seismol. Soc. America Bull., v. 29, p. 517-526;

Gutenberg, B., 1941a, Mechanism of faulting in southern Cal1fornia indicated by seismograms: Seismol. Soc. America Bull., v. 31, p. 263-302; Geol. Soc. America Bull., v. 52 , p. 1950 (abs.).

Gutenberg, B., 1941b, Changer in sea level, postglacial uplift, and mobility of the earth's interior: Geol. Soc. America Bull., v. 52, p. 721-772.

Gutenberg, B., 1943, Earthquake and structure in southern California: Geol. Soc. America Bull., v. 54, p. 499-526.

tenberg, B., 1950, Earthquakes in North America: Science, v. 111 , p. 319-324.

tenberg, B., 1953, Microseisms, microbaroms, storms, and wave in western North America: Am. Geophys. Union Trans., v. 34, p. 161-173.

tenberg, B., and Buwalda, J. P., 1935, Seismic reflection profile across Los Angeles Basin: Pan Am. Geologist, v. 63, p. 303; Geol. Soc. America Bull., proc. for 1935, v. 47 (1936), p. 327-328 (abs.); U. S. Geol. Survey Geophys. Abs. Bul1., 895-B: 59.

Gutenberg, B., and Richter, C. F., 1937, Depth and geographical distribution of deep-focus earthquakes: Geol. Soc. America Bul1., proc. for 1936, v. 48, p. 341 (abs.); v. 49 (1938), p. 249-288.

tenberg, B., and Richter, C. F., 1939, Depth and geographical distribution of deep-focus earthquakes (second paper): Geol. Soc. America Bull., v. 50, p. 1511-1528.

tenberg, B., and Richter, C. F., 1940, Seismicity of the earth: Geol. Soc. America Bull., v. 51, p. 1958 (abs.); Geol. Soc. America Special Paper 34, (1941), 131 p.; Geol. Soc. America Bull., v. 56 (1945), p. 603-688 (supplementary paper).

enberg, B., and Richter, C. F., 1949, Seismicity of the earth and associated phenomena: Princeton Univ. Press, $273 \mathrm{p}$.

enberg, B., Richter, C. F., and wood, H. O., 1932, The earthquake in Santa Monica Bay, California, on August 30, 1930: Seismol. Soc. America Bull., v. 22, p. 138$154, \mathrm{p} 1 \mathrm{~s} .11,12$

tenberg, B., Wood, H. O., and Buwalda, J. P., 1932, Experiments testing seimographic methods for determining crustal structure: Seismol. Soc. America Bull., v. 22, p. 185-246, p18. 19-23.

Hase, L. G., 1926, Little geological studies in southern california: Long Beach Calif., privately printed, 24 p. (copy at Univ. Southern Calif. Library).

\{aley, S., 1886, Japanese earthquake of 1856 causes tidal wave on California Coast: West Am. Scientist, v. 2, p. 62 (abs.).

all, F. R., 1952, Geology of the southwestern portion of the Las Flore quadrangle, Los Angeles county, California: M. A. thesis, Univ. Calif., Los Angeles, 44 p., 3 pls., 7 figs.

Aall, J. V., Jr., 1952, Artificially nourished and constructed beaches: U. S. Army, Corps of Engineers, Beach Erosion Board, Tech. Memo. 29, 25 p.; Third Conf. Coastal Eng., Berkeley, (1953), p. 119-136.
Hall, T., 1943, The Los Angeles sewage disposal problem, a report by the Municipal and County government section: Dec.* $*$

Hall, W. C., 1938, A model atudy of beach erosion: M. S. thesis, Univ. Calif., Berkeley, 42 p., 5 pls., photos, tables, diagrams.

Hall, W. C., 1941, A model study of effect of submerged breakwaters on wave action: Shore and Beach, v. 9 , p. 50-55, 61-62.

Hall, W. C., 1942, Beach protection measures: Military Engineer, v. 34, no. 200, p. 292-296; Shore and Beach, v. 10, p. $60-64$.

Hall, W. H., 1886, Physical data and statistics of California. Table and memoranda of data: Sacramento, $547 \mathrm{p}$.

Halton, J. E., Holden, E. R., 1950, Beach and stabilization thermite method: Naval Civil Eng. Research and Evaluation Lab., Port Hueneme, Calif., final memo, Aug. 25, 11 p. incl. illus., tables, Tech. Memo M-011. *

Hammond, E. H., 1951, Landforms of the Cape region, Baja California: Ph. D. thesis, Univ. Calif., Berkeley. *

Handin, J. W., 1949, The source, transportation, and deposition of beach sediment in southern california: $\mathrm{Ph}$. D. thesis, Univ. Calif., Los Angeles, 178 p., 12 pls; U. S. Army, Corps of Engineers, Beach Erosion Board Tech. Memo. 22, (1951), 126 p. incl. 21 tables, $12 \mathrm{pls}$.

Handin, J. W., 195l, The geological aspects of cosstal engineering: First Conf. on Cosstal Eng. Proc., Berkeley, p. 133-136.

Handin, J. W., and Ludwick, J. C., 1949, Accretion of beach sand behind a detached breakwater: Scripps Inst. oceanography, Submarine Geology Rept. no. 8, 15 p. 1 pl., 1 fig; U. S. Army, Corps of Engineers, Besch Erosion Board Tech. Memo. 16 (1950), 13 p

Hann, J., 1887, AtIas der Meteorologie: Gotha, Justur Perthes, 12 kolorierte Karten in Kupferstich mit 61 Darstellungen.

Hanna, G. D., 1925a, Tertic expanse of North American continent in Pacific Ocean: Pan Am. Geologist, v. 44, p. 147.

Hanna, G. D., 1925b, Was there a Pacific continent? Science, v. 62, no. 1613, p. $491-492$

Hanna, G. D., 1926, Expedition to the Revillagigedo Islands, Mexico, in 1925. I. General report: Calif. Acad. Sci. Proc., v. 15, p. 1-113.

Hanna, G. D., 1927, Geology of west Mexican islands: Pan Am. Geologist, v. 48, p. $1-24,8$ pls.

Hanna, G. D., 1928, The age of the diatom-bearing shale at Malaga Cove, Los Angeles County, California: Am. Assoc. Petroleum Geologists Bull., v. 12, p. 1109-1111.

Hanna, G. D., 1932, Desmostylus tooth dredged in Monterey Bay: Geol. Soc. America Bull., v. 43, p. 291 (abs.).

Hanna, G. D., 1951, Geology of the Farallon Irlands, in Geologic guidebook of the San Francisco Bay Counties, Calif. Div. Mines, Bull. 154, p. 301-310.

Hanna, G. D., 1952, Geology of the continental slope off central California: Calif. Acad. Sci. Proc., v. 27, p. 325-358, ple. 7-14.

Hanna, G. D., and church, C. C., 1927, A collection of Recent Foraminifera taken off San Francisco Bay, California Jour. Paleontology, v. 1, p. 195-202

Hanna, G. D., and Grant, W. M., 1926, Expedition to the Revillagigeo Islands, Mexico, in 1925. II. Miocene marine diatoms from Maria Madre Ioland, Mexico: Calif. Acad. Sci. Proc., v. 15, p. 115-193.

Hanna, M. A., 1926, Geology of the La Jolla quadrangle, California: Univ. Calif. Pub. Geology, v. 16, p. 127-246.

Hannum, W. T., 1944, Future beach planning for California: Shore and Beach, v. 12, p. 61-62.

Hannum, W. T., 1947, California's tate beach program: Shore and Beach, v. 15, p. 35-38 incl. discussion.

Hansen, H. A., and Pemberton, J. R., 1950, Reducing the risk in the offahore gamble: Petroleum World, v. 47 , no. 5, May, p. $2,3,5,6,8,10-12$. 
Harding, C. R., 1929, Location and design of Southern Pacific Company's Sulsun Bay Bridge as affected by consideration of earthquakes: Seismol. Soc. America Bull., v. 19, p. 162-166, pls. 15-18.

Harding, M. W., 1932, The quantity and significance of boron in sea water: M. S. thesis, Univ. Callf., 20 p., 3 figs.

Harding, M. W., and Moberg, E. G., 1934, The determination and quantity of boron in sea water: Fifth Pacific Sci. Cong. Proc., v. 3, p. 2093-2095.

Harney, L. A., Seur, J. F. T., Jr., and Robinson, A. R., 1949, A statistical study of wave conditions at four open-sea localities in the North Pacific ocean: Natl. Advisory Comm. for Aeronautics, tech. note TN 1493, 28 p. inc. tables, diagrams.

Harris, F. R., and Harlow, E. H., 1947, Subsidence of the Terminal Island-Long Beach area, California: Am. Soc. C1vil Eng. Proc., v. 73, p. 1197-1218; Am. Soc. C1vil Eng. Trans., v. 113 (1948), p. 375-396, discussion $397-403,788-792$.

Harts, W. W., 1901, Description of CoOs Bay, Oregon, and the improvement of its entrance by the government: Am. Soc. Civil eng. Trans., v. 46, p. 482-506, discuseion p. 507-550.

Harta, W. W., 1911, Harbour improvements on the Pacific Cosst of the United States: Inst. Civil. Eng., London, Proc., v. 183, p. 231-251, p1. 6 .

Harvey, D. R., 1928, Plankton of Mission Bay, San Diego, California: M. A. thesis, Untv. Southern Calif., 128 p. incl. 36 figures, tables and graphs.

Hasskar1, J. F. L., 1912, The more recent types of breakwater construction and the unit cost of several of importance in the U. S.: Eng. and Contracting, v. 37, p. 717-720.

Havemann, H., 1952, The earth's face determined by the core: Am. Geophys. Union Trans., v. 33, p. 749-754.

Hawgood, H., 1914, Los Angeles Harbour, California: Inst. Civil Eng., London, Proc., v. 195, p. 213-234.

Heck, N. H., 1924, A deep off the cosst of Mexico and Central America: Seismol. Soc. America Bull., v. 14, p. 200.

Heck, N. H., 1926, Earthquake epicenters in the North Pacific: Seismol. Soc. America Bull., v. 16, p. 182-186.

Heck, N. H., 1934, The earthquake services of the north-east Pacific region: Fifth Pacific Sci. Cong. Proc., v. 3, p. $2357-2363$.

Heck, N. H., 1938, Earthquakes and the western mountain region: Geol. Soc. America Bull., v. 49, p. 1-22.

Heck, N. H., 1947, List of selsmic sea waves: Seismol. Soc. America Bull., v. 37, p. 269-287. (First pub. in Internat. Geod. and Geophys. Union, Comm. pour. I'Elude des Raz de Maree, no. 4 (1934), p. 20-41).

Heck, N. H., and Bodle, R. R., 1930, U. S. earthquakes 1928: U. S. Cosst and Geod. Survey, serial 483, $29 \mathrm{p}$.

Heck, N. H., and Bodle, R. R., 1931, U. S. earthquakes 1929: U. S. Cost and Geod. Survey, serial 511, 55 p.

Heck, N. H., and Neumann, F., 1942, Earth motions in the vicinity of a fault slip: Geol. Soc. America Bull. v. 53, p. $179-194$.

Heck, N. H., and Service, J., 1926, Correct velocities for echo sounding in the Pacific Ocean: Science, v. 64, no. 1669 , p. 627-629.

Heiskanen, w., 1939, Catalogue of the isostatically reduced gravity stations: Isostatic Inst., Internat. Assoc. Geodesy pub. 5, Helsinki, 139 p.

Heizer, R. F., 1943, Aboriginal use of bitumen by the california Indians: Calif. Div. Mines Bull. 118, p. 74

Helzer, R. F, and Treganza, A. E., 1944, Mines and quarries of the Indians of California: Calif. Div. Mines Rept. 40 , p. 291-359.

Helfand, S., 1927, The distribution and association of marine shell-bearing mollusks and brachiopods of California, from Point Dure to Newport, as discovered by the dredgings of the launch Anton Dohrn; M. A. thesis, Univ. Southern Calif., 250 p., 19 maps.
Henderson, J., 1932, Caverns, ice caves, sink-holes, and natural bridges: Univ. Colorado Studies, v. 19, no. 4, p. 359-405, v. 20 (1933), nos. 2, 3, p. 115-158.

Herold, C. L., 1934, Fossil markings in the Carmelo Series (Upper Cretaceous ( ?), Point Lobos, California: Jour. Geology, v. 42 , p. 630-640.

Hershey, O. H., 1902, The Quaternary of southern California: Univ. Calif. Pub. Geology, v. 3, p. 1-30.

Hershey, O. H., 1903, Certain river terraces of the Klamath region, Callfornia: Am. Jour. Sc1., 4th ser., v. 16, p. $240-250$.

Hertle1n, L. G., 1928, Preliminary report on the peleontology of the Channel Islands, California: Jour. Paleontology, v. 2, p. 142-157, pls. 22-25.

Hertlein, L. G., and Grant, U. S., 1939, Geology and oil possibilities of southwestern San Diego County: Calif. Jour. Mines and Geology, v. 35, p. 57-78, map.

Hertlein, L. G. and Grant, U. S., 1944, The geology and paleontology of the marine Pliocene of San Diego, California, Part 1, Geology: San Diego Soc. Nat. Hist. Mem., v. 2, 72 p., 18 pls. *

Hertlein, L. G., and Emerson, W. K., 1953, Mollusks from clipperton Island (eastern Pecific) with the description of a new species of gastropod: San Diego Soc. Nat. History Trans., v. 11, p. 345-364, pls. 26, 27.

Hertlein, L. G., and Strong, A. M., 1940, Mollusks from the west coast of Mexico and Central America. Part I.: Zollogica, v. 25 , no. 25 , p. 369-430. Part II, v. 28 (1943), no. 19, p. $149-167$.

Hess, H. H., and MacClintock, P., 1936, Submerged valleys on continental slopes and changes of sea level: Science, v. 83 , no. 2153 , p. 332-334.

Hesse, R., Allee, W. C., and Schmidt, K. P., 1937, Ecological animal geography: New York, John Wiley and Sons. *

Hewatt, W. G., 1934, Ecological studies on selected marine intertidal communities of Monterey Bay: $\mathrm{Ph}$. D. thesis, Stanford univ., 1950 p., illus., pls.; Am. Midland Naturalist, v. 18 (1937), p. 161-206.

Hewatt, W. G., 1946, Mar1ne ecological studies on sante Cruz Island, California: Ecol. Mon., v. 16, p. 185-210.

Hickson, R. E., and Rodolf, F. W., 1951, Design and construction of jetties: First Conf. on Cosstel Eng. Proc., Berkeley, p. 227-245.

Hidaka, K., 1953, A contribution to the theory of upwelling and cosstal currents: Am. Geophys. Union Trans., v. 34 , p. 341 (abs.); v. 35 (1954), p. 431-444.

Hill, C. L., and Kofoid, C. A., 1927, Marine borers and their relation to marine construction on the Paciffc Coast: San Francisco Bay Marine Piling Comm., Final Rept., Univ. Calif. Press, San Francisco, 357 p.

Hill, M. L , 1928, Mechanics of faulting near Santa Barbara, California: Jour. Geology, v. 40, p. 535-556.

Hill, M. L., and Dibblee, T. W., Jr., 1953, San Andreas, Garlock, and Big Pines Fault, California: A study of the character, history, and tectonic significance of their displacements: Geol. Soc. America Bull., v. 64 , p. 443-458.

H111, R. T., 1928a, Transcontinental structural digression: Geol. Soc. America Bull., proc for 1927, v. 39, p. 265 (abs.).

Hill, R. T., 1928b, Southern California geology and Los Angeles earthquakes: Los Angeles, Pub. by Southern Calif. Acad. Sci., 232 p., illus., 4 ple.

Hill, R. T., 1929, Classification of the Pleistocene of California: Science, v. 69 , no. 1788 , p. 379-380.

Hinde, H. P., 1952, vertical distribution of salt marsh phanerogams in relation to tide levels: $\mathrm{Ph}$. D. thesis, Stanford Univ., 93 p., 6 tables, 5 pls., 8 figures.

Hinds, N. E. A., 1952, Evolution of the California landscape: Calif. Div. Mines Bull. 158, 240 p., IIlus., mape.

Hjelte, G., 1936, The beaches a a recreational asset: Shore and Beach, v. 4, p. 24-29, discussion p. 29-31. 
jelte, G., 1938, Progress and problems in California beach preservation: Shore and Beach, v. 6, p. 108-109, discussion p. 109-110.

obbs, W. H., 1916, Assumptions involved in the doctrine of isostatic compensation, with a note on Hecker's determination of gravity at sea: Jour. Geology, v. 24, p. $690-717$.

obbs, W. H., 1921, Crustal deformation in the Pacific and Atlantic regions: (reol. Snc. America Bull., proc. for 1920 , v. 32, p. 32-33 (abs.).

obbs, W. H., 1931, Earth features and their meaning: New York, Macmillan Co., 2nd ed.

obbs, W. H., 1944, New volcanoes and a new mountain range: Science, v. 99, no. 2572 p. 287-290.

ochstetter, F., 1868, uber das Erdbeben in Peru am 13 August 1868 und die dadurch veranlassten Fluthwellen in Pacifischen Ocean: Sitzungsberichte der Kaiserlichen Akad. der Wissenschaften, Vienna, v. 58 , no. 4, p. $837-860$. *

odge, E. T., 1934, Volcanic and seismic history of oregon: Fifth Pacific Sci. Cong. Proc., v. 3, p. 2451-2460.

ofer, H., 1909, Die Geologie, Gewinnung und der Transport des Erdols, in Engler (c.) and Höfer, H., Das Erdol, Leipzig, lst ed., v. 2, 967 p. *

olden, E. S., 1895, Earthquake shock felt at sea off Cape Mondocino: Pubs. Astron. Soc. Pacific, v. 7, p. 131. * den, E. S., 1898 , Catalogue of earthquakes on the Pacific Coast, 1769 to 1897: Smithsonian Misc. Coll no. 1087, 225 p.

older, C. F., 1901, An 1sle of surmer, Santa Catalina; its history, climate, sports, and antiquities: New York, R. V. McBride, 89 p. *

older, C. F., 1910, The Channel Islands of California: Chicago, A. C. Mclurg and Co., 397 p., illus. *

ollenback, M., 1941, Islands of adventure: Los Angeles Mus. Quarterly, v. 1, p. 2l-24. *

olmes, L. C., and Pendleton, R. L., 1918, Reconnaissance soil survey of the San Diego region, California: U. S. Dept. Agriculture, Bur. Soils, 1.*

oltsmark, B. E., 1949, The SOFAR project: Hawailan oceanographic survey, USS Fieberling, February to July 1947: U. S. Navy Electronics Lab., San Diego, Calif., oct. 28,58 p. incl. illus., diagrams. *

olway, R. S., 1904, Cold water belt along the west coast of the United States: M. S. thesis, Univ. Calif., Berkeley; Univ. Calif. Pub. Geology, v. 4 (1905), p. $263-286$.

olway, R. S., 1914, Physiographically unfinished entrances to San Francisco Bay: Univ. Calif. Pub. Geography, v. 1 , no. 3 , p. $81-126$, pls. 12-20.

olzman, J. E., 1950, Submarine geology of Cortes and Tanner Banks: M. S. thesis, Univ. Southern Calif., 49 p., 8 pls., 6 tables, 6 figures; Jour. Sed. Petrology, v. 22 (1952), p. 97-118.

onda, K., 1906, on the velocity of sea waves through the Pacific: Tokyo Sugaku-Buturigakkwai Kizi (proc. Tokyo Physical-Math. Soc.), v. 3, p. 165-169.*

oots, H. W., 1943, Origin, migration, and accumulation of oil in California: Calif. Div. Mines Bull. 118, p. $253-275$.

ots, H. W., Blount, A. L., and Jones, P. H., 1935, Marine oil shale, source of oil in Playa del Rey Field, California: Am. Assoc. Petroleum Geologists Bull., v. 19, p. $172-205$.

oover, J. 'N., 1932a, The littoral of northern California as a geographic province: Geogr. Rev., v. 23, p. 217229.

oover, J. W., 1932b, Ceomorphic littoral of northern California: Geol. Soc. America Bull., proc. for 1931, v. 43, p. 246 (abs.).
Hoover, M. B., 1934, The Farallon Islands: Stanford Univ. Press, 2nd ed., 18 p.*

Hoover-Young San Francisco Bay Bridge Commission, 1930, San Francisco Bay Bridge: Rept. of Hoover-Young Corm. to the President of the U. S. and the Governor of the State of Calif., 234 p., incl. 54 pla., tables.

Hornor, R. R., 1918, Notes on the black sand deposits of southern oregon and nor thern California: U. S. Bur. Mines Tech. Paper 196, 39 p., 8 pls.

Horonjeff, R., and Patrick, D. A., 1952, Action of marine borers and protective measures against attack: Second Conf. on Coastal Eng. Proc., Berkeley, p. 86-99.

Horrer, P. L., 1948a, Salinity as a tracer of upwelled water off southern California: Scripps Inst. Oceanography, Marine Life Research, physical oceanography III, tech. rept. no. 1,3 p.

Horrer, P. L., $1948 \mathrm{~b}$, Southern. swell and waves from a tropical storm at Long Beach, California: Scripps Inst. Oceanography, Wave Rept. 76 , 11 p., diagrams.

Horrer, P. L., 1949, Wave forces computed for a typical of fshore drilling site: Jour. Petroleum Tech., v. 1, no. 12 ; p. 299-304.

Horrer, P. L., 1950, Southern hemisphere swell and waves from a tropical storm at Long Beach, California: U. S. Army, Corps of Engineers, Beach Erosion Board Bull., v. 4 , no. 3 , p. $1-18$.

Horton, D. F., 1948, Shore effects of coastal structures: Military Eng., v. 40, no. 275 , p. 402-405, incl. 9 figs.

Hovick, J., 1945, Deep water wave measurements - V: Univ. Calif., Berkeley, fluid mechanics lab., tech. rept. HE-116-148, July 23, 11 p. photos, sketches, charts.

Howard, A. D., 1951, Development of the landscape of the San Francisco Bay Counties: Calif. Div. Mines Bull. 154 , p. $95-106$.

Howard, I., 1937, A quantitative study of marine phytoplankton from the Hancock Pacific Expeditions of 1933 and 1937: M. S. thesis, Univ. Southern Calif., 69 p., incl. 2 graphs, 16 tables, 2 maps.

Howe, H. V., 1926, Astoria: Mid-Tertic type of Pacific Coast: Pan Am. Geologist, v. 45, p. 295-306.

Hubbs, C. L., 1948, Changes in the fish fauna of western North America correlated with changes in ocean temperature: - Jour. Marine Research, v. 7, p. 459-482.

Hubbs, C. L., and Rechnizer, A. B., 1952, Report on experiments designed to determine effects of underwater explosions on fish life: Calif. Fish and Game, v. 38 , p. $333-366$.

Hudson, R. Y., and Moore, L. F., 1951, The hydraulic model as an aid in breakwater design: First conf. on Coastal Eng. Proc., Berkeley, p. 205-212.

Hughes, R. T., 1946, Gamma instrument - sunken ray recorder: Univ. Calif., Berkeley, fluid mechanics lab., tech. rept. HE-116-209, May 7, 3 p., diagram.

Hughes, R. T., 1947, Notes on observed surge at Berkeley Yacht Harbor: Univ. Calif., Berkeley, fluid mechanics lab., tech. rept., HE-116-239, March 18, I p., chart, diagrams.

Hughes, R. V., 1932, Theories on origin of petroleum: Pan Am. Geologist, v. 58 , p. 81-92.

Hundhausen, R. J., 1947, Chromiferous sand deposits in the Coos Bay area, Coos County, Oregon: U. S. Bur. Mines Rept. Inv. 4001,13 p., 6 figs.

Hunter, R. C., 1946, Report on cooperative beach erosion study at Santa Barbara, California: U. S. Army, Corps of Engineers, Los Angeles dist., Nov. 22, 43 p. incl. 5 tables, 13 pls., *

Huntington, E., 1914, The solar hypothesis of climatic changes: Geol. Soc. America Bull., v. 25, p. 477-590. 
Hurd, W. E., 1943, Northers of Mexican and Central American waters: U. S. Hydrog. Office, pilot chart of the Central Am. Waters, Wash., Oct. *

Hutchins, L. W., and Scharff, M., 1947, Maximum and minimum monthly mean sea surface temperatures charted from the "World atlas of sea surface temperatures:" Jour. Marine Research, v. 6, p. 264-268, 2 pls.

Hutton, W. E., and ZoBell, C. E., 1949, The occurrence and characteristics of marine methane oxidizing bacteria in marine sediments: Jour. Bacteriology, v. 58, p. $463-473$.

Hyatt, E., 1933, Combating a saline invasion in California: Civil Eng., v. 3, p. 580.

Hyatt, E., 1934, The Central Valley Project of California: C1vil. Eng., v. 4, p. 482-486.

Hyatt, E., 1935, Combating a saline invasion in California: C1vil. Eng., v. 5, p. 580-582.

Hyde, C. G., Gray, H. F., and Rawn, A. M., 1941, Report upon the collection, treatment and disposal of sewage and industrial wastes of the East Bay Cities, California, made for the seven cooperating cities of the East Bay: A rept. made to the City of Berkeley by the Board of Consulting Engineers. *

Imray, J. F., 1870, North Paclfic Pilot: Part I. Salling directions for the west coast of North America between Panama and Queen Charlotte Islands: London, James Imray \& Son, 2nd ed., 380 p., pls. Part II by Rosser, W. H., Includes "The 1slands of the North Pacific Ocean etc." *

Inman, D. L., 1949, Report on beach study in the vicinity of Mugu Lagoon, California: Scripps Inst. 'Oceanography, Submarine Geol. Rept. 5, 30 p., 27 figs.; Scripps Inst. Oceanography, Submarine Geol. Rept. 10 (1950), 42 p.; U. S. Army, Corps of Engineers, Beach Erosion Board Tech. Memo. 14 (1950), $47 \mathrm{p}$.

Inman, D. L., 1950. Submarine topography and sedimentation in the vicinity of Mugu submarine canyon, California: U. S. Army, Corps of Engineers, Beach Erosion Board Tech, Memo. 19, 45 p. Incl. f1gs., tables: Scripps Inst. Oceanography, Submarine Geol. Rept. 10, $42 \mathrm{p}$.

Inman, D. L., 1953a, Beach and nearshore processes along the southern California coast: Scripps Inst. Oceanography, Submarine Geol. Rept. 27, SIO ref. 53-35, 8 p., 2 figs.

Inman, D. L., 1953b, Areal and seasonal variations in beach and nearshore sediments at La Jolla, California: Ph. D. thesis, Univ. Calif., Los Angeles, 170 p., inc. 3 tables, 27 f1gs.; U. S. Army, Corps of Engineers, Beach Erosion Board, Tech. Memo. 39, 82 p., incl. 27 figs., 3 tables; app. I, 33 p., tables; app. II, 9 p. tables; app. III, 2 p. tables.

Inman, D. L., and Quinn, W. H., 1952, Currents in the sure 2one: Scr1pps Inst: Oceanography, Submarine Geol. Rept. 23, SIO ref. 52-10, I March, 10 p., 9 figs; Second Conf. on Cosstal Eng. Proc., Berkeley, p. 24-36.

Irelan, W., Jr., 1890, Recovering auriferous gravel from sea beaches and river beds by means of dredges, submarine armor, and other apparatus: Calif. State Min. Bur., 9th Ann. Rept. State Mineralogist, p. 38-39.

Irvine, C. D., 1908, The beach placers of the south Pacific coast: M1n. World, v. 29, no. 9, p. 321-322.

Isaacs, J. D., 1945a, A device for traversing the surf zone of ocean beaches: Univ. Calif., Berkeley, fluid mechanics lab., tech. rept. HE-116-90, March 25, 3 p. photos.

Isaacs, J. D., 1945b, Plans for the study of beaches I: Univ. Calif., Berkeley, fluid mechanics lab., tech. rept. HE116-92, July 16, 2 p., tables, photos.

Isaacs, J. D., 1945c, Beach survey at Surf, California: Un1v. Calif., Berkeley, fluid mechanics lab., tech. rept. HE-116-130, July 9, 3 p., table, photos, graphs.

Isaacs, J. D., 1945d, Survey and reconnalssance of miscellaneous Pacific Coast beaches: Univ. Calif., Berkeley, fluid mechanics lab., tech. rept. HE-116-131, July 10, 3 p. photos, graphs.

Isaacs, J. D., 1945e, L1ttoral currents at Estero Bay: Unfv. Calif., Berkeley, fluid mechanics lab., tech. rept., HE-116-132, July 12, 6 p., tables, photo, graphs.

Isaacs, J. D., 1945f, Report on beach survey with sea sled and mast at Plsmo, California: Univ. Calif., Berkeley, fluid mechanics lab., tech. rept. HE-116-135, July 12,
1 p., graph.

Isaacs, J. D., 19458, Beach survey at Pismo Beach, California Univ. Calif., Berkeley, fluid mechanics lab., tech. rept. HE-116-139, 3 p., tables, photos, sraphs.

Isarcs, J. D., 1945h, Beach survey at Coranado Beach, Cal1fornia: Univ. Calif., Berkeley, fluid mechanics lab., tech. rept. HE-116-141, July 12, 2 p., graphs, sketches.

Isaacs, J. D., 19451, Beach survey at Oceano, California: Univ. Calif., Berkeley, fluid mechanics lab., tech. rept. HE-116-149, July 24, 2 p. table, photos, graphs.

Isaacs, J. D., 1945j, Beach survey at Estero Bay, California: Univ. Calif., Berkeley, fluid mechanics lab., tech. rept. HE-116-154, July 12,2 p., table, photo, graphs.

Isaacs, J. D., 1945k, Beach and surf conditions at Carmel Beach, July 24, 1945: Univ. Cal1f., Berkeley, fluid mechanics lab., tech. rept. HE-116-178, Oct. 26, 5 p., tables, photos, graphs.

Isaacs, J. D., 1945m, Beach and surf conditions at Point Joe Bight, July 26, 1945: Univ. Calif., Berkeley, fluid mechanics lab., tech. rept. HE-116-183, Nov. 8, 4 p., tables, photos, graph, map.

Isaacs, J. D., $1947 \mathrm{a}$, Beach and surf conditions on beaches of the oregon and Washington coast between August 27 and September 27, 1945: Univ. Calif., Berkeley, fluid mechanics lab., tech. rept. HE-116-229, April 16, 26 p. maps, photos, sketch, graphs, tables.

Isaacs, J. D., 1947b, Graph1cal construction of refraction diagrams directly by orthogonals: Univ. Calif. Berkeley, fluid mechanics lab. tech. rept. HE-li6-273, Nov. 2,7 p., diagrams. See Johnson, J. W., O'Brien, M. P., and Isaacs, J. D., 1948.

Isaac8, J. D., 1948, Discussion of "Refraction of surface wa ves by currents," by Johnson, J. W.: Am. Geophys. Union Trans., v. 29, p. 739-742. (Reply by J. W. Johnson on p. 742).

Isaacs, J. D., and Bascom, W. N., 1947, Report on operation and characteristics of U. S. Army Dukws in oceanographic investigations with emphasis on beach and surf factors: Univ. Calif., Berkeley, fluid mechanics lab., tech. rept. HE-116-266, sept. 17, 26 p., graphs, photos.

Isaacs, J. D., and Bascom, W. N., 1949, Water-table elevations in some Pacific Coast beaches: Am. Geophys. Union Trans. v. 30, p. 293-294; Univ. Calif., Berkeley, fluid mechanic lab., tech. rept. HE-116-238, 3 p. graphs, photos.

Isaacs, J. D., and Saville, T., Jr., 1948, A comparison between recorded and forecast waves on the Pacific cosst Univ. Calif., Berkeley, fluld mechanics lab., tech. rept. पूE-116-285, May 17, 8 p., weather chart, graph; New York Acad. Sc1. Annals, v. 51 (1949), p. 502-510.

Isaacs, J. D., Schorr, S., and Ch1nn, A. J., 1947, Records of waves on the Pacific Coast of Californla and oregon. General information on wind waves and swells for marine operations: Univ. Calif., Berkeley, fluid mechanics lab., tech. rept. HE-116-263, July 10 - Aug. 12, 9 p., tables, diagrams, map, chart, photos; app., addendum I, (3 repts.).

Isaacs, J. D., and Wiegel, R. L., 1950, The thermopile wave meter: Univ, Calif., Berkeley, Inst. eng. research, tech. rept. ser. 3, 1ssue 311, 6 p., 4 pls; Am. Geophys. Union Trans., v. 31, p. 711-716.

Iversen, H. W., 1945, Sighting bar for observations of breaker height and distance to breakers: Univ. Cal1f., Berkeley, fluid mechan1cs lab., tech. rept. HE-116-42, Jan. 3 , 5 p., graphs, diagrams.

Iversen, H. W., and Morison, J. R., 1951, Forces on p1ling final report: Univ. Calif., Berkeley, Inst. eng. research, ser. 35 , issue 5, 20 p., 5 tables, 13 pls.

Ives, R. L., 1951, High sea levels of the Sonoran shore: Am. Jour. Sc1., v: 249, p. 215-223.

Jacobs, W. C., 1939, Sea level departures on the Callfornia Coast as related to the dynamics of the atmosphere over the North Pacific Ocean: Jour. Marine Research, v. 2, p. $181-194$.

Jacobs, W. C., 1942, on the energy exchange between sea and atmosphere: Jour. Marline Research, v. 5, p. 37-66.

Jacobs, W. C., 1943, Sources of atmospher1c heat and molsture over the North Pacific and North Atlantic Oceans: New York Acad. Sc1. Annals, v. 44, p. 19-40.

Jacobs, W. C., 1949, The distribution and some effects of the seasonal quantities of $\mathrm{E}$ - P (evaporation minus precipitation) over the North Atlantic and North Pacif1c: Arch1v für Meteorologie, Geophysik und B1okl1matologie, ser. A, band 2, p. $1-16$. 
acobs, W. C., and Clarke, K. B., 1943, Meteorological results of Cruise VII of the Carnegie, 1928-1929, in Scientific results of Cruise VII of the Carnegie during 1928-1929 under command of Captain J. P. Ault - Meteorology - I: Carnegie Inst. Wash., Dept. Terrestrial Magnetism, Pub. $544,168 \mathrm{p}$.

ahns, R. H. (editor) and Others, 1954, Geology of southern California: Calif. Div. Mines Bull. 170, 10 chapters. (Includes several chapters on marine geology). *

es, E. L., 1950, New marine fauna from Coos Bay, Oregon: Geol. Soc. America Bull., v. 61, p. 1539 (abs.).

arvis, C. S., 1921, Control of flood and tidal flow in the Sacramento and San Joaquin Rivers, California: Am. Soc. Civil Eng. Trans., v. 84, p. 455-485, incl. diagrams and discussion.

arvis, C. S., 1936, Defending the salt water barrier: Civil Eng., v. 6, p. 332 (Letter to the editor regarding article "Combating a saline invasion" by $\mathrm{E}$. Hyatt, 1935).

effreys, H., 1934, The seismology of the Pacific: Fifth Pacific Sci. Cong. Proc., v. 3, p. 2523-2626, discussion p. 2533 .

enkins, O. P., 1943a, Geomorphic provinces of California: Calif. Div. Mines Bull. 118 , p. 83-88.

enkins, O. P., 1943b, Salient geologic events in California and their relationship to mineral deposition: Calif. Div. Mines Bull. 118 , p. 89-93.

enkins, O. P., and others, 1933, Middle California and western Nevada, in Internat. Geol. Cong., XVI sess., U. S., 1933, gui debook 16, excursion C-1, U. S. Govt. Printing office, wash., 116 p., 18 pls., maps.

enkins, O. P. (editor) and others, 1951, Geologic guidebook of the San Francisco Bay Counties, history, landscape, geology, fossils, minerals, industry and routes to travel: Calif. Dept. Nat. Res. Bull. 154, 392 p. incl. illus. *

ohnson, A. G., 1935, Beach protection and development around Los Angeles: Shore and Beach, v. 3, p. 110-113. mison, A. G., 1940a, A report on protection and development of the beaches in the Westgate addition and Santa Monica Canyon addition: Los Angeles Dept. Public Works, Bur. of Eng., April. *

nson, A. G., 1940b, A report on erosion of the beaches in the Venice district: Los Angeles Dept. Public Works, Bur. of Eng., April. *

nson, A. G., 1940c, Southern California beach erosion. Problems aggrevated by unwise man-made structures and lack of centralized control: Shore and Beach, v. 8 , p. 106-109, 120, 121.

ohnson, A. G., 1951, Santa Monica Bay shoreline development plans: First Conf. on Coastal Eng. Proc., Berkeley, p. $271-276$.

ohnson, C. H., and Galeski, R. B., 1949, off'shore seismic problems affecting geologic evaluation: Am. Assoc. Petroleum Geologist Bull., v. 33, p. 2059-2060 (abs.); Oil and Gas Jour., v. 48, no. 29, Nov. 24, p. 140 (abs.).

ohnson, C. W., 1953, Notes on the geology of Guadalupe Island, Mexico: Am. Jour. Sci., v. 251, p. 231-236.

ohnson, D. W., 1910, Beach cusps: Geol. Soc. America Bull., v. 21 , p. $599-624$.

nson, D. W., 1944, Problems of terrace correlation: Geol. Soc. America Bull., v. 55, p. 793-818.

ohnson, I. M., 1924, Expedition of the California Academy of Sciences to the Gulf of California in 1921; The botany: Calif. Acad. Sci. Proc., v. 12, p. 951-1218 (geology, p. 952-957).

nson, J. W., 1944, Surf observations by ground photographs: Univ. Calif., Berkeley, fluid mechanics lab., tech. rept. HE-116-96, June 27, 2 p., graph, photo.

nson, J. W., 1945a, Generalized diagram for forecasting breaker and surf on a straight beach of infinite length: Univ. Calif., Berkeley, fluid mechanics lab., tech. rept. $\mathrm{HE}-116-13,4$ p., tables, graphs.

ohnson, J. W., 1945b, Refraction study at Monterey Harbor: Univ. Calif., Berkeley, fluid mechanics lab., tech. rept. HE-116-71, March 26, 12 p., tables, maps, graphs, photos.

Johnson, J. W., 1945c, Variability of wave period at Point Cypress, Feb. 24 and 28, 1945: Univ. Calif., Berkeley, fluid mechanics lab., tech. rept. HE-116-72, March 28,5 p., tables, graphs.

Johnson, J. W., 1945d, The refraction of surface waves by currents: Univ. Calif., Berkeley, fluid mechanics lab., tech. rept. HE-116-101, Dec. 12, 3 p., graphs, photos, chart; Am. Geophys. Union Trans., v. 28 (1947), p. 867-874, discussion by J. D. Isaacs, v. 29 (1948), p. $739-742$

Johnson, J. W., 1947a, Model study of Scripps Pier Beach: Univ. Calif., Berkeley, fluid mechanics lab., tech. rept. HE-116-44, April 4, 14 p., graphs, tables; Pub. in part in Johnson, J. W., $1948 \mathrm{a}$.

Johnson, J. W., 19470, Investigations of surface waves and related phenomena by the fluid mechanics laboratory, University of California: Univ. Calif., Berkeley, fluid mechanics lab., tech. rept. HE-116-228, Jan. 23, 24 p., graphs, diagrams; Pub. in part in Johnson, J. W., $1948 \mathrm{~d}$.

Johnson, J. W., 1948a, Scale effects in hydraulic models involving wave motion: Univ. Calif., Berkeley, fluid mechanics lab., tech. rept. HE-116-170, Sept. 22, 10 p., graphs; Am. Geophys. Union Trans., v. 30 (1949), p. $517-525$.

Johnson, J. W., 1948b, Recent contributions of wave research to harbor engineering: Univ. Calif., Berkeley, fluid mechanics lab., tech. rept. $\mathrm{HE}-116-267$, July 19, 10 p., photos, sketches, chart; U. S. Army, Corps of Engineers, Beach Erosion Board Bull., v. 3, no. 4 (1949), p. 1-19.

Johnson, J. W., 1948c, Investigations of wave and related problems: Univ. Calif., Berkeley, fluid mechanics lab., tech. rept. HE-116-274, June, 21 p., weather chart, photos, diagrams.

Johnson, J. W., 1948d, Model studies made at the University of California river and harbor laboratory: Am. Geophys. Union Trans., v. 29, p. 107-116.

Johnson, J. W., 1949a, Relationships between wind and waves, Abbotts Lagoon, California: Univ. Calif., Berkeley, Inst. eng. research, waves research lab., tech. rept. ser. 3, issue 306,6 p., 8 pls; Am. Geophys. Union Trans., v. 31 (1950), p. 386-392.

Johnson, J. W., 1949b, Final report on wave investigations completed on contract NObsr 43246: Univ. Calif., Berkeley, Inst. eng. research, waves research lab., tech. rept. ser. 3 , issue 309,3 p.

Johnson, J. W., 1950, Wave records on the Pacific Coast of the United States: Univ. Calif., Berkeley, Inst. eng. research, waves research lab., tech. rept. ser. 14, issue 4.

Johnson, J. W., 1952, Sand transport by littoral currents: Univ. Calif., Berkeley, Inst. eng. research, waves research lab., tech. rept. ser. 3 , issue 338 , 11 p., illus.; Fifth Hydraulic Conf. Proc., Iowa Inst. Hydraulic Research, Univ. Iowa, June 1952

Johnson, J. W., 1953a, Wave data for San Francisco Bay and vicinity: Univ. Calif., Berkeley, Inst. eng. research, waves research lab., tech. rept. ser. 3, issue 349 , 3 p., 5 pls.

Johnson, J. W., 1953b, Summary of wave data for Cape Mendocino, California: Univ. Calif., Berkeley, Inst. eng. research, waves research lab., ser. 3, issue 356, I p., +3 figs.

Johnson, J. W., and Isaacs, J. D., 1948, Action and effect of waves: Univ. Calif., Berkeley, fluid mechanics lab., tech., rept. HE-116-286, April, 7 p., photos, graphs, weather map; Western Construction News, v. 23, no. 4, April 1948, p. 97-102.

Johnson, J. W., and O'Brien, M. P., 1946, Graphical construction of wave refraction diagrams: Univ. Calif., Berkeley, fluid mechanics lab., tech. rept. HE-116-22l, Oct. 4, 21 p., tables, photos, graphs, maps, diagrams; Also see next reference.

Johnson, J. W., O'Brien, M. P., and Isaacs, J. D., 1948, Graphical construction of wave refraction diagrams: U. S. Navy Hydrog. Office, H. O. Pub. $605,45 \mathrm{p}$.

Johnson, J. W., and Wiegel, R. L., 1953, Summary of research on waves, surf, and beaches: Univ. Calif., Berkeley, Inst. eng. research, waves research lab., tech. rept. ser. 3 , issue $350,29 \mathrm{p}$.

Johnson, M. E., and Snook, H. J., 1927, Seashore animals of the Pacific Coast: New York, Macmillan Co., xiv + 659 p., 700 figs., 11 pls. * 
Johnson, M. W., 1939a, The study of species formation in certain eucalanus copepods in the North Pacific: Sixth Pacific Sci. Cong. Proc., v. 3, p. 565-568.

Johnson, M. W., 1939b, The correlation of water movements and dispersal of pelagic larval stages of certain littoral animals, especially the sand crab, Emerita: Jour. Marine Research, v. 2, p. 236-245.

Johnson, M. W., 1942, Notes on zooplankton: Preliminary discussions, in Scripps Inst. Oceanography, Records of observations, $\bar{v}$. 1 , no. 1 , p. 27-29.

Johnson, M. W., 1948, Sound as a tool in marine ecology, from data on biological noises and the deep scattering layer: Jour. Marine Research, v. 7, p. 443-458.

Johnson, M. W., Everest, F. A., and Young, R. W., 1947, The role of snapping shrimp (crangon and synalpheus) in the production of underwater noise in the sea: Biol. Bull., v. 93 , p. $122-138$.

Johnson, W. M., 1855, Extracts from a report on the features of the country between Pagaro and Salinas Rivers, California: Ann. Rept. U. S. Coast Survey 1854, app. 22, p. 31-32.

Johnson, W. M., 1856, Features of santa cruz Island, the valley of San Buenaventura, and the coast of north of Santa Barbara Channel: Ann. Rept. U. S. Coast Survey 1855, app. 28 , p. 186-188.

Johnson, W. M., 1858, Extracts from report on the topographical features of the coast adjacent to Santa Barbara Channel, California: Ann. Rept. U. S. Coast Survey 1857, app. 43 , p. $390-391$.

Joint Army - Navy Board, 1941, Report on a bridge from Hunters Point to Bay Farm Island across San Francisco Bay.*

joint Army - Navy Board, 1947, Report on additional crossings of San Francisco Bay: *

Joint Meteorological Committee, 1943-1944, Daily synoptic series, historical weather maps, northern hemisphere, sea level, 1899-1939, Wash., D. C. *

Jones, E. L., 1918, The neglected waters of the Pacific Coast, Washington, Oregon, and California: U. S. Coast and Geod. Survey, special pub. 48 , serial 81,21 p., pls., charts, diagrams.

Jones, F. A., 1910, The Jones Expedition to Tiburón Island, México: Min. World, v. 32, p. 269-270.

Jones, J. H., 1948, wave action on beaches: M. S. thesis, Univ. Calif., Berkeley. *

Jordan, E. K., 1926, Expedition to Guadalupe Island, Mexico, in 1922 - No. 4. Molluscan fauna of the Pleistocene of San Quintin Bay, Lower California: Calif. Acad. Sci. Proc., v. 15, p. 241-255.

Jordan, E. K., and Hertlein, L. G., 1926a, Expedition to the Revillagigedo Islands, Mexico in 1925 - IV. A Pliocene fauna from Maria Madre Island, Mexico: Calif. Acad. Sci. Proc., v. 15, p. 209-217.

Jordan, E. K., and Hertlein, L. G., 1926b, Expedition to the Revillagigedo Islands, Mexico, in 1925 - VII. Contribution to the geology and paleontology of the Tertiary of Cedros Island and adjacent parts of Lower California: Calif. Acad. Sci. Proc., v. 15, p. 409-464.

Kaplan, K., 1952, A method for drawing orthogonals seaward from shore: A discussion: U. S. Army, Corps of Engineers, Beach Erosion Board Bull., v. 6, no. 1, p. 18-21.

Kaplan, K., and Pape, H. E., Jr., 1951, Design of breakwaters First Conf. on Coastal Eng. Proc., Berkeley, p. 213-222.

Karlik, B., Foyn, E., Petterson, H., and Rona, E., 1939, The radioactivity of sea water. I. The uranium content of sea water: Medd. Oceanografiska Inst., Goteborg, N. S., no. 2 , p. 7-14.*

Keen, A. M., 1941, Molluscan species common to western North America and Japan: Sixth Pacific Sci. Cong. Proc., v. 3 , p. $479-483$

Keep, J., 1947, west Coast shells: Stanford Univ. Press, xii + 350 p., 334 figs., revised by J. L. Bailey Jr. *

Keller, W. D., 1941, Size distribution of sand from dunes, beaches and some sandstones: Geol. Soc. America Bull., v. 52, p. 1913 (abs.).

Keller, W. D., 1945, Size distribution of sand in some dunes, beaches, and sandstones: Am. Assoc. Petroleum Geologist Bull., v. 29, p. 215-221.

Kelley, v. C., 1932, Geology of the Santa Monica Mountains west of the Malibu Ranch, Ventura County, California: Master's thesis, Calif. Inst. Tech.*

Kelley, W. P., and Llebig, G. F., Jr., 1934, Base exchange in relation to composition of clay with special reference to effect of sea water: Am. Assoc. Petroleum Geologists Bull., v. 18, p. 358-367.

Kelton, E. C., 1940, Review of reports on Santa Barbara Harbor, California: U. S. Army, Corps of Engineers, Los Angeles district, 23 p., I map. *

Kelton, E. C., 1942, Report on cooperative beach erosion study, Mission Beach, California: U. S. Army, Corps of Engineers, Los Angeles district. *

Kemnitzer, L. E., 1933, Geology of San Nicolas and Santa Barbara Islands, California: M. S. thesis, Calif. Inst. Tech., 45 p., 29 pls., 3 maps.

Kemnitzer, L. E., 1936, The geology of San Nicolas Island, California: Am. Assoc. Petroleum Geologists Bull., v. 20, p. 1519 (abs.).

Kemnitzer, W. J., 1937, Billion barrels may ultimately be secured off Pacific Coast: 0 il and Gas Jour., v. 36 , no. 27 , Nov. 18, p. 39-40.

Kemp, J. F., 1902, The geological relations and distribution of platinum and associated metals: U. S. Geol. Survey Bull. 193, 95 p., 6 pls., 9 figs.

Kempkey, A., 1935, The salt water barrier:- Civil Eng., v. 5, p. 707 .

Kenyon, E. C., Jr., 1951, History of ocean outlets, Los Angel County Flood Control District: First Conf. on Coastal Eng., Berkeley, p. 277-282.

Kerr, A. R., 1938, Littoral erosion and deposition of Santa Monica Bay: M. A. thesis, Univ. Calif., Los Angeles, 49 p., incl. tables, 30 pls. *

Kew, W. S. W., 1927, Geologic sketch of Santa Rosa Island, Santa Barbara County, California: 011 Bull., v. 13, no. 12, p. 1257-1260, 1330; Geol. Soc. America Bull., v. 38, p. 645-654; Geol. Soc. America Bull., proc. for 1927, v. 39 (1928), p. 267 (abs.).

Killory, M. F., 1945a, Analysis of forecast and observed wave values at station no. 909 , March 10 to 17,1945 : Univ. Calif., Berkeley, fluid mechanics lab., tech. rept., HE-116-114, May 17, 8 p., graphs, weather maps.

Killory, M. F., 1945b, Analysis of forecast and observed wave values at station numbers 909 and 939, April 10-26, 1945: Univ. Calif., Berkeley, fluid mechanics lab., tech. rept. HE-116-147, July 24, 13 p., tables, graphs, weather maps.

Kindle, E. M., 1934, Role of facies in stratigraphic paleontology: Geol. Soc. America Bull., proc. for 1933, v. 45 , p. $409-430$.

King, c. O., 1953a, Tidelands litigation worsens as Alabama, too, gets into act: Petroleum World and $0 i l, v .50$ no. 4 , oct. 1, p. 1,3 .

King, c. O., 1953b, Senate takes' aid to education' bait in continental shelf bill: Petroleum world and 0il, v. 50 , no. 27 , July 2, p. 3 .

King, c. O., 1953c, Shelf bill goes to wite House minus school aid provision: Petroleum World and 011, v. 50, no. 32 , Aug. 6, p. 1,3

King, R. E., 1939, Geological reconnaissance in northern Sierra Madre Oocidental of Mexico: Geol. Soc. Americo Bull., v. 50, p. 1625-1722, 9 pls.

Kingman, J. J., 1936, The Shore Protection Board: Shore and Beach, v. 4, p. 150-151.

Kirk, P. L., and Moberg, E. G., 1933, Microdetermination of calcium in sea water: Indus. and Eng. Chemistry, Analetical Ed., v. 5, p. 95. 
napp, R. T., 1951, Determination of wave, surge, and ship motion, U. S. Naval Station, Long Beach, California: Final rept. of research program under contract with Bur. of Yards and Docks, U. S. Navy. *

pp, R. T., 1952, Wave-produced motion of moored ships: Second Conf. on Coastal Eng. Proc., Berkeley, p. 48-61.

app, R. T., and Vanoni, v. A., 1945, wave and Surge study for the Naval Operating Base, Terminal Island, California: Calif. Inst. Tech., hydraulics structures lab., pub. 55, 241 p., 233 figs., graphs.

niffen, F. B., 1929, The Delta country of the Colorado: Ph. D. thesis, Univ. Calif., Berkeley, 202 p. * iffen, F. B., 1931, Lower California studies. III The primitive cultural landscape of the Colorado Delta: Univ. Calif. Pub. Geography, v. 5, no. 2, p. 43-66, pls. 2-6, map.

iffen, F. B., 1932, Lower California studies. IV The natural landscape of the Colorado Delta: Univ. Calif. Pub. Geography, v. 5, no. 4, p. 149-244, pls. 19-30, 4 figs., map.

nopf, E. C., 1938, Santa Catalina, minerals and geology: Pacific Mineralogists, v. 5 , no. 2, p. 3-5. *

nox, G. L., 1937, The McDonald Island Gas Field: Am. Assoc. Petroleum Geologists Bull,, v. 21, p. 1613 (abs.).

nox, R. W., 1930, velocity of sound in sea water. Experiments made by the Coast and Geodetic Survey of the $U$. S. on the coast of northern California: U. S. Coast and Geod. Survey, Field Eng. Bull., June; * Abs. of this paper with ebove title in Internat. Hydrog. Bull., Monaco, oct. 1931, p. 251-257.

nox, R. W., 1953, Processing and charting the hydrographic survey: Surveying and Maping, v. 13, p. 20-29.

inudsen, V. O., Alford, R. S., and Fmling, J. W., 1948, Underwater amblent noise: Jour. Marine Research, v. 7, p. $410-429$.

czy, F. F., 1954, A survey on deep-sea features taken during the Swedish deep-sea expedition: Deep-Sea Research, v. 1, p. 176-184.

Lee, K. B., Fox, D. L., and Zechmeister, L., 1950, The nature of some fluorescing substances contained in a deep-sea mud: Archives of Biochemistry, v. 27, p. 449-452.

Cofoid, C. A., 1911, Dinoflagellata of the San Diego region. IV. The genus Gonyaulax, with notes on 1ts skeletal morphology and discussion of its generic and specific characteristics: Univ. Calif. Pub. Zoology, v. 8, p. $187-286$.

Fold, C. A., 1921, The marine borers of the San Francisco Bay region: Rept. on the San Francisco Bay Marine Plling Survey, v. 1, p. 23-61.

ford, C. A., 1928, The cold light of animals: Science, v. 67, no. 1746 , p. $x$.

Cofoid, C. A., and Miller, R. C., 1927, Marine borers and their relation to the marine construction on the Pacific Coast, in Biological sect. of the Final Rept. San Francisco Bay Marine Piling Comm., San Francisco, p. $188-343$.

Kofosd, C. A., and Swezy, 0., 1921, The free-living unarmored Dinoflagellata: Univ. Calif. Mem., v. 5,538 p., 12 pls.

Koning, L. P. G., 1952, Earthquakes in relation to their geographical distribution, depth, and magnitude. Part 5 , Central America and the Caribbean area, and part 6 , The Southern Antilles. Part 7, The Pacific Coast of North America and the Aleutian Arc: K. Nederland. Akad. Wetensch. Proc., v. 55, no. 3, p. 272-292.

ossina, E., 1921, Die Tiefen des Weltmeeres: Berlin Univ., Institut fur Meereskunde, Veröffentlichungen, neue folge, A. Geographischnaturwissenschaftliche Reibe, no. $9,70 \mathrm{p}$.

Crumbein, W. C.., 1942, Physical and chemical changes in sediments after deposition: Jour. Sed. Petrology, v. 12, p. 111-117.
Krumbein, W. C., 1947, Shore processes and beach characteristics: U. S. Army, Corps of Engineers, Beach Erosion Board Tech. Memo. 3, 35 p. Originally as Eng. Notes No. 17, Military Intelligence Div., office Chief of Engineers, U. S. Army, 1944 (restricted).

Krumbein, W. C., 1950, Geological aspects of beach engineering, in Application of geology to engineering practice, Geol. Soc. America Mem., Berkey volume, p. 195-223.

Krumbein, W. C., and Ohsiek, L. E., 1950, Pulsation transport of sand by shore agents: Am. Geophys. Union Trans., v. 31, p. 216-220, discussion p. 936-937.

Krynine, P. D., 1937, Reply to F. P. Shepard's comment on "Pleistocene glaciation of Siberia:" Am. Jour. Sci., 5th ser., v. 34 , p. 400.

Kuenen, Ph. H., 1946, Rate and mass of deep-sea sedimentation: Am. Jour. Sci., v. 244, p. 563-572.

Kuenen, $\mathrm{Ph}$. H., 1947, Two problems of marine geology: Atolls and canyons: Verh. konkl. Nederlandsche Akad. v. Wetensch. afd. Naturkunde, 2 e sect., v. 43 , no. 3 , 68 p., 4 pls.

Kuenen, Ph. H., 1950, Marine geology; New York, John Wiley and Sons, Inc., $568 \mathrm{p}$. *

Kuenen, Ph. H., and Menard, H. W., 1952, Turbidity currents, graded and non-graded deposits: Jour. Sed. Petrology, v. 22, p. $83-96$.

LaFond, E. C., 1938, Relationship between mean sea level and sand movements: Science, v. 88, p. 112-113.

LaFond, E. C., 1939a, Variations of sea level on the Pacific Coast of the United States: Jour. Marine Research, v. 2, p. 17-29.

LaFond, E. C., 1939b, Sand movements near the beach in relation to tides and waves: Sixth Pacific Sci. Cong. Proc., v. 2, p. 795-799.

LaFond, E. C., 1940, Sea-level and surface temperatures along the coast of California: Assoc. d'océanographie Physique, Union Gédésique et Géophysique Internat., Procēs-Verbaux no. 3 , p. $177-178$.

LaFond, E. C., 1949, Oceanographic research at the U. S. Navy Electronics Laboratory: Am. Geophys, Union Trans., v. 30 , p. $894-896$.

LaFond, E. C., Dietz, R. S., and Knauss, J. A., 1950, A sonic device for under-water sediment surveys: Jour. Sed. Petrology, v. 20, p. 107-110.

Lakes, A., 1899, Gold-bearing beach sands of California: Mines and Minerals, v. 19, p. 369.

Lakes, A., 1903a, Geologizing by the seaside. Illustrations of geological phenomena related to mining as shown in the cliffs and caves at La Jolla, near San Diego, Californ1a: Mines and Minerals, v. 23, p. 543-545.

Lakes, A., 1903b, The sea and mining. Illustrations shown at seacoast of manner of making and destruction of rocks by action of shellfish and erosion: Mines and Minerals, v. 24, p. $12-14$

Lamport, H. B., 1937, Southern California beaches: Shore and Beach, v. 5, p. 117-120.

Landes, K. K , 1952a, Our shrinking globe: Geol. Soc. America Bull., v. 63, p. 225-240.

Landes, K. K., 1952b, Our shrinking globe - a reply: Geol. Soc. America Bull., v. 63, p. 1073-1074.

Lang, H., 1916, Black sand of the Pacific Coast: Min, and Sci. Press, v. 113, Dec. 2, p. 811-813.

Lange, A., 1954, Caves: New science frontier of the west: Pac1f1c Discovery, v. 7, no. 3, May-June, p. 18-25.

Lapsley, W. W., 1937, Sand movement and beach erosion: M. S. thesis, Univ. Calif., Berkeley, 27 p. + app. 9 p., 8 pls., photos p. 10-16. (Includes model studies of Santa Barbara and Santa Monica).

Larsen, G. P., 1939, Santa Monica Beach, California: Shore and Beach, v. 7 , p. 135 .

Larsen, G. P., 1941, Remarkable progress in California. Shoreline Planning Association obtains passage of series of public beach bills in Legislature: Shore and Beach, v. 9, p. 99-101, 124-126, 128-129. 
Larsen, G. P., 1942a, Real progress continues in California. Definite acquisition and development follows passage of Shoreline Planning Association's bills for public beaches as state's great coastwide program takes shape: Shore and Beach, v. 10, p. 44-46.

Larsen, G. P., 1942b, Breakwaters along the California coast: Shore and Beach, v. 20, p. 69.

Larsen, G. P., 1943, New laws reinforce California progress. Bills enacted implementing state policy for comprehensive public beach acquisition and development program: Shore and Beach, v. 1l, p. 42-45.

Larsen, G. P., 1944a, California endeavors to end pollution: Shore and Beach, v. 12, p. 21-22.

Larsen, G. P., 1944b, The public beach program in California: Shore and Beach, v. 12, p. 58-61, incl. discussion.

Larsen, G. P., 1946, The beaches must belong to the people: California's statewide program: Shore and Beach, v. 14, p. $67-71$.

Laudermilk, J. D., 1944, The case of the vanishing island. Three exotic minerals found by geologists on Mt. San Onofre furnished the clue to the mystery of the sunken province of Catalinia: Westways, January, p. 18-19.

Lauer, E., 1948, wave velocity depth determination -- An experimental test of the theory: Univ. Calif., Berkeley, fluid mechanics lab., tech. rept. HE-116-195, il p., tables, map, graphs, photo.

Laverty, F. B., 1952, Recharging wells expected to stem sea-water intrusion. California to spend $\$ 750,000$ on pilot test: Civil Eng., v. 22, no. 5, p. 313-315.

Laverty, F. B., Jordan, L. W., and van der Goot, H. A., 1951, Report on tests for the creation of fresh water barriers to prevent salinity intrusion, performed in west coastal basin, Los Angeles County, California: Los Angeles Flood Control district, March 10, 70 p. *

Lawson, A. C., 1893a, The geology of Carmelo Bay: Univ. Calif. Pub. Geology, v. 1, p. 1-59.

Lawson, A. C., 1893b, The post-Pliocene diastrophism of the coast of southern California: Univ. Calif. Pub. Geology, v. 1, p. 115-160. Rev. by R. D. Salisbury in Jour. Geology, v. 2 (1894), p. 235-238.

Lawson, A. C., 1894, The geomorphogeny of the coast of northern California: Univ. Calif. Pub. Geology, v. 1, p. 241-272. Rev. by A. R. W. in Jour. Geology, v. 3 (1895), p. 116-117.

Lawson, A. C., 1895, Geology of Sen Francisco Peninsula: U. s. Geol. Survey, 15th ann. rept., p. 342-456. Rev. by A. H. Purdue, Jour. Geology, v. 4 (1896), p. 640-644.

Lawson, A. C., 1914, San Francisco. Tamalpais, San Francisco, Concord, San Mateo, and Haywards quadrangles: U. S. Geol. Survey Geol. Atlas, follo 193, 24 p., 15 maps, sections, $10 \mathrm{pls}$.

Lawson, A. C., 1924, The continental shelf off the cosst of California: Natl. Research Council Bull. 44, p. 3-23.

Lawson, A. C., 1939, Subsidence by thrusting: The discussion of a hypothetical fault: Geol. Soc. America Bull., v. 50, p. $1381-1394$.

Lawson, A. C., 1948, Some further implications of the doctrine of isostasy: Geol. Soc. America Bull., v. 59, p. 197-210.

Lawson, A. C., 1950, Sea bottom off the coast of California. A review of Special paper 31, Geological society of America, by Shepard and Fmery, 1941: Geol. Soc. America Bull., v. 61, p. 1225-1242.

Lawson, A. C., and others, 1908, The California earthquake of April 18, 1906. Report of the State Earthquake Investigation Comission: Carnegie Inst. Wash. Pub. 87 , v. 1,451 p., 146 pls.

Lawson, J. S., 1862, Extracts from a report showing the general character of Koos Bay, Oregon: Ann. Rept. U. S. Coast Survey 1861 , app. 30, p. 264-265, sketch 26 .

Lawson, L. M., 1950, River and tide effects - Lower Colorado River: Civil Eng., v. 20, no. 6, p. 31-33.

Lawton, C. H., 1936, Santa Barbara beach: Shore and Beach, v. 4, p. 63 .

Le conte, J., 1887, The flora of the coast islands in relation to recent changes in physical geography: Am. Jour. Sci., 3rd ser., v. 34, p. 457-460; Calif. Acad. Sc1. Bull., v. 2, p. 515-520; Am. Geologist, v. I (1888), p. 76-81.
Le Conte, J., 1891, Tertiary and post-Tertiary changes of the Atlantic and Pacific Coasts; with a note on the mutual relations of land-elevation and ice accumulation during the Quaternary period: Geol. Soc. America Bull., v. 2, p. 323-330; Am. Naturalist, v. 25, p. $482-483$ (abs.).

Lee, C. H., 1941, Sealing the lagoon lining at Treasure Island with salt: Am. Soc. Civil Engineers Trans., v. 10 p. 577-607.

Leeds, C. T., 1915, Report on flood control, Coastal Plain district, in Reports of the Board of Engineers Flood Control to the Board of Supervisors, Los Angeles County, Calif., July 27, app. 6, p. 165-237, illus., tables.

Leeds, C. T., 1916, Shore protection at Venice, California. General statement of damage which has been done: Prof. Mem., U. S. Army, Corps of Engineers, v. 8, no. 37, p. 42-58, diagrams, folded $\mathrm{pls}$.

Leeds, C. T., 1936, California's beach erosion and development problems: Shore and Beach, v. 4, p. 102-16y.

Leeds, C. T., Vanoni, V. A., and Knapp, R. T., 1934, Solving a flood and beach protection problem with an hydraulic model - A study of San Gabriel River mouth at Alamitos Bay Inlet, California: Am. Geophys. Union Trans., 15th ann. meet., pt. II, p. 579-593.

Leipper, D. F., 1947, Sea surface temperature variations influ encing fog formation in southern California: Scripps Inst. Oceanography, Oceanographic Rept. 9, 13 p., 11 figs

Leipper, D. F., 1948a, California stratus forecasting correlations, 1935 and other years: Am. Meteorol. Soc. Bull., v. 29 , no. 6, p. 294-297.

Leipper, D. F., 1948b, Fog development at San Diego, Californi Jour. Marine Research, v. 7, p. 337-346.

Leipper, D. F., 1950, Sea temperature variations associated with tidal currents in stratified shallow water over an irregular bottom. (A study based largely upon observa. tions in the vicinity of Scripps Pier, La Jolla, California): Ph. D. thesis, Univ. Calif., Los Angeles, 39 p., 8 figs.

Leoniard, A. G., 1925, The contest between land and sea near San Diego: North Dakota Univ. Quart. Jour., v. 15, p. $135-140,8$ figs.

Leslie, M., 1928, Daily and seasonal changes in the oxygen content of sea water, correlated with similar changes in temperature, chemical composition and plankton content M. S. thesis, Univ. Calif., Berkeley, 38 p., 5 figs., 4 tables.

Leslie, M., and Moberg, E. G., 1930, The oxygen content of sea water off the coast of southern California: Fourth Pacific Sci. Cong. Proc., v. 2B, p. 1035-1036 (abs

Lesser, R. M., 1951, Some observations of the velocity profile near the sea floor: Am. Geophys. Union Trans., v. 32, p. 207-211.

Lewis, R. C., 1927, Surface catches of marine diatoms and dinoflagellates off the coast of oregon by U. S. S. Guide in 1924: Scripps Inst. Oceanography Bull., tech. ser., v. 1, p. 189-196.

Lewis, R. C., 1929, The food habits of the California sardine in relation to the seasonal distribution of microplankton: M. s. thesis, Univ. Calif., Berkeley, 50 p. incl. tables, figs.; Scripps Inst. Oceanography Bull., tech. ser., v. 2, p. 155-180.

Leypoldt, H., 1934, Earth-movements in California determined from apparent variations in tidal datum planes: Selsmol. Soc. America Bull., v. 24, p. 63-68.

Leypoldt, H., 1937a, The determination of mean sea level: Am. Jour. Sc1., 5th ser., v. 33, p. 296-302.

Leypoldt, H., 1937b, California seiches and Philippine typhoon U. S. Naval Inst. Proc., v. 63 , no. 6, whole no. 412, Jun

Leypoldt, H., 1938, Periodicity of earth movements in Los Angeles Harbor: Seismol. Soc. America Bull., v. 28, p. $23-32$.

Leypoldt, H., 194la, Mean sea-level and sand movements: Science, v. 94, no. 2452, p. 607-609.

Leypoldt, H., 1941b, Shore line formation by currents: Shore and Beach, v. 9, p. 14-17, 29-31. Discussion by M. P. O'Brien, and O. F. Evans, 1941.

Leypoldt, H., 1941c, Sea-level changes as triger forces: Selsmol. Soc. America Bull., v. 31, p. 233-238. 
Leypoldt, H., 1942, Shoreline formation by currents: Shore and Beach, v. 10, p. 21.

ypoldt, H., 1947, Effect of sea level variation on Long Beach, California subsidence: Seismol. Soc. America Bull., v. 37, p. 289-290.

eypoldt, H., and McHenry, J. R., 1942, Block pattern of crustal movements in Long Beach: Seismol. Soc. America Bull., v. 32, p. 269-276.

Lian, H. M., 1952, The geology and paleontology of the Carpinteria district, Santa Barbara County, California: Ph. D. thesis, Univ. Calif., Los Angeles, 178 p., 16 figs., 9 pls., 9 tables.

Lieber, A. C., Jr., 1940, Recent experimentation on wave action. Field and laboratory progress indicate full understanding of wave mechanics and effects is attainable: Shore and Beach, v. 8, p. 85-91, 94-95.

Light, S. F., revised by Smith, R. I., Pitelka, F. A., Abbott, D. P., Weesner, F. M. and others, 1954, Intertidal invertebrates of the central California cosst: Berkeley and Los Angeles, Univ. Calif. Press.*

Lillevang, O. J., and Brant, R. W., 1937, Beach erosion model study: B. S. thesis in engineering, Univ. Calif., Berkeley, 21 p.

Lindgren, W., 1888, Notes on the geology of Baja California, Mexico: Calif. Acad. Sci. Proc., 2nd ser., v. 1, p. $173-196$.

indgren, W., and Knowlton, F. H., 1896, The age of the auriferous gravels of the Sierra Nevada. With a report on the flora of Independence Hill: Jour. Geology, v. 4, p. 881-906.

Lindsay, D. R., 1952, Geology of the central part of Solstice Canyon quadrangle, Los Angeles County, California: M. A. thesis, Univ. Calif., Los Angeles, 43 p., 3 pls., 19 figs.

Lipman, C. B., 1929, The chemical composition of sea-water: Papers from the Tortugas Lab. of the Carnegie Inst. Wash., v. 26 , pub. 391, p. 249-257.

Littlehales, G. W., 1890, The average form of isolated submarine peaks, and the interval which should obtain between deep-sea soundings taken to disclose the character of the bottom of the ocean: U.S. Hydrog. office pub. 95,7 p., 6 pls.

Littlebales, G. W., 1932a, Sounding the depths of the ocean for mapping the conformation and topography of the bottom: Am. Geophys. Union Trans,, 13th ann. meet., p. 33-37.

Littlehales, G. W., 1932b, The configuration of the oceanic basins: Natl. Research Council Bull. 85, Physics of the earth - v. Oceanography, p. 13-46.

Livingston, A., Jr., 1939, Geological journeys in southern California: Dubuque, Iowa, 2nd ed., Wm. C.'Brown Co., 154 p., illus. lst ed. by A. Livingston Jr. and W. C. Putnam, 1933, Pub. no. 1, Los Angeles Jr. College, Geol. Ser., v. 1, 104 p., illus.

Lockhart, W. M., 1939, Some upper-air observations made in the Pacific: Am. Geophys. Union Trans., 20th ann. meet., p. 348-352.

Loel, W., and Corey, W. H., 1932, The Vaqueros formation, Lower Miocene of California. I. Paleontology: Univ. Calif. Pub. Geology, v. 22, p. 31-410.

Logan, C. A., 1919, Platinum and allied metals in California: Calif. Div. Mines Bull. 85, 120 p., 10 photos, 4 pls.

Lombardi, L. V., 1949, A quantitative study of recent sediments in Halfmoon Bay, California: M. S. thesis, Stanford Univ., 64 p., maps, tables, diagrams. *

Longacre, L. L., 1948, A representative period for a watersupply study: Am. Geophys. Union Trans., v. 29, p. 682687; discussion by H. O. Banks p. 687-690.

Longwell, C. R., 1942, Review of submarine topography off the California Coast by F. P. Shepard and K. O. Emery,
Special Paper 31, Geological Society of America, 1941: Jour. Geomorphology, v. 5, p. 81-84.

Los Angeles County Flood Control District, 1950, Sewage reclamation spreading test adjacent to Azusa sewage treatment plant: Los Angeles County, Dec.*

Los Angeles County Regional Planning Commission, 1938, Marina del Rey. Report on proposed harbor at Playa del Rey: June. *

Los Angeles County Regional Planning Commission, 1940, The Master Plan of Shoreline Development for the LOB Angeles County Regional Planning District: Regional Planning Corm., County of Los Angeles, Calif., 47 p., illus.

Los Angeles County Regional Planning Commission, 1946, Shoreline development, County of Los Angeles, 1944; Report on the revised Master Plan of Shoreline Development, as amended by the Los Angeles County Regional Planning District...The Regional Planning Commission County of Los Angeles... The Board of Supervisors, County of Los Angeles, Los Angeles., 31 p. illus., plans, tables. *

Los Angeles Department of City Planning, 1941, Master Plan of Shoreline Development: July.*

Los Angeles Regional water Pollution Control Board, 1952, Los Angeles Harbor pollution survey: Los Angeles Regional water Pollution Control Board, no. 4. *

Louderback, G. D., 1913, The Monterey Series in California: Univ. Calif. Pub. Geology, v. 7, p. 177-241.

Louderback, G. D., 1919, Fundamental geological problems of the North Pacific Ocean region: Scripps Inst. for Biol. Research Bull. no. 9, p. 75-82.

Louderback, G. D., 1920, preliminary results of a study of the San Francisco Bay sediments; Geol. Soc. America BuIl., proc. for 1919, v. 31, p. 123-124 (abs.).

Louderback, G. D., 1921, Certain marked differential movements in the San Francisco Bay region: Geol. Soc. America Bull., proc. for $1920, \mathrm{v} .32, \mathrm{p} .45$ (abs.).

Louderback, G. D., 1924, Relation of marine organisms to the physical character of the bottom deposits: Natl. Research Council, Div. Geology and Geography, Comm. on Sedimentation, April 26, p. 59-63.

Louderback, G. D., 1930, An outline history of earth movements in the central coast region of California in late Pliocene and post-Pliocene time: Fourth Pacific Sci. Cong. Proc., v. 2B, p. 841-848.

Louderback, G. D., 1940, San Francisco Bay sediments: Sixth Pacific Sci. Cong. Proc., v. 2, p. 783-793.

Louderback, G. D., 1941, Development of San Francisco Bay: Geol. Soc. America Bull., v. 52, p. 1952 (abs.).

Louderback, G. D., 1944, The reputed destructive earthquake of January 16-18, 1840: Seismol. Soc. America Bull., v. 34, p. 103-107.

Louderback, G. D., 1951, Geologic history of San Francisco Bay: Calif. Div. Mines Bull., 154, p. 75-94.

Lowell, F. L. L., 1915a, Humboldt County: Calif. State Min. Bur., 14th Rept. State Mineralogist, p. 391-414.

Lowell, F. L. L., 1915b, Del Norte County: Black sands: Calif. State Min. Bur., 14th Rept. State Mineralogist, p. 375-379.

Lowenstam, H. A., 1954, Factors affecting the aragonite: calcite ratios in carbonate-secreting marine organisms: Jour. Geology, v. 62, p. 284-322.

Lucke, J. B., 1938, Marine shorelines reviewed: Jour. Geology, v. 46, p. 985-995.

Ludwick, J. C., Jr., 1950, Deep water sand layers off San Diego, Callfornia: Ph. D. thesis, Univ. Calif., Los Angeles, 56 p., app. 12 figs., 9 pls.

Lukens, R. R., 1933, Oceanographic work of the Coast and Geodetic survey during the past year: Am. Geophys. Union Trans., 14th ann. meet., p. 194-197.

McAdam, D., 1947a, Measurements of breaker heights by the use of an aerial camera: Univ. Calif., Berkeley, fluid mechanics lab., tech. rept. HE-116-244, April 28, 7 p., tables, photos. 
McAdam, D., 1947b, Submarine cable laying in Monterey Bay: Univ. Calif., Berkeley, fluid mechanics lab., tech. rept. HE-116-249, June 17, 3 p., photos.

McAdie, A. G., 1907, Catalog of earthquakes of the Pacific Coast 1897 to 1906: Smithsonian Misc. Coll., part of v. 49 , no. 1721 .

McAdie, A. G., 1913, The climate of San Francisco: U. S. Dept. Agriculture, Weather Bur. Bull., v. 44, $33 \mathrm{p}$.

Mcadie, A. G., 1914, The rainfall of California: Univ. Calif. Pub. Geography, v. 1, no. 4, p. $127-240$, pls. $21-28$.

McAfee, C. M., 1939, Extension of model study of Cabrillo Beach: M. S. thesis, Univ. Calif., Berkeley, 45 p., photos, maps, diagrams.

McArthur, W. P., 1850, Hydrographic notice of the western coast of the United States, from Monterey Bay to Columbia River (islands and rivers): Ann. Rept. U. S. Coast Survey 1850, app. 33, p. 124-125.

McClendon, J. F., Gault, C. C., Mulholland, S., 1917, The hydrogen ion concentration, $\mathrm{CO}_{2}$ content of sea-water: Carnegie Inst. Wash. Pub. 251, p. 21-69.

McComb, H. E., 1934, A tilt-compensation seismometer: Fifth Pacific Sci. Cong. Proc., v. 3, p. 2489-2494.

McConnaughey, B. H., and Fox, D. L., 1949, The anatomy and biology of the marine polychaete Thoacophelis mucronata (Treadwell) ophelidae: Univ. Calif. Pub. Zoology, v. 47, p. $319-340$.

McDonald, J. A., and Diediker, P. L., 1930, A preliminary report on the Foraminifera of San Francisco Bay, California: Micropalentology Bull., Stanford Univ., v. 2, p. 33-37.

McDonald, W. F., 1938, Atlas of climatic charts of the oceans: U. S. Dept. Agriculture, Weather Bur., W. B. no. 1247, 130 charts.

McEwen, G. F., 1910, Preliminary report on the hydrographic work carried on by the Marine Biological station of San Diego: Univ. Calif. Pub. Zoology, v. 6, p. 189-204.

McEwen, G. F., 1912, The distribution of ocean-temperatures along the west coast of North America deduced from Ekman's theory of the upwelling of cold water from the adjacent ocean depths: Internat. Rev. der Gesell. Hydrobiologie und Hydrographie, band 5, p. 243-286.

McEwen, G. F., 1914, Peculiarities of the California climate. Explained on the basis of general principles of atmospheric and oceanic circulation: Monthly weather Rev., v. 42, p. 14-23.

McEwen, G. F., 1915, Oceanic circulation and temperature off the Pacific Coast in Nature and Sci. on the Pacific Coast, San Francisco, EIder and Co., p. 133-140.

McEwen, G. F., 1916, summary and interpretation of the hydrographic observations made by the Scripps Institution for Biological Research of the University of California, 1908 to 1915: Univ. Calif. Pub. Zoology, v. 15, p. $255-356$, pls. $1-38$.

McEwen, G. F., 1918, Oceanic circulation and its bearing upon attempts to make seasonal weather forecasts. A sketch of observational methods and explanations: Scripps Inst. for Biological Research of the Univ. of Calif., Nov. 8 , no. 7,20 p.

McEwen, G. F., 1919a, ocean temperatures, their relation to solar radiation and oceanic circulation. Quantitative comparisons of certain empirical results with those deduced by principles and methods of mathematical physics, in Misc. Studies in Agriculture and Biology in Semicentennial Pubs, of the Univ. of Calif., 1868-1918, p. $335-421$.

McEwen, G. F., 1919b, The distribution of temperatures and salinities, and the circulation in the North Pacific Ocean: Scripps Inst. for Biological Research, Univ. of Calif., Bull., no. 9, p. 58-64.

McEwen, G. F., 1925, Ocean temperatures and seasonal rainfall in southern California. A review of their relation based upon records of the past nine years: Monthly Weather Rev., v. 53, p. 483-489.

McEwen, G. F., 1926, ocean temperatures and seasonal rainfall, a review of their relation based upon records of the past nine years in southern California: Scripps Inst.
Oceanography Bull. 12, p. 34-56.

McEwen, G. F., 1927, Recent progress in the dynamical oceanography of the northeastern part of the north Pacific Ocean: Am. Geophys. Union Trans., 8th ann. rept., in Nat1. Research Council Bull. 61, p. 222-235; Natl. Research Council, Div. Geology and Geography, Rept. Comm. Submarine Configuration and oceanic Circulation, app. E, April 30, 1927, p. 10-11.

McEwen, G. F., 1928a, Indicated seasonal rainfall in Calif ornia for 1928-1929: Am. Meteorol. Soc. Bull., v. 9, p. 178-179.

McEwen, G. F., 1928b, Ocean surface drift in the Pacific coastal belt off North America: Third Pan-Pacific Sc 1 . Cong. Proc., v. 1, p. 191-198.

McEwen, G. F., 1929, A mathematical theory of the vertical distribution of temperature and salinity in water under the action of radiation, conduction, evaporation, and mixing due to the resulting convection: Scripps Inst. Oceanography Bull., tech. ser., v. 2, p. 197-306; Misc. Studies in Agriculture and Biology in the Semicentennial Pub. of the Univ. of Calif., 1868-1918, p. 335-421.

MCEwen, G. F., 1930a, Results of evaporation studies conducted at the Scripps Institution of Oceanography and the California Institute of Technology: Scripps Inst. Oceanography Bull., tech. ser., v. 2, p. $401-415$.

McEwen, G. F., 1930b, Seasonal rainfall forecasting based on Pacific Ocean temperatures: Calif. Citrograph, $v$. 16 , no. 1, p. $3,22,23,26$.

McEwen, G. F., 1930c, Our rainfall: How is it formed and what becomes of it? Sci. Monthly, v. 31, p. 385-400.

McEwen, G. F., 1933, Oceanography and hydrology: Monthly averages of surface currents along the coast of central California computed from temperatures: Am. Geophys. Union Trans., 14th ann. meet., p. 33-34.

McEwen, G. F., 1934a, Oceanographic activities according to countries - the United States: Physical and Chemical: Fifth Pacific Sci. Cong. Proc., v. 1, app. 1, p. 317-331.

McEwen, G. F., 1934b, Monthly averages of surface currents along the coast of central California computed from temperatures: Fifth Pacific Sci. Cong. Proc., v. 3, p. $1761-1762$.

MCEwen, G. F., 1934c, Rate of upwelling in the region of San Diego computed from serial temperatures: Fifth Pacific Sci. Cong. Proc., v. 3, p. 1763.

McEwen, G. F., 1934d, Seasonal weather forecasting at the Scripps Institution of oceanography: Fifth Pacific Sci. Cong. Proc., v. 3, p. 1965-1967.

McEwen, G. F., 1934e, Methods of seasonal weather forecasting at the Scripps Institution of Oceanography: Am. Meteorol Soc. Bull., v. 15, p. 249-256.

McEwen, G. F., 1935a, Destructive waves along the California Coast: Shore and Beach, v. 3, p. 61-64.

McEwen, G. F., 1935b, Harbor and beach problems of Santa Barbara, California: Shore and Beach, v. 3, p. 122.

McEwen, G. F., 1936, Problems of long-range weather forecasting for the Pacific Coast: Am. Geophys. Union Trans., 17th ann. meet., p. 486-491.

McEwen, G. F., 1937a, Forecasting monthly averages of seasurface temperatures at shore stations along the coast of California: Assoc. d'Océanographie Physique, Union Géodésique et Géophysique Internat., Procès-Verbaux no. 2, p. 121-123.

McEwen, G. F., 1937b, Calculations of the rate of vertical displacement and turbulence in the San Diego region of the Pacific at monthly intervals: Assoc. d'Océanographie Physique, Union Géodésique et Géophysique Internat., Procès-Verbaux no. 2, p. 129-131.

McEwen, G. F., 1937c, Calculation of the velocity of horizonta surface currents in the eastern North Pacific: Assoc. d'océanographie Physique, Union Géodésique et Géophysique Internat., Procès-Verbaux no. 2, p. 132-134.

MCEwen, G. F., 1937d, Seasonal forecasts of California weather Calif. Monthly, Nov.

McEwen, G. F., 1937-1938, Some energy relations between the sea surface and the atmosphere: Jour. Marine Research, v. 1, p. $217-238$

McEwen, G. F., 1940a, Some calculations of vertical velocity and turbulence in the North Pacific near southern Calif ornia: Assoc. d'océanographie Physique, Union Géodésique et Géophysique Internat., Procès-Verbaux no. 3, p. 120121.

McEwen, G. F., 1940b, Vertical and off-shore dispersion of silt from southern California shore: Assoc. d'océanographie Physique, Union Géodésique et Géophysique Internat., Procèss-Verbaus no. 3, p. 195-196. 
McEwen, G. F., 1948, The dynamics of large horizontal eddies (axes vertical) in the ocean off southern California: Jour. Marine Research, v. 7, p. 188-216.

McEwen, G. F., 1950, A statistical model of instantaneous point and disk sources with applications to oceanographic observations: Am. Geophys. Union Trans., v. 31, p. 35-46.

McEwen, G. F., and Gorton, A. F., 1930, Indicated seasonal precipitation for 1930-31 in selected regions of California: Am. Meteorol. Soc. Bull., v. 11, p. 169-171.

McEwen, G. F., and staff, 1948, Research within physical oceanography and submarine geology at the Scripps Institution of Oceanography during April 1947 to April 1948: Am. Geophys. Union Trans., v. 29, p. 578-580.

McGee, W. J., 1900, The Gulf of California as an evidence of marine erosion, in Geol. Soc. Wash., records of meet.,

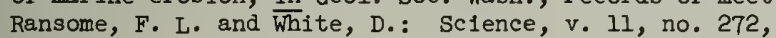
p. $429-430$.

McGowan, W. C., 1916, The U. S. seagoing dredge Col. P. S. Mich1e: Prof. Mem., v. 8, p. 622-648, pls. xi1-xxvi.

McHenry, J. R., 1942, Surveys show Long Beach, California is moving up, down and sideways: Eng. News-Record, v. 128 , no. 13, p. 477 .

McKay, E. C., 1946, Seismic sea wave of April 1, 1946: Am. Geophys. Union trans., v. 27, p. 453.

McKee, E. D., 1939, Some types of bedding in the Colorado River Delta: Jour. Geology, v. 47, p. 64-81.

McKee, E. D., 1953, Report on studies of stratification in modern sediments and in laboratory experiments: U. S. Navy, office of Naval Research, project nonr 164(00), NR 081 123, 61 p., 13 pls. (lịmited distribution).

McKee, R., and Schoth, H. A., 1941, Sand dune control in the United States: Shore and Beach, v. 9, p. 42-44.

McKinstry, C. H., 1905, The Delaware, Sandy Bay, and San Pedro breakwaters: Am. Soc. C1vil Englneers Trans., v. 54, A, p. $325-338,6$ pls., maps.

McLaughlin, W. T., and Brown, R. L., 1943, controlling coastal sand dunes in the Pacific northwest: Shore and Beach, v. 11, p. 7-24; U. S. Dept. Agr1culture c1re. 660 .

McLellan, M. E., 1925, Expedition of the California Academy of Sclences to the Revillagigedo Islands: Sclence, $v$. 62 , no. 1599 , p. 171-173.

McManus, A. B., 1934, Water circulation in Pacif1c regions: Fifth Pacific Sc1. Cong. Proc., v. 1, p. 703-712.

McManus, A. B., and Collins, E. B., 1934, Recent soundings gravity investigations, and mapping sea floors: Fifth Pactific Sc1. Cong. Proc., v. 2, p. 853-868.

McOuat, H. W., 1951, H1story of Los Angeles Harbor: First Conf. on Coastal Eng. Proc., Berkeley, p. 259-270.

MacCamy, R. C., 1952, Ellwood fleld p1le studies - application of diffraction theory: Univ. Calif., Berkeley, Inst. eng. research, ser. 35,1 ssue 7,6 p., 7 pls.

MacDonald, G. A., 1934, Sediments of Santa Monica Bay: Research paper, on file at Univ. Calif., Los Angeles, 37 p., 4 figs., 8 pls.

MacDonald, G. A., Shepard, F. P., and Cox, D. C., 1947, The tsunamis of April 1, 1946, in the Hawailan Islands: Pac1f1c Sc1., v. 1, no. 1. p. 21-37.

Macelwane, J. B., 1923, A study of the relation between the perfods of elastic waves and the distance traveled by them, based upon the selsmographic records of the California earthquake, January 31, 1922: Se1smol. Soc. America Bull., v. 13, p. 13-69, 7 pls.

Macelwane, J. B., 1934, The structure of the outer crust of the earth in the Paclfic ocean region: Fifth Pacific Sc1. Cong. Proc., v. 3, p. 2533-2538.

MasGinitie, G. E., 1927, Ecological aspects of Elkhorn Slough: M. A. thesis, Stanford Un1v., 206 p., 23 pls. acGinitie, G. E., 1935, Ecological aspects of a California marine estuary: Am. Midland Naturalist, v. 16, p. 629-765.
MacGinitie, G. E., 1939, Littoral marine communities: Am. Midland Naturalist, v. 21, p. 28-55.

MacGinitie, G. E., and MacGinitie, N., 1949, Natural history of marine animals: New York, McGraw Hill, 473 p. *

Ma, T. Y. H., 1952, The shiftings in pole-positions with diastrophisms since the end of the cretaceous, and the accompanying drift of continents: Research on the Past Climate and continental Drift, v. 5, 176 p., 22 pls., I chart, 7 figs., pub. by the author, sold at World Book Co., Taipeh, Ta1wan, China.

Mallet, R., 1858, Report upon the facts and theory of earthquake phenomena: Rept. British Assoc. Adv. Sci., v. 28 , p. 124-131.

Mann, A., 1907, Report on the diatoms of the Albatross voyages in the Pacif1c ocean, 1888 - 1904: U. S. Nat1. Herbarium Contr., v. 10, pt. 5, p. 221-419, 54 pls. *

Mao, Han-Lee, 1951, Eddy diffusivity coefficient of Pacific water of the California coast, determined by statistical paramiters of hydrodynamic equations: Ph. D. thesis, Univ. Calif., Los Angeles, 60 p., charts, 15 figs.

Marks, G. W., 1938, The copper content and copper tolerance of some species of mollusks of the southern California Coast: Biol. Bull., v. 75 , p. 224-237.

Marlette, J. W., 1954, The breakwater at Redondo Beach, California, and its effects on erosion and sedimentation: M. A. thesis, Univ. Southern Calif., 82 p., 14 figs., 6 pls., 3 tables.

Marmer, H. A., 1926, Coastal currents along the Pacific coast of the Unfted States: U. S. Coast and Geod. Survey, special pub. 121, serial 330, 80 p., incl. maps, tables, diagrams and 23 figs.

Marmer, H. A., 1927, Tidal datum planes: U. S. Coast and Geod. Survey, special pub. 135, 142 p.

Marmer, H. A., 1928, Mean sea level on the Pacific coast of the United States: Third Pan-Pacific Sc1. Cong. Proc., v. 1, p. 204-209.

Marmer, H. A., 1932, Tides and tidal currents in Natl. Research Council. Bull. 85, Physics of the earth - $\overline{\mathrm{V}}$, Oceanography, p. 229-309.

Marmer, H. A., 1949, Sea level changes along the coasts of the United States in recent years: Am. Geophys. Union Trans., v. 30 , p. 201-204.

Marmer, H. A., 1952, Changes in sea level determined from t1de observations: Second Cong. on Coastal Eng. Proc., Berkeley, p. $62-67$.

Marshall, N. B., 1951, Bathypelagic fishes as sound scatterers in the ocean: Jour. Marine Research, v. 10, p. 1-17.

Marshall, W. C., 1934, Description of Manhattan Beach area: Calif. O1l World, v. 27 , no. 11 , oct. 4, p. 8 .

Martens, J. H. C., 1939, Beaches, in Trask, P. D., Recent marine sediments, symposium pub. by Am. Assoc. Petroleum Geologists, Tulsa, Okla., p. 207-218.

Martin, L. T., 1930, Foraminifera from the intertidal zone of Monterey Bay, California: Micropaleontology Bull., Stanford Univ., v. 2 , no. 3 , p. 50-54.

Martin, L. T., 1931, Additional notes on the Foraminifera from the intertidal zone of Monterey Bay, California: Micropaleontology Bull., Stanford Univ., v. 3, no. 1, p. 13-14.

Martin, L. T., 1932, Observations on living Foraminifera from the intertidal zone of Monterey Bay, California: M. A. thesis, Stanford Univ. *

Martin, L. T., 1935, Foraminifera from Monterey Bay: Pan Am. Geologist, v. 63, p. 378 (abs.); Geol. Soc. America Bull., proc. for 1935 , v. 47 (1936), p. 416 (abs.).

Martin, L. T., 1937, Identification of Foraminifera from Monterey Bay, California: Geol. Soc. America Bull., proc. for 1936, v. 48, p. 384 (abs.).

Martin, L. T., and Keen, A. M., 1937, Geographic distribution of west American shallow-water Foraminifera: Geol. Soc. America Bull., proc. for 1936, v. 48, p. 384 (abs.).

Mason, E. H., 1930, Plankton of Anaheim Slough: M. A. thesis, Univ. Southern Calif., 224 p. Incl. tables, graphs, 1 map. 
Mason, H. L., 1929, Geological interpretation of endemism in the California Coast Range flora: Geol. Soc. America Bull., proc. for 1928, v. 40, p. 258 (abs.).

Mason, H. L., 1931, Pleistocene floras of the San Francisco Bay region: Geol. Soc. America Bull., proc. for 1930, v. 42, p. 365 (abs.).

Mason, M. A., 1942, Abrasion of beach sand: U. S. Army, Corps of Engineers, Beach Erosion Board Tech. Memo. $2,10 \mathrm{p}$.

Mason, M. A., 1948, Oceanographic activities of the Corps of Engineers: Am. Geophys. Union Trans., v. 29, p. $586-587$.

Mason, M. A., 1949a, Erosion et protection des cotes (beach erosion and shore protection): La Houille Blanche, no. 1, Jan-Feb., p. 1-24 (in French and English).

Mason, M. A., 1949b, Ocean wave research and its engineering applications: New York Aced. Sci. Annals, v. 51, p. 523-532.

Mason, M. A., 1950a, Geology in shore-control problems, in Trask, P. D., Applied sedimentation, symposium; New York, John Wiley and Sons, Inc., p. 276-290.

Mason, M. A., 1950b, The wind element in beach erosion: $U$. S. Army, Corps of Engineers, Beach Erosion Board Bull., v. 4 , no. 3 , p. 19-23.

Mason, M. A., 1951, The transformation of waves in shallow water: First Conf. on Coastal Eng. Proc., Berkeley, p. 22-32.

Masters, F. J., 1894, Did a Chanaman discover America? Geogr. Soc. Calif. Bull., v. 2, p. 59-76 incl. chart.

Masters, P., 1840, The coast of Mexico in the Pacific: Nautical Mag., v. for 1840, p. 73-82.

Matte1, A. C., 1917, Two Santa Barbara Channel earthquakes: Seismol. Soc. America Bull., v. 7, p. 60-66.

Maxson, J.H., 1931, Geomorphic features of northwestermost California: Pan Am. Geologist, v. 55, p. 358-359 (abs.); Geol. Soc. America Bull., proc. for 1931, v. 43 (1932), p. 224 (abs.).

Maxson, J. H., 1932, Structural relationships of the coast and continental margin of northern California: Pan Am. Geologist, v. 58, p. 66-67 (abs.); Geol. Soc. America Bull., proc. for 1932, v. 44 (1933), p. 152 (abs.).

Mayor, A. G., 1922, Hydrogen-ion concentration and electrical conductivity of the surface water of the Atlantic and Pacific: Carnegie Inst. Wash., Papers from the Dept. Marine Biology, v. 18, pub. no. 312 , p. $63-86,3$ charts.

Meaney, C. D., 1949, Mean sea-level - a basic engineering datum: Jour. U. S. Coast and Geod. Survey, no. 2, p. 34-35.

Means, T. H., 1928, Salt water problem. San Francisco Bay and delta of Sacramento and San Joaquin Rivers: San Francisco, 75 p., incl. Il tables, map.

Means, T. H., 1929, on salt water problems of San Francisco Bay and Delta, in Rept. Joint Comm. of the Senate and Assembly dealing with the water problems of the State, submitted to the Legislature of the State of Calif., Jan. 18, Sacramento, exhibit "C", p. 105-174 incl. tables.

Means, T. H., 1931, Variation and control of salinity in Sacramento - San Joaquin Delta and upper San Francisco Bay, 1931: Calif. Div, Water Res. Bull. 27, 437 p., 82 pls; Am. Geophys. Union Trans., 14th ann. meet., (1933), app. A, p. 392-393 (abs.).

Mears, E. G., 1943, New evidence regarding deep-water flow in the eastern Pacific: Am. Geophys. Union Trans., 24th ann. meet., p. 242-244.

Mears, E. G., 1944, Pacific Ocean handbook: Stanford Univ., James Ladd Delkin, vili + 192 p., 55 figs. *

Meek, R. T., 1945, Comparison of refraction methods utilized at amphibious training base at Coranado and Morro Bay: Univ. Calif., Berkeley, fluid mechanics lab., tech. rept. HE-116-93, April 14, 2 p.

Meinesz, F. A. V., 1930, Results of gravity determination upon the Pacific and the organization of further research: Fourth Pacific Sc1. Cong. Proc., v. 2B, p. 661-667.**
Meinesz, F. A. V., 1934, Recent soundings in the Pacific: Fifth Pacific Sc1. Cong. Proc., v. 2, p. 837-838.

Meinesz, F. A. V., 1941, Gravity over the continental edges: Nederl. Akad. van Wetensch. Proc., Amsterdam, v. 44, no. 8, p. $883-887$.

Meinesz, F. A. V., 1948, Gravity expeditions at sea 1923-1938 Netherlands Geod. Comm. Pub., v. 4, 233 p.

Melton, F. A., 1940, A tentative classification of sand dunes Its application to dune history in the southern high plains: Jour. Geology, v. 48, p. 113-174.

Menard, H. W., 1952, Deep ripple marks in the sea: Jour. Sed. Petrology, v. 22, p. 3-9.

Menard, H. W., and Dietz, R. S., 1951, Mendocino submarine escarpment: Geol. Soc. America Bull., v. 62, p. 1507 (abs.); Jour. Geology, v. 60 (1952), p. 266-278, chart.

Menard, H. W., Dill, R. F., Hamilton, E. L., Moore, D. G., Shumway, G., Silverman, M. and Stewart, H. B., 1954, Underwater mapping by diving geologists: Am. Assoc. Petroleum Geologists Bull., v. 38, p. 129-147.

Menard, E. W., and Ludwick, J. C., 1951, Applications of hydraulics to the study of marine turbidity currents: Soc. Econ. Paleontologists and Mineralogists, special pub. 2, p. 2-13.

Mendenhall, W. C., 1905, Development of underground waters in the western coastal plain region of southern California: U. S. Geol. Survey Water Supply Paper 139, 105 p., 8 pls., 1 map.

Menzies, R. J., 1951, The phylogeny, systematics distribution and natural history of lemnoria: $\mathrm{Ph}$. D. thesis, Univ. Southern Calif., 520 p. incl. 10 tables, 71 figs., 8 maps.

Merriam, P. D., 1949, Geology of the El Segundo sand hills: M. S. thesis, Univ. Southern Calif., 42 p., 15 pls., 6 figs.

Merrill, F. J. H., 1914, Geology and mineral resources of San Diego and Imperial Counties: Calif. Div. Mines, Rept. State Mineralogist 1913-1914, p. 1-113.

Merrill, F. J.H., 1915, San Diego County: Calif. State Mining Bur., 14th Rept. State Mineralogist, p. 637-722.

Merrill, F. J. H., 1917, Los Angeles County: Calif. State Mining Bur., 15th Rept. State Mineralogist, p. 465-514.

Messner, W. E., 1954, Flotation of Del Monte sand: Mineral Information Service, Calif. Div. Mines, v. 7 , no. 6 , p. 5-8.

Metcalf and Eddy, 1944, Technical report to the Board of Public Works, city of Los Angeles, upon the sewage disposal problem of Los Angeles and associated communitis April 25. *

Meyer, R. D., 1936, A model study of wave action on beaches: M. S. thesis, Univ. Calif., Berkeley, 39 p. *

Michael, E. L., 1911, Classification and vertical distribution of the Chaetognatha of the San Diego region including the rediscription of some doubtful species of the group: Univ. Calif. Pub. Zoology, v. 8, p. 21-186, pls. $1-8$.

Michael, E. L., 1919, The problem of the organic fertility of the North Pacific Ocean: Scripps Inst. for Biol. Research Bull., no. 9, p. 51-57.

Michael, E. L., 1921, Effect of upwelling water upon the organic fertility of the sea in the region of southern California First Pan-Pacific Sci. Conf. Proc., pt. 2 p. 555-559.

Michael, E. L., and McEwen, G. F., 1915, Hydrographic, plankton, and dredging records of the Scripps Institution for Biological Research of the University of California, 1901 to 1912, compiled and arranged under the supervision of W. E. Ritter: Univ. Calif. Pub. Zoology, v. 15, p. 1-206.

Michsel, E. L., and McEwen, G. F., 1916, Continuation of hydrographic, plankton, and dredging records of the Scripps Institution for Biological Research of the University of California (1913-1915). Compiled and arranged under the supervision of W. E. Ritter: Univ. Calif. Pub. Zoology, v. 15, p. 207-254. 
Miller, H. E., and Nusbaum, I., 1952, The oxygen resources of San Diego Bay, in San Diego Regional Water Pollution Control Board, Rept. upon the extent, effects and limitations of waste disposal into San Diego Bay, app. III, p. 81-94; Reprinted in sewage and Indus. Wastes, v. 24 , p. 1512-1527 but Nusbaum as senior author.

Miller, J. C., 1953, Geologic and engineering aspects of continental shelves: $0 i 1$ and Gas Jour., v. 51, March 2, p. $78-82$.

Miller, R. C., Ramage, W. D., and Lazier, E. L., 1928, Study of physical and chemical conditions in San Francisco Bay especially in relation to tides: Univ. Calif. Pub. Zoology, v. 31, p. 201-267.

Miller, R. L., 1954, A model for the analysis of environments of sedimentation: Jour. Geology, v. 62, p. 108-113.

Miller, w. J., 1935, Geomorphology of the southern Peninsular Range of California: Geol. Soc. America Bull., v. 46, p. 1535-1562.

Miller, W. J., 1940, Some features of faulting in southern California: Jour. Geology, v. 48, p. 385-420.

Mills, B., 1932a, Standard to make test on island off Santa Barbara: 0il Weekly v. 64 , no. 9 , Feb. 12, p. 53.

Mills, B., 1932b, Steel island off Rincon ready within three weeks: 0il Weekly, v. 67 , no. 2 , Sept. 26, p. 34 .

Mills, B., 1932c, ocean test between Rincon and Carpinteria important: oil Weekly, v. 67 , no. 2, Sept. 26 , p. 35.

Mills, B., 1932d, California has several tideland possibilities: 0il Weekly, v. 67 , no. 3, oct. 3, p. 44 .

Mills, B., 1932e, Huntington Beach votes favor tideland drilling: oil Weekly, v. 67 , no. 3 , oct. 3 , p. 44.

Mills, B., 1932f, Tideland drilling tabooed in Huntington Beach Field: 0il Weekly, v. 67, no. 10, Nov. 21, p. 42.

Mills, B., 1932g, "Steel Island" well should complete early next year: 0il Weekly, v. 67, no. 10, Nov. 21, p. 43.

Mills, B., 1936, Multiple wells under one location and deviated boring advanced by Elwood ocean drilling: Oil Weekly, v. 80 , no. 5 , Jan. 13, p. $25-28,30$.

Milner, F., 1941, Model study of wave refraction in a submarine valley: M. S. thesis, Univ. Calif., Berkeley, $61 \mathrm{p}$. incl. figs.

Mitchell, G. D., 1928, The Santa Cruz earthquakes of October 1926: Seismol. Soc. America Bull., v. 18, p. 153-213, pls. 15-17.

Miyabe, N., 1934, An investigation of the Sanriku tsunami based on mirigram data: Earthquake Research Inst., Tokyo Imperial Univ. Bull., supp., v. 1, p. 112-125. *

Moberg, E. G., 1925, Chemical studies of marine plankton and its environment in the San Diego region: $\mathrm{Ph}$. D. thesis, Univ. Calif., Berkeley, 122 p., incl. figs., tables.

Moberg, E. G., 1928a, The interrelation between diatoms, their chemical environment, and upwelling in the sea, off the coast of soutiern California: Natl. Acad. Sci. Proc., v. 14, p. $511-518$.

Moberg, E. G., 1928b, The hydrogen ion concentration of sea water off the coast of southern California: Third Pan-Pacific Sci. Cong. Proc., v. 1, p. 221-229.

Moberg, E. G., 1928c, The phosphate, silicate and fixed nitrogen content of sea water: Third Pan-Pacific Sci. Cong. Proc., v. I, p. 229-232.

Moberg, E. G., 1928d, Chemical composition of marine plankton: Third Pan-Pacific Sci. Cong. Proc., v. 1, p. 233-236.

Moberg, E. G., 1930a, Circulation of the waters of the Pacific as indicated by their physical and chemical properties: Science, v. 72 , no. 1867, p. 374.

Moberg, E. G., 1930b, The distribution of oxygen in the Pacific, in Contr. Marine Biology, Stanford Univ. Press, p. $69-78$.

Moberg, E. G., 1930c, The interrelation between diatoms, their chemical environment, and upwelling water in the sea, off the coast of southern California: Fourth Pacific Sci. Cong. Proc., v. 2A, p. 309-316; v. 3, p. $443-444$ (abs.).

Moberg, E. G., and Allen, W. E., 1927, Effect of tidal changes on physical, chemical, and biological conditions in the sea water of the San Diego region. I. Observations on the effect of tidal changes on physical and chemical conditions of sea water in the San Diego region, by $E$. G. Moberg; II. Half-hourly collections of marine microplankton taken at the Scripps Institution Pier in 1923 by W. E. Allen: Scripps Inst. Oceanography Bull., tech. ser., v. 1, p. 1-17.

Moberg, E. G., and Fleming, R. H., 1934, The distribution of nitrogen compounds in the sea near southern California: Fifth Pacific Sci. Cong. Proc., v. 3, p. 2085-2088.

Moberg, E. G., Fleming, R. H., Heusner, K., and Revelle, R., 1937, The organic nitrogen content of marine sediments off the west coast of North America: Assoc. d'Océanographie Physique, Union Géodésique et Géophysique Internat., Procès-Verbaux no. 2, p. 154; Geol. Soc. America, proc. for 1936, p. 316 (abs.).

Moberg, E. G., and Graham, H. W., 1930, The distribution of oxygen in the Pacific as an index of the circulation of the water: Internat. Geod. and Geophys. Union, Stockholm Assembly, Carnegie Inst. Wash., Dept. Terrestrial Magnetism and Electricity, sect. of oceanography, p. 95-97.

Moberg, E. G., and Harding, M. W., 1933, The boron content of sea water: Science, v. 77 , no. 2004 , p. 510.

Moberg, E. G., and Revelle, R., 1937, The distribution of dissolved calcium in the North Pacific: Assoc. d'océanographie Physique, Union Géodesique et Géophysique Internat., Procès-Verbaux no. 2, p. 153.

Moberg, E. G., Seiwell, H. R., Graham, H. W., and Paul, J. H., 1930, The phosphate-content of the surface-water in the Pacific as related to the circulation: Internat. Geod. and Geophys. Union. Stockholm Assembly, Carnegie Inst. Wash., Dept. Terrestrial Magnetism and Electricity, sect. of oceanography, p. 98-100.

Moffitt,F. H., 1953a, Analysis of non-uniform, short-crested ocean waves for depth determination, based on wave velocity method, from timed vertical photographs taken over Clatsop Spit, Oregon: Univ. Calif., Berkeley, Inst. eng. research, waves research lab., ser. 74 , issue 2,9 p. incl. tables +6 figs.

Moffitt, F. H., 1953b, Analysis of controlled terrestrial photographs taken at Davenport, California, for wave velocity method of depth determination: Univ. Calif., Berkeley, Inst. eng. research, wave research lab., ser. 74 , issue 3,6 p., 11 figs.

Moffitt, J., and orr, R. T., 1938, Recent disasterous effects of oil pollution on birds in the San Francisco Bay region: Calif. Fish and Game, v. 24, p. 239-244.

Montgomery, R. B., and Wooster, W. S., 1954, Thermosteric anomaly and the analysis of serial oceanographic data: Deep-Sea Research, v. 2, p. 63-70.

Moody, G. B., 1935, Geology of Santa Rosa Island: Pan Am. Geologist, v. 63, p. 316-317 (abs.); Am. Assoc. Petroleum Geologists Bull., v. 19, p. 136 (abs.); Geol. Soc. America Bull., proc. for 1935, v. 47, (1936), p. 338-339 (abs.).

Moore, D. G., 1951, The marine geology of San Pedro shelf: M. S. thesis, Univ. Southern Calif., 87 p., 7 pls., 7 figs; Jour. Sed. Petrology, v. $24^{\prime}(1954)$, p. 162-181.

Morey, B. F., 1944, Preliminary report on beach survey of Point Reyes, California, determined from aerial photographs: Univ. Calif., Berkeley, fluid mechanics lab., tech. rept. HE-116-32, Nov. 29, 2 p., graph.

Morey, B. F., 1945, The analysis of aerial photographs for wave length, height of breakers, period, and stage of tide: Univ. Calif., Berkeley, fluid mechanics lab., tech. rept. HE-116-102, May 3, 8 p. of tables.

Morgan, F. A., 1930, Tideland development in California: 0il and Gas Jour., v. 28, March 13, p. 114, 118, 122, 240, 242.

Morrison, R. L., 1930, A study of mollusks found at Mission Bay, San Diego, California: their classification and special attention to their distribution: M. A. thesis, Univ. Southern Calif., 94 p., 6 pls., 11 figs., 3 maps., graph.

Moser, J. F., 1898, Report on the work of the steamer Albatross: Rept. U. S. Fish Comm. for 1897, p. exlvii-clxxi (abs.). 
Moulton, G. F., 1928, Loss of red color of rocks: Am. Assoc. Petroleum Geologists Bull., v. 12, p. 767-769.

Mouton, M. W., 1952, The continental shelf: The Hague, Martinus Nijhoff, 367 p. *

Moyer, D. A., 1929a, The relation of a fossil Foraminifera fauna from Lomita Quarry, San Pedro, California, to a Recent Foraminifera from off the coast of San Pedro, California: M. S. thesis, Univ. Southern Calif., 22 p.

Moyer, D. A., 1929b, Shallow water Foraminifera from off Point Fermin, San Pedro, California: Micropaleontology Bull., Stanford Univ., v. 1, no. 11, p. 5-10, incl. 2 tables.

Munch, J. F., 1945, A comparison of breaker helght to breaker depth from data at a Standard Oil pier, Estero Bay: Univ. Calif., Berkeley, fluid mechanics lab., tech. rept. HE-116-197, June 9, 10 p., tables.

Munk, W. H., 1940, Internal waves in the Gulf of California: M. S. thesis, Calif. Inst. Tech., 59 p., incl. $13 \mathrm{flgs}$; Jour. Marine Research, v. 4 (1941), p. 81-91.

Munk, W. H., 1947a, Incease in the period of waves traveling over large distances: with applications to tsunamis, swell and seismic surface waves: Ph. D. thesis, Univ. Calif., 33 p., 13 pls; Am. Geophys. Union Trans., v. 28, p. 198-217; Geol. Soc. Am. Bull., v. 58, p. 1267 (abs.).

Munk, W. H., 1947b, A critical wind speed for air-sea boundary processes: Jour. Marine Research, v. 6, p. 203-218.

Munk, W. H., 1948, Wave action on structures: Am. Inst. Min. and Metall. Eng., tech. pub. no. 2322, p. 1-18.

Munk, W. H., 1949a, Surf beats: Scripps Inst. Oceanography, Wave Rept. 87, 6 p. incl. diagrams, tables; Am. Geophys. Union Trans., v. 30, p. 849-854.

Munk, W. H., 1949b, The solitary wave theory and its application to surf problems: Scripps Inst. Oceanography, Wave Rept. 79,49 p. incl. tables, diagrams; New York Acad. Sci. Annals, v. 51 , p. $376-424$.

Munk, W. H., 1950, on the wind-driven ocean circulation: Jour. Metéorology, v. 7, p. 39-93.

Munk, W. H., 1951, Origin and generation of waves: Scripps Inst. Oceanography, Wave Rept. 99 , SIO ref. 51-57, p. 1-4, incl. diagrams; First Conf. on Coastal Eng. Proc., Berkeley, p. 1-4.

Munk, W. H., 1952, Ocean waves a meteorological tool: Scripps Inst. Oceanography, wave Rept. 88, SIO ref. 52-18, 11 p., incl. tables, diagrams; Compendium of Meteorology, pub. by Am. Meteorol. Soc., p. 1090-1100.

Munk, W. H., 1953, Small tsunamis waves reaching California from the Japanese earthquake of March 4, 1952: Seismol. Soc. America Bull., v. 43, p. 219-222.

Munk, W. H., and Anderson, E. R., 1948, Notes on a theory of the thermocline: Jour. Marine Research, v. 7, p. 276-295.

Munk, W. H., and Arthur, R. S., 1952, Forecasting ocean waves: Scripps Inst. Oceanography, Wave Rept. 89, SIO ref. $52-19$, \& p. incl. tables, diagrams; Compendium of Meteorology, pub. by Am. Meteorol. Soc., p. 1082-1089.

Munk, W. H., and Traylor, M. A., 1945, Forecasting longshore currents: Scripps Inst. Oceanography, Wave Project Rept. 46,6 p., 3 figs.

Munk, W. H., 1947, Refraction of ocean waves; a process linking underwater topography to beach erosion: Jour. Geology, v. 55, p. 1-26; Scripps Inst. Oceanography, Wave Ript. 62.

Murphy, H. E., 1924, Preliminary quantitative study of marine zooplankton at La Jolla, California: Ecology, v. 5, p. $283-286$.

Murphy, L. M., 1950, U. S. earthquakes 1947: U. S. Coast and Geod. Survey, serial $730,61 \mathrm{p}$.

Murphy, L. M., and Cloud, W. K., 1953, U. S. earthquakes 1951: U. S. Coast and Geod. Survey, serial $762,50 \mathrm{p}$.

Murphy, L. M., and Ulrich, F. P., 1951a, U. S. earthquakes 1948: U. S. Coast and Geod. Survey, serial 746, 50 p.

Murphy, L. M., and Ulrich, F. P., 1951b, U. S. earthquakes 1949: U. S. Coast and Geod. Survey, serial 748,64 p.

Murphy, L. M., and Ulrich, F. P., 1952, U. S. earthquakes 1950: U. S. Coast and Geod. Survey, serial $755,47 \mathrm{p}$.

Murray-Aaron, E. R., 1947, Tidelands pools of Huntington Beach oil Field: Calif. Oil Fields, v. 33, no. 1, p. 3-11, map.

Murray-Aaron, E. R., 1948, Tideland pools of Huntington
Beach 01l Field: Calif. O1l Fields, v. 33, no. 1, (1947), p. 3-10, 6 pls., 1 chart.

Murray, स. W., 1939, Submarine scarp off Mendocino, Californis U. S. Coast and Geod. Survey, Field Eng. Bull., Dec., no. $13, p .27-33$.

Murray, J., and Lee, G. V., 1909, The depth and marine deposit of the Pacific: Mus. Comp. Zoology Mem., v. 17, 169 p., 5 pls., 3 maps.

Myers, E. H., 1942, A quantitative study of the productivity of the Foraminifera in the sea: Am. Philos. Soc. Proc., v. $85, \mathrm{p} .325-342,1 \mathrm{pl}$.

Myers, E. H., 1943, Life activities of Foraminifera in relation to marine ecology: Am. Philos. Soc. Proc., v. 86 , p. $439-458,1$ pl.

National Petroleur Council, 1953, Submerged lands productive capacity: Natl. Petroleum Council headquarters, 601 Commonwealth Bld., 1625 K St., N. W., Wash., 6, D. C. *

Natland, M. L., 1933a, Distribution of some Recent and fossil Foraminifera in the southern California region: Pan Am. Geologist, v. 59, p. 378-379 (abs.); Geol. Soc. America Bull., proc. for 1933 , v. 45 (1934), p. 393 (abs.).

Natland, M. L., 1933b, The temperature and depth-distribution of some Recent and fossil Foraminifera in the southern California region: Scripps Inst. Oceanography Bull., tech. ser., v. 3, p. 225-230, 1 table.

Natland, M. L., and Kuenen, Ph. H., 1951, Sedimentary history of the Ventura Basin, California, and the action of turbidity currents: Soc. Econ. Paleontologists and Mineralogists, special pub. no. 2, p. 75-107.

Natland, M. L., Revelle, R., and Rittenberg, S. C., 1941, Recent marine ecological investigations of Paleontologica. significance at the Scripps Institution of Oceanography: Natl. Research Council, Rept. Subcomm. on the Ecology of Marine organisms, no. 1, p. 34-41 (reprinted July 1944

Nelburger, M., 1948, The reflection of diffuse radiation by the sea surface: Am. Geophys. Union Trans., v. 29, p. 647-652.

Neiburger, M., Beer, C. G. P. and Leopold, L. B., 1945, The California stratus investigation of 1944: U. S. Dept. Commerce, Weather Bur., Wash., 83 p. *

Nelson, E. W., 1922, Lower California and its natural resource Natl. Acad. Sci. Mem., v. 16, 194 p., 34 pls., 1 chart. *

Nelson, J. W., Dean, W. C., Kocher, A. E., Watson, E. B., and Carpenter, E. J., 1920, Soll survey of the ventura area, California: U. S. Dept. Agriculture, Bur. Soils, 87 p., 1 fig., 3 pls., map.

Nelson, J. W., Zinn, C. J., Strahorn, A. T., Watson, E. B., and Dunn, J. E., 1919, Soil survey of the LOs Angeles area, California: U. S. Dept. Agriculture, Bur. Soils, 78 p., 1 fig., 3 pls., map.

Nelson, N. C., 1909, Shell mounds of the San Francisco Bay region: Univ. Calif. Pub. Am. Archaeology and Ethnology, v. 7 , p. 309-356, pls. 32-35, map.

Nelson, N. C., 1910, The Ellis Landing shell mound: Univ. Calif. Pub. Am. Archaeology and Ethnology, v. 7, p. 357-426, pls. 36-50.

Nelson, R. N., and Schenck, H. G., 1928, Calcareous algae in Pacific Coast limestones: Geol. Soc. America Bull., proc. for 1925, v. 39, p. 266 . (abs.).

Nettleton, L. L., 1951, Gravity operations in water covered areas: 0il and Gas Jour., v. 150, no. 7, p. 235-239, $284-286$.

Neumann, F., 1929, The velocity of selsmic surface waves over Pacific paths: Selsmol. Soc. America Bull., v. 19, p. $63-76$.

Neumann, F., 1932, U. S. earthquakes 1931: U. S. Coast and Geod. Survey, serial 553, 26 p.

Neumann, F., 1934, U. S. earthquakes 1932: U. S. Coast and Geod. Survey, serial 563, 21 p.

Neumann, F., 1935, U. S. earthquakes 1933: U. S. Coast and Geod. Survey, gerial $579,82 \mathrm{p}$.

Neumann, F., 1936, U. S. earthquakes 1934: U. S. Coast and Geod. Survey, serial 593, $99 \mathrm{p}$.

Neumann, F., 1937, U. S. earthquakes 1935: U. S. Coast and Geod. Survey, serial $600,90 \mathrm{p}$. 
Neumann, F., 1938, U. S. earthquakes 1936: U. S. Coast and Geod. Survey, serial 610, $44 \mathrm{p}$.

Neumann, F., 1940a, U. S. earthquakes 1937: U. S. Coast and Geod. Survey, serial $619,54 \mathrm{p}$.

Neumann, F., 1940b, U. S. earthquakes 1938: U. S. Coast and Geod. Survey, serial 629, $59 \mathrm{p}$.

Neumann, F., 1942, U. S. earthquakes 1940: U. S. Coast and Geod. Survey, serial $647,74 \mathrm{p}$.

Neumann, F., 1943, U. S. earthquakes 1941: U. S. Coast and Geod. Survey, serial $655,69 \mathrm{p}$.

Neumann, F., 1952, Earthquake investigation in the U. S.: U. S. Coast and Geod. Survey, special pub. 282,37 p.

Neumann, F., and Bodle, R. R., 1932, U. S. earthquakes 1930: U. S. Coast and Geod. Survey, serial 539, 25 p.

Newell, I. M., 1948, Marine molluscan provinces of western North America: a critique and a new analysis: Am. Philos. Soc. Proc., v. 92, no. 3, p. 155-166.

Nicholls, C. P. L., 1936a, Practical observations on the needs and uses of public beaches: Shore and Beach, $v$. 4 , p. $82-88$.

Nicholis, C. P. L., 1936b, Rip tides and how to avold their perils: Calif. Beaches Assoc., v. 1, no. 9. *

Nicholls, C. P. L., 1936c, Oil pollution of southern California beaches: Shore and Beach, v. 4, p. 128-136, discussion p. 136-138.

Nicholls, C. P. L., 1939, Water safety at the ocean beach: Shore and Beach, v. 7, p. 148-157.

Nicholls, C. P. L., 1941, Sand, surf and-sense! Hazards to be guarded against on the beach and in the water, and a model seashore safety code: Shore and Beach, v. 9, p. $48-49,64$.

Nicholson, G. F., 1929, Variations in levels, 1919 to 1927, in Los Angeles Harbor: Seismol. Soc. America Bull., v. 19 , p. $200-205$.

Nicholson, G. F., Grant, U. S., Shepard, F. P., and Crowell, J. C., 1946, Report on Malibu Yacht Harbor site for Malibu Quarterdeck Improvement Co.: Los Angeles, mimeo. rept., Sept. $25,145 \mathrm{p} .+53 \mathrm{pls}$. and description of pls.

Nicol, D., 1942, Statistical analysis of new Foraminiferal species of Elphidium from the west coast of North America: M. A. thesis, Stanford Univ., 43 p.

N1col, D., 1944, New west american species of the Foraminiferal genus Elphidium: Jour. Paleontology, v. 18, p. 172-185, pl. 29 .

Nightingale, H. W., 1937, Red water organisms: Seattle, wash., Argus Press.*

Norris, R. M., 1949, The geology of a portion of the westerr Santa Ynez Range, Santa Barbara County, California: M. A. thesis, Univ. Calif., Los Angeles, 76 p., 4 pls., 17 figs.

Norris, R. M., 1951, The marine geology of the San Nicolas Island region, California: Scripps Inst. Oceanography, Submarine Geology Rept. 21, 14 p., 5 figs., charts.; $\mathrm{Ph}$. D. thesis, Univ. Calif., Los Angeles, 124 p., 26 pls.

Norris, R. M., 1952, Recent history of a sand spit at San Nicolas Island, California: Jour. Sed. Petrology, v. 22, p. $224-228$.

Novelli, G. D., 1943, Bacterial Oxidation of hydrocarbons in marine sediments: Soc. Experimental Biology and Medicine: v. 52 , p. $133-134$.

Nusbaum, I., and Miller, H. E., 1952, The oxygen resources of San Diego Bay, in San Diego Regional Water Pollution Control Board, 1952, Report upon the extent, effects and limitations of waste disposal into San Diego Bay, app. III, p. 81-94.

Oakeshott, G. B., 1951, Southern coastal region, in Symposium on possible future petroleum provinces of North America: Am. Assoc. Petroleum Geologists Bull., v. 35, p. 253-255.

O'Brien, M. P., 1931, Estuary tidal prisms related to entrance areas: Civil Eng., v. 1, p. 738-739.

O'Brien, M. P., 1935, Salt-water barrier not technically feasible: Civil Eng., v. 5, p. 705.

O'Brien, M. P., 1936a, The cosst of California as a beach erosion laboratory: Shore an Beach, v. 4, D. 74-79.

O'Brien, M. P., 1936b, Shoreline phenomena and research:
Shore and Beach, v. 4, p. 120-122, discussion p. 122-125.

O'Brien, M. P., 1939, Beach restoration at Santa Barbara. II. Engineering aspects and measures: Shore and Beach, v. 9, p. $92-97$.

O'Brien, M. P., 1941, Shore line formation by currents: Shore and Beach, v. 9, p. 46.

O'Brien, M. P., 1944, Wave refraction near the Monterey Breakwater: Univ. Calif., Berkeley, fluid mechanics lab., tech. rept. HE-116-5, Aug. 19, 2 p.

O'Brien, M. P., 1945a, Wave observations at Estero Bay: Univ. Calif., Berkeley, fluid mechanics lab., tech. rept. HE-116-61, Feb. 27, 3 p.

O'Brien, M. P., 1945b, Report on surf characteristics of landing craft: Univ. Calif., Berkeley, fluid mechanics lab., tech. rept. HE-116-104, May 11, 43 p., graphs, photos, tables.

O'Brien, M. P., 1946a, The causes of plunging and spilling breakers: Univ. Calif., Berkeley, fluid mechanics lab., tech. rept. HE-116-192, Jan. 23, 3 p., graphs, photos; U. S. Army, Corps of Engineers, Beach Erosion Board Bull., v. 3, no. 3, p. $7-10$ (1949).

O'Brien, M. P., 1946b, Preliminary report on seismic sea waves from Aleutian earthquakes of April 1, 1946: Univ. Calif., Berkeley, fluid mechanics lab., tech. rept. HE-116-207, April 25, $10 \mathrm{p}$.

O'Brien, M. P., 1947a, Memorandum concerning the depth and angle at the point of breaking: Univ. Calif., Berkeley, fluid mechanics lab., tech. rept. HE-116-67, Feb. 10, 6 p., tables, graphs.

O'Brien. M. P., 19470, Wave refraction at Long Beach and Santa Barbara, California: Univ. Calif., Berkeley, f'luid mechanics lab., tech. rept. HE-116-246, 14 p., tables, photos, diagrams; U. S. Army, Corps of Engineers, Beach Erosion Board Bull., v. 4, no. 1, p. 1-14.

O'Brien, M. P., and Cherno, J., 1934, Model law for formation of salt water through fresh: Am. Soc. Civil Eng. Trans., v. 99 , p. 576-609.

O'Brien, M. P., and Johnson, J. W., 1947, Wartime research on waves and surf: Military Engineer, v. 39, no. 260 , p. $239-242$

O'Brien, M. P., and Nilmeier, H. P., 1945, wave observation stations - III, Jan. 12 - Jan. 13, 1945: Univ. Calif., Berkeley, fluid mechanics lab., tech. rept. HE-116-53, Feb. 2, 2 p.

Oldroyd, I. S., 1924-1927, The marine shells of the west coast of North America: Stanford Univ. Pub. Geol. Sci., v. 1, no. 1, 247 p., 57 pls; v. 2, pt. 1, 297 p., 29 pls.; v. 2, pt. 2, 304 p., 72 pls.; v. 2, pt. 3, 339 p., $108 \mathrm{pls}$

Olsson-Seffer, P., 1908, Relation of wind to topography of coastal drift sands: Jour. Geology, v. 16, p. 549-564.

Olsson-Seffer, P., 1910a, Genesis and development of sand formations on marine coasts: Augustana Library Pub. 7 , Rock Island, Ill., p. 1-41.

Olsson-Seffer, P., 1910b, The sand strand flora of marine coasts: Augustana Library Pub. 7, Rock Island, Ill., p. $42-183$.

Omori, F., 1907, Notes on the Valparaiso and Aleutian earthquake of August 17, 1906: Imperial Earthquake Inv. Comm. Bull., Tokyo, v. 1, no. 2, p. 75-113.

Orange County Planning Commission, 1941, The Master Plan of Shoreline Development for Orange County: orange County, Calif., 83 p., diagrams.

Orr, P. C., 1952, The orca goes underground: The American Caver, Bull. 14 of the Natl. Speleological Soc., Sept., p. $21-23$.

Osborn, P., undated, Refraction of long swell off. La Jolla, 18-30 seconds: Scripps Inst. Oceanography, Wave Rept. 84,3 p., 5 figs. *

O'Shaughnessy, M. M., 1924, Ocean Beach Esplanade, San Francisco, California: Am. Soc. Civil Eng. Trans., v. 87 , p. 492-534, incl. illus, and discussion, 2 pls.; Am. Soc. Civil Eng. Proc., v. 49 (1923), p. 1846-1859; discussion v. 50 (1924), p. 223-225, 351-372, 651-656.

Osmont, V. C., 1904, A geological section of the Cosst Ranges north of San Francisco: Univ. Calif. Pub. Geology, v. 4 , p. $39-87$. 
Osorio Tafall, B. F., 1943, El Mar de Cortés y la productividad fitoplanctónica de sus augas: Anales Escuela Nac. Ciencias Biologicas, v. 3, p. 73-118.

osorio Tafall, B. F., 1944, La Expedición del M. N. Gracioso por aguas del extremo noroeste Mexicano: Anales Escuela Nac. Ciencias Biologicas, v. 3, p. 331-360.

osor1o Tafall, B. F., 1948, La Isla de Cedros, Baja California: Boletin de la Soc. Mexicana de Geografia y Estadistica, v. 66, p. 319-402, 26 figs (photos), 7 maps.

Packard, E. L., 1918, A quantitative analysis of the molluscan fauna of San Franc1sco Bay: Univ. Calif. Pub. Zoology, v. 18 , p. 299-336.

Page, G. B., 1950, Beach erosion and composition of sand dunes, Playa del Rey - El Segundo area, California: M. A. thesis, Univ. Calif., Los Angeles, 50 p., 25 pls., 10 tables.

Pagenhart, E. H., 1931, Oceanographic work of the U. S. Coast and Geodetic Survey during the past year: Am. Geophys. Union Trans., 12th ann. meet., p. 155-160.

Pagurigan, F., 1941, Geologic investigation of the San Pedro Point area, California: M. A. thesis, Stanford Univ., 51 p., 18 pls., graphs.

Palmberg, H. G., 1941, Letter to the editor in relation to the "Burning of the Minnie A. Caine:" Shore and Beach, v. 9 , p. 65 and photo.

Palmer, A. H., 1917, Fog along the California coast: Monthly Weather Rev., v. 45, p. 496-499.

Palmer, R. H., 1928, Sand holes of the strand: Jour. Geology, v. 36, p. $176-180$.

Pamphlets on Mining, 1879-1883, Bound volume at Univ. Calif., Berkeley. 12 articles on mining debris. *

Pardee, J. T., 1934, Beach placers of the Oregon Coast: U. S. Geol. Survey Circ. 8, 41 p.

Paredes, T., 1920, El petróleo en algunas islas del Golfo de California: Secretaria de Industria, Comercio y Trabajo, Mexico, p. 1-15; Boletin del petróleo, v: 9, no. 5, p. $403-. *$

Parkin, E. J., 1948, Vertical movement in the Los Angeles region, 1906-1946: Am. Geophys. Union Trans., v. 29, p. $17-26$.

Patrick, D. A., 1950, Ground water adjacent to four Pacific ocean beaches: Univ. Calif., Berkeley, Inst. eng. research, tech. rept. HE-155-35, $6 \mathrm{p}$.

Patrick, D. A., 1953, Comparison of beach elevation at limits of backwash and uprush with U. S. Coast and Geodetic Survey tide predictions on several Pacific coast beaches: Am. Geophys. Union Trans., v. 34, p. 337 (abs.); U. S. Army, Corps of Engineers, Beach Erosion Board Bull., v. 7 , no. 2 , p. 23 (abs.).

Patterson, R. S., 1950, Report to Orange County Board of Supervisors and orange county Harbor Commission on the improvement of upper Newport Bay, Newport Bay Harbor, Orange County, California. July, 100 p., 28 pls. *

Patton, C. P., 1953, Climatology of summer fogs in the San Francisco Bay area: Ph. D. thesis, Univ. Calif., Berkeley, $167 \mathrm{p}$. incl. 32 maps, 13 figs., 5 tables, (See bibliography at the end of this paper for many references on meteorology of the Bay region).

Patton, R. S., 1930, Echo-sounding: Am. Geophys. Union Trans., lith ann. meet., p. 236-240.

Patton, R. S., 1941, Relation of tide to property boundaries: Shore and Beach, v. 9, p. 35-39, 56-59.

Patton, R. S., and Marmer, H. A., 1932, The waves of the sea in Natl. Research Council Bull. 85, Physics of the earth - v, Oceanography, p. 207-228.

Pattullo, J., 1952, Mixed layer depth determined from critical gradient frequency: Scripps Inst. Oceanography, Oceanographic Rept. 28 , SIO ref. 52-25, 10 p., 8 diagrams.
Paul, A. B., 1894, The black sand gold question: Min. and Sci. Press, v. 69, oct. 13, p. 230-231.

Pease, W. H., 1868, on the existence of an atoll near the west coast of America and proof of its elevation: Calif. Acad. Sci. Proc., v. 3 (1863-1867), p. 199-201.

Pecham, S. F., 1897, on the nature and origin of petroleum: Am. Philos. Soc. Proc., v. 36, p. 103-112.

Peel, K. P., 1951, Location of harbors: First Conf. on Coastal Eng., Berkeley, p. 179-185.

P'e1, C., 1929, Ecology of North American Diatomaceae: Micropaleontology Bull., Stanford Univ., v. 1, no. 10, p. 5-11.

Pelline, J. E., 1952, The geology of adjacent parts of the Las Flores and Topanga quadrangles, Santa Monica Mountains, California: M. A. thesis, Univ. Calif., Los Angeles, 58 p., 10 pls.

Pentegoff, V. P., 1947, Contamination of ground water from a proposed ship canal, Los Angeles Harbor, California: Geol. Soc. America Bull., v. 58, p. 1217 (abs.).

Petracek, F. J., Fax, D. L., and Zechmeister, L., 1951, The fluorescing substances of an intertidal ocean mud: Archives of Blochemistry, v. 30 , p. 466-468.

Petterssen, s., 1938, On the causes and the forecasting of the California fog: Am. Meteorol. Soc. Bull., v. 19, p. 49-55.

Phelps, A., 1937, The variation in the silicate content of the water in Monterey Bay, California, during 1932, 1933 and 1934: Ar. Philos. Soc. Trans., v. 29, pt. II, p. 53-188, incl. 13 figs., 6 tables.

Phelps, A., 1940, Oceanographic activities of the Hopkins Marine Station, Pacific Grove, California: Sixth Pacific Sci. Cong. Proc., v. 3, p. 113.

Phleger, F. B., 1951, Displaced Foraminifera faunas: Soc. Econ. Paleontologists and Mineralogists, special pub. no. 2 , p. 66-75.

Pierce, J. W., 1948, Salt water infiltration into the Alameda County water district: Eng. thesis, Stanford Univ., $48 \mathrm{p.}, 18$ maps and diagrams.

Pierce, W. D., and Pool, D., 1938, The fauna and Plora of the El Segundo sand dunes: Southern Calif. Acad. Sci. Bull., v. 37, p. 93-104, see also later volumes.

Piggot, C. S., 1932, Radium-content of ocean bottom sediments: Am. Geophys. Union Trans., 13th ann. meet., p. 233-238.

Piggot, C. S., 1944, II. Radium content of ocean-bottom sediments, in Scientific results of Cruise VII of the Carnegie during 1928-1929 under command of Captain J. P. Ault, oceanography II, Carnegie Inst. Wash. pub. 556, p. 183-196 incl. 2 figs, 1 pl.

Piggot, C. S., and Urry, W. D., 1942, Time relations in ocean sediments: Geol. Soc. America Bull., v. 53, p. 1187-1210.

Pinckard, J. H., Kittredge, J. S., Fox, D. L., Haxo, F. T., and Zechmeister, L., 1953, Pigments from a marine 'red water' population of the dinoflagellate prorocentrum micans: Archives of Biochemistry and Biophyiics, v. 44, p. $189-199$.

Piper, A. M., Garrett, A. A., and others, 1953, Native and contaminated ground waters in the Long Beach-Santa Ana area, California: U. S. Geol. Survey Water-Supply Paper 1136, 320 p., 19 pls., 29 figs., 33 tables.

Piper, A. M., and Poland, J. F., 1945, Ground water for emergency public supply at San Diego, California: U. S. Geol. Survey Ground-Water branch, duplicated rept., March 27. *

Place, J. L., 1952, The Pacific face of the Santa Monica Mountains, southern California: a geographic interpretation: M. A. thesis, Univ. Calif., Los Angeles, 114 p., 21 figs., 4 pls.

Poland, J. F., 1943, Saline contamination of coastal ground water in southern California: Western City, v. 19, p. 46 , 48,50 . 
Poland, J. F., 1947, Summary statement of ground water conditions along the coast of orange County, California: Directors of Orange County Water District, $20 \mathrm{p}$.

poland, J. F., 1950, Ground water in California: Min. Eng., v. 187, p. 279-284, discussion p. 1168-1169; Am. Inst. Metall. Eng. Trans., v. 187.

Poland, J. F., Garrett, A. A., and Mann, J. F., 1948, Progress report on water supply for the Point Mugu Naval Base, Ventura County, California: U. S. Geol. Survey, GroundWater branch, duplicated rept., Aug. 20, $51 \mathrm{p.} *$

oland, J. F., Garrett, A. A., and Sinnott, A., 1948, Geology, hydrology and chemical character of the ground waters in the Torrance - Santa Monica area, Los Angeles County, California: U. S. Geol. Survey Ground-Water branch, duplicated rept., May, $472 \mathrm{p}$.

oland, J., and Piper, A. M., and Others, 1945, Geologic features in the coastal zone of the Long Beach-Santa Ana area, California, with particular respect to ground water conditions: U. S. Geol. Survey, Water-Supply manuscript, $327 \mathrm{p}$.

oland, J. F., and Others, 1946, Hydrology of the Long BeachSanta Ana area, California, with special reference to the watertightness of the Newport Inglewood structural zone: U.S. Geol. Survey Ground-Water branch, duplicated rept., June.*

ollak, C. N., 1953, Legal battle certain over island drillsite off California Cast: Petroleum World and 0il, v. 50 , no. 3 , Jan. 15, p. 1 .

omeroy, H. R., 1936, Planning in relation to the beaches: Shore and Beach, v. 4, p. 113-119, discussion p. 119-120.

orter, J. C., 1936, State-wide planning for shore development and protection: Shore and Beach, v. 4, p. 1ll-112, discussion p. $112-113$.

oss, E. G., 1937, New coastal highway over Pedro Mountain, California: Shore and Beach, v. 5, p. 84-85.

ostel, A. C., 1937, Santa Barbara will study its beach erosion problem with federal aid: Western City, v. 13, no. 3, p. 21-22.

ostel, A. C., 1939, Beach restoration at Santa Barbara I. General arrangements: Shore and Beach, v. 7, p. 91-92.

ratt, W. E., 1947, Petroleurn on continental shelves: Am. Assoc. Petroleum Geologists Bull., v. 31, p. 657-672. Discussion, v. 34, p. 1589-1592.

rice, F., 1936, Legal problems in connection with the protection and development of California's beaches: Shore and Beach, v. 4, p. 138-145, discussion p. 145-147.

urcell, G., 1914, Improvements in Los Angeles Harbor, California: Inst. Civil Eng., London, Proc., v. 195, p. 235243.

urer, E. A., 1936, Studies of certain coastal sand dune plants of southern California: Ecol. Mon., v. 6, p. 1-87, incl. 22 pls.; Ph. D. thesis, Univ. Southern Calif.

urer, E. A., 1942, Plant ecology of the coastal salt marshlands of San Diego County, California: Ecol. Mon., v. 12, p. $81-111$.

outnam, J. A., 1947, Estimating storm-wave conditions in San Francisco Bay: Am. Geophys. Union Trans., v. 28, p. $271-278$.

rutnam, J. A., and Arthur, R. S., 1948, Diffraction of water waves by breakwaters: Am. Geophys. Union Trans., v. 29, p. $481-490$.

rutnam, J. A., and Bermel, K. J., 1946, Interim report number 2: Breakwater model studies, U. S. Navy Drydocks, Hunters Point, California: Univ. Calif., Berkeley, Inst, eng. research, tech. rept. $140-2$. *

nam, J. A., Bermel, K. J., and Johnson, J. W., 1947 , Suspended-matter sampling and current observations in the vicinity of Hunters Point, San Francisco Bay: Am. Geophys. Union Trans., v. 28, p. $742-746$.

tnam, J. A., Munk, W. T., and Traylor, M. A., 1948, An investigation of longshore currents: Univ. Calif., Berkeley, fluid mechanics lab., tech. rept. HE-116-279, 11 p. tables, photos, diagrams. See next ref.

outnam, J. A., Munk, W. H., and Traylor, M. A., 1949, The prediction of longshore currents: Am. Geophys. Union Trans., v. 30, p. 337-345.

Putnam, w. C., 1930, Terrace levels in the Ventura district, California: M. A. thesis, Stanford Univ., 116 p., 20 pls. Putnam, W. C., 1937a, Physiography of the Ventura region, California: $\mathrm{Ph}$. D. thesis, Calif. Inst. Tech.*

Putnam, W. C., 1937b, The marine cycle of erosion for a steeply sloping shoreline of emergence: Jour. Geology, v. 45, p. 844-850; Rev. in Jour. Geomorphology, v. I, p. 261-262 (in French).

Putnam, W. C., 1937c, Sequential development of a steeply sloping shoreline of emergence: Geol. Soc. America Bull., proc. for 1936 , v. 48 , p. 310 (abs.).

Putnam, W. C., 1938, Geomorphology of the Ventura region, California: Geol. Soc. America Bull., v. 49, p. 1897 (abs.); v. 53 (1942), p. 691-754.

Putnam, W. C., 1940, Evidence from the ventura region, California for a possible eustatic change of sea level: Sixth Pacific Sci. Cong. Proc., v. 2, p. 849-850.

Putz, R. R., 1950a, Idealized reconstructions of ocean surface waves as inferred from measurements on twenty-five subsurface pressure records: Univ. Calif., Berkeley, Inst. eng. research, waves research lab., tech. rept., ser. 3, issue 317,8 p., 25 pls.

Putz, R. R., 1950b, Wave-height variability; prediction of distribution function: Univ. Calif., Berkeley, Inst. eng. research, waves research lab., tech. rept., ser. 3 , issue 318 , 18 p., 16 pls; Also Wave-period variability...ibid, ser. 3, issue 325 (1951), l1 p., 9 pls.; Joint variation of wave hejght and wave period for ocean swell: ibid, ser. 3, issue 328 (1951), 8 p., 8 pls.; Heights and periods of pairs of successive waves for ocean swells: ibid, ser. 3 , issue 330,7 p., 13 pls.; Apparently all these references have been combined for a published paper with title of "Statistical distributions for ocean waves:" Am. Geophys. Union Trans., v. 33, (1952), p. 685-692.

Putz, R. R., 1953, ocean-wave record analysis - ordinate distribution and wave heights: Univ. Calif., Berkeley, Inst. eng. research, waves research lab., ser. 3, issue 351, 16 p., 11 figs.

Pyles, E. E., 1954, So you want to drill in the 'tidelands:' Petroleum World and 0il, v. 51, no. 25, June 24, p. 20-2l.

Raitt, R. W., 1948, Sound scatterers in the sea: Jour. Marine Research, v. 7, p. 393-409.

Raitt, R. W., 1949, Studies of ocean-bottom structure off southern California with explosive waves: Geol. Soc. America Bull., v. 60, p. 1915 (abs.).

Raitt, R. W., 1950, Seismic studies of the Pacific ocean floor off California: Geophysics, v. 15, p. 156 (abs.).

Raitt, R. W., 1954, Geophysical measurements, in Oceanographic instrumentation, Isaacs, J. D., and Iseliñ, C. O'D. editors, pub. 309, Natl. Acad. Sciences - Natl. Research Council, p. 70-84 incl. discussion.

Rakestraw, N. W., Rudd, P. D., and Dole, M., 1951, Istopic composition of oxygen in air dissolved in Pacific Ocean water as a function of depth: Jour. Am. Chem. Soc., v. 73, p. 2976 .

Rand, W. W., 1931, Preliminary report of the geoiogy of Santa Cruz Island: Santa Barbara County, California: Calif. Bur. Mines, 27th Rept. State Mineralogist (also listed as Mining In Calif., chap. 2), p. 214-219.

Rand, w. W., 1933, The geology of Santa Cruz Isiand, Calif ornia: Ph. D. thesis, Univ. Calif., Berkeley, 175 p. + tables, photos, and figs.

Rand, w. W., 1951, Ventura Basin, in Symposium on possible future petrcleum provences of North America: Am. Assoc. Petroleum Geologis's Bull., v. 35, ₹. 231-24C.

Randolph, G. C., 1935, Santa Catalira Island: The Mineralogist, v. 3, no. 8, p. 7-8.

Rankin, E. P., 1913, Local distribution of the piankton of San Francisco Bay: M. S. thesis, Univ. Cailif., Berkeley. *

Rankin, W. D., 1931, Some notes on the Foraminifera of Newport Lagoon, Orange County, California: Micropalenology Bull., Stanford Univ., v. 2, no. 4, p. $75-76$. 
Ransome, F. L., 1894, The geology of Angel Island: Univ. Calif. Pub. Geology, v. 1, p. 193-240.

Rappleye, Н. S., 1933, Recent areal subsidence found in releveling. Changes in elevation of as much as $4 \mathrm{ft}$. since 1920 discovered over a large area centering on San Jose, California, by precise levels just completed, with all indications that the subsidence is still continuing: Eng. News-Record; v. 110, p. 845.

Rawn, A. M., and Bowerman, F. R., 1951, Factors influencing and limiting the location of sewer ocean outfalls: First Conf. on Coastal Eng. Proc., Berkeley, p. 186-191.

Ray, M. S., 1934, The Farallones, the painted world and other poems of California with fifty-three illustrations and with a supplementary history and description of the Farallones, including notes on their plant, bird, and animal life: San Francisco.*

Raymond, R. W., 1880, A new method of dredging, applicable to some kinds of mining operations: Am. Inst. Ming. Eng., v. 8, p. 254-260.

Reagan, J. W., 1915, Research report of 1915. Typewritten report recording eyewitness accounts of early floods, changes in river cources, deposition of sediment in harbors and on lowlands (which counter-act the effect of subsidence). Copy on file in the Library of the Univ. of Calif., Los Angeles. *

Rechnitzer, A. B., 1952, A wave of fish: Nat. History Mag., Sept.

Reed, R. D., 1930a, Small ên echelon fractures in Santa Barbara County, California: Am. Assoc. Petroleum Geologists Bull., v. 14, p. 320-322.

Reed, R. D., 1930b, Recent sands of California: Jour. Geology, v. 38, p. 223-245.

Reed, R. D., 1933a, Geology of California: Am. Assoc. Petroleum Geologists, Tulsa, Okla., 355 p., illus. *

Reed, R. D., 1933b, Plelstocene history in the Carpinteria district: Pan Am. Geologist, v. 59, p. 306 (abs.); Geol. Soc. America Bull., proc. for 1933, v. 45 (1934), p. 304 (abs.).

Reed, R. D., 1934, Unsolved geological problems of Pacific Cosst: Pan Am. Geologists, v. 61, p. 179-186.

Reed, R. D., 1938, San Benito trough: Geol. Soc. America Bull., proc. for 1937, v. 49, p. 249-250 (abs.).

Reed, R. D., 1943a, Position of the California oil fields as related to geologic structure: Calif. Div. Mines Bull. 118, p. 95-97,

Reed, R. D., 1943b, California's record in the geologic history of the world: Calif. Div. Mines Bull. 118, p. $99-118$.

Reed, R. D., and Hollister, J. S., 1936, Structural evolution of southern California: Am. Assoc. Petroleum Geologists, Tulsa, Okla.; Am. Assoc. Petroleum Geologists Bull., v. 20 , p. $1529-1692,9$ pls., 6 tables, 57 figs.

Reed, T. R., 1934, Weather types of the north-east Pacific ocean as related to the weather of the north Pacific Coast: Fifth Pacific Sci. Cong. Proc., v. 3, p. 19431944 .

Reed, W. G., 1914, The Japan current and the climate of California: Mon. Weather Rev., v. 42, p. 100-101 (abs.).

Reiche, P., 1937, Geology of the Lucia quadrangle, California: Univ. Calif. Pub. Geology, v. 24, p. 115-168.

Reid, H. F., 1918, Note on the velocity of long waves and the average depth of the ocean: Seismol. Soc. America Bull., v. 8, p. 34-37.

Reid, R. O., 1948a, The equatorial currents of the eastern Pacific as maintained by the stress of the wind: Jour. Marine Research, v. 7, p. 74-99; Scripps Inst. Oceanography, SIO rept. 11,25 p. incl. tables, diagrams.

Reid, R. O., 1948b, A model of the vertical structure of mass in equatorial wind-driven currents of baroclinic ocean: Jour. Marine Research, v. 7, p. 304-312.

Remondino, P. C., 1892, The mediterranean shore of America.
Southern california: its climate, physical, and meteorological conditions: Philadelphia and London, F. A. Davis Co., 160 p., illus.

Revelle, R., 1935, Preliminary remarks on the deep-sea bottom samples collected in the Pacific on the last cruise of the Carnegie: Jour. Sed. Petrology, v. 5, p. 37-39.

Revelle, R., 1936, Marine bottom samples collected in the Pacific Ocean by the Carnegie on its Seventh Crulse: Ph. D. thesis, Univ. Calif., 317 p., 1llus. *

Revelle, R., 1937a, The colloidal fractions of Pacific deepsea clays: Assoc. d'océanographie Physique, Union Géodésique et Géophysique Internat., Procęs-Verbaux no. 2, p. 158; Geol. Soc. America Bull., proc. for 1936, v. 48 (1937), p. 317 (abs.).

Revelle, R., 1937b, Colloidal fractions of Pacific deep-sea clays: Geol. Soc. America Bull., proc. for 1936, p. 317 (abs.).

Revelle, R., 1938, Recent of fshore sediments from southern California: Geol. Soc. America Bull., v. 49, p. 18971893 (abs.).

Revelle, R., 1939a, Problems of sediment transportation off the cosst of Calffornia: Am. Assoc. Petroleum Geologists Bull., v. 23, p. 1878-1879 (abs.).

Revelle, R., 1939b, sediments of the Gulf of California: Geol. Soc. America Bull., v. 50, p. 1929 (abs.).

Revelle, R., 1940, Current measurements near the sea bottom: Assoc. d'océanographie Physique, Union Géodésique et Géophysique Internat., Procès-Verbaux no. 3, p. 114115 (abs.).

Revelle, R., 194l, Criteria for recognition of sea water in ground-waters: Am. Geophys. Union Trans., 22nd anı. meet., p. 593-597.

Revelle, R., 1943, Soundings in the Gulf of California and off the west cosst of Lower California in 1939: Scripps Inst. Oceanography, Records of Observations, v. 1 , no. 2, p. $81-83$.

Revelle, R., 1944, I. Marine bottom samples collected in the pacific Ocean by the Carnegie on its Seventh Cruise, in Scientific results of Cruise VII of the Carnegie during 1928-1929 under command of Captain J. P. Ault, Oceanography - II, Carnegie Inst. Wash. pub. 556, p. 1-180 incl. 13 pls., 10 charts, 45 figs.*

Revelle, R., 1950, $1940 \mathrm{E}$. W. Scripps cruise to the Gulf of California. Part $v$. Sedimentation and oceanography: Survey of field observations: Geol. Soc. America Mem. 43,6 p.

Revelle, R., and Emery, K. 0., 1951, Barite concretions from the ocean floor: Geol. Soc. America Bull., v. 62, p. $707-724$.

Revelle, R., and Fleming, R. H., 1934, The solubility product constant of calcium carbonate in sea water: Fifth Pacific Sci. Cong. Proc., v. 3, p. 2089-2092.

Revelle, R., and Shepard, F. P., 1939a, Current measurements near the sea bottom: Geol. Soc. America Bull., v. 50, p. 1929-1930 (abs.).

Revelle, R., and Shepard, F. P., 1939b, Sediments off the California coast; in Trask, P. D., Recent marine sediments, a symposium pub. by Am. Assoc. Petroleum Geologists, Tulsa, Okla., p. 245-282.

Revelle, R., and Shepard, F. P., 1943, Current measurements of $f$ the California coast in 1938 and 1939, in Scripps Inst. Oceanography, Records of observations, v. 1 , no. 2 , p. $85-87$.

Rhodes, A. D., 1951, Puddled-clay cutoff walls stop sea-water intrusion: Civil Eng., v. 21, p. 21-23.

Rice, E. K., 1951, Discharge from submerged outfalls: M. S. thesis, Univ. Calif., Berkeley, 60 p. incl. illus.

Richardson, B., 1930, Evaporation as a function of insolation: American Soc. Engineers Proc., v. 56, p. 945-960.

R1chardson, B., 1932a, Photoelectric measurements (made during the summer of 1930) of the penetration of light (wavelength 2,900 to 4,800 Angstrom units) in sea-water, and the results of laboratory photoelectric measurements (made during the summer of 1931) of the absorption-coefficient of sea water: Am. Geophys. Union Trans., 13th ann. meet., p. 225

Richardson, B., 1932b, A method for computing the amount of evaporation of sea-water from a tank by changes in salinity, with experimental results obtained on board the Scripps August 13-24, 1928: Am. Geophys. Union Trans., 13th ann. meet., p. 394-398. 
Richardson, B., 1934, Photo-electric measurements of the penetration of light in sea water, and the results of laboratory photo-electric measurements of the absorption coefficient of sea water: Fifth Pacific Sc1. Cong. Proc., v. 3, p. 2083-2084 (abs.).

Richardson, B., 1935, Solar radiation at the Scripps Institution of Oceanography, La Jolla, California, 1928-34: Monthly Weather Rev., v. 63, p. 92-93.

Richardson, R. W., 1923, Shoreline physiography of the Santa Lucia Mountains: M. A. thesis, Stanford Univ., 87 p. incl. $18 \mathrm{figs}$. and pls., 3 maps.

Richardson, R. W., 1943, Summer air transport along the coast of central California: A micro-climat1c study of a wind gap and some observed effects of wind on trees: Ph. D. thesis, Univ. Calif., Berkeley. *

Richter, C. F., 1940, Earthquake epicenters and structure of the Pacific region of North America (southern part): Sixth Pacific Sci. Cong. Proc., v. 1, p. 113-118.

Richter, C. M., 1887, ocean currents contiguous to the cosst of California: Calif. Acad. Sci. Bull., v. 2, no. 7 , p. $337-350,8$ pls.

Ricketts, E. F., and Calvin, J., 1939, Between Pacific tides: Stanford Un1v. Press., xxil + 320 p., 45 pls; 2nd ed. 1948, xxvii + 365 p.; 3rd ed. revised by J. W. Hedgepeth, 1952 , xi1 + 502 p., 134 figs., 46 pls. *

Rigdon, V. E., 1924, The geography of the Carquinez Stra1t: M. A. thesis, Univ. Calif., Berkeley. *

Rittenberg, S. C., 1940, Bacteriological analysis of some long cores of marine sediments: Jour. Marine Research, v. 3, p. 19l-201.

Rittenberg, S. C., 1941, Studies on marine sulfate-reducing bacterla: Ph. D. thesis. Univ. Callf., La Jolla, 115 p. incl. figs.

Ritter, W. E., 1901, Some observations bearing on the probable subsidence during Recent geological times of the island of Santa Catalina off the coast of southern California: Science, v. 14, no. 354, p. 575-577.

Ritter, W. E., 1902, A summer's dredging on the coast of southern Californ1a: Sclence, v. 15 , no. 367 , p. 55-65.

aitter, W. E., 1924, The biological and physical oceanography of the eastern Pacific ocean - A general view: Pan Pacific Sc1. Cong. Proc., v. 2, p. 1577-1583.

kobertson, G. K., 1932, The geology of the Santa Monica Mountains in the vicinity of Topanga Canyon, Los Angeles County, California: M. S. thesis, 56 p., 12 pls.

Robertson, R. R., 1942, Problems of the Sacramento River: Military Eng., v. 34, no. 202, p. 392-396.

Robins, T. M., 1935, Combating water problems in California: Civil Eng., v. 5, no. 1, p. 32.

Robinson, M. K., 1951, Sea temperature in the North Pacific area, $20^{\circ}-40 \mathrm{~N}$., $125^{\circ}-155^{\circ} \mathrm{W} .:$ Scripps Inst. Oceanography, SIo ref. $51-20,14$ p., 36 figs.

Rode, K., 1930, Geomorphogenie des Ben Lomond (Kalifornien). Eine studie über Terrassenblldung durch marine Abrasion: Zeitschrift Geomorphologle, band 5 , heft 1-2, p. 16-78, 14 figs., 1 pl. (Manuscript translation by J. E. Kesseli, dept. geography, Univ. Calif., Berkeley).

Rodgers, A. F., and Bache, A. D., 1864, Determination of position, and salling directions for clearing the Fanny Rock, near the North Farallones, off San Francisco entrance, California: Ann. Rept. U. S. Coast Survey 1863, app. 10, p. 83-84.

Rolland, M. C., 1952, Sand by-passing plant at Salina Cruz, Mexico: Second Conf. on Coastal Eng. Proc., Berkeley, p. $177-186$.

Roop, F. C., 1946, A study relating data from the seismic sea wave of April 1, 1946 to the theory of its propagation: Un1v. Calif., Berkeley, fluid mechanics lab., tech. rept. HE-116-212, 16 p.; He-116-215, 77 p., tables, graphs, maps.
Rosenfeld, W. D., 1948, Fatty acid transformations by anaerobic bacter1a: Archives of Biochemistry, v. 16, p. 263-273.

Rossby, C. -G., 1951, on the vertical and horizontal concentration of momentum in air and ocean currents. I. Introductory comments and basic principles, with particular reference to the vertical concentration of momentum in ocean currents: Tellus, v. 3, p. 15-27.

Rosser, W. H., 1870, North Pacific pilot: Part II, The seaman's guide to the islands of the North Pacific with an appendix on the winds, weather, currents, etc., of the North and South Pacific: London, James Imray and Son, 313 p., pls., app. 120 p., pls. Part I. by J. F. Imray includes "Sailing directions for the west coast of North America between Panama and Queen Charlotte Islands."

Rothwell, w. T., Jr., 1944, Preliminary ecological study of some Recent Pacific Ostracoda: Geol. Soc. America Bull., v. 55, p. $1470-1471$.

Rothwell, W. T., Jr., 1946, The ostracoda in paleongeography: Am. Assoc. Petroleum Geologists Bull., v. 30, p. 20872088 (abs.).

Rotschi, H., 1951, Study of the iron, manganese and nickel contents of some deep-sea cores: Cahiers Centre Recherche Océanographie, no. 4, p. 2-22. * (In French).

Rude, G. T., 1933, Hydrographic data: Geol. Soc. America Bull., v. 44, p. 517-528.

Rude, G. T., 1934, Recent progress in hydrograph1c surveying: Fifth Pacific Sci. Cong. Proc., v. 2, p. 1239-1258.

Rudnick, P., 1951, Correlograms for Pacif1c Ocean waves: Second Berkeley Symposium Mathematical Statistics and Probability Proc., Un1v. Calif. Press, p. 627-638.

Rudnick, P. and Cochrane, J. D., 1951, Diurnal flucuations in bathytermograms: Jour. Marine Research, v. 10, p. 257-262, Scripps Inst. Oceanography, SIO ref. 52-15, Apr1l 1, 1952, 6 p, incl. tables, diagrams.

Russell, F. S., 1934, The study of copepods as a factor in oceanic economy: Fifth Pacific Sci. Cong. Proc. v. 3, p. 2023-2034.

Russell, R. J., 1926, Climates of California: Univ. Calif. Pubs. Geography, v. 2, p. 73-84, 1 map. Reprinted Nov. 30, 1938 .

Saito, Y., 1951, on the velocity of the vertical flow in the ocean: Jour. Inst. Polytech., Osaka City Univ., ser. B., v. 2, p. 1-4.*

Salsbury, M. E., 1925, Design of Rincon seawall located in ventura County, California: Thesis in Eng., Calif. Inst. Tech., 16 p., incl. 5 pls.

Salsbury, R. D., 1909, Physical geography of the Pleistocene with special reference to Plelstocene conditions: Jour. Geology, v. 17, p. 589-599.

Sanchez, P. C., 1934a, A brief contribution on the possibility of the existance of fiords on the Mexican Coast: Fifth Pactfic Sol. Cong. Proc., v. 1, p. 735.

Sanchez, P. C., 1934b, Studies on the Bay of Acapulco: Fifth Pactific Sc1. Cong. Proc., v. 2, p. 901-905.

Sanchez, P. C., 1934c, Gravity anomalles in the Republic of Mexico: Fifth Pacific Sc1. Cong. Proc., v. 2, p. 11591164.

Sanchez, P. C., 1934d, The work in the Pacific region of geography and climatology: Fifth Pacific Sci. Cong. Proc., v. 2, p. 1373-1377.

sanchez, P. C., 1934e, The Bay of Acapulco and its relation to the earthquakes in the southern part of the Mexican Republic: Am. Geophys. Union Trans., 15th ann. meet., pt. 1 , p. 83-91.

San Diego Regional Water Pollution Control Board, 1952, Report upon the extent, effects and limitations of waste disposal into San Diego Bay: Calif. State Printing office, 95 p. Incl. figs., tables, maps.

Sanford, J. J., 1908, Construction of ports on sandy shores. Ports of the United States on the Atlant1c Ocean, Gulf 
of Mexico, Pacific ocean and the Great Lakes: Eleventh Internat. Navigation Cong., St. Petersburg, 22 p., 2 pls.

San Francisco Bay Marine Piling Committee, 1921, Report of the San Francisco Bay Marine Piling Survey, prepared under the supervision of the San Francisco Bay Marine Piling Committee of the American Wood-Preservers' Assoc., San Francisco, 104 p., 36 pls., 1 map.

San Francisco Bay Marine Piling Committee, 1922, The San Francisco Bay Marine Piling Survey; Second annual progress report, prepared under the supervision of the San Francisco Bay Marine Piling Committee of the American Wood-Preservers' Association, San Francisco, 82 p., 16 pls.

San Francisco Bay Marine Piling Committee, 1923, The San Francisco Bay Marine Plling Survey; Third annual progress report, prepared under the direction of the San Francisco Bay Marine Piling Committee, National Research Council, and the American Wood-Preservers' Association: San Francisco, 55 p., 6 pls.; app. I, II, III, reprints of papers by R. C. Miller, 1922, 1923, and H. F. Blum, 1922, pub. in Univ. Calif. Pub. Zoology, v. 22.

Sargent, M. S., and Walker, T. J., 1948, Diatom populations associated with eddies of $f$ southern California in 1941: Jour. Marine Research, v. 7, p. 490-505.

Saur, J. T. F., Jr., 1950, Oceanographic features of Nodales Channel with application to underwater sound: U. S. Navy Electronics Lab., San Diego, USNEL rept. 188, June $12,21 \mathrm{p}$. incl. diagrams, illus.

Saville, T., Jr., 1947, Comparison of recorded and forecast waves on the California and oregon Coast from June to September: Univ. Calif., Berkeley, fluid mechanics lab., tech. rept. HE-116-268, oct. 30,3 p., graphs.

Saville, T., Jr., 1948, Report on ooutherly swell, February 4, 1948: Univ. Calif., Berkeley, fluid mechanics lab., tech. rept. HE-116-294, 1 p., photos, sketch.

Saville, T., Jr., 1951, A method for drawing orthogonals seaward from shore: U. S. Army, Corps of Engineers, Beach Erosion Board Bull., v. 5, no. 4, p. 1-6.

Saville, T. Jr., and Caldwell, J. M., 1953, Accuracy of hydrographic surveying in and near the surf zone: U. S. Army, Corps of Engineers, Beach Erosion Board Tech. Memo. 32, 17 p., app. 14 tables; Third Conf. on Coastal Eng. Proc., Berkeley, p. 31-47.

Scanlon, T. S., Jr., and Osborn, P., 1950, Mark II tsunami recorder: Scripps Inst. oceanography, Wave Rept. 97, 12 p., 14 figs.

Schaffer, F. X., 1940?, Untermeerische Conyons: Zentralbl. Mineralogie, Abt. B., Nr. 4, p. 98-99. *

Schaufele, H. J, 1951, Erosion and corrosion on marine structures, Elwood, California: First Conf. on Coastal Eng. Proc., Berkeley, p. 326-334.

Scheer, B. T., and Fox, D. L., 1947, Attachment of sedentary marine organisms to petroleum surfaces: Soc. Expt. Biology and Medicine Proc., v. 65, p. 92-95.

Scheffauer, F. C., 1927, Dredge Culebra on San Francisco bar. With discussion: Military Engineer, v. 19, no. 107, p. 416-419.

Schenck, H. G., 1928, The biostratigraphic aspect of micropaleontology: Jour. Paleontology, v. 2, p. 158-165, pl. 26.

Schenck, H. G., 1940, Applied paleontology: Am. Assoc. Petroleum Geologists Bull., v. 24, p. 1752-1778.

Schenck, H. G. and Keen, A. M., 1935, West American marine Molluscan provinces: Geol. Soc. Emerica Bull., proc. for 1935, p. 413-414 (abs.); Pan Am. Geologist, v. 63, p. $376-377$ (abs.).

Schenck, H. G. and Keen, A. M., 1936a, Bathymetric distribution of marine Pelecypoda: Geol. Soc. America Bull., proc. for 1935 , v. 47 , p. $367-368$ (abs.).

Schenck, H. G. and Keen, A. M., 1936b, Marine molluscan provinces of western North America: Am. Philos. Soc. Proc., v. 76, p. 921-938.

Schenck, H. G., and Keen, A. M., 1937, An index-method for comparing molluscan faunules: Am. Philos. Soc. Proc., v. 77, p. $161-182$.

Schermerhorn, I. Y., 1897, Breakwater construction on the American coast: Engineers' Club of Phila. Proc., v. 14 , no. 3 , p. $205-228$.

Schneider, W. A., 1954, An oceanographic investigation of Santa Monica Bay. August 25 to September 15, 1954: Los Angeles, Dept. Public Works, Bur. Sanitation, unpdg., figs., graphs.

-Schott, G., 1934, The distribution of rain over the Pacific Ocean: Fifth Pacific Sei. Cong. Proc., v. 3, p. 19871990.

Schott, G., 1935, Geographie des Indischen und Stillen Ozeans: Hamburg, C. Boysen, 3 rd ed., xix, 413 p. incl. illus., tables, diagrams, maps. *

Schulz, B., 1914, Beiträge zur Kenntnis der oberflächenverhältnisse der ozeane auf Grund der Beobachtungen von L. Mecking auf Reisen Zwischen New York - Suez - Hongkong - San Francisco sowie deutscher Schiffe an der Südküste Arabiens und im Persischen Golfe: Annalen der Hydrographie und Maritimen Meteorologie, v. 42, p. $392-405$.

Schupp, R. D., 1953, A study of the cobble beach cusps along Santa Monica Bay, California: M. S. thesis, Univ. Southern Calif., 131 p. incl. 43 pls., 14 figs., 2 tables.

Schureman, P., 1936, Variation in yearly sea level, in Bowie, W., Geodetic operations in the United States, January 1, 1933, to December 31, 1935: U. S. Coast and Geod. Survey, special pub. 207, p. 23-25.

Scofield, E. C., 1934, Early life history of the California sardine (Sardina caerulea), with special reference to distribution of eggs and larvae: Calif. Div. Fish and Game, Fish Bull. no. 41, p. 1-48.

Scott, T. A., 1936, The contractors ' and constructors point of view on coastal and waterfront work: Shore and Beach, v. 4, p. 8-10, discussion p. 10-12.

Scripps Institution of Oceanography, 1944a, Waves in shallow water: Change in wave height along the Scripps Institution Pier with special emphasis on breaker characteristics: Wave Rept. 1,9 p., 5 photos, 6 figs.

Scripps Institution of Oceanography, 1944b, Foam line analysi Wave Rept. 19, 3 p., 2 graphs.

Scripps Institution of Oceanography, 1944c, Surf conditions as related to landing operations: Wave Project Rept. 22, 6 p.

Scripps Institution of Oceanography, 1944d, Effect of bottom slope on breaker characteristics as observed along the Scripps Institution Pier: Wave Project Rept. 24,10 p., 5 photos.

Scripps Institution of oceanography, 1944e, A method of presenting refraction corrections: Wave Rept. 31 , 4 p., 1 fig.

Scripps Institution of oceanography, 1944f, Method of determining depth in shallow water from aerial photographs (wave velocity method): Pt. I, 9 p., figs., graphs. Pt. II, 5 p., photos.

Scripps Institution of Oceanography, $1944 \mathrm{~g}$, Waves in shallow water: The velocity of waves in shallow water as derived from observations along the Scripps Institution Pier: Wave Rept. II, 19 p., 9 figs. 4 tables.

Scripps Institution of oceanography, $1944 \mathrm{~h}$, waves in shallow water: Comparison between forecast and observed heights of breakers: Rept. III, 5 p., 2 figs., 4 tables.

Scripps Institution of Oceanography, $1945 a$, Observed changes in wave height from deep to shallow water: Wave Project Rept. 27, 14 p., 3 figs.

Scripps Institution of Oceanography, 19450 , Effect of wave refraction on breaker heights. A comparison between computed and observed changes along the beach to the north of La Jolla: Wave Project Rept. 38, 15 p., 6 figs., 6 pls.

Scripps Institution of oceanography, 1945c, Longshore current Wave Project Rept. 40, 12 p., 6 figs.

Scripps Institution of oceanography, 1945d, Effect of surf and beach gradients on landings with LCVP's and LCM's: Wave Project Rept. 68, 34 p., app. tables, graphs. 
Scripps Institution of Oceanography, 1947, A statistical study of wave conditions at five open sea localities along the California coast: Wave Project Rept. 68, 34 p., app. tables, graphs.

cripps Institution of Oceanography, 1949a, Physical and chemical data Cruise 1 - February 28 to March $16,1949$. Marine Life Research Program: Physical and chemical data rept. 1, unpaged, 10 figs.

ipps Institution of Oceanography, 1949b, Physical and chemical data Cruise 2 - March 28 to April 12, 1949. Marine Iife Research Program: Physical and chemical data rept. 2, unpaged, 10 figs.

cripps Institution of Oceanography, 1949c, Physical and chemical data Cruise 3 - April 28 to May 14, 1949. Marine Life Research Program: Physical and chemical data rept. 3, unpaged, 10 figs.

cripps Institution of Oceanography, 1949d, Physical and chemical data Cruibe 4 - May 28 to June 10, 1949. Marine Life Research Program: Physical and chemical data rept. 5 , unpaged, $10 \mathrm{figs.}$

ipps Institution of Oceanography, 1950a, Physical and chemical data Cruise 6 - August 3 to August $22,1949$. Marine Life Research Program: Physical and chemical data rept. 6 , unpaged, 4 figs.

Scripps Institution of Oceanography, 1950b, Physical and chemical data Cruise 7 - September 5 to September 18, 1949. Marine Life Research Program: Physical and Chemical data rept. 7 , unpaged, 4 figs.

ripps Institution of Oceanography, 1950c, Physical and chemical data Cruise 8 - october 3 to october 20, 1949. Marine Life Research Program: Physical and chemical data rept. 8 , unpaged, 4 figs.

Scripps Institution of Oceanography, 1950d, Physical and chemical data Cruise 9 - November 8 to November 25, 1949: Marine Life Research Program: Physical and chemical data rept. 9, unpaged, 4 figs.

cripps Institution of Oceanography, 1950e, Physical and chemical data Cruise 10 - January 5 to January 8, 1950. Marine Life Research Program: Physical and chemical data rept. 10, iv, 17 p., 5 figs.

scripps Institution of Oceanography, 1950f, Station positions, California Cooperative Sardine Research Program: Tech. rept. of Nov. $1,4 \mathrm{p}$, incl. tables, chart.

ripps Institution of Oceanography, 1950g, Progress report number 4, 1 November 1949 to 31 March 1950, Marine Life Research Program: 28 p., 14 figs.

Scripps Institution of Oceanography, 1951a, Physical and chemical data Cruise 11 - Jan. 31 to Feb. 19, 1950. Marine Life Research Program: Physical and chemical data rept. 11 , iv, 58 p., 4 figs.

ripps Institution of Oceanography, 1951b, Physical and chemical data Gruise 12 - March 2 to March 17, 1950, Marine Life Research Program: Physical and chemical data rept. 12, iv, 55 p., 4 figs.

Scripps Institution of Oceanography, 1951c, Physical and chemical date Cruise 13 - April 4 to April 17, 1950. Marine Life Research Program: Physical and chemical data rept. 13, iv, 61 p., 4 figs.

cripps Institution of oceanography, 1951d, Physical and chemical data Cruise 14 - May 3 to May 18, 1951. Marine Life Research Program: Physical and chemical data rept. $14, v_{.}, 66$ p., 5 figs.

ripps Institution of Oceanography, 195le, Physical and chemical data Cruise 15 - June 6 to June 23, 1950. Marine Iffe Research Program: Physical and chemical data rept. 15, v., 53 p., 5 figs.

Scripps Institution of Oceanography, 1951f, Physical and chemical data Cruise - 16 July 6 to July 24, 1950. Marine Life Research Program: Physical and chemical data rept. 16, v., 70 p., 5 figs.

cripps Institution of Oceanography, 1951g, Acoustic oceanography. Progress report December 15, 1949 - June 30 , 1951: SIO ref. 51-10, 14 p., illus.

cripps Institution of Oceanography, 1951h, Physical and chemical data Cruise $17-5-19$ August 1950. Marine Life Research Program: Ref. 51-32, 44 p., 12 figs. ripps Institution of Oceanography, 19511, Physical and chemical data Cruise 18 - 6-22 September 1950. Marine Life Research Program: Physical and chemical data rept. 18,65 p., 5 figs.

Scripps Institution of oceanography, 1951j, Physical and chemical data Cruise 19. October 11 to October 20, 1950. Marine Life Research Program: Physical and cbemical data rept. 19, 93 p., 8 figs.

Scripps Institution of Oceanography, 1951k, Physical and chemical data, Cruise 19 appendix. October 11, to october 20, 1950. Marine Life Research Program: Ref. $51-29,31 \mathrm{p}$.

Scripps Institution of Oceanography, 1951L, Physical and chemical data Cruise 20. 9-28 November 1950. Marine Life Research Program: Ref. 51-47, 74 p., 8 figs.

Scripps Institution of Oceanography, 1951m, Physical and chemical data Cruise 21. 9-29 January 1951. Marine Life Research Program: Ref. 51-55, 63 p., 5 figs.

Scripps Institution of Oceanography, 1951n, Preliminary report of temperature and salinity, cruises 15 through 25 - 6 June 1950 to 16 May 1951. Marine Life Research Program: Ref. 5l-1l, vi., 10 p., incl. figs.

Scripps Institution of Oceanography, 19510, Preliminary report of temperature, salinity, and current measurements, cruises 24 through 27 - 2 April 1951 to 20 July 1951. Marine Life Research Program: Ref. 51-30, 4 p., figs.

Scripps Institution of Oceanography, 1951p, Preliminary report of temperature and salinity, Cruises 28 and 29-31 July 1951 to 13 September 1951. Marine Iife Research Program: Ref. 51-38, 2 figs.

Scripps Institution of Oceanography, 1951q, Preliminary report of temperature and salinity, Cruise $30-26$ September 1951 to 8 october 1951. Marine Life Research Program: Ref. 51-50, 2 figs.

Scripps Institution of Oceanography, 1951r, Preliminary report of temperature, salinity and current measurements, Cruise 31-30. October 1951 to 12 November 1951. Marine Life Research Program Ref. 51-52, 3 p., figs.

Scripps Institution of Oceanography, 1952a, Physical and chemical data Cruise 22 - 6-25 February 1951. Marine Life Research Program: Ref. 52-6, 49 p., 5 figs.

Scripps Institution of oceanography, 1952b, Physical and chemical data Cruise 23 - 8-23 March 1951. Marine Life Research Program: Ref. 52-9, 67 p., 5 figs.

Scripps Institution of oceanography, 1952c, Preliminary report of temperature, salinity, and current measurements, Cruise 32 - 25 November to 9 December 1951. Marine Life Research Program: Ref. 52-1, 3 figs.

Scripps Institution of Oceanography, 1952d, Preliminary report of temperature, salinity, and current measurements, Cruise 33, 8-28 January 1952. Marine Life Research Program: Ref. 52-7, 3 figs.

Scripps Institution of Oceanography, 1952e, Physical and chemical data Cruise 34-6-23 February 1952. Marine Life Research Program: Ref. 52-24, 76 p., 9 figs.

Scripps Institution of Oceanography, 1952f, Physical and chemical data Cruise 34 - 6-23 February 1952. Marine Life Research Program: Ref. 52-36, 96 p., 16 figs.

Scripps Institution of Oceanography, 1952g, Physical and chemical data, Cruise 36 - 2-28 April 1952. Marine Life Research Program: Ref. 52-37, 94 p., 8 figs.

Scripps Institution of Oceanography, 1952h, Progress report, July - September 1952: Ref. 52-67, 10 p., 9 figs.

Scripps Institution of Oceanography, 1952i, Quarterly progress report no. 11, January - March 1952: U. S. Army, Corps: of Engineers, Beach Erosion Board Bull., v. 6, no. 4, p. 14-18; Quarterly Progress report no. 12, April - June 1952, 1bid, p. 18-26.

Scripps Institution of Oceanography, 1953a, Semi-annual progress report: Ref. 53-11, 7 p., 4 figs.

Scripps Institution of Oceanography, 1953b, Quarterly progress report, october - December 1952: Ref. 53-18, 10 p., 6 figs.

Scripps Institution of Oceanography, 1953c, Quarterly progress report no. 13, July - September 1952: U. S. Army, Corps of Engineers, Beach Erosion Board Bull., v. 7 , no. 1 , p. 36-42.

Scripps Institution of oceanography, 1953d, Quarteriy progress report no. 15, January - March 1953: U. S. Army, Corps of Engineers, Beach Erosion Board Bull., v. 7 , no. 3 , p. 14 .

Scripps Institution of Oceanography, 1953e, Shipboard report Capricorn Expedition, 26 September 1952 - 21 February 1953: Ref. 53-15, 60 p., 12 figs.

Scripps Institution of Oceanography, 1953f, Progress report on research sponsored by the Beach Erosion Bcard: U. S. Army, Corps of Engineers, Beach Erosion Board Bull., v. 7 , no. 4, p. 16 .

Scripps Institution of Oceanography, 1953g, Quarterly progress report on oceanographic instrumentation - July - September: SIO ref. 56-66, 11 p., 3 figs.

Sears, C. B., 1876, Principles of tidal harbor improvement as applied at Wilmington, California: Am. Soc. Civil Eng. Trans., v. 5, p. 388-426. 
Seiwell, H. R., 1950, Problems in statistical analysis of geophysical time series: Science, v. 112, no. 2905, p. $243-246$.

Severy, H. W., 1923, The occurrence of copper and zinc in certain marine animals: Jour. Biological Chemistry, v. 55 , p. $79-92$.

Shaler, N. S., 1892, The story of our continent: Boston, Ginn and Co.*

Shaler, N. S., 1894, Sea and land; features of coasts and oceans with special reference to the life of man: New York, Charles Scribner's Sons, 252 p. *

Shaler, N. S., 1895, Evidences as to change of sealevel: Geol. Soc. America Bull., v. 6, p. 141-166.

Shaler, N. S., 1896, The share of volcanic dust and pumice in marine deposits: Geol. Soc. America Bull., v. 7, p. $490-492$

Shalevetz, S., 1952, World news on mineral occurrences California: Rocks and Minerals: v. 27, p. 138. (Catalina Island).

Shalow1tz, A. L., 1951, Cartography in the submerged lands oll cases: U. S. Coast and Geod. Survey Jour., no. 4, p. $68-78$.

Shalowitz, A. L., 1953, The concept of a bay as inland waters: Surveying and Mapping, v. 13, p. $432-440$.

Shaw, P. A. and Towers, C. L., 1937, Water Pollution problems in California: Cal1f. Fish and Game. v. 23, p. 262-285.

Shepard, F. P., 1931, Recent information concerning submarine valleys: Natl. Research Counc1l, Div. Geology and Geography, Rept. Comm. Submarine configuration and Oceanic Circulation, April 25, app. $V$ of ann. rept. of div., p. 88-93.

Shepard, F. P., 1932, Sediments of the continental shelves: Geol. Soc. America Bull., v. 43, p. 1017-1040; proc. for 1931, p. 126 (abs.); Pan-Am. Geolog1st, v. 57, p. 58-59 (abs.).

Shepard, F. P., 1933a, Canyons beneath the seas: Sc1. Montbly, v. 37, p. 31-39.

Shepard, F. P., 1933b, Investigations of submarine valleys: Am. Geophys. Union Trans., 14th ann. meet., p. 170-173.

Shepard, F. P., 1933c, Submarine valleys: Geog. Rev., v. 23, p. $77-89$.

Shepard, F. P., 1934a, Investigation of California submarine canyons: Geol. Soc. America Bull., proc. for 1933, v. 45 , p. $107-108$ (abs.).

Shepard, F. P., 1934b, American submarine canyons: Scott1sh Geog. Mag., v. 50, p. 212-218, 2 pls.

Shepard, F. P., 1934c, Detalled surveys of submarine canyons: Science, v. 80, no. 2079, p. 410-411.

Shepard, F. P., 1935a, Explorations of California submarine canyons: Am. Geophys. Union Trans., 16th ann. meet., p. 245-246; Geol. Soc. America Bull., proc. for 1934, v. 46, p. 106-107 (abs.).

Shepard, F. P., 1935b, Submarine canyons of the American coasts: Ze1tschr. fur Geomorphologie, band 9, p. 99-105.

Shepard, F. P., 1935c, Exact conf1guration of two California submarine canyons: Geol. Soc. America Bull., proc. for 1934 , v. 46, p. 106-107 (abs.).

Shepard, F. P., 1935d, Gravel cusps of the Cal1fornia Coast related to tides: Science, v. 82 , no. 2124 , p. 251-253.

Shepard, F. P., 1935e, Geological mapping of the ocean bottom: Sclence, v. 82 , no. 2139 , p. 614-615.

Shepard, F. P., 1936a, Undertow, rip tide or "rip current:" Sclence, v. 84, p. 181-182.

Shepard, F. P., 1936b, The submarine canyons: Harvard Univ. Alumn1 Bull., June 5, p. 1126-1128.

Shepard, F. P., 1936c, Changes of sea level as the cause of submarine canyons: Geol. Soc. America Bull., proc. for 1935, v. 47, p. 104 (abs.).

Shepard, F. P., 1936d, New discoverles from the California submarine canyons: Geol. Soc. America Bull., proc. for 1935, v. 47, p. 104-105 (abs.)

Shepard, F. P., 1936e, Northward continuation of the San Andreas fault: Geol. Soc. Amer1ca Bull., proc. for 1935, v. 47, p. 105 (abs.).

Shepard, F. P., 19361, Continued exploration of california aubmarine canyons: Am. Geophys. Union Trans., 17th ann. meet., p. 221-223.

Shepard, F. P., $1936 \mathrm{~g}$, The underlying causes of submarine canyons: Natl. Acad. Sc1. Proc., v. 22, p. 496-502; Science, v. 83 , no. 2160 , p. 484 (abs.).
Shepard, F. P., 1936h, Submerged valleys on continental olopes and changes in sea level: Sclence, v. 83, no. 2165 , p. 620-621.

Shepard, F. P., 1937a, Shifting bottom in submarine canyon heads: Sclence, v. 86 , no. 2240 , p. 522-523.

Shepard, F. P., 1937b, Daly's submarine canyon hypothesis: Am. Jour. Sc1., 5th ser., v. 33, p. 369-379.

Shepard, F. P., 1937c, Discussion of P. D. Krynine's "Pleistocene glaciation of Siberia:" Am. Jour. Sc1., 5 th ser., v. 34, p. $399-400$.

Shepard, F. P., 1937d, Horizontal shift feulting off Punta Gorda, California: Geol. Soc. America Bull., proc. for 1936, v. 48, p. 101 (abs.).

Shepard, F. P., 1937e, Salt domes related to the M18sissipp1 submarine trough: Geol. Soc. Amerlca Bull., proc. for 1936 , v. 48 , p. 101-102 (abs.).

Shepard, F. P., 1937f, Sediments off the California Coast: Am. Assoc. Petroleum Geologists Bull., v. 21, p. 1614 (abs.).

Shepard, F. P., 1937g, Investigation of submarine topography during the past year: Am. Geophys. Union Trans., 18th ann. meet., p. 226-228.

Shepard, F. P., 1938a, The entgma of the submarine canyons: Sc1. Am., v. 159, p. 130-132.

Shepard, F. P., 1938b, Investigations in submarine geology off the California Coast: Geol. Soc. America Bull., proc. for 1937, v. 49, p. 114 (abs.).

Shepard, F. P., 1938c, Changing depths in submarine canyon heads: Geol. Soc. America Bull., proc. for 1937, v. 49, p. 252 (abs.).

Shepard, F. P., 1938d, San Clemente submarine fault: Geol. Soc. America Bull., proc. for 1937, v. 49, p. 252 (abs.).

Shepard, F. P., 1938e, California submarine canyons: Geol. Sóc. America Bull., v. 49, p. 1900 (abs.).

Shepard, F. P., 1938f, Submarine canyons off the california Coast: Calif. Jour. Mines and Geology, 34th Rept. State Mineralogist, p. 298-310.

Shepard, F. P., 1938g, Beach cusps and tides: a discussion: Am. Jour. Sci., 5th ser., v. 35, p. 309-310.

Shepard, F. P., 1938h, Classification of marine shorelines: a reply: Jour. Geology, v. 46, p. 996-1006.

Shepard, F. P., 1938i, Structural trends of $f$ the California Coast: Am. Assoc. Petroleum Geologist Bull., v. 22, p. 1716 (abs.)

Shepard, F. P., 1939a, Discussion: example of wind-deposition shoreline: Jour. Geology, v. 47, p. 436-437.

Shepard, F. P., 1939b, Continental shelf sediments, in Trask, P. D., Recent marine sediments, symposium pub. by Am. Assoc. Petroleum Geologists, Tulsa, Okla., p. 219-229.

Shepard, F. P., 1939c, Depth change in submarine canyon beads: Geol. Soc. Amerlca Bull., v. 50, p. 1933 (abs.)

Shepard, F. P., 1939d, Nondepositional surfaces of $f$ the cal1fornia Coast: Geol. Soc. America Bull., v. 50, p. 1959 (abs.).

Shepard, F. P., 1939e, Tectonic development off the California Coast: oil Weekly, v. 93 , no. 3 , March 27, p. 69 (abs.).

Shepard, F. P., 1940a, Nondepositional environments off the California Coast: Wash. Acad. Sci. Jour., v. 30, p. 486 (abs.).

Shepard, F. P., 1940b, The California sea floor in relation to former lowered sea levels: S1xth Pacific Sc1. Cong. Proc., v. 2 , p. $851-852$.

Shepard, F. P., 1940c, Continental shelf sediments: Pan Am. Geologist, v. 73 , p. 21-28.

Shepard, F. P., 1940d, Submarine geology and geophysics: Nature, v. 146, p. 431.

Shepard, F. P., 1940e, Submarine geology and geophysics: Nature, v. 146 , no. 3700 , p. $431-432$

Shepard, F. P., 194la, Nondepositional physiographic environments off the califarnia Coast: Geol. Soc. America Bull., v. 52, p. 1869-1886.

Shepard, F. P., 1941b, Submarine rellef of the Gulf of Cal1forn1a: Geol. Soc. America Bull., v. 52, p. 1933-1934 (abs.).

Shepard, F. P., 194lc, Hypothet1cal submarine valleys: Geol. Soc. America Bull., v. 52, p. 134 (abs.).

Shepard, F. P., 1942a, Further discussion of the term "low and ball:" Jour. Geology, v. 50, p. 216-217.

Shepard, F. P., 1942b, Structures in prolongation of the San Andreas fault zone: Geol. Soc. America Bull., v. 53, p. $1821-1822$ (abs.).

Shepard, F. P., 1942c, Oceanographic investigations of submarine canyons: Tulsa Geol. Soc. Digest, v. 10 (1941-42) p. 43-44 (abs.).

Shepard, F. P., 1943a, Imaginary submarine canyons: Sc1ence, v. 98 , no. 2540, p. 208-209. 
nepard, F. P., 1943b, Shoreline erosion at La Jolla, California. Special instruments developed in study of factors responsible for slow recession of coast: Civil Eng., v. 13 , no. 2 , p. $80-82$.

epard, F. P., 1946, Submarine canyons and war research: Geol. Soc. Amer1ca Bull., v. 57, p. 1229 (abs.).

epard, F. P., 1947a, Diving operations in California submarine canyons: Geol. Soc. America Bull., v. 58, p. 1227 (abs.).

nepard, F. P., 1947b, Submarine geology studies in the Pacific: Am. Assoc. Petroleum Geologists Bull., v. 31 , p. $178-180$.

lepard, F. P., 1948 a, Submarine geology: New York, Harper and Brothers, $348 \mathrm{p}$. *

1epard, F. P., 1948b, Invest1gation of head of Monterey submarine canyon: Scripps Inst. Oceanography, Submarine Geology Rept. 1, 15 p., 3 f1gs., 2 charts.

lepard, F. P., 1948c, Evidence of world-wide submergence: Jour. Marine Research, v. 7, p. 661-678.

epard, F. P., 1948d, Detalled studies of submarine canyons at La Jolla, California: Geol. Soc. America Bull., v. 59, p. 1351.

lepard, F. P., 1949a, Dangerous currents in the surf: Physics Today, v. 2, p. 20-29.

lepard, F. P., 1949b, Terwestr1al topography of submarine canyons revealed by diving: Geol. Soc. America Bull., v. 60 , p. 1597-1612.

lepard, F. P., 1949c, Significance of depth changes in submarine canyon heads: Geol. Soc. America Bull., v. 60 , p. 1945 (abs.).

lepard, F. P., 1949d, Submarine geology and stratigraphy: World Oil, Dec. 8 p.

lepard, F. P., 1949e, Submarine canyons: Sci. Am., v. 180, p. $40-43$.

lepard, F. P., 1950a, Mass movement of sand into deep water: Oil and Gas Jour., v. 48, no. 51, April 27, p. $177-178$.

lepard, F. P., 1950b, Photography related to investigation of shore processes, in Symposium of Information relative to uses of aerial photographs by geologists: Photogrammetr1c Eng., v. 16, p. 756-769.

lepard, F. P., 1950c, Longshore current observation in southern California: U. S. Army, Corps of Engineers, Beach Erosion Board Tech. Memo. 13, 54 p.

lepard, F. P., 1950d, Contour charts in the San Diego area: Scripps Inst. Oceanography, Submarine Geology Rept. 13,6 p., 4 charts.

epard, F. P., 1950e, 1940 E. W. Scripps cruise to the Gulf of California. Part III. Submarine topography of the Gulf of California: Geol. Soc. America Mem. 43, $32 \mathrm{p}$. ard, F. P., 1950f, Longshore-bars and longshore-troughs: U. S. Army, Corps of Engineers, Beach Erosion Board Tech. Memo. 15, 32 p.; Scripps Inst. Oceanography, Submarine Geology Rept. 6 (1949), 35 p. 19 figs.

iepard, F. P., 1950g, Beach cycles in southern California: U. S. Army, Corps of Engineers, Beach Erosion Board Tech. Memo. 20, 26 p.; Scr1pps Inst. Oceanography, Submarine Geology Rept. 11, 18 p., 11lus.

epard, F. P., 195la, Mass movements in submarine canyon heads: Am. Geophys. Union Trans., v. 32, p. 405-418; Scr1pps Inst. oceanography, Submarine Geology Rept. 17.

lepard, F. P., 1951b, Sand and gravel in deep-water depos1ts: World 011, v. 132, p. $61-68$.

lepard, F. P., 1952c, Composite origin of submarine canyons: Geol. Soc. America Bull., v. 62, p. 1512 (abs.).

lepard, F. P., 1951d, Transportation of sand into deep water: Soc. Economic Paleontologists and Mineralogists, special pub. 2, p. 53-65; Scr1pps Inst. of oceanography, Ref. $52-17$ (1952).

lepard, F. P., 195le, Submarine canyons: A joint product of rivers and submarine processes: Science, v. 114, no. 2949, p. 7-9; U. S. Coast and Geod. Survey Jour., no. 4 , p. $58-60$.

lepard, F. P., 1952a, Composite origin of submarine canyons: Jour. Geology, v. 60, p. 84-96.

lepard, F. P., 1952b, Revised nomenclature for depositional cosstal features: Am. Assoc. Petroleum Geologists Bull., v. 36, p. 1902-1912.

lepard, F. P., 1953, Canyons on the sea floor: Idea and Experiment: a University at Work, v. 11, no. 4, p. 6-9. lepard, F. P., 1953a, Submarine canyons: Comptes Rendus, 19th sess., Cong. Geol. Inst., sect. 4, fasc. 4, p. 127-149. *

lepard, F. P., and Beard, C. N., 1938, Submarine canyons: Distribution and longitudinal profiles: Geog. Rev., v. 28 , p. $439-451$. snepard, F. P. and Emery, K. O., 1937, New bathymetric complation off California and its tectonic significance: Geol. Soc. America Bull., proc. for 1936, v. 48, p. 102 (abs.).

Shepard, F. P. and Emery, K. O., 1941, Submarine topography off the California coest: Canyons and tectonic interpretations: Geol. Soc. America, special paper 31, 171 p., 42 figs., 18 pls., 4 charts.

Shepard, F. P. and Emery, K. O., 1945, Submarine photography off the California coast: Geol. Soc. America Bull., v. 56, p. 1197 (abs.); Jour. Geology, v. 54 (1946), p. $306-321$.

Shepard, F. P., Emery, K. O., and LaFond, E. C., 1941, Rip currents; a process of geological importance: Jour. Geology, v. 49, p. 337-369.

Shepard, F. P., and Grant, U. S., 1947, Wave erosion along the southern California coast: Geol. Soc. America Bull., v. 58, p. 919-926.

Shepard, F. P., Grant, U. S., and D1etz, R. S., 1939, The emergence of (Santa) Catalina Island: Am. Jour. Sc1., v. 237, p. $651-655$.

Shepard, F. P., and Inman, D. L., 1949, Nearshore water c1rculation related to bottom topography and wave refraction: Scripps Inst. Oceanography, Submarine Geology Rept. 4, 21 p., 1llus.; Am. Geophys. Union Trans., v. 31 (1950), p. 196-212.

Shepard, F. P., and Inman, D. L., 195la, Nearshore c1rculation: Scripps Inst. Oceanography, Submarine Geology Rept. 14, 12 p. 9 f1gs.; First Conf. on Cosstal Eng. Proc., Berkeley, p. 50-59.

Shepard, F. P., and Inman, D. L., 1951b, Sand movement on the shallow inter-canyon shelf at La Jolla, Callfornia: U. S. Army, Corps of Engineers, Beach Erosion Board Tech. Memo. 26, 29 p.; Scripps Inst. Oceanography, Submarine Geology Rept. 21 (1952).

Shepard, F. P., Inman, D. L., and F1sher, R. L., 1951, Mar1ne beaches of the United States: Geol. Soc. America Bull., v. $62, \mathrm{p}, 1477-1478$.

Shepard, F. P., and LaFond, E. C., 1939, Undertow: Sclence, v. 89, no. 2300 , p. $78-79$.

Shepard, F. P., and LaFond, E. C., 1940, Sand movements along the Scripps Institution P1er: Am. Jour. Sc1., v. 238, p. $272-285$.

Shepard, F. P., and LaFond, E. C., 1942, Mean sea level and sand movement; a reply: Sclence, v. 95 , no. 2460 , p. 193-194.

Shepard, F. P., and MacDonald, G. A., 1934, Sediments of Santa Monica Bay: Pan Am. Geolog1st, v. 61, p. 317 (abs.).

Shepard, F. P., and MacDonald, G. A., 1938, Sediments of Santa Monica Bay, California: Am. Assoc. Petroleum Geologists Bull., v. 22, p. 201-216.

Shepard, F. P., Revelle, R., and Dietz, R. S., 1939, Oceanbottom currents off the California Coast: Science, $v$. 89 , no. 2317 , p. $488-489$.

Shepard, F. P., Revelle, R., Dletz, R. S., and Emery, K. O., 1938, Coring operations off the Calffornia Coast: Geol. Soc. America Bull., v. 49, p. 1900-1901 (abs.).

Shepard, F. P., and Sayner, D. B., 1953, Longshore and coastal currents at Scripps Inst1tution Pier: U. S. Army, Corps of Engineers, Beach Erosion Board Bull., v. 7, no. 1, p. $1-9$.

Shepard, F. P., and Stetson, H. C., 1939, Age of excavation of North American submarine canyons: Geol. Soc. America Buil., v. 50, p. 1934 (abs.).

Shepard, F. P., and Wrath, W. F., 1937, Mar1ne sediments around Catalina Island: Jour. Sed. Petrology, v. 7, p. 41-50.

Shepherd, E. S., 1940, Note on the fluorine content of rocks and ocean-bottom samples: Am. Jour. Sc1., v. 238, p. $117-128$.

Shepherd, E. S., 1946, Note on the fluorine content of rocks and ocean-bottom samples, in Sclentific results of Cruise VII of the Carnegle during 1928-1929, under command of Captain J. P. Ault - oceanography IV: Carnegie Inst. Wash., Dept. Terrestrial Magnet1sm Pub. 571, p. 83-86.

Sherman, A. G., 1917, A history of Newport Beach: Los Angeles, Times-Mirror Press.

Sherzer, W. H., 1910, Criteria for the recognition of the various types of sand grains: Geol. Soc. America Bull., v. 21 , p. $625-662$. 
Shipmasters and others, 1879, Breakwater and harbor or refuge. Abstract of statements made by shipmasters and others at public sessions of the board of engineers for the pacific coast in regard to location of a breakwater and harbor of refuge between San Frarcisco and the Straits of Fuca: Bound in Pamphlets on California, v. 14, Univ. Calif., Berkeley Library, art. no. 20,40 p. *

Shuck, O. T., 1869, Calffornia scrap-book: A repository of useful information and select reading: San Francisco, New York, H. H. Bancroft and Co., 704 p. 1llus.

Shuler, W. R., 1951, Review of report, navigation on Alamitos Bay, California: U. S. Army, Corps of Engineers, Los Angeles dist., iv, 48 p., 2 pls., 5 app.

Shuler, W. R., 1952, Shore-protection report on survey of Anaheim Bay Harbor, California: U. S. Army, Corps of Engineers, Los Angeles dist., iv, 64 p., 4 app.

Silva, P. C., 1948, A survey of the marine algae of California from Carmel Bay to Point Conception: M. A. thesis, Stanford Univ., 124 p., tables. *

Simmons, н. B., 1952, Selinity problems: Second Conf. on Coastal Eng. Proc., Berkeley, p. 68-85.

Simpson, T. R., 1946, Salinas Basin investigation: Cal1f. Div. Water Res. Bull. 52, 230 p., 21 pls., 36 tables. 52B, 1bid, Summary rept., 42 p. *

Sinnott, A., 1941, A textural study of certain beaches south of San Francisco: Master's thesis, Stanford Univ., 61 p., $18 \mathrm{pls}$.

Sisler, F. D., 1949, The utilization of molecular hydrogen by anaeroblc bacterla in marine sediments: Ph. D. thesis, Univ. Calif., Los Angeles, 118 p., 17 tables, 6 figs. *

Sisler, F. D., and ZoBell, C. E., 1950, Hydrogen-utilizing, sulfate reducing bacteria in marine sediments: Jour. Bacterlology, v. 60, p. 747-756; Rept. of Progress Fundamental Research on Occurrence and Recovery of Petroleum, 1950-1951, p. 158-167.

Sisler, F. D., and ZoBell, C. E., 195la, Nitrogen fixation by sulfate-reducing bacteria indicated by nitrogen/argon ratios: Sclence, v. 113, no. 2940, p. 511-512; Rept. of Progress - Fundamental Research on Occurrence and Recovery of Petroleum, 1950-1951, p. 179-180.

Sisler, F. D., and ZoBell, C. E., 1951b, Hydrogen utilization by some marine sulfate-reducing bacteria: Jour. Bacter10logy, v. 62, p. 117-127.

Skeats, E. M., 1923, Geological survey of San Diego and Imperial Counties: 011 Age, v. 20 , no. 3, Sept., p. 11.

Skogsberg, T., 1932, Hopkins Marine Station, Pacific Grove, California: Natl. Research Counc1l, D1v. Geology and Geography, Rept. Comm. Submarine Configuration and Oceanic Circulation, Apr11 23, p. 61-63.

Skogsberg, T., 1933, Oceanographic work at the Hopkins Marine Station, Stanford University, for the year 1932: Am. Geophys. Unton Trans., 14th ann. meet., p. 221-222.

Skogsberg, T., 1934, Hopkins Marine Station, Pacific Grove, California - Report on hydrograph1c work in Monterey Bay in 1933: Am. Geophys. Union Trans., 15th ann. meet., pt. 1, p. 220-221.

Skogaberg, T., 1936, Hydrography of Monterey Bay, California. Thermal conditions, 1929-1933: Am. Philos. Soc. Trans., v. 29, pt. I, p. 1-152, incl. 45 figs., tables.

Skogsberg, T., and Phelps, A., 1946, Hydrography of Monterey Bay, California. Thermal conditions, part II (1934-1937): Am. Philos. Soc. Proc., v. 90, p. 350-386.

Sleggs, G. F., 1927, Marine phytoplaniton in the region of La Jolla, California, during the summer of 1924: Scripps Inst. Oceanography Bull., tech. ser., v. 1, p. 93-117.

Slocum, G., 1931, Bucket observations of sea-surface temperatures: Monthly Weather Rev., v. 59, p. 49-50.

Smith, A. G., and MacKenzle, G., Jr., 1948, The marine mollusks and brachiopods of Monterey Bay, California, and vicinity: Calif. Acad. Sc1. Proc., v. 26, p. 147-245, pls. 3, 4, 4 figs.
Smith, C. D., Jr., 1950, The intense Pacific Cost storms of October 26-28, 1950: Monthly weather Rev., v. 78 , p. 191-195.

Smith, J. P., 1904, Periodic migrations between the Asiatic and the American Coasts of the Pacific Ocean: Am. Jour. Sci., 4th ser., v. 17, p. 217-233.

Smith, J. P., 1910, The geologic record of California: Jour. Geology, v. 18, p. 216-227.

Smith, J. P., 1919, Climatic relations of the Tertlary and Quaternary faunas of the California region: Callf. Acad. Sci. Proc., 4th ser., v. 9, p. 123-173.

Smith, J. S., 1936, The immediate problems of national beach protection: Shore and Beach, v. 4, p. 105-107.

Smith, J. S., 1937, Annual address of the President: Shore and Beach, v. 5, p. 5-7.

Smith, P. A., 1938, Revised classification of marine shorelines by F. P. Shepard (review): Jour. Geomorphology, v. 1, p. $254-255$.

Smith, P. A., 1940, Submarine physiographic types: Geol. Soc. America Bull., v. 51, p. 2007 (abs.).

Smith, P. V., Jr., 1954, Studies on origin of petroleum: occurrence of hydrocarbons in Recent sediments: Am. Assoc. Petroleum Geologists Bull., v. 38, p. 377-404.

Smith, W. D., 1919, Earthquakes in Oregon: Se1smol. Soc. America Bull., v. 9 , p. 59-71, pl. 6 .

Smith, W. D., 1930, oregon shoreline: a report of progress: Geol. Soc. America Bull., proc. for 1929, v. 41, p. 153 (abs.).

Sm1th, W. D., 1933a, Geology of the oregon cosst line: Pan Am. Geologist, v. 59, p. 33-44.

Smith, W. D., 1933b, Physiography of the Oregon Coast: Pan Am. Geologist, v. 59, p. 97-114.

Smith, W. D., 1933c, Special physiographic features of oregon Coast: Pan Am. Geologist, v. 59, p. 190-206, 241-258.

Smith, W. D., 1940, Oregon shore line: Geol. Soc. America Bull., v. 51, p. 2033 (abs.).

Smith, W. S. T., 1897, The geology of Santa Catalina Irland: Cal1f. Acad. Sc1. Proc., 3rd ser., Geology, v. 1, p. $1-71,2$ pls. and map.

Smith, W. S. T., 1898, A geological sketch of San clemente I land: U. S. Geol. Survey, 18th ann. rept., pt. II, p. 459-496, pls. 1xxxiv-xcvi, figs. 82-85.

Smith, W. S. T., 1899, Some aspects of erosion in relation to the theory of the peneplain: Univ. Calif. Pub. Geology, v. 2, p. 155-178.

Smith, W. S. T., 1900, A topographic study of the 1slands of southern California: Univ. Calif. Pub. Geology, v. 2 p. 179-230; Science, v. 11, p. 221 (abs.); Am. Geog. Soc. Bull., v. 33 (1901), p. 62-63 (abs.).

Smith, W. S. T., 1902, The submarine valleys of the Californis cosst: Science, v. 15 , no. 382 , p. $670-672$.

Smith, W. S. T., 1933, Marine terraces on Santa Catalina Irland: Am. Jour. Sc1., 5th ser., v. 25, p. 123-136.

Snavely, P. D., Jr., 1951, Geology of the coastal area betweer Cape Kiwanda and Cape Foulweather, Oregon: M. A. thesis, Univ. Calif., Los Angeles, 42 p., 1 fig., 2 pls., 2 tables; U. S. Geol. Survey, 011 and Gas Inv. Prelim. Map. no. 97 .

Sneddon, R., 1948, offshore California gets geophysical survey: Petroleum Engineer, v. 20 , no. 1, p. 242-248.

Snodgras8, F. E., 1951, wave recorders: F1rst Conf. on Cosstal Eng. Proc., Berkeley, p. 69-81.

Snodgrass, F. E., 1952, Ocean wave measurements: Un1v. Calif. Berkeley, Inst. eng. research, waves research lab., tech. rept. ser. 3 , 1ssue $342,40 \mathrm{p}$.

Snodgrass, F. E., 1954, Wave measurements, in Oceanograph1c instrumentation, Isaacs, J. D., and Iselin, C. O'D., editors, pub. 309, Nat1. Acad, Sclences - Nat1. Researc Counc11, p. 139-165 incl. discussion.

Snodgrass, F. E., Morison, J. R., Hall, M. A., Granthem, K. N. and Wlegel, R. L., 1952, Ellwood fleld pile studies preliminary report: Univ. Callf., Berkeley, Inst. eng. research, ser. 35 , issue $6,27 \mathrm{p} ., 40 \mathrm{pls}$.

Snodgrass, F. E., Rice, E. K., and Hall, M. A., 1951, wave forces on piling (Monterey fleld test): Univ. Calif., Berkeley, Inst: eng. research, ser. 35, 1ssue 4, 9 p., 18 
nodgrass, F. E., and Stiling, D. E., 1951, Analysis of wave recorders: Univ. Calif., Berkeley, Inst. eng. research, ser. 3 , issue $307,13 \mathrm{p} ., 1 \mathrm{pl}$.

Somers, P., 1952, Developments in the science of coastal engineering: U. S. Army, Corps of Engineers, Beach Erosion Board Bull., v. 6, no. 3, p. 14-19.

Sommer, H., and Clark, F. N., 1946, Effect of red water on marine life in Santa Monica Bay, California: Calif. Fish and Game, v. 32, p. 100-101.

Somer, H., Whedon, W. F., Kofoid, C. A., and Stohler, R., 1937, Relation of paralytic shell-fish poison to certain plankton organisms of the genus Gonyaulax: Archives of Pathology, v. 24, p. 537-559.

oper, E. K., 1938, Geology of the central Santa Monica Mountains, Los Angeles County: Calif. Jour. Mines and Geology, 34th Rept. State Mineralogist, p. 131-180.

sosedko, A. F., 1950, The settling of the region of Long Beach (California) as a result of the exploitation of petroleum oil fields: Nature (U. S. S. R.), v. 39, no. 10 , p. 47-48. (In Russian)*

oule, F. M., 1934, Sounding velocities in the Pacific: Fifth Pacific Sci. Cong. Proc., v. 2, p. 873-886.

oule, F. M., 1944a, Sounding velocity, in Scientific results of Cruise VII of the Carnegie during 1928-1929 under command of captain J. P. Ault. Oceanography I-A. Observations and results in physical oceanography: Carnegie Inst. Wash., Dept. Terrestrial Magnetism and Electricity Pub. 545, p. 61-65.

oule, F. M., 1944b, Determination of salinity, in Scientific results of Cruise VII of the Carnegie during 1928-1929 under command of Captain J. P. Ault. Oceanography - I-A. observations and results in physical oceanography: Carnegie Inst. Wash., Dept. Terrestrial Magnetism and Electricity Pub. 545, p. 67-77.

parks, N. R., 1936, The Eureka earthquake of June 6, 1932 : Seismol. Soc. America Bull., v. 26, p. 13-27.

ipencer, J. W., 1890, The high continental elevation preceding the Pleistocene period: Geol. Soc. America Bull., v. 1, p. $65-70$.

pencer, J. W., 1897, Great changes of level in Mexico and the inter-oceanic connections: Geol. Soc. America Bull., v. 9, p. 13-34.

tapleton, C. R., 1952, Recreation and its problems on the Santa Monica Venice shoreline, southern California: M. A. thesis, Univ. Calif., Los Angeles, 143 p., 33 figs.*

tanford University, 1951, Ocean we ve slopes in relation to ship stabilization: Tech. memo. 4, 22 p., diagrams. *

itanton, T. E., Jr., 1938, Tests show resistence to sea water of California cements: Shore and Beach, v. 6 , p. 34-36, 3 photos on back cover.

tearns, R. E. C., 1875, Discovery of fossil teeth of ar elephant on Santa Rosa Island: Calif. Acad. Sci. Proc., v. $5(1873-1874)$, p. 152 .

teinbeck, J., 1941, The log from the Sea of Cortez: New York, Viking Press, lxvi1 + $282 \mathrm{p}$. *

einbeck, J., and Ricketts, E. F., 1941, Sea of Cortez: New York, V1king Press, $x+598$ p., 40 pls., 2 charts. *

telzenmuller, W. B., 1949, Beach Erosion Board research: U. S. Army, Corps of Engineers, Beach Erosion Board Bull., v. 3, no. 3, p. 1-4.

tephenson, E. B., 1932, Temperature-gradients in ocean-waters: Am. Geophys. Union Trans., 13th ann. meet., p. 238-243.

tephenson, E. L., 1945, Magnetometer surveys on black sands of the Oregon Coast: U. S. Bur. Mines, Rept. Inv. 3814 , 18 p., 8 figs.

Stevenson, R. E., 1954, The marshlands at Newport Bay, California: Ph. D. thesis, Univ. Southern Calif., 199 p., incl. 51 figs.

venson, R. E., and Emery, K. 0., 1951, Biological and physical-chemical conditions in Newport Bay, California:
Geol. Soc. America Bull., v. 62, p. 1482 (abs.).

Stille, H., 1936, The present tectonic state of the earth: Am. Assoc. Petroleum Geologists Bull., v. 20, p. 849-880.

Stock, C., 1935, Exiled elephants of the Channel Islands, California: Sci. Monthly, v. 41, p. 205-214.

Stock, C., 1936, Ice age elephants of the Channel Islands: Westways, v. 28, June, p. 14-15.

Stock, C., 1943, Foxes and elephants of the channel Islands: Los Angeles Mus. Quart., v. 3, nos. 2-4, p. 6-9, 5 figs.

Stock, C., 1946, Progress in paleontological research on the Pacific Coast, 1917-1944: Geol. Soc. America Bull., v. 57, p. 319-354.

Stock, C., and Furlong, E. L., 1928, The Pleistocene elephants of Santa Rosa Island, California: Science, v. 68, no. 1754, p. 140-141: Pan Am. Geologist, v. 49, p. 315 (abs.); Geol. Soc. America Bull., v. 40 (1929), p. 176 (abs.), p. 257 (abs.).

Stockman, L. P., 1932, Unique features in steel island constructed for drilling in the Pacific 2,700 feet from shore: 0il and Gas Jour., v. 31, no. 28, Dec. 1, p. 13,38

Stockman, L. P., 1939, California's tideland drilling: 0il and Gas Jour., v. 38, sept. 21, p. 56, 57.

Stockman, L. P., 1949a, Settling spreads in Wilmington Field: Petroleum World, v. 46, no. 4, p. 29-30.

Stockman, L. P., 1949b, Wilmington subsidence: Petroleum World, v. 46, no. 9 , p. 14-15.

Stockman, L. P., 1949c, Marked improvement in California petroleum industry: Petroleum World, v. 46, no. 12, p. 17-21

Stockmann, W. B., 1946, Characteristic features of the coastal circulation in the sea and their connexion (connection) with the transverse non-uniformity of the wind: Comtes Rendus (Doklady) de I'Acad. des Sci., de I'URSS., v. 54, no. 3 , p. $227-230$.

Stoddard, C. W., 1912, With egg pickers of the Farallones, in In the foot prints of the padres: San Francisco, 3rd ed., p. 144-158.*

Storie, R. E., and Carpenter, E. J., 1929, Soil survey of the Oceanside area, California: U. S. Dept. Agriculture, Bur. Chemistry and Soils, ser. 1929, no. 11, 41 p., 3 pls., map.

Storie, R. E., and Carpenter, E. J., 1930, Soil survey of the El Cajon area, California: U. S. Dept. Agriculture, Bur. Chemistry and Soils, ser. 1930, no. 15, 42 p., map.

Storie, R. E., Cole, R. C., Owen, B. C., Koehler, L. F., Anderson, C. A., Leighty, W. J. and Retzer, J. L., 1944, Soil survey of the Santa Cruz area, California: U. S. Dept. Agriculture, Soil Survey ser. 1935, no. 25.*

Stormont, D. H., 1951, New seismic test - oil companies to resume offshore exploration after developing black-powder methods to reduce fish kill: 011 and Gas Jour., v. 50, no. $13, \mathrm{p} .40$.

Stormont, D. H., 1951a, New seismic test. Oil companies to resume off-shore exploration after developing black-powder method to reduce fish kill: $0 i l$ and Gas Jour., v. 50, no. 13 , Aug. 2 , p. 40 .

Stormont, D. H., 1951b, Development problem. Big islands, little islands, breakwater sites, and a mining method proposed for tapping San Pedro Bay reserves: $0 i l$ and Gas Jour., v. 50, no. 18 , Sept. 6, p. 58-59.

stormont, D. H., 1951c, Oil-drainage question. Long Beach Harbor operations are getting too close to tidelands reserve area, Justice Department charges: Oil and Gas Jour., v. 50, no. 19, sept. 13, p. E1-82.

Stormont, D. H., 1952a, Island drilling delayed. Strike puts off work on island off Seal Beach from which Morterey will drill a test on 1,400 acres underwater lease: 0il and Gas Jour., v. 51, June 30, p. 45.

Stormont, D. H., 1952b, Monterey trial blocked: $0 i l$ and Gas Jour., v. 51 , no. 24 , oct. 20 , p. 91.

Stormont, D. ㅍ., 1952c, Drilling platform trial set: 0il and Gas Jour., v. 51 , no. 22 , oct. 6, p. 75.

Stormont, D. H., 1953, Offshore core drilling: Oil and Gas Jour., v. 52, no. 1, p. 98-99.

Stormont, D. H., 1954a, Drill bits thread harbor field: 0il and Gas Jour., Marck 1, p. 42-43.

Stormont, D. H., 1954b, Seismic picture good. Long Beach oil prospects look better, but municipality faces subsidence 
risk if sub-city reservoirs are drained: 0 il and Gas Jour., v. 53, no. 6 , June 14, p. 108.

Stormont, D. H., 1954c, Test drilling ahead. Monterey island venture already below 4,000 ft.: 011 and Gas Jour., v. 53 , no. 6 , June 14, p. 109 . Also shore note no. 8 , June 28, p. 182 .

Strabov, N. M., 1953, Diagenesis of sediments and its significance for sedimentary ore formation: News of Sci. Academies of U.S. S. R., geol. ser., no. 5, Sept.-oct., p. $12-49$ (in Russian).

Streblow, A. G., 1951, Breakwater construction: First Conf. on Coastal Eng. Proc., Berkeley, p. 223-226.

Streets, T. H., 1878, The discolored water of the Gulf of California: Am. Naturalist, v. 12, p. 85-92.

Streiff, A., 1936, Feasibility of the use of a barrier to exclude salt water: Civil Eng., v. 6 , no. 1, p. 45.

Studds, R. F. A., 1950, oceanographic activities of the U.S. Coast and Geod. Survey: Am. Geophys. Union Trans., v. 31, p. $786-788$.

Studds, R. F., 1951, coast and Geodetic Survey data - an aid to the coastal engineer: First Conf. on Costal Eng. Proc., Berkeley, p. 102-125.

Stump, R. S., 1944a, Forecasting procedure for Coronado, California: Univ. Calif., Berkeley, fluid mechanics lab., tech. rept. HE-116-36, 3 p., graphs.

Stump, R. S., 1944b, Summary of observed wave data from Point Reyes, July, August, September 1944: Univ. Calif., Berkeley, fluid mechanics lab., tech. rept. HE-116-39, 4 p., tables.

Stump, R. S., 1944c, Summary of observed wave data from Humboldt Bay: Univ. Calif., Berkeley, fluid mechanics lab., tech. rept. HE-116-40, 1 p., 2 tables.

Stump, R. S., 1945a, wave forecasts for Fort ord: Univ. C lif., Berkeley, fluid mechanics lab., tech. rept. $\mathrm{HE}-116-46,2 \mathrm{p}$.

Stump, R. S., 1945b, Forecast and observed surf characterist1cs for three localities on the northern California Coast for July, August, September 1944: Univ. Calif., Berkeley, fluid mechanics lab., tech. rept. HE-116-52, 40 p., tables, graphs, maps, photos.

Stump, R. S., 1945c, Comparison of wave data from Estero Bay observation stations: Univ. Calif., Berkeley, fluid mechanics lab., tech. rept. HE-116-75, 3 p., graphs, supplement.

Stump, R. S., 1945d, Alteration of Estero Bay decay graph for use at Fort ord and Coronado: Univ. Calif., Berkeley, fluid mechanics lab., tech. rept. HE-116-77, 1 p., graph.

Stump, R. S., 1945e, Report on forecasting discrepancies: Univ. Calif., Berkeley, fluid mechanics lab., tech. rept. HE-116-82, 5 p., tables.

Stump, R. S., 1945f, Comparison of forecast and observed surf conditions California cosst from october 1944 through March 1945: Univ. Calif., Berkeley, fluid mechanics lab., tech. rept. HE-116-95, 121 p., tables, maps, graphs, photos.

Stump, R. S., $1945 \mathrm{~g}$, Biweekly comparison of observed and forcast surf conditions for the California Coast - No. 1. May 1 - 14, 1945: Univ. Calif., Berkeley, fluid mechanics lab., tech. rept. HE-116-121, 8 p., tables.

Stump, R. S., 1945h, Biweekly comparison of observed and forecast surf conditions for the California coast No. III. June 1- 15, 1945: Univ. Calif., Berkeley, fluid mechanics lab., tech. rept. HE-116-133, 13 p., tables, graphs.

Stump, R. S., 1945i, Forecast and observed surf, California Coast, April 1945: Univ. Calif., Berkeley, fluid mechanics lab., tech. rept. HE-116-152, 12 p., tables, graphs.

Stump, R. S., 1945j, Biweekly comparison of observed and forecast surf conditions for the California Coast, No. v. July 1 - 15, 1945: Univ. Calif., Berkeley, fluid mechanics lab., tech. rept. $[E-116-161,7$ p. tables, graphs.

Stump, R. S., 1945k, Biweekly comparison of observed forecast surf conditions for the California Coast, No. VI. July 16 - 31, 1945: Univ. Calif., Berkeley, fluid mechanics lab., tech. rept. HE-116-162, 9 p., tables, graphs.
Stump, R. S., 1946a, Comparison of breaker heights and periods measured from photographs and observed from shore: Univ. Calif., Berkeley, fluid mechanics lab., tech. rept. HE-116-196, 5 p., tables, graphs.

Stump, R. S., 1946b, Surf conditions for Humboldt Bay, Table Bluff Station, December 1945 - January 1946: Univ. Calif., Berkeley, fluid mechanics lab., tech. rept. HE-116-199, 5 p., tables.

Stump, R. S., 1946c, Summary of surf observations and forecasts for selected storms in the north Pacific, August 1944 - 1945: Univ. Calif., Berkeley, fluid mechanics lab., tech. rept. HE-116-203, 61 p., tables, graphs. App. 2 p.

Stump, R. S., 1946d, Daily record of deep water wave conditions - Monterey Bay, August 1944 - July 1945: Univ. Calif., fluid mechanics lab., tech. rept. HE-116-206, 12 p., tables.

Stump, R. S., 1946e, Comparison of breaker height with depth of breaking, Table Bluff, January 1946: Univ. Calif,, Berkeley, fluid mechanics lab., tech. rept. HE-116-214, $10 \mathrm{p}$. , tables, graphs, diagrams.

Stump, R. S., 1948a, Forecasting waves and surf: Univ. Calif., Berkeley, fluid mechanics lab, tech, rept. HE-116-184, 6 p., weather maps, graphs, photos. See next ref.

Stump, R. S., $1948 \mathrm{~b}$, Forecasting waves and surf - results of war research of interest to engineers: Shore and Beach, v. 16 , no. 1 .

Stump, R. S., and Bascom, W. N., 1947, Surf observations and photographic data obtained by field party and comparison with hindcasts: Table Bluff Station. December 1945January 1946: Univ. Calif., Berkeley, fluid mechanics lab., tech. rept. HE-116-205, 27 p., tables, photos, graphs, map.

Stump, R. S., and Hermanson, R. T., 1945a, Biweekly comparison of observed and forecast surf conditions for the California Coest - No. II. May 15 - 31, 1945: Univ. Calif., Berkeley, fluid mechanics lab., tech. rept. HE-116-122, 7 p., tables.

Stump, R. S., and Hermanson, R. T., 1945b, Comparison of forecast and observed waves from two Pacific storms Univ. Calif., Berkeley, fluid mechanics lab., tech. rept. HE-116-124, 26 p., tables, weather maps, photos.

Stump, R. S., and Hermanson, R. T., 1945c, Biweekly comparison of observed and forecast surf conditions for the california Coast, No. IV. June 16 - 31, 1945: Univ. Calif., Berkeley, fluid mechanics lab., tech. rept. HE-116-160, 9 p., tables, graphs.

Stump, R. S., and Hermanson, R. T., 1945d, Biweekly comparison of observed and forecast surf conditions for the California Coast, No. VII. Augrist 1 - 15, 1945: Univ. Calif., Berkeley, fluid mechanics lab., tech. rept. HE-116-168, 11 p., tables, graphs.

Stump, R. S., and Hermanson, R. T., $1945 e$, Biweekly comparison of observed and forecast surf conditions for the California Coast, no. VIII. August $16-31,1945$ : Univ. Calif., Berkeley, fluid mechanics lab., tech. rept., HE-116-169, 7 p., tables, graphs.

Stump, R. S., and Johnson, J. W., 1944, Relationship between predicted and observed tides at Point Reyes, Const Guard Life Boat Station, Point Reyes, California: Univ. Calif., Berkeley, fluid mechanics lab., tech. rept. HE-116-16, 9 p., tables, graphs.

Sumner, F. B., Louderback, G. D., Schmitt, W. I., and Johnston, E. C., 1914, A report upon the physical conditions in San Francisco Bay, based upon the operations of the U. S. Fisheries steamer Albatross during the years 1912 and 1913: Univ. Calif. Pub. Zoology, v. 14, p. 1-198, pls. $1-13$.

Sverdrup, H. U., 1934, The circulation of the Pacific: Fifth Pacific Sc1. Cong. Proc., v. 3, p. 2141-2145.

Sverdrup, H. U., 1936, An oceanographer's interest in beaches: Shore and Beach, v. 4, p. 151-153.

Sverdrup, H. U., 1937, Oceanographic research at the Scripps Institution of Oceanography during April 1936 to April 1937: Am. Geophys. Union Trans., 18th ann. meet., p. $210-216$.

Sverdrup, H. U., 1937-1938, on the process of upwelling: Jour. Marine Research, v. 1, p. 155-164.

Sverdrup, H. U., 1938a, Oceanic circulation: Fifth Internat. Cong. Adolied Mechanics Proc., p. 279-293.

Sverdrup, H. U., 1938b, Oceanographic problems of the coast of California: Am. Geophys. Union Trans., 19th ann. meet. p. 173-174. 
Sverdrup, H. U., 1938c, Research within physical oceanography and submarine geology at the Scripps Institution of Oceanography during April, 1937, to April, 1938: Am. Geophys. Union Trans., 19th ann. meet., p. 238-242. erdrup, H. U., 1938d, on the explanation of the oxygen minima and maxima in the oceans: Extrait du Jour. du Conseil Internat. pour l'Exploration de la Mer, v. 13, no. 2 , p. $1-10$.

drup, H. U., 1939a, Research within physical oceanography and submarine geology at the Scripps Institution of oceanography during April 1938 to April 1939: Am. Geophys. Union Trans., 20th ann. meet., p. 422-427.

erdrup, H. U., 1939b, Cruises of the E. W. Scripps in 1939: Sci. Monthly, v. 49, p. 389-391.

drup, H. U., 1939c, Physics and geophysics with special reference to problems in physical oceanography: Faculty research lecture at the Univ. Calif. at Los Angeles, no. 13 (1938), Univ. Calif. Press, Berkeley, 23 p. iverdrup, H. U., 1940a, The currents of the Pacific Ocean and their bearing on the climates of the coasts: Science, v. 91 no. 91, p. $273-282$.

iverdrup., H. U., 1940b, The Gulf of California: Assoc. d'océanographie Physique, Union Géodésique et Géophysique Internat., Procès-Verbaux no. 3, p. 170-171.

iverdrup, H. U., 1940c, Do permanent deep-sea currents exist? Assoc. d'océanographie Physique, Union Géodésique et Géophysique Internat., Procès-Verbaux no. 3, p. 182-183. rdrup, H. U., 1940d, Research within physical oceanography and submarine geology at the Scripps Institution of oceanography during April 1939 to April 1940: Am. Geophys. Union Trans., 2lst ann. meet., p. 343-346. iverdrup, H. U., 1940e, Activities of the Scripps Institution of Oceanography, La Jolla, California: Sixth Pacific Sci. Cong. Proc., v. 3, p. 114-123.

iverdrup, H. U., 1940f, The Gulf of California. Preliminary discussion of the cruise of the E. W. Scripps in February and March 1939: Sixth Pacific sci. Cong. Proc., v. 3 , p. 161-166.

rdrup, H. U., $1940 \mathrm{~g}$, The unity of the sciences of the sea: Sigma X Quarterly, v. 28, no. 3, p. 105-115.

verdrup, H. U., 194la, The Pacific Ocean: Science, v. 94, no. 2439, p. $287-293$.

verdrup, H. U., 1941b, Water masses and currents of the North Pacific ocean: Science, v. 93 , no. 2419, p. 436. rdrup, H. U., 194lc, An analysis of the ocean currents off the American west coast between $400 \mathrm{~N}$ and $40{ }^{\circ} \mathrm{S}$, in Proc. of the Dedicatory Exercises, Hancock Hall., Univ. Chron. ser., no. 7, Univ. Southern Calif. Press, Los Angeles, p. 17-20.

rdrup, H. U., 1942, Oceanography for Meteorologists: New York, Prentice-Hall, Inc., $246 \mathrm{p}$ : *

verdrup, H. U., 1944a, Observations and results in physical oceanography, in Scientific results of Cruise VII of the Carnegie during 1928-1929 under command of Captain J. P. Ault. Oceanography I-A: Carnegie Inst. Wash., Dept. Terrestrial Mangetism and Electricity pub. 545, p. 83-114.

verdrup, H. U., 1944b, The California current, in Science in the University, Univ. Calif. Press., Berkeley and Los Angeles, p. 97-111.

verdrup, H. U., 1946, The humidity gradient over the sea surface: Jour. Meteorology, v. 3, p. 1-8.

verdrup, H. U., 1947, Wind driven currents in a baroclinic ocean; with application to the equatorial currents of the eastern Pacific: Natl. Acad. Sci. Proc., v. 33, p. 318-326.

rdrup, H. U., and Allen, W. E., 1939, Distribution of diatoms in relation to the character of water masses and currents off southern California in 1938: Jour. Marine Research, v. 2, p. 131-144.

verdrup, H. U., and Fleming, J. A., 1944, Observations and results in physical oceanography, in Scientific results of Cruise VII of the Carnegie during 1928-1929 under command of Captain J. P. Ault. Oceanography I-A: Carnegle Inst. Wash., Dept. Terrestrial Magnetism and Electricity pub. 545, p. 115-148, incl. 38 figs.

verdrup, H. U., and Fleming, R. H., 1941, The waters off the coast of southern California, March to July 1937: Scripps Inst. Oceanography Bull., tech. ser., v. 4, p. $261-378$.

rdrup, H. U., Johnson, M. W., and Fleming, R. H., 1942, The oceans: their physics, chemistry and general biology: New York, Prentice-Hall, Inc., 1087 p., illus. rdrup, H. U., and Munk, W. H., 1947, Wind, sea and swell: theory of relations for forecasting: U. S. Navy Hydrog.
Office, tech. rept. 1, H. 0. Pub. 601, 44 p.

Sverdrup, H. U., and Staff, 1941, Research within physical oceanography and submarine geology at the Scripps Institution of Oceanography during April 1940 to April 1941: Am. Geophys. Union. Trans., 22nd ann. meet., p. $490-494$.

Sverdrup, H. U., and Staff, 1942a, Research within physical and oceanography and submarine geology at the Scripps Institution of Oceanography during April 1941 to April 1942: Am. Geophys. Union Trans., 23rd ann. meet., p. 323-325.

Sverdrup, H. U., and Staff, 1942b, Oceanographic observations on the E. W. Scripps cruises of 1938: Scripps Inst. Oceanography, Records of observations, v. 1, no. 1 , 64 p., 11 figs., 39 charts.

Sverdrup, H. U., and Staff, 1943a, Research within physical oceanography during April 1942 to April 1943: Am. Geophys. Union Trans., 24th ann. meet., p. 244-246.

Sverdrup, H. U., and Staff, 1943b, Oceanographic observations of the Scripps Institution in 1939: Scripps Inst. Oceanography, Records of observations, v. 1, no. 2, p. 65-159, 4 figs, 20 charts.

Sverdrup, H. U. and Staff, 1944, Oceanographic observations on the E. W. Scripps cruises in 1940: Scripps Inst. oceanography, Records of observations, v. 1, no. 3 , p. $161-248$.

Sverdrup, H. U., and Staff, 1945a, Research within physical oceanography and submarine geology at the Scripps Institution of Oceanography during April 1944 to April 1945: Am. Geophys. Union Trans., v. 26, p. 127-128.

Sverdrup, H. U., and Staff, 1945b, Research within physical oceanography and submarine geology at the Scripps Institution of Oceanography during April 1943 to April 1944: Am. Geophys. Union Trans., v. 26, p. 605.

Sverdrup, H. U., and Staff, 1946, Research within physical oceanography and submarine geology at the Scripps Institution of Oceanography during April 1945 to April 1946: Am. Geophys. Union Trans., v. 27, p. 571-573.

Sverdrup, H. U., and Staff, $1947 \mathrm{a}$, Research within physical oceanography and submarine geology at the Scripps Institution of Oceanography during April 1946 to April 1947: Am. Geophys, Union Trans., v. 28, p. 801-802.

Sverdrup, H. U., and Staff, 1947b, Oceanographic observations on the E. W. Scripps Inst. Oceanography, Records of observations, v. 1, no. 4, p. 249-407.

Swain, F. E., 1951, Determination of flows in interconnected estuarine channels produced by the combined effects of tidal fluctuations and gravity flows: Am. Geophys. Union Trans., v. 32, p. 653-672.

Swainson, 0. W., 1936, Velocity and ray paths of sound waves in sea water: U. S. Coast and Geod. Survey Field Engineers Bull., v. 10, p. 1-64.*

Swainson, 0. W., 1944, Earthquakes of southern Mexico and Central America with special reference to Professor wm. H. Hobbs' theory on "New volcanoes and a new mountain range:" Am. Geophys. Union Trans., 25th ann. meet., pt. 2, p. 277-281.

Swainson, O. W., McIlwraith, C. G., and Dyk, K., 1934, The velocity and ray paths of sound waves in deep water: U. S. Coast and Geod. Survey, 37 p. (mimeo) *

Sweeney, J., 1930, Pier construction for ocean drilling in California: oil Field Engineer, v. 7, no. 6, p. 44-48.

Swinnerton, A. C., 1927, Observations on some details of wave erosion: wave furrows and shore potholes: Jour. Geology, v. 35, p. 171-179.

Sykes, G., 1926, The delta and estuary of the Colorado River: Geog. Rev., v. 16, p. $232-255$, 1 pl. *

Sykes, G., 1937, The Colorado Delta: Am. Geog. Soc. special pub. 19, 193 p., map; Carnegie Inst. Wash., pub. no. 460 (excellent bibliography); Rev. by W. F. Read, Jour. Geol., v. 46 (1938), p. 790 .

Sykes, G., 1938, End of a great delta: Pan-Am. Geologist, v. 69, p. $241-248$.

Symons, T. W., 1893, Jetty harbors of the Pacific Coast: Am. Soc. Civil Engineers Trans., v. 28, p. 155-184, 9 pls., discussion, p. 372-389.

Taber, S., 1920, The Inglewood earthquake in southern California, June 21, 1920: Seismol. Soc. America Bull., v. 10 , p. 129-145, pls. 7 - 14 . 
Takahashi, J., 1925, Diatom theory of origin of Petroleum in California: Geol. Soc. America Bull., proc. for 1924 , v. 36, p. 206 (abs.), discussion p. 207.

Takshashi, J., 1928, on the diatom theory of the origin of petroleum in California: Third Pan-Pacific Sci. Cong. Proc., v. 2, p. 1613-1614 (abs.).

Taliaferro, N. L., 1943, Geologic history and structure of the central Coast Ranges of California: Calif. Div. Mines Bull. 118, p. 119-163.

Tanner, Z. L., 1892a, Report of the investigations of the U. S. Fish Commission steamer Albatross for the year ending Jure 30, 1889: Rept. U. S. Fish Comm. for 1888 , pt. 16, p. $395-512,3$ pls.

Tanner, Z. L., 1892b, Cable surveys from California to the Hawailan Islands. 1891-92: Geog. Soc. Pacific Trans. and Proc., v. 3, p. 63-83.

Tanner, z. L., 1893, Report upon the investigations of the U. S. Fish Commission steamer Albatross July 1, 1889, to June 30, 1891: Rept. U. S. Fish Comm. 1889-1891, p. 207-342, 1 pl.

Tanner, Z. L., 1894, Report upon the investigations of the U. S. Fish Commission steamer Albatross for the year ending June 30, 1892: Rept. U. S. Fish Comm. 1892, pt. 18, p. 1-64, 1 pl.

Tanner, Z. L., 1896, Report upon the operations of the United States Fish Commission steamer Albatross for the year ending June 30, 1894: Rept. U. S. Comm. Fish and Fisheries (1894), p. 197-219.

Taylor, A. E., and Grant, U. S., 1947, Effects of a vertically moving surface on spirit leveling: Seismol. Soc. America Bull., v. 37, p. 315-329.

Taylor, C. V., and Vaughan, T. W., 1934, Oceanographic activities according to countries - The United States: Marine biology on the Pacific Coast: Fifth Pacific Sci. Cong. Proc., v. 1, app. 1, p. 331-340.

Thayer, L. A., 1935, Some experiments on the biogenetic origin of petroleum: $\mathrm{Ph}$. D. thesis, Stanford Univ., 357 p, 57 figs., 30 tables. *

Thayer, L. A., 1937, Present status of the hypothesis of biogenesis of petroleum: Drilling and Production Practice 1936, Am. Petroleum Inst., p. 385-404 incl. discussion.

Thayer, W. N., 1916, The physiography of Mexico: Jour. Geology, v. 24, p. 61-94.

Thom, W. T., Jr., 1938, Opportunities and needs for collaborative research in the further study of continental borders: Geol. Soc. America Bull., v. 49, p. 1964-1965 (abs.).

Thomasson, H. G., Jr., 1951, Geology and ground-water resources of the south-coast basins of Santa Barbara County, California: U. S. Geol. Survey Water-Supply Paper 1108, $144 \mathrm{p}$.

Thompson, W. C., 1949, Ocean floor investigations along Santa Barbara County coast: Am. Assoc. Petroleum Geologists Bull., v. 33, p. 2062 (abs.); 0il and Gas Jour., v. 48, no. 29 , Nov. 24, p. 139 (abs.).

Thompson, W. F., assisted by Thompson, J. B., 1919, The spawning of the grunion (Leuresthes tenuis): Calif. Fish and Game Comm., Fish Bull. 3, 27 p.

Thompson, W. O., 1933, Observations on the stratification of beach deposits: Geol. Soc. America Bull., proc. for 1932, v. 44, p. 171 (abs.).

Thompson, W. 0., 1934, Original structures of beaches: Ph. D. thesis, Stanford Univ., 227 p., 60 pls., 11 figs., graphs *; Abs. dissertations, v. 10, p. 77-82 (1934-1935); Geol. Soc. America Bull., proc. for 1935, v. 47 (1936), p. 1ll112 (abs.).

Thompson, W. O., 1937, original structures of beaches, bars, and dunes: Geol. Soc. America Bull., v. 48, p. 723-752.

Thompson, T. G., and Robinson, R. J., 1932, Chemistry of the sea in Natl. Research Council Bull. 85, Physics of the eart $\overline{h-v}$, Oceanography, p. 95-203.

Thompson, T. G., Thomss, B. G., and Barnes, C. A., 1934,
Distribution of dissolved oxygen in the North Pacific Ocean; in James Johnstone Memorial Vólume, London, Univ. Liverpool Press, p. 203-234.

Thomson, A., 1934, Intertropical circulation over the Pacific ocean: Fifth Pacific Sci. Cong. proc., v. 1, p. 675-680.

Thorade, ‥, 1909, joer die Kalifornischen Meereströmungen, oberflàchentemperaturen und Strömungen, an der Westküste Nordamerikas: Annalen der Hydrographie und Maritimer. Meteorologie, band 37, p. $17-34,63-77$, pls. $5,10-11$.

Thorade, H., 1914, Die Geschwindigkeit von Triftströmungen und die Ekmansche Theorie: Annalen der Hydrographie und Maritimen Meteorologie, v. 42, p. 379-391.

Thornton, D. L., 1946, Seismic sea waves: Engineering, London, v. 161 , p. $484-485$.

Tibby, R. B., 1937a, Drift bottles released of $f$ coast of southern California: Science, v. 86, no. 2232, p. $328-329$.

Tibby, R. B., 19370, The relation between surface water temperature and the distribution of spawn of the California sardine, Sardinops caerulea: Calif. Fish and Game, v. 23 , p. 132-137.

Tibby, R. B., 1939, Report on returns of drift bottles release off southern California, 1937: Calif. Fish and Game, Fish Bull. 55, p. 1-36.

Tibby, R. B., 1941, The water masses off the west coast of North America: Jour. Marine Research, v. 4, p. 112-121.

Tibby, R. B., 1943, Oceanographic results from the E. W. Scripps Cruise VIII, May 10 to July 10, 1939, in Scripps Inst. Oceanography, Records of observations, v. 1 , no. 2 , p. $67-80$.

Tibby, R. B., 1944, Results of oceanographic investigations off the California coast, 1939-1940: Ph. D. thesis, Univ. Calif., 161 p., incl. 123 charts, 23 figs., tables.

Tilden, C. A., 1925, A quantitative study of certain marine microscopic organisms taken by the marine station launch Anton Dorhn during 1923 and 1924: M. A. thesis, Univ. Southern Calif., 58 p. incl. charts, tables.

Todd, D. K., 1952, Discussion of ground-water controlled through spreading: Am. Soc. Civil Eng. Trans., v. 117, p. 1061-1063.

Todd, D. K., 1953, Sea-water intrusion in coastal aquifers: Am. Geophys. Union Trans., v. 34, p. 749-754.

Todd, D. K., and Wiegel, R. L., 1951, Local storms of the Pacific Coast and their effects on wave and beach conditions: Univ. Calif., Berkeley, Inst. eng. research, waves research lab., Tech. rept. ser. 3 , issue 324 , 15 p., 8 pls.

Todd, D. K., and Wiegel, R. L., 1952, Near-coastal storms and associated waves: Am. Geophys. Union Trans., v. 33, p. 217-225.

Toit, A. L., du, 1940, An hypothesis of submarine canyons: Geol. Mag., v. 77, p. 395-404.

Tolman, C. F., and Poland, J. F., 1940, Ground-water, saltwater infiltration, and ground-surface recession in Santa Clara valley, Santa clara county, California: Am. Geophys. Union Trans., 2lst ann. meet., p. 23-35.

Topp, E. P., 1929, Physico chemical studies of the sea water in the San Pedro Bay region. Changes in salinity, specific gravity, oxygen content, throughout seasonal, and tidal cycles, with biological interpretations: $M$. $\mathrm{s}$. thesis, Univ. Southern Calif., $90 \mathrm{p}$. incl. figs. and tables, 6 charts, 2 maps, 8 pls. (Includes 23 p. review of chemistry and biology of sea water).

Torrey, H. B., 1902, An unusual occurrence of Dinoflagellata on the California Coast: Am. Naturalist, v. 36 , p. $187-192$.

Tower, M. L., 1910, Notes on the bar harbors at the entrances to Coos Bay, and Umpqua and Siuslaw Rivers, Oregon: Am. Soc. Civil Eng. Proc., v. 36, p. 1348-1358, 1 pl.

Tower, M. L., 1913, Rebuilding jetties at Humboldt Bay, California: Prof. Mem., U. S. Army, Corps of Engineers, v. 5, p. $499-518,2$ pls.

Townley, S. D., and Allen, M. W., 1939, Descriptive catalogue of earthquakes of the Pacific Coast of the United States, 1769 to 1928: Seismol. Soc. America Bull., v. 29, p. 1-297. (See Clark, J. T., 1944 for index) 
Townsend, C. Н., 1901, Dredging and other records of the United States Commission Steamer Albatross with bibliography relative to the work of the vessel: U. S. Comm. Fish and Fisheries Rept. 1900, p. 387-562, 7 pls.

Trask, B., 1907, Fossil Peak, Santa Catalina Island: Southern Calif. Acad. Sci. Bull., v. 3, no. 3, p. 140.

Trask, J. B., 1854, Report on the geology of the Coast Mountains and part of the Sierra Nevada: Embracing their industrial resources in agriculture and mining: Calif. Senate Doc. 9, sess. 1854, 95 p.

Trask, J. B., 1856, on earthquakes in California from 1812 to 1855: Calif. Acad. Nat. Sci. Proc., v. 1, pt. 2, p. $80-82$.

Trask, J. B., 1857, on the direction and velocity of the earthquake in California, January 9, 1857: Calif. Acad. Nat. Sci. Proc., v. 1, pt. 2, p. 98.

Trask, P. D., 1924, Unique garnet sand forming along the beach at the mouth of the Sur River, Monterey County, California: Geol. Soc. America Bull., proc. for 1923, v. 35, p. 165 (abs.).

Trask, P. D., 1926a, Geology of Point Sur quadrangle, California: Univ. Calif. Pub. Geology, v. 16, p. 119-186.

Trask, P. D., 1926b, Geomorphogeny of the northern part of the Santa Lucia Coast Range, California: Am. Jour. Sci., 5th ser., v. 12, p. 293-300.

Trask, P. D., 1927a, Oceanography and oil deposits: Am. Geophys. Union Trans., in Nat1. Research Council Bull. $61, \mathrm{p} .235-240$.

Trask, P. D., 1927b, Results of distillation and other studies of the organic nature of some modern sediments: Am. Assoc. Petroleum Geologists Bull., v. 1l, p. 12211230.

Trask, P. D., 1928, The potential value of several Recent American coastal and inland deposits as future source beds of petroleum: Am. Assoc. Petroleum Geologists Bull., v. 12, p. 1057-1068.

Trask, P. D., 1930, Summary of results obtained to date by the American Petroleum Institute research investigation on the origin and environment of source sediments: Am. Assoc. Petroleum Geologists Bull., v. 14, p. 311-314.

Trask, P. D., 1931a, Compaction of sediments: Am. Assoc. Petroleum Geologists Bull., v. I5, p. 271-276.

Trask, P. D., 1931b, Sedimentation in the Channel Islands region, California: Econ. Geology, v. 26, p. 24-43.

Trask, P. D., 1932a, Studies of Recent marine sediments conducted by the American Petroleum Institute: Natl. Research Council Bull. 89, Rept. Comm. Sed., 1930-32, p. 60-67.

Trask, P. D., 1932b, Relation of calcium carbonate content of sediments to salinity of the surface waters: Geol. Soc. America Bull., proc. for 1931, v. 43, p. 182 (abs.).

Trask, P. D., 1934, Deposition of organic matter in Recent sediments: Am. Assoc. Petroleum Geologists Bull., v. 18, p. 27-33; Problems of Petroleum Geology, Pub. by Am. Assoc. Petroleum Geologists, Tulsa, Okla., ed. by Wrather, W. E. and Lakes, F. H., 1934, p. 27-33.

Trask, P. D., 1937b, Calcium-carbonate content of some California Mesozoic and Tertiary sediments: Geol. Soc. America Bull., proc. for 1936, v. 48, p. 339 (abs.); v. 49 (1938), p. $1169-1181$.

Trask, P. D., 1939, Organic content of Recent marine sediments, in Recent marine sediments, symposium, pub. by Am. Assoc. Petroleum Geologists, Tulsa, Okla., p. 428 453.

Trask, P. D., 1950, Engineering geology of San Francisco Bay: Geol. Soc. America Bull., v. 61, p. 1531 (abs.).

Trask, P. D., 1952a, Stationary dredge for by-passing sand at Salina Cruz Harbor, Isthmus of Tehuantepec, Mexico: U. S. Army, Corps of Engineers, Beach Erosion Board Bull., v. 6, no. 2, p. 24-31; Univ. Calif., Berkeley, Inst. eng. Research, ser. 14, issue $10,7 \mathrm{p} ., 10 \mathrm{pls}$.

Trask, P. D., 1952b, Source of beach sand at Santa Barbara, California as indicated by mineral grain studies: U. S. Army, Corps of Engineers, Beach Erosion Board Tech. Memo. 28, 24 p.; Univ. Calif., Berkeley, Inst. eng. research., ser. 14 , issue 11,17 p., 6 pls. (Pub. in part in Trask, P. D., 1952c).

Trask, P. D., 1952c, Santa Barbara studies; Compilation of basic data: Univ. Calif., Berkeley, Inst. eng. research, ser. 14, issue 12, 2 p., 104 pls., 24 tables.

Trask, P. D., and Hammar, H. E., 1931, Distribution of organic matter in Recent sediments: Geol. Soc. America Bull., proc. for 1930 , v. 42, p. 184-185 (abs.).
Trask, P. D., assisted by Hammar, H. E., and Wu., C. C., 1932, origin and environment of source sediments of petroleum: Houston, Texas, Gulf Pub. Co., xv, 323 p. incl. illus. *

Trask, P. D., and Patnode, H. W., 1942, Source beds of petroleum: Tulsa, Okla., Am. Assoc. Petroleum Geologists, xiv, 566 p. incl. 11lus. *

Trask, P. D., and Rolston, J. W., 1950a, Engineering geology of San Francisco Bay, California: Geol. Soc. America Bull., v. 61, p. 1531 (abs.); v. 62 (1951), p. 10791110 .

Trask, P. D., and Rolston, J. W., 1950b, Relation of strength of sediments to water content and grain size: Science, v. 111, p. 666-667.

Trask, P. D., and Scott, T., 1954, Bore hole studies of the naturally impounded fill at Santa Barbara, California: U. S. Army, Corps of Engineers, Beach Erosion Board Bull. 49,36 p. incl. 15 figs., 7 tables.

Trask, P. D., and Wu, C. C., 1930a, Free sulfur in Recent sediments: Geol. Soc. America Bull., proc. for 1929 , v. 41 , p. $89-90$ (abs.).

Trask, P. D., and Wu, C. C., 1930b, Does petroleum form in sediments at time of deposition? Am. Assoc. Petroleum Geologists Bull., v. 14, p. 1451-1463.

Treasher, R. C., 1937, Submerged valleys on continental shelves and changes of sea level: a resume: Geol. Soc. Oregon Country News Letter, v. 3, no. 4, p. 34-36. *

Troster, J. G., 1949, Recent marine sedimentation in Halfmoon Bay, California: M. S. thesis, Stanford Univ., 61 p., pls., diagrams. *

Trowbridge, W. P., 1855, Report.... on the tidal and magnetic observations of the western corst of the United States: Rept. U. S. Coast Survey 1854, app. 30, p. 37-40.

Trowbridge, W. P., 1856a, Extracts from letters addresses to the Superintendent stating particulars relative to Bodega Bay and its vicinity, and South Farallon Island, California: Rept. U. S. Coast Survey 1855, app. 27, p. 185-186, chart J no. 5 (No. 46).

Trowbridge, W. P., 1856b, Tidal and magnetic operations on the western coast: Rept. U. S. Coast Survey 1855 , app. 34, p. 223-226.

Troxell, H. C., and Others, 1942, Floods of March 1938 in southern California: U. S. Geol. Survey Water-Supply Paper 844, 399 p., 26 pls., 40 figs., 32 tables.

Tucker, G. H., 1951, Relation of fishes and other organisms to the scattering of underwater sound: Jour. Marine Research, v. 10 , p. 215-238; U. S. Navy Electronics Lab., San Diego, (USNEL rept. 179). Nov. 30, 24 p. incl. illus.

Tucker, W. P., 1927, Mineral resources of Santa Catalina Island: Calif. Bur. Mines, 23rd Rept. State Mineralogist (also listed as Mining in Calif., chap. 1), p. 32-39.

Tudor, R. A., 1948, A report to Department of Public Works on additional toll crossings of San Francisco Bay: San Francisco, 144 p. *

Tudor, R. A., 1949, A report to Department of Public Works on additional toll crossings of San Francisco Bay as proposed by consultants to Assembly Interim Cormittee Calif. Div. San Francisco Bay Toll Crossings, San Francisco, 178 p. *

Tudor, R. A., 1951, A report to Department of Public Works on proposed highway toll crossing, Richmond - San Raftel Bridge: Div. San Francisco Bay Toll Crossings, Berkeley, Calif., 233 p. *

Twenhofel, W. H., 1943, Origin of the black sands of the coast of southwest Oregon: Oregon state Dept. Geology and Mineral Industries Bull. 24, p. 1-25.

Twenhofel, W. H., 1946, Beach and river sands of the coastal region of southwest oregon with particular reference to black sands: Am. Jour. Sci., v. 244, p. 114-139, 200-214.

Twenhofel, W. H., 1946a, Mineralogical and physical composition of the sands of the Oregon coast from coos Bay to the mouth of the Columbia River: Oregon Dept. Geol. and Min. Indus. Bull. $30,64 \mathrm{p} ., 8 \mathrm{pls}$. incl. maps.* 
Uchupi, E., 1954, Submarine geology of the Santa Rosa Cortes Ridge: M. Ș. thesis, Univ. Southern Calif., 72 p., incl. $11 \mathrm{pls} ., 2$ figs., 4 tables.

Udden, J. A., 1914, Mechanical composition of clastic sediments: Geol. Soc. America Bull., v. 25, p. 655-744.

Ufford, C. W., 1947a, Internal waves in the ocean: Am. Geophys. Union Trans., v. 28, p. 79-86.

Ufford, C. W., 19470, Internal waves measured at three stations: Am. Geophys. Union Trans., v. 28, p. 87-95.

Ufford, C. W., 1947c, The theory of intr nal waves: Am. Geophys. Union Trans. v. 28, p. 96-_.1.

Umbgrove, J. H. F., 1947, The pulse of the earth: The Hague, Martinus Nijhoff, 2nd ed., 358 p. incl. 204 figs., 8 pls., 2 tables.

Updegraff, D. M., 1948, The production of phenol and paracresol by marine bacteria: Jour. Bacteriology, v. 57, p. 555-564.

Upham, W., 1890, Quaternary changes of levels: Geol. Mag., v. 7, p. $492-497$.

Upham, W., 1899, Evidences of epeirogenic movements causing and terminating the ice age: Geol. Soc. America Bull., v. 10, p. 5-10.

Upson, J. E., 1949a, Former marine shore-lines of the Gaviota quadrangle, Santa Barbara County, California: Geol. Soc. America Bull., v. 60, p. 1925-1926 (abs.); Jour. Geology, v. 59 (1951), p. 415-446.

Upson, J. E., 1949b, Late Pleistocene and Recent changes of sea-level along the coast of Santa Barbara County, California: Am. Jour. Sci., v. 247, p. 94-115.

Upson, J. E., and Others, 1951, Geology and ground-water resources of the south-coast basin of Santa Barbara County, California: U. S. Geol. Survey Water-Supply Paper 1108, 144 p., 9 pls., 11 figs., 17 tables.

Upson, J. E., and Thomasson, H. G., Jr., 1951, Geology and water resources of the Santa Ynez River Basin, Santa Barbara County, California: U. S. Geol. Survey WaterSupply Paper 1107, 194 p.

Urry, W. D., 1940, Radio-elements in water and sediments of the ocean: Geol. Soc. America Bull., v. 51, p. 2010 $\left(a b_{0}\right)$.

Urry, W. D., 1948, Radioactivity of ocean sediments VII. Rate of deposition of deep-sea sediments: Jour. Marine Research, v. 7, p. 618-634.

Urry, W. D., and Piggot, C. S., 1942, Radioactivity of ocean sediments. V. Concentrations of the radio-elements and their significance in red clay: Am. Jour. Sci., v. 240, p. 93-103.

U. S. Army Air Weather Service, 1945, Average monthly wind velocities on routes from Hawail to the west cosst: Special study no. 28 , Wash. *

U. S. Army, Corps of Engineers, 1931, Study of tidal currents and silt movement in the San Francisco Bay area with particular reference to the effect of a salt water barrier upon them: San Francisco dist. *

U. S. Board appointed to locate a deep-water harbor at Port Los Angeles or an San Pedro, California, 1897, Deep-water harbor at Port Los Angeles or at San Pedro, California. Letter of the Secretary of War, in response to a resolution of the $S$ nate dated March 3, 1897, directing him; "To transmit to the senate the report made to him by the Board appointed to locate a deep-water harbor at Port Los Angeles or at San Pedro, California, under provisions of the River and Harbor Act of June 3, 1896, together with plans, specifications and estimates made by said Board," together with accompanying maps, and papers. Wash. (Also see - Congressional Documents, 1897). *

U. S. Bureau of Fisheries, 1906, Dredging and hydrographic records of the U. S. Fisheries steamer Albatross for 1904 and 1905: U. S. Bur. Fish. Doc. 604, Rept. and spec. papers, 1905 (1907), 80 p., incl. tables.

U. S. Bureau of Fisheries, 1921, Dredging and hydrographic records of the U. S. Fisheries steamer Albatross 1911 1920: Bur Fisheries Doc. 897, app. III to Rept. U. S. Comm. of Fisheries for 1920 , $190 \mathrm{p}$.
U. S. Coast and Geodetic Survey, 1913, Table of depths for channels and harbors, coasts of the United States including Porto Rico, the Hawaitan Islands, and the Philippine Islands: Wash., $175 \mathrm{p}$.

U. S. Coast and Geodetic Survey, 1915, Lengths, in statute miles, of general coast line and tidal shore lines of U. S., and outlying territories: Serial 22, 3 p.

U. S. Coast and Geodetic Survey, 1947, Tidal current charts, San Francisco Bay: Serial 484, 5 th ed., 12 charts.

U. S. Coast and Geodetic Survey, 1948, Surface water temperatures at Coast and Geodetic Survey tide stations, Pacific Ocean: TW-2, $47 \mathrm{p}$.

U. S. Coast and Geodetic Survey, 1950, Density of sea water at Coast and Geodetic Survey tide stations, Pacific Ocean: Special Pub. 281,37 p.

U. S. Coast and Geudetic Survey, 1952, Surface water temperatures at tide stations: Pacific Coast and South America and Pacific Ocean islands: Special Pub. 280 (formerly TW-2) revised $1952,59 \mathrm{p}$.

U. S. Coast and Geodetic Survey, 1953, Tide tables west coast of North and South America (including the Hawailan Islan for the year 1954: Serial 765, $210 \mathrm{p}$.

U. S. Coast and Geodetic Survey, 1953a, The tsunamis of $\mathrm{N}$ vember 4,1952 , as recorded at tide stations: Special pub. 300,62 p. *

U. S. Coast Survey, 1864, Table showing the least water in the channels of certain harbors, rivers, and anchorages or the coasts of che United States; Reprinted from the list of 1859 and revised with additions and tidal data: Ann. Rept. U. S. Coast Survey 1862 , app. 5, p. 86-92.

U. S. Coast Survey, 1867, Type Curves of the tides of the Pacific Coast of the United States: Ann. Rept. U. S. Coast Survey 1865, app. 11, p. 138.

U. S. Cumission of Fish and Fisheries, 1898, Records of observations made on board the U. S. Fish Commission steamer Albatross 1911 - 1920: Bur. Fisheries Doc. 897 , app. III to Rept. U. S. Corm. of Fisheries for $1920,190 \mathrm{p}$.

U. S. Hydrographic office, 1875, The navigation of the Pacific Ocean, China Seas, etc., translated at the U. S. Hydrographic Office from the French of Mons. F. Labrosse by J. W. Miller: U. S. Hydrog. Office Pub. $58 \mathrm{p} ., 360 \mathrm{p}$. *

U. S. Hydrographic office, 1892, Submarine cables: R pt. no. 103,67 p., maps, charts. *

U. S. Hydrographic office, 1932a, List of oceanic depths in the North Pacific Ocean observed by the U. S. S. Ramapo and received at the Hydrographic office between october 1929 and January 1931: H. 0. 210A, 86 p. incl. tables, chart.

U. S. Bydrographic office, 1932b, List of oceanic depths in the Pacific Ocean received at the Hydrographic office during the years 1929 to 1931 inclusive: H. O. 210B, 69 p. of tables, chart.

U. S. Hydrographic office, 1934a, List of oceanic depths in the North Pacific Ocean received at the Hydrographic office during the years 1931 to 1933 inclusive: H. O. $210 \mathrm{C}, 48 \mathrm{p}$. tables, chart.

U. S. Hydrographic office, 1934b, Dynamic oceanographic data for the Central Eastern Pacific Ocean collected by the U. S. S. Hannibal and the Yacht Velero III and surface temperature and salinity data for the eastern Pacific ocean collected by U. S. Naval vessels: H. 0. 212,53 p. incl. tables. U. S. S. Hannibal temperature and salinity data by R. H. Fleming.

U. S. Hydrographic office, 1936, List of oceanic depths in the Pacific Ocean received at the Hydrographic office during the years 1932 to 1934 inclusive: H. O. 210E, chart, 68 p. tables.

U. S. Hydrographic office, 1943a, Wind waves and swell: principles in forecasting: H. $0.11,275,61 \mathrm{p}$

U. S. Hydrographic office, 1943b, Monthly surface temperature charts of the North Pacific Ocean: Chart 10577. (Shows isotherms for each $5^{\circ} \mathrm{F}$ ).

U. S. Hydrographic office, 1944a, Current chart of Central American waters: Chart 10690. (Show resultant currents; that is the main direction and force of the surface currents in each $1^{\circ}$ quadrangle; and prevailing currents, the frequency of direction and average drifts. Also shows sea surface temperatures).

U. S. Hydrographic OIfice, 1944b, World atlas of sea surface temperature charts: H. O. 225. 2nd ed. (Paper bound copies of monthly temperature charts for all oceans 
showing mean sea surface temperatures over a period of 30 years. Size $26 \times 38$ inches.)

U. S. Hydrographic Office, $1944 c$, Breakers and surf: Principles in forecasting: H. 0. 234, 52 p., 19 figs., 4 pls.

U. S. Hydrographic Office, 1944d, Atlas of sea and swell charts, northeastern Pacific Ocean: H. O. 799D (formerly H. O. Misc. 10712D).

U. S. Hydrographic Office, 1947a, Atlas of surface currents, Northeast Pacific ocean. Also sea surface temperatures: H. 0.570 .

U. S. Hydrographic Office, 19470, Bottom sediment chart of the Gulf of Panama, Central America - West coast: Chart 1019-BS. (Shows the character of sea bottom in water shoaler than 100 fathoms by overprint on standard navigational chart).

U. S. Hydrographic Office, 1951, Sailing directions - West coasts of Mexico and Central America. The United States to Columbia, including the Gulfs of California and Panama: H. O. 84 . *

U. S. Naval Civil Engineering Research and Evaluation Laboratory, 1951, Report of marine borer conference. A symosium. May 10-12, 1951: Port Hueneme, Calif. *

U. S. Navy, 1948, Report on investigation of capacity of Mare Island Strait for the disposal of sewage: vallejo, Calif., Public Works Dept., Mare Island Naval Shipyard. *

U. S. Waterways Experiment Station, Vicksburg, Mississippi, 1935, A model study of maintenance works at Ballona Creek outlet, Venice, California: U. S. Army, Corps of Engineers, paper no. 18, $44 \mathrm{p}$.

U. S. Waterways Experiment Station, Vicksburg, Mississippi, 1936, Model study of maintenance works at Ballons Creek outlet, Venice, California: Tech. memo. no. 100-1, Dec. 12.*

U. S. Waterways Experiment Station, Vicksburg, Mississippi, $1947 \mathrm{a}$, Model study of wave and surge action, Naval operating Base, Terminal Island, San Pedro, California: U. S. Army, Corps of Engineers, Tech. Memo. 2-237, 94 p., 29 photos, 87 pls., app. 4 p., 6 pls., 3 photos.

U. S. Waterways Experiment Station, Vicksburg, Mississippi, 19470, Wave and surge action, Point Fermin Naval Supply Depot, San Pedro, California. Model investigation: U. S. Army, Corps of Engineers, Tech. Memo. 2-238, 57 p., 32 pls.

U. S. Waterways Experiment Station, Vicksburg, Mississippi, $1947 \mathrm{c}$, Breakwater location, U. S. Nava I Air Station, Alameda, California. Model investigation: U. S. Army, Corps of Engineers, Tech. Memo. 2-242. *

U. S. Waterways Experiment Station, Vicksburg, Mississippi, 1949, Wave and surge action, Long Beach Harbor, Long Beach, California - model investigation: U. S. Army, Corps of Engineers, Tech. Memo. 2-265, 34 p., 51 pls.

U. S. Waterways Experiment Station, Vicksburg, Mississippi, 1950, Review of model study for breakwater location, Alameda Naval Air Station: U. S. Army, Corps of Engineers, 32 p., 8 maps, diagrams.

Van Dorn, W. G., 1953, Wind stress on an artificial pond: Jour. Marine Research, v. 12, p. 249-276.

Vanoni, V. A., and Carr, J. H., 1951, Harbor surging: First Conf. on Coastal Eng. Proc., Berkeley, p. 60-68.

Varney, F. M., and Redwine, L. E., 1937, A hydraulic coring instrument for submarine geologic investigations: Natl. Research Council, Div. Geology and Geography, Comm. Sedimentation 1936-1937, P. D. Trask, choirman, p. 107113 (reprinted April 1938).

Vaughan, T. W., 1930a, Investigations of geological significance at the Scripps Institution of Oceanography: Pan Am. Geologist, v. 54, p. 70-71 (abs.).

Vaughan, T. W., 1930b, Recent oceanographic research at the Scripps Institution of Oceanography, University of California: Am. Geophys. Union Trans., llth ann. meet., p. $240-245$.

Vaughan, T. W., 1930c, Sea-cliff recession at La Jolla. Fourth report committee on features and changes of the shoreline of the Pacific Coast: Natl. Research Council, Div. Geology and Geography, rept. May 3, 1930, app. M, $2 \mathrm{p}$.

Vaughan, T. W., 1930d, The oceanographic point of view, in
Contributions to Marine Biology, Stanford Univ. Press, p. $40-56$.

Vaughan, T. W., 1931, Investigations of geological significance at the Scripps Institution of oceanography: Geol. Soc. America Bull., proc. for 1930, v. 42, p. 293-294 (abs.).

Vaughan, T. W., 1932a, Problemas principales de la oceanografla del Pacifico: Memorias Consejo Oceanografico Ibero-Americano, Nov. I, $31 \mathrm{p}$.

Vaughan, T. W., 1932b, Oceanographic work at the Scripps Institution of oceanography, University of California, La Jolla, California, July 1, 1931 to April 18, 1932: Am. Geophys. Union Trans., 13th ann. meet., p. 200-206.

Vaughan, T. W., 1932c, Outstanding problems of the oceanography of the Pacific: Sci. Monthly, v. 34, p. 128-146.

Vaughan, T. W., 1932d, Rate of sea cliff recession on the property of the Scripps Institution of oceanography at La Jolla, California: Science, v. 75, no. 1939, p. 250.

Vaughan, T. W., 1933, Oceanographic research at the Scripps Institution of Oceanography, University of California, April 1932 to April 1933: Am. Geophys. Union Trans., 14th ann. meet., p. 209-219.

vaughan, T. W., 1934, Present trends in the investigation of relations of marine organisms to their environment: Ecol. Mon., v. 4, p. 501-522.

Vaughan, T. W., 1935a, Studies of marine bottom deposits at the Scripps Institution of Oceanography: Natl. Research Council, Bull. 98, Div. Geology and Geography, Rept. Corm. Sedimentation, 1932-1934, p. 218-224.

vaughan, T. W., 1935b, Oceanographic research at the Scripps Institution during April 1934 to April 1935: Am. Geophys. Union Trans., 16th ann. meet., p. 221-226.

Vaughan, T. W., 1936, Oceanographic research at the Scripps Institution during April 1935 to April 1936: Am. Geophys. Union Trans., 17th ann. meet., p. 214-219.

Vaughan, T. W., 1940, Ecology of modern marine. organisms with reference to paleontology: Geol. Soc. America Bull., v. 52, p. $433-468$.

Vaughan, T. W. and Others, 1937, International aspects of oceanography: wash., Natl. Acad. Sci., xvii, 225 p., 10 Pigs., 36 pls.

Veach, J. A., 1859, Occurrance of boracic acid in the seawater of the Pacific: Calif. Acad. Nat. Sci. Proc., v. $2(1858-1862)$, p. $7-8$

Verbeek, R. D. M., 1885-1886, Krakatau: Batavia, Imprimerie de I'Etat, pt. I (1885), p. 1-104, pt. II (1886), xxxvii, p. 105-467. (See p. 396-461 on water movement).

Verrill, G. E., 1930, A coast city protects its harbor by constructing a new breakwater costing $\$ 750,000$ : Western City, v. 6, no. 9, p. 14-16, 41.

Vickery, F. P., 1927a, The interpretation of the physiography of the Los Angeles coastal belt: Am. Assoc. Petroleum Geologists Bull., v. 11 , p. $417-424$.

Vickery, F. P., 19270, Piracy and the persistence of antecedent streams on the Los Angeles coastal belt: Geol. Soc. America Bull., proc. for 1926, v. 38, p. 207 (abs.).

Voorthuysen, J. H. van, 1953, Some remarks about the PlioPleistocene microbiostratigraphy in northwestern Europe and in North America: Jour. Paleontology, v. 27, p. $601-604$.

Wade, J. A., and Brown, K. W., 1934, Treatment of Pacific Coast water supplies: Civil Eng., v. 4, p. 478-481.

Walford, L. A., 1951, The deep-sea layer of life: Sci. Am., v. 185 , no. 2 , p. $24-28$.

Walker, B. W., 1947, The beach-spawning grunion: Aquarium Jour., Nov., p. 8-12, 31.

Walker, G. T., 1934, Seesonal fluctuations in the North Pacific Ocean: Fifth Pacific Sci. Cong. Proc., v. 3, p. 1945-1947.

Walters, L., 1953, Notes on some shoreline minerals of San Francisco, California: Rocks and Minerals, v. 28 , p. 563-566.

Wanless, H. R., 1950, Selection of aerial photographs for teaching geology. Aerial photograph collection: Photogrammetric Eng., Dec., p. 796-806. 
Ward, H. A., 1952, A method of separating multiple systems of ocean waves for detalled study of directions and other properties: U. S. Army, Corps of Engineers, Beach Erosion Board Bull., v. 6, no. 3, p. 1-13.

Warne, A., 1936, Terraces of the San Pedro Hills: Unpub. seminar rept. in geology, Univ. Calif., Los Angeles, 30 p., illus. *

Warner, S. E., 1946a, Report on sea sled investigations: Univ. Calif., Berkeley, fluid mechanics lab., tech. rept. HE-116-136, 5 p., photos.

Warner, S. E., 1946b, Progress report on small sea sled: Univ. Calif., Berkeley, fluid mechanics lab., tech. rept. HE-1 $16-211,6$ p. photos, maps.

Warner, S. E., 1947, Sumnary of operations with spar buoy equipment in deep water, October 23 and 24,1945 : Univ. Calif., Berkeley, fluid mechanics lab., tech. rept. HE-116-241, 11 p., tables, graphs, charts, sketches. Revised by R. G. Folsom.

Washburne, C. W., 1904, Beach gold and its sources: oregon Univ. Bull., new ser., v. 1, no. 4 , p. 18-19.

Washington, H. S., 1901, A chemical study of the glaucophane schists: Am. Jour. Sci., 4th ser., v. 1l, p. 35-59.

Watts, G. M. and Others, 1953, Development and field tests of a sampler for suspended sediment in wave action: U. S. Army, Corps of Engineers, Beach Erosion Board Tech. Memo 34, 41 p. incl. 20 figs., 6 tables.

Weaver, C. E., 1944, Geology of the Cretaceous (Gualala group) and Tertiary formations along the Pacific Coast between Point Arena and Fort Ross, California: Wash. Univ. Pub. Geology, v. 6 , no. 1 , p. $1-29,13$ pls.

Weaver, C. E., 1945, Geology of oregon and Washington and its relation to occurrences of oil and gas: Am. Assoc. Petroleum Geologists Bull., v. 29, p. $1377-1415$.

Weaver, C. E., 1949, Geology of the Coast Ranges immediately north of the San Francisco Bay region, California: Geol. Soc. America Mem. 35, 242 p., 14 pls., 2 figs.

Weaver, D. K., 1937, Pumping slant holes at Huntington Beach, Callfornia: 0il and Gas Jour., v. 36 , no. 5 June 17 , p. 70-72, 75, 76, 79; Petroleum world, v. 34, no. 6 , p. 45-59.

Weaver, D. K., and Wilhelm, V. H., 1943, Huntington Beach Oil Field: Calif. Div. Mines Bull. 118, p. 329-331.

Webb, R. W., 1936, Paleontology of the Pleistocene of Point Loma, San Diego County, California: Ph. D. thesis, Calif. Inst. Tech., 18 p., 1 pl.

Weber, B. V., 1946, 01l-bearing basins, their facies and conditions of accumulation of source material for the formation of oil: Comptes Rendus (Doklady) de I'Acad. des Sci. de I'URSS, v. 53, no. 5, p. 447-450.

Weeks, L. G., 1952, Factors of sedimentary basin development that control oil occurrences: Am. Assoc. Petroleum Geologists Bull., v. 36 , p. 2071-2124.

Welker, S. C., 1954, California's first of fshore well being drilled from million-dollar concrete island: 011 and Gas Jour., v. 53, no. 7, June 21, p. 156.

Wells, H., 1937, Seashore life: San Francisco, Harr Wagner, 271 p. 3rd ed.; Sacramento, State Printing office, 1948 , xxiv, $271 \mathrm{p} . *$

Wells, R. C., 1921, Physico-chemical investigation of the water of the Pacific Ocean: First Pan-Pacific Sc1. Conf. Proc., pt. 2, p. 635-636.

Werenskiold, W., 1922, Mean monthly air transport over the North Pacific Ocean: Norsk Meteorologisk Inst. Geofysiske Publikationer, v. 2, no. 9.

Wharton, M., 1929, Constructing the world's greatest artificial harbor: Explosives Eng., v. 7, no. 10, p. 369-372.

Wharton, M., 1948, Shooting for oil: Explosives Eng., v. 26, no. $5, \mathrm{p} .142-146,155$.

Whedon, W. F., 1939, A three year survey of the phytoplankton in the region of San Francisco, California: Internat. Rev. der Gesell. Hydrobiologie und Hydrographie, band 38 , p. $459-476$.

Whedon, W. F., and Kofoid, C. A., 1936. Dinoflagellata of the San Francisco region. I. On the skeletal morphology of two new species, Gonyyaulax catanella and $G$. acatanella: Univ. Calif. Pub. Zoology, v. 4I, p. $\overline{25}-34$

Wheeler, G., 1936, Davis's study of California marine terraces: Union Geographique Internat., Comptes Rendus du Cong. Internat. de Geographie Varsovie, 1934, Travaux de la sect. II, p. 531-532.

Whitcroft, H. T., 1944, The bathymetry of the Central America region, west coast of Mexico and northern Central America: Am. Geophys. Union Trans., 25th ann. meet., pt. IV, p. 606-608.

White, A. B., 1945, Deep water wave measurements - III: Univ. Calif., Berkeley, fluid mechanics lab., tech. rept. HE-116-115, 7 p., tables, photos, charts.

White, D., 19ll, Value of floral evidence in marine strata as indicative of nearness of shores: Geol. Soc. America Bull., v. 22, p. 221-227.

Whiting, W. D., and.others, 1858, Report made to the Superintendent, showing the least water in channel entrances to certain harbors, rivers, and anchores on the coasts of the United States: Ann. Rept. U. S. Coast Survey 1857 , app. 21, p. $178-184$.

Whitney, J. D., 1865, Geological survey of California. Geology volume .I. Report of progress and synopsis of the fieldwork from 1860 to 1864: Philadelphia, Caxton Press of Sherman and Co., $498 \mathrm{p}$.

Whitney, P. C., 1935, Tidal action on shore line: Shore and Beach, v. $3, \mathrm{p} .16-18$

Whittemore, G. F., 1916, Construction of concrete block at end of South Jetty, Humboldt Bay, California: Prof. Mem., Ụ. S. Army, Corps of Engineers, v. 8, p. 31-41, $1 \mathrm{pl}$.

Whittemore, G. F., 1917, Taking cross-sections, Humboldt Jetties, California: Prof'. Mem., U. S. Army, Corps of Engineers, v. 9, p. 536-541, 3 pls.

Whittemore, G. F., 1926, Construction of Humboldt Bay Jetties: Military Engineer, v. 18, no. 97, p. 60-63.

Whittemore, G. F., 1928, The construction of Noyo Jetties: Military Engineer, v. 20, no. 113, p. 392-393.

Whitworth, G. W., 1932, Subsidence and the foundation problem in San Francisco: Am. Assoc. Civil Eng., San Francisco sect., Sept. *

Wiegel, R. L., 1947a, Recognition of underwater obstructions from aerial photographs: Univ. Calif., Berkeley, fluid mechanics lab., tech. rept. HE-116-248, 4 p., table, map, photos, sketches.

Wiegel, R. L., 19470 , Beach and surf conditions at Halfmoon Bay, California, April 28 and 29, 1947: Univ. Cal1f., Berkeley, fluid mechanics lab., tech. rept. HE-1l6-256, 6 p., table, map, photos, graphs.

Wiegel, R. L., 1947c, Breaker analysis from sea sled photographs, Merriweather Station, Cape Lookout, oregon, September 27, 1945: Univ. Calif., Berkeley, fluid mechanics lab., tech. rept. HE-116-258, 2 p., graphs, photos.

Wiegel, R. L., 1948, First report on the Mark V (Thermopile Wave Meter): Univ. Calif., Berkeley, fluid mechanics lab. tech. rept. $\mathrm{HE}-116-287,7 \mathrm{p}$. , photos, graphs, charts, sketches.

Wiegel, R. L., 1949, An analysis of data from wave recorders on the Pacific Coast of the United States: Univ. Calif., Berkeley, fluid mechanics lab., tech. rept. HE-116-289, 5 p., map, graphs, photos; Am. Geophys. Union Trans., v. 30, p. $700-704$.

Wiegel, R. L., and Kimberley, H. L., 1950, Southern swell observed at Oceanside, California: Am. Geophys. Union Trans., v. 31, p. 332 (abs.), p. 717-722.

Wiegel, R. L., and Todd, D. K., and Kimberley, H. L., 1950, A study of two local storms and their effect on wave and beach conditions at Camp Pendleton, Oceanside, California: Univ. Calif., Berkeley, Inst. eng. research, ser. 29 , issue 27 . * 
Wiegel, R. L., Patrick, D. A. and Kimberley, H. L., 1953, Wave, longshore current and beach profile records for Santa Margarita River Beach, Oceanaide, California -

1949: Univ. Calif., Berkeley, Inst. eng. research, waves research lab., ser. 3, issue 357,6 p., incl. tables $7 \mathrm{figs}$.

Wiggins, I. L., 1929, Flora of San Diego County, California; a phytogeographic and taxonomic study: Thesis, Stanford Univ. *

Wilcox, G. A., 1911, The terraces of the upper San Francisco Bay region, with an appendix on the geology of the Sui sun-Portrero Hills: M. S. thesis, Univ. Calif., Berkeley. *

Williams, E. A., and Isaacs, J. D., 1952, The refraction of groups and of the waves which they generate in shallow water: Am. Geophys. Union Trans., v. 33, p. 523-530.

Williams, W., 1948, Paradox in stone: Pacific Discovery, v. 1 , no. 6 , p. 4-7.

Williamson, R. S., and Heuer, W. H., 1871, Report upon the removal of Blossom Rock in San Francisco Harbor, California: U. S. Govt. Printing Office, Wash., (1870), 40 p., 11 pls.

Willis, B., 1900, Some coast migrations, Santa Lucia Range, California: Geol. Soc. America Bull., v. 1l, p. 417-432.

Willis, B., 1925, A study of the Santa Barbara earthquake of June 29, 1925: Seismol. Soc. America Bull., v. 15, p. 255-278, pls. 28,29 .

Willis, B., 1938a, San Andreas rift, California: Jour. Geology, v. 46, p. 793-827.

Willis, B., 1938b, San Andreas rift in southwestern California: Jour. Geology, v. 46, p. 1017-1057.

Wilson, G. M., 1946, Diving chamber permits gravity surveys on ocean bottom: 0il weekly, v. 121, no. 9, April 29, p. $22-23$.

Wilson, I. F., 1948, Buried topography, initial structures, and sedimentation in Santa Rosalía area, Ba ja California, Mexico: Am. Assoc. Petroleum Geologists Bull., v. 32, p. $1762-1807$.

Wilson, M. E., 1907, Shore topography near Davenport, Santa Cruz County: Calif. Physical Geography Club Bull., v. 1 , no. 2 , p. 11-17 incl. 2 pls.

Wilson, R. M., 1928a, Seismic sea waves at Hilo, 1927: Monthly Bull. Hawaiian volcano Observatory, v. 16, no. 3 , p. 21-25.

Wilson, R. M., 1928b, The seismic sea wave at Hilo: Monthly Bull. Hawrilian Volcano observatory, v. 16 , no. 6 , p. $41-42$.

Wilson, R. W., 1936, A new Pleistocene dear-mouse from Santa Rosa Island, California: Jour. Mammalogy, v. 17, p. $408-410$.

Wilstam, A., 1926, Forecasting water-power supply for hydroelectric plants of the Southern California Edison Company from ocean temperatures: Scripps Inst. Oceanography Bull. 12, p. 60-67.

Windle, E., 1931, History of Santa Catalina Island: Avalon, Catalina Islander, $162 \mathrm{p.}$ *

Winsted, H. L., 1913, The sea caves at La Jolla, California: Jour. Geography, v. 12, p. 125-126.

Wisser, E., 1954, Geology and ore deposits of Baja California, Mexico: Econ. Geology, v. 49, p. 44-76 (see extensive bibliog.).

Wittich, E., 1910, Strandlinien an der siedkueste von Niederkalifornien: Globus, band 97, p. 379.*

Wittich, E., 1912, Über Meeresschwankungen an der Küste von Kalifornien: Monatsber, d. deutsch. Geol. Ges., band 64, p. 505-512. *

Wittich, E., 1913, Nuevas observaciones acerca de levantamientos modernos en la Baja California: Acta d. 1, Sesión de Verano (12 Julio 1913), Soc. Geol. Mex. *
Wittich, E., 1916a, Die Salzlager am Ojo de Liebre an der Westkuste von Nieder-Kalifornien: Centralbl. für Mineralogie, p. 25-32. *

Wittich, E., 1916b, Las salinas de OJo de Libre en la Bahia Sebastian Vizcaino, Baja California: Bol. Minero, v. 2, no. 5, p. 235- .*

Wittich, E., 1920, La emersion moderna de la costa occidental de la Baja California: Soc. Cientifica "Antonio Alzate," Mem., v. 35 (1914-1916), p. 121-144, p1s. 14-23.

Wood, G. L., 193n, The Pacific basin: Oxford, The Clarendon Press, xil, 340 p., illus. *

Wood, H. O., 1915, on a possible causal mechanism for heavefault slipping in the California Coast Range region: Seismol. Soc. America Bull., v. 5, p. 214-229; Geol. Soc. America Bull., proc. for 1915, v. 26 (1916), p. 404 (abs.).

Wood, H. O., 1933a, The-Long Beach earthquake: Science, v. 78 , no. 2016 , p. $147-148$.

Wood, H. O., 1933b, Preliminary report on the Long Beach earthquake: Seismol. Soc. America Bull., v. 23, p. 43-56, pls. 4-10.

Wood, H. O., 1947, Earthquakes in southern California with geologic relations: Seismol. Soc. America Bull., v. 37, pt. I, p. 107-157, pt. II, p. 217-258.

Wood, H. O., and Heck, N. H., 1951, Earthquake history of the United States. Part II - Stronger earthquakes of California and western Nevada: U. S. Cosst and Geod. Survey, serial 609 , revised ed., $35 \mathrm{p}$.

Woodford, A. 0., 1924, The Catalina metamorphic facies of the Franciscan series: Univ. Calif. Pub. Geology, v. 15, p. $49-68$.

Woodford, A. 0., 1925, The San onofre breccia: Univ. Calif. Pub. Geology, v. 15, p. 159-280.

Woodford, A. O., 1928, The San Quintin volcanic field, Lower California: Am. Jour. Sci., 5th ser., v. 15, p. 337-345.

woodford, A. O., 1935, Rhomboid ripple marks: Am. Jour. Sci., 5th ser., v. 29, p. 518-525.

woodford, A. 0., 1951, Stream gradients and Monterey Sea Valley: Geol. Soc. America Bull., v. 62, p. 799-852, $1 \mathrm{pl}$.

Woodford, A. O., and Bailey, T. L., 1928, Northwestern continuation of the San onofre Breccia: Univ. Calif. Pub. Geology, v. 17, p. 187-191.

Woodring, W. P., 1930, Warm-water Paunas of the so-called Pliocene of San Pedro, California: Geol. Soc. America Bull., proc. for 1929, v. 41, p. 211-212 (abs.).

woodring, W. P., 1935, Fossils from the marine Pleistocene terraces of the San Pedro Hills, California: Am. Jour. Sci., 5th ser., v. 29, p. 292-305.

Woodring, W. P., 1938a, Lower Pliocene mollusks and echinoids from the Los Angeles Basin, California, and their inferred environment: U. S. Geol. Survey Prof. Paper 190, 67 p., 9 pls.

Woodring, W. P., 1938b, Pliocene and Pleistocene deformation in the California Coast Ranges: Geol. Soc. America Bull., proc. for 1937, v. 49, p. 121 (abs.).

Woodring, W. P., 1947, Marine terrace deposits of mountainous coasts: Wash. Acad. Sci. Jour., v. 37, p. 376

woodring, W. P., 1952, Pliocene-Pleistocene boundary in California Coast Ranges: Am. Jour. Sc1., v. 250, p. 401-410.

woodring, W. P., Bramlette, M. N., and Kew, W. S. W., 1946 , Geology and paleontology of Palos Verdes Hilla, California: U. S. Geol. Survey Prof. Paper 207, 145 p. *

Woodring, W. P., Bramlette, M. N., and Kleinpell, R. M., 1936, Miocene stratigraphy and paleontology of the Palos verdes Hills, California: Am. Assoc. Petroleum Geologists Bull., v. 20, p. 125-149.

woodring, W. P., Bramlette, M. N., and Lohman, K. E., 1943, Stratigraphy and paleontology of Santa Maria diatrict, California: Am. Assoc. Petroleum Geologists Bull., v. 27, p. $1335-1360$.

Woodring, W. P., and Kew, W. S. W., 1932, Tertiary and Pleistocene deposits of the San Pedro Hills, California: wash. Acad. Sci. Jour., v. 22, p. 39-40 (abs.).

Woodson, J. B., 1941, California County preserves ocean front. Purchases beaches, lake and island to protect beauty spots shoreward of new coastal highway: Shore and Beach, v. 9, p. 24, 2 photos on cover. Reprinted from Calif. Highways and Public Works, July 1940. 
woollard, G. P., 1949, Gravity anamalies and the nature of the earth's crust: Am. Geophys. Union Trans., v. 30, p. 189-201.

Woollard, G. P., 1951, Report of the special comittee on the geophysical and geological study of continents, 1950-1951: Am. Geophys. Unton Trans., v. 32, p. 634647.

Wooster, W. S., 1950, Methods in chem1cal oceanography employed in the California Cooperative Sardine Research Program: Scripps Inst. Oceanography, tech. rept. 25, 22 p., 8 figs.

Wooster, W. S., 1951, Operation Northern Hollday, August September 1951; preliminary report: Scripps Inst. Oceanography, SIO ref. $51-46,14$ p., diagrams.

wooster, W. S., 1952, Shellbeck Expedition, 17 May to 27 August 1952: Scripps Inst. Oceanography, SIO ref. $52-63,14$ p., 8 figs.

Worts, G. F., Jr., and others, 1951, Geology and groundwater resources of the Santa Maria Valley area, Santa Barbara County, Callfornia: U. S. Geol. Survey waterSupply Paper 1000, 169 p., 6 pls., 9 figs., 16 tables.

Wrath, W. F., 1936, Marine sedimentation around Catalina and San Clemente Islands: M. S. thesis, Univ. Illino1s, 31 p. *

Wright, R., 1937, Magnetic iron sulphide of Pliocene of Ventura Basin, California: Am. Assoc. Petroleum Geologists Bull., v. 21, p. 627-629.

Wyman, R. Z., 1878, Meteorological charts of the North Pacific ocean from the equator to latitude $45^{\circ}$ north and from the American Cosst to the 180th meridian: giving information regarding winds, calms, fog, rain, squalls, weather, barometer, and temperature of the air and of sea water at the surface; all for every five degrees square, and for each month: U. S. Bydrog. Office, 4 p., 15 charts.

Yale, C. G., 1879, Pactfic Coast harbors. A description of the harbors, landings, roadsteads and routes on the coastline of California, Oregon and Washington: San Francisco, 11, 43 p. + chart.

Yale, c. G., 1913, Beach mining in California and oregon: Mineral Res. U. S., 1912, p. 253-254.

Yates, L. G., 1889, Prellminary notes on the geology of the Anacapes: West Am. Sc1., v. 6, p. 155-156.

Yates, L. G., 1890a, Notes on the geology and scenery of the 1slands forming the southerly line of the Santa Barbara Channel: Am. Geologist, v. 5, p. 43-52 incl. sketches.

Yates, L. G., 1890b, Stray notes on the geology of the Channel Islands: Calif. State Min. Bur., 9th Ann. Rept. State Mineralogist, p. $171-174$.

Yates, L. G., 1890c, The mollusca of the Channel Islands of California: Calif. State Min. Bur., 9th Ann. Rept., State Mineralogist, p. 175-178.

Yates, L. G., 1890d, Insular floras: Calif. State Min. Bur. 9th Ann. Rept., State Mineralogists, p. 179-188.

Yates, L. G., 1892, Pecullar geologic processes on the Channel Islands of California: Geol. Soc. America Bull., v. 3, p. 133 (abs.).

Yates, L. G., 1902, Prehistoric Calffornia, 1ts topography, flora and fauna - with the evidence of the time of the advent of man, and his development, from the records of his past found in the soil: Southern Calif. Acad. Sc1. Bull., v. 1, p. 81-86, pls. 1-3 and continued in later numbers.

Yoshida, K. and Mao, H-L., 1954, Upwelling off the California Coast: Am. Geophys. Union Trans., v. 35, p. 377 (abs.).

Young, A. A., 1945, Evaporation investigations in southern California: U. S. Dept. Agriculture, Soll Conservation Service, Div. Irrigation, $188 \mathrm{p}$. *

Young, A. A., 1947a, Evaporation from water surfaces in Callfornia; a summary of pan records and coefficients 1881 to 1946: Calif. Div. Water Res. Bull. 54, pt. I, 68 p., 4 f1gs., 17 tables.

Young, A. A., 1947b, some recent evaporation investigations: Am. Geophys. Union Trans., v. 28, p. 279-284.

Young, R. T., Jr., 1939, Measurements on the transparency of sea-water off the coast of southern California: Jour.
Marine Research, v. 2, p. 117-125.

Young, R. T., 1943, A note on some laboratory measurements of the transparency of sea water: Jour. Marine Research, v. 5, p. $111-115$.

Young, R. T., and Gordon, R. D., 1939, Report on the penetration of light in the Pacific Ocean off the const of southern California: Scr1pps Inst. Oceanography Bull., tech. ser., v. 4, p. 197-218.

Young, W. R., 1929, Report on salt water barrier below confluence of Sacramento and San Joaquin Rivers, California: Calif. D1v. Water Res. Bull. 22.*

Zander, G., and Gleason, G. B., 1947, South cosstal basin investigation-overdraft on ground water basins: Callf. Div. Water Res. Bull. 53, 256 p.

ZoBell, C. E., 1933, Photochemical nitrification in sea water: Science, v. 77 , no. 1984 , p. $27-28$.

ZoBell, C. E., 1935, Some preliminary observations on oxidation reduction conditions in marine bottom deposits in the Gulf of Catalina: Natl. Research Council Bull. 98, Rept. Corm. Sedimentation, 1932-1934, p. 223-224.

ZoBell, C. E., 1936, oxidation-reduction conditions in marine sediments with particular reference to $O / R$ potentials, oxygen deficit and bacteria: Assoc. d'océanographie Physique, Edinburgh, p. 57-58; * Assoc. d'Océanographique Union Géodés1que et Geophysique Internat. Procès-Verbaux no. 2 (1937), p. 159-160.

ZoBell, C. E., 1938, Studies on the bacterial flora of marine bottom sediments: Jour. Sed. Petrology, v. 8, p. 10-18.

ZoBell, C. E., 1939, Occurrence and act1vity of bacteria in marine sediments, in Trask, P. D., Recent marine sediments Symposium, pub. by Am. Assoc. Petroleum Geologists, Tulsa, Oklas, p. 416-427.

ZoBell, C. E., 1941, The culture requirements of heterotrophic aerobes: Jour. Mar. Res., v. 4, p. 42-75.

ZoBell, C. E., 1942a, Bacteria of the marine world: Sci. Monthly, v. 55, p. 320-330.

ZoBell, c. E., 1942b, Changes produced by microorganisms in sec 1ments after deposition: Jour. Sed. Pet., v. 12, p. 127-1?

ZoBell, C. E., 1942c, Microorganisms in marine air: Am. Assoc. Adv. Sc1., pub. 17, p. 55-68.

ZoBell, C. E., 1943, Influence of bacterial activity on source sediment. A contribution from API Research Project 43A: Annual report of progress - Fundamental Research on Petroleum, 1943, Am. Petroleum Inst., p. 105-113; 011 Weekly, v. 109, April 26, 1943, p. 1-12.

ZoBell, C. E., 1944, Review of scope and accomplishments on API Research Project 43A. "Transformation of organic material into petroleum-bacteriological and sedimentation phases:" Ann. Rept. Progress Fundamental Research on occurrence and Recovery of Petroleum, 1943, Am. Petroleum Inst., p. 103-104.

ZoBell, C. E., 1946a, Marine microbiology. A monograph on hydrobacteriology: Waltham, Mass., Chronica Botanica co. xiv, 240 p. *

ZoBell, C. E., 1946b, Studies on redox potential of marine sediments: Am. Assoc. Petroleum Geologists Bull., v. 30, p. 477-513; Rept. Progress - Fundamental Research on Occurrance and Recovery of Petroleum, 1944-1945, Am. Petroleum Inst., p. 79-98.

ZoBell, C. E., 1946-1947, Biennial report for 1945-1947 on API research Project 43A. Bacteriological and sedimentation phase of the Transformation of organic material into petroleum: Fundamental Research on Occurrance and Recovery of Petroleum, 1946-1947, Am. Petroleum Inst., $1-14$.

ZoBell, C. E., 1947a, To what depths are bacterla active in marine bottom deposits: Fourth Internat. Cong. for Microbiology, Copenhagen, p. 453.

ZoBell, c. E., 19470, Bacterial release of oll from oll-bearing materials: World 0il, Aug. 25, and Sept. 1, 19 p.

ZoBell, C. E., 1947c, Marine bacteriology: Ann. Rev. Biochemi p. $565-586$.

ZoBell, C. E., 1947d, Microbial transformation of molecular hydrogen in marine sediments, with particular reference to petroleum: Am. Assoc. Petroleum Geologists Bull., v. 31, p. 1709-1751.

ZoBell, C. E., 1949, Biennial report for 1945-1947 on A.P.I. Research Project 43A. Bacterialogical and sedimentation phases of the transformation of organic material into petroleum: Rept. Progress - Fundamental Research on Occurrance and Recovery of Petroleum, 1946-1947, Am. Petroleum Inst., p. 100-106. 
ZoBell, C. E., 1950, Bacterial activities and the origin of oil: World 0il, v. 130, June, p. 128-138; Rept.

Progress - Fundamental Research on Occurrance and

Recovery of Petroleum, 1950-1951, Am. Petroleum Inst., 1. 101-114.

ZoBell, C. E., and Anderson, D. Q., 1936, Vertical distribution of bacteria in marine sediments: Am. Assoc. Petroleum Geologists Bull., v. 20, p. 258-269.

ZoBell, C. E., and Feltham, C. B., 1934a, Are there specific marine bacteria? Fifth Pacific Sci. Cong. Proc., v. 3, p. 2097-2100.

ZoBell, C. E., and Feltham, C. B., 1934b, Preliminary studies on the distribution and characteristics of marine bacteria: Scripps Inst. Oceanography Bull., tech. ser., v. 3, p. $279-296$

ZoBell, C. E., and Feltham, C. B., 1942, The becterial flora of a marine mud flat as an ecological factor: Ecology, v. 23, p. $69-78$.
ZoBell, C. F., Grant, C. W., and Hars, H. F., 1943, Marine microorganisms which oxidize petroleum hydrocarbons: Am. Assoc. Petroleum Geologists Bull., v. 27, p. 11751193.

ZoBe11, C. E., and Mathews, H. M., 1936, A quantitative study of the bacterial flora of sea and land breezes: Natl. Acad. Sci. Proc. v. 22, p. 567-572.

ZoBell, C. E., and Rittenberg, S. C., 1938, The occurrence and characteristics of chitinoclastic bacteria in the sea: Jour. Bacteriology, v. 35, p. 275-287;

Zodac, P., 1952, The sand collector - Beach sand from Catalins Island: Rocks and Minera1s, v. 27, p. 280, 284. 
Abrasion of sediments and Rocks (See also: Shape and Roundness of Sanci, Gravel, Rocks etc.): Anderson, G. E., 1926; Butcher, W. S., 1951a; Dietz, R. S., Emery, K. O. and Shepard, F. P., 1942; Dietz, R. S. and Menard, H. W., 1951b; Emery, K. O. and Dietz, R. S., 1950; Johnson, J. W., 1952; Krumbein, W. C., 1950; Mason, M. A., 1942; Nicholson, G. F., Grant, U. S., Shepard, F. P. and Crowell, J. C., 1946; Schaufele H. J., 1951; Uchupi, E., 1954

Absorption (See also: Extinction Coefficient, Light, Transparency, Turbid Water): California Academy of Sciences, California Division of Fish and Game, Scripps Institution of Oceanography, U. S. Fish and Wildlife Service, 1950; Richardson, B., 1934 (absorption coefficlent); ZOBelI, C. E., 1936 ( $\mathrm{O}_{2}$ absorption)

Abyssal: Agassiz, A., 1905; Belknap, G. E., 1874a (tables of bottom samples), 1874b; Carsola, A. J. and Dietz, R. S., 1952; Clark, A. H., 1914; Davidson, G., 1875b, 1897; Dietz, R. S., 1952a, 1954; Dietz, R. S., Menard, H. W. and Hamilton, E. L., 1952; Dill, R. F., 1952; Emery, K. O., 1954a, 1954b; Emery, K. O. and Natland, M. L., 1952; Evans, R. D., Kip, A. F. and Moberg, E. G., 1938; Fleming; J. A., Sverdrup, H. U., Ennis, C. C., Seaton, S. L. and Hendrix, W. C., 1945; Fox, D. L., Updegraff, D. M. and Novelli, G. D., 1944; Galliher, E. W., 1935a; Göes, A., 1896; Graham, H. W. and Moberg, E. G., 1944; Grim, R. E., Dietz, R. S. and Bradley, W. F., 1949; Heck, N. H., 1924; Holway, R. S., 1905; Jeffreys, H., 1934; Koczy, F. F., 1954; Kuenen, Ph. H., 1946; Murray, J. and Lee, G. V., 1909; Piggot, C. S., 1932; Piggot, C. S. and Urry, W. D., 1942; Revelle, R., 1935, 1936, 1937a, 1937b; Revelle, R. and Shepard, F. P., 1939b; Scripps Institution and Oceanography, 1950e; Shepard, F. P., 1937f, 194la, 1949d, 1950a, 195le; Shepard, F. P., Revelle, R., Dietz, R. S. and Emery, K. O., 1938; Shepherd, E. S., 1940 ,

1946; Shumway, G. A., 1953; Tanner, Z. L., 1892b, 1894; Trask, P. D. and Hammar, H. E., 1931; Urry, W. D., 1948; Urry, W. D. and Piggot, C. S., 1942; Vaughan, T. W., 1940; White, D., 1911; Woollard, G. P., 1951; ZoBell, C. E., 1942 a

Accretion, Aggradation, Progradation (See also: Sedimentation): Anonymous, 1916a, 1935, 1938a; Beach Erosion Board, 1942a, 1948b, $1948 \mathrm{~h}, 1948 \mathrm{i}, 1948 \mathrm{j}$, 1949a, 1951, 1952a, 1953a, 1953c; California, University of, 1952a; Carpenter, F. A., 1924; Congressional Documents, 1938a, 1940a, 1942b, $1942 \mathrm{c}, 1949 \mathrm{a}, 1949 \mathrm{~b}, 1949 \mathrm{~d}, 1949 \mathrm{f}, 1949-50 \mathrm{~b}$, 1953b; Crowell, J. C., 1952; Dietz, R. S., 1947b; Dietz, R. S., Emery, K. O. and Shepard, F. P., 1942; Dunbam, J. V., 1951; Eaton, R. O., 1951; Emery, K. O. and Dietz, R. S., 1950 (accretion in nodule formation); Goldberg, J., 1940; Grant, U. S., 1938, 1948; Grant, U. S. and Shepard, F. P., 1940; Gulliver, F. P., 1896; Hall, J. V., 'Jr., 1952; Hall, W. C., 1942; Handin, J. W., 1949, 1951; Handin, J. W. and Ludwick, J. C., 1949; Hawgood, H., 1914; Horton, D. F., 1948; Hunter, R. C., 1946; Inman, D. L., 1949, 1953a; Johnson, A. G., 1935, 1940c, 1951; Johnson, J. W., 1948b, 1948d; Krumbein, W. C. and Ohsiek, L. E., 1950; Lapsley, W. W., 1937; Larsen, G. P., 1942b; Leeds, C. T., 1916, 1936; Leeds, C. T., Vanoni, v. A. and Knapp, R. T. 1934; Leypoldt, H., 1941b; Livingston, A., Jr., 1939; Los Angeles County Regional Planning Commission, 1940; Marlette, J. W., 1954; Mason, M. A., 1949a, McAfee, C. M., Jr., 1939; Nicholson, G. F., Grant, U. S., Shepard, F. P. and Crowell, J. C., 1946; O'Brien, M. P., 1936a, 1939, 1947b; Orange County Planning Comission, 1941; Pardee, J. T., 1934; Peel, K. P., 1951; Place, J. I., 1952; Postel, A. C., 1937, 1939; Putnam, W. C., 1938; Richardson, R. W., 1923; Schupp, R. D., 1953; Sears, C. B., 1876; Shepard, F. P., 1938a, 1948b, 1950c; Shuler, W. R., 1951, 1952; Smith, W. D., 1930; Somers, P., 1952;
Stevenson, R. E., 1954; Symons, T. W., 1893; Trask P. D., and Scott, T., 1954; U. S. Waterways Experim Station, Vicksburg, Mississippi, 1935, 1936; Verril: G. E., 1930

Advection, including Advection currents: McEwen, G. F., 1950; Robinson, M. K., 1951; Scripps Institution of Oceanography, $1952 i$

Aeration (See also: Bacteria, Eh, Oxidizing or Aerobic Enviroment, oxygen): Hinde, H. P., 1952; Stevenson, R. E. , 1954

Algae, Kelp, Sea Weed (See also: Diatoms, Dinoflagellates, Phytoplankton, Plankton, Vegetation): Anonymous, 1940d, 1941b; Allen, W. E., 1920 , 1940b; Andrews, H. L., 1945; Bascom, W. N., 1950b; Branner, J. C., 1900, 1913; Brongersma-Sanders, M. 1948; California Bureau of Sanitary Engineering, 1952; Coe, W. R., 1932, 1945, 1947, 1948; Coe, W. R., and Allen, W. E., 1937; Coe, W. R. and Fox, D. L., 1942; Cohee, G. V., 1938; Congressional Documents, 1940a; Couch, E. B., 1915; Crooke, R. C., Elvitsky, A. W. et al, 1953; Crowell, J. C., 1952; Dapples, E. C., 1942; Davidson, G., 1856, 1864; Dawson, E. Y., 1946, 1950, 1951, 1952; Emery, K. O., 1944, 1946b, 1948, 1950d, 1952b, 1954a, 1954e; Emery, K. O. and Tschudy, R. H., 1941; Erickson, C. E., 1952, 1953; Evans, R. D., Kip, A. F. and Moberg, E. G., 1938; Fewkes, J. W., 1889; Fox, D. L., 1937, 1944b, 1950; Fox, D. L., and Anderson, L. J., 1941; Fox, D. L., Updegraff, D. M. and Novelli, G. D., 1944; Fox, L. S., 1930; Fraser, C. McL., 1943; Gee, H., 1932; Gislén, T., 1943, 1944; Gorgy, S., Rakestraw, N. W. and Fox, D. L., 1948; Gorsline, D. S., 1954; Graham, H. W., 1934; Haase, L. G., 1926; Hanna, G. D., 1952; Herold, C. L., 1934; Hewatt, W. G., 1934; Hinde, H. P., 1952; Johnson, D. W., 1910; Johnson, M. W. Everest, F. A. and Young, R. W., 1947; Kemnitzer, L. E., 1933; Knox, R. W., 1953; McConnaughey, B. H. and Fox, D. L., 1949; McEwen, G. F., 1935a; MacGinitie, G. E., 1935; Martin, L. T., 1930; Menard, H. W., Dill, R. F., Hamilton, E. L., Moore, D. G., Silverman, M. and Stewart, H. B., 1954; Michael, E. L., 1921; Munk, W. H., 1950; Nelson, R. N., and Schenck, H. G., 1928; Nicholls, C. P. L., 1939; Norris, R. M., 1952; O'Brien, M. P., 1939; Péi, C., 1929; Purer, E. A., 1942; Revelie, R. and Shepard, F. P., 1939b; Richardson, R. W., 1923; Ritter, W. E., 1902; Rothwell, W. T., Jr., 1944; San Diego Regional water Pollution Control Board, 1952; Scripps Institution of Oceanography, 1953e; Shepard, F. P., 1941a, 1947a, 1948b, 1948c, $1949 \mathrm{~b}, 1950 \mathrm{c}, 1950 \mathrm{~g}, 1951 \mathrm{a}, 195 \mathrm{ld}$, 1953; Shepard F. P. and Emery, K. 0., 1945; Shepard, F. P. and Grant, U. S., 1947; Shumway, G. A., 1953; Silva, P. C., 1948; Smith, A. G. and MacKenzie, G., Jr., 1948; Stevenson, R. E., 1954; Taylor, C. V., and vaughan, T. W., 1934; Thompson, W. C., 1949; Todd, D. K. and Wiegel, R. L., 1952; Topp, E. P., 1929; Trask, P. D., 1934, 1939; Trask, P. D. and Scott, T., 1954; U. S. Hydrographic Office, 1875; Vaughan, T. W., 1940; White, D., 1911; Wright, R., 1937; ZoBell, C. E., 1939, 1941, 1942b, 1942c, 1946-1947, 1947c, 1947d; ZoBell, C. E. and Feltham, C. B., 1942

Algae, Calcareous: Emery, K. O. and Tschudy, R. H., 1941; Nelson, R. N. and Schenck, H. G., 1928; Vaughen, T. W. , 1940

Alluvium: Shepard, F. P., 1948d (in submarine canyon)

Aluminum: Anonymous, $1954 \mathrm{~m}$; Galliher, E. W., 1935a, 1935c; Goldberg, E. D., 1954; Lipman, C. B., 1929; Revelle, R., 1935, 1937a, 1937b; Revelle, R, and Emery, K. 0., 1951; Stanton, T. E., Jr., 1938; Thompson, T. G. and Robinson, R. J., 1932; ZoBell, C. E., 1939, 1942 b

Angle of Repose: McKee, E. D., 1953

Ammonia, Ammonium (See also: Gases, Nitrogen): Ahlstrom, E. H., 1950; Brongersma-Sanders, M., 1948; Dietz, R. S., Emery, K. O. and Shepard, F. P., 
1942; Dill, R. F., 1952; Emery, K. O., 1946b; Emery, K. O. and Rittenberg, S. C., 1952; Fox, D. L., 1950; Galliher, E. W., 1933; Gee, H., 1932; McEwen, G. F., 1934a; Michael, E. L., 1921; Moberg, E. G., 1925, 1928c, 1930c; Moberg, E. G. and Fleming, R. H., 1934; Scripps Institution of Oceanography, 1953e; Stanton, T. E., Jr., 1938; Sverdrup, H. U., 1940e; Thompson, T. G. and Robinson, R. J., 1932; Trask, P. D., 1934, 1939; Vaughan, T. W., 1936; ZoBell, C. E., 1938, 1939, 1941, 1942a, 1942b, 1946-1947, 1947c, 1947d, 1950; ZoBell, C. E. and Feltham, C. B., 1942; ZoBell, C. E. and Rittenberg, S. C., 1938

Anaerobic - see Bacteria, Reducing or Anaerobic Environment Andesite (See also: Igneous Rock, Rock): Boos, M. F., 1940; Butcher, W. S., 1951a; Chesterman, C. W., 1952; Clements, T. and Dana, S. W., 1944; Emery, K. O., 1948; Emery, K. O. and Shepard, F. P., 1941, 1945; Holzman, J. E., 1950; Shepard, F. P., 194la; Shepard, F. P. and Wrath, W. F., 1937; Shumway, G. A., 1953; Uchupi, E. 1954

Andesite Line: Carsola, A. J. and Dietz, R. S., 1952

Animal Trails, Tracks, Holes etc. (deep sea). (See also: Minor Surface Features of Sediments): Emery, K. O., $1952 b, 1953 b$

Anticline: Butcher, W. S., 195la; Dietz, R. S., 19470; Emery, K. O., 1948; Fox, L. S., 1930; Moore, D. G., 1951; Morgan, F. A., 1930; Nicholls, C. P. L., 1936c; Shepard, F. P. and Emery, K. O., 1941; Skeats, E. M., 1923; Stormant, D. H., 1954b

Antimony: Thompson, T. G. and Fobinson, R. J., 1932; Vaughan, T. W., 1933

Aplte (See also: Igneous rock, Rock): Butcher, W. S., 1951 a

Aragonite (See also: Mineralogy): Bandy, 0. L., 1954; Lowenstam, H. A., 1954

Argon: Sisler, F. D. and ZoBell, C. E., 1951b

Arsenic: Gorgy, S., Rakestraw, N. W. and Fox, D. I., 1948; McEwen, G. F. and Staff, 1948; Moberg, E. G. and Harding, M. W., 1933; Revelle, R. and Emery, K. O., 1951; Thompson, T. G. and Robinson, R. J., 1932; Trask, P. D., 1939; Vaughan, T. W., 1933

Artificial Beach Nourishment: Anonymous, 1938a, 1940d, 1941b; Beach Erosion Board, 1942a, 1948a, 1948h, 1948i, $1948 \mathrm{j}, 1949 \mathrm{a}, 1950 \mathrm{~b}, 1952 \mathrm{f}, 1953 \mathrm{c}, 1954 \mathrm{a}, 1954 \mathrm{c}$; Butler, M. M., 1936; Congressional Documents, 1938a, $1940 \mathrm{a}, 1940 \mathrm{e}, 1940 \mathrm{f}, 1941,1942 \mathrm{~b}, 1943,1949 \mathrm{f}$, 1953a, 1953b; Cram, C. M., 1931; Eaton, R. O., 1951; Friedman, S. L., 1949; Gee, H. C., 1938; Hall, J. V., Jr., 1952; Hall, w. C., 1942; Handin, J. W., 1949, 1951; Hannum, W. T., 1947; Horton, D. F., 1948; Hunter, R. C., 1946; Johnson, A. G., 1935, 1940c, 1951; Kenyon, E. C., Jr., 1951; Leeds, C. T., 1936; Leypoldt, H., 1941b; Livingston, A., Jr., 1937; Los Angeles County Regional Planning Commission, 1940; Mason, M. A., 1948; McAfee, C. M., Jr., 1939; Merriam, P. D., 1949; Nicholson, G. F., Grant, U. S., Shepard, F. P. and Crowell, J. C., 1946; O'Brien, M. P., 1936a, 1939; Orange County Planning Commission, 1941; Page, G. B., 1950; Shuler, W. R., 1951, 1952

Ash (See also: Pumice, Rock, Volcanic rock): Cohee, G. V., 1938

\section{Asphaltum - see Petroleum}

Attached Organisms - see Fouling

Auriferous Beach Sands (See also: Beach Placers, Black Sands, Gold, mineralogy): Anonymous, 1884, 1894a, 1894b, 1906b; Averill, C. V., 194l; Averill, C. V. and others, 1946; Blake, W. P., 1854; California Miners Association, 1899; Chase, A. W., 1875; Day, D. T., $1899,1900,1907 a, 1907 b ;$ Day, D. T. and Richards, R. H., 1906; DeGroot, H., 1890; Diller, J. S., 1896, 1901, 1903; Edman, J. A., 1894, 1906; Goodyear, W. A., 1873; Griggs, A. B., 1945; Haase, L. G., 1926; Hornor, R. R., 1918; Irelan, w., Jr., 1890; Irvine, C. D., 1908; Kemp, J. F., 1902; Lakes, A., 1899, 1903a, 1903b; Lang, H., 1916; Logan, C. A., 1919; Pardee, J. T., 1934; Paul, A. B., 1894; Raymond, R. W., 1880; Stephenson, E. L., 1945; Twenhofel, W. H., 1943; Washburne, C. W., 1904; Yale, C. G., 1913

Authigenic Minerals (See also: Diagenesis, various authigenic minerals): Beach Erosion Board, 1953c; Butcher, W. S., 195la; Carsola, A. J. and Dietz, R. S., 1952; Cohee, G. V., 1938; Dietz, R. S. and Emery, K. O., 1938a, 1938b; Dill, R. F., 1952; Emery,
K. O., $1947 \mathrm{~b}$ and 1947c (authigenic sands), 1948, 1952a; Emery, K. O., Butcher, W. S., Gould, H. R. and Shepard, F. P., 1952; Emery, K. O. and Rittenberg, S. C., 1952; Galliher, E. W., 1932b, 1933, 1935a, 1935b, 1935c, 1937; Goldberg, E. D. , 1954; Grim, R. E., Dietz, R. S., and Bradley, W. F., 1949; Holzman, J. E., 1950; Inman, D. L., 1950; Krumbein, W. C., 1942; Norris, R. M., 1951; Revelle, R. and Emery, K. O., 1951; Shepard, F. P. and Emery, K. O., 1945; Shumway, G. A., 1953; Strahov, N. M., 1953; Uchupi, E., 1954

Backswash - see Swash and Backswash; Swash Marks

Bacteria (See also: Aeration, Eh, Oxidizing or Aerobic Environment, Reducing or Anaerobic Environment, other factors influencing or influenced by bacterial action): Anonymous, 1944b; Bartholomew, J. W. and Rittenberg, S. C., 1949; California Academy of Sciences, California Division of Fish and Game, Scripps Institution of Oceanography of the University of California, and U. S. Fish and Wildlife Service, 1950, 195la, 1951b; California Academy of Sciences, California Division of Fish and Game, Scripps Institution of Oceanography of the University of California, U. S. Fish and Wildife Service, and Hopkins Marine Station, Stanford University, 1951; California Bureau of Engineering, 1952; California Department Public Health, 1951; Coe, W. R. 1945, 1947, 1948; Coe, W. R. and Fox, D. L., 1942, 1944; Dietz, R. S., Emery, K. O. and Shepard, F. P., 1942; Dill, R. F., 1952; Emery, K. 0., 1952b; Emery, K. O., and Rittenberg, S. C., 1952; Ewing, G. C., 1950a, 1950c; Fox, D. L., 1937, 1944a, 1944b, 1950; Fox, D. L. and Anderson, L. J., 1941; Fox, D. L. and Coe, W. R., 1943; Fox, D. L., Isaacs, J. D. and Corcoran, E. F., 1952; Fox, D. L., Updegraff, D. M., and Novelli, G. D., 1944;

Galliher, E. W., 1933, 1935a, 1935c; Gee, H. 1932; Gorsline, D. S., 1954; Hewatt, W. G., 1934; Hutton, W. E. and ZoBell, C. E., 1949; Krumbein, W. C., 1942; McEwen, G. F., 1934a; Miller, R. C., Ramage, W. D., and Lazier, E. L., 1928; Moberg, E. G., 1925; Moberg, E. G. and Fleming, R. H., 1934; Moberg, E. G., Fleming, R. H., Heusner, K. and $R^{\prime}$ velle, R., 1937; Moulton, G. F., 1928; Natland, M. L., Revelle, R. and Rittenberg, S. C., 1941; Novell1, G. D., 1943; Rakestraw, H. W., Rudd, P. D. and Dole, M., 1951; Revelle, R., 1941, 1950; Revelle, R. and Shepard, F. P., 1939b; Rittenverg, S. C., 1940, 1941; San Diego Regional Water Pollution Control Board, 1952; Sisler, F. D., 1949; Sisler, F. D. and ZoBell, C. E., 1950, 1951a, 1951b; Smith, P. V., 1954; Stevenson, R. E., 1954; Stevenson, R. E., 1954; Sverdrup, H. U., 1937, 1938c, 1938d, 1940e, 1940g; Thayer, L. A., 1937; Thompson, T. G. and Robinson, R. J., 1932; Topp, E. P., 1929; Trask, P. D., 1934, 1936, 1939; Updegraff, D. M., 1948; Vaughan, T. W., 1930b, 1932b, 1933, 1935a, 1935b, 1936; White, D., 1911; Wright, R., 1937; ZoBell, C. E., 1935, 1936, 1937, 1938 , $1939,1941,1942 \mathrm{a}, 1942 \mathrm{~b}, 1942 \mathrm{c}, 1943,1944,1946 \mathrm{a}$, $1946 \mathrm{~b}, 1946-1947,1947 \mathrm{a}, 1947 \mathrm{~b}, 1947 \mathrm{c}, 1947 \mathrm{~d}, 1949$, 1950; ZoBell, C. E. and Anderson, D. Q., 1936; ZoBell, C. E. and Feltham, C. B., 1934a, 1934b, 1942; ZoBell, C. E., Grant, C. W. and Haas, H. F., 1943; ZoBell, C. E. and Mathews, H. W., 1936; ZoBell, C. E. and Rittenberg, S. C., 1938 Aerobes: California Academy of Sciences, California Division of Fish and Game, Scripps Institution of Oceanography, U. S. Fish and Wildlife Service, 1950; Emery, K. O. and Rittenberg, S. C., 1952; Revelle, R., 1950; Rittenberg, S. C., 1940; Rosenfeld, W. D., 1948; Trask, P. D., 1934; Updegraff, D. M., 1948; ZoBel1, C. E., 1935, 1936, 1938, 1939, 1942a, $1942 \mathrm{~b}, 1944,1946 \mathrm{~b}, 1946-1947$, 1947b, 1947c, $1947 \mathrm{~d}$, 1950; ZoBell, C. E. and Anderson, D. Q., 1936, 1942; ZoBell, C. E., Grant, C. W. and Haas, H. F., 1943; ZoBell, C. F. and Rittenberg, S. C., 1938; Anaerobes: Dill, R. F., 1952; Emery, K. O. and Rittenberg, S. C., 1952; Galliher, E. W., 1933, 1935c; Gee, H., 1932; Hoots, H. W., 1943; Natland, M. L., Revelle, R. and Rittenberg, S. C., 1941; Revelle, R., 1950; Rittenberg, S. C., 1940, 1941; Rosenfeld, W. D., 1948; Sisler, F. D., 1949; Sisler, F. D. and ZoBell, C. E., 1950, 1951a, 1951b; 
Smitn, P. V., Jr., 1954; Sverdrup, H. U., 1940e, 1940g; Thayer, L. A., 1937; Trask, P. D., 1934, 1936; Updegraff, D. M., 1948; ZoBell, C. E., 1935, 1936 , 1938, 1939, 1942a, 1942b, 1943, 1944, 1946b, $1946-1947,1947 \mathrm{~b}, 1947 \mathrm{c}, 1947 \mathrm{~d}, 1949$, 1950; ZоBe1l, C. E. and Anderson, D. Q., 1936; ZoBell, C. E. and Feltham, C. B., 1942; ZoBell, C. E., Grant, C. W. and Hass, H. F., 1943; ZoBell, C. E. and Rittenberg, S. C., 1938

Bank (See also: Seamounts, Submarine Mountains, Submarine Topography): A^den, J., 1853, 1854b; Allen, W. E., 1927d; Bache, A. D., 1856b, 1864a; Bandy, O. L., 1953a; Bucher, W. H., 1940; Buffington, E. C. 1951; Butcher, W. S., 1951a, 1951b; Carsola, A. J., and Dietz, R. S., 1952; Clements, T. and Dana, S. W. 1944; Clements, T. and Emery, K. O., 1947; Cockerell, T. D. A., 1938b; Colbert, L. O., 1939; Corey, W. H., 1951; Daly, R. A., 1934; Dana, S. W., 1942; Davidson, G., 1859, 1864, 1897; Dietz, R., 1941, $1947 a, 1952 a, 1952 b, 1954 ;$ Dietz, R. S. and Emery, K. O., 1938a, 1938b; Dietz, R. S., Emery, K. O. and Shepard, F. P., 1942; Dietz, R. S. and LaFond, E. C., 1950; Dill, R. F., 1952; Dunham, J. W., 1951; Dunkle, M. B., 1944, 1950; Eardley, A. J., 1954; Emery, K. O., 1941a, 1947a, 1947b, 1947c, $1948,1950 \mathrm{~b}, 1952 \mathrm{a}, 1952 \mathrm{~b}, 1953 \mathrm{~b}, 1954 \mathrm{a}, 1954 \mathrm{~b}$, 1954d; Emery, K. O., Butcher, W. S., Gould, H. R. and Shepard, F. P., 1952; Emery, K. O. and Dietz, R. S., 1950; Emery K. O. and Rittenberg, S. C., 1952; Emery, K. O. and Shepard, F. P., 1945; Garrison, L. E. and Taksaksi, K. L., 1950; Gorsline, D. S., 1954; Grim, R. E., Dietz, R. S. and Bradley, W. F., 1949; Handin, J. W., 1949; Hinds, N. E. A., 1952; Holway, R. S., 1905; Holzman, J. E., 1950; Isaacs, J. D. and Bascom, W. N., 1947; Isaacs, J. D., Schoor, S. and Chinn, A. J., 1947; Kuenen, Ph. H. 1947; Laws on, A. C. , 1924, 1950; Littlehales, G. W., 1890; Ludwick, J. C., Jr., 1950; Lukens, R. R., 1933; MacDonald, G. A., 1934; McEwen, G. F., 1916; Ma, T. Y. H., 1952; Menard, H. W., 1952; Miller, J. C., 1953; Munk, W. H., and Traylor, M. A., 1947; Nicholson, G. F., Grant, U. S., Shepard, F. P. and Crowell, J. C., 1946; Olsson-Seffer, P., 1910a; Pardee, J. T., 1934; Revelle, R. and Shepard, F. P., 1939a, 1939b, 1943; Sanchez, P. C., 1934e; Schupp, R. D., 1953; Shepard, F. P., 1932, 1937b, 1938d, 1938f, 1939d, 1940a, 1940b, 1941a, 1947b, 1949e, 1950d, 1951b, 1951e, 1952a; shepard, F. P. and Emery, K. 0., 1941, 1945; Shuck, 0. T., 1869; Shumway, G. A., 1953; Smith, W. S. T., 1900; Spencer, J. W., 1890; Sverdrup, H. U. and staff, 1943b; Tanner, Z. L., 1892a, 1892b; Trask, P. D., 1931b, 1939; Uchup1, E., 1954; Wooster, W. S., 1952

Barite (See also: Authigenic Minerals, Barium, Diagenesis, Nodules): Emery, K. 0., 1948; Emery, K. O. and Shepard, F. P., 1945; Revelle, R. and Emery, K. 0., 1951

Barium (See also: Barlte): Goldberg, E. D., 1954; Evans, R. D., Kip, A. F. and Moberg, E. G., 1938; Revelle, R., 1935; Revelle, R. and Emery, K. O., 1951; Thompson, T. G. and Robinson, R. J., 1932; Vaughan, T. W., 1933

Barrier Beach, Barrier Island (See also: Bars, Lagoons, Reefs): Anonymous, 1940d; Atwill, E. R., 1942 (barrfer sand reefs); Beach Erosion Board, 1948j; Black, G. L., 1954; Cook, E. H., 1908; Falrbanks, H.W., 1904; Grant, U. S., 1940; Hall, J. V., Jr., 1952; Hall, W. C., 1942; Johnson, A. G., 1935; Livingston, A., Jr., 1939; Pease, W. H., 1868; Shaler, N. S., 1895; Shepard, F. P., 1950e, 1952b; Smith, W. D., 1933b; Smith, W. S. T., 1897; Stevenson, R. E., 1954; Trask, P. D., 1939

Bars (See also: Barrier Beach): Anonymous, 1938a, 1940; Alden, J., 1853, 1854a, 1856; Bache, A. D., 1856a, 1864a; 1950e; Bascom, W. N., Wlegel, R. I. and Chinn, A. J., 1948; Beach Erosion Board, 1948b, 1951, 1952a; Blinn, F. S., 1928; Bullard, F. M. and Mills, R. A., 1951; Buwalda, J., 1936; Calffornia, University of', i952a; Coe, W. R., 1947; Congressional Documents, 194Ca, 1942c, 1949d; Crandall, H., 1915; Davidson, G., 1864; Dietz, R. S., 1947b; Gillette, C. E., 1905; Goldberg, J., 1940; Grant, U. S., 1948; Guillver, F. P., 1896; Handin, J. W., 1949, 1951; Hanna, M. A.,
1926; Hinds, N. E. A., 1952; Hoover, J. W., 1932a; Howard, A. D., 1951; Inman, D. L., 1950; Isaacs, J. D., 1945d, 1947a; Isaacs, J. D. and Bascom, W. N., 1947; Ives, R. L., 1951; Johnson, J. W., 1947a, 1948a; Johnson, W. M., 1855; Krumbein, W. C. and Ohs1ek, L. E., 1950; Lawson, A. C., 1893a; Leeds, C. T., 1936; Leeds, C. T., Vanon1, V. A. and Knapp, R. T., 1934; Leypoldt, H., 194lb; LIvingston, A., Jr., 1939; Lucke, J. B., 1938; McAdam, D., 1947a; MacDonald, G. A., 1934; MacGinitie, G. E., 1935; McGowan, W. C., 1916; Merriam, P. D., 1949; Moffitt, J. and orr, R. T., 1938; Nicholson, G. F., Grant, U. S., Shepard, F. P. and Crowell, J. C., 1946; Norris, R. M., 1952; Page, G. B., 1950; Palmberg, H. G., 1941; Pardee, J. T., 1934; Pratt, W. E., 1947; Putnam, J. A., Munk, W. H. and Traylor, M. A., 1949; Sanford, J. J., 1908; Scripps Inst1tution of Oceanography, 1944c, 1945c; Scheffauer, F. C., 1927; Shepard, F. P., 1932, 1948b, 1950b, $1950 \mathrm{c}, 1950 \mathrm{~g}, 1951 \mathrm{~b}, 1952 \mathrm{~b}$; Shepard, F. P. and Emery, K. O., 1941; Shepard, F. P., Emery, K. O. and LaFond, E. C., 1941; Shepard, F. P. and Inman, D. L., 1951b; shuler, W. R., 1952; Sinnott, A., 1941; Smith, W. D., 1933b, 1933c; Smith, W. S. T., 1900; Spencer, J. W., 1890 ; Storie, R. E. and Carpenter, E. J., 1929, 1930; Symons, T. W., 1893; Thompson, W. O., 1937; Todd, D. K. and Wiegel, R. L., 1952; Trask, P. D., 1952b; Wanless, H. R., 1950; Watts, G. M. and others, 1953; Weaver, C. E., 1949; Whittemore, G. F., 1917, 1928; Wiegel, R. L., 1947b; Wiegel, R. L., Patrick, D. A. and Kfmberley, H. L., 1953; Williams, E. A. and Isaacs, J. D., 1952; Yale, C. G., 1879

Gravel Bars: Johnson, D. W., 1910; Whittemore, G. F. . .1928

Harbor, Bay, Estuary, Lagoon, Swamp, etc., Bars within: Alden, J. 1852; Arnold, J. L., 1928; Bache, A. D. 1852 , 1856a, 1862, 1864b; Bascom, W. N., 1950b; Beach Erosion Board, 1952b; Bruff, S. C. 1946; Congressional Documents, 1880a, 1908e, 1941; Davidson, G., 1873c, 1884; Diller, J. S., 1903; Eaton, R. O., 1951; Emery, K. O., 1950d; Fenton, M. A. and Fenton, C. L., 1934; Gibsen, W. M., 1951; Harts, W. W., 1901, 1911; Inman, D. L., 1949; Kenyon, E. C., Jr., 1951; Lawson, J. S., 1862; Louderback, G. D., 1940; McKee, E. D., 1953; McOuat, H. W., 1951; Moore, D. G., 1951; Morrison, R. L., 1930; O'Brien, M. P., 1931; Sanchez, P. C., 1934b; Scheffauer, F. C. , 1927; Scripps Instutution of Oceanography, 1953c; Sears, C. B., 1876; Soper, E. K., 1938; Stevenson, R. E., 1954; Tower, M. L., 1910; Trask, P. D., 1939

Longshore and Offshore Bars: Atwill, E. R., 1942; California, University of, 1952a; Congressional Documents, 1953b; Crook, R. C., Elvitsky, A. W., et al, 1953; Davis, W. M., 1925; Eaton, R. O., 1951; Gilbert, G. K., 1917; Gorsline, D. S., 1954; Grant, U. S., 1940; Gulliver, F. P., 1896; Hall, W. C., 1942a; Inman, D. L., 1953b; Johnson, J. W., 1952; Kniffen, F. B., 1932; Marlette, J. W., 1954; Shepard, F. P., 1942a, 1950e, 1950f, 1952b; Thompson, W. O., 1937 Low and Ball: Shepard, F. P., 1942a, 1950f, 1952b;

Basalt (see also: $\overline{\text { Rock, }}$, Volcanic Rock)': Butcher, W. S., 195la; Carsola, A. J., Dietz, R. S., Russell, R. D., 1949; Carsola, A. J. and Dietz, R. S., 1952; Chesterman, C. W., 1952; Clements, T. and Dana, S. W., 1944; Cohee, G. V., 1938; Emery, K. O., and Shepard, F. P., 1941, 1945; Emery, K. O., 1948; Gorsline, D. S., 1954; Hanna, G. D., 1952; Hinds, N. E. A., 1952; Holzman, J. E. 1950; Landes, K. K., 1952a; Shepard, F. P. and Emery, K. O., 1941, 1945; Shumway, G. A., 1953; Uchupi, E., 1954

Base Exchange (See also: Clay): Galliher, E. W., 1935a; Kelley, W. P. and Llebig, G. F., Jr., 1934; Krumbein, W. C., 1942; Revelle, R., 1935, 1941; ZoBell, C. E., $1942 b$

Base Level - see Equilibrium

Basement - see Bedrock

Basin (See also: Geosyncline, Syncline, Trench, Trough): Agass12, A., 1905; Beal, C. H., 1945; Blacke, W. P., 1856; Bucher, W. H., 1939, 1940; Buffington, E. C., 1951; Butcher, W. S., 1951a; Buwalda, J. P., 1948; Clark, B. L., 1931; Clements, T. and Emery, K. O., 1947; Cohee, G. V., 1938; 
Congressional Documents, 1953b; Crouch, R. W., 1951; Crowell, J. C., 1952; Cupp, E. E. and Allen W. E., 1938; Daly, R. A., 1934; Dapples, E. C., 1942; Davis, W. M., 1933; Dletz, R. S., 1938, 1952a, 1952b; Dietz, R. S., Emery, K. O. and Shepard, F. P., 1942; Dietz, R. S., Menard, H. W., and Hamilton, E. L., 1952; Dunkle, M. B., 1944; Dyk, K., and Swainson, O. W., 1953; Eardley, A. J. 1954; Emery, K. 0., 1947a, 1947c, 1950b, 1950e, $1951,1952 a, 1952 b, 1953 a, 1953 b, 1954 b, 1954 d ;$ Emery, K. O., Butcher, W. S., Gould, H. R. and Shepard, F. P., 1952; Emery, K. O. and Natland, M. L., 1952; Emery, K. O. and Rittenberg, S. C., 1951, 1952; Emery, K. 0. and Shepard, F. P., 1941, 1945; Fleming, R. H., and Revelle, R., 1939; Galliher, E. W., 1933; Garrison, L. E. and Takasak1, K. L., 1950; Grim, R. E., Dietz, R. S. and Bradley, W. F., 1949; Handin, J. W., 1949; Hinds, N. E. A., 1952; Holway, R. S., 1905; Holzman, J. E., 1950; Hoots, H. W., 1943; Inman, D. I., 1949, 1950; Koczy, F. F., 1954; Krynine, P. D., 1937; Kuenen, Ph. H., 1946, 1947; Landes, K. K., 1952b; Lawson, A. C., 1924, 1950; Littlehales, G. W., $1932 b$ (ocean basin); Ludwick, J. C., Jr., 1950; Ma, T. Y. H., 1952; Marlette, J. W., 1954; Macelwane, J. B., 1934 (ocean basin); Moberg, E. G., Fleming, R. H., Heusner, K., and Revelle, R., 1937; Moore, D. G., 1951; Natland, M. L., Revelle, R. and Rittenberg, S. C., 1941; Norris, R. M., 1951; Pratt, W. E., 1947; Raitt, R. W., 1949, 1954 Revelle, R., 1935 (ocean basin); 1938, 1939a, 1939b, 1950; Revelle, R. and Emery, K. O., 1951; Revelle, R. and Shepard, F. P., 1939a, 1939b, 1943; Schupp, R. D., 1953; Shaler, N. S., 1895; Shepard, F. P., 1932 , 1934c, 1935a, 1937d, 1937f, 1938d, 1938e, $1938 \mathrm{f}, 1939 d, 1940 \mathrm{a}, 1940 \mathrm{c}, 1941 \mathrm{a}, 1942 \mathrm{~b}, 194 \mathrm{7b}$, 1948c, 1949d, 1950a, 1950d, 1950e, 1950e, 1951b, 1951d, 1951e, 1952a; Shepard, F. P. and Emery, K. 0., 1941; Shepard, F. P., Emery, K. O. and LaFond, E. C., 1941; Shepard, F. P. and MacDonald, G. A., 1938; Shepard, F. P., Revelle, R. and Dietz, R. S., 1939; Shepard, F. P., Revelle, R., Dletz, R. S. and Emery K. O., 1938; Shumway, G. A., 1953; Smith, P. A., 1940; Smith, P. V., Jr., 1954; Smith, W. S. T., 1900; Stevenson, R. E., 1954; Sverdrup, H. U., 1939a, 1939b, 1940d, 1940f; Sverdrup, H. U., and Staff, 1941, 1943b; Thom, W. T., Jr., 1938; Trask, P. D., 1927a, 1927b, 1928, 1930, 1931a, 1931b, 1932a, 1937b, 1939; Uchup1, E., 1954; Vaughan, T. W., 1940; Weber, B. V., 1946; Weeks, L. G., 1952; Woodring, W. P., 1938a; Wooster, W. S., 1951; Wright, R., 1937; ZoBell, C. E., 1944; ZoBell, C. E., and Anderson, D. Q., 1936

Basin and Range Topography (See also: Continental Borderland, Submarine Topography): Landes, K. K., 1952a; Shepard, F. P., 1939e, 1940c

Bathythermographs (В.T.) (See also: Instrumentation, Temperature, Thermocline, Water Mass, Water Type): Burt, W. V. and Bush, V., 1949; California Academy of Sciences, California Division of Fish and Game, Scripps Institution of Oceanography of the University of California, and U. S. Fish and wildlife Service, 1950, 1951b; Carsola, A. J., 1947; Dawson, E. Y., 1950; Emery, K. O., 1948, 1953a; Ewing, G. C., 1950a; Le1pper, D. F., 1950; Robinson, M. K., 1951; Rudn1ck, P. and Cochrane, J. D., 1951; Saur, J. T. F., Jr., 1950

(See also: Embayment, Estuary, Harbor, Lagoon): Anonymous, 1950c; Alden, J., 1852, 1856; Alexander, A. H., 1936; Arnold, D., 1896, Arnold, D. and Arnold, R., 1902; Arnold, R., 1900; Atwill, E. R., 1942; Bache, A. D. , 1852, 1854a, 1854b, 1859, 1864b; Banks, H. O., Gleason, G. B. and Richter, R. C., 1950; Barrows, A. L., 1917, 1919; Bascom, W. N., 1950b; Bathgate, V. M., 1913; Beach Erosion Board, 1948b, 1952, 1954c; Blgelow, H. B. and Leslie, M., 1930; Blinn, F. S., 1928; Bruff, S. C., 1940, 1946; Californta Bureau of Santtary Engineering, 1952; California Department of Fish and Game, 1951; Californ1a Department of Public Works, 1932a, 1950; Chace, B. W., 1953; Congressional Documents, 1880a, 1880b, 1909, 1938c, 1943, 1949b, 1949d, 1949-1950a; Coxe, L. C., 1949; Crooks, R. C., Elvitsky, A. W. et al, 1953; Davis, W. M., 1932; Davidson, G., 1859 , 1864, 1873; Dietz, R. S., Emery, K. O. and Shepard, F. P., 1942; Disney, L. P. and Overshiner, W. H.,
1925; Eaton, R. O., 1951; Eldredge, Z. S. and Molera, E. J., 1909; Emery, K. 0., 1945a, 1946b; Folsom, R. G., 1944c; Forrest, D. R., 1951a; Fox, D. L., Updegraff, D. M. and Novelli, G. D., 1944; Galliher, E. W., 1932b, 1935a, 1935c, 1937, 1939; Gibson, W. M., 1951; Gllbert, G. K., 1917; Gorsline, D. S., 1954; Grim, R. E., Dietz, R. S. and Bradley, W. F., 1949; Grunsky, C. E., 1921; Hanna, M. A., 1926; Harding, C. R., 1929; Harts, W. W., 1901, 1911; Harvey, D. R., 1928; Hewatt, W. G., 1934; Hickson, R. E. and Rodolf, F. W., 195l; Hinds, N. E. A., 1952; Hoover-Young San Francisco Bay Bridge Commission, 1930; Howard, A. D., 1951; Isaacs, J. D., 1945e; Isaacs, J. D. and Bascom, W. N., 1947; James, E. L., 1950; Johnson, A. G., 1935, 1951; Johnson, D. W., 1910; Johnson, J. W., 1953a; Kenyon, E. C., Jr., 1951; Kerr, A. R., 1938; Knox, G. L., 1937; Lawson, A. C., 1894; Lawson, J. S., 1862; Leeds, C. T., Vanoni, V. A. and Knapp, R. T., 1934; Lombardi, L. V., 1949; Louderback, G. D., 1920, 1921, 1924, 1940, 1941, 1951; McAdam, D., 1947b; McGowan, W. C., 1916; McKinstry, C. H., 1905; MacDonald, G. A. and Shepard, F. P. and Cox, D. C., 1947; Martin, L. T., 1930, 1931, 1932, 1935, 1937; Mason, H. L., 1931; Means, T. H. , 1928, 1931; Meek, R. T., 1945; Miller, H. E. and Nusbaum, I., 1952; Moffit, J. and Orr, R. T., 1938; Moore, D. G., 1951; Morrison, R. L., 1930; Nelson, N. C., 1909, 1910; Novelli, G. D., 1943; O'Brien, M. P., 1945a; Patterson, R. L., 1950; Pierce, J. W., 1948; Putnam, J. A., Bermel, K. J. and Johnson, J. W., 1947; Rankin, E. P., 1913; Reed, R. D., 1938; Revelle, R., 1950; Revelle, R. and Shepard, F. P., 1939b; Robertson, R. R., 1942; Sanchez, P. C., 1934b, 1934e; San Diego Regional water Pollution Control Board, 1952; Schupp, R. D., 1953; Scripps Institution of Oceanography, 1953c; Shaler, N. C., 1892; Shalowitz, A. L., 1951, 1953; Shepard, F. P., 1932, 1949d, 1950c, 1950f; Shepard, F. P. and Emery, K. 0., 1941; Shepard, F. P. and Inman, D. L., 1951b; Shepard, F. P. and LaFond, E. C., 1942; Shepard, F. P. and MacDonald, G. A., 1938; Shipmesters and athers, 1879; Shuler, W. R., 1952; Silva, P. C., 1948; Sisler, F. P. and ZoBell, C. E., 1950; Skogsberg, T., 1936, 1946; Smith, A. G. and MacKenzie, G., Jr., 1948; Somers, P., 1952; Sommer, H. and Clark, F. N., 1946; Stevenson, R. E., 1954; Stump, R. S., 1945c, 1945d, 1946b; Sumner, F. B., Louderback, G. D., Schmitt, W. L. and Johnston, E. C., 1914; Sverdrup, H. U., 1939c; Trask, P. D., 1928, 1931, 1950; Trask, P. D. and Rolston, J. W., 1950a, 1950b; Troster, J. G., 1949; Trowbridge, W. P., 1856b; U. S. Cosst and Geodet1c Survey, 1947; Van Dorn, W. G., 1953; Whittemore, G. F., 1916, 1917, 1926; W1egel, R. L., 1947b; Williams, E. A. and Isaacs, J. D., 1952; Williamson, R. S. and Heuer, W. H., 1871; ZoBell, C. E., $1941,1942 a, 1942 b, 1946-1947$; ZoBell, C. E. and Anderson, D. Q., 1936; ZoBell, C. E. and Feltham, C. B., 1942; ZoBell, C. E., Grant, C. W. and Haas, H. F., 1943

Bayhead Beach - see Pocket or Bayhead Beach

Beach and Nearshore, includes beaches and immediate offshore region: Anonymous, $1882 \mathrm{~b}, 1882 \mathrm{c}, 1884,1891$, $1894 \mathrm{a}, 1894 \mathrm{~b}, 1915,1916 \mathrm{a}, 1916 \mathrm{~b}, 1916 \mathrm{c}, 1916 \mathrm{~d}$, $1916 \mathrm{e}, 1917$, 1925b, 1933c, 1933d, 1933e, 1935, $1938 \mathrm{a}, 1938 \mathrm{~b}, 1940 \mathrm{~b}, 1940 \mathrm{c}, 1940 \mathrm{~d}, 1941 \mathrm{~b}, 1944 \mathrm{a}$, $1945,1949 a, 1949 \mathrm{c}, 1950 \mathrm{a}, 1950 \mathrm{~b}, 1950 \mathrm{c}, 1951 \mathrm{~d}$, 1952f, 1954b, 1954j, 1954m; Alrich, L. and Smith, H. G., 1948; Alexander, A. H., 1936; Allen, W. B., 1932; Allen, W. E., 1935; Anderson, F. M., 1896-1902, 1897; Anderson, G. E., 1926; Arnold, J. L., 1928; Arthur, R. S., 1950; Ashley, G. H., 1896; Atwill, E. R., 1942; Averill, C. V. and Others, 1946; Bache, A. D., 1852; Baldw1n, E. M., 1945; Barnes, A. J., 1937; Bartlett, W. A., 1852; Bascom, W. N., 1946a, 1945b, 1947a, 1947c, 1947d, 1948a, 1950a, 1950c, 1951; Bascom, W. N., W1egel, R. L., and Chinn, A. J., 1948; Beach Erosion Board, $1938,1939,1942 \mathrm{a}, 1942 \mathrm{~b}, 1942 \mathrm{c}, 1946,1947-1950$, $1948 \mathrm{a}, 1948 \mathrm{~b}, 1948 \mathrm{c}, 1948 \mathrm{~d}, 1948 \mathrm{e}, 1948 \mathrm{f}, 1948 \mathrm{~g}$, $1948 \mathrm{~h}, 1948 \mathrm{l}, 1948 \mathrm{j}, 1949 \mathrm{a}, 1950 \mathrm{a}, 1950 \mathrm{~b}, 1951$, $1952 a, 1952 b, 1953 a, 1953 b, 1953 c, 1954 a$, 1954b, 1954c; Black, G. L., 1954; Blackman, J. W. B., 1936; Blake, W. P., 1853, 1854, 1856; Blinn, F. S., 1928; Bond, A. H., 1927; Boos, M. F., 
1940; Bowers, S., 1890; Branner, J. C., 1900; Brant, I., 1925; Bremer, C. St. J., 1933; Brown, C. B., 1942; Brown, E. I., 1939; Bruff, S. C., 1940, 1946; Bullard, F. M. and Mills, R. A., 1951; Burt, W. V. and Saur, J. F. T., Jr., 1948; Butler, M. M., 1936; Buwalda, J., 1936; Byerley, P., 1942; California Legislature, 1931b; California Miners' Association, 1899; California, University of, 1945, 1949, 1951c, $1952 a, 1952 b, 1952 c, 1952 d, 1953 a, 1953 b, 1954 a$, 1954b; Carpenter, F. A., 1924; Carsola, A. J. and Dletz, R. S., 1952; Carter, G. F., 1948; Cartwrigh土, L. D., Jr., 1928; Chace, B. W., 1953; Chase, A. W., 1875; Clark, A., 1933; Clark, F. N., 1938; Clements, T. and Dana, S. W., 1944; Clements, T. and Emery, K. O., 1947; Coe, W. R., 1947, 1948, 1953; Congressional Documents, 1938a, 1938c, 1940a, 1940e, 1940f, $1941,1942 b, 1942 \mathrm{c}, 1943,1949 \mathrm{a}, 1949 \mathrm{~b}, 1949 \mathrm{c}, 1949 \mathrm{~d}$ 1949f, 1949-1950b, 1953; Cook, E. H., 1908; Corning, L. H., 1944; Cotton, C. A., 1942; Couch, E. B., 1915; Cram, C. M., 1931; Crandall, H., 1915, Crooke, R. C., Elvitsky, A. W. et al, 1953; Crowell, J. C., 1947, 1952; Darrow, W. E., 1942; Dasher, J., Fraas, F. and Gabriel, A., 1942; Davidson, G., 1864, 1873a, 1873c, 1897; Davis, W. M., 1932, 1933; Day, D. T., 1899, 1900, 1907a, 1907b; Day, D. T. and Richards, R. H., 1906; Deacon, G. E. R. 1949; Degroot, H., 1890; Dickey, L. K., 1936; Dietz, R. S., 1947D; Dietz, R. S. and Menard, H. W., 1951b; Diller, J. S., 1896, 1898, 1901, 1902, 1903, 1915, 1940; Drury, N. B., 1936; Dunham, J. W., 1951; Dunkle, M. B., 1944; Eaton, R. O., 1951; Edman, J. A., 1894, 1906; Einstein, H. A., 1951; Emery, K. O., 1944, 1945a, 1945b, 1946b, 1950d, 1954c; Emery, K. O. and Foster, J. F., 1948; Emery K. O. and Gale, J. F., 1951; Emery, K. O. and Stevenson, R. E., 1950; Emery, K. O. and Tschudy, R. H., 1941; Emmonds, S. F. and Merrill, G. P., 1894; Erickson, C. E., 1952, 1953; Evans, O. F., 1941, 1945; Fairbanks, H. W., 1904; Fewkes, J. W., 1899; Fisher, R. L. and Mills, R., 1952; Fox, D. L., 1950; Friedman, S. L., 1949; Gee, H. C., 1938; Gibbs, R. E., 1900; Gillespie, C. G., 1936; Gillette, C. E., 1905; Goldberg, J., 1940; Goldberg, W. A., 1873, 1890; Goodyear, W. A., 1873; 1890; Gorsline, D. S., 1954; Grant, U. S., 1938, 1940, 1943, 1944, 1946, 1948; Grant, U. S. and Shepard, F. P., 1937, 1938a, 1938b, 1940, 1946; Grant, U. S. and Sheppard, W. E., 1939; Granthem, K. N., 1953; Greater Los Angeles Citizens Committee, Inc., 1944; Greene, E. L., 1887; Griesbach, J. O., 1947; Griffin, D. F., 1944; Griggs, A. B., 1945; Griggs, A. B. and Wells, F. G., 1942; Gulliver, F. P., 1896; Guttenberg, B., 1936a; Handin, J. W., 1949, 1951; Handin, J. W. and Ludwick, J. C., 1950; Hanna, M. A., 1926; Hannum, W. T., 1944, 1947; Hewatt, W. G., 1934; Hjelte, G., 1936, 1938; Hoover, J. W., 1932a; Horrer, P. L. 1949; Horton, D. F. 1948; Hundhausen, R. J., 1947; Inman, D. L., 1949, 1950, 1953a, 1953b; Inman, D. L. and Quinn, W. H. 1952; Irelan, W., Jr., 1890; Irvine, C. D., 1908; Isaacs, J. D., 1945a, 1945b, 1945c, 1945d, 1945f, $1945 \mathrm{~g}, 1945 \mathrm{~h}, 19451,1945 \mathrm{~J}, 1945 \mathrm{k}, 1945 \mathrm{~m}, 1947 \mathrm{a}$; Isaacs, J. D. and Bascom, W. N., 1947, 1949; Isaacs, J. D., Schorr, S. and Chinn, A. J., 1947; Ives, R. L., 1951; Johnson, A. G., 1935, 1940a, 1940b, 1940c, 1951; Johnson, D. W., 1910; Johnson, J. W., $1947 \mathrm{a}, 1947 \mathrm{~b}, 1948 \mathrm{a}, 1948 \mathrm{~b}, 1948 \mathrm{c}, 1948 \mathrm{~d}, 1952$; Johnson, J. W., and Wiegel, R. L., 1953; Johnson, M. W., 1939b; Johnson, W. M., 1856; Jones, E. L., 1918; Jones, J. H., 1948; Keller, W. D., 1941, 1945; Kelton, E. C., 1940, 1942; Kemnitzer, L. E., 1933; Kemp, J. F., 1902; Kenyon, E. C., Jr., 1951; Kerr, A. R., 1938; Kindle, E. M., 1934; Kingman, J. J., 1936; Kniffen, F. B., 1932; Krumbein, W. C. and ohsiek, L. E., 1950; LaFond, E. C., 1938, 1939a, 1939b; Lakes, A., 1899, 1903a, 1903b; Lamport, H. B., 1937; Lang, H., 1916; Lapsley, W. W., 1937; Larsen, G. P., 1939, 1941, 1942a, 1942b, 1943, 1944a, 1944b, 1946; Lauer, E., 1948; Lawson, A. C., 1893a, 1895, 1914, 1924; Lawton, C. H., 1936; Leeds, C. T., 1915, 1916, 1936; Leeds, C. T., Vanoni, V. A., and Knapp, R. T., 1934; Leypoldt, H., 194la, 1941b, 1942; Lieber, A. C., Jr., 1940; Lillevang, O. J., and Brant, R. W., 1937; Lindsay, D. R., 1952; Livingston, A., Jr., 1939; Logan, C.
A., 1919; Lombardi, L. V., 1949; Los Angeles County Regional Planning Commission, 1940, 1946; Los Angeles Department of City Planning, 1941; Louderback, G. D., 1915a, 1915b, 1920, 1940; Lucke, J. B., 1938; McAdam, D., 1947a; McConnaughey, B. H. and Fox, D. L., 1949; MacDonald, G. A., 1934; MacDonald, G. A., Shepard, F. P. and Cox, D. C. 1947; MacGinitie, G. E., 1935, 1939; McEwen, G. F., 1935a, 1935b; McGowan, W. C., 1916; McKee, E. D., 1953; McLaughlin, R. P., 1921; Marlette, J. W., 1954; Martens, J. H. C., 1939; Mason, E. H., 1930; Mason, M. A., 1942, 1948, 1949a, 1950a, 1950b, 1951; Masters, P., 1840; Mendenhall, W. C., 1905; Merriam, P. D., 1949; Merrill, F. J. H., 1917; Messner, W. E., 1954; Meyer, R. D., 1936; Mills, B., 1932c, 1932d; Moffit, F. H., 1953b; Moffitt, J. and orr, R. T., 1938; Morey, B. F., 1944; Munk, W. H. and Traylor, M. A., 1945, 1947; Nelson, J. W., Dean, W. C., Kocker, A. E., Watson, E. B. and Carpenter, E. J., 1920; Nelsan, J. W., Zinn, C. J., Strakorn, A. T., Watson, E. B., and Dunn, J. E., 1919; Nicholls, C. P. L., 1936a, 1936c, 1939; 1941; Nicholson, G. F., Grant, U. S., Shepard, F. P., and Crowell, J. C., 1946; Norris, R. M., 1951, 1952; O'Brien, M. P., 1931, $1936 \mathrm{a}, 1936 \mathrm{~b}, 1939,1941,1945 \mathrm{~b}, 1946 \mathrm{a}, 1947 \mathrm{~b}$; O'Brien, M. P. and Johnson, J. W., 1947; OlssonSeffer, P., 1908, 1910a; Orange County Planning Commission, 1941; O'Shaughnessy, M. M., 1924; Page, G. B., 1950; Paguirigan, F., 1941; Palmberg, H. G., 1941; Palmer, R. H., 1928; Pardee, J. T., 1934; Patrick, D. A., 1953; Patton, R. S. 1941; Paul, A. B., 1894; Peel, K. P., 1951; Petracek, F. J., Fox, D. L. and Zechmeister, L., 1951; Place, J. L., 1952; Pomeroy, H. R., 1936; Porter, J. C., 1936; Poss, E. G., 1937; Postel, A. C., 1937, 1939; Price, F., 1936; Purer, E. A., 1942; Putnam, J. A. and Arthur, R. S., 1948; Putnam, J. A., Munk, W. H. and Traylor, M. A., 1949; Putnam, W. C., 1938; Pyles, E. E., 1954; Raymond, R. W., 1880; Rechnitzer, A. B., 1952; Reed, R. D., 1930b; Reiche, P., 1937; Remondino, P. C., 1892; Revelle, R. 1950; Revelle, R. and Shepard, F. P., 1939b; Richardson, R. W., 1923; Ritter, W. E., 1901; Rolland, M. C., 1952; Salsbury, M. E., 1925; Sanchez, P. C., 1934e; Sanford, J. J., 1908; Saville, T. J. and Caldwell, J. M., 1953; Schaufele, H. J., 1951; Schupp, R. D., 1953; scott, T. A., 1936; Scripps Institution of oceanography, 1944a, 1944c, 1944d, 1944g, 1945c, 1945d, 1952i, 1953c, 1953f; Sears, c. B., 1876; Shaler, N. S., 1894, 1895, 1896; Shalevetz, S. 1952; Shaw, P. A. T. and Towers, C. L., 1937; Shepard, F. P., 1935d, 1936a, 1937f, 1938a, 1938g, $1938 \mathrm{~h}, 1939 \mathrm{a}, 1940 \mathrm{c}, 1942 \mathrm{a}, 1943 \mathrm{~b}, 1947 \mathrm{~b}, 1948 \mathrm{~b}$, $1949 \mathrm{a}, 1949 \mathrm{~b}, 1949 \mathrm{~d}, 1950 \mathrm{~b}, 1950 \mathrm{c}, 1950 \mathrm{f}, 1950 \mathrm{~g}$, 1951a, 1951b, 1952a, 1952b; Shepard, F. P. and Emery, K. O., 1941; Shepard, F. P., Emery, K. 0. and LaFond, E. C., 1941; Shepard, F. P. and Grant, U. S., 1947; Shepard, F. P. and Inman, D. L., 1949 1951a, 1951b; Shepard, F. P., Inman, D. L. and F1she R. L., 1951; Shepard, F. P. and LaFond, E. C., 1940, 1942; Shepard, F. P. and MacDonald, G. A., 1938; Sh zer, W. H., 1910; Shuler, W. R., 1951, 1952; Shumwa G. A., 1953; Sinnott, A., 1941; Smith, A. G. and Ma Kenzie, G., J., 1948; Smith, J. S., 1936, 1937; Sm P. A., 1938; Smith, W. D., 1919, 1930, 1933a, 1933b, 1933c; Smith, W. S. T., 1897, 1898, 1900; Somers, P. 1952; Stapleton, C. R., 1952; Stelzenmuller, W. B., 1949; Stephenson, E. L., 1945; Stevenson, R. E., 1954; Storie, R. E. and Carpenter, E. J., 1929, 1930; Stump, R. S., 1946e; Stump, R. S. and Bascom, W. N., 1947; Sverdrup, H. U., 1936, 1939a, $1940 \mathrm{~g}$; Sverdrup, H. U. and Staff, 1941, 1942a, 1946; Symons, T. W., 1893; Thayer, L. A., 1935; Thompson, W. F. and Thompson, J. B., 1919; Thompson, W. O., 1933, 1934, 1936, 1937 (beach structures); Todd, D. K. and Wiegel, R. L., 1951 1952; Tower, M. L., 1910, 1913; Trask, P. D., 1924 1930, 1952a, 1952b, 1952c; Twenhofel, W. H., 1943, 1946, 1946a; Updegraff, D. M., 1948; Upson, J. E., 1951; U. S. Waterways Experiment Station, Vioksburg, Mississippi, 1935, 1936; Vaughan, T. W., 1931, 1940; Verrill, G. E., 1930; Vickery, F. P., 1927a; Walker, B. W., 1947; Walters, L., 1953; Wanless. 
H. R., 1950; Ward, H. A., 1952; Warner, S. E., 1946a, 1946b; Washburne, C. W., 1904; Watts, G. M. and Others, 1953; Weaver, C. E., 1949; White, D., 1911; Whitney, J. D., 1865; Whitney, P. C., 1935; Whittemore, G. F., 1916, 1917, 1926, 1928; Wiegel, R. L., 1947b; Wiegel, R. L., and Kimberley, H. L., 1950; Wiegel, R. L., Patrick, D. A. and Kimberley, H. L., 1953; Wiegel, R. L, Todd, D. K. and Kimberley, H. L., 1950; Williams, E. A. and Isaacs, J. D., 1952; Wilson, M. E., 1907; Wittich, E., 1920; Woodford, A. O., 1935; Woodson, J. B., 1941; Yale, C. G., 1879, 1913; ZoBell, C. E., 1942a; ZoBell, C. E. and Anderson, D. Q., 1936; ZoBell, C. E. and Rittenberg, S. C., 1938; Zodac, P., 1952 Beach and Nearshore Slope, Gradient (See also: Beach slope vs. Grain size): Anonymous, 1915, 1917, 1933e, $1938 \mathrm{a}, 1940 \mathrm{~d}$, 1941b; Bascom, W. N., 1946b, 1947c, 1950c; Beach Erosion Board, 1942a, 1948a, 1948b, 1948h, 1952a, 1952b, 1953c; Brown, E. I., 1939; California, University of 1952a, 1952b; Congressional Documents, 1938a, 1942b, 1949f; Crowell, J. C., 1947, 1952; Deacon, G. E. R., 1949; Dietz, R. S. and Menard, H. W., 1951b; Eaton, R. O., 1951; Emery, K. O., 1945a; Emery, K. O. and Gale, J. F., 1951; Evans, O. F., 1941; Goldberg, J., 1940; Gorsline, D. S., 1954; Grant, U. S., 1938, 1943, 1948; Hall, J. V., Jr., 1952; Handin, J. W., 1949, 1951; Handin, J. w. and Ludwick, J. C., 1949; Harts, W. W., 1901; Inman, D. L., 1949, 1950, 1953b; Isaacs, J. D., 1945d, 1945f, 1945k, 1947a; Isaacs, J. D. and Bascom, W. N., 1947; Johnson, D. W., 1910; Johnson, J. W., 1947a, 1952; Krumbein, W. C., 1947, 1950; Lawton, C. H., 1936; Livingston, A., Jr., 1939; McKee, E. D., 1953; Marlette, J. W., 1954; Mason, M. A., 1950a, 1951; Nelson, J. W., Zinn, C. J., Strahorn, A. T., Watson, E. B. and Dunn, J. E., 1919; Nicholls, C. P. L., 1939; Nicholson, G. F., Grant, U. S., Shepard, F. P. and Crowell, J. C., 1946; Norr is, R. M., 1951; O'Brien, M. P., 1936a, 1939, 1945b, 1946a; Olsson, Seffer, P., 1910a; Patrick, D. A., 1953; Putnam, J. A., Munk, W. H. and Traylor, M. A., 1949; Scripps Institution of Oceanography, 1944c, 1944d, 1945d; Schupp, R. D., 1953; Shepard, F. P., 1950c, 1950f; Shepard, F. P., Inman, D. L. and Fisher, R. L., 1951; Shuler, W. R., 1952; Sinnott, A., 1941; Smith, W. D., 1933c; Stelzenmuller, W. B., 1949; Symons, T. W., 1893; Thompson, W. F. and Thompson, J. B., 1919; Thompson, W. O., 1933, 1934, 1937; Trask, P. D., 1952a; Trask, P. D. and Scott, T., 1954;

Vaughan, T. W., 1931; Verr1ll, G. E., 1930; Watts, G. M. and Others, 1953; Wiegel, R. L., 1947b; Woodford, A. O., 1935

Beach Conglomerate - see Cobble Bedch

Beach Crest - see Berm

Beach Cusps (See also: Cobble beach, Gravel): Branner, J. C., 1900; Dietz, R. S., 19470; Evans, O. F., 1945; Handin, J. W., 1951; Isaacs, J. D., 1945b, 1945c, 1945d; Isaacs, J. D. and Bascom, W. N., 1947; Johnson, D. W., 1910, 1944; Johnson, J. W., 1952; Krumbein, W. C., 1947; McKee, E. D., 1953; MacDonald, G. A., Shepard, F. P. and Cox, D. C., 1947; Norris, R. M., 1951; Richardson, R. W., 1923; Schupp, R. D., 1953; Shaler, N. S., 1894; Shepard, F. P., 1935d, 1938g, 1950b, 1950c, 1950f, 1952b; Thompson, W. O., 1933, 1934, 1937; Wanless, H. R., 1950; Wiegel, R. L., 1947b; Wiegel, R. L., Patrick, D. A. and Kimberley, H. L., 1953

Beach Cycles (See also: Cut and/or Fill): Anonymous, 1933e, 1938a, 1940d; Bascom, W. N., 1950c (beach changes) Beach Erosion Board, 1948b, 1948h, 1948i, 1948 j, 1953c; California, University of, 1952b; Carpenter, F. A., 1924; Congressional Documents, 1938a, 1940a, 1942b, 1949b, 1949-1950b, 1953b; Davis, W. M. 1933; Dietz, R. S., 1947b; Eaton, R. O., 1951; Evans, O.F., 1941; Friedman, S. L., 1949; Grant, U. S., 1938, 1940; Grant, U. S. and Shepard, F. P., 1937; Hall, W. C., 1942; Inman, D. L., 1949, 1953a; Isaacs, J. D. and Bascom, W. N., 1947; Johnson, A. G., 1940c; Krumbein, W. C., 1947, 1950; LaFond, E. C., 1938; Lang, H., 1916; Leeds, C. T., 1916, 1936; Leeds, C. T., Vanoni, v. A. and Knapp, R. T., 1934; Leypoldt, H., 194la;
Lieber, A. C., Jr., 1940; McGowan, W. C., 1916; Mason, M. A., 1949a; Nelson, J. W., Dean, W. C., Locher, A. E., Watson, E. B. and Carpenter, E. J., 1920; N1cholson, G. F., Grant, U. S., Shepard, F. P., and Crowell, J. C., 1946; O'Brien, M. P., 1939; Orange County Planning Commission, 1941; Pardee, J. T., 1934; Revelle, R. and Shepard, F. P., 1939b; Saville, T., Jr., and Caldwell, J. M., 1953; Schupp, R. D., 1953; Scripps Institution of Oceanography, 1944d; Shepard, F. P., 1938g, 1940c, 1950b, 1950f, 1950g; Shepard, F. P., and Inman, D. L., 1949, 1951b; Shepard, F. P. and LaFond, E. C., 1940, 1942; Smith, W. D., 1933b; Somers, P., 1952; Stelzenmuller, W. B., 1949; Storie, R. E. and Carpenter, E. J., 1930; Trask, P. D., 1952b; Whitney, P. C., 1935

Beach Cycles, Seasonal: Anonymous, 1938b; Bascom, W. N., 1950c; Beach Erosion Board, 1952a, 1953b; California, University of, 1952a; Congressional Documents, 1942b, 1949f, 1953b; Crowell, J. C., 1952; Dietz, R. S., 1947b; Emery, K. O. and Foster, J. F., 1948; Goldberg, J., 1940; Grant, U. S., 1943; Grant, U. S. and Shepard, F. P., 1937, 1938a; Gulliver, F. P., 1896; Hall, J. V., Jr., 1952; Hall, W. C., 1942; Handin, J. W., 1949; Inman, D. L., 1949, 1953a, 1953b; Isaacs, J. D. and Bascom, W. N., 1947; Johnson, A. G., 1940c, 1951; Johnson, J. W., 1952; Krumbein, W. C. and Ohsiek, L. E., 1950; LaFond, E. C., 1938; Lawton, C. H., 1936; Leeds, C. T., 1936; Munk, W. H., 1949b; Nicholson, G. F., Grant, U. S., Shepard, F. P. and Crowell, J. C., 1946; O'Brien, M. P., 1936a; Page, G. B., 1950; Revelle, R. and Shepard, F. P., 1939b; Scripps Institution of Oceanography; 1952i, 1953c; Shepard, F. P., 1941a, 1947b, 1950c, 1950f, 1950g, 1951a; Shepard, F. P. and Inman, D. L., 195Ib; Shepard, F. P. and LaFond, E. C., 1940; Smith, W. D., 1933b; Somers, P., 1952; Todd, D. K. and Wiegel, R. L., 1952; Tower, M. L., 1910; Wiegel, R. L., 19470

Beach Drift - see Littoral Drift

Beach Equilibrilm - see Equilibrium

Beach Erosion, Retrograding, Degrading: Anonymous, 1916a, $1916 \mathrm{~d}, 1933 \mathrm{e}, 1935,1938 \mathrm{a}, 1940 \mathrm{~b}, 1940 \mathrm{c}, 1941 \mathrm{~b}$; Arthur, R. S., 1950; Bascom, W. N., 1946a, 1946b, 1950c; Beach Erosion Board, 1938, 1939, 1942a, 1942b, $1942 \mathrm{c}, 1946,1947-1950,1948 \mathrm{~b}, 1948 \mathrm{c}, 1948 \mathrm{~d}, 1948 \mathrm{~h}$, $1948 i, 1948 j, 1949 a, 1950 a, 1950 b, 1952 a, 1953 c$, 1954a; Blackman, J. W. B., 1936; Blinn, F. S., 1928; Brown, E. I., 1939; Butler, M. M., 1936; California Legislature, 1931b; California, University of, 1952a; Carsola, A. J. and Dietz, R. S., 1952; Chase, A. W., 1875; Congressional Documents, $1938 \mathrm{a}, 1940 \mathrm{a}, 1940 \mathrm{e}, 1940 \mathrm{f}, 1942 \mathrm{~b}, 1942 \mathrm{c}, 1943$, $1949 \mathrm{~b}, 1949 \mathrm{c}, 1949 \mathrm{~d}, 1949 \mathrm{f}, 1949-1950 \mathrm{~b}, 1953 \mathrm{~b} ;$ Cram, C. M., 1931; Dietz, R. S., 1947b; Eaton, R. 0., 1951; Emery, K. O., 1945a; Emery, K. O. and Foster, J. F., 1948; Frledman, S. L., 1949; Gee, H. C., 1938; Gibbs, R. E., 1900; Gillette, C. E., 1905; Grant, U. S., 1938, 1946, 1948; Griffin, D. F., 1944; Gulliver, F. P., 1896; Hall, J. V., Jr., 1952; Hall, W. C., 1938, 1942; Handin, J. W., 1949, 1951; Handin, J. W. and Ludwick, J. C., 1949; Hannum, G. W. T., 1944, 1947; Hjelte, G., 1936; Horrer, P. L., 1949; Horton, D. F., 1948; Hunter, R. C., 1946; Inman, D. L., 1949, 1953a; Isaacs, J. D., 1947a; Johnson, A. G., 1935, 1940a, 1940b, 1940c, 1951; Johnson, D. W., 1910; Johnson, J. W., 1947b, 1948b, 1948d; Kelton, E. C., Jr., 1942, 1951; Kerr, A. R., 1938; Krumbein, W. C. and Ohsiek, L. E., 1950; LaFond, E. C., 1936b; Lapsley, W. W., 1937; Larsen, G. P., 1941, 1942a, 1942b, 1943, 1944b, 1946; Lawton, C. H., 1936; Leeds, C. T., 1916, 1936; Leeds, C. T., Vanoni, V. A. and Knapp, R. T., 1934; Leypoldt, H., 1941b; Lillevang, O. J. and Brant, R. W., 1937; Livingston, S., Jr., 1939; Los Angeles County Regional Planning Comission, 1940, 1946; McAfee, C. M., Jr., 1939; McEwen, G. F., 1935a, 1935b; McKee, E. D., 1953; MacDonald, G. A., Shepard, F. P. and Cox, D. C., 1947; Marlette, J. W., 1954; Mason, M. A., 1942, 1949a, 1950a, 1950b; Punk, W. H. and Traylor, M. A., 1947; Nicholls, C. P. L., 1936a; Nicholson, G. F., Grant, U. S., Shepard, F. P. and Crowell, J. C., 1946; Norris, R. M., 1951; O'Brien, M. P., $1936 \mathrm{a}, 1936 \mathrm{~b}, 1941$, 19470; O'Brien, M. P. and 
Johnson, J. W., 1947; Olsson-Seffer, P., 1910a; Orange County Planning Commission, 1941; O'Shaughnessy, M. M., 1924; Palmberg, H. G., 1941; Pardee, J. T., 1934; Patrick, D. A., 1953; Place, J. L., 1952; Postel, A. C., 1937, 1939; Putnam, J. A. and Arthur, R. S., 1948; Putnam, J. A., Munk, W. H. and Traylor, M. A., 1949; Putnam, W. C., 1938; Schaufele, H. J., 1951; Schupp, R. D., 1953; Shaler, N. S., 1896; Shepard, F. P., 1935d, 1948b, 1950f, 195la; Shepard, F. P., Emery, K. O. and LaFond, E. C., 1941; Shuier, W. R., 1951, 1952; Smith, J. S., 1936; Smith, W. D., 1933a; Somers, P., 1952; Stevenson, R. E., 1954; Sverdrup, H. U., 1940g; Sverdrup, H. U. and Staff, 1942a; Thompson, W. F. and Thompson, J. B., 1919; Thompson, W. O., 1937; Todd, D. K. and Wiegel, R. L., 1952; Trask, P. D., 1952b; U. S. Waterways Experiment Station, Vicksburg, Mississippi, 1935, 1936; Vaughan, T. W., 1940; Whittemore, G. F., 1926

Beach Gradient - see Beach and Nearshore Slope, Gradient Beach, Origin of: Johnson, D. W., 19?0; Norris, R. M., 2951 Beach Placers (See also: Auriferous Beach Sands, Black Sands, Heavy Minerals, Magnetie Minerals, Mineralogy, various minerals making up beach placers): Anonymous, 1906b, 1949c, 1950a, 1950b; Averill, C. V., 1941; Blake, W. P., 1854; Boos, M. F., 1940; California Miners' Association, 1899; Day, D. T., 1899, 1900, 1907a, 1907b; Day, D. T. and Richards, R. H., 1906; DeGroot, H. 1890; Griggs, A. B., 1945; Diller, J. S., 1901, 1903; Edman, J. A., 1894; Hornor, R. R., 1918; Irelan, W., Jr., 1890; Irvine, C. D., 1908; Kemps, J. F., 1902; Lakes, A., 1903b; Logan, C. A., 1919; Pardee, J. T., 1934; Paul, A. B., 1894; Raymond, R. W., 1880; Yale, C. G., 1913

Beach Profile, including Nearshore Profile: Anonymous, 1933e, $1938 \mathrm{a}, 1940 \mathrm{~d}$; Bascom, W. N., 1946b, 1947a, $1947 \mathrm{c}$, 1947d, 1950a, 1950c; Bascom, W. N., Wiegel, R. L., and Chinn, A. J., 1948; Beach Erosion Board, $1948 \mathrm{a}, 1948 \mathrm{~h}, 1948 \mathrm{i}, 1948 \mathrm{j}, 1952 \mathrm{a}, 1953 \mathrm{c}$; Brown, E. I., 1939; Burt, W. V. and Saur, J. F. T., Jr., 1948; Butler, M. M., 1936; California, University of, 1945, 1952a, 1954b; Congressional Documents, 1938a; 1940a, 1942b, 1949f, 1953b; Emery, K. 0. and Foster, J. F., 1948; Grant, U. S., 1943 , 1948; Handin, J. W., 1949; Horton, D. F., 1948; Inman, D. L., 1949, 1953b; Isaacs, J. D., 1945a, $1945 \mathrm{~b}, 1945 \mathrm{~h}, 1945 \mathrm{i}, 1945 \mathrm{j}, 1945 \mathrm{k}, 1945 \mathrm{~m}, 1947 \mathrm{a}$; Isaacs, J. D. and Bascom, W. N., 1947, 1949; Johnson, A. G., 1935; Johnson, J. W., 1947a, 1947b, I948a, 1952; Krumbein, w. C., 1947; LaFond, E. C., 1938; Lauer, E., 1948; Leeđs, C. T., Vanoni, V. A. and Knapp, R. T., 1934; Livingston, A., Jr., 1939; McAdam, D., 1947a; Marlette, J. W., 1954; Mason, M. A., 1948; Moffitt, F. H., 1953b; Morey, B. F., 1944; Nicholson, G. F., Grant, U. S., Shepard, F. P. and CroweIl, J. C., 1946; O'Brien, M. P., 1936a, 1945b, 1946a; Page, G. B., 1950; Pardee, J. T., 1934; Patrick, D. A., 1953; Putnam, J. A., Munk, W. H. and Traylor, M. A., 1949; Saville, T., Jr., and Caldwell, J. M., 1953; Scripps Institution of Oceanography, 1944a, 1944c, 1944d, 1944g; Shepard, F. P., 1942a, I950f, 1950g; Shepard, F. P. and Inmen, D. L., I951b; Shepard, F. P. and LaFond, E. C., 1940; Shuler, W. R., 1951, 1952; Sinnott, A., 1941; Stump, R. S., 1946e; Stump, R. S. and Bascom, W. N., 1947; Sverdrup, H. U., 1939a; Sverdrup, H. U. and Staff, 1946; Symons, T. W. 1893; Thompson, W. F. and Thompson, J. B., 1919; Thompson, W. O., I937; U. S. Waterways Experiment Station, Vicksburg, Mississippi, 1935; Warner, S. E., 1946b; Wiegel, R. I., 19470; Wiegel, R. L., Patrick, D. A. and Kimberley, H. L., 1953

Beach Ridge (See also: Beach Profile, Berm, Ridge): Emery, K. O., 1950a; Hertlein, L. G. and Grant, U. S., 1944; Johnson, D. W., 1944; Smith, W. D., 1933c; Thompson, W. O., 1937

Beach Slope - see Beach and Nearshore Slope, Gradient Beach Slope vs Grain size (See also: Beach and Nearshore Slope, Grain size): Anonymous, 1933e, 1940d; Bascom, W. N., 1950c; Beach Erosion Board, 1952a; Brown, E. I., 1939; Handin, J. W., 1949; Handin, J. W. and Ludwick, J. C., 1950; Inman, D. I., 1953b; Krumbein, W. C., 1950; Nicholls, C. P. L., 1939; Norris, R. M., 1951; Sinnott, A., 1941 Beach, Subsurface of - see Subsurface of Beach Beach Width: Anonymous, 1941b; Bartlett, w. A., 1852; Beach Erosion Board, 1948h, 1948i, 1954a; Brown, E. I., 1939; Congressional Documents, 1949-1950b, 1953b; Dunkle, M. B., 1944; Grant, U. S., 1948; Handin, J. W., 1949; Johnson, A. G., 1940c, 1951; Los Angeles County Regional Planning Commission, 1946; Marlette, J. W., 1954; Martens, J. H. C., 1939; Nelson, J., Dean, W. C., Kocher, A. E., Watson, E. B., Carpenter, E. J., 1920; Nicholson, G. F., Grant, U. S., Shepard, F. P. and Crowell, J. C., 1946; O'Brien, M. P., 1939; Orange County Planning Commission, 194l; Shepard, F. P., Inman, D. L. and Fisher, R. L., 1951; Shuler, W. R., 1952

Bedrock, Basement Rock, Outcrop (See also: Source Rocks): Anonymous, 1951d; Butcher, W. S., 1951a; California, University of, 1953a, 1953b; Coxe, L. C., 1949; Crooke, R. C. , Elvitsky, A. W. et al, 1953; Crouch, R. W., 1954; Dietz, R. S., Emery, K. 0 . and Shepard, F. P., 1942; Dietz, R. S., Menard, H. W. and Hamilton, E. L., 1954; Emery, K. O., 1951, 1952; Emery, K. O., Butcher, W. S., Gould, H. R. and Shepard, F. P., 1952; Emery, K. O., and Shepard, F. P., 1941, 1945; Fox, L. S., 1930; Gorsline, D. S., 1954; Hanna, G. D., 1952; Krumbein, w. C., 1947; Lawson, A. C., 1894; Louderback, G. D., 1920; Menard, H. W., 1952; Menard, H. W., Dill, R. F., Hamilton, E. L.. Moore, D. G., Shumway, G., Silverman, M. and stewart, H. B., 1954; Thompson, W. C., 1949; Trask, P. D. and Rolston, J. W., 1950a; Trask, P. D. and Scott, T., 1954; Uchupi, E., 1954

Bench - see Wave Cut Terrace

Berm, Beach Scarp, Beach Crest: Anonymous, 1938a, 1938b; Bascom. W. N., 1946b, 1950c; Beach Erosion Board, 1948h, 1952a; California, University of, 1952a, 1954b; Congressional Documents, 1938a, 1953b; Eaton, R. O., 195l; Emery, K. 0. and Gale, J. F., 1951; Grant, U. S. and Shepard, F. P., 1937; Hall, J. V., Jr., 1952; Handin, J. W., I951; Handin, J. W. and Ludwick, J. C., 1949; Isaacs, J. D. and Bascom, W. N., 1947; Krumbein, W. C., 1950; MacDonald, G. A., Shepard, F. P. and Cox, D. C., 1947; Mason, M. A., 1942; Norris, R. M., 1951; O'Brien, M. P., 1939; Schupp, R. D., 1953; Shepard, F. P., 1943b, 1950b, 1950c, 1950g; Shepard, F. P., and Inman, D. L., 1951b; Shuier, W. R., 1952; Thompson, W. O., 1937; Todd, D. K. and Wiegel, R. L., 1952; Trask, P. D., 1952a; Trask, P. D. and Scott, T., 1954; Watts, G. M. and Others, 1953; Wiegel, R. L., Patrick, D. A. and Kimberley, H. L., 1953

Beryllium: Lowenstam, H. A., 1954; Revelle, R., 1935; Vaughan, T. W. , 1933; Goldberg, E. D., 1954

\section{Bicarbonates - see Carbonates}

B1smuth: Revelle, R., 1935; Vaughan, T. W., 1933

Black Mud (See also: Mud, Iron Sulfides): Belknap, G. E., 1874a: California Department of Fish and Game, 1951; Callfornia Department of Public Health, 1951; Crooke, R. C , Elvitsky, A. W. et al, 1953; Davidson, G., 1897; Emery, K. O. and Dietz, R. S., 194I; Emery, K. O. and Rittenberg, S. C., 1952; Fox, D. L., Updegraff, D. M. and Noveli1, G. D. , 1944; Galliher, E. W., 1933, 1935a, 1935c; Gorsline, D. S., 1954; Louderback, G. D., 1920 , 1940; McKee, E. D., 1939; Marlette, J. W., 1954; Moore, D. G., 1951; Moyer, D. A., 1929b; Revelle, R., 1950; San Diego Regional Water Pollution Control Board, 1952; Shepard, F. P. and Emery, K. 0., 1941; Shepard, F. P., Revelie, R. and Dietz, R. S., 1939; Stevenson, R. E., 1954; Trask, P. D., 1939; Woodford, A. O., 1951; Wright, R., 1937; ZoBelI, C. E., 1935, 1942b; ZoBell, C. E., and Feltham, C. B., 1942

Black Sands (See also: Auriferous Beach Sands, Beach Placers, Heavy Minerals, Magnetic Minerals, Mineralogy, various minerals composing black sands): Anonymous, 1882c, 1884, 1894a, 1894b, 1906b, 1950a, 1950b, 1951d, 1954j; Averill, c. V., 1941; Averill, C. V. and Others, 1946; Belknap, G. E., $1874 a$; Boos, M. F., 1940; Builard, F. M. and Mills, R. A., 1951; California Miners' Association, 1899; Crooke, R. C., Elvitsky, A. W. et al, 1953; 
Dasher, J., Fraas, F. and Gabriel, A., 1942; Day, D. T., 1907a, 1907b; Day, D. T. and Richard, R. H., 1906; DeGroot, H., 1890; Diller, J. S., 1896, 1901, 1903; Edman, J. A., 1894, 1906; Emery, K. O., 1944, 1945a; Fraser, C. McL., 1943; Goodyear, W. A., 1873; Griggs, A. B., 1945; Griggs, A. B. and Wells, F. G., 1942; Haase, L. G., 1926; Hornor, R. R., 1918; Hundhausen, R. J., 1947; Irvine, C. D., 1908; Lakes, A., 1903a, 1903b; Lang, H., 1916; Logan, C. A., 1919; Lowell, F. L. L., 1915a, 1915b; Moore, D. G., 1951; Pardee, J. T., 1934; Paul, A. B., 1894: Stephenson. E. L., 1945; Stevenson, R. E., 1954; Sverärup, H. U. and Staff, 1942a; Twenhofel, W. H., 1943, 1946, 1946a; Yale, C. G., 1913

\section{Black Silt: Moore, D. G., 1951}

Blowholes - see Minor Features, Rocky Coasts

Blue mud (See also: Green mud, Mud): Arnold, J. L., 1928; Belknap, G. E., 1874; Crooke, R. C., Elvitsky, A. W. et al, 1953; Davidson, G., 1897; Hanna, G. D., 1952; Kuenen, Ph. H., 1946; Moyer, D. A. 1929b; P1ggot, C. S., 1932; Revelle, R. and Emery, K. O., 1951; Shepherd, E. S., 1946; Vaughan, T. W., 1940

\section{Bog - see Swamp}

\section{- see Boron}

Boring organisms (See also: Burrowing organisms, Organisms): Becker, G. F., 1888; Blake, J., 1868b; Crooke, R. C., Elvitsky, A. W., et al, 1953; Ell1ott, F. E., Tressler, W. L. and Myers, W. H., 1953; Fox, D. L. and Coe, W. R., 1943; Johnson, M. W., 1948; Johnson, M. W., Everest, F. A. and Young, R. W., 1947; Louderback, G. D., 1924; Scripps Institution of Oceanography, 1953a

Rock Boring organisms: Barrows, A. L., 1913, 1919; Butcher, W. S., 1951a; Chesterman, C. W., 1952; Cohee, G. V., 1938; Dietz, R. S., Emery, K. O. and Shepard, F. P., 1942; Emery, K. 0., Butcher, W. S., Gould, H. R., and Shepard, F. F., 1952; Emery, K. O. and Dietz, R. S., 1950; Emery, K. O. and Shepard, F. P., 1945; Emery, K. O. and Tschudy, R. H., 1941; Fenton, M. A. and Fenton, C. L., 1934; Hanna, G. D., 1952; Herold, C. L. 1934; Lakes, A., 1903b; Lawson, A. C., 1893a, 1893b; MacDonald, G. A., 1934; Menard, H. W., Dill, R. F., Hamilton, E. L., Moore, D. G., Shumway, G., Silverman, M. and Stewart, H. B., 1954; Moore, D. G., 1951; Osmont, V. C., 1904; Putnam, W. C., 1938; Revelle, R. and Shepard, F. P., 1939b; Shepard, F. P., 1948c, 1948d, 1949b; Shepard, F. P., Emery, K. O. and LaFond, E. C., 1941; Shumway, G. A., 1953; Vaughan, T. W., 1936; Wilson, M. E., 1907

Wood Boring Organisms: Atwood, W. G. and Johnson, A. A. , 1924; Barnard, J. L., 1952; Barrows, A. L., 1917; Fraser, C., 1928; Graham, H. W. and Gay, H. 1945; Hill, C. L. and Kofoid, C. A., 1927; Horonjeff, R. and Patrick, D. A., 1952; Kofoid, C. A., 1921; Kofo1d, C. A. and Miller, R. C., 1927; Means, T. H., 1928, 1929; Menzies, R. J., 1951; San Francisco Bay Marine Piling Committee, 1921, 1922, 1923; U. S. Naval Civil Engineering Research and Evaluation Laboratory, 1951; Vaughan, T. W., 1936

Boron including Boric Acid: Emery, K. 0., 1946b; Foote, F J., 1932; Goldberg, E. D., 1954; Harding, M. W., 1932; Harding, M. W., and Moberg, E. G., 1934; McClendon, J. F., Gault, C. C. and Mulholland, S., 1917; Moberg, E. G., and Harding, H. W., 1933; Revelle, R., 1935, 1941; Revelle, R. and Emery, K. O., 1951; Shuck, O. T., 1869; Thompson, T. G. and Robinson, R. J., 1932; Trask, P. D., 1939; Vaughan, T. W., 1933; Veach, J. A., 1859

Bottom Currents (See also: Currents; Submarine Canyons, Currents in): Brant, I., 1925; Buffington, E. C., 1952; Crowell, J. C., 1952; Dav1s, W. M., 1933; Dietz, R. S., 1952a, 1954; Dietz, R. S. and Menard, H. W., 1951b; Dietz, R. S., Menard, H. W., and Hamilton, E. L., 1954; Dill, R. F., Dletz, R. S. and Stewart, H., 1954; Eaton, R. O., 1951; Emery, K. O., 1948, 1954d; Emery, K. O., Butcher, W. S., Gould, H. R. and Shepard, F. P., 1952; Goldberg, E. D., 1954; Gorsline, D. S., 1954; Folway, R. S., 1905; Inman, D. L. and Quinn, W. H., 1952; Johnson, J. W., 1948b; Ludw1ck, J. C.,
Jr., 1950; Lesser, R. M., 1951; Natland, M. L., 1933b; Reed, R. D., 1933a; Revelle, R., 1940; Revelle, R. and Shepard, F. P., 1939a, 1943: Scripps Institution of Oceanography, 19521, 1953e; Shepard, F. P., 1938e, 1939d, 1940a, 1941a, 1948b, 1948c, 195le; Shepard, F. P. and Emery, K. O., 1941; Shepard, F. P. and Inman, D. L., 1949, 195la; Shepard, F. P. and LaFond, E. C., 1939; Shepard, F. P., Revelle, R. and Dietz, R. S., 1939; Sherzer, W. H., 1910; Sverdrup, H. U., 1939a (including bottom velocity profile), 1940d; Sverdrup, H. U. and Staff, 1943b

Bottom Flow, i.e. Turbidity currents. (Also see: Bottom Currents, Interflow, Turbidity Currents): Menard, H. W. and Ludwick, J. C., 1951

Bottom Friction - see Friction

Bottom Photography - see Photography

Bottom Surge - see Surge

Bottom Temperature - see Temperature

Breakwater - see Engineering

Breccia (See also: Rock): Butcher, w. S., 195la; Carsola, A. J. and Dietz, R. .S., 1952; Dietz, R. S., Emery, K. O. and Shepard, F. P., 1942; Emery, K. 0., 1948; Emery, K. O. and Shepard, F. P., 1941, 1945; Shepard, F. P., 1936f; Shepard, F. P. and Emery, K. O., 1941

Bridge - see Land Bridge, Natural Bridge, Sea Arch Bromine (See also: Halogens): Vaughan, T. W., 1940 Brown Mud (See also: Red Clay): Belknap, G. E., 1874a, 1874b; Davidson, G., 1897; Galliher, E. W., 1935a; Tanner, Z. L., 1894; Woodford, A. O., 1951

Buffer Effect: Moberg, E. G. and Harding, H. W., 1933 Burrowing organisms (See also: Organisms): Arnold, J. L., 1928; California Department of Public Health, 1951; Coe, W. R. and Fox, D. L., 1944; Dapples, E. C., 1942; Dill, R. F., 1952; Dill, R. F. Dietz, R. S. and Stewart, H., 1954; Emery, K. O., 1945a, 1952b, 1953b; Emery, K. O. and Rittenberg, S. C., 1952; Fox, D. and Coe, W. R., 1943; Fox, D. L., Crane, S. C. and McConnaughey, B. H., 1948; Galliher, E. W., 1935c; Herold, C. L., 1934; Hinde, H. P., 1952; Johnson, D. W., 1910; Kuenen, $\mathrm{Ph} . \mathrm{H}$. and Menard, H. W., 1952; Louderback, G. D., 1924; MacGin1tie, G. E., 1935, 1939; Morrison, R. L., 1930; Palmer, R. H., 1928; Shepard, F. P., 1948c; Shepard, F. P. and Emery, K. 0., 1945; ZoBell, C. E., 1938, 1942b; ZoBell, C. E. and Feltham, C. B., 1942

By-passing of Sediment (See also: Nondeposition, Winnowing): Beach Erosion Board, 1951; Butcher, W. S., 195la; Congressional Documents, 1953b; Dietz, R. S. and Menard, H. W., 1951b; Emery, K. O., 1952; Holzman, J. E., 1950; Revelle, R. and Shepard, F. P., 1939b; Uchupi, E., 1954

Cadmium: Vaughan, T. W., 1933

Calcareous Sediments and Rocks (See also: Algae, Carbonates, Coquina, Limestone, Marl, Organic sediments, Reefs, Shells): Belknap, G. E., 1874a; Emery, K. 0 . Butcher, W. S., Gould, H. R. and Shepard, F. P. 1952; Goldberg, E. D., 1954; Gorsline, D. S., 1954; Hoots, H. W., 1943; Kindle, E. M., 1934; Ludwick, J. C., Jr., 1950; Pease, W. H., 1868 (coral sand); Revelle, R., 1950; Revelle, R. and Shepard, F. P., 1939b; Shepard, F. R., 1932, 1941a; Shepard, F. P., and Emery, K. O., 1941; Shepard, F.P. and Grant, U. S., 1947; Shepard, F. P., Revelle, R. and Dietz, R. S., 1939; Shepard, F. P. and Wrath; w. F., 1937; Weeks, L. G., 1952; ZoBell, C. E. and Feltham, C. B., 1942

Calcite (See also: Calcareous Sediments and Rocks, Carbonates, Limestone, Marl, Mineralogy): Emery, K. O., Butcher, W. S., Gould, H. R. and Shepard, F. P., 1952; Lowenstam, H. A., 1954

Calcium (See also: Algae, Calcareous Sediments and Rocks, Calcite, Carbonates, Coquina, Limestone, Marl, Organic sediments, Shells): Dietz, R. S., Emery, K. O. and Shepard, F. P., 1942; Fox, D. L. and Coe, W. R., 1943; Galliher, E. W., 1935c; Gee, H., 1932; Kelley, W. P. and Lieb1g, G. F., 1934; Kirk, P. L. and Moberg, E. G., 1933; Lipman, C. B., 1929; Lowenstam, H. A., 1954 (also Sr/Ca ratio); McKee, E. D., 1953; Moberg, E. G. and Revelle, R., 1937; Revelle, R., 1941; Scrlpps Institution of oceanography, 1953e; Stanton, T. E., Jr., 1938; 
Sverdrup, H. U., 1940e; Sverdrup, H. U. ana statI, 1941 (also Ca/Cl ratio); Sverdrup, H. U. and Staff, 1942a, 1943b, (also Ca/Cl rat1o), 1945b; Thompson, T. G. and Robinson, R. J., 1932; Vaughan, T. W., 1930a, 1930b, 1931, 1932b, 1940; ZoBell, C. E., 1939,1941

Calcium Carbonate - see Carbonates

$\mathrm{Calcium} / \mathrm{Chloride}$ Ratio ( $\mathrm{Ca} / \mathrm{Cl}$ ) - see Calcium

Carbonate/Nitrogen ratio $\left(\mathrm{CO}_{3} / \mathrm{N}\right)$ - see Carbon/Nitrogen Ratio $(\mathrm{C} / \mathrm{N})$

Carbonates, $\mathrm{Ca}$ and $\mathrm{Mg}$ Carbonates and Bicarbonates (See also: Algae, Aragonite, Calcareous Sediments and Rocks, Calcite, Calcium, Chlorinity, Coquina, Limestone, Magnesium, Marl, Organic sediments, Shells): Chesterman, C. W., 1952; Cohee, G. V., 1938; Crouch, R. W., 1954; Dietz, R. S., Emery, K. O. and Shepard, F. P., 1942; Dill, R. F., 1952; Emery, K. O., 1941b, 1946b, 1948, 1950d, 1954b $\left(\mathrm{CaCO}_{3}\right.$ for all environments); Emery, K. O., Butcher, W. S., Gould, H. R. and Shepard, F. P., 1952; Fmery, K. O. and Foster, J. F., 1948; Emery, K. O. and Rittenberg, S. C., 1952 (also $\mathrm{CO}_{3} / \mathrm{N}$ ratio); Emery, K. O. and Stevenson, R. E., 1950; Emery, K. O. and Tschudy, R. H., 1941; Evans, R. D., Kip, A. F. and Moberg, E. G., 1938; Fleming, R. H. and Revelle, R., 1939; Galliher, E. W., 1933; Gee, H., 1932; Gee, H., Greenberg, D. M. and Moberg, E. G., 1932; Goldberg, E. D., 1954; Gorsline, D. S., 1954; Graham, H. W. and Moberg, E. G., 1944; Greenberg, D. M., Moberg, E. G. and Allen, E. C., 1932; Holzman, J. E., 1950; Inman, D. L., 1953b; Lipman, C. B., 1929; Lowenstam, H. A., 1954; McEwen, G. F., 1934a; McKee, E. D., 1953; Merriam, P. D., 1949; Moberg, E. G., 1928b, 1930c; Moberg, E. G. and Harding, M. W., 1933; Norris, R. M., 1951; Revelle, R., 1935, 1937a, 1937o, 1938, 1941 (also $\mathrm{Cl} / \mathrm{CO}_{3}$ ratio); Revelle, R. and mery, K. 0., 1951; Revelle, R. and Fleming, R. H., 1934; Revelle, R. and Shepard, F. P., 1939b; Scripps, Institution of oceanography, 1953e; Shepard, F. P., and Grant, U. S., 1947; Shepard, F. P. and Wrath, W. F., 1937; Sisler, F. O. and ZoBell, C. E., 195lb; Stanton, T. E. Jr., 1938; Stevenson, R. E., and Emery K. O., 1951; Sumner, F. B., Louderback, G. D., Schmitt, W. L. and Johnston, E. C., 1914; Sverdrup, H. U., 1939a, $1940 \mathrm{~g}$; Sverdrup, H. U. and Staff, 1942a; Thompson, T. G. and Robinson, R. J., 1932; Trask, P. D., $1931 b, 1932 a, 1932 b, 1937 a, 1937 b, 1939$; Uchup1, E., 1954; Urry, W. D. and Piggot, C. S., 1942; Vaughan, T. W., 1930a, 1930b, 1930d, 1931, 1933, 1940; White, D., 1911; Williams, W., 1948; ZoBell, C. E., $1938,1939,1942 \mathrm{a}, 1942 \mathrm{~b}, 1946-1947,194 \mathrm{7b}$, 1947c, 1947d; ZoBell, C. E. and Anderson, D. Q., 1936

Carbon Dioxide and Carbon Monoxide (See also: Gases): Ahlstrom, E. H., 1950; Allen, E. C., 1933; Allen, W. E., 1941c; Brongersma-Sanders, M. 1948; Bullock, F. W., 1933; Cartwright, L. D., Jr., 1928; Couch, E. B., 1915; Dietz, R. S., 1952a; Dietz, R. S., Emery, K. O. and Shepard, F. P., 1942; Dill, R. F., 1952; Emery, K. O., 1946b; Emery, K. O. and Rittenberg, S. C., 1952; Fox, D. L., 1950; Galliher, E. W., 1933; Gee, H., 1932; Gislén, T., 1943; Goldberg, E. D., Baker, M. and Fox, D. L., 1952; Graham, H. W. and Moberg, E. G., 1944; Greenberg, D. M., Moberg, E. G. and Allen, E. C., 1932; Hutton, W. E. and ZoBell, C. E., 1949; Krumbein, W. C., 1942; McClendon, F. F., Gault, C. C. and Mulholland, S., 1917; McEwen, G. F., 1915, 1919b, 1934a; Mayor, A. G., 1922; Michael, E. L., 1919, 1921; Miller, R. C., Ramage, W. D. and Lazier, E. L., 1928; Morrison, R. L., 1930; Moberg, E. G., 1925, 1928a, 1928b, 1930c; Moberg, E. G. and Allen, W. E., 1927; Revelle, R. and Fleming, R. H., 1934; Revelle, R. and Shepard, F. P., 1939b; Sisler, F. D. and ZoBell, C. E., 195la, 1951b; Sommer, H. and Clark, F. N., 1946; Stevenson, R. E., 1954; Sverdrup, H. U., 1940e, 1940g, 1944b; Sverdrup, H. U. and Staff, 1941, 1943a; Tilden, C. A., 1925; Thompson, T. G. and Robinson, R. J., 1932; Trask, P. D., 1934, 1939; Vaughan, T. W., $1930 b, 1930 d, 1932 a, 1932 b, 1932 c, 1933,1936$; Wells, R. C., 1921; ZoBell, C. E., 1939, 1942a, $1942 b, 1943,1946 \mathrm{~b}, 1946-1947,1947 \mathrm{~b}, 1947 \mathrm{c}, 1947 \mathrm{~d}$,
1950; ZoBell, C. E. and Feltham, C. B., 1942; ZoBell C. E., Grant, C. W. and Haas, H. F., 1943

Carbonic Acid: Emery, K. O., 1946b; McEwen, G. F., 1934a; Revelle, R., 1941; Revelle, R. and Fleming, R. H., 1934; Sverdrup, H. U. and Staff, 1941; Vaughan, T. W., 1933; Williams, W., 1948; ZoBell, C. E., $1942 b, 1947 \mathrm{~b}$

Carbon - see organic matter

Carbon/Nitrogen Ratio (C/N): Dill, R. F., 1952; Emery, K. 0. and Rittenberg, S. C., 1951, 1952 (also $\mathrm{CO}_{3} / \mathrm{N}$ ratio) Krumbein, W. C., 1942; Revelle, R. and Shepard, F. P., 1939b; Trask, P. D., 1931b, 1936, 1939; Trask, P. D. and Hammer, H. E., 1931

Carotenoids - see Pigments

Cavernous Sand: Emery, K. O., 1945a; Emery, K. O. and Stevenson, R. E., 1950

Cement of Sediments and Rocks (See also: Calcite, Carbonates, Limonite, Silica): Butcher, w. S., 195la; Carsola, A. J. and Dietz, R. S., 1952; Chesterman, C. W., 1952; Dapples, E. C., 1942; Dietz, R. S. and Emery, K. O., 1938b; Dietz, R. S., Emery, K. O., and Shepard, F. P., 1942; Emery, K. O., 1945a, 1946b; Emery, K. O., Butcher, W. S., Gould, H. R. and Shepard, F. P., 1952; Emery, K. O. and Foster, J. F., 1948; Emery, K. O. and Shepard, F. P., 1945; Emery, K. O. and Stevenson, R. E., 1950; Krumbein, W. C., 1942; Merriam, P. D., 1949; Revelle, R. and Emery, K. O., 1951; Shepard, F. P. and Grant, U. S., 1947

Cenozoic: Shepard, F. P., 1952a

Cesium: Thompson, T. G. and Robinson, R. J., 1932

Channels: Anonymous, 1940d, 1951b, 1952e; Berch Erosion Board, 1951, 1952b; Blake, J., 1868b; Blinn, F. S., 1928; Bowman, A., 1873; Bucher, W. H., 1940; California, University of, 1945a; Congressional Documente $1908 \mathrm{~g}, 1926,1938 \mathrm{~b}$; 1938d, 1941, 1949a, 1949e; Davidson, G., 1864; Davis, W. M., 1932; Emery, K. O., and Dietz, R. S., 1941; Galliher, E. W., 1933 , 1935a; Herhardt, J. R. and Jehn, K. H., 1954; Gilbert, G. D., 1917; Gorsline, D. S., 1954; Gulliver, F. P., 1896; Inman, D. L., 1949 (tidal inlet); James, E. L., 1950; Lawson, J. S., 1862; LeConte; J., 1891; Louderback, G. D., 1920, 1940; Mcouat, H. W., 1951; Menard, H. W., 1952; Menard, H. W. and Ludwick, J. C., 1951; Nicholson, G. F., Grant, U. S., Shepard, F. P. and Crowell, J. C., 1946; O'Brien, M. P., 1936a (tidal inlet); Revelle, R. and Emery, K. O., 1951; Shalowitz, A. L., 1951; Shepard, F. P., 1950b, 195le, 1952a; Shuler, W. R., 1952; Smith, W. S. T., 1897; Stevenson, R. E. 1954; Swain, F. E., 1951; Toit, A. L. du., 1940; Upham, W., 1899; U. S. Coast Survey, 1864; ZoBell, C. E. and Feltham, C. B., 1942 Beach and Nearshore: Anonymous, 1940d; Arthur, R. S., 1950; Congressional Documents, 1938b; Darrow, W. E., 1942; Davidson, G., 1873c; Emery, K. 0., 1945a; Gibson, W. M., 1951; Grant, U. S., 1948; Johnson, D. W., 1910; McKee, E. D., 1953; Munk, W. H., and Traylor, M. A., 1947; Palmer, R. H. 1928; Schupp, R. D., 1953; Shepard, F. P., 1950f, $1950 \mathrm{~g}$; Shepard, F. P., Emery, K. O. and LaFond, E. C., 1941; Thompson, w. O., 1937; Tower, M. L., 1910,1913

Submarine Canyons and Continental Slope Channels: Bucher, W. $\overline{\text { H., 19}} 4 \overline{0}$; Buffington, E. C., 1951, 1952; Dietz, R. S., 1954; Dill, R. F., Dietz, R. S. and Stewart, H., 1954; Menard, H. W. and Ludwick, J. C., 1951; Shepard, F. P., 1936f; Shepard, F. P. and Emery, K. 0., 1941

Surge Channels: Hanna, G. D., 1951, 1952; Hinds, N. E. A., 1952

Chert: Cohee, G. V., 1938; Dietz, R. S., Emery, K. O. and Shepard, F. P., 1942; Emery, K. 0., 1941a; Emery, K. O. and Shevard, F. P., 1945; Emery, K. O. and Tschudy, R. H., 1941; Hanna, G. D., 1952; Shepard, F. P. and MacDonald, G. A., 1938; Shurnway, G. A., 1953

Chlorides - see Chlorinity, Sulfate/Chloride Ratio Chlorine - see chlorinity

Chlorinity, Chlorine, Chlorides (See also: Calcium, Halogens, Sulfate/Chloride Ratio): California Academy of Sciences, California Division of Fish and Game, Scripps Institution of Oceanography, of the University of California, and U. S. Fish and Wildifie Service, 1950; California Bureau of Sanitary 
Engineering, 1952; California Department of Fisb and Game, 1951; Devaputra, D. Thompson, T. G. and Utterback, C. E., 1932; Emery, K. O., 1946b, 1953a, 1954d; Emery, K. 0. and Rittenberg, S. C., 1951, 1952; Graham, H. W. and Gay, H., 1945; Harding, M. W., 1932; Hinde, H. P., 1952; Lipman, C. B., 1929; McClendon, J. F., Gault, C. C. and Mulholland, S., 1917; McEwen, G. F., 1934a; McKee, E. D., 1953; Patrick, D. A., 1950; Phelps, A., 1940; Revelle, R., $1941\left(\mathrm{Cl} / \mathrm{CO}_{3}\right), 1950$; Revelle, R. and Emery, K. O., 1951; San Diego Regional Water Pollution Control Board, 1952; Scripps Institution of Oceanography, 1950g; Schneider, W. A., 1954; Skogsberg, T., 1936; Smith, P. V., Jr., 1954; Stanton, T. E., Jr., 1938; Sverdrup, H. U., 1939a; Sverdrup, H. U. and Staff, 1942a, 1943b; Thompson, T. G. and Robinson, R. J., 1932; Tilden, C. A., 1925; Topp, E. P., 1929; Urry, W. D., and Piggot, C. S., 1942; U. S. Hydrographic Office, 1934b; Vaughan, T. W., 1940; Veach, J. A., 1859; wooster, W. S., 1950, 1952; ZoBell, C. E., 1941

Chlorite (See also: Rock): Emery, K. O. and Tschudy, R. H., 1941

Chlorophyll: California Academy of Sciences, California Division of Fish and Game, Scripps Institution of oceanography of the University of California, and U. S. Fish and Wildlife Service, 1950, 1951b; Grabam, H. W., 1943

Chromium: Revelle, R. and Emery, K. O., 1951

Classification of Shorelines - see Shorelines

Clastics (see also: Rock): Revelle, R., 1939b

Clay (See also: Phillipsite, Red Clay): Including Clays in: Bays, Estuaries, Harbors, Lagoons, Marshes, Sloughs, Tide Flats etc; Anonymous, 1906a; Arnold, J. L., 1928; Buck, C. D., 1928; California Department of Fish and Game, 1951; California Department of Public Health, 1951; Collins, L. B., 1931; Congressional Documents, 1940e; Coxe, L. C., 1949; Crooke, R. C., Elvitsky, A. W. et al, 1953; Dapples, E. C., 1942; Djetz, R. S., 1941; Dietz, R. S., Emery, K. 0. and Shepard, F. P., 1942; Emery, K. 0., Butcher, W. S., Gould, H. R. and Shepard, F. P., 1952; Emery, K. O. and Dietz, R. S., 194l; Emery, K. 0. and Gould, H., 1948; Galliher, E. W., 1932b, 1935a, 1935c; Grim, R. E., Dietz, R. S. and Bradley, W. F., 1949; Hoover-Young San Francisco Bay Bridge Commission, 1930; Inman, D. L., 1949; Kelley, W. P. and Liebig, G. F., Jr., 1934; Lawson, A. C., 1914; Louderback, G. D., 1940; McKee, E. D., 1953; MacGinitie, G. E., 1927, 1935; Menard, H. W. and Ludwick, J. C., 1951; Moberg, E. G., Fleming, R. H., Heusner, K. and Revelle, R., 1937; Nelson, J. W., Dean, W. C., Kocher, A. E., Watson, E. B. and Carpenter, E. J., 1920; Putnam, J. A., Bermel, K. J. and Johnson, J. W., 1947; Revelle, R., 1941 1950; Revelle, R. and Shepard, F. P., 1939b; San Diego Regional Water Pollution Control Board, 1952; Sears, C. B., 1876; Shepard, F. P., 1949d, 1951b; Sisler, F. P. and ZoBell, C. E., 1950; Smith, A. G. and MacKenzie, G., Jr., 1948; Stevenson, R. E., 1954; Trask, P. D., 1928, 1931a, 1934, 1939 (also delta), 1950; Trask, P. D. and Rolston, J. W., 1950a, 1950b; Vaughan, T. W., 1933, 1942b; ZoBell, C. E., 1938, 1942b, 1943, 1946b, 1946-1947, 1947b; ZoBell, C. E. and Anderson, D. Q., 1936; ZoBell, C. E., and Feltham, C. B., 1942

Abyssal (See also: Red Clay); Belknap, G. E., 1874a; D1etz, R. S., 1941; Goldberg, E. D., 1954; Grim, R. E., Dietz, R. S. and Bradley, W. F., 1949; Revelle, R., 1935, 1937a; Scripps Institution of Oceanography, 1953e; Shepard, F. P., 1950a; Urry, W. D. and Piggot, C. S., 1942

Bank: Emery, K. O., 1948; Grim, R. E., Dietz, R. S. and Bradley, W. F., 1949

Basin: Dietz, R. S., Emery, K. 0. and Shepard, F. P., 1942; Emery, K. O. and Rittenberg, S. C., 1952; Grim, R. E., Dietz, R. S. and Bradley, W. F., 1949; Revelle, R., 1938, 1939b (brown clay), 194la;

Shepard, F. P., 1939d, 1940a, 1951d; Trask, P. D., $1931 b$ (green clay)

Beach and Nearshore: Anonymous, 1915, 1916a; California, University of, 1953a, 1953b; Congressional Documents, 1953b; Griggs, A. B. and Wells, F. G., 1942; Hall, J. V., Jr., 1952; Johnson, A. G., 1935;
McKee, E. D., 1953; Mason, E. H., 1930; Merriam, P. D., 1949 (coastal sand dunes); Shuler, W. R. 1952 (clay-balls); Trask, P. D., and Scott, T. 1954; Twenhofel, W. H., 1946; Vaughan, T. W., 1940 Continental Shelf: Crooke, R. C., Elvitsky, A. W. et al, 1953; Dill, R. F., 1952; Emery, K. O. and Gould, H., 1948; Galliher, E. W., 1935b; Gorsline, D. S., 1954; Grim, R. E., Dietz, R. S. and Bradley, W. F., 1949; MacDonald, G. A., 1934; Moore, D. G., 1951 (also black clay); Revelle, R. and Emery, K. $0 ., 1951$ (continental borderland); Revelle, R. and Shepard, F. P., 1939b (continental borderland); Shepard, F. P., 1932, 1939b, 1949b; Shepard, F. P. and MacDonald, G. A., 1938; Shepard, F. P. and Wrath, W. F., 1937

Continental Slope: Dill, R. F., 1952

Submarine Canyons: Cohee, G. V., 1938; Emery, K. O., Butcher, W. S., Gould, H. R. and Shepard, F. P., 1952; Grim, R. E., Dietz, R. S. and Bradley, W. F., 1949; Marlette, J. W., 1954; Shepard, F. P., 1933c, 1948b, 1953; Shepard, F. P. and Emery, K. 0., 1941; Woodford, A. O., 1951

Claystone (See also: Clay, Mudstone, Rock): Butcher, W. S., $1951 a$

Cliff Erosion: Anonymous, 1916a, 1938a, 1940c; Allen, W. E. 194la; Ashley, G. H., 1931; Bascom, W. N., 1946a; Beach Erosion Board, 1948i, 1953c; Bruff, S. C., 1946; Buwalda, J., 1936; Congressional Documents, $1942 b, 1949 b$, 1949f; Couch, E. B., 1915; Davis, W. M., 1932; Davis, W. M., Putnam, W. C. and Richards, G. L., Jr., 1931; Diller, J. S., 1902; Emery, K. O., $1941 b, 1946 b$, 1954a; Emmonds, S. F. and Merrill, G. P., 1894; Fairbanks, H. W., 1897, 1904; Goldberg, J., 1940; Grant, U. S. and Shepard, F. P., 1937, 1938b; Hall, W. C., 1942; Handin, J. w., 1949; Hanna, M. A., 1926; Hannum, G. W. T., 1944; Harts, W. W., 1911; Hertlein, L. G. and Grant, U. S., 1944; Inman, D. L., 1953a; Isaacs, J. D., 1947a; Lakes, A., 1903b; Lawson, A. C., 1893b, 1914; Leypoldt, H., 1941b; Leeds, C. T., 1936; Leonard, A. G., 1925; Livingston, A., Jr., 1939; Louderback, G. D., 1940; McKee, E. D., 1953; McLellan, M. E., 1925; O'Brien, M. P., 1939; O'Shaughnessy, M. M., 1924; Page, G. B., 1950; Place, J. I., 1952; Putnam, W. C., 1938; Revelle, R. and Shepard, F. P., 1939b; Richardson, R. W., 1923; Shepard, F. P., 194la, $1943 \mathrm{~b}, 1950 \mathrm{~b}, 1950 \mathrm{c}, 1950 \mathrm{~g}$; Shepard, F. P. and Grant, U. S., 1947; Shepard, F. P. and Innan, D. L., 1951b; Shuler, W. R., 1951, 1952; Smith, W. D., 1930; Smith, W. S. T., 1897, 1900; Stevenson, R. E., 1954; Swinnerton, A. C., 1927; Trask, P. D., 1952b; Vaughan, T. W., 1930a, 1930b, 1930c, 1931, 1932d; Walters, L., 1953; Wanless, H. R., 1950; Williams, W., 1948; Wilson, M. E., 1907; Yates, L. G., 1890b

Cliff Erosion, Rate: Anonymous, 1938a; Emery, K. 0., 1941b; Grant, U. S. and Shepard, F. P., 1937, 19383; Handin, J. W., 1949, 1951; Hertlein, L. G. and Grant, U. S., 1944; Inman, D. L., 1953a; Krumbein, W. C., 1947; Lakes, A., 1903b; Lawson, A. C., 1893a; Leeds, C. T., 1936; Livingston, A., Jr., 1939; O'Brien, M. P., 1936a, 1939; Schupp, R. D., 1953; Shepard, F. P., 1943b, 1949b; Shepard and Grant, U. S., 1947; Shepard, F. P. and Inman, D. L., 1951b; Vaughan, T. W., 1930a, 1930c, 1931, 1932d

Coagulation (See also: Precipitation): Revelle, R. and Shepard, F. P., 1939b

Coastal Plain: Cotton, C. A., 1942; Gulliver, F. P., 1896; King, R. E., 1939

Coastal Sand Dunes: Anonymous, 1938a, 1950d, 1950e, 1954m; Aldrich, L. and Smith, H. G., 1948; Alexander, C. S., 1950; Anderson, F. M., 1896-1902; Baldwin, E. M., 1945; Bascom, W. N., 1947c, 1947d, 1950c; Beach Erosion Board, 1948a, 1948h, 1948i, 1952a, 1953c, 1954a; Beal, C. H., 1915; Blake, J., 1868a; Blake, w. P., 1853, 1856; Bowers, S., 1878; Bremner, C. St. J., 1933 (dune structure); Butler, M. M., 1936; California, University of, 1952a; Campbel1, M. P., 1915; Carpenter, E. J. and Storie, R. E., 1929; Cockerel1, T. D. A., 1938a; Congressional Documents, 1940a, 1949b, 1953b; cooper, W. S., 1927, 1934; Darton, N. H., 1921; Davidson, G., 1864, 1897; Diller, J. s., 1896, 1898, 1901; Dunkle, M. B., 1950; Eaton, R. O., 1951; Eckis, R., 1934; Emery, K. O., 1945a, 1952a, 1954b; Emery, K. 0. and Stevenson, R. E., 1950; Fairbanks, H. W., 1904; 
Gibbs, R. E., 1900; Gilbert, G. K., 1917; Golaberg, J., 1940; Gorsline, D. S., 1954; Grant, U. S., 1944; Grant, U. S. and Sheppard, W. E., 1939; Griesbach, J. 0., 1947; Gulliver, F. P., 1896; Hall, W. C., 1942; Handin, J. W., 1949, 1951; Hinds, N. E. A., 1952; Holmes, L. C. and Pendleton, R. L., 1918; Hoover, J. W., 1932; Inman, D. L., 1949; Isaacs, J. D., 1945d, 1945k; Isaacs, J. D. and Bascom, W. N., 1947, 1949; Ives, R. L., 1951; James, E. L., 1950; Johnson, A. G., 1935, 1940c (as source of beach material), 1951; Johnson, J. W., 1949a; Keller, W. D., 1941, 1945; Kemnitzer, L. E., 1933; Kniffen, F. B., 1932; Krumbein, W. C., 1947; Lawson, A. C., 1914; Lawson, J. S., 1862; Lawton, C. H., 1936; Leeds, C. T., 1936; Lian, H. M., 1952; Livingston, A., Jr., 1939; MacDonald, G. A., 1934; McKee, E. D., 1953; McKee, R. and Schoth, H. A., 1941; McLaughlin, W. T. and Brown, R. L., 1943; Marlette, J. W., 1954; Marshall, W. C., 1934; Martens, J. H. C., 1939; Mason, M. A., 1950b; Melton, F. A., 1940; Mendenhall, W. C., 1905; Merriam, P. D., 1949; Messner, W. E., 1954; Morrison, R. L., 1930; Nelson, E. W., 1922; Nelson, J. W., Dean, W. C., Kocher, A. E., Watson, E. B. and Carpenter, E. J. 1920; Nelson, J. W., Zinn, C. J., Strahorn, A. T., Watson, E. B. and Dunn, J. E., 1919; Nicholson, G. F., Grant, U. S., Shepard, F. P. and Crowell, J. C., 1946; Norris, R. M., 1951, 1952; O'Brien, M. P., 1936a, 1939; 01sson-Seffer, P., 1908, 1910a (types of dunes), 1910b; Page, G. B., 1950 (profiles); Pierce, W. D. and Pool, D., 1938; Place, J. L., 1952; Purer, E. A., 1936 (origin), 1942; Reed, R. D., 1930b; Revelle, R. and Shepard, F. P., 1939b; Richardson, R. W., 1923; Sanford, J. J., 1908; Sears, C. B., 1876; Shepard, F. P., 1939a, 1949b; Shepard, F. P. and Emery, K. 0., 1941; Shepard, F. P. and MacDonald, G. A., 1938; Sinnott, A., 1941; Smith, P. A., 1940; Smith, W. D., 1933a, 1933b, 1933c; Shaveley, P. D., Jr., 1951; Stock, C., 1935, 1936; Storie, R. E. and Carpenter, E. J., 1929, 1930; Storie, R. E., Cole, R. C., Owen, B. C., Koehler, L. F., Anderson, C. A., Leighty, W. J. and Retzer, J. L., 1944; Symons, T. W., 1893; Thompson, W. O., 1934, 1937; Twenhofel, W. H., 1946; Vickery, F. P., 1927a; Wanless, H. R., 1950; Weaver, C. E., 1949; White, D., 1911; Wiggins, I. L., 1929 (?); Woodring, W. P., Bramlette, M. N. and Kew, w. S. W., 1946; Yates, L. G., 1892

Coastai Sand Dune Movement (See also: Wind Transport): Blake, J., 1868a, 1868b; Cambell, M. R., 1915; Leeds, C. T., 1936 (wind blown sand, sand drift); Smith, W. D., $1933 \mathrm{c}$

Cobalt: Goldberg, E. D., 1954; Lowenstam, H. A., 1954; Scripps Institution of Oceanography, 1953e

Cobble Beach, Shingle Beach (See also: Beach Cusps, Gravel): Anonymous, 1938a; Anderson, C. A., 1950; Ashley, G. H., 1896; Bartlett, W. A., 1852; Beach Erosion Board, 1948i, 1952a; California, University of, 1952a; Carsola, A. J., and Dietz, R. S., 1952; Cartwright, L. D., Jr., 1928; Clements, T. and Dana, S. W., 1944; Congressional Documents, 1938a, $1940 \mathrm{a}, 1942 \mathrm{~b}, 1949 \mathrm{f}, 1953 \mathrm{~b}$; Cook, E. H., 1908; Couch, E. B., 1915; Davis, W. M., 1932; Emery, K. 0 . and Tschudy, R. H., 1941 (also beach conglomerate); Haase, L. G., 1926; Hall, W. C., 1938; Handin, J. W., 1949; Hoover, J. W., 1932a; Horton, D. F., 1948; Inman, D. L., 1953b; Isaacs, J. D. and Bascom, W. N., 1947; Johnson, D. W., 1910; Johnson, W. M., 1856; Krumbein, W. C., 1947; Lawson, A. C., 1894; Leeds, C. T., 1916, 1936; McKee, E. D., 1953; Marlette, J. W., 1954; Martens, J. H. C. 1939; Mason, M. A., 1942; Norris, R. M., 1951; Paguirigan, F., 194l; Putnam, W. C., 1938; Richardson, R. W., 1923; Ritter, W. E., 1901; Schupp, R. D., 1953; Shepard, F. P., 1935d, 1938g, 1950b, 1950g; Smith, W. S. T., 1898; Thompson, W. O., 1937; Walters, L., 1953; Whitney, J. D., 1865; Willis, B., 1900 (beach conglomerate)

Cobbles - see Gravel

Colloi's, including Colloidal sediments (See also: Precipitation of Sediments, various types of colloidal sediments): Allen, W. E., 194ld; Dietz, R. S., Emery, K. O. and Shepard, F. P., 1942; Emery, K. O., 1946b; Emery, K. O. and Dietz, R. S., 1950; Fox, D. L., 1950; Fox, D. L., Isaacs, J. D. and
Corcoran, E. F., 1952; Galliher, E. W., 1933; Goldberg, E. D., 1954; Revelle, R., 1935, 1937b, 1950; Revelle, R. and Emery, K. O., 1951; Scripps Institution of Oceanography, 1953e; Trask, P. D., 193la; Urry, W. D. and Piggot, C. S., 1942; ZoBell. C. E., 1938, 1939, 1942b, 19470; ZoBell, C. E. and Anderson, D. Q., 1936

Collophane: Carsola, A. J. and Dietz, R. S., 1952; Dietz, R. S., Emery, K. O. and Shepard, F. P., 1942; Emery, K. O., 194la, 1948; Emery, K. O., Butcher, W. S., Gould, H. R. and Shepard, F. P., 1952; Emery, K. O. and Dietz, R. S., 1950; Holzman, J. E., 1950; Uchupi, E. , 1954

Color of Sediments (See also: various colors of sediments): Anonymous, 1954m; Cartwright, L. D., Jr., 1928; Dietz, R. S., Emery, K. O. and Shepard, F. P., 1942; Emery, K. O., Butcher, W. S., Gould, H. R. and Shepard, F. P., 1952; Emery, K. O. and Dietz, R. S., 1950; Galliher, E. W., 1935c; Gorsline, D. S., 1954; Holzman, J. E., 1950; Krumbein, W. C., 1942; Moore, D. G., 1951; Nelson, J. W., Dean, W. C., Kocher, A. E., Watson, E. B. and Carpenter E. J., 1920; Nelson, J. W., Zinn, C. J., Strahorn, A. T., Watson, E. B. and Dunn, J. E., 1919; Norris, R. M., 1951; Page, G. B., 1950; Revelle, R. and Shepard, F. P., 1939b; Stevenson, R. E., 1954; Trask, P. D. and Scott, T., 1954; ZoBell, C. E., 1938

Compaction: Cohee, G. V., 1938; Dill, R. F., 1952; Emery, K. O., 1945a, 1948, 1950e; Emery, K. 0., and Dietz, R. S., 1941; Emery, K. O. and Rittenberg, S. C., 1951, 1952; Krumbein, w. C., 1942, 1947; Natland, M. L., Revelle, R. and Rittenberg, S. C., 1941; Piggot, C. S. and Urry, W. D., 1942; Revelle, R., 1950; Shepard, F. P., 1949b; Stockman, L. P., 1949b; Sverdrup, H. U. and Staff, 1941; Trask, P. D., 193la; Varney, F. M. and Redwine, L. E., 1937; ZoBell, C. E., 1944

Competance: Handin, J. W. and Ludwick, J. C., 1949

Concentration of Sediments in the Surf Zone (See also: Beach Cycles, Littoral Drift, Rip Currents, Suspended Sediments, Transport of Sediments): Grant, U. S., 1943; Handin, J. W., 1949; LaFond, E. C., 1939b; Marlette, J.W., 1954; Munk, W. H., 1949b; Shepard, F. P., 1942a, 1950c, 1950f, 1950g; Shepard, F. P., Emery, K. O. and LaFond, E. C., 1941; Shepard, F. P. and LaFond, E. C., 1940, 1942; Watts, G. M. and Others, 1953

Concrete: Schaufele, H. J., 1951

Concretions (See also: Barite, Manganese, Nodures, Dolites, Phosphorite): Emery, K. 0., 1945a, 1946b, 1950a, 1950d; Emery, K. O. and Shepard, F. P., 1945; Galliher, E. W., 1933; Kemnitzer, L. E., 1933; Krumbein, W. C., 1942; Lakes, A., 1903b; Revelle, R. and Emery, K. O., 195l; Shepard, F. P., 1949b, 1950b; Shepard, F. P. and Emery, K. O., 1941; Wooster, W. S., 1951

Condensation (See also: Fog, Meteorology): Sverdrup, H. U., 19390

Conduction: Goldberg, E. D., 1954 (electrical conductivity); Leipper, D. F., 1947; Lipman, C. B., 1929; McEwen, G. F., 1929, 1933, 1934a, 1937b; Mayor, A. G., 1922 (electrical conductivity); Moberg, E. C., 1928a, 1930c; Scripps Institution of Oceanography, 1953e (thermal conductivity); Sverdrup, H. U., $193 \varepsilon_{a}$

Conglomerate (See also: Cobble Beach): Butcher, W. S., 1951a; Cohee, G. V., 1938; Clark, B. L., 1931; Dietz, R. S., Emery, K. O. and Shepard, F. P., 1942; Emery, K. O., Butcher, W. S., Gould, H. R., and Shepard, F. P., 1952; Emery, K. O. and Dietz, R. S., 1950; Emery, K. O. and Natland, M. L., 1952; Emery, K. 0 . and Shepard, F. P., 1945; Emery, K. 0. and Tschudy, R. H., 1941; Hanna, G. D., 1952; Hinds, N. E. A., 1952; Landes, K. K., 1952a; McKee, E. D., 1953; Shepard, F. P., 1935c, 1936f, 1941a, 1949b; Shepard, F. P. and Emery, K. O., 1941; Shepard, F. P. and MacDonald, G. A., 1938; Shepard, F. P. and Wrath, W. F., 1937; Thompson, W. O., 1937; Trask, P. D., 1931b; Uchupi, E., 1954; Vaughan, T. W., 1936, 1940; Willis, B., 1900

Consolidation, Lithification: Trask, P. D., 193la; Trask, P. D. and Rolston, J. W., $1950 \mathrm{~b}$

Continental Borderland: Butcher, W. S., 195la; Congressional 
Documents, 1953b; Dietz, R. S., 1938, 1952a, 1952b; Dietz, R. S., Emery, K. O. and Shepard, F. P., 1942; Eardley, A. J., 1954; Emery, K. 0., 1952a; Emery, K. O. and Rittenberg, S. C., 1952; Handin, J. W., 1949; Hinds, N. E. A., 1952; Holzman, J. E., 1950; Krynine, P. D., 1937; Ludwick, J. C., Jr., 1950; Norris, R. M., 1951; Revelle, R. and Emery, K. O., 1951; Revelle, R. and Shepard, F. P., 1939b; Schupp, R. D., 1953; Shepard, F. P., 1937c, 1948c, 1951a; Shepard, F. P. and Emery, K. O., 1941; Shurnway, G. A., 1953; Sverdrup, H. U., 1939a; Uchupi, E., 1954; Upson, J. E., 1951; Wisser, E., 1954

Continenta? Drift: Bucher, W. H., 1939; Gutenberg, B., 1936b; Ma, T. Y. H., 1952

Continental Shelf: Anonymous, 1938a, 1940d, 1946a, 1950b, 1952e, 1954j; Agassiz, A., 1905; Allen, W. E., 1923f, 1945; Anderson, F. M., 1896-1902; Armstrong, T. A., 1954; Banđy, O. L., 1953a; Beach Erosion Board, 1948h, 1948i, 1952b, 1954a; Belknap, G. E., 1874b; Bucher, W. E., 1940; Buffington, E. C., 1951, 1952; Butcher, W. S., 1951a; Bullard, E. C., 1940; California, University of, 1954b; Chesterman, C. W., 1952; Clark, B. L., 1931; Clary, W. W., 1949; Cohee, G.V., 1938; Congressional Documents, 1953b; Crooke, R. C., Elvitsky, A. W., et al, 1953; Crowell, J. C., 1947, 1952; Daly, R. A., 1939; Davidson, G., 1875a, 1875b, 1887, 1897; Davis, W. M., Putnam, W. C. and Richards, G. J., Jr., 1931; Defant, A., 1950a; Dietz, R. S., 1938, 1951 (continental terrace), 1952a, 1952b; Dietz, R. S., Emery, K. O. and Shepard, F. P., 1942; Dietz, R. S. and Menard, H. W., 1951a, 1951b; Dill, R. F., 1952; Dill, R. F., Dietz, R. S. and Stewart, H., 1954; Diller, J. S., 1902; Dunham, J. W., 1951; Dunkle, M. P., 1944, 1950; Eaton, J. E., 1932, 1943; Eaton, R. 0., 1951; Emery, K. 0., 1947b, $1947 \mathrm{c}, 1950 \mathrm{c}, 1951,1952 \mathrm{a}, 1952 \mathrm{~b}, 1954 \mathrm{~b}$; Emery, K. O., Butcher, W. S., Gould, H. R. and Shepard, F. P., 1952; Emery, K. O. and Dietz, R. S., 1950; Emery, K. O. and Gould, H., 1948; Emery, K. O. and Rittenberg, S. C., 1952; Emery, K. O. and Shepard, F. P., 1941, 1945; Emmonds, S. F. and Merrill, G. P., 1894; Ewing, G. C., 1950c; Fairbanks, H. W., 1897, 1904; Fisher, R. L. and Mills, R., 1952; Fleming, R. H., 1937-1938; Ford, J. L. C., 1942; Fox, D. L., 1937; Gale, H. S. and Others, 1932; Galliher, E. W., 1935a, 1935b; Garrison, L. E. and Takasaki, K. L., 1950; Gorsline, D. G., 1954; Grim, R. E., Dietz, R. S. and Bradley, W. F., 1949; Gross, H. E., 1945; Gutenberg, B., 194la; Handin, J. W., 1949; Handin, J. W. and Luđwick, J. C., 1949; Hanna, G. D., 1952; Hansen, H. A. and Pemberton, J. R., 1950; Hershey, O. H., 1902, 1903; Hill, R. T., 1928b; Hinds, N. E. A., 1952; Hobbs, W. H., 1921; Holway, R. S., 1905; Horrer, P. L., 1950; Hughes, R. V., 1932; Inman, D. L., 1949, 1950, 1953b; Jeffreys, H., 1934; Jenkins, O. P., 1943a; Kuenen, Ph. H., 1947; LaFond, E. C., Dietz, R. S. and Knauss, J. A., 1950; Landes, K. K., 1952a; Lawson, A. C., 1893a, 1893b, 1924, 1939, 1950; Leconte, J., 1891; Leeds, C. T., 1936; Littlehales, G. W., 1932a; Louderback, G. D., 1930; Lukens, R. R., 1933; McEwen, G. F., 1927; MacDonald, G. A., 1934; Ma, T. Y. H., 1952; Marlette, J. W., 1954; Maxson, J. H., 1932; Meinesz, F. V. A., 1941; Miller, J. C., 1953; Miller, R. L., 1954; Mitchell, G. D., 1928; Moore, D. G., 1951; Mouton, M. W., 1952; Norris, R. M., 1951; O'Brien, M. P., 1936a, 1939; Pardee, J. T., 1934; Patton, R. S., 1930; Pratt, W. E., 1947; Putnam, W. C., 1937b; Revelle, R., 1938, 1950; Revelle, R., and Shepard, F. P., 1939a, 1939b, 1943; Richter, C. F., 1940; Richter, C. M., 1887; Richardson, R. W., 1923; Rotbwell, W. T. J., 1946; Rude, G. T., 1934; Sanford, J. J., 1908; Schupp, R. D., 1953; Scripps Institution of Oceanography, 1952i; Shaler, N. S., 1892, 1895; Shepard, F. P., 1932, 1933a, 1933b, 1933c, 1934a, 1934b, $1935 \mathrm{a}, 1935 \mathrm{e}, 1937 \mathrm{~b}, 1937 \mathrm{~d}, 1937 \mathrm{e}, 1937 \mathrm{f}, 1937 \mathrm{~g}$, $1938 \mathrm{f}, 1939 \mathrm{~b}, 1939 \mathrm{~d}, 1940 \mathrm{a}, 1940 \mathrm{c}, 1940 \mathrm{~d}, 1940 \mathrm{e}$, $1941 \mathrm{a}, 1941 \mathrm{~b}, 1942 \mathrm{~b}, 1943 \mathrm{a}, 1947 \mathrm{~b}, 1948 \mathrm{c}, 1949 \mathrm{~b}$, $1949 \mathrm{c}, 1949 \mathrm{~d}, 1950 \mathrm{e}, 1951 \mathrm{a}, 1951 \mathrm{e}, 1952 \mathrm{a}, 1953$; Shepard, F. P. and Emery, K. 0., 1941, 1945; Shepard, F. P. and Inman, D. L., 1949, 1951b;
Shepard, F. P. and MacDonald, G. A., 1934, 1938; Shepard, F. P., Revelle, R. and Dietz, R. S., 1939 Shuler, W. R., 1952; Smith, W. D., 1919, 1933a, 1933b, 1933c; Smith, W. S. T., 1900, 1902; Sneddon, R. 1948; Spencer, J. W., 1890; Sverdrup, H. U., 1939a, $1940 \mathrm{~g}, 1944 \mathrm{~b}$; Sverdrup, H. U. and Staff, 1941; Thompson, w. C., 1949 Toit, A. L., du., 1940; Trask, P. D., 1930, 1931b, 1939; Treasher, R. C. 1937; Udden, J. A., 1914; Updegraff, D. M., 1948; Upham, W., 1899; Vaughan, T. W., 194C; Ward, H. A., 1952; Weeks, L. G., 1952; Wharton, M., 1948; Woodford, A. 0., 1951; Woodring, W. P., 1938a; Woollard, G. P., 195l; ZoBell, C. E., 1938

Continental Shelf, Glaciation on: Davidson, G., 1875a; Shepard, F. P., 1932

Continental Shelf, Gradient, Slope: Anonymous, 1938a; Beach Erosion Board, 1952b; Butcher, W. S., 195la; Congressional Documents, 1953b; Dietz, R. S. and Menard, H. W., 1951b; Dill, R. F., 1952; Emery, K. O., Butcher, W. S., Gould, H. R. and Shepard, F. P., 1952; Inman, D. L., 1950; Lawson, A. C., 1893a, 1924, 1950; Leeds, C. T., 1936; MacDonald, G. A., 1934; Marlette, J. W., 1954; Moore, D. G., 1951; Norris, R. M., 1951; O'Brien, M. P., 1936a, 1939; Putnam, W. C., 1937b; Shepard, F. P. and Emery, K. O., 1941; Shepard, F. P. and MacDorald, G. A., 1938; Shuler, W. R., 1952; Smith, W. D., 1933c; Smith, W. S. T., 1900; Woodford, A. O., 1951

Continental Shelf, origin: Erosion (subaerial or submarine erosion, generally by waves and currents): Bucher, W. H., 1940; Davidson, G., 1875a; Dietz, R. S., 1951, 1952b; Dietz, R. S., Enery, K. O. and Shepard, F. P., 1942; Dietz, R. S. and Menard, H. W., 195la and 1951b (also includes the continental slope); Eaton, R. O., 1951; Fairbanks, H. W., 1897; Lawson, A. C., 1893a; MacDonald, G. A., 1934; Miller, J. C., 1953; Pratt, W. E., 1947; Schupp, R. D., 1953; Shepard, F. P., 1949d, 1950e; Shepard, F. P. and Emery, K. O., 1941; Shepard, F. P. and MacDonald, G. A., 1938; Smith, W. D., 1933b; Smith, W. S. T., 1900,1902

Sedimenation: Bucher, W. H., 1940; Bullard, E. C., 1940; Dietz, R. S., 1951, 1952b; Dietz, R. S. and Menard, H. W., 195la and $1951 \mathrm{lb}$ (also includes the continental slope); Eaton, R. 0., 1951; Fairbanks, H. W., 1897; Miller, J. C., 1953; Pratt, W. E., 1947; Shepard, F. P., 1938f, 1940e, 1949d; Shepard, F. P. and Emery, K. 0., 1945; Shepard, F. P. and MacDonald, G. A., 1938; Smith, W. S. T., 1900

Structural, including faulting and warping: Bullard, E. C., 1940; Dietz, R. S., 1951, 1952b; Emery, K. 0., 1950c; Lawson, A. C., 1924, 1939; Miller, J. C., 1953; Pratt, W. E., 1947; Shepard, F. P., 1940e; Toit, A. L. du, 1940 (also includes the continental slope)

Other: Davidson, G., 1875a; Dietz, R. S. and Menard, H.W., 1951a, 1951b; Eaton, R. O., 1951; Miller, J. C., 1953; Toit, A. L. du, 1940

Continental Shelf Profiles: Anonymous, 1938a; Dietz, R. S. and Menard, H. W., 1951b; Dill, R. F., 1952; Inman, D. L., 1950; LaFond, E. C., Dietz, R. S. and Knauss, J. A., 1950; Lawson, A. C., 1924; Shepard, F. P. and MacDonald, G. A., 1938; Shepard, F. P. and Wrath, W. F., 1937 (insular shelf) l Shelf, Width: Beach Erosion Board, 1948h, 1948i; Belknap, G. E., 1874b; Congressional Documents, 1953b; Dietz, H. W. and Menard, H. W., 1951b; Dunkle, M. B., 1950; Fairbanks, H. W., 1897; Ford, J. L. C., 1942; Handin, J. W., 1949; Hansen, H. A. and Pemberton, J. R., 1950; Inman, D. L., 1950; Kuenen, Ph. H., 1947; Lawson, A. C., 1924, 1950; Leeds, C. T., 1936; Marlette, J. W., 1954; Miller, J. C., 1953; Moore, D. G., 1951; Pardee, J. T., 1934; Pratt, W. E., 1947; Sanford, J. J., 1908; Shepard, F. P., 1939b, 1940c; Shuler, W. R., 1952 Smith, W. D., 1933b; Smith, W. S. T., 1900, 1902; Sneddon, R., 1948; Sverdrup, H. U. and Staff, 1941; Wharton, M., 1948

Continental Slope: Beal, C. H., 1945; Bucher, W. H., 1940; Butcher, W. S., 195la; Buffington, E. C., 1951, 1952; Carsola, A. J. and Dietz, R. S., 1952; Chesterman, C. W., 1952; Clements, T. anđ Emery, 
K. O., 1947; Cochraste, J. D. and Arthur, R. S. 1948; Cohee, G. V., 1938; Congressional Documents, 1953b; Crowell, J. C., 1952; Daly, R. A., 1939; Davis, W. M, 1933; Dietz, R. S., 1938, 1951, 1952a, 1952b; Dietz, R. S., Emery, K. 0., and Shepard, F. P., 1942; Dietz, R. S. and Menard, H. W., 195la, 1951b; Dill, R. F., 1952; Dill, R. F., Dietz, R. S. and Stewart, H., 1954; Diller, J. S., 1915; Eardley, A. J., 1954; Emery, K. 0., 1948, 1950c, 1951, 1952b, 1953a, 1954a, 1954b, 1954d; Emery, K. O., Butcher, W. S., Gould, H. R. and Shepard, F. P., 1952; Emery, K. O. and Rittenberg, S. C., 1952; Emery, K. O. and Shepard, F. P., 1945; Fleming, R. H., 1937-1938; Handin, J. W., 1949; Hanna, G. D., 1952; Hansen, H. A. and Pemberton, J. R., 1950; Hess, H. H. and MacClintock, P., 1936; Hill, R. T., 1928b; Hinds, N. E. A., 1952; Holway, R. S., 1905; Inman, D. L., 1950; Kuenen, Ph. H., 1947; Landes, K. K., 1952a; Lawson, A. C., 1924, 1939, 1950; Littlehales, G. W., 1932a, 1932b; Ma, T. Y. H., 1952; Maxson, J. H., 1932; Menard, H. W. and Dietz, R. S., 1951; Menard, H. W. and Ludwick, J. C., 1951; Pratt, W. E., 1947; Raitt, R. W., 1949; Revelle, R. and Shepard, F. P., 1939b; Sanford, J. J., 1908; Shaler, N. S., 1895; Shepard, F. P., 1932, 1933a, 1934b, 1936c, $1936 \mathrm{e}, 1936 \mathrm{f}, 1937 \mathrm{~g}, 1938 \mathrm{f}, 1938 \mathrm{i}, 1939 \mathrm{~b}, 1940 \mathrm{~b}$, $1940 \mathrm{c}, 1940 \mathrm{~d}, 1940 \mathrm{e}, 194 \mathrm{a}, 194 \mathrm{c}, 1943 \mathrm{a}, 1950 \mathrm{e}$, 1951a, 1951b, 1951e, 1952a; Shepard, F. P. and Beard, C. N., 1938; Shepard, F. P., and Emery, K. 0., 1941; Shepard, F. P. and MacDonald, G. A., 1938; Shepard, F. P. and Stetson, H. C., 1939; Shumway, G. A., 1953; Smith, W. S. T., 1900, 1902 ; Sverdrup, H. U., 1940g; Toit, A. L. du., 1940; Trask, P. D., 1939; Trask, P. D. and Hammar, H. E., 1931; Udden, J. A., 1914; Vaughan, T. W., 1940; Woodford, A. 0., 1951; Wooster, W. S., 1951

Continental Slope, Coarse Material at Break in Slope: Shepard, F. P., 1944d

Continental Slope, Gradient: Dietz, R. S., 1952b; Dietz, R. S. and Menard, H. W., 1951b; Dill, R. F., 1952 ; Emery, K. O., 1950c; Inman, D. L., 1950; Lawson, A. C., 1924; Littlehales, G. W., 1932a, 1932b; Sanford, J. J., 1908; Shepard, F. P., 194la; Shepard, F. P. and Beard, C. N., 1938; Shumway, G. A., 1953; Smith, W. S. T., 1900; Toit, A. L. du., 1940

Continental slope, origin:

Erosion: Bucher, W. H., 1940; Dietz, R. S. and Menard, H. W., 195la and 1951b (also includes the continental shelf)

Sedimentation: Bucher, W. H., 1940; Dietz, R. S., 1951 (also includes the continental shelf); Dietz, R. S. and Menard, H. W., 1951a, 1951b; Emery, K. 0., 1950c

Structural, including faulting and warping: Dietz, R. S., 1951, $1952 \mathrm{~b}$ (also includes the continental shelf); Dilier, J. S., 1915; Emery, K. O., 1950c, Landes, K. K., 1952a; Lawson, A. C., 1939, 1950; Shepard, F. P., 1940e; Toit, A. L. du, 1940 Other: Dietz, R. S., 1951; Dietz, R. S. and Menard, H. W., 195la, 1951b; Emery, K. O., 1950c

Continental Terrace - see Continental Shelf

Convection, including Convection Currents: Brongersma-Sanders, M., 1948; Bullock, F. W., 1933; Cummings, N. W., 1950; Ewing, G. C., 1950b; McEwen, G. F., 1916, 1929, 1933, 19370, 1937-1938; Moberg, E. G., 1930b; Revelle, R. and Shepard, F. P., 1939b; Rice, E. K., 1951; Scripps Institution of Oceanography, 1952i; Sverdrup, H. U., 1938a, 1939b, 1944b; Sverdrup, H. U. and Allen, W. E., 1939 (connection layer); Uchupi, E., 1954 (convection layer)

Convergence, Waves etc.: Arthur, R. S., 1950; Burt, W. V. and Saur, J. F. T., Jr., 1948; California Academy of Sciences, California Division of Fish and Game, Scripps Institution of Oceanography of the University of California, and U. S. Fish and Wildlife Service, 1950; Cochrane, J. D. and Arthur, R. S. 1948; Congressional Documents, 1953; Dawson, E. Y., 1952; Dunham, J. W., 1951; Ewing, G. C., 1950b, 1950c; Grant, U. S., 1946; Grant, U. S. and Shepard, F. P., 1946; Handin, J. W., 1951; Horrer 1950; Inman, D. L., 1949, 1953a; Marlette, J. W., 1954; Munk, W. H., 1948; Munk, W. H. and Anderson,
E. R., 1948; Munk, W. H. and Traylor, M. A., 1947 ; Nicholson, G. F., Grant, U. S., Shepard, F. P. and Crowell, J. C., 1946; Peel, K. P., 1951; Scripps Institution of oceanography, 1953c; Shepard, F. P., 1949a, 1950b, 1950c, 1950g, 1951a, 1952a; Shepard, F. P. and Grant, U. S., 1947; Shepard, F. P. and Inman, D. L., 1949, 1951a, 1951b; Shepard, F. P. and Saymer, D. B., 1953; Sverdrup H. U., 1938a; Vaughan, T. W., 1940; Williams, E. A. and Isaacs, J. D., 1952

Cooling: Jacobs, W. C., 1949; McEwen, G. F., 1934b; Sverdrup, H. U., $1938 \mathrm{a}, 1939 \mathrm{c}$

Copepods (See also: Plankton, Zooplankton): Allen, W. E., 1920, 1923f, 1927c; Bigelow, H. B. and Leslie, M., 1930; Bush, J. B., 1930; California Academy of Sciences, California Division of Fish and Game, Scripps Institution of Oceanography of the University of California, and U. S. Fish and Wildife Service, 1950; California Academy of Sciences, California Division of Fish and Game, Stanford University, Hopkins Marine Station, U. S. Fish and Wildife Service, South Pacific Fisheries Investigation, University of California, Scripps Institution of Oceanography, 1953; Dietz, R. S., 1948; Esterly, C. 0., 1911, 1912, 1923, 1928b; Johnson, M. W., 1939a; Lewis, R. C., 1927; Mason, E. H. 1930; Moberg, E G., 1925, 1928d; Murphy, H. E. , 1924; Russell, F. S., 1934 (including composition of); Taylor, C. V. and Vaughan, T. W., 1934 Vaughan, T. W., 1934; ZoBell, C. E., 1942a

Copper: Ahlstrom, E. H., 1950; Marks, G. W., 1938; Revelle, R. and Emery, K. O., 1951; Thompson, T. G. and Robinson, R. J., 1932; Trask, P. D., 1939; ZoBell, C. E., 1939

Coprolites: Coe, W. R., 1945; Dapples, E. C., 1942; Dietz, R. S., Emery, K. O. and Shepard, F. P., 1942; Emery, K. 0., 1948; Emery, K. 0., Butcher, W. S., Gould, H. R. and Shepard, F. P., 1952; Fox, D. L., 1937, 1950; Fox, D. I. and Anderson, L. J., 1941; Fox, D. L., Updegraff, D. M., Novelli, G. D., 1944; Galliber, E. W., 1932, 1935a, 1935c; Phleger, F. B., 1951; Vaughan, T. W., 1933

Coquina (See also: Carbonates, Limestone, Marl, Shells): Ha11, J. V., Jr., 1952; McKee, E. D., 1953

Coral Reefs - see Corals, Reefs

Corals: Anonymous, 1942; Butcher, W. S., 195la; Carsola, A. J. and Dietz, R. S., 1952; Dietz, R. S., Emery, K. O. and Shepard, F. P., 1942; Dietz, R. S., Menard, H. W., and Hamilton, E. L., 1954; Durham, J. W., 1942; Emery, K. 0., Butcher, W. S., Gould, H. R. and Shepard, F. P., 1952; Emery, K. O. and Dietz, R. S., 1950; Emery, K. O. and Stevenson, R. E., 1950; Fraser, C. McL., 1943; Haase, I. G., 1926; Hanna, G. D., 1952; Hertlein, L. G. and Emerson, W. K., 1953; Natland, M. L., Revelle, R. and Rittenberg, S. C., 1941; Pease, W. H., 1868 (also coral sand); Shepard, F. P., 1932; Shepard, F. P. and MacDonald, G. A., 1938; Shepard, F. P. and Emery, K. O., 1945; Uchupi, E., 1954; Vaughan, T. W., 1930d, 1931, 1940

Cores and Coring (See also: Dredging, Snapper Samples): Anonymous, 1944b; Atwill, E. R., 1942; Bartholomew, J. W. and Rittenberg, S. C., 1949; California, University of, 1953a, 1953b; Cohee, G. V., 1938; Crouch, R. W., 1951; Dietz, R. S., 1954; Dietz, R. S., Emery, K. O., and Shepard, F. P., 1942; Dill, R. F., 1952; Dill, R. F., Dietz, R. S. and Stewart, H., 1952, 1954; Emery, K. 0., 1954b; Emery, K. O. and Dietz, R. S., 1939, 1941; Emery, K. O. and Natland, M. L., 1952; Emery, K. O. and Rittenberg, S. C., 1951, 1952; Emery, K. O. and Shepard, F. P., 1945; Emery, K. O. and Tschudy, R. H., 1941; Emiliani, C., 1954; Ford, J. L. C. 1942; Fox, D. L., 1937, 1944a, 1944b, 1950; Fox, D. L. and Anderson, L. P., 1941; Fox, D. L., Updegraff, D. M. and Novelli, G. D., 1944; Galliher, E. W., 1935b, 1935c; Garrison, L. E. and Takasaki, K. L., 1950; Gorsline, D. S., 1954; Harding, C. R., 1929; Hoots, H. W., 1943; HooverYoung San Francisco Bay Bridge Commission, 1930; Inman, D. L., 1950; Kuenen, Ph. H., 1947; Kuenen, $\mathrm{Ph}$. H. and Menard, H. W., 1952; Louderback, G. D. 1920, 1940; Ludwick, J. C., Jr., 1950; MacDonald, G. A., 1934; Marlette, J. W., 1954; Moberg, E. G. Fleming, R. H., Heusner, K. and Revelle, R., 1937; 
Natland, M. L., Revelle, K. and Rittenberg, s. C., 1941; Phleger, F. B., 1951; Piggot, C. S., 1944; Piggot, C. S. and Urry, W. D., 1942; Revelle, R., 1938, 1939b, 1950; Revelle, R. and Emery, K. O., 1951; Revelle, R. and Shepard, F. P., 1939b; Rittenberg, S. C., 1940; Rotschi, H., 1951; Scripps Institution of Oceanography, 1952i, 1953e; Shepard, F. P., 1938b, 1939d, 1940a, 1940d, 1940e, $1941 \mathrm{a}, 1947 \mathrm{~b}, 1948 \mathrm{~b}, 1948 \mathrm{c}, 1949 \mathrm{~b}, 1949 \mathrm{~d}, 1949 \mathrm{e}$ 1950a, 1950d, 1951a, 1951b, 1951d, 1953; Shepard, F. P., and Emery, K. 0., 1941; Shepard, F. P., Revelle, R., Dietz, R. S. and Emery, K. O., 1938; Shepard, F. P. and Stetson, H. C., 1939; Smith, P. V., Jr., 1954; Stormont, D. H., 1953; Sverdrup, H. U., 1938c, 1939a, 1940e; Sverdrup, H. U. and Staff, 1941; Trask, P. D., 1931b; Trask, P. D. and Rolston, J. W., 1950a; Trask, P. D. and Scott, T., 1954; Urry, W. D. and Piggot, C. S., 1942; Varney, F. M. and Redwine, L. E., 1937; Wooster, W. S., 1951; ZoBel1, C. E., 1936, 1938, 1939, 1942a, 1942b, 1947c; ZoBell, C. E. and Anderson, D. Q., 1936; ZoBell, C. E. and Feltham, C. B., 1942

oriolis Force: Hidaka, K., 1953; Munk, W. H., 1950; Nicholson, F. F., Grant, U. S., Shepard, F. P. and Crowell, J. C., 1946; Sverdrup, H. U., 1939c

orrosion: Bates, C. C. and Glenn, A. H., 1948; Sweeney, J., 1930

eep (See also: Littoral Drift, Traction, Transport of Sediments): Grant, U. S., 1938

escentric Beaches - see Cuspate Forelands

retaceous: Butcher, W. S., 195la; Carsola, A. J. and Dietz, R. S., 1952; Cohee, G. C., 1938; Coxe, L. C., 1949; Eardley, A. J., 1954; Emery, K. 0., 194la, 1941b, 1941c, 1946b, 1951, 1952a; Emery, K. O., Butcher, W. S., Gould, H. R. and Shepard, F. P., 1952; Emery, K. O. and Shepard, F. P., 1941, 1945; Emery, K. O. and Tschudy, R. H., 1941; Hanna, G. D., 1952; Kew, W. S. W., 1928; Mason, H. L., 1929; Revelle, R. and Emery, K. O., 1951; Shepard, F. P., 1936d; Shepard, F. P. and Emery, K. O., 1941; Shepard, F. P. and MacDonald, G. A., 1938

ross-Bedding (See also: Lamination): Anonymous, 1951d; Merriam, P. D., 1949; Olsson-Seffer, P., 1908a; Shepard, F. P., 1949d, 1951b; Thompson, W. O., 1933,1934

urrents (See also: Bottom Currents, Convection Currents, Eddies, Littoral and Longshore Currents, Sediment Transport, Turbidity Currents; Submarine Canyons, Currents in; Submarine Canyons, origin of): Anonymous, 1859, 1891, 1929a, 1933e, 1938a, 1940c, 1940d, 1950b, 1950d, 1954j; Agassiz, A., 1905; Ahlstrom, E. H., 1950; Alden, J., 1854b; Allen, W. E., 1921a, 1921e, 1925, 1940c, 1941a, 1941c, 1945, 1946b; Andrews, H. L., 1945; Arthur, R. S., 1950; Bartsch, P., 192la, 1921b; Bascom, W. N., $1946 \mathrm{a}, 1947 \mathrm{c}$; Bates, C. C. and Glenn, A. H., 1948; Beach Erosion Board, 1942a, 1948a, 1948b, 1948i, 1952b, 1953b, 1953c; Benest, H., 1899; Berghaus, H., 1891; Bigelow, H. B. and Leslie, M., 1930; Bishop, S. E., 1904; Blake, D., 1926; Blake, W. P., 1856; Branner, J. C., 1913; Brant, I., 1925; Brongersma-Sanders, M., 1948; Brooks, C. W., 1875; Brown, E. I., 1939; Bruff, S. C., 1946; Buck, C. D., 1928; Buffington, E. C., 1952; Bullard, F. M. and Mills, R. A., 1951; Bullock, F. W., 1933; Butcher, W. S., 195la; California Academy of Sciences, California Division of Fish and Game, Scripps Institution of Oceanography of the University of California and U. S. Fish and Wildlife Service, 1950, 1951a, 1951b; California Academy of Sciences, California Division of Fish and Game, Scripps Institution of oceanography of the University of California, U. S. Fish and Wildlife Service, and Hopkins Marine Station, Stanford University, 1951; California Academy of Sciences, California Division of Fish and Game, Stanford University, Hopkins Marine Station, U. S. Fish and Wildlife Service, South Pacific Fisheries Investigations, University of California, Scripps Institution of Oceanography, 1952, 1953; California Department of Public Works, 1952f; California, University of, 1952a; Carpenter, F. A., 1924; Carsola, A. J., 1947; Carsola, A. J. and Dietz, R. S., 1952; Chase, J. L., 1948; Clark, A. H., 1914; Cockerell, T. D. A., 1938b;
Coe, W. R., 1945, 1947, 1953; Colbert, L. 0., 1939; Congressional Documents, 1880c, 1908a, 1938a, 1940a, 1942b, 1942c; Couch, E. B., 1915; Crooke, R. C., Elvitsky, A. W., et al, 1953; Crowell, J. C., 1947; Dall, W. H., 1904, 1911; Davidson, G., 1856, 1859, 1864, 1869, 1873a, 1873c, 1875a, 1884, 1897; Davis, H. 1872; Davis, W. M., 1925, 1933, 1934; Dawson, E. Y., 1951; Defant, A., 1950b; DeGroot, H., 1890; Dietz, R. S., 1952a, 1952b; Dietz, R. S., Emery, K. O. and shepard, F. P., 1942; Dill, R. F., 1952; Disney, L. P. and Overshiner, W. H., 1925; Dunham, J. W., 1951; Dunkle, M. B., 1950; Durham, J.W., 1952; Eaton, R. O., 1951; Eddy, H. P., Hyde, C. G., Kennedy, C. C. and Reynolds, L. B., 1936; Eldredge, Z. S. and Molera, E. J., 1909;

Elliott, F. E., Tressler, W. I. and Myers, W. H., 1953; Emery, K. 0., 1947b, 1948, 1952a, 1952b, 1953b, 1954d; Emery, K. O., Butcher, W. S., Gould, H. R. and Shepard, F. P., 1952; Emery, K. O. and Dietz, R. S., 1950; Emery, K. 0. and Rittenberg, S. C., 1952; Emery, K. O. and Shepard, F. P., 1945; Emery, K. O. and Tschudy, R. H., 1941; Emilian1, C. and Epstein, S., 1953; Epstein, S. and Mayeda, T., 1953; Evans, O. F., 1941; Evans, R. D., Kipp, A. F. and Moberg, E. G., 1938; Ewing, G. C., 1950b; Findlay, A. G., 1851;

Fleming, R. H., 1939b, 1940b, 1942; Fleming, R. H., Revelle, R., 1939; Fleming, J. A., and Sverdrup, H. U., Ennis, C. C., Seaton, S. L. and Hendrix, W. C., 1945; Folsom, R. G., 1944c; Fries, A. A., 1912; Galliher, E. W., 1933, 1935c; Gilbert, G. K., 1917; Gilbert, J. Y. and Allen, W. E., 1943; Gislén, T., 1943, 1944; Goldberg, J., 1940; Gorton, A. F., 1930a, 1930b; Graham, H. W., 1934, 1941a, 1941b; Graham, H. W. and Moberg, E. G., 1944; Grant, U. S., 1938; Grant, U. S. and Shepard, F. P., 1937, 1938a, 1940, 1946; Great Britain Hydrographic Office 1866; Griggs, A. B. and Wells, F. G., 1942; Gulliver, F. P., 1896; Hall, W. C., 1942; Handin, J. W., 1949; Hanna, M. A., 1926; Harts, W. W., 1911; Hawgood, H., 1914; Hertlein, I. G., and Emerson, W. K., 1953; Hewatt, W. G., 1946; Hidaka, K., 1953; Hinds, N. E. A., 1952; Holway, R. S., 1905; Holzman, J. E., 1950; Hoover, J. W., 1932a; Hoover-Young San Francisco Bay Bridge Commission, 1930; Horonjeff, R. and Patrick, D. A., 1952; Horrer, P. L., 1948a; Horton, D. F., 1948; Hough, J. L., 1942; Hyde, C. G., Gray, H. F. and Rawn, A. M., 1941; Inman, D. L., 1949, 1950, 1953a, 1953b; Inman, D. L. and Quinn, W. H., 1952; Isaacs, J. D., 1945c, 1948; Isaacs, J. D. and Bascom, W. N., 1947; Jacobs, W. C., 1939, 1943 Johnson, A. G., 1935, 1940c; Johnson, D. W., 1910, 1944; Johnson, M. W., 1939a; Johnson, M. W., Everest, F. A. and Young, R. W., 1947; Jones, E. L., 1918; Kindle, E. M., 1934; Kniffen, F. B., 1932 (in Gulf of California and Colorado River); Koczy, F. F., 1954; Krumbein, W. C., 1947; Kuenen, Ph., H. and Menard, H. W., 1952; LaFond, E. C., 1938, 1939a, 1940; Larsen, G. P., 1942a, 1942b; Lawson, A. C., 1894, 1950; Lawton, C. H., 1936; Leeds, C. T., 1936; Leeds, C. T., Vanoni, N. A. and Knapp, R. T., 1934; Leipper, D. F., 1947; Leslie, M., 1928; Louderback, G. D., 1940 , 1951; Leypoldt, H., 1941a, 1942; McAdie, A. G., 1914; McAfee, C. M., Jr., 1939; McEwen, G. F., $1910,1912,1914,1915,1916,1918,1919 a$, 1919b, 1927, 1928b, 1930b, 1930c, 1933, 1934a, 1934b, 1934 c, 1936, 1937c, 1937a, 1937-1938, 1948; McEwen, G. F. and Staff, 1948; McManus, A. B. 1934; MacDonald, C. A., 1834; MacGinitie, G. E., 1935; Mao, H., 1951; Marlette, J. W., 1954; Marmer, H. A., 1926; Mason, E. H., 1930; Mason, M. A., 1942, 1948, 1949a, 1950a, 1950b, 1951; Mayor, A. G., 1922; Means, T. H., 1928, 1931; Means, E. G., 1943, 1944; Menard, H. W., 1952; Michae1, E. L., 1919, 1921; Michael, E. L. and McEwen, G. F., 1915; Moberg, E. G., 1925, 1927, 1930b; Moberg, E. G., 1925, 1927, 1930b; Moberg, E. G., Fleming, R. H., Heusner, K. and Revelle, R., 1937; Moberg, E. G. and Graham, H. W., 1930; Moberg, E. G., Seiwell, H. R., Graham, H. W. and Paul, J. H., 1930; Moore, D. G., 1951; Morrison, R. L., 1930; Munk, W. H., 1940, 1947b, 1950; Munk, w. H. and Anderson, E. R., 1948; 
Munk, W. H. and Traylor, M. A., 1947; Myers, E. H., 1943; Nicholls, C. P. L., 1936a, 1936c, 1939; Nicholson, G. F., Grant, U. S., Shepard, F. P. and Crowell, J. C., 1946; Norris, R. M., 1952; O'Brien, M. P., 1936a, 1936b, 1939, 1941, 1946a, 1947b; Olsson-Seffer, P., 1910a; Osorio Tafall, B. F., 1944; Pardee, J. T., 1934; Patton, C. P., 1953; Pratt, W. E., 1947; Putnam, J. A., Bermel, K. J. and Johnson, J. W., 1947; Putnam, w. C., 1938; Rawn, A. M. and Bowerman, F. R., 1951; Reed, R. D., 1933a; Reed, W. G., 1914; Re1d, R. O., 1948a, 1948b; Remondino, P. C., 1892; Revelle, R., 1939a, 1950; Revelle, R. and Shepard, F. P., 1939a, 1939b, 1943; Rice, E. K., 1951; Richardson, R. W., 1923; Richter, C. M., 1887; Ritter, W. E., 1902, 1924; Rode, K., 1930; Rolland, M. C., 1952; Rossby, C.-G., 1951; Rosser, W. H., 1870; Rude, G. T., 1933; Russell, F. S., 1934; Sanchez, P. C., 1934c; San Diego Regional Water Pollution Control Board, 1952; Sargent, M. S. and Walker, T. J., 1948; Saur, J. T. F., Jr., 1950; Schneider, W. A., 1954; Schott, G., 1934, 1935; Schupp, R. D., 1953; Scofield, E. C., 1934; Scripps Institution of Oceanography, 1944c, 1949a, 1949b, 1949c, 1949d, $1949 \mathrm{e}, 1950 \mathrm{a}, 1950 \mathrm{~b}, 1950 \mathrm{c}, 1950 \mathrm{~d}, 1950 \mathrm{e}, 1950 \mathrm{f}$, $1950 \mathrm{~g}, 1951 \mathrm{a}, 1951 \mathrm{~b}, 1951 \mathrm{c}, 1951 \mathrm{~d}, 195 \mathrm{le}, 195 \mathrm{lf}$, $1951 \mathrm{~h}, 1951 \mathrm{i}, 1951 \mathrm{l}, 195 \mathrm{~lm}, 195 \mathrm{ln}, 19510,1951 \mathrm{r}$, $1952 \mathrm{a}, 1952 \mathrm{~b}, 1952 \mathrm{c}, 1952 \mathrm{~d}, 1952 \mathrm{e}, 1952 \mathrm{f}, 1952 \mathrm{~g}$, $1952 i, 1953 b, 1953 c, 1953 d, 1953 e$; Shaler, N. S., 1895; Shepard, F. P., 1932, 1933b, 1936a, 1936f, $1937 \mathrm{~b}, 1938 \mathrm{~b}, 1938 \mathrm{c}, 1938 \mathrm{f}, 1939 \mathrm{e}, 1940 \mathrm{c}, 1940 \mathrm{~d}$, $1942 \mathrm{a}, 1943 \mathrm{~b}, 1947 \mathrm{a}, 1948 \mathrm{~b}, 1949 \mathrm{a}, 1949 \mathrm{~b}, 1949 \mathrm{~d}$, $1949 \mathrm{e}, 1950 \mathrm{~b}, 1950 \mathrm{c}$ (seasonal currents), 1950e, 1950f, 1950g, 195la, 195le, 1952a; Shepard, F. P. and Emery, K. O., 1941, 1945; Shepard, F. P. and Inman, D. L., 1949, 1951b: Shepard, F. P. and LaFond, E. C., 1939, 1940, 1942; Shepard, F. P. and MacDonald, G. A., 1938; Shepard, F. P. and Wrath, W. F., 1937; Shuck, O. T., 1869; Shumway, G. A., 1953; Shipmasters and others, 1879; Sinnott, A., 1941; Skosberg, T., 1932, 1933, 1934, 1936; Skosberg, T. and Phelps, A., 1946; Smith, J. P., 1904; Smith, W. D., 1933b, 1933c; Smith, W. S. T., 1897; Somers, P., 1952; Stelzenmuller, Wm. B., 1949; Stockmann, W. B., 1946; Surner, F. B., Louderback, G. D., Schmitt, W. L. and Johnston, E. C., 1914; Sverdrup, H. U., 1934, 1936, 1937-1938, $1938 \mathrm{a}, 1938 \mathrm{~b}, 1938 \mathrm{c}, 1938 \mathrm{~d}, 1939 \mathrm{a}, 1939 \mathrm{~b}, 1939 \mathrm{c}$, $1940 \mathrm{a}, 1940 \mathrm{~b}, 1940 \mathrm{c}, 1940 \mathrm{~d}, 1940 \mathrm{e}, 1940 \mathrm{f}, 1941 \mathrm{~b}$, $1941 c$, 1942, 1944a, 1944b, 1947; Sverdrup, H. U. and Allen, W. E., 1938; Sverdrup, H. U. and Fleming, J. A., 1944; Sverdrup, H. U. and Fleming, R. H. 1941; Sverdrup, H. U. and Johnson, M. W. and Fleming, R. H., 1942; Sverdrup, H. U. and Staff, $1941,1942 \mathrm{a}, 1942 \mathrm{~b}, 1943 \mathrm{~b}, 1944,1945 \mathrm{~b}, 1946,1947 \mathrm{~b}$; Symons, T. W., 1893; Tanner, Z. L., 1892a (drift), $1892 b$ (submarine currents), 1893 (drift), 1894 (drift); Thorade, H., 1909, 1914; Tibby, R. B., 1937a, 1937b, 1939, 1943, 1944; Tilden, C. A., 1925; Topp, E. P., 1929; Trask, P. D., 1931a, 1931b, 1932a, 1934, 1939, 1952a, 1952b; Twenhofel, W. H., 1943, 1946; Uchup1, E., 1954; Ufford, C. W., 1947b; U. S. Bureau of Fisheries, 1921 (drift); U. S. Hydrographic office, 1875, 1944a, 1947a; U. S. Waterways Experiment Station, Vicksburg, Mississippi, 1950; VanDorn, W. G., 1953; Vaughan, T. W., 1931, 1932a, 1932c, 1933, 1934, 1940; White, D., 1911; Woodford, A. 0., 1935; Wooster, W. S., 1952; Yale, C. G., 1879; ZoBell, C. E., 1942a, $1947 \mathrm{c}$

Cuspate Forelands, Cuspate Coasts, Hooks, Crescentric Beaches: Davis, W. M., 1932; Evans, O. F., 1941; Gulliver, F. P., 1896; Leypoldt, H., 1941b, 1942; O'Brien, M. P., 1941; Reiche, P., 1937; Shaler, N. S., 1895; Smith, W. S. T., 1902; Stevenson, R. E., 1954

Cusps - see Beach Cusps

Cut and/or Fill, Depth Changes. Generally applies to beach and nearshore and in submarine canyons. (See also: Beach Cycles; Submarine Canyon, Changes in; Turbidity Currents): Anonymous, 1938a, 1940d; Bascom, W. N., 1946d; Beach Erosion Board, 1948a, $1948 \mathrm{j}, 1949 \mathrm{a}, 1952 \mathrm{a}, 1953 \mathrm{~b}$, 1954b; California, University of, 1952a, 1952d, 1953a, 1953b, $1954 a$, 1954b; Congressional Documents, 1940a, 1953b; Dletz, R. S., 19470; Dletz, R. S. and Menard, H. W., 1951b; Dietz, R. S., Menard, H. W. and Hamilton, E. L., 1954 (fill in deep sea); Eaton, J. E., 1943 Emery, K. O., Butcher, W. S., Gould, H. R. and Shepard, F. P., 1952 (fill in basins); Emery, K. O and Rittenberg, S. C., 1952 (fill in basins); Frie man, S. L., 1949; Grant, U. S. and Shepard, F. P., 1937, 1938a; Hall, J. V., Jr., 1952; Harris, F. R. and Harlow, E. H., 1948; Harts, W. W., 1901;

Inman, D. L., 1949, 1953a, 1953b; Johnson, D. W., 1910; Johns on, J. W., 1947b; LaFond, E. C., 1938; Moberg, E. G. and Allen, W. E., 1927; Munk, W. H., $1949 \mathrm{~b}$ (bottom sediment movement); Norris, R. M., 1952 (shifting sand); O'Brien, M. P., 1939; Palmer, R. H., 1928 (shifting sand); Revelle, R. and Shepard, F. P., 1939b; Scripps Institution of Oceanography, 1952i, 1953f; Shepard, F. P., 1938g, $1947 \mathrm{~b}, 1950 \mathrm{c}, 1950 \mathrm{e}, 1950 \mathrm{~g}, 195 \mathrm{la}$; Shepard, F.

P., Emery, K. O. and LaFond, E. C., 1941; Shepard, F. P. and Inman, D. L., 1951b; Shepard, F. P. and LaFond, E. C., 1940, 1942; Shepard, F. P. and MacDonald, G. A., 1938 (shifting of bottom materia Shuler, W. R., 1951, 1952; Stelzenmuller, W. B., 1949; Thompson, W. F. and Thompson, J. B., 1919; Tower, M. L., 1913; Trask, P. D., 1952a; Trask, P. D. and Scott, T., 1954

Cycles - see Beach Cycles

Dacite (See also: Igneous Rock, Rock): Butcher, W. S., 195la Clements, T. and Dana, S. W., 1944; Emery, K. 0 . and Shepard, F. P., 1945; Holzman, J. E., 1950

Decomposition of Organic Matter - see organic Matter, Decomposition of

Deeps - see Trench

Deflation - see Wind Transport

Deformation - see Warping

Degrade - see Beach Erosion

Dehydration - see Temperature of Hydration and Dehydration

Delta (See also: Submarine Canyon, Terminal End): Anonymous, $1929 b, 1933 b, 1938 a, 1941 b, 1951 b ;$ Allen, W. E., 1933a; Anderson, C. A., 1950; Beach Erosion Board, 1948i, 1948j, 1953a; Blake, W. P., 1856; Brown, C. B., 1942; Bucher, W. H., 1940; California Depar ment of Public Works, 1932a; California, Universit of, 1952a; Carpenter, E. J. and storie, R. E., 1929; Congressional Documents, 1908f, 1953b, 1954t Dapples, E. C., 1942; Darrow, W. E., 1942; Dietz, R. S. and Menard, H. W., 1951b; Eaton, J. E., 1932 Eldredge, Z. S. and Molera, E. J., 1909; Emery, K. O., Butcher, W. S., Gould, H. R. and Shepard, F. P., 1952; Fox, C. K., 1936; Gilbert, G. K., 191 Grant, U. S., 1944; Grunsky, C. E., 1907; Gulliver F. P., 1896; Johnson, D. W., 1910; King, R. E., 1939; Kniffen, F. B., 1929, 1931, 1932; Knox, G. L., 1937; Kuenen, Ph. H., 1947; Lawson, A. C., $1893 a, 18936,1894,1914,1924,1950$; Lawson, L. M., 1950; Leeds, C. T., 1915; Livingston, A. Jr., 1939; Louderback, G. D., 1940; McKee, E. D., 1939, 1953; Means, T. H., 1928, 1931; Nelson, E. W., 1922; Nelson, N. C., 1909; O'Brien, M. P., 1936a; Orange County Planning Comnission, 1941; Putnam, W. C., 1938; Revelle, R. and Shepard, F. P., 1939b; Robertson, R. R., 1942; Sanchez, P. C. 1934c; Schupp, R. D., 1953; Scripps Institution of Oceanography, 1953c; Shaler, N. S., 1895 ( $t$ ida delta); Shepard, F. P., 1932, 1933a, 1937e, 1937g 1938f, 194la, 1949d, 1950d, (fan in basin), 1950e, 1951d; Shepard, F. P. and Emery, K. O., 1941; Shuler, W. R., 1951, 1952; Smith, P. A., 1940; Smith, W. D., 1933b; Spencer, J. W., 1890; Steven son, R. E., 1954; Sykes, G., 1926, 1937, 1938; Thompson, W. O., 1937; Trask, P. D., 1928, 1931b, 1934, 1939; Trask, P. D., and Hammar, H. E., 1931 Trowbridge, W. P., 1856b; Wanless, H. R., 1950

Density, generally refers to density of water: Allen, $W$ E., 194lc; Bigelow, H. B. and Leslie, M., 1930; Bullock, F. W., 1933; Dall, W. H., 1911; Dietz, R. S., 1947b; Emery, K. O., 1954d; Emery, K. 0 . and Rittenberg, S. C., 1952; Ewing, G. C., 1950a; Fleming, J. A., Sverdrup, H. U., Ennis, C. C., Seaton, S. L., and Hendrix, W. C., 1945; Fleming, R. H., 1942; Grahem, H. W., 1934; Graham, H. W. and Moberg, E. G., 1944; Harvey, D. R., 1928; Hidaka, K., 1953; Holway, R. S., 1905; Jacobs, W. C., 1939, 1949; LaFond, E. C., 1939a; Lesser, R. M., 1951; McEwen, G. F., 1910, 1916, 1928b, 19 
McKee, E. D., 1953; Menard, H. W. and Ludwick, J. C., 1951; Merrill, F. J. H., 1915; Moberg, E. G., 1928a, 1930c; Moberg, E. G. and Fleming, R. H., 1934; Munk, W. H., 1940; Munk, W. H. and Anderson, E. R., 1948; Nicholson, G. F., Grant, U. S., Shepard, F. P. and Crowell, J. C., 1946 (sand grains); Reid, R. O., 1948b; Revelle, R. and Shepard, F. P., 1939b; Rudnick, P. and Cochrane, J. D., 1951; Scripps Institution of Oceanography, $1949 \mathrm{a}$ to $1950 \mathrm{e}, 1950 \mathrm{a}$ to $1950 \mathrm{e}, 1950 \mathrm{~g}$, 1951a to 1951f, 1951h, 19511, 1951j. 1951L, 1951m, 1952a, $1952 b$, 1952e, 1952f, 1952g; Shepard, F. P.

1950c; Shepard, F. P. and Emery, K. O., 1941; Sverdrup, H. U., 1934, 1937-1938, 1938a, 1939a, 1939c, 1940g, 194la, 1941b, 1944a; Sverdrup, B. U. and Fleming, J. A., 1944; Sverdrup, H. U., Johnson, M. W. and Fleming, R. H., 1942; Sverdrup, H. U., and Staff, 1941, 1944, 1947b; Tibby, R. B., 1943; Topp, E. P., 1929; Trask, P. D., 1939; Ufford, C. W., 1947a, 1947c; U. S. Bureau of Fisheries, 1921; U. S. Coast and Geodetic Survey, 1950; U. S. Hydrographic office, 1934b; Vaughan, T. W., 1930b, 1932a, 1932c, 1940; Wiegel, R. L., Patrick, D. A. and Kimerley, H. L., 1953 (sand grains); Young, R. T., Jr., 1939

Density Currents - see Turbidity Currents; Submarine Canyons, origin of

Density Stratification - see Stratification, Water

Depositional Folds: Emery, K. 0., 1946b

Depth Changes - see Cut and/or Fill; Submarine Canyons, Changes in

Detritus, Detrital Sediments (See also: various detrital sediment types): Beach Erosion Board, 1953c; Coe, W. R., 1945, 1947, 1948; Coe, W. R. and Fox, D. L., 1942, 1944, 1945a; Crouch, R. W., 1954; Davidson, G., 1897; Dietz, R. S., Emery, K. O. and Shepard, F. P., 1942; Emery, K. 0., 1946b, 1947c, 1952a; Emery, K. O. and Dietz, R. S., 1950; Fox, D. L., 1950; Fox, D. L. and Coe, W. R., 1943; Fox, D. L., Updegraff, D. M. and Novelli, G. D., 1944; Goldberg, E. D., 1954; Gorsline, D. S., 1954; Piggot, C. S., 1944; Revelle, R., 1950; Revelle, R. and Emery, K. O., 195l; Shaler, N. S., 1895; Sverdrup, H. U., 1938d (organic); ZoBell, C. E., 1938

Diabase: Norris, R. M., 1951; Shepard, F. P., 1938e

Diagenesis (See also: Authigenic Minerals, Bacteria etc. and all the factors causing or bringing out diagenetic changes in sediments): Dapples, E. C., 1942; Dill, R. F., 1952; Dietz, R. S., 1941; Dietz, R. S. and Emery, K. O., 1938a, 1938b; Emery, K. 0., 1947a, 1948, 1950e; Emery, K. 0. and Dietz, R. S., 1950; Emery, K. O. and Rittenberg, S. C., 1951, 1952; Fox, D. L., Updegraff, D. M. and Novelli, G. D., 1944; Galliher, E. W. 1932b, 1933, 1935a, 1935c, 1937; Grim, R. E., Dietz, R. S. and Bradley, W. F., 1949; Krumbein, W. C., 1942; Osorio Tafall, B. F., 1943; Revelle, R., 1941, 1950; Revelle, R, and Emery, K. O., 1951; Sverdrup, H. U. and Staff, 1941; Trask, P. D., 1931b, 1934, 1939; Vaughan, T. W., 1935a; Weeks, L. G., 1952; ZoBell, C. E., 1938, 1939, $1942 \mathrm{a}, 1942 \mathrm{~b}, 1946 \mathrm{~b}, 1947 \mathrm{c}$

Diastrophism (See also: Continental Shelf, origin; Continental Slope, Origin; Emergence, Folding, orogenesis; Submarine Canyon, origin; Submergence, Subsidence, Tilting, Warping): Anonymous, 1925a; Ashley, G. H., 1931; Bailey, T. L., 1943; Bow1e, W., 1924a; Bucher, W. H., 1939, 1940; Chamberlin, R. T., 1944; Clark, B. L., 1930; Congressional Documents, 1953b; Daly, R. A., 1934; Davis, W. M., 1932, 1933; Dietz, R. S. and Menard, H. W., 1951b; Eardley, A. J., 1954; Emery, K. O., Butcher, W. S., Gould, H. R. and Shepard, F. P., 1952; Emery, K. O. and Dietz, R. S., 1950; Emery, K. O. and Shepard, F. P., 1945; Galliher, E. W., 1935a; Gutenberg, B., 1933; Hobbs, W. H., 1921; Johnson, D., 1944; Landes, K. K. , 1952a; Lawson, A. C., 1893b, 1939; LeConte, J., 1891; Louderback, G. D., 1921, 1941 ; Ma, T. Y. H., 1952; Maxson, J. H , 1932; Norris, R. M., 1951; Putnam, W. C., 1938; Revelle, R., 1950; Sanchez, P. C., 1934a, 1934c; Shepard, F. P., $1935 \mathrm{a}, 1936 \mathrm{c}, 1936 \mathrm{~g}, 1937 \mathrm{~d}, 1938 \mathrm{~d}, 1940 \mathrm{~b}, 1941 \mathrm{~b}$, $1949 b, 1950$ e, 1951c; Shepard, F. P. and Emery, K. 0., 1937, 1941; Smith, W. D., 1933b; Spencer, J.W.,
1890; Sverdrup, H. U. and Staff, 1942a; Trask, P. D., 1931b; Uchupi, E., 1954; Upham, W., 1899; Upson, J. E., 1949b; Willis, B., 1900; Wisser, E., 1954; Wood, H. O., 1915; Woodring, W. P., 1938b

Diatoms (See also: Algae, Phytoplankton, Plankton): Anonymous, 1882b, 1891, 1944b; Ahlstrom, E. H., 1950; Allen, W. E., 1921a, 1921d, 1922a, 1922b, 1922c, $1923 a, 1923 b, 1923 c, 1923 d, 1923 e, 1923 f, 1924 a$, $1924 \mathrm{~b}, 1925,1926,1927 \mathrm{a}, 1927 \mathrm{~b}, 1927 \mathrm{c}, 1927 \mathrm{~d}$, $1928 \mathrm{a}, 1928 \mathrm{~b}, 1928 \mathrm{c}, 1929,1930 \mathrm{a}, 1930 \mathrm{~b}, 1933 \mathrm{a}$, $1934 \mathrm{a}, 1934 \mathrm{~b}, 1936,1937 \mathrm{~b}, 1938 \mathrm{a}, 1938 \mathrm{~b}, 1938 \mathrm{c}$, $1939 \mathrm{a}, 1939 \mathrm{~b}, 1939 \mathrm{c}, 1940 \mathrm{a}, 1940 \mathrm{~b}, 1940 \mathrm{c}, 1940 \mathrm{~d}$, $1941 \mathrm{a}, 1941 \mathrm{~b}, 1941 \mathrm{c}, 1941 \mathrm{~d}, 1942 \mathrm{a}, 1942 \mathrm{~b}, 1945$, 1946a,; Allen, W. E. and Lewis, R., 1927;

Bigelow, H. B. and Leslie, M., 1930; Buley, H. M., 1929; Bullock, F. W., 1933; Bush, J. B., 1930; California Academy of Sciences, California Division of Fish and Game, Scripps Institution of oceanography of the University of California, and U. S. Fish and wildlife Service, 1950, 195la; California Academy of Sciences, California Division of Fish and Game, Stanford University, Hopkins Marine Station, U. S. Fish and Wildlife Service, South Pacific Fishery Investigation, University of California, Scripps Institution of Oceanography, 1953; Chesterman, C. W., 1952; Coe, W. R., 1945, 1947; Coe, W. R. and Allen, W. E., 1937, 1942, 1944; Couch, E. B., 1915; Cupp, E. E., 1930, 1934a, 1934b, 1943; Cupp, E. E. and Allen, W. E., 1938; Dietz, R. S., 1952a; Dietz, R. S. and Emery, K. O., 1938; Dietz, R. S., Emery, K. O. and Shepard, F. P., 1942; Dietz, R. S. and LaFond, E. C., 1950; Dill, R. F., 1949; Dorman, H. P., 1927a, 1927b; Emery, K. O., 1952b, $1954 a$, Emery, K. O. and Dietz, R. S., 1941, 1950; Emery, K. O. and Shepard, F. P., 1945; Fleming, R. H., 1939a; Fox, D. B., 1929, 1930; Fox, D. L., 1944b, 1950; Fox, D. L. and Anderson, L J., 1941; Fox, D. L. and Coe, W. R., 1943; Fox, D. L., Isaacs, J. D. and Corcoran, E. F., 1952; Fox, D. L., Updegraff, D. M. and Novell1, G. D., 1944; Galliher, E. W., 1933; Gaylord, E. G. and Hanna, G. D., 1925; Gilbert, J. Y. and Allen, W. E., 1943; Gilsen, T., 1944; Goldberg, E. D., 1952, 1954; Goldberg, E. D., Walker, T. J. and Whisenand, A., 1952; Graham, H. W., 1934, 194la; Graham, H. W. and Moberg, E. G., 1944; Hanna, G. D., 1928, 1952; Harvey, D. R., 1928; Horrer, P. L., 1948a; Howard, L., 1934; Hughes, R. V., 1932; Leslie, M., 1928; Lewis, R. C., 1927, 1929; Mann, A., 1907; Mason, E. H., 1930; MeConnaughey, B. H. and Fox, D. L., 1949; Michael, E. L., 1919, 1921; Moberg, E. G., 1925, 1928a, 1928d, 1930c; Moberg, E. G. and Allen, W. E., 1927; Moyer, D. A., 1929b; Natland, M. L., Revelle, R. and Rittenberg, S. C., 1941; Osorio Tafall, B. F., 1943; P'e1, C., 1929; Revelle, R., 1939b; Ritter, W. E., 1902; Rosenfeld, W. D., 1948; Sargent, M. S. and Walker, T. J., 1948; Schneider, W. A., 1954; Sleggs, G. F., 1927; Sommer, H. and Clark, F. N., 1946; Sverdrup, H. U. and Allen, W. E., 1939; Sverdrup, H. U. and Staff, 1941, 1942b; Taylor, C. V. and Vaughan, T. W., 1934; Thayer, L. A., 1935; Thompson, T. G. and Robinson, R. J., 1932; Tilden, C. A., 1925; Topp, E. P., 1929; Trask, P. D., 1939; Trask, P. D. and Hammar, H. E., 1931; Vaughan, T. W., $1930 b, 1932 a, 1932 b, 1932 c, 1933,1940$; Whedon, W. F., 1939; ZoBell, C. E., 1939, 1941, 1942a, $1942 b, 1942 \mathrm{c}, 1946 \mathrm{~b}, 1946-1947$, 1947c; ZoBell, C. E. and Feltham, C. B., 1942; ZoBell, C. E., Grant, C. W. and Haas, H. F., 1943

Diatomg in Relation to origin of Petroleum (See aiso: Petroleum, Source Beds of Petroleum): Fox, D. L., 1944b; Fox, D. L. and Anderson, L. J., 1941; Fox, D. L., Updegraff, D. M. and Novelli, G. D., 1944; Gester, G. C., 1927; Hughes, R. V., 1932; Takahask1, J., 1925, 1928; Thayer, L. A., 1935; Trask, P. D., 1939; Trask, P. D. and Hammar, H. E., 1931; ZoBell, C. E., 1946b, 1946-1947; ZoBell, C. E., Grant, C. W. and Haas, H. F., 1943

Diatoms in Sediments, including Diatomaceous Sediments: Allen, W. E., 1941b, 1941d; Ford, J. L. C., 1942; Fox, D. L., 1944b, 1950; Fox, D. L. and Anderson, L. J., 1941; Fox, D. L., Updegraff, D. M. and Novelli, G. D., 1944; Gaylord, E. G. and Hanna, G. 
D., 1925; Gester, G. C., 1927; Hughes, R. V., 1932; Mann, A., 1907; Michael, E. L., 1919; Natland, M. L., Revelle, R. and Rittenberg, S. C., 1941; Piggot, C. S., 1932; Revelle, R., 1950; Scripps Institution of Oceanography, 1953e; Shumway, G. A., 1953; Sverdrup, H. U. and Staff, 1941; Takahashi, J., 1925, 1928; Thayer, L. A., 1935; Trask, P. D., 1939; Trask, P. D. and Hammar, H. E., 1931; ZoBell, C. E., 1939, 1946-1947; ZoBell, C. E. and Feltham, C. B., 1942; ZoBell, C. E., Grant, C. W. and Haas, H. F., 1943

Diffraction of Waves (See also: Wave Refraction): Handin, J. W. and Ludwick, J. C., 1949; Marlette, J. W., 1954; Munk, W. H. and Traylor, M. A., 1947; O'Brien, M. P. and Johnson, J. W., 1947; Ward, H. A., 1952

Diffusion: Ahlstrom, E. H., 1950; California Academy of Sciences, California Division of Fish and Game, Scripps Institution of oceanography of the University of California, and U. S. Fish and Wildlife Service, 1951b; Emery, K. 0. and Rittenberg, S. C., 1952; Ewing, G. C., 1950b; Inman, D. L., 1953; Krumbein, W. C., 1942; McEwen, G. F., 1916, 1919a, 1934a, 1934c, 1937o, 1940b, 1950; Mao, H., 1951; Miller, H. E. and Nusbaum, I., 1952; Munk, W. H. and Traylor, M. A., 1947; Phelps, A., 1937; Rawn, A. M. and Bowerman, F. R., 1951 Rice, E. K., 1951; San Diego Regional Water Pollution Control Board, 1952; Scripps Institution of Oceanography, 19521; Shepard, F. P., 19470; Sisler, F. D. and ZoBell, 1951a; Sverdrup, H. U., 1938a, 1938b, 1938c, 1938d, 1939c, 1941, 1944b; Sverdrup, H. U. and Staff, 1946; Tibby, R. B., 1944; ZoBell, C. E., 1942a, 1947d; ZoBell, C. E. and Feltham, C. B., 1942

Dilation: Emery, K. O. and Foster, J. F., 1948; Grant, U. S., 1946; Olsson-Seffer, P., 1910a

Dinoflagellates (See also: Phytoplankton, Plankton): Anonymous, 1943, 1944b; Allen, w. E., 192la, 1921d, $1921 e, 1922 a, 1922 b, 1923 a, 1923 c, 1923 d, 1923 \mathrm{f}$, $1924 \mathrm{a}, 1924 \mathrm{~b}, 1925,1927 \mathrm{a}, 1927 \mathrm{~b}, 1927 \mathrm{c}, 1927 \mathrm{~d}$, $1928 \mathrm{a}, 1928 \mathrm{~b}, 1928 \mathrm{c}, 1929,1930 \mathrm{a}, 1930 \mathrm{~b}, 1933 \mathrm{a}$, $1933 \mathrm{~b}, 1934 \mathrm{a}, 1935,1936,1937 \mathrm{a}, 1938 \mathrm{a}, 1939$, $1940 \mathrm{~b}, 1940 \mathrm{c}, 1940 \mathrm{~d}, 194 \mathrm{a}, 1942 \mathrm{~b}, 1943,1945$, 1946a, 1946b; Allen, W. E. and Lewis, R., 1927; Bathgate, v. M., 1913; Bonnot, P. and Phillips, J. B., 1938; Bongersma-Sanders, M., 1948; Buley, H. M., 1929; California Academy of Sciences, California Division of Fish and Game, Stanford University, Hopkins Marine Station, U. S. Fish and Wildlife Service, South Pacific Fishery Investigation, University of California, Scripps Institution of Oceanography, 1953; Coe, W. R., 1945, 1947; Coe, W. R. and Fox, D. L., 1942, 1944; Connell, C. H. and Cross, J. B., 1950; Cupp, E. E., 1930, 1934a; Dapples, E. C., 1942; Dawson, E. Y., 1951; Dorman, H. P., 1927a, 1927b; Fox, D. B., 1929; Fox, D. B., 1944b, 1950; Fox, D. L. and Coe, W. R., 1943; Fox, D. L., Isaacs, J. D. and Corcoran, E. F., 1952; Graham, H. W., 1934, 1941b; Harvey, D. R., 1928; Kniffen, F. B., 1932; Kofoid, C. A., 1911, 1928; Kofoid, C. A. and Swezy, 0., 1921; Leslie, M., 1928; Lewis, R. C., 1927, 1929; Mason, E. H., 1930; Moberg, E. G., 1925; Moberg, E. G. and Allen, W. E., 1927; Osorio Tafall, B. F., 1943; Pinchard, J. H., Kittredge, J. S., Fox, D. L., Haxo, F. T. and Zechmeister, L., 1953; Ritter, W. E., 1902; Sleggs, G. F., 1927; Sommer, H. and Clark, F. N., 1946; Sverdrup, H. U., 1939b; Tilden, C. A., 1925; Topp, E. P., 1929; Torrey, H. B., 1902; Whedon, W. F., 1939; Whedon, W. F. and Kofoid, C. A., 1936; ZoBell, C. E., $1947 \mathrm{c}$

Diorite (See also: Igenous Rock, Rock): Butcher, W. S., 195la; Chesterman, C. W., 1952; Clements, T. and Dana, S. W., 1944; Cohee, G. V., 1938; Holzman, J. E., 1950; Shumvay, G. A., 1953

Discolored Water - see Red Water, Turbid Water

Disconformity: Louderback, G. D., 1920; Shepard, F. P., 1932

Dispersion (See also: Diffusion): California Academy of Sciences, California Division of Fish and Game, Scripps Institution of oceanography, University of California, and U. S. Fish and Wildlife Service,
1950; Fox, D. L., 1950; Johnson, M. W., 1939; McEwen, G. F., 1940b; Munk, W. H., 1947; Revelle, R. and Shepard, F. P., 1939b; Sverdrup, H. U., 1939a; Sverdrup, H. U. and Staff, 1945a, 19450 Divergence of Waves etc. (See also: Wave Refraction): Arthur, R. S., 1950; Congressional Documents, 1953b; Dunham, J. W., 1951; Ewing, G. C., 1950b, 1950c; Grant, U. S., 1946; Grant, U. S. and Shepard, F. P., 1946; Horrer, P. L., 1950; Inman, D. L., 1953a; Munk, W. H., 1948; Munk, W. H. and Anderson, E. R., 1948; Munk, W. H. and Traylor, M. A., 1947; Nicholson, G. F., Grant, U. S., Shepard, F. P. and Crowell, J. C., 1946; Peel, K. P., 1951; Scripps Institution of oceanography, 1953c; Shepard, F. P., 1950c, 1950g; Shepard, F. P. and Inman, D. L., 1949; Sverdrup, H. U., 1937-1938, 1938a; Williams, E. A. and Isaacs, J. D., 1952

Divides - (See also: Saddles): Grant, U. S. and Shepard, F. P., 1940

Domes: Shepard, F. P., 1937e; Shepard, F. P., and Emery, K. 0., 1937

Downwelling (See also: Upwelling): California Academy of Sciences, California Division of Fish and Game, Stanford University, Hopkins Marine Station, South Pacific Fishery Investigation, University of Calffornia, Scripps Institution of Oceanography, 1952

Dŕedging (See also: Cores and Coring, Snapper Samples): Anonymous, 1906a, 1938a, 1938b, 1940d, 1941b, 1951b; Beach Erosion Board, 1948a, 1948 j, 1949a, 1954a; Blinn, F. S., 1928; Bucher, W. H., 1940; Butcher, W. S., 195la; California University of, 1954b; Carsola, A. J., Dietz, R. S. and Russell, R. D., 1949; Church, C. C., 1929; Clark, A., 1933; Clements, T. and Dana, S. W., 1944; Cohee, G. V., 1938; Colbert, L. O., 1939; Congressional Documents, 1880a, $1908 \mathrm{~g}$, $1926,1934 \mathrm{~b}, 1938 \mathrm{a}, 1938 \mathrm{~b}, 1940 \mathrm{a}, 1940 \mathrm{c}, 1940 \mathrm{~d}$, $1940 \mathrm{e}, 1940 \mathrm{f}, 1941,1942 \mathrm{~b}, 1943,1949 \mathrm{a}, 1949 \mathrm{~d}$, $1949 \mathrm{e}, 1949 \mathrm{f}, 1949-1950 \mathrm{~b}, 1953 \mathrm{a}, 1953 \mathrm{~b}$; Coxe, L. C., 1949; Crouch, R. W., 1954; Dana, S. W., 1942; David, L. R., 1946, 1947; Davis, W. M., 1933; Davidson, G., 1884; Dietz, R. S., 1954; Dietz, R. S. and Emery, K. O., 1938a, 1938b; Dietz, R. S., Emery, K. O. and Shepard, F. P. 1942; Dietz, R. S., Menard, H. W., and Hamilton, E. L., 1954; Eaton, R. O., 1951; Emery, K. O., $1941 \mathrm{a}, 1947 \mathrm{a}, 1947 \mathrm{~b}, 1947 \mathrm{c}, 1948,1952 \mathrm{~b}, 1954 \mathrm{~b}$; Emery, K. O., Butcher, W. S., Gould, H. R. and Shepard, F. P., 1952; Emery, K. O. and Dietz, R. S., 1950; Emery, K. O. and Gould, H., 1948; Emery, K. O. and Shepard, F. P., 1945; Emery, K. O. and Tschudy, R. H., 194I; Farrand, W. H., 1929; Fraser, C. McL., 1943; Galliher, E. W., 1935a, 1935b; Garrison, L. E., and Takasaki, K. L., 1950; Gillette, C. E., 1905; Gorsline, D. S., 1954; Hall, J. v., Jr., 1952; Hanna, G. D., 1952; Handin, J. W., 1949; Harding, C. R., 1929; Hawgood, H., 1914; Hertlein, L. G. and Emerson, W. K., 1953; Hewatt, W. G., 1946; Holzman, J. E., 1950; Hoots, H. W., 1943; Forton, D. F., 1948; Inman, D. L., 1950; James, E. L., 1950; Johnson, A. G., 1940c, 1951; Johnson, M. W., Everest, F. A. and Young, R. W., 1947; Kenyon, E. C., Jr., 1951; Kuenen, Ph. H., 1947; Lapsley, W. W., 1937; Leeds, C. T., 1915, 1936; Louderback, G. D., 1920, 1940; McAfee, C. M., Jr., 1939; McEwen, G. F., 1935b; McGowan, W. C., 1916; MacDonald, G. A., 1934; MacGinitie, G. E., 1939; Martin, L. T., 1935; Menard, H. W. and Ludwick, J. C., 1951; Michael, E. L. and McEwen, G. F., 1916; Moore, D. G., 1951; Morrison, R. L., 1930; Nelson, J. W., Zinn, C. J., Strahorn, A. T., Watson, E. B. and Dunn, J. E., 1919; Nicholson, G. F., 1929; Nicholson, G. F., Grant, U. S., Shepard, F. P. and Crowell, J. C., 1946; Norris, R. M., 1951; O'Brien, M. P., 1939; Packard, E. L., 1918; Postel, A. C., 1939; Raymond, R. W., 1880; Revelle, R. and Emery, K. O., 1951; Revelle, R. and Shepard, F. P:, 1939b; Rittenberg, S. C., 1940; Ritter, W. E., 1901, 1902; Rothwell, W. T., Jr., 1944, 1946; Shepard, F. P., 1933b, 1935a, 1935e, 1936c, 1936d, 1936f, 1937e, 1938b, 1938d, 1939d, 1940a, 1940c, 
$1940 \mathrm{~d}, 1940 \mathrm{e}, 1941 \mathrm{a}, 194 \mathrm{~Tb}, 1949 \mathrm{~d}, 1949 \mathrm{e}, 1950 \mathrm{e}$, 1953; Shepard, F. P. and Beard, C. N., 1938; Shepard, F. P. and Enery, K. O., 1941, 1945; Shepard, F. P. and MacDonald, G. A., 1938; Shepard, F. P. and Wrath, W. F., 1937; Shuler, W. R., 1951, 1952; Shumway, G. A., 1953; Stevenson, R. E., 1954; Sumner, F. B., Louderback, G. D., Schmitt, W. L., and Johnson, E. C., 1914; Sverdrup, H. U., 1938c; Townsend, C. H., 1901; Trask, P. D. and Scott, T., 1954; Uchupi, E., 1954; Vaughan, T. W., 1936; Woodring, W. P., 1938a; Wooster, w. S., 1951

Drift - see Littoral Drift, Longshore Currents, Continental Drift

Drowned Valley - see Submarine Canyons

Dynamic Height Anomalies and Topography: Bigelow, H. B. and Leslie, M., 1930; California Academy of Sciences, California Division of Fish and Game, Scripps Institution of Oceanography of the University of California, and U. S. Fish and Wildlife Service, 1950, 1951a; Fleming, J. A., Sverdrup, H. U., Ennis, C. C., Seaton, S. I. and Hendrix, W. C., 1945; Fleming, R. H., 1942; Fleming, R. H. and Revelle, R., 1939; Montgomery, R. B. and Wooster, W. S., 1954; Munk, W. H., 1940; Scripps Institution of Oceanography, 1949a, 1949b, $1949 \mathrm{c}, 1949 \mathrm{~d}, 1949 \mathrm{e}, 1950 \mathrm{f}, 1950 \mathrm{~g}, 195 \mathrm{la}, 1951 \mathrm{~b}$, 1951c, 1951d, 1951e, 1951f, 1951g, 1951h, 1951i, $1951 \mathrm{j}, 1951 \mathrm{k}, 1951 \mathrm{~L}, 1951 \mathrm{~m}, 1952 \mathrm{a}, 1952 \mathrm{~b}, 1952 \mathrm{e}$, 1952f, 1952g, 1953b; Sverdrup, H. U., 1937-1938, 1938a, 1944a; Sverdrup, H. U. and Fleming, J. A., 1944; Sverdrup, H. U. and Staff, 1942b, 1943b, 1944, 19470; Tibby, R. B., 1943, 1944

Eddies, including Eddy Currents: Bigelow, H. B. and Leslie, M., 1930; Bruff, S. C., 1946; California Academy of Sciences, California Division of Fish and Game, Scripps Institution of Oceanography of the University of California, and U. S. Fish and Wildlife Service, 195la, 1951b; California Academy of Sciences, California Division of Fish and Game, Stanford University, Hopkins Marine Station, U. S. Fish and Wildlife Service, South Pacific Fishery Investigation, University of California, Scripps Institution of Oceanography, 1952, 1953; Chase, J. L., 1948; Crooke, R. C., Elvitsky, A. W., et al, 1953; Crowell, J. C., 1947; Davidson, G., 1873c, 1887; Davis, W. M., 1933; Dawson, E. Y., 1951, 1952; Defant, A., 1950a, 1950b; Dietz, R. S., 1952b, 1953; Dietz, R. S. and Menard, H. N., 1951b; Dill, R. F., 1952; Evans, O. F., 1941; Ewing, G. C., 1950b; Fleming, R. H., 1942; Gilbert, G. K., 1917; Gislên, T., 1943; Graham, H. W., 1941b; Graham, H. W. and Moberg, E. G., 1944; Gulliver, F. P., 1896; Handin, J. W. and Ludwick, J. C., 1949; Hewatt, W. G., 1946; Holway, R. S., 1905; Horrer, P. L., 1948a; Hubbs, C. L., 1948; Inman, D. L., 1950, 1953a; Johnson, M. W., 1939b; Krumbein, W. C., 1947; Kuenen, Ph. H. and Menard, H. W., 1952; LaFond, E. C., 1939a; Leipper, D. F., 1950; Leypoldt, H., 1941b, 1942; McEwen, G. F., 1934d, 1948, 1950; McEwen, G. F., and Staff, 1948; MaO, H., 1951; Menard, H. W. and Ludwick, J. C., 1951; Munk, W. H., 1947b, 1950; Munk, W. H. and Anderson, E. R., 1948; Revelle, R., 1939a, 1940; Revelle, R. and Shepard, F. P., 1939a, 1939b; Richardson, R. W., 1923; Richter, C. M., 1887; Rossby, C.-G., 1951; Sargent, M. S. and Walker, T. J., 1948; Schaufele, H. J., 1951; Shepard, F. P., 1940a, 1941a, 1948b, 1949e, 1950b, 1950c, 1950g; Shepard, F. P. and Emery, K. O., 1941; Shepard, F. P., Emery, K. O. and LaFond, E. C., 1941; Shepard, F. P. and Inman, D. L., 1949; Sheperd, F. P., Revelle, R. and Dietz, R. S., 1939; Skogsberg, T., 1936; Sverdrup, H. U., $1937-1938,1938 \mathrm{~b}, 1938 \mathrm{c}, 1939 \mathrm{a}, 1939 \mathrm{c}, 1940 \mathrm{e}$, 1941c; Sverdrup, H. U. and Allen, W. E., 1939; Sverdrup, H. U. and Staff, 1942b, 1943b, 1946, 1947a; Tibby, R. B., 1943, 1944; Trask, P. D., 1952b; Uchupi, E., 1954; U. S. Waterways Experiment Station, Vicksburg, Mississippi, 1950; Whittemore, G. F., 1928; Yale, C. G., 1879

Eh (oxidation-reduction potential): Dill, R. F., 1952; Emery, K. 0., 1954d; Emery, K. 0. and Rittenberg, S. C., 1951, 1952; Hutton, W. E., and ZoBell,
C. E., 1949; Krumbein, W. C., 1942; Natland, M. L., Revelle, R. and Rittenberg, S. C., 1941; Revelle, R., 194l, 1950; Revelle, R. and Shepard, F. P., 1939b; Sisler, F. D. and ZoBell, C. E., 1951b; Smith, P. V., Jr., 1954; Stevenson, R. E., 1954; Sverdrup, H. U., 1940e; Vaughan, T. W., 1935a, 1935b; ZoBell, C. E., 1935, 1936, 1938, 1939 , 1941, 1942a, 1942b, 1943, 1944, 1946b, 19461947, 1947c, 1947d; ZoBell, C. E. and Anderson, D. Q., 1936; ZoBell, C. E. and Feltham, C. G., 1942

Electrical Conductivity - see Conduction

Elevated Sea Cliff (See also: Sea Cliffs): Davis, W. M., Putnam, W. C. and Richards, G. L., Jr., 1931

Ellutriation: Emery, K. O. and Foster, J. F., 1948

Embayment (see also: Bay, Estuary, Harbor, Lagoon): Anderson, C. A., 1941; Dietz, R. S., Emery, K. 0 . and Shepard, F. P., 1942; Gorsline, D. S., 1954; Herold, C. L., 1934; O'Brien, M. P. and Johnson, J. W., 1947; Shepard, F. P., 1936c; Smith, W. D., 1933b; Trask, P. D., 1931b

Emergence (See also: Diastrophism, Uplift, Warping): Anonymous, 1925a; Baldwin, E. M., 1945; Blake, J., 1868; Bowman, A., 1873; Bruff, s. C., 1940, 1946; Clements, T., 1946; Congressional Documents, 1953b; Corey, W. H., 1951, 1952; Cotton, C. A., 1944; Dall, W. H., 1911; Darton, N. H., 1921; Davidson, G., 1873d, 1875a; Davis, W. M., 1931, 1932, 1933; Eaton, J. E., 1943; Emery, K. O., Butcher, W. S., Gould, H. R. and Shepard, F. P., 1952; Emmonds, S. F. and Merrill, G. P., 1894; Goldberg, J., 1940; Hanna, M. A., 1926; Jenkins, O. P., 1943b; Lawson, A. C., 1893a, 1893b, 1894; Lucke, J. B., 1938; Maxson, J. H., 1931, 1932; Merrill, F. J. H., 1915; Pease, w. H., 1868; Putnam, W. C., 1938; Reed, R. D., 1934; Sanchez, P. C., 1934a; Shaler, N. S., 1895; Shepard, F. P., 1937d, 1940b, 1941a, 1949d, 1950e, 1950f, 1952a; Shepard, F. P. and Emery, K. O., 1945; Smith, J. P., 1910; Stevenson, R. E., 1954; Thompson, W. O., 1937; Toit, A. L. du, 1940; Weeks, L. G., 1952; Wheeler, G., 1936; Willis, B., 1900; Woodring, W. P. 1947

Encrusting Organisms - see Fouling

Endenism: Cockerell, T. D. A., 1938b

Engineering, including breakwaters, groins, jetties, marine drilling platforms, piers, sea walls, submarine cables and pipelines: Anonymous, 1906, 1915, 1916a, $1916 \mathrm{~b}, 1916 \mathrm{c}, 1916 \mathrm{~d}, 1916 \mathrm{e}, 1917,1925 \mathrm{~b}, 1933 \mathrm{~d}$, $1933 \mathrm{e}, 1935,1938 \mathrm{a}, 1938 \mathrm{~b}, 1940 \mathrm{~b}, 1940 \mathrm{c}, 1940 \mathrm{~d}$, $1941 b, 1944 a, 1950 f, 1951 b, 1952 d, 1952 f, 1952 g$, $1952 \mathrm{~L}, 1952 \mathrm{~m}, 1952 \mathrm{n}, 19520,1953 \mathrm{~b}, 1953 \mathrm{j}, 1954 \mathrm{c}$, 1954d, 1954i, 1954k; Aldrich, L. and Smith, H. G., 1948; Alexander, A. H., 1936; Allen, W. B., 1932; Archer, W. E., 1934; Arthur, R. S., 1951; Atwood, W. G. and Johnson, A. A., 1924; Bascom, W. N., 1947c; Bates, C. C. and Glenn, A. H., 1948; Beach Erosion Board, 1939, 1942a, 1948d, $1948 \mathrm{~h}, 1948 \mathrm{i}, 1948 \mathrm{j}, 1949 \mathrm{a}, 1950 \mathrm{~b}, 1951,1952 \mathrm{a}$, 1953a, 1953c, 1954a, 1954c; Benest, H., 1899; Blackman, J. W. B., 1936; Blinn, F. S., 1928; Boase, A. J., 1938; Bond, A. H., 1927; Brown, E. I., 1939; Bullington, J. P., 1940; Burt, W. V. and Saur, J. F. T., Jr., 1948; Butler, M. M., 1936; Buwalde, J., 1936; Caldwell, J. M., 1950; California, University of, 1952a, 1952a, 1953a, 1953b, 1954b; Clements, T. and Emery, K. O., 1947; Coe, W. R., 1932; Colden, C. J., 1926; Collins, L. B., 1931; Collins, L. B., Gilbert, J. C. and Simon, J. H., 1933; Congressional Documents, 1880b, 1880c, 1892, 1897, 1908a, $1908 \mathrm{r}, 1934 \mathrm{~b}, 1938 \mathrm{a}, 1938 \mathrm{c}, 1940 \mathrm{a}, 1940 \mathrm{~b}, 194 \mathrm{cc}$, $1940 \mathrm{~d}, 1940 \mathrm{e}, 1940 \mathrm{f}, 1941,1942 \mathrm{~b}, 1942 \mathrm{c}, 1943$, $1949 \mathrm{a}, 1949 \mathrm{~b}, 1949 \mathrm{c}, 1949 \mathrm{~d}$, 1949f, 1949-1950b, 1953a, 1953b; Corning, L. H., 1944; Coxe, L. C., 1949; Cram, C. M., 1931; Crowell, J. C., 1952; Darrow, W. E., 1942; Davidson, W. S. and Swanson, R. B., 1947; Dickey, L. K., 1936; Dunham, J. W., 1951; Eaton, R. O., 1951; Fox, L. S., 1930; Fries, A. A., 1912; Gaillard, D. D., 1904; Gee, H. C., 1938; Gilbert, J. C. and Simon, J. H., 1933; Gillette, C. E., 1905; Goldberg, J., 1940; Grant, U. S., 1938; Grant, U. S. and Shepard, F. P., 1937, 1938b, 1940; 
Granthem, K. N., 1953; Griffin, D. F., 1944; Hall, J. V., Jr., 1952; Hall, W. C., 1938, 1941; Halton, J. E. and Holden, E. R., 1950; Handin, J. W. , 1949, 1951; Handin, J. W. and Ludwick, J. C., 1949; Hannum, G. W. T., 1947; Hansen, H. A. and Pemberton, J. R., 1950; Harding, C. R., 1929; Harts, W. W., 1901, 1911; Hasskarl, J. F. L., 1912; Hawgood, H., 1914; Hickson, R. E. and Rodolf, F. W., 1951; HJelte, G., 1938;

Hoover-Young San Francisco Bay Bridge Commission, 1930; Horonjeff, R. and Patrick, D. A., 1952; Horrer, P. L., 1949, 1950; Horton, D. F., 1948; Hudson, R. Y. and Moore, L. F., 1951; Hunter, R. C., 1946; Inman, D. L., 1949, 1953a; Isaacs, J. D., 1947a; Isaacs, J. D. and Bascom, W. N., 1947; Iversen, H. W. and Morison, J. R., 1951; Johnson, A. G., 1935, 1940c, 1951; Johnson, J. W., 1947b, 1948b, 1948d, 1952; Johnson, J. W., and Isaacs, J. D., 1948; Kaplan, K. and Pape, H. E., Jr., 195l; Kenyon, E. C., Jr., 1951; Knapp, R. T., 1952; Knapp, R. T. and Vanoni, V. A., 1945; Kofo1d, C. A., 1921; Kofo1d, C. A. and Miller, R. C., 1927; Krumbein, W. C., 1950; LaFond, E. C., Dietz, R. S. and Knauss, J. A., 1950; Lamport, H. B., 1937; Lapsley, W. W., 1937;

Larsen, G. P., 1942b, 1946; Lawton, C. H., 1936; Leeds, C. T., 1916, 1936; Leeds, C. T., Vanon1, V. A. and Knapp, R. T., 1934; Leypoldt, H., 1937a, 1941b; Lieber, A. C., Jr., 1940; Livingston, A., Jr., 1940; Los Angeles County Regional Planning Commission, 1940; McAdam, D., 1947b; McAfee, C. M., Jr., 1939; McCamy, R. C., 1952; McEwen, G. F., 1935a, 1935b; McEwen, G. F. and Staff, 1948; McGowan, W. C., 1916; McKinstry, C. H., 1905; Mcouat, H. W., 1951; Marlette, J. W., 1954; Mason, M. A., 1942, 1949a, 1949b, 1950a, 1950b; Miller, J. C., 1953; Mills, B., 1932b, 1932g; Moore, D. G., 1951; Munk, W. H., 1948; Munk, W. H. and Traylor, M. A., 1947; Nicholson, G. F., Grant, U. S., Shepard, F. P. and Crowell, J. C., 1946; Nicholls, C. P. L., 1936a, 1941; O'Brien, M. P., $1936 \mathrm{a}, 1936 \mathrm{~b}, 1939$, 1941, 1944, 1947b; O'Brien, M. P. and Johnson, J. W., 1947; Orange County Planning Commission, 1941; O'Shaughnessy, M. M., 1924; Page, G. B., 1950; Palmberg, H. G., 1941; Peel, K. P., 1951; Pentegoff, V. P., 1947; Pomeroy, H. R., 1936; Postel, A. C., 1937, 1939; Pratt, W. E., 1947; Price, F., 1936; Purcell, G., 1914; Putnam, J. A. and Arthur, R. S., 1948; Putnam, J. A. and Bermel, K. J., 1946; Putnam, J. A., Munk, W. H. and Tray.lor, M. A., 1949; Pyles, E. E., 1954; Rawn, A. W. and Bowerman, F. R., 1951; Revelle, R. and Shepard, F. P., 1939b; Rolland, M. C., 1952; Salsbury, M. E. 1925; Sanford, J. J., 1908; San Francisco Bay Marine Piling Committee, 1921, 1922, 1923; Saville, T., Jr., 1951; Schaufele, H. J., 1951; Schermerhorn, L. Y., 1897; Schupp, R. D., 1953; Scott, T. A., 1936; Scripps Institution of Oceanography, 1944c; Sears, C. B., 1876; Shepard, F. P., 1933c, 1938a, 1948b, 1949b, 1950c, 1950g, 195la; Shepard, F. P. and Inman, D. L., 1951a, 1951b; Shepard, F. P. and LaFond, E. C., 1942; Shepard, F. P. and MacDonald, G. A., 1938; Shuler, W. R., 1951, 1952; Smith, J. S., 1936; Snodgrass, F. E., Morison, J. R., Hall, M. A., Granthem, K. N. and Wiegel, R. L., 1952; Snodgrass, F. E., Rice, E. K. and Hall, M. A., 1951; Somers, P., 1952; Stanton, T. E., Jr., 1938; Stelzenmuller, W. B., 1949; Stockman, L. P., 1932, 1949c; Stormont, D. H., 1951b, 1952a, 1952c; Streblow, A. G., 1951; Sweeney, J., 1930; Symons, T. W., 1893; Tanner, Z. L., 1892b, 1894; Tower, M. L., 1910, 1913; Trask, P. D., 1952a, 1952b; Trask, P. D. and Scott, T., 1954; Tudor, R. A., $1948,1949,1951 ;$ U. S. Hydrographic office, 1892 ; U. S. Waterways Experiment Station, Vicksburg, Miss1ssippi, 1935, 1936, 1947a, 1947b, 1947c, 1949, 1950; Vanoni, V. A. and Carr, J. H., 1951; Verr1ll, G. E., 1930; Ward, H. A., 1952; Welker, S. C., 1954; Wharton, M., 1929; Whittemore, G. F.' 1916, 1917, 1926, 1928; Whitworth, G. W., 1932; Williams, E. A. and Isaacs, J. D., 1952

Eocene (See also: Tertiary): Butcher, W. S., 195la; Corey, W. H., 1951, 1952; Emery, K. O., 1941a, 1941b, 194lc, 1946b, 1951; Emery, K. O., Butcher, W. S., Gould, H. R. and Shepard, F. P., 1952; Emery, K. O. and Shepard, F. P., 1941, 1945; Emery, K. 0. and Tschudy, R. H., 1941; Emiliani, C., 1954; Mason, H. L., 1929; Norris, R. M., 1951; Shepard, F. P., 1936d, 1936f, 1948c, 1949b; Shepard, F. P. and Emery, K. 0., 1941

Equilibrium, Stability, Profile of Equilibrium, Base Level. Generally applied to beaches.: Anonymous, 1938a; Bascom, W. N., 1950c; Beach Erosion Board, 1950b, 1952a, 1954a; Butler, M. M., 1936; California, University of, 1952a; Dietz, R. S. and Menard, $\mathrm{H}$. W., 1951b (wave base and equilibrium on continental shelf); D1ll, R. F., Dietz, R. S. and Stewart, H., 1954; Eaton, R. O., 1951; Einstein, H. A., 1951; Goldberg, J., 1940; Grant, U. S., 1938, 1948; Gulliver, F. P., 1896; Halton, J. E. and Holden, E. R., 1950; Handin, J. W., 1949, 1951; Handin, J. W. and Ludwick, J. C. , 1950; Horton, D. F. 1948; Inman, D. L., 1949; Johns on, J. W., 1947b, 1948a, 1952; Leeds, C. T., 1936; MCAfee, C. M., 193 Menard, H. W. and Ludwick, J. C., 1951; M1ller, J. C., 1953; Nicholson, G. F., Grant, U. S., Shepard, F. P. and Crowell, J. C., 1946; Shepard, F. P., 1950f; Thompson, W. O., 1937; Trask, P. D., 1952b; Wiegel, R. L., Patrick, D. A., Kimberley, H. L., 1953

Erosion - see Beach Erosion, Cliff Erosion; Continental Shelf origin; Continental Slope, Origin; Marine Erosion Escarpment or Submarine Slopes (See also: Faulting, Fault Scarps, Seismology, Submarine Topography): Anonymous, 195la, 1952e; Butcher, W. S., 195la; Byerly, P., 1938b; Byerly, P. and Evernden, J. F., 1950b; Clements, T. and Emery, K. 0., 1947; Colbert, L. O., 1939; Davis, W. M., 1933; D1etz, R. S. and Bmery, K. O., 1938a, 1938b; Dietz, R. S., Emery, K. 0. and Shepard, F. P., 1942; Dietz, R. S., Menard, H. W., and Hamilton, E. L., 1954; Dill, R. F., 1952; Eardley, A. J., 1954; Emery, K. 0., 1947c, 1948, 1952b, 1953b, 1954b; Emery, K. O., Butcher, W. S., Gould, H. R. and Shepard, F. P., 1952; Emery, K. O. and Dietz, R. S., 1950; Emery, K. O. and Shepard, F. P., 1941; Hanna, G. D., 1952; Hertle1n, L. G. and Emerson, W. K., 1953; Hinds, N. E. A., 1952; Holzman, J. E., 1950; Jenkins, O. P., 1943a; Kemn1tzer, L. E. 1933; Koczy, F. F., 1954; Kuenen, Ph. H., 1947; Landes, K. K., 1952a; Laws on, A. C., 1950; Littlehales, G. W., 1932b; Ludw1ck, J. C., Jr., 1950; McGee, W. J., 1900; Ma, T. Y. H., 1952; Menard, H. W., 1952; Menard, H. W. and Dletz, R. S., 1951; Moore, D. G., 1951; Murray, H.W., 1939; Revelle, R. and Shepard, F. P., 1939a, 1939b; Scripps Institution of Oceanography, 1953e; Shaler, N. S., 1895; Shepard, F. P., 1936e, 1936f, 1937d, 1937e, 1937g, 1938d, 1938i, 1939d, $1939 \mathrm{e}, 1940 \mathrm{a}, 1940 \mathrm{~b}, 1941 \mathrm{a}, 194 \mathrm{lb}, 1942 \mathrm{~b}, 1950 \mathrm{~d}$, 1950e, 1951a, 1952a; Shepard, F. P. and Emery, K. O., 1937, 1941; Shepard, F. P. and Wrath, W. F., 1937; Stevenson, R. E., 1954; Studds, R. F. A., 1950; Trask, P. D., 1930, 1931a, 1931b, 1932a, 1934; Uchupi, E., 1954; Wooster, W. S., 1951

Estuary (See also: Bay, Embayment, Harbor, Lagoon, Marsh, Salt Marsh, Swamp, T1de Flat): Anonymous, 1950c; Alexander, A. H., 1936; Bache, A. D., 1862; Beach Erosion Board, 1948b; Blinn, F. S., 1928; Bruff, S. C., 1940, 1946; Buch, C. D., 1928; Buwalda, J., 1936; Caldwell, J. M., 1950; California Bureau of Sanitary Engineering, 1952; California Department of Fish and Game, 1951; Conaressional Documents, 1908e; Dall, W. H., 1911; Dapples, E.C., 1942; Eaton, R.0., 1952; Ellio+t, F.E et a], 1953; Emery, K. 0., 1945a, 1945b, 1950d; Fox, D. L., Updegraff, D. M. and Novelli, G. D. 1944; Frledman, S. L., 1949; Galliher, E. W., 1932b, 1933; Gilbert, G. K., 1917; Gislén, T., 1943; Goodyear, W. A., 1873; Graham, H. W. and Gay, H., 1945; Grant, U. S. and Shepard, F. P., 1937; Harvey, D. R., 1928; Lawson, A. C., 1894; Leypoldt, H., 1941b; McKee, E. D., 1939, 1953; MacGinitie, G. E., 1935, 1939; MacDonala, G. A., Shepard, F. P. and Cox, D. C., 1947; MacGinitie, G. E. and MacGinitie, N., 1949; Mason, E. H., 1930; Mason, H. L., 1931; Morrison, R. L., 1930; o'Brien, M. P., 1931; Page, G. B., 1950; 
Purer, E. A., 1942

Revelle, R. and Shepard, F. P., 1939b; Sanchez, P. C., 1934a; San Diego Regional Water Pollution Control Board, 1952; Scripps Institution of Oceanography, 1953c; Sears, C. B., 1876; Shepard, F. P., 1932, 1935a, 1938f, 1949b, 1950c, 1950e, 1950f, 1952a; Shepard, F. P. and Enery, K. O., 1941; Shepard, F. P. and MacDonald, G. A., 1938; Simmonds, H. B., 1952; Sisler, F. D. and ZoBell, C. E., 1950; Smith, P. V., Jr., 1954; Smith, W. D., 1933a, 1933c; Somers, P., 1952; Stevenson, R. E., 1954; Stevenson, R. E., and Emery, K. O., 1951; Swain, F. E., 1951; Sykes, G., 1926; Thompson, W. O., 1937; Updegraff, D. M., 1948; Wanless, H. R., 1950; Weaver, C. E., 1949; White, D., 1911; ZoBell, C. E., $1941,1942 a, 1946-1947,1947$ a

stuary Flushing - see Flushing of Estuary

vaporation: Anderson, C. A., 1950; Bigelow, H. B. and Leslie, M., 1930; California Academy of Sciences, California Division of Fish and Game, Scripps Institution of Oceanography, U. S. Fish and Wildlife Service, 1950; California Bureau of Sanitary Engineering, 1952; Clarke, K. B., 1934; Clark, W. O., 1915; Copeland, C. A., 1933; Cumings, N. W., 1921, 1950; Dall, W. H., 1911; Dunkle, M. B., 1944; Elliott, F. E., Tressler, W. L. and Myers, W. H., 1953; Emery, K. O., 1941b, 1946b; Emery, K. O. and Foster, J. F., 1948 (In beach sands); Emery, K. O. and Gale, J. F., 1951; Fleming, R. H. and Revelle, R., 1939; Gislén, T., 1944; Hall, W. H., 1886; Harvey, D. R., 1928; Hinde, H. P., 1952; Jacobs, W. C., $1939,1942,1943$ (also seasonal evaporation, rate of evaporation), 1949; Jacobs, W. C. and Clarke, K. B., 1943; LaFond, E. C., 1940; Leipper, D. F., 1947; McEwen, G. F., 1918, 1919a, 1929, $1930 \mathrm{a}, 1930 \mathrm{~b}, 1930 \mathrm{c}, 1933,1934 \mathrm{a}, 1934 \mathrm{~b}, 1934 \mathrm{~d}$, 1936, 1937b, 1937d, 1937-1938; Merrill, F.

J. H., 1915; Miller, R. C., Ramage, W. D. and Laz1er, E. L., 1928; Moberg, E. G., 1928a, 1930c; Moberg, E. C., and Allen, W. E., 1927; Munk, W. H., 1947b; Munk, W. H. and Anderson, E. R., 1948; Olsson-Seffer, P., 1908; Osorio Tafall, B. F., 1944; Purer, E. A., 1936, 1942; Richardson, B., 1930, 1932b; San Diego Regional water pollution Control Board, 1952 (bay, estuary); Stevenson, R. E., 1954; Sverdrup, H. U., 1938a, $1939 \mathrm{a}, 1939 \mathrm{~b}, 1939 \mathrm{c}, 1940 \mathrm{e}, 1940 \mathrm{~g}, 1941 \mathrm{a}, 194 \mathrm{lc}$; Sverdrup, H. U. and Staff, 1945a, 1945b; Tibby, R. B., 1941; Trask, P. D., 1939; Vaughan, T. W., $1930 b, 1932 c, 1940$ (precipitation vs evaporation); Young, A. A., 1945, 1947a, 19470

tinction Coefficient (See also: Absorption, Light, Transparency, Turbid Water): Young, R. T., Jr., 1939

cplosives or Explosions (See also: Geophysics, Sound): Aplin, J. A., 1947; Bell, G. K., 1948; Dyk, K. and Swainson, O. W., 1953; Hubbs, C. L. and Rechnizer, A. B., 1952; Raitt, R. W., 1954; Scripps Institution of Oceanography, 1945a; Stormont, D. H., 195la

ulting, Submarine (See also: Continental Shelf, Origin; Continental Slope, origin; Escarpment, fault Scarps, Seismology; Submarine Canyon, Origin; Submarine Topography): Anonymous, 1932c, 1952e, 19521; Anderson, C. A., 1941, 1950; Armstrong, T. A., 1954; Ashauer, H., Hollister, J. S. and Reed, R. D., 1936; Beach Erosion Board, 1948j; Beal, C. H., 1945; Benioff, Н., 1938; Bremner, C. St. J., 1933; Brown, E. I., 1939; Bucher, W. H., 1940; Butcher, W. S., 1951a; Buwalda, J. P., 1936, 1948; Byerly, P., 1927, 1937, 1938a, 1938b, 1940b; Byerly, P. and Evernden, J. F., 1950b; Chase, J. L., 1948; Clark, B. L., 1931; Clements, T. and Emery, K. O., 1947; Corey, W. H., 1952; Cottom, C. A., 1942; Crooke, R. C., Elvitsky, A. W., et al, 1953; Crosley, W. S., 1927; Dietz, R. S., 1952a; Dietz, R. S., Emery, K. O. and Shepard, F. P., 1942; Dietz, R. S., Menard, H. W. and Hamilton, E. L., 1952, 1954; Diller, J. S., 1915; Driver, H. L., 1948; Eardley, A. J., 1954; Eaton, J. E., 1933; Emery, K. O., 1941a, 1950b, 1951, 1952b; Emery, K. 0., Butcher, W. S., Gould, H. R. and Shepard, F. P., 1952; Emery, K. O. and Shepard, F. P., 1945; Gorsline, D. S., 1954;
Grant, U. S., 1944; Gutenberg, B., 1939, 194la; Gutenberg, B., Richter, C. F. and Wood, H. P., 1932; Harding, C. R., 1929; Heck, N. H., 1926; Hill, M. L., 1928; Hill, M. L. and Dibblee, T. W., Jr., 1953; Hill, R. T., 1928a, 1928b; Hinds, N. E. A., 1952; Hodge, E. T., 1934; Folzman, J. E., 1950; Kemnitzer, L. E., 1933; Koczy, F. F., 1954; Krynine, P. D., 1937; Kuenen, Ph. H., 1947; Lakes, A., 1903a; Loudermilk, J. D., 1944; Landes, K. K., 1952a; Lange, A., 1954; Lawson, A. C., 1893b, 1950; Leypoldt, H., 1938, 1941c; Louderback, G. D., 1930, 1940;

MacDonald, G. A., 1934; Maxson, J. H., 1931, 1932; Menard, H. W. and Dietz, R. S., 1951; Menard, H. W., Dill, R. F., Hamilton, E. L., Moore, D. G., Shumway, G., Silverman, M. and Stewart, H. B., 1954; Miller, W. J., 1940; Mitchell, G. D., 1928; Moore, D. G., 1951; Munk, W. H., 1940; Munk, W. H. and Traylor, M. A., 1947; Murray, H. W., 1939; Nicholls, C. P. L., 1936c; Nicholson, G. F., 1929; Norr1s, R. M., 1951; Poland, J. F., 1947; Revelle, R., 1939b; Revelle, R. and Emery, K. O., 1951; Revelle, R. and Shepard, F. P., 1939b; Richter, C. F., 1940; Scripps Institution of Oceanography, 1953e; Shaler, N. S., 1895; Shepard, F. P., 1933b, 1934b, 1935b, 1936e, 1936f, $1937 \mathrm{~b}, 1937 \mathrm{c}, 1937 \mathrm{~d}, 1937 \mathrm{~g}, 1938 \mathrm{~d}, 1938 \mathrm{~h}, 1939 \mathrm{e}$, $1940 \mathrm{~d}, 194 \mathrm{la}, 194 \mathrm{bb}, 1942 \mathrm{~b}, 1947 \mathrm{~b}, 1949 \mathrm{c}, 1950 \mathrm{~d}$ 1950e; Shepard; F. P. and Emery, K. O., 1937, 1941; Shepard, F. P. and MacDonald, G. A., 1938; Shepard, F. P., Revelle, R. and Dletz, R. S., 1939; Shepard, F. P. and Wrath, W. F., 1937; Smith, P. A., 1938, 1940; Smith, W. D., 1919, 1933a, 1933b; Sparks, N. R., 1936; Stormont, D. H., 1951c, 1954b; Sverarup, H. U., 1938c, 1939a; Sverdrup, H. U. and Staff, 1941, 1942a; Thom, W. T., Jr., 1938; To1t, A. L., du, 1940; Trask, P. D. and Rolston, J. W., 1950a; Uchupi, E., 1954; Vaughan, T. W., 1936; Weaver, C. E., 1949; Willis, B., 1925, 1938a, 1938b; Wisser, E., 1954; Wood, H. O., 1915, 1947

Fault Scarps, Submarine (See also: Escarpment, Faulting, Selsmology, Submarine Topography): Byerly, P., 1938b; Dietz, R. S., Emery, K. O. and Shepard, F. P., 1942; Dletz, R. S., Menard, H. W. and Hamilton, E. L., 1952, 1954; Emery, K. O., 1947c; Emery, K. O. and Shepard, F. P., 1945; Hill, R. T., 1928a; Jenkins, O. P., 1943a; Revelle, R., 1939b; Revelle, R. and Emery, K. O., 1951; Shepard, F. P., 1937b, 1938d, 1940e, 1941a, 1949c, 1950e; Shepard, F. P. and Emery, K. O., 1941; Shepard, F. P. and MacDcnald, G. A., 1938; Shepard, F. P., Revelle, R. and Dietz, R. S., 1939; Shepard, F. P. and Wrath, W. F., 1937; Sverdrup, H. U., 1938c, 1939a; Sverdrup, H. U. and Staff, 1941, 1942a; Toit, A. L., du, 1940; Uchupi, E., 1954

Felsite (See also: Igneous Rock, Rock): Butcher, W. S., $1951 \mathrm{a}$

Fetch: Gorsline, D. G., 1954; Granthem, K. N., 1953; Nicholson, G. F., Grant, U. S., Shepard, F. P. and Crowell, J. C., 1946; O'Brien, M. P. and Johnson, J. W., 1947; Stevenson, R. E., 1954; VanDorn, W. G., 1953

Fill - see Cut and/or Fill

Fiords: Sanchez, P. C., 1934 a

Floating Sediments (See also: Rafting): Emery, K. O., 1945b; Emery, K. O. and Gale, J. F., 1951

Floculation: Dietz, R. S., 1952b; Fox, D. L., 1950; Gilbert, G. K., 1917; Menard, H. W. and Ludwick, J. C., 1951; U. S. Waterways Experiment Station, Vicksburg, Mississippi, 1950

Flora (See also: Algae, Diatoms, Dinoflagellates, Phytoplankton, Plankton, Vegetation): Axelrod, D. I., 1939; Carpenter, E. J. and Storie, R. E., 1929; Chaney, R. W., 1936a, 1936b, 1940; Chaney, R. W. and Dorf, E., 1934; Chaney, R. W. and Mason, H. L., 1934; Cockerell, T. D. A., 1938b, 1940; Dawson, E. Y., 1952; Dill, R. F., 1952; Durham, J. W., 1952; Emery, K. O., 1946b, 1952b; Fox, D. I., 1937, 1950; Fraser, C. MCL., 1943; Galliher, E. W., 1933; Gilbert, G. K., 1917 Goodyear, W. A., 1873; Graham, H. W., 1934; Greene, E. L., 1886, 1887; Harding, H. W. and 
Moberg, E. G., 1934; Hinde, H. P., 1952; Hoover, J. W., 1932b; Kemn1tzer, L. E., 1933; Kindle, E. M., 1934; LeConte, J., 1887; McConnaughey, B. H. and Fox, D. L., 1949; MacGinitie, G. E., 1927, 1935; Mason, H. L., 1931; Moberg, E. G., 1928a, 1928b; Moberg, E. G. and Fleming, R. H., 1934; Olsson-Seffer, P., 1910a, 1910b; Pease, W. H., 1868; Purer, E. A., 1942; Richter, C. M., 1887; Shaler, N. S., 1895; Shepard, F. P., 1948c, 1951a; Stevenson, R. E., 1954; Stevenson, R. E. and Emery, K. 0., 195l; Sverdrup, H. U., 194la, 1941c; Trask, P. D., 1934, 1939; White, D., 1911; Williams, W., 1948; Wright, R., 1937; Yates, L. G., 1890d, 1902; ZoBell, C. E., 1933, 1947d; ZoBell, C. E. and Feltham, C. B., 1942 Florescence - see Luminescence

Florine, Florine (See also: Halogens): Dietz, R. S., Emery, K. 0. and Shepard, F. P., 1942; Emery, K. O. and Dietz, R. S., 1950; McEwen, G. F., 1934a; Revelle, R. and Emery, K. O., 1951; Sheperd, E. S., 1940, 1946; Thompson, T. G. and Robinson, R. J., 1932

Flushing of Estuary, Tidal Flushing: Crooke, R. C., Elvitsky, A. W. et al, 1953; Elliott, F. E., Tressler, W. L. and Myers, W. H., 1953; Kenyon, E. C., Jr., 1951

Fluting - see Minor Features, Rocky Coasts

Fog (See also: Meteorology and Climate): Anderson, J. B., 1931; Beach Erosion Board, 1949b; Byers, H. R., 1930, 1931; Blake, D., 1926; Crooke, R. C., Elvitsky, A. W., et al, 1953; Great Britain Meteorological office, 1950; Greenwell, W. E., 1858; Hoover-Young San Francisco Bay Bridge Commission, 1930; Leipper, D. F., 1947, 1948a, 1948b; McEwen, G. F., 1930c; Neiburger, M., Beer, C. G. P. and Leopold, L. B., 1945; Palmer, A. H., 1917; Patton, C. P., 1953; Petterssen, S., 1938; Yale, C. G., 1879

Folding (See also: Diastrophism, Warping): Anderson, C. A., 1941; Bucher, W. H., 1940; Butcher, W. S., 1951a; Chase, J. L., 1948; Emery, K. O., 1950d; Emery, K. O., Butcher, W. S., Gould, H. R. and Shepard, F. P., 1952; Shepard, F. P. and Emery, K. O., 1941; Stille, Н., 1936; Weaver, C. E., 1949; Woodring, W. P. and Kew, W. S. W., 1932

Foraminifera (See also: Pyrite): Anonymous, 1942; Anderson, F. M., 1926; Anderson, R., 1927; Atwill, E. R., 1942; Bagg, R. M., Jr., 1912; Bailey, T. L., 1935; Bandy, O. L., 1952, 1953a, 1953b, 1954; Bush, J. B., 1930; Butcher, W. S., 195la, 1951b; Carsola, A. J. and Dietz, R. S., 1952; Chesterman, C. W., 1952; Church, C. C., 1929; Clements, T. and Dana, S. W., 1949; Coe, W. R., 1948; Coe, W. R. and Allen, W. E., 1937; Cohee, G. V., 1938; Crouch, R. W., 1951, 1952, 1954; Cushman, J. A., 1925; Cushman, J. A. and Valentine, W. W., 1930; David, L., 1947; Dietz, R. S., 1941; Dietz, R. S., Emery, K. O., 1938a, 1938b; Dietz, R. S., Emery, K. O. and Shepard, F. P., 1942; Dill, R. F., 1952; Dill, R. F., Dietz, R. S. and Stewart, H., 1954; Emery, K. 0., 1941a, 1947a, $1947 \mathrm{~b}, 1948,1952 \mathrm{a}, 1952 \mathrm{~b}, 1953 \mathrm{~b}, 1954 \mathrm{~b}, 1954 \mathrm{~d}$; Emery, K. O., Butcher, W. S., Gould, H. R. and Shepard, F. P., 1952; Emery, K. O. and Dietz, R. S., 1941, 1950; Emery, K. O. and Natland, M. L., 1952; Emery, K. O. and Rittenberg, S. C., 1952; Emery, K. 0. and Shepard, F. P., 1945; Emery, K. O. and Stevenson, R. E., 1950; Emiliani, C., 1954; Emiliani, C. and Epstein, S., 1953; Farrand, W. H., 1929; Galliher, E. W., 1935a, 1933b, 1935c, 1937; Garrison, L. E. and Takasaki K. L., 1950; Göes, A., 1896; Goodwin, J. C. and Thomson, J. N., 1954; Gorsline, D. S., 1954; Grim, R. E., Dietz, R. S., and Bradley, W. F., 1949; Eanns, G. D., 1952; Hanna, G. D. and Church, C. C., 1927; Holzman, J. E., 1950; Hoots, H. W., Blount, A. L. and Jones, P. H., 1935; Inman, D. L., 1950; Kindle, E. M., 1934; Ludwick, J. C. Jr., 1950; MacDonald, J. A. and Diediker, P. L. 1930; Martin, L. T., 1930, 1931, 1932, 1935, 1937; Martin, L. T. and Keen, A. M., 1937; Menard, H. W., 1952; Moore, D. G., 1951; Moyer, D. A., 1929a, 1929b; Myers, E. H., 1942, 1943; Natland, M. L., 1933a, 1933b; Natland, M. L., Revelle, R. and Rittenberg, S. C., 1941; Nicol, D., 1942, 1944;
Norris, R. M., 1951; Phleger, F. B., 1951; Piggot, C. S. and Urry, w. D., 1942; Rankin, W. D. 1931; Revelle, R., 1935, 1950; Revelle, R. and Emery, K. O., 1951; Revelle, R. and Shepard, F. P., 1939b (also foraminiferal sand); Rothwell, W. T., Jr., 1944; Schenck, H. G., 1940; Scripps Institution of oceanography, 1953e; Shepard, F. P., 1932, 1941a, 1949d, 1951a, 1951b, 1951d, 1953; Shepard, F. P. and Emery, K. 0., 1941, 1945; Shepard, F. P. and Wrath, W. F., 1937; Shumway, G. A., 1953; Sverdrup, H. U., 1939a, 1940e; Tanner, Z. L., 1892b; Taylor, C. V. and Vaughan, T. W., 1934; Topp, E. C., 1929; Trask, P. D., 1931b, 1937a, 1937b; Uchupi, E., 1954; Vaughan, T. W., 1930a, 1930b, 1931, 1932b, 1933, 1935b, 1940; Voorthuysen, J. H., van, 1953; wright, R., 1937

Foraminiferal 0oze - see ooze, General

Forecasting of Waves - see Wave Forecasting

Foreset: Thompson, W. 0., 1934; Shepard, F. P., 19418 Fouling, including Attached, Encrusting and Fouling organisms (See also: Organisms): Allen, W. E., 1939, 1941c; Bates, C. C. and Glenn, A. H., 1948; Carsola, A. J. and Dietz, R. S., 1952; Cartwright, L. D., Jr., 1928; Chadwick, W. L., Clark, F. S., and Fox, D. L., 1950; Coe, W. R., 1932; Coe, W. R. and Allen, W. E., 1937; Coe, W. R. and Fox, D. L., 1942, 1944; Cohee, G. V., 1938; Crooke, R. C., Elvitsky, A.W. et al, 1953; Dietz, R. S., Emery, K. O. and Shepard, F. P., 1942; Elliott, F. E., Tressler, W. L. and Myers, W. H., 1953; Emery, K. 0., 1947a, 1947b, 1948; Emery, K. 0. Butcher, W. S., Gould, H. R. and Shepard, F. P., 1952; Emery, K. O. and Shepard, F. P., 1945; Graham, H. W. and Gay, H., 1945; Holzman, J. E., 1950; Johnson, M. W., Everest, F. A. and Young, R. W., 1947; Scheer, B. T. and Fox, D. L., 1947; Shepard, F. P., 1947a; Shepard, F. P. and Emery, K. O., 1946; Sverdrup, H. U., 1940e; Vaughan, T. W., 1933; Z.oBell, C. E., 1942a, $1947 \mathrm{c}$

Friction, i.e. Bottom Friction, Wind Friction: Dall, W. H., 1911; Dill, R. F., Dietz, R. S. and Stewart, H., 1954; Fleming, R. H., 1937-1938; Hidaka, K., 1953; Inman, D. L. and Quinn, W. H., 1952; Munk, W. H., 1950; Nicholson, G. F., Grant, U. S., Shepard, F. P. and Crowell, J. C., 1946; Revelle, R. and Shepard, F. P., 1939b, 1943; Scripps Institution of Oceanography, 19521, 1953c; Shepard, F. P. and Emery, K. 0., 1941; Sverdrup, H. U., 1938a, 1939a, 1939c; Swain, F. E., 1951

Frosting, or Frosted Sand Grains: Dill, R. F., Dietz, R. S. and Stewart, H., 1954; Merriam, P. D., 1949; Shepard, F. P. and MacDonald, G. A., 1938; Thompson, W. O., 1937

Gabbro (See also: Igneous Rock, Rock): Cobee, G. V., 1938; Louderback, G. D., 1940

Gallium: Revelle, R. and Emery, K. O., 1951

Gases (See also: Ammonia, Carbon Dioxide and Carbon Monoxide, Hydrogen, Hydrogen Sulfide, Methane, Nitrogen Submarine 011 and Gas Seeps): Atwill, E. R., 1942; Dall, W. H., 1911; Dawson, E. Y., 1951; Dietz, R. S., Emery, K. O. and Shepard, F. P., 1942; Emery, K. 0. and Rittenberg, S. C., 1952; Ford, J. L. C., 1942; Fox, D. L. and Anderson, L. J., 1941; Fox, D. L. and Updegraff, D. M. and Novelli, G. D., 1944; Fox, L. S., 1930; Hutton, W. E. and ZoBell, C. E., 1949; Krumbein, W. C., 1942; MacDonald, G. A., 1934; Morrison, R..L., 1930; Revelle, R., 1950; Shepard, F. P., 1951d; Sisler, F. P. and ZoBell, C. E., 1951b; Stevenson, R. E., 1954; Tanner, Z. L., 1896; Thayer, L. A., 1937; Thompson, T. G. and Robinson, R. J., 1932; ZoBell, C. E., 1938, 1939, $1942 \mathrm{a}, 1942 \mathrm{~b}, 1946 \mathrm{~b}, 1946-1947,1947 \mathrm{~b}, 1947 \mathrm{c}$, $1947 \mathrm{~d}, 1949,1950$

Gas Seeps - see Submarine 0il and Gas Seeps

Geology and Paleonotology: (Including Coasts): Anonymous, 1925a, 1932d; Anderson, C. A., 1941, 1950; Arnold D., 1896; Arnold, R., 1900; Balley, T. L., 1935, 1943, 1947; Black, G. L., 1954; Buwalda, J. P., 1927, 1936; Chace, E. P. and Chace, E. M., 1919; Chaney, R. W., 1936, 1940; Chaney, R. W. and Dorf, E., 1934; Clark, B. L., 1921, 1930, 1933?; Congressional Documents, 1953b; Corey, W. H., 1952 Crandall, H., 1915; Crooks, R. C., Elvitsky, A. W. 
et al, 1953; Darton, N. H., 1921; David, L.,

1947; Davis, W. M., 1932; Dickerson, R. E., 1932;

Diller, J. S., 1902; Durham, J. W., 1949, 1950a, 1950b, 1950c, 1952; Eardley, A. J., 1954; Eaton, J. E., 1939, 1943; Eckis, R., 1936; Ellis, A. J. and Lee, E. H., 1919; Bmery, K. O., 1954e; Emery, K. O., Butcher, W. S., Gould, H. R. and Shepard, F. P., 1952; Emiliani, C. and Epstein, S., 1953; Emmonds, S. F. and Merrill, G. P., 1894; Geylord, E. G. and Hanna, G. D., 1925; Gester, G. C., 1927; Goldberg, E. D., 1954; Goodyear, W. S., 1889, 1890; Gorsline, D. S., 1954; Grant, U. S., 1936; Griesbach, J. O., 1947; Hanna, G. D., 1925a, 1925b, 1928; Hanna, M. A., 1926; Hоwe, Н. V., 1926; Jenkins, О. Р. (editor) and others, 1951; Johnson, I. M., 1924; Kelley, V. C., 1932; Kindle, E. M., 1934; King, R. E., 1939; Louderback, G. D., 1913; Lawson, A. C., 1895; Mason, H. L., 1929, 1931; Merrill, F. J. H., 1915, 1917; Miller, W. J., 1935; Moyer, D. A., 1929; Myers, E. H., 1942; Nicholson, G. F., Grant, U. S., Shepard, F. P. and Crowell, J. C., 1946; Pelline, J. E., 1952; Putnam, w. C., 1938; Reed, R. D., 1933b, 1934 , 1938, 1943a, 1943b; Reed, R. D. and Hollister, J. S., 1936; Relche, P., 1937; Robertson, G. K., 1932; Rothwell, W. T., Jr., 1944, 1946; Sanchez, P. C., 1934b; Shepard, F. P. and Emery, K. O., 1941; Smith, J. P., 1904, 1919; Smith, W. D., 1933a, 1933c; Soper, E. K., 1938; Spencer, J. W., 1897; stock, C., 1943, 1946; Sverdrup, H. U. and Staff, 194l; Tallaferro, N. L., 1943; Thomasson, H. G., Jr., 1951; Thompson, W. O., 1937; Trask, P. D., 1924, 1926a, 1937b; Upson, J. E., 1951; Weaver, C. E., 1944; Weaver, D. K. and Wilhelm, V. H., 1943; Webb, R. W., 1936; Wh1te, D., 1911; Wilcox, G. A., 1911; Wilson, I. F., 1948; Wittich, E., 1920; Woodford, A. 0., 1924, 1925, 1928; Woodford, A. O. and Bailey, T. L., 1928; Woodring, W. P., 1930, 1935, 1938a, 1938b, 1952; Woodring, W. P., Bramlette, W. N. and Kew, W. S. W., 1946; Woodring, W. P., Bramlette, W. N. and Kleinpell, R. M., 1936; Woodring, W. P., Bramlette, W. N. and Lohman, K. E., 1943; Woodring, W. P., and Kew, W. S. W., 1932; Wright, R., 1937

Valifornia Coastal Islands: Anonymous, 1887 , 1932e, 1949a; Anderson, $\bar{F}$. M., 1896-1902; Anderson, R. E., Redwine, L. E. and McGovney, P. E., 1949; Arnold, D., 1897; Bagg, R. M., Jr., 1912; Bailey, E. H., 1940, 1941; Bailey, T. L., 1947; Becker, G. F., 1888; Blake, W. P., 1856, 1868, 1898; Bowers, S., 1878, 1890; Bowie, W., 1924a; Bremner, C. St. J., 1890, 1932, 1933; Butcher, W. S., 1951a; Chaney, R. W., 1928; Chaney, R. W. and Mason, H. L., 1934; Clements, T., 1946, 1948; Cockerell, T. D. A., 1937, 1938a, 1938b, 1938c, 1939, 1940; Crickmay, c. H., 1929a, 1929b; Dall, W. H. and Harris, G. D., 1892; Dietz, R. S., Emery, K. O. and Shepard, F. P. 1942; Driver, H. L., 1948; Dunkle, M. B., 1944, 1950; Ellis, A. J. and Lee, E. H., 1919; Emery, K. O., 1954d; Emery, K. O., Butcher, W. S., Gould, H. R. and Shepard, F. P., 1952; Fairbanks, H. W., 1904; Fewkes, J. W., 1889; Fisher, E. M., 1930; Goodyear, W. A., 1890; Griesbach, J. 0., 1947; Hanna, G. D., 1951; Heizer, R. F. and Treganza, A. E., 1944; Hertlein, L. G., 1928; Hill, R. T., 1928b; Hobbs, W. H., 1931; Kemnitzer, L. E., 1933, 1936; Kew, w. s. W., 1927, 1928; Knopf, E. C., 1938; Loudermilk, J. D., 1944 (Catalinia); Livingston, A., Jr., 1939; Loel, W. and Corey, W. H., 1932; Menard, H. W., Dill, R. F., Hamilton, E. L., Moore, D. G., Shumway, G., Silverman, M. and Stewart, H. B., 1954; Miller, W. J., 1940; Mills, B., 1932a; Moody, G. B., 1935; Nelson, R. N. and Schenck, H. G., 1928; Norris, R. M., 1951; orr, P. C., 1952; Rand, W. W., 1931; Randolph, G. C., 1933, 1935; Ransome, F. L., 1894; Shepard, F. P., Grant, U. S. and Dietz, R. S., 1939; Smith, W. S. T., 1897, 1898, 1899, 1900, 1933; Stearns, R. E. C., 1875; stock, C., 1935, 1936; Stock, C. and Furlong, E. L., 1928; Trask, B., 1907; Trowbridge, W. P., 1856a; Tucker, W. P., 1927; Uchupi, E., 1954; Washington, H. S., 1901;
Weeks, L. G., 1952; Whitney, J. D., 1865; Willis, B., 1900, 1925; Wilson, R. W., 1936; Woodford, A. O., 1924, 1925; Yates, L. G., 1889, 1890a, $1890 \mathrm{~b}, 1890 \mathrm{c}, 1902$

Mexican Coastal Islands including Gulf of California: Anderson, C. A. , 1941, 1950; Butcher, W. S., 1951a; Darton, N. H., 1921; Durham, J. W., 1950c; Emery, K. O., Butcher, W. S., Gould, H. R. and Shepard, F. P., 1952; Gorsline, D. G., 1954; Hanna, G. D., 1926, 1927; Hanna, G. D. and Grant, W. M., 1926; Johnson, C. W., 1953; Johnson, I. M., 1924; Jones, F. A., 1910; Jordan, E. K., 1926; Jordan, E. K. and Hertlein, L. G., 1926a, 1926b; McLellan, M. E., 1925; Osorio Tafall, B. R., 1943, 1948; Paredes, T., 1920; Sanchez, P. C., 1934b; Sverdrup, H. U. and Staff, 1941; Wilson, I. F., 1948

Geophysical Suryeys etc. (See also: Explosives or Explosions, Sound): Anonymous, 1948, 1952h, 1954e; Aplin, J. A., 1947; Bell, G. K., 1948; Butcher, W. S., 1951a; Byerly, P., 1938b; Dyk, K. and Swainson, 0. W., 1953; Eardley, A. J., 1954; Emery, K. O. and Rittenberg, S. C., 1952; Gutenberg, B. and Buwalda, J. P., 1935; Gutenberg, B., Wood, H. O. and Buwalda, J. P., 1932; Havemann, H., 1952; Hubbs, C. L. and Rechnizer, A. B., 1952; Johnson, C. H. and Galeski, R. B., 1949; Meinesz, F. A. V., 1948; Nettleton, L. L., 1951; Raitt, R. W., 1949, 1950, 1954; Shepard, F. P., 1940c, 1941a; Sneddon, R., 1948; Stephenson, E. L., 1945; Stormont, D. H., 1951, 1951a, 1953, 1954b; Swainson, 0. W., McIlwraith, C. G. and Dyk, K., 1934; Thom, W. T., Jr., 1938; Wharton, M., 1948; Woollard, G. P., 1951 Geosyncline (See also: Syncline, Trench): Revelle, R.,

Germanium: Revelle, R., 1935; Vaughan, T. W., 1933 Glacial - see Sea Level Changes, Glacial

Glacial Deposits: Urry, W. D., 1940

Glaciation - see Continental Shelf, Glaciation on Glauconite (See also: Authigenic Minerals, Diagenesis): Beach Erosion Board, 1953c; Butcher, W. S. 1951a; Cohee, G. V., 1938; Congressional Documents, 1953b; Coxe, L. C., 1949; Dana, S. W., 1942; Dapples, E. C., 1942; Dietz, R. S., 1941; Dietz, R. S., Emery, K. O., 1938a, 1938b; Dietz, R. S., Emery, K. O. and Shepard, F. P., 1942; Dill, R. F., 1952; Dill, R. F., Dietz, R. S. and Stewart, H., 1954; Emery, K. O., $1941 \mathrm{a}, 1947 \mathrm{a}, 1947 \mathrm{~b}, 1948,1952 \mathrm{a}, 1952 \mathrm{~b}, 1953 \mathrm{~b}$; Emery, K. 0., Butcher, W. S., Gould, H. R. and Shepard, F. P., 1952; Emery, K. 0. and Dietz, R. S., 1950; Emery, K. O. and Rittenberg, S. C., 1952; Galliher, E. W., 1935a, 1935b, 1935c, 1937, 1939; Grim, R. E., Dietz, R. S. and Bradley, W. F., 1949; Holzman, J. E., 1950; Inman, D. L., 1950; Krumbein, N. C., 1942; Norris, R. M., 1951; Revelle, R., 1950; Revelle, R. and Emery, K. O., 1951; Revelle, R. and Shepard, F. P., 1939b, 1941a; Shepard, F. P. and Emery, K. O., 1941; Shepard, F. P. and MacDonald, G. A., 1938; Shepard, F. P., Revelle, R. and Dietz, R. S., 1939; Thompson, T. G. and Robinson, R. J., 1932; Uchupi, E., 1954; Woodford, A. O., 1951

Glaucophane (See also: Rock, Schist): Butcher, W. S., 1951a; Emery, K. 0., 1947b, 1947c

Globergerina 0oze (See also: Pelagic Sediments): Emery, K. O., 1954b; Emery, K. O. and Dietz, R. S., 1941; Emery, K. O. and Natland, M. L., 1952; Göes, A., 1896; Menard, H. W., 1952; Michael, E. L., 1919; Piggot, C. S., 1932, 1944; Piggot, C. S. and Urry, W. D., 1942; Revelle, R., 1935, 1937a, 1937b; Scripps Institution of Oceanography, 1953e; Shepherd, E. S., 1946; Takahashi, J., 1925; Vaughan, T. W., 1933, 1940; White, D., 1911

Gneiss (See also: Metamorphic Rock, Rock): Shumway, G. A., 1953; Trask, P. D., $1952 a$

Gold (See also: Aurlferous Beach Sands, Beach Placers): Piggot, C. S., 1933, 1944; Thompson, T. G. and Robinson, R. J., 1932; Trask, P. D., 1939

Grabens (See also: Trench, Trough): Dietz, R. S., Menard, F. W., and Hamilton, E. L., 1954; Koczy, F. F., 1954

Graded Bedding: Dill, R. F., Dietz, R. S. and Stewart, H., 
1954; Emery, K. O. and Natland, M. L., 1952; Menard, H. W. and Ludwick, J. C., 1951

Gradient - see Beach and Nearshore, Continental Shelf, Continental Slope, Submarine Canyon

Grain Size: Atwill, E. R., 1942; Bucher, W. H., 1940; Carsola, A. J., 1947; Crooke, R. A., Elvitsky, A. W. et al, 1953; Dana, S. W., 1942; Dapples, E. C., 1942; Dietz, R. S., 1941; Emery, K. O., 1950d; Emery, K. O., Butcher, W. S., Gould, H. R. and Shepard, F. P., 1952; Emery, K. O., and Dietz, R. S., 194l; Emery, K. O. and Gould, H. 1948; Galliher, E. W., 1935c; Garrison, L. E. and Takasaki, K. L., 1950; Gilbert, J. Y. and Allen, W. E., 1943; Gorsline, D. S., 1954; Hoover-Young San Francisco Bay Bridge Commission, 1930; Inman, D. L., 1950; Krumbein, W. G., 1942; Kuenen, Ph. H. and Menard, H. W., 1952; Leeds, C. T., 1915; Lesser, R. M., 1951; Louderback, G. D., 1940; McKee, E. D., 1939, 1953; Menard, H. W., 1952; Menard, H. W. and Ludwick, J. C., 1951; Miller, R. L., 1954; Moberg, E. G., Fleming, R. H., Heusner, K. and Revelle, R., 1937; Moyer, D. A., 1929b; Munk, W. H., 1941; Natland, M. L., Revelle, R. and Rittenberg, S. C., 194l; Norris, R. M., 1951; Putnam, J. A., Bermel, K. J. and Johnson, J. W., 1947; Revelle, R., 1938, 1939b; Revelle, R. and Emery, K. 0., 1951; Revelle, R. and Shepard, F. P., 1939b; Rittenberg, S. C., 1940; Sumner, F. B., Louderback, G. D., Schmitt, W. L. and Johnston, E. C., 1914; Stevenson, R. E., 1954; Sverdrup, H. U., 1939a, 1940e; Trask, P. D., 1927a, 1927b, 193la, 1931b, 1932a, 1934, 1939; Trask, P. D. and Rolston, J. W., 1950b; Udden, J. A., 1914; ZoBell, C. E., 1938, 1942a, 1942b, 1943 Abyssal: Emery, K. O., 1954b; Revelle, R., 1935 Bank: Clements, T. and Dana, S. N., 1944; Emery, K. O., 1948, 1954b; Emery, K. O., Butcher, W. S. Gould, H. R. and Shepard, F. P., 1952; Garrison, L. E. and Takasaki, K. L., 1950; Grim, R. E., Dietz, R. S. and Bradley, W. F., 1949; Holzman, J. E., 1950; Uchupi, E., 1954

Basin: Emery, K. O., 1950e, 1954b; Emery, K. 0. and Rittenberg, S. C., 1951, 1952; Garrison, L. E. and Takasaki, K. L., 1950; Ludwick, J. C., Jr., 1950; Revelle, R., 1938, 1939b; Revelle, R. and Shepard, F. P., 1939b; Shepard, F. P., 1951b; Smith, P. V., Jr., 1954; Trask, P. D., $1931 b, 1932 a$

Beach and Nearshore: Anonymous, 1933e, 1938a, 1940d, 1950d; Bascom, W. N., 1950c; Beach Erosion Board, 1942a, 1948b, 1948h, 1948i, 1952a 1952b, 1953b, 1953c; Boos, M. F., 1940; Brown, E. I., 1939; Bullard, F. M. and Mills, R. A., 1951; California, University of, 1952a, 1954b; Coe, i. R., 1947; Congressional Documents, 1938a, 1940a, 1953b; Eaton, R. 0., 1951; Einstein, H. A., 1951; Emery, K. 0., 1945a, 1945b, 1946b, 1954b, 1954c (gravel); Emery, K. O. and Foster, J. F., 1948; Emery, K. O. and Gale, J. F., 1951; Emery, K. O. and Stevenson, R. E., 1950; Fisher, R. L. and Mills, R., 1952; Gee, H. C., 1938; Gorsline, D. S., 1954; Grant, U. S., 1938, 1943, 1946; Grant, U. S. and Shepard, F. P., 1940; Griggs, A. B. and Wells, F. G., 1942; Ḣall, J. V., Jr., 1952; Hall, W. C., 1942; Handin, J. W., 1949, 1951; Handin, J. W. and Ludwick, J. C., 1949; Inman, D. L., 1949, 1950, 1953b; Isaacs, J. D., 1945b, 1945c, 1945d, 1945 g, 1945i, 1945J, $1945 \mathrm{k}, 1945 \mathrm{~m}, 1947 \mathrm{a}$; Isaacs, J. D. and Bascom, W. N., 1947; Johnson, J. W., 1952; Keller, W. D., 1941, 1945; Krumbein, W. C., 1947, 1950; Lang, H., 1916; Louderback, G. D., 1940; Marlette, J. W., 1954; Martens, J. H. C., 1939; Mason, M. A., 1942, 1949a; Munk, W. H., 1949b; Nicholson, G. F., Grant, U. S., Shepard, F. P. and Crowell, J. C., 1946; Nicholls, C. P. L., 1939; Norris, R. M., 1951; O'Brien, M. P., 1931, 1936a, 1939; Olsson-Seffer, P., 1910a; Page, G. B., 1950; Palmer, R. H., 1928; Reed, R. D., 1930b; Revelle, R. and Shepard, F. P., 1939b; Schupp, R. D., 1953; Scripps Institution of oceanography, 1952i, 1953c; Shepard, F. P., 1950c, 1950g; Shepard, F. P. and Inman, D. L. and Fisher, R. L., 1951; Shuler, W. R., 1951, 1952; Sinnott, A., 1941; Stelzenmuller,
W. B., 1949; Stump, R. S. and Bascom, W. N., 1947; Thompson, W. O., 1934, 1937; Trask, P. D., 1952a, 1952b; Trask, P. D. and Scott, T., 1954 (also median diameter vs. sorting); Twenhofel, W. H., 1946; Watts, G. M. and Others, 1953; Wiegel, R. L., 1947b; Wiegel, R. L., Patrick, D. A. and Kimberley, H. L., 1953; Woodford, A. O., 1935 Cosstal Sand Dunes: Congressional Documents, 1953b; Emery, K. O., 1954b; Gorsline, D. S., 1954; Handin, J. W., 1949; Isaacs, J. D., 1945k; Keller, W. D., 1941, 1945; Krumbein, W. C., 1947; Merriam, P. D., 1949; Olsson-Seffer, P., 1908, 1910a; Page, G. B., 1950; Reed, R. D., 1936b; Sinnott, A., 1941; Thompson, W. O., 1937; Twenhofel, W. H., 1946

Continental and Insular Shelves: Beach Erosion Board, 1952b; Cohee, G. V., 1938; Crooks, R. C., Elvitsky, A. W., et al, 1953; Dill, R. F., 1952; Eaton, R. O., 1951; Emery, K. O., 1952a, 1954b; Emery, K. O., Butcher, W. S., Gould, H. R. and Shepard, F. P., 1952; Fisher, R. L. and Mills, R., 1952; Garrison, L. E. and Takasaki, K. L., 1950; Inman, D. L., 1950; MacDonald, G. A., 1934; Marlette, J. W., 1954; Miller, R. L., 1954; Moore, D. G., 1951; Norris, R. M., 1951; Revelle, R. and Shepard, F. P., 1939b; Schneider, W. A., 1954; Shepard, F. P.. 1932, 1940c, 1949d; Shepard, F. P. and MacDonald, G. A., 1934, 1938; Shepard, F. P. and Wrath, W. F., 1937 Continental Slope: Dill, R. F., 1952; Emery, K. O., 1954b; Emery, K. O. and Rittenberg, S. C., 1952

Submarine Canyons: Cohee, G. V., 1938; Congressional Document, 1953b; Dill, R. F., Dietz, R. S. and Stewart, H., 1954; Garrison, L. E. and Takasaki, K. L., 1950; Handin, J. W., 1949; Ludwick, J. C., Jr., 1950; MacDoneld, G. A., 1934; Marlette, J. W., 1954; Shepard, F. P., 1934a, 1951a, 1951d; Shepard, F. P. and MacDonald, G. A., 1934; Shepard, F. P. and Emery, K. O., 1941

Granite and Granodiorite: Butcher, W. S., 195la; Dietz, R. S., Emery, K. O. and Shepard, F. P., 1942; Emery, K. O. and Shepard, F. P., 1945; Galliher, E. W., 1935a, 1935c; Hanna, G. D., 1952; Holzman, J. E., 1950; Kuenen, $\mathrm{Ph}$. H., 1947; Landes, K. K., 1952a; Lawson, A. C., 1893a; Revelle, R. and Shepard, F. P., 1939b; Shepard, F. P., 1936d, $1936 \mathrm{f}, 1936 \mathrm{e}, 1936 \mathrm{~g}, 1949 \mathrm{e}, 1950 \mathrm{e}, 1951 \mathrm{c}, 1952 \mathrm{a}$; Shepard, F. P. and Emery, K. 0., 194l; Shumway, G. A., 1953; Trask, P. D., 1952a

Ground Water (See also: Water Table): Revel.le, R., 1941; Revelle, R. and Emery, K. O., 1951

Gravel (See also: Cobble Beach): Anderson, C. A., 1941; Arnold, J. L., 1928; Blake, J., 1868b; Buck, C. D., 1928; Collins, L. B., 1931; Congressional Documents, 1880a; Crooke, R. G., Elvitsky, A. W. et al, 1953; Emery, K. O., 1941a, 1941c, 1947a; 0 . and Gould, H., 1948; Emery, K. O. and Shepard, F. P., 1941, 1945; Emery, K. O. and Tschudy, R. H., 194l; Everest, F. A., Young, R. W. and Johnson, M. W., 1948; Fraser, C. McL., 1943; Galliher, E. W., 1933, 1935c; Goodyear, W. A., 1873; Gregory, H. E., 1915; Hanna, G. D., 1951; Harding, C. R., 1929; Hoover-Young San Francisco Bay Bridge Commission, 1930; Johnson, M. W., 1948; Johnson, M. W., Everest, F. A. and Young, R. W., 1947; Lawson, A. C., 1894; Lesser, R. M., 1951; Louderback, G. D., 1920, 1924, 1940; Menard, H. W., 1952; Menard, H. W. and Ludwick, J. C., 1951; Morrison, R. L., 1930; Packard, E. L., 1918; Revelle, R., 1950; Revelle, R. and Shepard, F. P., 1939b; Schupp, R. D., 1953; Shepard, F. P., 1941a, 1948c, 1952a; Smith, A. G. and MacKenzie, G., Jr., 1948; Sumner, F. B., Louderback, G. D., Schmitt, W. L. and Johnston, E. C., 1914; Trask, P. D., 1931b, 1950; Trask, P. D. and Rolston, J. W., 1950 a Abyssal: Belkmap, G. E., 1874a; Emery, K. 0 . and Natland, M. L., 1952; Shepard, F. P., 1949d, 1950a, 1951b; Shumway, G. A., 1953

Bank and Seamount: Butcher, W. S., 195la; Carsola, A. J. and Dietz, R. S., 1952; Clements, T. and Dana, S. W., 1944; Dietz, R. S., Emery, K. 0. and Shepard, F. P., 1942 
Emery, K. 0., 1947a, 1947b, 1948; kmery, K. 0. Butcher, W. S., Gould, I. R. and Shepard, F. P., 1952; Emery, K. O. and Dietz, R. S., 1950;

Emery, K. 0. and Rittenberg, S. C., 1952; Emery, K. O. and Shepard, F. P., 1945; Garrison, L. E. and Takasaki, K. L., 1950; Hanna, G. D., 1952;

Holzman, J. E., 1950; Menard, H. W., 1952;

Shepard, F. P., 1938f, 1940b, 194la, 1949e, 195le;

Shepard, F. P. and Emery, K. 0., 1941, 1945;

Shumway, G. A., 1953; Uchupi, E., 1954

Basin: Emery, K. O. and Shepard, F. P., 1945; Shepard, F. P., 1951b

Beach and Nearshore: Anonymous, 1938a, 1938b, 1940d, 1950e; Bascom, W. N., 1946b, 1950c; Beach Erosion Board, 19481, 1949a, 1953a, 1954a;

Blake, W. P., 1856; Chase, A. W., 1875; CongressIonal Documents, 1940a, 1953b; Davis, W. M., 1932; Diller, J. S., 1898, 1902; Edman, J. A., 1894 , 1906; Emery, K. 0., 1946b, 1954c; Emery, K. 0. and Tschudy, R. H., 1941; Emonds, S. F. and Merrill, G. P., 1894; Fraser, C. McL., 1943; Goodyear, W. A., 1873; Grant, U. S., 1943; Grant, U. S. and Shepard, F. P., 1938a; Griggs, A. B. and Wells, F. G., 1942; Gulliver, F. P., 1896; Inman, D. L., 1949, 1953a, 1953b; Irelan, W. Jr., 1890; Isa.c8, J. D., 1945d; Johnson, A. G., 1935; Johnson, D. W., 1910; Lindsey, D. R., 1952; Louderback, G. D., 1940; McKee, E. D., 1953; MacDonald, G. A., 1934; Marlette, J. W., 1954; Martens, J. H. C., 1939; Mason, E. H., 1930; Mason, M. A., 1942; Merrill, F. J. H., 1917; Nelson, J. W., Dean, W. C., Kocher, A. E. Watson, E. B. and Carpenter, E. J., 1920; N1cholson, G. F., Grant, U. S., Shepard, F. P. and Crowell, J. C., 1946 (also lag gravel on beach); Norris, R. M., 1951; O'Brien, M. P., 1939; Paguirigan, F., 1941; Pardee, J. T., 1934; Putnam, W. C., 1938; R1tter, W. E., 1901; Schupp, R. D., 1953; Shaler, N. S., 1895; Shepard, F. P., 1941a, 1950c; Shepard, F. P. and Grant, U. S., 1947; Shepard, F. P. and Inman, D. L. 1951b; Shepard, F. P. and LaFond, E. C., 1940; Smith, A. G. and MacKenzie, G. Jr., 1948; Smith, W. S. T., 1897; Stevenson, R. E., 1954; Swinnerton, A. C., 1927; Thompson, W. O., 1937; Vaughan, T. W., 1940; Willis, B., 1900; Yale, C. G., 1913

Continental and Insular Shelves: Butcher, W. S., 195la; Crooke, R. C., Elvitsky, A. W., et al, 1953; Davidson, G., 1897; Davis, W. M., Putnam, W. C. and R1chards, G. L., Jr., 1931; Emery, K. O., 1947a, 1947c, 1952a; Emery, K. 0., Butcher, W. S., Gould, H. R. and Shepard, F. P., 1952; Emery, K. O. and Shepard, F. P., 1945; Galliber, E. W., 1935a, 1935b; Gorsline, D. S., 1954; Handin, J. W., 1949; Hanna, G. D., 1952; Inman, D. L., 1950; LaFond, E. C., Dietz, R. S. and Knauss, J. A., 1950; MacDonald, G. A., 1934; Moore, D. G., 1951; Norr1s, R. M., 1951; Pardee, J. T., 1934; Revelle, R. and Shepard, F. P., 1939b; Shepard, F. P., 1932, 1939b, 1941a, 1949b, 1949d; Shepard, F. P. and MacDonald, G. A., 1938; Shepard, F. P. and Wrath, W. F., 1937 Continental slope: Emery, K. O., 1950c; Hanns, G. D., 1952; shepard, F. P., 1952a

Submarine Canyons: Anonymous, 1939; Cohee, G. V., 1938; Davidson, G., 1887, 1897; Emery, K. O. and Shepard, F. P., 1945; Emery, K. O. and Tschudy, R. H., 1941; Inman, D. L., 1950; Kuenen, $\mathrm{Pb}$. H., 1947; Marlette, J. W., 1954; Revelle, R. and Shepard, F. P., 1939b; R1chardson, R. W., 1923; Shepard, F. P., 1932, 1933e, 1937b, 1938e, $1939 \mathrm{~d}, 1940 \mathrm{~b}, 1940 \mathrm{~d}, 1940 \mathrm{e}, 1941 \mathrm{a}, 1947 \mathrm{a}, 1948 \mathrm{~b}$, 1949e, 1951d, 1952a, 1953; Shepard, F. P. and Beard, C. N., 1938; Shepard, F. P., Revelle, R., Dietz, R. S. and Emery, K. O., 1938; Woodford, A. $0 ., 1951$

Gravel Bars - see Bars

Gravel Beach - see Cobble Beach

Gravity: Bauer, L. A., 1911; Bowle, W., 1924b; Briggs, I. J., 1916; Daly, R. A., 1934, 1939; Eardley, A. J., 1954; Emery, K. O., 1950c; Forbush, S. E., 1934; Gutenberg, B., 1933, 1941b, 1950; Heck, N. H., 1938; Helskanen, W., 1939; Hobbs, W. H., 1916; Jeffreys, H., 1934; Johnson, M. W., 1939b;
Koczy, F. F., 1954; Lawson, A. C., 1948; McManus, A. B. and Collins, E. B., 1934; Meinesz, F. A. V., 1930, 1941, 1948; Nettleton, I. L., 1951; Pratt, W. E., 1947; Ra1tt, R. W., 1954; Sanchez, P. C., 1934c, 1934d; Veughan, T. W., 1937; Wilson, G. M., 1946; Wood, H. O., 1915; Woolard, G. P., 1949,1951

Gray Mud: Evans, R. D., Kip, A. F. and Moberg, E. G., 1938; Galliher, E. W., 1933, 1935a; Richardson, R. W., 1923

Gray Sand: Bache, A. D., 1856a; Belknap, G. E., 1874a; California Department of Public Health, 1951; Crooke, R. C., Elvitsky, A. W., et al, 1953

Graywacke: Shumway, G. A., 1953

Grazing: Emery, K. O., 1954a; Fleming, R. H., 1939a; Sverdrup, H. U. and Allen, W. E., 1939

Green Mud: Belknap, G. E., 1874a; Cal1fornia Department of Public Health, 1951; Crooke, R. C., Elvitsky, A. W., et al, 1953; Davidson, G., 1887, 1897; Dietz, R. S., 1952a; Dill, R. F., 1952; Dill, R. F., Dietz; R. S. and Stewart, H., 1952; Emery, K. O., 1953b; Emery, K. O. and Dietz, R. S., 1941; Emery, K. O. and Rittenberg, S. C., 1952; Fox, D. L., Updegraff, D. M. and Novell1, G. D., 1944; Grim, R. E., Dietz, R. S. and Bradley, W. F., 1949; Hanna, G. D., 1952; Kuenen, Ph. H., 1946; Marlette, J. W., 1954; Michael, E. L. and McEwen, G. F., 1915; Moyer, D. A., 1929b; Natland, M. L., Revelle, R. and Rittenberg, S. C., 1941; Norr1s, R. M., 1951; Revelle, R., 1939b, 1950; Revelle, R. and Emery, K. O., 1941; RichardBon, R. W., 1923; Shepard, F. P. and Emery, K. O., 1941; Sverdrup, H. U., 1938c, 1939a; Sverdrup, H. U. and Staff, 1941; Tanner, Z. L., 1892a; Udden, J. A., 1914; Vaughan, T. W., 1940; Woodford, A. 0., 1951

Groins - see Engineering

Gullies especially on the Continental Slope: Benest, Н. 1899; Bucher, W. H., 1940; Buffington, E. C., 1951 and 1952 (characteristics and origin); Butcher, W. S., 1951a; Dietz, R. S., 1952a, 1954; Kuenen, Ph. H., 1947; McEwen, G. F. and Staff, 1948; Menard, H. W. and Ludwick, J. C., 1951; Norr1s, R. M., 1951; Thompson, W. C., 1949; Thompson, W. F. and Thompson, J. B., 1919; Toit, A. I. du, 1940; Shepard, F. P., 19370, $1941 \mathrm{c}$ (origin), 1943a, 1948d, 1952a

Gypsum: Emery, K. O., 1950d

Halogens (See also: Bromine, Chlorinity, Floride, Iodine): Bullock, F. W., 1933; Sverdrup, Н. U., 1939a

Hanging Valleys, Rocky Coasts: Smith, W. D., $1933 \mathrm{c}$

Harbor: Anonymous, 1906a, 1925b, 1938a, 1938b, 1940d, 1952f; Allen, W. B., 1932; Bascom, W. N., 1950b; Beach Erosion Board, 1942a, 1948a, 1948c, 1948e, $1948 \mathrm{f}, 1948 \mathrm{~g}, 1948 \mathrm{~b}, 19481,1948 \mathrm{j}, 1949 \mathrm{a}, 1951$, 1952a, 1954a, 1954e; Blinn, F. S., 1928; Broshous, C. R., 1938; Bruff, S. C., 1946; Bullock, F. W., 1933; Caldwell, J. M., 1950; California Department of Public Health, 1951; California, University of, 1952a, 1954a, 1954b; Chace, B. W., 1953; Colden, C. J., 1926; CongressIonal Documents, $1880 \mathrm{~b}, 1880 \mathrm{c}, 1897,1908 \mathrm{a}, 1908 \mathrm{e}$, $1908 \mathrm{~g}, 1908 \mathrm{~h}, 1909,1910,1926,1934 \mathrm{~b}, 1938 \mathrm{a}$ $1938 \mathrm{~b}, 1938 \mathrm{c}, 1938 \mathrm{~d}, 1940 \mathrm{a}, 1940 \mathrm{~b}, 1940 \mathrm{c}, 1940 \mathrm{~d}$, $1940 \mathrm{e}, 1940 \mathrm{f}, 194 \mathrm{l}, 1942 \mathrm{a}, 1942 \mathrm{~b}, 1942 \mathrm{c}, 1943$, $1949 \mathrm{a}, 1949 \mathrm{~b}, 1949 \mathrm{c}, 1949 \mathrm{~d}, 1949 \mathrm{e}, 1949 \mathrm{f}, 1949-$ 1950a, 1949-1950b, 1953a; Darrow, W. E., 1942; Davidson, G., 1884; Dunham, J. W., 1951; Eaton, R. O., 1951; Ewing, G. C., 1950c; Fries, A. A., 1912; Glllette, C. E., 1905; Gilluly, J. and Grant, U. S., 1947; Grant, U. S., 1938; Handin, J. W., 1949; Harts, W. W., 1901, 1911; Harvey, D. R., 1928; Hawgood, H., 1914; H1ckson, R. E. and Rodolf, F. W., 1951; Hoover, J. W., 1932a; Horton, D. F., 1948; Hough, J. L., 1942; Hudson, R. Y. and Moore, L. F., 1951; Hughes, R. T., 1947; Isaacs, J. D., 1948; Isaacs, J. D. and Bascom, W. N., 1947; Johnson, A. G., 1940, 1951; Johnson, J. W., 1948a, 1948d; Kaplan, K. and Pape, H. E., Jr., 1951; Kelton, E. C., 1940; Kenyon, E. C., Jr., 1951; Knapp, R. T. and Vanoni, V. A., 1945; Lapsley, W. W., 1937; Lawton, C. H., 1936; Leeds, C. T., 1915, 1936; Livingston, A., Jr., 1939; Los Angeles County 
Regional Planning Commission, 1938; Los Angeles Regional Water Pollution Control Board, 1952; Marlette, J. W., 1954; Mason, M. A., 1949b; McAfee, C. M., Jr., 1939; McArthur, W. P., 1850; McEwen, G. F., 1935b; McGowan, W. C., 1916; McKee, E. D., 1953; McOuat, H. W., 1951; Nelson, J. W., Zinn, C. J., Strahorn, A. T., Watson, E. B. and Dunn, J. E., 1919; Nicholson, G. F., 1929; Nicholson, G. F., Grant, U. S., Shepard, F. P. and Crowell, J. C., 1946; O'Brien, M. P., 1939; Peel, K. P., 1951; Pentegoff, V. P., 1947; Postel, A. C., 1939; Purcell, G., 1914; Sears, C. B., 1876; Shepard, F. P., 1949b, 1950c; Shepard, F. P. and Inman, D. L., 1951b; Smith, W. D., 1933a; Somers, P., 1952; Streblow, A. G., 1951; Studds, R. F. A., 1950; Symons, T. W., 1893; T1lden, C. A., 1925; Tower, M. L., 1910; Trask, P. D., 1931, 1952a; Trask, P. D. and Scott, T., 1954; U. S. Board Appointed to Locate a DeepWater Harbor at Port Los Angeles or at San Pedro, California, 1897; U. S. Cosst and Geodetic Survey, 1913; U. S. Waterways Experiment Station, Vicksburg, Mississipp1, 1947a, 1947b, 1949, 1950; Vanoni, V. A. and Carr, J. H., 1951; Verrill, G. E., 1930; Wharton, M., 1929; Whiting, W. D. and Others, 1858; Whittemore, G. F., 1916, 1917, 1926; Williamson, R. S. and Heuer, W. H., 1871; ZoBell, C. E., 1941

Headlands, Rocky Headlands, Promitories: Anonymous, 1938a, 1940d; Arnold, R., 1900; Barrows, A. L., 1913; Bascom, W. N., 1950b; Beach Erosion Board, 1942a, 1948a, 1948h, 1948i, 1949a, 1953c, 1954a; Blake, W. P., 1856; Brown, E. I., 1939; Bruff, S. C., 1946; California, University of, 1954a; Chase, A. W., 1875; Congressional Documents, 1938a, 1938c, 1940a, 1949b, 1949f, 1953b; Davidson, G., 1864 , 1875a; Davis, W. M., 1932; Davis, W. M., Putnam, W. C. and Richards, G. L., Jr., 1931; Dietz, R. S., 1947b; Diller, J. S., 1896; Drury, N. B., 1938; Dunham, J. W., 1951; Dunkle, M. B., 1944, 1950; Eaton, R. O., 1951; Emmonds, S. F. and Merrill, G. P., 1894; Fewkes, J. W., 1889; Frledman, S. L., 1949; Goldberg, J., 1940; Gulliver, F. P., 1896; Handin, J. W., 1949, 1951; Hannum, G. W. T., 1947; Harts, W. W., 1911; Hawgood, H., 1914; Hinds, N. E. A., 1952; Hoover, J. W., 1932a; Inman, D. L., 1940, 1953a, 1953b; Ives, R. L., 1951; Krumbein, W. C., 1947; Krumbein, W. C. and Ohsiek, L. E., 1950; Kuenen, Ph. H., 1937; Lawson, A. C., 1924; Leeds, C. T., 1936; Leypoldt, H., 194la, 1941b; Livingston, A. Jr., 1939; Louderback, G. D., 1940; MacDonald, G. A., 1934; Masters, P., 1840; Munk, W. H. and Traylor, M. A., 1947; Nicholson, G. F., Grant, U. S., Shepard, F. P. and Crowell, J. C., 1946; Norris, R. M., 1951, 1952; O'Brien, M. P., 1936a; O'Brien, M. P. and Johnson, J. W., 1947; Page, G. B., 1950; Pardee, J. T., 1934; Peel, K. P., 1951; Price, F., 1936; Putnam, J. A. and Arthur, R. S., 1948; Putnam, W. C., 1938; Scripps Institution of Oceanography, 1954b; Schupp, R. D., 1953; Shalowitz, A. L., 1951; Shepard, F. P., 1950c, 1950g, 1952a; Shepard, F. P. and Emery, K. O., and LaFond, E. C., 1941; Shepard, F. P. and Grant, U. S., 1947; Shepard, F. P. and Inman, D. L., 1949; Shepard, F. P. and LaFond, E. C., 1942; Smith, W. D., 1933b, 1933c; Snavely, P. D., Jr., 1951; Stevenson, R. E., 1954; Symons, T. W., 1893; Thompson, W. 0., 1937; Tower, M. L., 1910; Trask, P. D., 1952a, 1952b; Twenhofel W. H., 1943; Willis, B., 1900; Wilson, M. E., 1907

Heating: Jacobs, W. C., 1942 and 1943 (heat exchange), 1949; LaFond, E. C : , 1939a, 1940; McEwen, G. F., 1950; Sverdrup, H. U., 1937-1938, 1938a, 1939c, 1940g (heat budget)

Heavy Minerals:

$$
\text { Abyssal: Koczy, F. F., } 1954
$$

Bank: Butcher, W. S., 1951a; Dana, S. W., 1942; Emery, K. 0., 1948; Emery, K. 0., Butcher, w. S., Gould, H. R. and Shepard, F. P., 1952; Holzman, J. E., 1950; Uchup1, 'E., 1954 Basin: Emery, K. O., Butcher, W. S., Gould, H. R. and Shepard, F. P., 1952; Emery, K. O. and Rittenberg, S. C., 1952; Ludw1ck, J. W., Ir.,
1950

Beach and Nearshore: Anonymous, 1950a, 1951d, 1954J; Averili, C. V. and others, 1946; Boos, M. F., 1940; Bullard, F. M. and M1lls, R. A., 1951; Congressional Documents, 1953b; Edman, J. A., 1894; Griggs, A. B. and Wells, F. G., 1942; Handin, J. W., 1949, 1951; Hundheusen, R. J., 1947; Inman, D. L., 1950, 1953b; Lakes, A., 1899; Marlette, J. W. , 1954; Martens, J. H. C., 1939; Scripps Institution of Oceanography, 19521, 1953c; Shepard, F. P., Inman, D. L. and Floher, R. L., 1951; Sinnott, A., 1941; Thompson, W. O., 1937; Trask, P. D., 1924, 1952b; Twenhofel, w. H., 1943; Yale, C. G., 1913

Coastal Sand Dunes: Handin, J. W., 1949; Merriam, P. D., 1949

Continental Shelf: Anonymous, 1950b, 1954J;

Butcher, W. S., 195la; Emery, K. O., Butcher, w. S., Gould, H. R. and Shepard, F. P., 1952; Gorsline, D. S., 1954; Inman, D. L., 1950; Marlette, J. W., 1954; Shepard, F. P. and Wrath, W. F., 1937 Submarine Canyons: Cohee, G. V., 1938; Crowell, J. C., 1952; Dill, R. F., Dietz, R. S. and Stewart, H., 1954; Marlette, J. W., 1954

Helium: Piggot, C. S. and Urry, W. D., 1942; Sisler, F. D. and ZoBell, C. E., 1951b

Holdfasts: Andrews, H. L., 1945; Couch, E. B., 1915; Crowell, J. C:, 1952; Emery, K. 0. and Trchudy, R. H., 1941; Ritter, W. E., 1902; Shumway, G. A., 1953; Trask, P. D., 1939

Hooks - see Cuspate Forelands

Horst (See also: Submarine Topography): Koczy, F. F., 1954 Hydration - see Temperature of Hydration and Dehydration Hydrogen: Fox, D. L. and Anderson, L. J., 1941; Galliher, E. W., 1933; Rosenfeld, W. D., 1948; S1sler, F. D. and ZoBell, C. E., 1950, 1951a, 1951b; Trask, P. D., 1939; ZoBell, C. E., 1939, 1942b, $1944,1946 \mathrm{~b}, 1946-1947,1947 \mathrm{~b}, 1947 \mathrm{c}, 1947 \mathrm{~d}, 1949$,

Hydrogen Ion Concentration - see $\mathrm{pH}$

Hydrogen Sulfide (See also: Gases, Hyärogen, Iron, Iron Sulfides, Pyrite, Sulfur): Brongersma-Sanders, M., 1948; California Department of Fish and Game, 1951; Callfornia Department of Public Health, 1951; Cohee, G. V., 1938; Dapples, E. C., 1942; Dill, R. F., 1952; Emery, K. 0., 1946b; Emery, K. O. and Rittenberg, S. C., 1952; Ford, J. L. C. 1942; Fox, D. L., 1950; Fox, D. L. and Anderson, L. J., 1941; Fox, D. L., Updegraff, D. M. and Novell1, G. D., 1944; Galliher, E. W., 1933, 1935a, 1935c; Hoots, H. W., 1943; Horonjeff, R. and Patrick, D. A., 1952; Inman, D. L., 1950; Krumbein, W. C., 1942; Louderback, G. D., 1940; McKee, E. D., 1953; Marlette, J. W., 1954; Miller, R. C., Ramage, W. D. and Lazler, E. L., 1928; Moore, D. G., 1951; Moulton, G. F., 1928; Natland, M. L., Revelle, R. and Rittenberg, S. C., 1941; Revelle, R., 1939b, 1941, 1950; Rittenberg, S. C., 1940; San Diego Regional Water Pollution Control Board, 1952; Shepard, F. P., 1951a; Shepard, F. P., Inman, D. L. and Fisher, R. L., 1951; Sisler, F. D. and ZoBell, C. E., 1950, 1951a, 1951b; Stevenson, R. E., 1954; Stevenson, R. E. and Emery, K. O., 1951; Sverdrup, H. U., 1939a, 1940d; Sverdrup, H. U. and Staff, 1941; Thompson, T. G. and Robinson, R. J., 1932; Trask, P. D., 1939; Trask, P. D. and Scott, T., 1954; Vaughan, T. W., 1940; Wr1ght, R., 1937; ZoBell, C. E., 1938, 1939, 1942a, $1942 \mathrm{~b}, 1946$, $1946-1947,1947 \mathrm{~b}, 1947 \mathrm{c}, 1947 \mathrm{~d}, 1950$; ZoBell, C. E. and Feltham, C. B., 1942

Hydrotroilite - see Iron Sulfides

Hyaroxides - see Iron Oxides

Igneous Rocks (See also: Rock and various rock types): Butcher, W. S., 1951a; Clements, T. and Dana, S. W., 1944; Davis, W. M., Putnam, W. C. and Richards, G. L., Jr., 1931; Emery, K. 0., 1941a, 1946b, 1948; Emery, K. 0., Butcher, W. S., Gould, H. R. and Shepard, F. P., 1952; Emery, K. O. and Dletz, R. S., 1950; Emery, K. O. and Shepard, F. P., 1941, 1945; Gorsline, D. S., 1954; Holzman, J. E., 1950; Kew, W. S. W., 1928; Moore, D. G., 1951; Norris, R. M., 1951; Revelle, R. and Shepard, F. P. 1939b; Shepard, F. P. and Emery, K. O., 1941; Shepard, F. F. and Wrath, W. F., 1937; Shumway, G. A., 1953; 
Uchupi, E., 1954

Ignition Los 8: Trask, P. D., 1927b; Putnam, J. A., Bermel, K. J. and Johnson, J. W., 1947

Imbrecation: Emery, K. O. and Stevenson, R. E., 1950 Insoluble Residue (See also: Heavy Minerals): Dietz, R. S., Emery, K. O. and Shepard, F. P., 1942; Emery, K. 0., 1946b, 1948; Emery, K. 0., Butcher, W. S., Gould, H. R. and Shepard, F. P., 1952; Emery, K. O. and Dietz, R. S., 1950; Emery, K. O. and Rittenberg, S. C., 1952; Gorsline, D. S., 1954; Holzman, J. E., 1950; Shepard, F. P., $1949 \mathrm{~b}$

Insolution: Fleming, R. H. and Revelle, R., 1939

Interflow i.e. turbidity currents (See also: Bottom Flow, Turbidity Currents): Menard, H. W. and Ludwick, J. C., 1951

Instrumentation: Bascom, W. N., 1948a; Beach Erosion Board, 1952b; California, University of, 1954a; Colbert, L. O., 1939; Fox, L. S., 1930 (diving); O'Brien, M. P. and Johnson, J. W., 1947; Scripps Institution of Oceanography, 1952h; Sverdrup, H. U., 1938c, 1939a; U. S. Bureau of Fisheries, 1921

Biological Instrumentation: Allen, W. E., 1928d, 1930a, 1940a, 1940d; Bullock, F. M., 1933; California Academy of Sciences, California Division of Fish and Game, Scripps Institution of oceanography, U. S. Fish and Wildlife Service, 1950; Coe, W. R. and Allen, W. E., 1937; Rittenberg, S. C., 1940; ZoBell, C. E., 1947d; ZoBell, C. E. and Feltham, C. B., $1934 \mathrm{~b}, 1942$

Marine Geological Instrumentation: Anonymous, 1939; Armstrong, T. A., 1954; Atwill, E. R., 1942; Bascom, W. N., 1950a; Beach Erosion Board, 1944b, 1949c; California, University of, 1945; Dietz, R. S., 1954; Emery, K. O. and Dietz, R. S., 1939, 1941; Emery, K. O. and Gould, H. R., 1948; Emery, K. O. and Shepard, F. P., 1945; Fisher, R. L., and Mills, R., 1952; Folsom, R. G., 1944; Fox, L. S., 1930; Hanna, G. D., 1952; Isaacs, J. D., 1945a, 1945f; LaFond, E. C., 1939b; LaFond, E. C., Dietz, R. S. and Knauss, J. A., 1950; Menard, H. W., Dill, R. F., Hamilton, E. L., Moore, D. G., Shumway, G., Silverman, M. and Stewart, H. B., 1954; Raitt, R. W., 1954; Revelle, R. and Shepard, F. P., 1939b; Rittenberg, S. C., 1940; Scripps Institution of Oceanography, 19521; Shepard, F. P., 1938b, 1940e, 1947a, 1948d, 1949b; Shepard, F. P. and Emery, K. O., 1945; Shepard, F. P., Revelle, R., Dietz, R. S. and Emery, K. O., 1938; Trask, P. D., 1927a; Varney, F. M. and Redwine, L. E., 1937; Warner, S. E. 1946a, 1946b, 1947; Watts, G. M. and Others, 1953; Wilson, G. M., 1946

Oceanographic Instrumentation: Bascom, W. N. 1947b, 1947e, 1948b; Beach Erosion Board, 1949b, 1949c; California Academy of Sciences, Californis Division of Fish and Game, Scripps Institution of Oceanography, U. S. Fish and Wildlife Service, 1950; California, University of, 1945; Chinn, A. J., 1949; Dyk, K. and Swainson, O. W., 1953; Everest, F. A., Young, R. W., and Johnson, M. W. 1948; Folson, R. G., 1944c, 1945a, 1945b, 1945c, 1948a, 1948b, 1949; Forrest, D. R., 1950; Fox, D. L., Isaacs, J. D. and Corcoran, E. F., 1952; Gerhardt, J. R. and Jehn, K. H., 1954; Goldberg, E. D. , Baker, M. and Fox, D. L., 1952; Gorgy, S., Rakestraw, H. W. and Fox, D. L., 1948 (chemical); Hughes, R. T., 1946; Inman, D. L. and Quinn, W. H., 1952; Isaacs, J. D. and Wiegel, R. L., 1950; Iversen, H. W., 1945; Johnson, J. W., 1948b, 1948c; Knapp, R. T., 1952; Lesser, R. M., 1951; 0'Brien, M. P. and Johnson, J. W., 1947; Revelle, R. and Shepard, F. P., 1943; Scanlon, T. S., Jr. and Osborn, P., 1950; Schneider, W. A., 1954; Scripps Institution of Oceanography, $1950 \mathrm{~g}, 1951 \mathrm{~g}, 1953 \mathrm{~b}$; 1953c, 1953g; Shepard, F. P., Emery, K. O. and LaFond, E. C. , 1941; Shepard, F. P. and Inman, D. L., 1949; Shepard, F. P. and LaFond, E. C., 1940; Snodgrass, F. E., 1951, 1952, 1954; Sverdrup, H. U., 1940d; Sverdrup, H. U. and Staff, 1943a; Thompson, T. G. and Robinson, R. J., 1932 (chemical); Tibby, R. B., 1937a; Wiegel, R. L., 1948; U. S. Commission of Fish and Fisheries, 1898; Young, R. T., Jr., 1939, 1943; Young, R. T., Jr. and Gordon, R. D., 1939
Insular shelf (See also: Continental Shelf): Beach Erosion Board, 1948h; Butcher, W. S., 195la; Dana, S. W., 1942; Emery, K. 0. 1947c; Emery, K. O., Butcher, W. S., Gould, H. R. and Shepard, F. P., 1952; Menard, H. W., Dill, R. F., Hamilton, E. L., Moore, D. G., Shumway, G., Silverman, M. and stewart, H. B., 1954; Miller, J. C., 1953; Norris, R. M., 1951; Shepard, F. P., 1932, 1941a; Shepard, F. P. and Emery, K. O., 1941; Shepard, F. P., Grant, U. S. and Dietz, R. S., 1939; Shepard, F. P. and Wrath, W. F., 1937; Smith, W. S. T., 1897; Stock, C., 1935; Uchupi, E., 1954; Wrath, W. F., 1938

Internal Waves: California Academy of Sciences, California Division of Fish and Game, Scripps Institution of Oceanography, U. S. Fish and Wildlife Service, 1950; Crowell, J. C., 1947; Defant, A., 1950a, 1950b; Dietz, R. S. and Menard, H. W., 1951b; Emery, K. O., Butcher, W. S., Gould, H. R. and Shepard, F. P., 1952; Ewing, G. C., 1950a, 1950b; Fleming, R. H., 1937-1938; Gilbert, J. Y. and Allen, W. E., 1943; LaFond, E. C., 1949; Leipper, D. F., 1950; Menard, H. W., 1952; Menard, H. W. and Ludwick, J. C., 1951; Munk, W. H., 1940, 1941; Revelle, R., 1939b, 1950; Rudnick, P. and Cochrane, J. D., 1951; Scripps Institution of Oceanography, 1950g; Shepard, F. P., 1941a, 1949d; Shepard, F. P. and Emery, K. O., 1941; Skogsberg, T., 1936; Sverdrup, H. U., 1939c, 1940f; Ufford, C. W., $1947 \mathrm{a}, 1947 \mathrm{~b}, 1947 \mathrm{c}$

Interstitial sedimentation (See also: Sedimentation): Galliher, E. W., 1935c

Interstitial Water and Water Content of Sediments: Crooke, R. C., Elvitsky, A. W., et al, 1953; Emery, K. O. and Dietz, R. S., 1941; Krumbein, W. C., 1942; Natland, M. L., Revelle, R. and Rittenberg, S. C., 1941; Sverdrup, H. U., 1939a; Sverdrup, H. U. and Staff, 1941; Trask, P. D., 1927a, 1927b, 1932a, 1939; Trask, P. D. and wu, C. C., 1930b; ZoBell, C. E., $1938,1942 a, 1942 b$

Abyssal: Dill, R. F., 1952; Revelle, R., 1937a, 1937b; Scripps Institution of Oceanography, $1953 \mathrm{e}$

Basin: Emery, K. O., 1950e; Emery, K. O. and Rittenberg, S. C., 1951, 1952; Revelle, R., 1950 (Gulf of California); Rittenberg, S. C., 1940 (Gulf of California); Smith, P. V., Jr., 1954; Trask, P. D., 1931a, 1931b

Bays, Estuaries, Lagoon, Mud Flat, Salt Marsh:

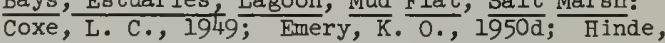
H. P., 1952; Petracek, F. J., Fox, D. L. and Zechmeister, C., 1951; Stevenson, R. E., 1954; Stevenson, R. E., and Emery, K. O., 1951; Trask, P. D. and Rolston, J. W., 1950b

Beach and Nearshore: Emery, K. O., 1945a; Emery, K. O. and Foster, J. F., 1948; Emery, K. O. and Gale, J. F., 1951; Emery, K. O. and Stevenson, R. E., 1950; Grant, U. S., 1946; Krumbein, W. C., 1950; Palmer, R. H., 1928; Stump, R. S. and Bascom, w. N., 1947

Coastal Sand Dunes: Olsson-Seffer, P., 1908, 1910a; Purer, E. A., 1936

Continental Shelf: Dill, R. F., 1952; Fox, D. L. 1937; Revel $\overline{l e, ~ R}$. and Emery, K. O., 1951

Iodine (See also: Halogens): Evans, R. D., Kipp, A. F. and Moberg, E. G., 1938; McEwen, G. F., 19348; Sverdrup, H. U., 1939a; Sverdrup, H. U. and Staff, 1941; Thompson, T. G. and Robinson, R. J., 1932; Trask, P. D., 1939; Vaughan, T. W., 1940

Ionium - see Radioactivity

Iron (See also: Beach Placers, Black Sands, Heavy Minerals, Iron oxides and Hydroxides, Iron Sulfides, Limonite, Magnetic Minerals, Mineralogy, Pyrite, Sulfur): Anonymous, 1954m; Ahlstrom, E. H., 1950; Brongersma-Sanders, M. , 1948; Cartwright, L. D. Jr., 1928; Dapples, E. C., 1942; D11l, R. F., 1952; Emery, K. O., 1952a; Emery, K. O., Butcher, W. S., Gould, H. R. and Shepard, F. P., 1952; Fleming, R. H., 1938a; Galliher, E. W., 1933, 1935a, 1935c, 1937; Goldberg, E. D., 1952, 1954; Goldberg, E. D., Walker, T. J. and Whisenand, A., 1952; Inman, D. L., 1950; Koe, K. B., Fox, D. L. and Zechmeister, L., 1950; Krumbein, W. C., 1942; L1pman, C. B., 1929; McEwen, G. F., 1934a; Messner, W. E., 1954; Moulton, G. F., 1928; 
Natland, M. L., Revelle, R. and Rittenberg, S. C., 1941; Piggot, C. S., 1932, 1944; Revelle, R., 1935, 1937a, 1937b, 1950; Revelle, R. and Emery, K. O., 1951; Rotschi, H., 1951; Scripps Institution of Oceanography, 1953e; Sisler, F. D. and ZoBell, C. E., 195la; Stanton, T. E., Jr., 1938; Stevenson, R. E., 1954; Sverdrup, H. U., 1940d, 1940e; Sverdrup, H. U. and Staff, 1941; Thompson, T. G. and Robinson, R. J., 1932; Trask, P. D., 1939; Updegraff, D. M., 1948; Vaughan, T. W.' 1935a; Wright, R., 1937; ZoBell, C. E., 1935 , 1936 , 1939, 1941, 1942a, 1942b, 1943, 1946b, 1947b, $1947 \mathrm{c}, 1947 \mathrm{~d}, 1950 ; \mathrm{ZoBell}, \mathrm{C} . \mathrm{E}$. and Anderson, D. Q., 1936 (deposition of iron)

Iron Oxides and Hydroxides (See also: Iron, Limonite): Emery, K. O., Butcher, W. S., Gould, H. R. and Shepard, F. P., 1952; Galliher, E. W., 1933, 1935c; Goldberg, E. D., 1954; Scripps Institution of Oceanography, 1953e; Stanton, T. E., Jr., 1938; Stevenson, R. E., 1954; Vaughan, T. W., 1935a; Wright, R., 1937

Iron sulfides including Melnikovite, Hydrotroilite (See also: Pyrite, Sulfur): Emery, K. O. and Rittenberg, S. C., 1952; Galliher, E. W., 1933, 1935c; Louderback, G. D., 1940; McKee, E. D., 1953; Natland, M. L., Revelle, R. and Rittenberg, S. C., 1941; Revelle, R., 1950; Sisler, F. D., 1949; Sisler, R. D. and ZoBell, C. E., 1950, 1951; Stevenson, R. E., 1954; Stevenson, R. E. and Emery, K. O., 1951; Sverdrup, H. U., 1940d; Sverdrup, H. U. and Staff, 1941; Thompson, T. G., and Robinson, R. J., 1932; Trask, P. D., 1939; Vaughan, T. W., 1935a; Wright, R., 1937; ZoBell, C. E., 1935, 1939, 1942a, 1947b, 1947c, 1947a, 1950

Isostasy: Daly, R. A., 1934, 1939; Dill, R. F., Dietz, R. S. and Stewart, H., 1954; Hodge, E. T., 1934; Lawson, A. C., 1924, 1939, 1948; Menard, H. W. and Dietz, R. S., 1951; Woolard, G. P., 1951

\section{Jetties - see Engineering}

Joints (on Rocky Coasts) - see Minor Features, Rocky Coasts Jurassic: Emery, K. O., 1941a, 1948; Emery, K. O. and Shepard, F. P., 1941, 1945; Holzman, J. E., 1950; Shepard, F. P. and Emery, K. 0., 1941; Shepard, F. P. and MacDonald, G. A., 1938; Shepard, F. P. and Wrath, W. F., 1937

Lagoon (See also: Bay, Embayment, Estuary, Harbor, Marsh, Reefs, Salt Marsh, Swamp, Tide Flat): Anonymous, 1940d; Alden, J., 1852; Anderson, C. A., 1950; Arnold, J. L., 1928; Atwill, E. R., 1942; Bache, A. D., 1862; Bascom, W. N., 1946b; Beach Erosion Board, 1948h; Blake, W. P., 1856; Bruff, S. C., 1946; Clark, A., 1933; Clark, W. O., 1915; Congressional Documents, 1940a; Daly, R. A., 1934; Dapples, E. C., 1942; Davidson, G., 1856, 1897; Daws on, E. Y., 1952; Diller, J. S., 1903; Emery, K. O., 1950d; Fraser, C. McL., 1943; Gislen, T., 1943; Goldberg, J., 1940; Gorsline, D. S., 1954; Grant, U. S. and Sheppard, W. E., 1934; Handin, J. W., 1949; Handin, J. W. and Ludwick, J. C., 1949; Hertlein, L. G. and Emerson, W. K., 1953; Howard, A. D., 1951; Inman, D. L., 1949, 1950, 1953b; Ives, R. L., 1951; Johnson, J. W., 1949a; Kenyon, E. C., Jr., 1951; Lawson, A. C., 1893a, 1894, 1914; Lee,. C. H., 1941; Leeds, C. T., 1915; Leypoldt, H., 1941b; Livingston, A., Jr., 1939; MacDonald, G. A., 1934; McKee, E. D., 1953; McOuat, H. W., 1951; Merrill, F. J. H., 1917; Michael, E. L., 1921; Miller, H. E. and Nausbaum, I., 1952; Morrison, R. L., 1930; Natland, M. L., 1933a; Natland, M. L. Revelle, R. and Rittenberg, S. C., 1941; Nelson, E. W., 1922; Nelson, J. W., Zinn, C. J., Stahorn, A. T., Watson, E. B. and Dunn, J. E., 1919; Nicholson, G. F., Grant, U. S., Shepard, F. P. and Crowell, J. C., 1946; Norris, R. M., 1951, 1952; Page, G. B., 1950; pardee, J. T., 1934; Patrick, D. A., 1950; Pease, W. H., 1868; Rankin, W. D., 1931; Revelle, R., 1950; Rothwell, W. T., Jr., 1946; Sanchez, P. C., 1934c; Scripps Inst1tution of oceanography, 1953c; Shepard, F. P., 1932, 1950c, 1952b; Shepard, F. P., Inman, D. L. and Fisher, R. L., 1951; Shuler, W. R., 1951;
Smith, W. D., 1933c; Somers, P., 1952; Soper, E. K., 1938; Stevenson, R. E., 1954; Storie, R. E. and Carpenter, E. J., 1929; Trask, P. D., 1939, 1952a; Trowbridge, W. P., 1856b; Vaughan, T. W., 1940; Veach, J. A., 1859; Weaver, C. E., 1949; ZoBell, C. E., 1939; ZoBell, C. E. and Feltham, C. B., 1942

Lamination, Stratification (See also: Graded Bedding, Sand Layers): Atwill, E. R., 1942; Butcher, W. S., 1951a; Cohee, G. V., 1938; Dapples, E. C., 1942; Dill, R. F., Dietz, R. S. and Stewart, H., 1954; Emery, K. 0., 1945a, 1950d; Emery, K. C. and Dietz, R. S., 1941; Emery, K. 0. and Natland, M. L., 1952; Emery, K. 0. and Rittenberg, S. C., 1952 Emery, K. O. and Stevenson, R. E., 1950; Ford, J. L. C., 1942; Fox, L. S., 1930; Galliber, E. W., 1935a, 1935c; Garrison, L. E. and Takasak1, K. L., 1950; Inman, D. L., 1949, 1953b; Kuenen, Ph. H. and Menard, H. W., 1952; Lang, H., 1916; Louderback, G. D., 1920, 1940; McKee, E. D., 1935, 1953; MacDonald, G. A., 1934; Martens, J. в. C., 1939; Moore, D. G., 1951; Natland, M. L., Revelle, R. and Rittenberg, S. C., 194l; Olsson-Seffer, P., 1908; Page, G. B., 1950; Palmer, R. В., 1928; Phlege F. B., 1951; Piggot, C. S., 1944; Reed, R. D., 1930b; Revelle, R., 1939, 1950; Scripps Institution of Ocean graphy, 1953e; Shepard, F. P., 194la, 1949b, 1951d;

Shepard, F. P., Inman, D. L. and Fisher, R. L., 1951; Shepard, F. P. and MacDonald, G. A., 1938; Sinnott, A 1941; Sverdrup, H. U., 1939a; Sverdrup, H. U. and Staff, 1941; Thompson, w. 0., 1933, 1937; Trask, P. D., 1931b; Trask, P. D. and Scott, T., 1954; Woodford, A. O., 1951; ZoBell, C. E., $1938,1942 \mathrm{~b}, 1944,1946 \mathrm{~b} ; \mathrm{ZOBell}, \mathrm{C} . \mathrm{E}$. and Anderson, D. Q., 1936

Land Bridges, 1.e., former land bridges connecting the channel Islands to the mainland: Bruff, S. C., 1946; Cockerell, T. D. A., 1938b; Chaney, R. W. and Mason, H. L., 1934; Dunkle, M. B., 1950; Emilian1, C. and Epstein, S., 1953; Goodyear, W. A., 1890; Landes, K. K., 1952a; Norris, R. M., 1951; Shepard, F. P., 1948c, 1949e; Stock, C., 1936; Stock, C. and Furlong, E. L., 1928

Landslides - see Submarine Slumping; Submarine Canyons, origin of

Lead: Piggot, C. S. and Urry, W. D., 1942; Revelle, R. and Emery, K. O., 1951; Trask, P. D., 1939

Legal, beaches unless otherwise noted. (See also: Tidelands): Anonymous, 1933c, 1941b, 1944a; Alexander, A. H., 1936; Barnes, A. J., 1937; Beach Erosion Board, 1939 , 19481, 1954a, 1954c; Bingham, J. W., 1938 (fisheries); Blodget, R. M., 1949 (tidelands); California Legislature, 1874 (marsh lands); Congressional Documents, 1881, 1949f, 1949-1950b, 1953; Fitzgerald, J. N. J., 1952 (tidelands); Friedman, S. L., 1949; Griffin, D. F., 1944; Hannum, G. W. T., 1947; Hjelte, G., 1938; Johnson, A. G., 1935, 1951; Kingman, J. J., 1936; Lamport, H. B., 1937; Larson, G. P., 1939, 1941, 1942a, 1943, 1946; Leeds, C. T., 1915, 1936; Los Angeles County Regional Planing Commission, 1940; McOuat, H. W., 1951; Morgan, F. A., 1930; Mouton, M. W., 1952 (international law of tidelands, flaheries etc.); Nicholson, G. F., Grant, U. S., Shepard, F. P. and Crowell, J. C., 1946; O'Brien, M. P., 1939; Orange county Planning Commission, 1940; Patton, R. S., 1941; Pollak, C. N., 1953 (tidelands) Porter, J. S., 1936; Price, F., 1936; Pyles, E. E., 1954 (tidelands); Shalowitz, A. L., 1953 (tidelands); Shaw, P. A. and Towers, C. L., 1937; Shuler, W. R., 1952; Smith, J. S., 1936, 1937; Stockman, L. P., 1932 (tidelands); Woodson, J. B., 1941

Lenses: Anonymous, 1951d; Butcher, W. S., 1951a; Dietz, R. S., Emery, K. O. and Shepard, F. P., 1942; Emery, K. 0., 1950d; Emery, K. 0., Butcher, W. S., Gould, H. R. and Shepard, F. P., 1952; Emery, K. O. and Natland, M. L., 1952 Griggs, A. B. and Wells, F. G., 1942; Hall, J. V., Jr., 1952; Shepard, F. P., 1951b; Stevenson, R. E., 1954; Thompson, W. C., 1949; Thompson, W. O., 1937; Trask, P. D., 1924

Levees, Natural: Buffington, E. C., 1951, 1952; Dietz, R. S., 1952a, 1953 (leeved banks); Dill, R. F., Dietz, R. S. and Stewart, H., 1952, 1954; Landes, K. K., 
1952a; Menard, H. W. and Ludwick, J. C., 1951; Shepard, F. P., 1950d, 1951c, 1953; Stevenson, R. E., 1954

Light (See also: Absorption, Extinction Coefficient, Light Reflection off Sea Water, Transparency, Turbid Water): Allen, W. E., 1920, 1927a, 1928c, 1930a, 1940b, 1940d, 194la, 194lc, 1946a; Andrews, H. L., 1945; Bongersma-Sanders, M., 1948; Bullock, F. W., 1933; Burt, W., 1952; California Academy of Sciences, California Division of Fish and Game, Scripps Institution of Oceanography of the University of California, and U. S. Fish and Wildlife Service, 1950, 195la; Coe, W. R., 1948; Connell, C. H. and Cross, J. B., 1950; Couch, E. B., 1915; Bmery, K. 0. and Tschudy, R. H., 1941; Esterly, C. 0., 1911; Ewing, G. C., 1950a; Fleming, R. B., 1939a; Fox, D. L. and Anderson, L. J., 1941; Gislên, T., 1944; Hewatt, W. G., 1937; Johnson, M. W., 1939b, 1948; Kindle, E. M. , 1934; MacGinitie, G. E., 1927, 1937; Miller, R. C., Ramage, W. D. and Lazier, E. L., 1928; Moberg, E. G., 1925, 1928a, 1930c; Morrison, R. L., 1930 Myers, Е. H., 1942, 1943; P'e1, C., 1929; Purer, E. A., 1936, 1942; Richardson, B., 1932a, 1934; Scripps Institution of Oceanography, 1952i; Sverdrup, H. U., 1940e, 1940g; T1lden, C. A., 1925; Topp, E. P., 1929; Trask, P. D., 1939; Vaughan, T. W., 1930b, 1930d, 1932a, 1932b, 1932c, 1934, 1940; Young, R. T., Jr., 1939 (including scattering of light); Young, R. T. and Gordon, R. D., 1939; ZoBell, C. E., 1942a, 1942b, $1947 \mathrm{c}$ Light Reflection off Sea Water: Ewing, G. C., 1950a Limestone (See also: Carbonates, Coquina, Marl, Rock, Sedimentary Rock, Shells): Anderson, C. A., 1941; Butcher, W. S., 195la; Cohee, G. V., 1938; Dapples, G. C., 1942; Dietz, R. S., Emery, K. O. and Shepard, F. P., 1942; Emery, K. O., 194la, 1941b, 1952a; Emery, K. O., Butcher, W. S., Gould, H. R. and Shepard, F. P., 1952; Emery, K. O. and Shepard, F. P., 1945; Emery, K. O. and Tschudy, R. H., 1941; Gee, H., 1932; Hinds, N. E. A., 1952; Holzman, J. E., 1950; Inman, D. L., 1950; Landes, K. K., 1952a; MacDonald, G. A. 1934; Moore, D. G., 1951; Nelson, R. N. and Schenck, H. G., 1928; Shepard, F. P., 1936f, 1949b, 1953; Shepard, F. P. and Emery, K. O., 1945; Shepard, F. P. and Grant, U. S., 1947; Shumway, G. A., 1953; Trask, P. D., 1932b; Uchupi, E., 1954; ZoBell, C. E., 19470, $1947 \mathrm{~d}$ Limonite (See also: Iron, Iron Oxides and Hydroxides): Butcher, W. S., 1951a; Cohee, G. V., 1938; Dapples, E. C., 1942; Dill, R. F., 1952; Emery, K. O., Butcher, W. S., Gould, H. R. and Shepard, F. P., 1952; Galliher, E. W., 1933; Holzman, J. E., 1950; Revelle, R. and Shepard, F. P., 1939b Lithification - see Consolidation

Lithium: McEwen, G. F., 1934a; Revelle, R. and Emery, K. O., 1951; Thompson, T. G. and Robinson, R. J., 1932; Vaughan, T. W., 1933

Littoral Currents - see Longshore and Littoral Currents Littoral Drift, Beach Drift, Longshore Drift (See also: Concentration of Sediment in the Surf Zone, Creep, Suspended Sediment, Traction, Transport of Sediment): Anonymous, 1916a, 1917, 1938a, 1940d, 1941b; Beach Erosion Board, 1942a, 1948a, 1948b, 1948i, 1948j, $1949 a, 1950 b, 1951,1952 a, 1953 a, 1953 c, 1954 a$; Blinn, F. S., 1928; Brown, E. I., 1939; California, University of, 1952a, 1952b; Congressional Documents, 1938a, 1940a, 194l, 1942b, 1942c, $1949 \mathrm{f}$ 1949-1950b, 1953b; Crowell, J. C., 1952; Dunham, J. W., 1951; Eaton, R. O., 1951; Fisher, R. L. and Mills, R., 1952; Gee, Н. C., 1938; Gilbert, G. K., 1917; Goldberg, J., 1940; Grant, U. S., 1938, 1940; Grant, U. S. and Shepard, F. P., 1938b, 1940; Griffin, D. F., 1944; Gulliver, F. P., 1896; Hall, J. V., Jr., 1992; Hall, W. C., 1938, 1942; Eandin, J. W., 1949, 1951; Handin, J. W. and Ludwick, J. C., 1949; Hannum, G. W. T., 1947; Harts, W. W., 1911; Hawgood, H., 1914; Horton, D. F., 1948; Hunter, R. C., 1946; Inman, D. L., 1949, 1953a, 1953b; Isaac8, J. D. and Bascom, W. N., 1947; Johnson, A. G., 1935, 1940c; Johnson, J. W., 1947b, 1948b, 1952; Krumbein, W. C., 1950; Krumbein, W. C. and Ohsiek, L. E., 1950; Lapsley, W. W., 1937; Larsen, G. P., 1942b;
Leeds, C. T., 1916, 1936; Leeds, C. T., Vanon1, V. A. and Knapp, R. T., 1934; Livingston, A., Jr., 1939; Los Angeles County Regional Planning Commission, 1940; McAfee, C. M., Jr., 1939; Marlette, J. W., 1954; Martens, J. H. C., 1939; Mason, M. A., 1942, 1949c, 1950a, 1950b;

Nicholson, G. F., Grant, U. S., Shepard, F. P. and Crowell, J. C., 1946; Norris, R. M., 1951, 1952; O'Brien, M. P., 1931, 1936a, 1939, 1947b; O'Brien, M. P. and Johnson, J. W., 1947; Orange County Planning Commission, 1941; Page, G. B., 1950; Peel, K. P., 1951; Place, J. L., 1952; Postel, A. C., 1937, 1939; Rolland, M. C., 1952; Saville, T., Jr. and Caldwell, J. M., 1953; Schupp, R. D., 1953; Scripps Institution of Oceanography, 19521; Sears, C. B., 1876; Shepard, F. P., 1935d, 1947b, 1950e, 1951a; Shepard, F. P. and Inman, D. L., 1951b; Shuler, W. R., 1951, 1952; Somers, P., 1952; Stelzenmuller, W. B., 1949; Tower, M. L., 1910; Trask, P. D., 1952a, 1952b; Trask, P. D. and Scott, T., 1954; U. S. Waterways Experiment Station, V.icksburg, Mississ1pp1, 1935, 1936; Ward, H. A., 1952; Watts, G. M. and Others, 1953; Wiegel, R. L. and Kimberley, H. L., 1950; Williams, E. A. and Isaacs, J. D., 1952; Yale, C. G., 1879

Littoral Drift: Rate: Handin, J. W., 1949; Lo8 Angeles County Regional Planning Commission, 1940; Marlette, J. W., 1954; O'Brien, M. P., 1936a; Orange County Planning Commission, 1941; Trask, P. D., and Scott, T., 1954

Longshore Bars - see Bars

Longshore or Littoral Currents (See also: Currents, Littoral Drift): Anonymous, 1916a, 1917, 1933e; Anderson, C. A., 1950; Bascom, W. N., 1946b; Bascom, W. N., Wiegel, R. L. and Chinn, A. J., 1948; Beach Erosion Board, 1948b, 1951, 1952b; Blinn, F. S., 1928; Burt, W. V. and Saur, J. F. T., Jr., 1948; Butcher, W. S., 1951a; Chase, J. L., 1948; Coe, W. R., 1953; Congressional Documents, 1938a, 1942b, 1949f; Crowell, J. C., 1947, 1950, 1952; Davis, W. M., 1932; Dietz, R. S. and Menard, H. W., 1951b; Emery, K. O., Butcher, W. S., Gould, H. R. and Shepard, F. P.; 1952; Evans, O. F., 1941; Folsom, R. G., 1945b; Gillette, C. E., 1905; Goldberg, J., 1940; Gorsline, D. S., 1954; Grant, U. S., 1943; Grant, U. S. and Shepard, F. P., 1937, 1940; Hall, J. V., Jr., 1952; Handin, J. W., 1949, 1951; Handin, J. W. and Ludwick, J. C., 1950; Hawgood, H., 1914; Hidawa, K., 1953; Inman, D. L., 1949, 1950, 1953a, 1953b; Inman, D. L. and Quinn, W. H., 1952; Isaacs, J. D., 1945e, $1945 \mathrm{k}, 1945 \mathrm{~m}$; Isaacs, J. D. and Bascom, W. N., 1947; Johnson, D. W., 1910; Johnson, J. W., 1947b, 1948d, 1952; Krumbein, W. C., 1950; Krumbein, W. C. and Ohsiek, L. E., 1950; Lapsley, W. W., 1937; Leeds, C. T., 1936; Livingston, A., Jr., 1939; Leypoldt, H., 1941b; McAfee, C. M., Jr., 1939; McGowan, w. C., 1916; Mason, M. A., 1942; Moore, D. G., 195l; Munk, W. H., 1949b; Munk, W. H. and Traylor, M. A., 1945, 1947; Nicholls, C. P. L., 1936a, 1941; Nicholson, G. F., Grant, U. S., Shepard, F. P. and Crowell, J. C., 1946; Norris, R. M., 1951; O'Brien, M. P., 1941, 1945b; O'Brien, M. P. and Johnson, J. W., 1947; Page, G. B., 1950; Place, J. L., 1952; Postel, A. C., 1937; Purer, E. P., 1942; Putnam, J. A., Munk, W. H. and Traylor, M. A., 1948, 1949; Putnam, W. C., 1937b, 1938; Saville, T., Jr., 1948; Schupp, R. D., 1953; Scripps Institution of Oceanography, $1944 c$, 1945c; Shepard, F. P., 1935d, 1949a, 1950c, 1950f, 1950g, 1951a, 1952a; Shepard, F. P., Emery, K. O. and LaFond, E. C., 1941; Shepard, F. P. and Inman, D. L., 1949, 1951a, 1951b; Shepard, F. P. and LaFond, E. C., 1939; Shepard, F. P. and Sayner, D. B., 1953; Sinnott, A., 1941; Smith, W. D., 1933c; Stevenson, R. E., 1954; Stump, R. S., 1944b, 1944c; Stump, R. S. and Bascom, W. N., 1947; Thompson, W. O., 1937; Tower, M. L., 1910; U. S. Hydrograph1C off1ce, 1944c; U. S. Waterways Experinent Station, Vicksburg, Mississippi, 1935; Verrill, G. E., 1930; Whitemore, G. F., 1928; Wiegel, R. L., 1947b; Wiegel, R. L., Patrick, D. A. and Kimberley, H. L., 1953 Longshore Drift - see Littoral Drift Longshore Trough - see Trough 
Low and Ball - see Bars, Troughs

Luminescence, Bioluminescence, Fluorescence, Phosphorescence: Allen, W. E., 1921d, 1937a, 1939d, 1946a; Crooke, R. C., Elvitsky, A. W. et al, 1953; Koe, K. B., Fox, D. L. and Zechmeister, L., 1950; Kofold, C. A., 1928; Petracek, F. J., Fox, D. L. and Zechmeister, L., 1951

Lumps in Sediments: Emery, K. 0., Butcher, W. S., Gould, H. R. and Shepard, F. P., 1952

Magnesium (See also: Carbonates): Galliher, E. W., 1935a, 1935c; Kelley, W. P. and Liebig, G. F., Jr., 1934; Lipman, C. B., 1929; McKee, E. D., 1953; Revelle, R., 1935 (including $\mathrm{MgCO}_{3}$ ), 1941; Revelle, R. and Emery, K. O., 1951; Stanton, T. E., Jr., 1938; Thompson, T. G. and Robinson, R. J., 1932; Vaughan, T. W., 1940; ZoBell, C. E., 1939

Magnetic Minerals (See also: Beach Placers, Black Sands, Heavy Minerals, Mineralogy, various magnetic minerals): Twenhofel, W. H., 1946

Manganese, including Manganese Nodules and Concretions (See also: Concretions, Nodules): Ahlstrom, E. H., 1950; Butcher, W. S., 1951a; Carsola, A. J. and Dietz, R. S., 1952; Dietz, R. S., 1954; Dietz, R. S., Emery, K. O. and Shepard, F. P., 1942; Emery, K. O., 194la; Emery, K. 0., Butcher, W. S., Gould, H. R. and Shepard, F. P., 1952; Emery, K. O. and Dietz, R. S., 1950; Emery, K. 0. and Natland, M. L., 1952; Emery, K. O. and Shepard, F. P., 1945; Galliher, E. W., 1933; Goldberg, E. D., 1954; Krumbein, W. C., 1942; Menard, H. W., 1952; Piggot, C. S., 1932, 1944; Revelle, R., 1935, 1937a, 1937b; Revelle, R. and Emery, K. 0., 1951; Rotschi, H., 1951; Scripps Institution of Oceanography, 1953e; Shepard, F. P., 1941a, 1948c; Shumway, G. A., 1953; Sverdrup, H. U., 1940e; Thompson, T. G. and Robinson, R. J., 1932; Uchup1, E., 1954; Wooster, W. S., 1951; ZoBell, C. E., 1939, 1941, 1942a, 1942b, 1943 $1946 \mathrm{~b}, 1947 \mathrm{c}, 1950$; ZoBell, C. E., Grant, C.'W. and Haas, H. F., 1943

Marble (See also: Metamorphic Rock, Rock): Gorsline, D. S., 1954

Marine Drilling Platforms - see Engineering

Marine Erosion - see Continental Shelf, Origin; Continental Slope, origin: Wave and Marine Erosion

Marl: Butcher, W. S., 1951a; Congressional Documents, 1907; Emery, K. 0., 1950d; Emery, K. 0., Butcher, w. S., Gould, H. R. and Shepard, F. P., 1952; Revelle, R., 1950; Trask, P. D., 1939

Marsh (See also: Estuary, Lagoon, Salt Marsh, Swamp, Tide Flat): Anonymous, 1951b; Beach Erosion Board, 1948j; California Legislature, 1874; Carpenter, E. J. and Storie, R. E., 1929; Congressional Documents, 1908f, 1908g, 1940a, 1940d, 1949e; Davidson, G., 1897; Emery, K. O., 1950d, 1954b; Gilbert, G. K., 1917; Grant, U. S., 1944; Grant, U. S. and Sheppard, W. E., 1939; Hinds, N. E. A., 1952; Johnson, A. G., 1935; Lawson, A. C., 1895 1914; Leeds, C. T., 1915; Livingston, A., Jr., 1939; Louderback, G. D., 1940; McKee, E. D., 1953; McOuat, H.W., 1951; Mason, E. H., 1930; Means, T. H., 1928; Moore, D. G., 1951; Nelson, E. W., 1922; Nelson, J. W., Dean, W. C., Kocher, A. E., Watson, E. B. and Carpenter, E. J., 1920; Nelson, J. W., Zinn, C. J., Strahorn, A. T., watson, E. B. and Dunn, J. E., 1919; Nelson, N. C., 1910; Nicholson, G. F., Grant, U. S., Sheppard, F. P. and Crowell, J.C., 1946 (tidal marsh); Orange County Planning Commission, 1941; Page, G. B., 1950; Purer, E. A., 1942; Scripps Institution of Oceanography, 1953c (tidal marsh): Shepard, F. P. and Emery, K. 0., 1941; Shuler, W. R., 1952; Somers, P., 1952; Storie, R. E. and Carpenter, E. J., 1929; Stevenson, R. E., 1954; Stevenson, R. E. and Emery, K. O., 1951; Studds, R. F. A., 1951; Veach, J. A., 1859; ZoBell, C. E. and Feltham, C. B., 1942

Masking of Sediment: Butcher, W. S., 195la; Emery, K. 0., 1952a; Emery, K. O. and Dietz, R. S., 1950; Garrison, L. E. and Takasak1, K. L., 1950; Shepard, F. P., 1941a; Shepard, F. P. and Wrath, W. F., 1937

Mass Mortality (See also: Explosives or Explosions, Red Water): Allen, W. E., 192ld; Coe, W. R., 1953; Connell, C. H. and Cross, J. B., 1950; Dietz, R. S.,
Emery, K. O. and Shepard, F. P., 1942; Hofer, H., 1909; Kofoid, C. A., 1911, 1928; Pecham, S. F., 1897; Sommer, H. and Clark, F. N., 1946; Sommer, H., Whedon, W. F., Kofoid, C. A. and Stohler, R., 1937; Stormont, D. H., 1951a; Tanner, Z. L.,

1896; Torrey, H. B., 1902; Whedon, W. F., 1939 Median Diameter - see Grain Size

Melnikovite - see Iron Sulfides

Mesozoic: Kuenen, $\mathrm{Ph}$. H., 1947

Metamorphic Rocks (See also: Rock, various metamorphic rocks): Butcher, W. S., 195la; Clements, T. and Dana, S. W., 1944; Clements, T. and Emery, K. O., 1947; Dill, R. F., Dietz, R. S. and Stewart, H., 1954; Emery, K. O., 194la, 1941b, 1946b, $1947 \mathrm{c}$, 1948, 1951; Emery, K. 0., Butcher, W. S., Gould, H. R. and Shepard, F. P., 1952; Emery, K. O. and Dietz, R. S., 1950; Emery, K. O. and Shepard, F. P., 1941, 1945; Emery, K. O. and Tschudy, R. H., 1941; Galliher, E. W., 1935a; Gorsline, D. S., 1954; Hanna, G. D., 1952; Hansen, H. A. and Pemberton, J. R., 1950; Holzman, J. E., 1950; Moore, D. G., 1951; Raitt, R. W., 1949; Shepard, F. P. and Wrath, W. F., 1937; Shumway, G. A., 1953; Uchupi, E., 1954

Meteorology and Climate, Paleoclimate (See also: Fog, Paleogeography, storm, wind): Anonymous, 1938a, 1940d; Ahlstrom, G. H., 1950; Allen, W. E., 1934b, 194la; Allison, J. M., 1940; Alpert, L., 1946a, 1946b; Anderson, J. B., 1931; Anderson, W., 1939; Army Air Forces, Weather Information Branch, 1943; Arnold, R., 1909; Ashley, G. H., 1896; Axelrod, D. I., 1939; Bache, A. D., 1856e; Bandy, O. L., 1953b; Bartsch, P., 192la; Bascom, W. N., Wiegel, R. L. and Chinn, A. J., 1948; Beach Erosion Board, 1948a, 1953c; Beals, E. A., 1919; Beck, A. L., 1922; Beer, C. G. P. and Leopold, L. B., 1947; Bell, W. E., Bassler, F. F., Buck, F. E., Murphy, D. E., Writt, J. J. and Beauchamp, E. E., 1944; Berghaus, A., 1891; Bishop, S. E., 1904; Blake, D., 1926; Blake, J., 1873; Blochman, L. F., 1923; Bond, A. H., 1927; Brown, E. I., 1939; Bruff, S. C., 1940; Bullock, F. W., 1933; Burt; W. V. and Saur, J. F. T., Jr., 1948; Byers, H. R., 1930, 1931, 1934; California Academy of Sciences, California Division of Fish and Game, Scripps Institution of Oceanography of the University of California, and U.S. Fish and Wildlife Service, 1950; Campbell, M. R., 1915; Carpenter, F. A., 1924; Carter, G. F., 1948; Chaney, R. W., 1928 1936a, 1936b, 1940; Chaney, R. W. and Dorf, E., 1934; Clark, B. L., 1921; Clarke, K. B., 1934; Congressional Documents, 1938a, 1940a, 1943c, 1949b, 1949-1950b; Copeland, C. A., 1933; Crickmay, C. H., 1929a, 1929b; Crooke, R. C., Elvitsky, A. W., et al, 1953; Dall, W. H., 1904, 1911; Darrow, W. E., 1942; Davidson, G., 1859, 1864, 1886, 1875a; Davis, W. M., 1932; Dawson, E. W., 1951; Dietz, R. S., Emery, K. O. and Shepard, F. P., 1942; Disney, L. P. and Overshiner, W. H., 1925; Donnelly, M., 1943; Dunkle, M. B., 1944, 1950; Durham, J. W., 1949, 1950a, 1950b, 1952; Eaton, R. 0., 1951; Emery, K. O., Butcher, W. S., Gould, H. R. and Shepard, F. P., 1952; Emery, K. O. and Dietz, R. S., 1950; Emiliani, C., 1954; Emiliani, C., and Epstein, S., 1953; Findlay, A. G., 1851; Folsom, R. G., 1944d, 1945b; Gislēn, T., 1943, 1944; Gorsline, D. S., 1954; Gorton, A. F., 1930a, 1930b, 1930c, 1931a, 1931b, 1932, 1933, 1934; Gorton, A. F. and Partridge, A. G., 1930, 1936a; Grant, U. S., 1936; Great Britain Meteorological office, 1950; Gutenberg, B., 1941b, 1953; Hall, J. V., Jr., 1952; Hall, W. H.,. 1886; Handin, J. W., 1949; Hann, J., 1887; Hanna, G. D., 1925b; Hess, H. H. and Macclintock, P., 1936; Hewatt, W. G., 1937; Horrer, P. L., 1949; Hoover, J. W., 1932a, 1932b; Hoover-Young San Francisco Bay Bridge Commission, 1930; Hubbs, C. L., 1948; Huntington, E., 1914; Inman, D. L., 1949, 1953a; Isaacs, J. D. and Bascom, W. N., 1947; Isaacs, J. D. and Saville, T., Jr., 1948; Jacobs, W. C., 1939, 1942, 1943; Jacobs, W. C. and Clarke, K. B., 1943; Johnson, A. G., 1935; Johnson, J. W., 1953b; Johnson, J. W. and Isaacs, J. D., 1948; Jobnson, M. W., Everest, F. A. and Young, R. W., 1947; Joint Meteorological Committee, 1943-1944; Jones, E. L., 
1918; Killroy, M. F., 1945a, 1945b; LaFond, E. C., 1938, 1939a, 1940; Lockhart, W. M., 1939; Longacre, L. I., 1948; Leipper, D. F., 1947, 1948a, 1948b; McAdie, A. G., 1913, 1914; McDonald, W. F., 1938; McEwen, G. F., 1912, 1914, 1915, 1918, 1919b, 1925, $1926,1927,1928 \mathrm{a}, 1930 \mathrm{~b}, 1939 \mathrm{c}, 1933,1934 \mathrm{a}, 1934 \mathrm{~d}$, 1934e, 1936, 1937a, 1937d, 1937-1938; McEwen, G. F., and Gorton, A. F., 1930; McEwen, G. F. and Staff, 1948; Marmer, H. A., 1926, 1952; Mason, H. L., 1931; Merriam, P. D., 1949; Miller, R. C., Ramage, W. D. and Lazier, E. L., 1928; Moberg, E. G. and Fleming, R. H., 1934; Munk, W. H., 1947a, $1947 \mathrm{~b}, 1948$, 1950, 1952; Munk, W. H. and Arthur, R. S., 1952; Munk, W. H. and Traylor, M. A., 1947; Neiburger, M., 1948; Neiburger, M., Beer, C. G. O. and Leopold, L. B., 1945; Nelson, R. N. and Schenck, H. G., 1928; Nicholson, G. F., Grant, U. S., Shepard, F. P., and Crowell, J. C., 1946; OBrien, M. O., 1936a, 1947b; Osorio Tafall, B. F., 1943, 1948; Palmer, A. H., 1917; Patton, C. P., 1953; Petterssen, S., 1938; Purer, E. A., 1936, 1942; Putnam, J. A., 1947; Putnam, w. C., 1938; Reed, T. R., 1934; Reed, W. G., 1914; Remondino, P. C., 1892; Revelle, R., 1939b; Richardson, B., 1930, 1935; Richardson, R. W., 1923, 1943; Richter, C. M., 1887; Ritter, W. E., 1924; Rossby, C.-G., 1951; Rosser, W. H., 1870; Rudnick, P. and Cochrane, J. D., 1951; Russell, R. J., 1926; Salisbury, R. D., 1909; San Diego Regional Water Pollution Control Board, 1952; San Francisco Bay Marine Piling Committee, 192l; Saur, J. T. F., Jr., 1947; Saville, T., Jr., 1947; Schenck, H. G. and Keen, A. M., 1935; Schott, G., 1934, 1935 Scripps Institution of Oceanography, 1944h, 1945b, $1949 \mathrm{a}, 1949 \mathrm{~b}, 1949 \mathrm{c}, 1949 \mathrm{~d}, 1949 \mathrm{e}, 1950 \mathrm{a}, 1950 \mathrm{~b}$, $1950 \mathrm{c}, 1950 \mathrm{~d}, 1950 \mathrm{e}, 1950 \mathrm{f}, 1950 \mathrm{~g}, 1951 \mathrm{a}, 1951 \mathrm{~b}$, 1951c, 195ld, 195le, 195lf, 195lh, 1951i, 1951j, $1951 \mathrm{~L}, 1951 \mathrm{~m}, 1952 \mathrm{a}, 1952 \mathrm{~b}, 1952 \mathrm{e}, 1952 \mathrm{f}, 1952 \mathrm{~g}$, 1953e; Shepard, F. P., 1939c, 1948c, 1951a;

Shepard, F. P. and Wrath, W. F., 1937; Shuck, O. T., 1869 (climate); Shuler, w. R., 1951; Smith, C. D., Jr., 1950; Smith, J. P., 1919; Smith, W. D., 1933a; Stelzenmuller, Wm. B., 1949; Stevenson, R. E., 1954; Stump, R. S., 1946a; Stump, R. S. and Bascom, W. N., 1947; Stump, R. S. and Hermans on, R. T., 1945b; Sverdrup, H, U., 1939a, 1939c, 1940a, 1940d, 1940g, 1941a, 1942, 1946; Sverdrup, H. U. and Staff, 1941, 1946; Tanner, Z. L., 1892a, 1893; Thomson, A., 1934; Thorade, H., 1909; Tilden, C. A., 1925; Todd, D. K. and Wiegel, R. L., 1951, 1952; Topp, E. P., 1929; Trask, J. B., 1856; Trask, P. D., 1939, 1952b; Troxell, H. C. and Others; 1942; Upham, W., 1899; U. S. Army Air Weather Service, 1945; U. S. Commission of Fish and Fisheries, 1898; U. S. Hydrographic Office, 1934b; Váughan, T. W., 1930b, 1932c, 1933, 1936, 1940; Walker, G. T., 1934; Werenskiold, W., 1922; Wiegel, R. L. and Kimberley, H. L., 1950; Wiegel, R. L., Patrick, D. A. and Kimberley, H. L., 1950; Wilstam, A., 1926; Woodford, A. O., 1925; Wyman, R. H., 1878; Yates, L. G., 1890d; Yoshida, K. and MaO, H. L., 1954 Methane (See also: Gases, Hydrogen, Submarine Oil and Gas Seeps): Fox, D. L., and Anderson, L. J., 1941; Hutton, W. E., and ZoBell, C. E., 1949; Revelle, R., 1950; Shepard, F. P., 1951d; Sisler, F. D. and ZoBell, C. E., 1951b; Thayer, L. A., 1937; ZoBell, C. E., 1938, 1939, 1942b, 1946b, 1947c, 1947 a, 1949,1950

Micaceous Minerals (See also: Mineralogy): Dietz, R. S. Emery, K. O. and Shepard, F. P., 1942; Emery, K. O., Butcher, W. S., Gould, H. R. and Shepard, F. P., 1952; Galliher, E. W., 1935c; Inman, D. L., 1953b; McKee, E. D., 1953; Thompson, W. O., 1934

Microseisms (See also: Seismology): Byerly, P., 1942; Donn, W. L., 1954; Gutenberg, B., 1936a, 1953 Mineralogy (See also: Auriferous Beach Sands, Beach Placers, Black Sands, Heavy Minerals, Magnetic Minerals, Micaceous Minerals, various sediment and minera. types): Beach Erosion Board, 1952b; Dana, S. W. 1942; Dietz, R. S., 1941; Dietz, R. S., Bmery, K. O. and Shepard, F. P., 1942; Emery, K. O., 1947e; Emery, K. O., Butcher, W. S., Gould, H. R. and Shepard, F. P., 1952; Emery, K. 0. and Dietz, R. S., 1941; Emery, K. O. and Shepard, F. P., 1945:
Galliher, E. W., 1932b, 1933, 1935a, 1935c, 1937; Gee, H., 1932; Handin, J. W., 1949, 1951; Inman, D. L., 1950; Krumbein, W. C., 1942; Lowenstam, H. A., 1954; McKee, E. D., 1953; Revelle, R., 1935; Revelle, R. and Emery, K. O., 1951; Shepard, F. P. and Wrath, W. F., 1937; Somers, P., 1952; Stevenson, R. E., 1954; Trask, P. D. and Rolston, J. W., 1950b; Veach, J. A., 1859

Abyssal: Goldberg, E. D., 1954; Grim, R. E., Dietz, R. S. and Bradley, W. F., 1949; Revelle, R., 1935, 1937a, 1937b; Scripps Institution of Oceanography, 1953e

Bank: Dietz, R. S. and Emery, K. O., 1938b; Dietz,

R. S., Emery, K. O. and Shepard, F. P., 1942; Emery, K. O., Butcher, W. S., Gould, H. R. and Shepard, F. P., 1952; Emery, K. O. and Dietz, R. S., 1950; Grim, R. E., Dietz, R. S. and Bradley, W. F., 1949; Holzman, J. E., 1950; Uchupi, E., 1954

Basin: Emery, K. O., Butcher, W. S., Gould, H. R., and Shepard, F. P., 1952; Emery, K. O. and Rittenberg, S. C., 1952; Grim, R. E., Dietz, R. S. and Bradley, W. F., 1949; Ludwick, J. C., Jr., 1950; Revelle, R. and Shepard, F. P., 1939b' Beach and Nearshore: Anonymous, 1884, 1894a, 1906b, $\overline{1949 \mathrm{c}}, \overline{1950 \mathrm{a}}, 1950 \mathrm{~b}, 1950 \mathrm{~d}, 1951 \mathrm{~d}, 1954 \mathrm{j}, 1954 \mathrm{~m}$; Averill, C. V. and Others, 1946; Beach Erosion Board, 1948i, 1953c; Boos, M. F., 1940; Bullard, F. M. and Mills, R. A., 1951; California, University of, 1952a, 1952b, 1952c; Chase, A. W., 1875; Congressional Documents, 1942b, 1953b; Dasher, J., Fraas, F. and Gabriel, A., 1942; Day, D. T., $1899,1900,1907 \mathrm{a}, 1907 \mathrm{~b}$; Day, D. T. and Richards, R. H., 1906; Diller, J. S., 1896, 1901, 1903; Edman, J. A., 1894, 1906; Emery, K. 0., 1944, 1945b; Emery, K. O. and Gale, J. F., 1951; Emery, K. O. and Rittenberg, S. C., 1952; Emery, K. O. and Stevenson, R. E., 1950; Gorsline, D. S., 1954; Griesbach, J. O., 1947; Griggs, A. B., 1945; Griggs, A. B. and Wells, F. G., 1942; Handin, J. W., 1949, 1951; Hornor, R. R., 1918; Hundhausen, R. J., 1947; Inman, D. L., 1950, 1953a, 1953b; Irvine, C. D., 1908; Kemp, J. F., 1902; Krumbein, W. C., 1947, 1950; Lakes, A., 1899, 1903a; Lang, H., 1916; Lowell, F. L. L., 1915a, 1915b; McKee, E. D., 1953; Marlette, J. W., 1954; Martens, J. H. C., 1939; Mason, M. A., 1942; Merrill, F. J. H., 1917; Messner, W. E., 1954; O'Brien, M. P., 1936a; Pardee, J. T., 1934; Paul, A. B., 1894; Reed, R. D., 1930b; Schupp, R. D., 1953; Scripps Institution of Oceanography, 1952i, 1953c; Shalevetz, S., 1952; Shepard, F. P., 1950c; Sherzer, W. H., 1910; Sinnott, A., 1941; Smith, W. S. T., 1898; Stephenson, E. L., 1945; Sverdrup, H. U. and Staff, 1942a; Thompson, W. O., 1937; Trask, P. D., 1924, 1952b; Twenhofel, W. H., 1943, 1946, 1946a; Walters, L., 1953; Wiegel, R. L., Patrick, D. A. and Kimberley, H. I., 1953; Yale, C. G., 1913; Zodac, P., 1952

Coastal Sand Dunes: Anonymous, 1954; Diller, J. S., 1898; Gorkline, D. S., 1954; Griesbach, J. O., 1947; Handin, J. W., 1949, 1951; Merriam, P. D., 1949; Mesner, W. E., 1954; Olsson-Seffer, P., 1910a, 1910b; Page, G. B., 1950; Reed, R. D., 1930b; Richardson, R. W., 1923

Continental Shelf: Anonymous, 1950b, 1954j; Beach Frosion Board, 1952b; Butcher, W. S., 195la; Chesterman, C. W., 1952; Cohee, G. V., 1938; Galliher, E. W., 1935b; Gorsline, D. S., 1954; Grim, R. E., Dietz, R. S. and Bradley, W. F., 1949; Inman, D. L., 1950; MacDonald, G. A., 1934; Marlette, J. W., 1954; Moore, D. G., 1951; Scripps Institution of Oceanography, 19521;

Shepard, F. P., 1932; Shepard, F. P. and MacDonald, G. A., 1938

Continental Slope: Dill, R. F., 1952; Hanna, G. D., 1952; Udden, J. A., 1914 Submarine Canyons: Cohee, G. V., 1938; Dill, R. F., Dietz, R. S. and Stewart, H., 1954; Fisher, R. L. and Mills, R., 1952; Marlette, J. W., 1954; Phleger, F. B., 1951; Scripps Institution of Oceanography, 19521

Minor Features, Beaches (See also: Rill Marks, Ripple Marks, Swash Marks): Anonymous, 194lb; California, University of, 1952a; Emery, K. 0., 1944, 1945a; Emery, K. O. and Foster, J. F., 1948; Emery, K. 0. 
and Gale, J. F., 1951; Fox, D. L., 1950; Lakes, A., 1903a; McKee, E. D., 1953; Nicholson, G. F., Grant, U. S., Shepard, F. P. and Crowell, J. C., 1946; Palmer, R. H., 1928; Shepard, F. P., Inman, D. L. and Fisher, R. L., 1951; Thompson, W. O., 1937; Woodford, A. 0., 1935

Minor Features, Rocky Coasts (See also: Solution Basins): Davis, W. M., Putnar, W. C. and Richards, G. L., Jr., 1931 (undercutting); Diller, J. S., 1896 (potholes); Emery, K. O., 1946b (joints, fluting, stone lace); Lange, A., 1954 (blowholes); Smith, W. D., 1933c, (spout holes); Swinnerton, A. C., 1927 (potholes); Williams, W., 1948 (potholes)

Minor Surface Features of Sediments (See also: Animal Tracks, Rills, Ripple Marks, Swash Marks); Scripps Institution of Oceanography, 19521; Shepard, F. P. and Emery, K. 0., 1945

Miocene (See also: Tertiary): Butcher, w. S., 195la; California, University of, 1953a, 1953b; Carsola, A. J. and Dietz, R. S., 1952; Cohee, G. V., 1938; Corey, W. H., 1951, 1952; Crouch, R. W., 1954; Dietz, R. S., Emery, K. O. and Shepard, F. P., 1942; Emery, K. 0., 194la, 1946b, 19470, 1948, 1950b, 1951, 1952a; Emery, K. O., Butcher, W. S., Gould, H. R. and Shepard, F. P., 1952; Bmery, K. O. and Dietz, R. S., 1950; Emery, K. O. and Shepard, F. P., 1941, 1945; Emery, K. O. and Tschudy, R. H., 194l; Emillan1, C., 1954; Hanna, G. D., 1952; Holzman, J. E., 1950; Inman, D. L., 1949, 1950; James, E. L., 1950; Kew, W. S. W. , 1928; Laws on, A. C., 1893b; Mason, H. L. , 1929; Moore, D. G., 1951; Norris, R. M., 1951; Revelle, R. and Shepard, F. P., 1939b; Shepard, F. P., 1949b; 1951b; Shepard, F. P. and Emery, K. O., 1941; Shepard, F. P. and MacDonald, G. A., 1938; Shepard, F. P. and Stetson, H. C., 1939; Shepard, F. P. and Wrath, W. F., 1937; Shumway, G. A., 1953; Sverdrup, H. U., 1938c; Sverdrup, H. U. and Staff, 194l; Trask, P. D., 1931b; Uchup1, E., 1954

Mixing (See also: Diffusion, Dispersion): Ahlstrom, $\mathrm{E}$. H., 1950; Allen, W. E., 194la; Bullock, F. W., 1933; California Academy of Sciences, California Department of Fish and Game, Stanford University, Hopkins Marine Station, U. S. Fish and Wildlife Service, South Pacific Fishery Investigation, University of California, Scripps Institution of oceanography, 1953; California Academy of Sclences, California Division of Fish and Game, Scripps Institution of oceanography, U. S. Firh and Wildlife Service, 1950; Dietz, R. S., Emery, K. O. and Shepard, F. P., 1942; Dietz, R. S. and LaFond, E. C., 1950; Dill, R. F., Dietz, R. S. and Stewart, H., 1954; Emery, K. 0., 1954d; Emery, K. O. and Rittenberg, S. C., 1952; Epstein, S. and Mayeda, T., 1953; Fleming, R. H., 1939a, 1940a; Fleming, R. H., 1939a, 1940a; Fleming, R. H. and Moberg, E. G. and Revelle, R., 1937b; Graham, H. W., 1941a; H1daka, K., 1953; Horrer, P. L., 1948a; Jacobs, W. C., 1949; Kuenen, Ph. H. and Menard, H. W., 1952; Lelpper, D. F., 1950; McEwen, G. F., 1929; Mao, H., 1951; Menard, H. W. and Ludwick, J. C., 1951; Moberg, E. G., 1928a, 1930a, 1930b, 1930r; Moberg, E. G. and Fleming, R. H., 1934; Munk, W. H., 19470; Pattullo, J., 1952; Rawn, A. M. and Bowerman, F. R., 1951; Saur, J. T. F., Jr., 1950; Scripps Institution of Oceanography, 1950g; Sverdrup, H. U., 1938a, 1938b, $1939 \mathrm{a}, 1939 \mathrm{c}, 1940 \mathrm{c}, 1940 \mathrm{e}, 1940 \mathrm{~g}, 1941 \mathrm{a}, 1941 \mathrm{~b}$; Sverdrup, H. U. and Staff, 1945a, 1947a; Tibby, R. B., 1939, 1941; Trask, P. D., 1939; Uchupi, E. , 1954

Mock valley - see Submarine Canyon

Models (See also: Engineering): Blinn, F. S., 1928; Gee, H. C., 1938; Granthem, K. N , 1953; Hall, w. C., 1938, 1941; Hudson, R. Y. and Moore, L. F., 1951; Lapsley, W. W., 1937; Leeds, C. T., Vanon1, V. A. and Knapp, R. T., 1934; L1llevang, O. J. and Brant, R. W., 1937; Johnson, J. W., 1947a, $1948 \mathrm{a}, 1948 \mathrm{~b}, 1948 \mathrm{~d} ;$ Johnson, J. W. and Wiegel, R. L., 1953; Knapp, R. T., 1951; Knapp, R. T. and Vanoni, v. A., 1945; McAfee, C. M., Jr., 1939; Meyer, R. D., 1936; Miller, R. L., 1954; Milner, F., 1941; Putnam, J. A. and Bermel, K. J., 1946; Reid, R. O., 1948b; U. S. Waterways Experi- ment Station, Vicksburg, Mississippi, 1935, 1936, $1947 \mathrm{a}, 1947 \mathrm{~b}, 1947 \mathrm{c}, 1949,1950$

Molybdenum: Revelle, R. and Emery, K. 0., 1951

Mountain Arcs: Lawson, A. C., 1939

Mud (Also see: various mud types): Anonymous, 1944b; Allen, W. E., 1939; Anderson, C. A., 1950; Arnold, D. and Arnold, R., 1902; Arnold, J. L., 1928; Bartholmew, J. W. and Rittenberg, S. C., 1949; Belknap, G. E., 1874a; Bruff, S. C., 1946; Buck, C. D., 1928; California Department of F1sh and Game, 1951; California Department of Public Kealth, 1951; Coe, W. R., 1945; Collins, L. B., 1931; Congressional Documents, 1880a; Coxe, L. C., 1949; Crooke, R. C., Elvitaky, A. W. et al, 1953; Dana, S. W., 1942; Dapples, E. C., 1942; Eldredge, Z. S. and Molera, E. J., 1909; Emery, K. O., Butcher, W. S., Gould, H. R. and Shepard, F. P., 1952; Emery, K. O. and Dietz, R. S., 1939, 1941; Evans, R. D., Kip, A. F. and Moberg, E. G., 1938; Ford, J. L. C., 1942; Fox, D. L., 1937, 1944a, 1944b, 1950; Fox, D. L. and Anderson, L. J., 1941; Fox, D. L., Isaacs, J. D. and Corcoran, E. F., 1952; Fox, D. L., Updegraff, D. M. and Novelli, G. D., 1944; Fraser, C. MCL., 1943; Galliher, E. W., 1933, 1935a, 1935c; Gilbert, G. K., 1917; Gislén, T., 1943, 1944; Harding, C. R., 1929; Hinde, H. P., 1952; Hoots, H. W., 1943; Hoover-Young San Francisco Bay Bridge Comission, 1930; Johnson, M. W., Everest, F. A. and Young, R. W., 1947; Kindle, E. M., 1934; Koe, K. B., Fox, D. L. and Zechme1ster, L., 1950; Lesser, R. M., 1951; Louderback, G. D., 1920, 1924, 1940; McKee, E. D., 1939; MacGin1t1e, G. E., 1935, 1939; Michael, E. L. and McEwen, G. F., 1915; Morr18on, R. L., 1930; Moyer, D. A., 1929b; Natland, M. L., Revelle, R. and Rittenberg, S. C., 1941; Norris, R. M., 1951; Novell1, G. D., 1943; Packard, E. L., 1918; Pease, W. H., 1868; Revelle, R., 1939a; San Diego Regional Water Pollution Contro Board, 1952; Saur, J. T. F., Jr., 1950; Sears, C. B., 1876; Shepard, F. P., 1938b, 1951a, 1951b; Shepard, F. P. and Emery, K. 0., 1941, 1945; Shepard, F. P., Emery, K. O. and LaFond, E. C. 1941; Smith, A. G. and MacKenzie, G., Jr., 1948; Soper, E. K., 1938; Stevenson, R. E., 1954; Sumner, F. B., Louderback, G. D., Schmitt, W. L. and Johnson, E. C., 1914; Sverdrup, H. U., 1938c, 1939a, 1940d; Sverdrup, н. U. and Staff, 1941; Tanner, Z. L., 1892a; Thayer, L. A., 1937; Thompson, T. G. and Robinson, R. J., 1932; Trask, P. D., 1939; Trask, P. D. and Rolston, J. W., 1950a; Trask, P. D. and Wu, C. C., 1930a, 1930b; Vaughan, T. W., 1933, 1935a, 1935b; Wright, R., 1937; ZoBell, C. E., 1935, 1936, 1939, 1941, $1942 b, 1946 \mathrm{~b}, 1946-1947,1947 \mathrm{c}, 1947 \mathrm{~d}, 1949$; ZoBell, C. E. and Anderson, D. Q., 1936; ZoBell, C. E. and Feltham, C. B., 1942; ZoBell, C. E., Grant, C. W. and Haas, H. F., 1943

Abyssal: Belknap, G. E., 1874a, 1874b; Davidson, G., 1897; Evans, R. D., Kip, A. F. and Moberg, E. G., 1939; Fox, D. L., Updegraff, D. M. and Novell1, G. D., 1944; Piggot, C. S., 1932; Revelle, R., 1935; Shepard, F. P., 1949d; Shepherd, E. S., 1946; Tanner, Z. L., 1894; Vaughan, T. W., 1940; White, D., 1911; ZoBell, C. E. and Feltham, C. B., 1942

Bank: Emery, K. O., 19470, 1948; Hanna, G. D., 1952; Shepard, F. P., 19410

Basin: Dietz, R. S., 1952a; Dietz, R. S., Emery, K. O. and Shepard, F. P., 1942; Bmery, K. O., 1953b, 1947c; Emery, K. O. and Rittenberg, S. C., 1951, 1952; Emery, K. O. and Shepard, F. P., 1945; Ford, J. L. C., 1942; Grim, R. E., Dietz, R. S. and Bradley, W. F., 1949; Kuenen, Ph. H., 1946; Ludwick, J. S., Jr., 1950; Phleger, F. B., 1951; Revelle, R., 1939a, 1939b, 1950; Revelle, R. and Emery, K. O., 1951; Shepard, F. P., 1940a, 194la, 1950e, 1951d; Shepard, F. P., Revelle, R. and Dietz, R. S., 1939; Shepard, F. P., Revelle, R., Dietz, R. S. and Emery, K. O., 1938; Sm1th, P. V., Jr., 1954; Vaughan, T. W., 1940; Weeks, L. G., 1952

Beach and Nearshore: Bruff, S. C., 1946; CongressIonal Dळuments, 1940a; Emery, K. O., 1945a; Fox, D. L., 1950; Kindle, E. M., 1934; Kniffen, F. B., 1932; Krumbein, W. C., 1947; Louderback, G. 
D., 1920, 1940; Mason, E. H., 1930; Palmer, R. H., 1928; Petracek, F. J., Fox, D. L. and Zechmeister, L., 1951; ZoBell, C. E. and Rittenberg, S. C., 1938

Continental Shelf: Beach Erosion Board, 1952b; Butcher, W. S., 1951a; Davidson, G., 1897; Dietz, R. S. and Menard, H. W., 1951b; D11l, R. F., 1952; Emery, K. O., 1952a; Emery, K. O. and Butcher, W. S., Gould, H. R. and Shepard, F. P., 1952; Fox, D. L., 1937; Galliher, E. W., 1933, 1935a, 1935c; Gorsline, D. S., 1954; Grim, R. E., Dletz, R. S. and Bradley, W. F., 1949; Hanna, G. D., 1952; LaFond, E. C., Dietz, R. S. and Knausa, J. A., 1950; Marlette, J. W., 1954; Norris, R. M., 1951; Pardee, J. T., 1934; Revelle, R. and Emery, K. O. 1951; Shepard, F. P., 1932, 1949b, 1949d; Shepard, F. P. and MacDonald, G. A., 1938; Thompson, W. C., 1949; Udden, J. A., 1914

Continental Slope: Dill, R. F., 1952; Hanna, G. D., 1952; Udden, J. A., 1914

Submarine Canyons: Anonymous, 1939; Cohee, G. V., 1938; Davidson, G., 1887, 1897; Dill, R. F. Dietz, R. S. and Stewart, H., 1952; Fisher, R. L. and Mills, R., 1952; Kuenen, $\mathrm{Ph}$. H., 1947; Ludwick, J. C., Jr., 1950; Marlette, J. W., 1954; Menard, H. W. and Ludwick, J. C., 1951; Norris, R. M., 1951; Phleger, F. B., 1951; R1chardson, R. W. 1923; Shepard, F. P., 1938a, 1938f, 1939d, 1941a, $1947 \mathrm{a}, 1948 \mathrm{~b}, 1948 \mathrm{c}, 1950 \mathrm{~d}, 1951 \mathrm{a}, 1953$; Shepard, F. P. and Emery, K. 0., 1941; Shepard, F. P. and MacDonald, G. A., 1938; Shepard, F. P., Revelle, R. and Dletz, R. S., 1939; Shepard, F. P., Revelle, R., Dietz, R. S. and Emery, K. O., 1938; Tanner, Z. L., 1892b, 1894; Woodford, A. 0., 1951

Mud Eaters - see Scavengers

Mud Flat (See also: Estuary, Lagoon, Marsh, Salt Flat, Tide Flat): Anonymous, 1942; Bush, J. B., 1930; Galliher, E. W., 1932b; Hanna, M. A., 1926; Hinde, H. P., 1952; Norrison, R. L., 1930; Petracek, F. J., Fox, D. L. and Zechme1ster, L., 1951; Sears, C. B., 1876; S18ler, F. D. and ZoBell, C. E., 1950; ZoBell, C. E., 1946-1947

Mudflow - see Submarine Slumping, Turbidity Currents

Mudstone (See also: 'Rock, Sedimentary Rock): Crouch, R. W., 1954; Dietz, R. S., Emery, K. O. and Shepard, F. P., 1942; Emery, K. O., 1941a, 1948; Emery, K. 0. and Shepard, F. P., 1945; Holzman, J. E., 1950; Moore, D. G., 1951; Shepard, F. P., 1951b; Shepard, F. P. and Emery, K. O., 1941

Natural Bridge (See also: Sea Arch, Sea Cave): Anonymous, 1882a; Drury, N. B., 1936; Leonard, A. G., 1925; R1chardson, R. W., 1923; Shaler, N. S., 1894

Natural Levees - see Levees, Natural

Nearshore Profile - see Beach Profile

Nearshore Zone - see Beach and Nearshore

Nickel: Goldberg, E. D., 1954; Lowenstam, H. A., 1954; Revelle, R. and Emery, K. O., 1951; Rotsch1, H., 1951; Scripp Institution of oceanography, 1953e; Thompson, T. G. and Robinson, R. J., 1932

Nip (See also: Minor Features, Rocky Coests): Gorsline, D. S., 1954; Gulliver, F. P., 1896; Shepard, F. P., 1939 a

Nitrogen Including nitrogen compounds (See also: Amonia, C/N Ratio, Geses, Nutrients): Ahlstrom E. H., 1950; Allen, W. E., 1941; Atw1ll, E. R., 1942; Bigelow, H. B. and Leslie, M., 1930; BrongersmaSanders, M., 1948; Bullock, F. M., 1933; Crouch, R. W., 1951; Dill, R. F., 1952; Emery, K. O. and Rittenberg, S. C., 1951, 1952; Fleming, R. H., 1939a; Ford, J. L. C., 1942; Fox, D. L., 1950; Fox, D. L., Isaacs, J. D. and corcoran, E. F., 1952;. Galliher, E. W., 1933, 1935a; Gee, H., 1932; Giolen, T., 1944; Graham, H. W., 1934, 1941b; Hoots, H. W., 1943; Hutton, W. E. and ZoBell, C. E., 1949; Koe, K. B., Fox, D. L. and Zechme1ster, L., 1950; Krumbein, W. C., 1942; L1pman, C. B., 1929; McEwen, G. F., 1915, 1934a; Michael, E. L., 1919, 1921; Moberg, E. G., 1r25, 1928a, 1928c; Moberg, E. G. and Fleming, R. H., 1934; Moberg, E. G., Fleming, R. H., Heusner, K. and Revelle, R., 1937; Revelle, R. and Shepard, F., 1939b; Rittenberg, S. C., 1940; Scr1pps Institution of oceanography, 1953e; Siller, F. D. and ZoBell, C. E., 195la, 1951b; Smith, P. V., Jr., 1954; Sverdrup, H. U., 1938c, 1939a, 1940e, 1940g, 1941a; Sverdrup, H. U. and Staff, 1942a; Thompson, T. G. and Robinson, R. J., 1932; Tilden, C. A., 1925; Trask, P. D., 1927a, 19270, 1931b, 1934, 1936, 1939; Trask, P. D. and Hammar, H. E. 1931; Trask, P. D. and Hammar, H. E. and Wu, C. C., 1932; Updegraff, D. M., 1948; Urry, W. D. and Piggot, C. S., 1942; Vaughan, T. W., 1930b, 1930d, 1932a, 1932c, 1936, 1940; Weeks, L. G., 1952; ZoBell, C. E., 1933, 1935, 1938, 1939, 1941, 1942a, $1942 \mathrm{~b}, 1943,1946 \mathrm{~b}, 1946-1947,1947 \mathrm{~b}, 1947 \mathrm{c}, 1947 \mathrm{~d}$, 1950; ZoBell, C. E. and Anderson, D. Q., 1936; ZoBell, C. E. and Feltham, C. B., 1934a, 1942;

ZoBell, C. E., Grant, C. W., and Haas, H. P., 1943; ZoBell, C. E. and Rittenberg, S. C., 1938

Nodules (See also: Manganese, Phosphorite): Butcher, W. S., 1951a; Carsola, A. J. and Dietz, R. S., 1952; Dietz, R. S., 1954; Dietz, R. S. and Emery, K. O., 1938a; Dietz, R. S., Emery, K. O. and shepard, F. P., 1942; Emery, K. 0., 1947a, 1947b; Emery, K. O., Butלher, W. S., Gould, H. R. and Shepard, F. P., 1952; Emery, K. O. and Dietz, R. S., 1950; Emery, K. O. and Shepard, F. P., 1945; Galliher, E. W., 1932b; Goldberg, E. D., 1954; Hoots, H. W., Blount, A. L. and Jones, P. H., 1935; P1ggot, C. S., 1944; Revelle, R. and Emery, K. O., 1951; Shepard, F. P. and Emery, K. O., 1941; Shumway, G. A., 1953; Thompson, T. G. and Robinson, R. J., 1932; Uchupi, E., 1954

Nondeposition (See also: By-passing of Sediment, Winnowing): Crooke, R. C., Elvitaky, A. W. et al, 1953; Dietz, R. S., Emery, K. O. and Shepard, F. P., 1942; Emery, K. O., 1952a; Emery, K. O. and Dietz, R. S., 1950; Galliher, E. W., 1933; Grant, U. S., 1943; Holzman, J. E., 1950; Norr1s, R. M., 1951; Shepard, F. P., 1932, 1938e, 1939d, 1941a, 1952a; Stevenson, R. E., 1954; Uchup1, E., 1954

Nutrients (See also: Nitrogen, Phosphorous, Silica): Ahlstrom, E. H., 1950; Allen, W. E., 1921c, 1933a, 194la; Bigelow, H. B. and Leslie, M., 1930; Brongersma-Sanders, M., 1948; California Academy of Sclences, California Department of Fish and Game, Stanford University, Hopkins Marine Station, U. S. Fish and Wildife Service, South Pacific Fishery Investigation, University of California, Scripps Institution of Oceanography, 1952, 1953; California Academy of Sciences, California Division of Fish and Game, Scripps Institution of Oceanography of the University of California and U. S. Fish and Wildlife Service, 1950, 1951b; Carsola, A. J. and Dietz, R. S., 1952; Dawson, E. Y., 1951; Dietz, R. S., 1952a; Dill, R. F., 1952; Emery, K. O., 1954a; Emery, K. O. and Dietz, R. S., 1950; Fleming, R. H., 1939a; Fleming, R. H. and Revelle, R., 1939; Ford, J. L. C., 1942; Fox, D. L., 1950; Fox, D. L., Isaace, J. D. and Corcoran, E. F., 1952; Gislen, T., 1944; Goldberg, E. D., Walker, T. J. and Whisenand, A., 1952; Gorsline, D. S., 1954; Graham, H. W., 1934, 1941a, 1941b; Graham, H. W. and Moberg, E. G., 1944; H1daka, K., 1953; McEwen, G. F., 1934a; Moberg, E. G., 1928 (source of), 1930c; Moberg, E. G. and Fleming, R. H., 1934; Myers, E. H., 1942, 1943; Natland, M. L., Revelle, R. and Rittenberg, S. C., 1941; Revelle, R. and Shepard, F. P., 1939b; Sargent, M. S. and Walker, T. J., 1948; Sommer, H. and Clark, F. N., 1946; Sverdrup, H. U., 1940 g, 1941a, 1944b; Sverdrup, H. U. and Allen, W. E., 1939; Sverdrup, H. U. and Staff, 1940, 1941; ThompBon, T. G. and Robinson, R. J., 1932; Tlbby, R. B., 1939; Tilden, C. A., 1925; Trask, P. D., 1934, 1939; Updegraff, D. M., 1948; Vaughan, T. W., 1930b, $1932 b, 1932 c, 1934,1940$; ZoBell, C. E., 1941, $1942 a, 1942 b, 19470,1947 c, 1947 d ;$ ZoBell, C. E. and Anderson, D. Q., 1936; ZuBel1, C. E. and Feltham, C. B., 1942

Ocean Basin - see Basin

Offshore Bars - see Bars

offehore Troughs - see Troughs

011 - see Petroleum

Oil Seeps - see Submarine 011 and Gas Seeps

Oligocene: Butcher, W. S., 1951a; Corey, W. H., 1951, 1952; Emery, K. O., Butcher, W. S., Gould, H. R. and Shepard, F. P., 1952; Emilian1, C., 1954; Norr18, R. M., 1951; Uchup1, E., 1954

Oolites: Chesterman, C. W., 1952; Dietz, R. S. and Emery, 
K. O., 19380; Dietz, R. S., Emery, K. O. and Shepard, F. P., 1942; Emery, K. O., 1947a; Emery, K. O. and Dietz, R. S., 1950

Dozes, General (See also: Globergerina Ooze, Pelagic Sediments, Pteropod Ooze, Radiolarian Ooze): Davidson, G., 1875b; Dietz, R. S., Emery, K. 0. and Shepard, F. P., 1942; Emery, K. O. and Dietz, R. S., 1941 (foraminiferal ooze): Revelle, R., 1935 (siliceous); Shepard, F. P., 1951b; Tanner, Z. L., 1892b; Trask, P. D., 1939; Vaughan, T. W., 1940 (organic)

organic Matter, including organic Carbon (See also: Bacteria, $\mathrm{C} / \mathrm{N}$ Ratio, Diatoms in Relation to origin of Petroleum; Organic Matter, Decomposition of; Petroleum):

General includes bays, estuaries, lagoons etc.:

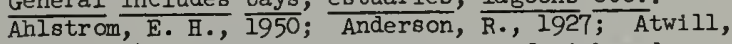
E. R., 1942; California Department of Fish and Game, 1951; Coe, W. R., 1945, 1947; Coe, W. R. and Fox, D. L., 1942; Dana, S. W., 1942; Dapples, E. C., 1942; Dawson, E. Y., 1951; Dietz, R. S., 1952a; Dietz, R. S., Emery, K. O. and Shepard, F. P., 1942; Dill, R. F., 1952; Emery, K. O., 1950e, 1954b; Emery, K. O. and Dietz, R. S., 1941, 1950; Fox, D. L., 1944a, 1944b, 1950; Fox, D. L., 1944a, 1944b, 1950; Fox, D. L. and Coe, W. R., 1943; Fox, D. L., Crane, S. C. and McConnaughey, B. H., 1948; Fox, D. L., Updegraff, D. M. and Novelli, G. D., 1944; Galliher, E. W., 1933, 1935a, 1935c; Gester, G. C., 1927; Gorsline, D. S., 1954; Graham, H. W., 1943; Grim, R. E., Dietz, R. S. and Bradley, W. F., 1949; Hoots, H. W., 1943; Hoots, H. W., Blount, A. L. and Jones, P. H., 1935; Hughes, R. V., 1932; Inman, D. L., 1950; Koe, K. B., Fox, D: L. and Zechmeister, L., 1950; Krumbein, W. C., 1942; Leslle, M. and Moberg, E. G., 1930; Moberg, E. G., Fleming, R. H., Heusner, K. and Revelle, R., 1937; Morrison, R. L., 1930; Putnam, J. A., Bermel, K. L. and Johnson, J. W., 1947; Revelle, R., 1938, 1941, 1950; Revelle, R. and Emery, K. O., 1951; Revelle, R. and Shepard, F. P., 1939b; Rittenberg, S. C., 1940; Rosenfeld, W. D., 1948; San Diego Regional Water Pollution Control Board, 1952; Smith, P. V., Jr., 1954; Stevenson, R. E., 1954; Stevenson, R. E. and Emery, K. O., 1951; Sverdrup, H. U., 1939a, 1940d, 1940g, 1941a; Takahaski, J., 1925; Thayer, L. A., 1937; Trask, P. D., 1927a, 1927b, 1928, 1930, 1931b, $1932 a$, 1934, 1936, 1939; Trask, P. D. and Hammar, H. E., 1931; Trask, P. D., Hanmar, H. E. and Wu, C. C., 1932; Trask, P. D. and Wu, C. C., 1930a, 1930b; Vaughan, T. W., 1940; Weeks, L. G., 1952; ZoBell, C. E., 1938, 1939, 1941, 1942b, 1943, 1944, 1946b, 1946-1947, 1947b, 1947c, 1947d, 1949, 1950; ZoBell, C. E. and Anderson, D. Q., 1936; ZoBell, C. E. and Feltham, C. B., 1934, 1942; ZoBell, C. E., Grant, C. W. and Hass, H. F., 1943; ZoBell, C. E. and Rittenberg, S. C., 1938 Abyssal: Dill, R. F., 1952; Emery, K. O., 1954b; Goldberg, E. D., 1954; Grim, R. E., Dietz, R. S. and Bradley, W. F., 1949; Piggot, C. S., 1932, 1944; Revelle, R., 1935a; Scripps Institution of Oceanography, 1953e; Shumway, G. A., 1953; Trask, P. D., and Harmar, H. E., 1931; White, D., 1911

Bank: Dietz, R. S., Emery, K. O. and Shepard, F. P., 1942; Emery, K. O., 1948, 1954b; Emery, K. O., Butcher, W. S., Gould, H. R. and Shepard, F. P., 1952; Emery, K. 0. and Rittenberg, S. C., 1951, 1952; Holzman, J. E., 1950; Uchup1, E., 1954 Basin: Corey, W. H., 1952; Emery, K. O., 1954b, 1954d; Emery, K. O., Butcher, W. S., Gould, H. R. and Shepard, F. P., 1952; Emery, K. O. and Rittenberg, S. C., 1951, 1952; Fleming, R. H. and Revelle, R., 1939; Gr1m, R. E., Dietz, R. S. and Bradley, W. F., 1949; Pratt, W. E., 1947; Revelle, R., 1939b; Revelle, R. and Shepard, F. P., 1939b; Smith, P. V., Jr., 1954; Trask, P.'D., 1927a, 1927b, 1928, 1930, 1931b, 1939; Weeks, L. G., 1952; Woodring, W. P., 1938a; ZoBell, C. E., 1935

Beach and Nearshore: Anonymous, 1950d; Coe, W. R., 1948; Fmery, K. O., 1946b, 1954b; Fox, D. L., Isaacs, J. D., Corcoran, E. F., 1952; Gorsline, D. S., 1954; Handin, J. W., 1949;
McConnaughey, B. H. and Fox, D. L., 1949; Nelson, J. W., Dean, W. C., Kocher, A. E., Watson, E. B. and Carpenter, E. J., 1920; Nelson, J. W., Zinn, C. J., Strahorn, A. T., Watson, E. B. and Dunn, J. E., 1919; Petracek, F. J., Fox, D. L. and Zechmeister, L., 1951; Shepard, F. P., Inman, D. L. and Fisher, R. L., 1951; Thompson, W. O., 1937; Trask, P. D., 1930; Trask, P. D. and Scott, T., 1954; ZoBell, C. E., 1935

Coastal Sand Dunes: Blake, J., 1868a; Emery,

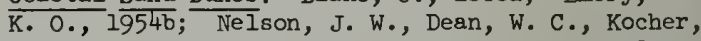
A. E., Watson, E. B. and Carpenter, E. J., 1920; Nelson, J. W., Zinn, C. J., Strahorn, A. T., Watson, E. B. and Dunn, J. E., 1919; Olsson-Seffer, P., 19106

Continental and Insular Shelves: Dill, R. F., 1952; Emery, K. 0., 1952a, 1954b; Emery, K. O., Butcher, W. S., Gould, H. R. and Shepard, F. P., 1952; Galliher, E. W., 1933, 1935a, 1935c; Gorsline, D. S., 1954; Grim, R. E., Dietz, R. S. and Bradley, W. F., 1949; MacDonald, G. A., 1934; Pratt, W. E., 1947; Shepard, F. P., 195la; Shepard, F. P. and Wrath, W. F., 1937; Trask, P. D., 1930, 1939 Continental Slope: Dill, R. F., 1952; Emery, K. O., 1954b; Trask, P. D., 1930, 1939; Trask, P. D. and Hammar, H. E., 1931 Sea Water: Ahlstrom, E. H., 1950; Allen, W. E., 1941c; California Academy of Sciences, California Division of Fish and Game, Scripps Institution of Oceanography, U. S. Fish and Wildlife Service, 1950; Couch, E. B., 1915; Evans, R. D., Kip, A. F. and Moberg, E. G., 1938; Ewing, G. C., 1950a, 1950c; Fleming, R. H., 1939a; Fox, D. L., 1952; Goldberg, E. G., Baker, M. and Fox, D. L., 1952; Gorsline, D. S., 1954; Holzman, J. E., 1950; Hutton, W. E. and ZoBell, C. E., 1949; McEwen, G. F., 1919b; Moberg, E. G., 1925, 1928d, 1930b; Moberg, E. G., Seiwell, H. R., Graham, H. W. and Paul, J. H., 1930; Putnam, J. A., Bermel, K. L. and Johnson, J. W., 1947; Sverdrup, H. U. and Fleming, R. H., 1941; Thompson, R. G. and Robinson, R. J., 1932; Vaughan, T. W., 1934; Young, R. T., Jr., 1939

Submarine Canyons: Emery, K. O., Butcher, W. S., Gould, H. R. and Shepard, F. P., 1952; MacDonald, G. A., 1934; Shepard, F. P., 1951a

organic Matter, Decomposition or oxidation of (See also: Bacteria, Diatoms in Relation to Origin of Petroleum, Organic Matter): Ahlstrom, E. H., 1950; Allen, W. E., 1941a; Barrows, A. L., 1913; Cohee, G. V., 1938; Dapples, E. C., 1942; Dietz, R. S., Emery, K. O. and Shepard, F. P., 1942; Emery, K. O., 1950d, 1952b; Fleming, R. H., 1939a; Fox, D. L., 1950; Fox, D. L. and Anderson, L. J., 1941; Fox, D. L., Updegraff, D. M. and Novelli, G. D., 1944; Galliher, E. W., 1933, 1935a; Graham, H. W. and Moberg, E. G., 1944; Hoots, H. W., 1943; Moberg, E. G., 1928a, 1928b, 1930b, 1930c; Moberg, E. G. and Allen, W. E., 1927; Moulton, G. F., 1928; Revelle, R. and Shepard, F. P., 1939b; Rittenberg, S. C., 1940; Shepard, F. P., 1951a; Sverdrup, H. U., 1940g, 1941a; Takahash1, J., 1925; Thayer, L. A., 1937; Trask, P. D., 1934, 1939; White, D., 1911; ZoBell, C. E., 1938, 1939, 1942a, 1942b, 1946b, 1946-1947, $1947 \mathrm{~b}, 1947 \mathrm{c}, 1947 \mathrm{~d}, 1950 ; \mathrm{Z}$; Bell, C. E. and Anderson, D. Q., 1936; ZoBell, C. E. and Feltham, C. B., 1934, 1942; ZoBell, C. E. and Rittenberg, S. C., 1938

organic Sediments (See also: Calcareuus Sediments and Rocks, Carbonates, Coquina, Limestone, Marl, Shells, various oozes): Emery, K. O., 19470, 1947c; Emery, K. O., Butcher, W. S., Gould, H. R. and Shepard, F. P., 1952; Sverdrup, H. U., 1938d; Uchupi, E., 1954

orientation of Pebbles, Petrofabric Diagrams: Krumbein, W. C., 1947; Schupp, R. D., 1953

orogenesis (See also: Diastrophism): Havemann, H., 1952

organisms (See also: Burrowing organism, Fouling, Scavengers): Anonymous, 1944b; Andrews, H. L., 1945;

Armstrong, T. A., 1954; Arnold, D. and Arnold, R., 1902; Arnold, J. L., 1928; Barrows, A. L., 1913; Bartsch, P., 1912, 1921a; Beach Erosion Board, 1952b; Blake, J., 1868b; Bruff, S. C., 1946; 
Burch, B. L., 1947; Burch, J. Q., 1945; Bush, J. B., 1930; Butcher, W. S., 1951a; California Academy of Sciences, California Division of Fish and Game, Scripps Institution of Oceanography of the University of California, and U. S. Fish and Wildlife Service, 195la, 1951b; California Academy of Sciences, California Division of Fish and Game, Scripps Institution of Oceanography of the University of California, U. S. Fish and Wildlife Service, and Hopkins Marine Station, Stanford University, 1951; California Department of Fish and Game, 1951; California Department of Public Health, 1951; Carpenter, P. P., 1857; Carsola, A. J. and Dletz, R. S., 1952; Chesterman, C. W., 1952; Clark, A., 1933; Clark, A. H., 1914, 1933; Clark, B. L., 1931; Clark, F. N., 1938; Cockerell, T. D. A., 1938b, 1940; Coe, W. R., 1932, 1945, 1947, 1948, 1953; Coe, W. R. and Allen, W. E., 1937; Coe, W. R. and Fox, D. L., 1942, 1944; Cohee, G. V., 1938; Dall, W. H., 1921; Dapples, E. C., 1942; David, L. R., 1946, 1947; Davidson, G., 1875b; Dietz, R. S. and Emery, K. O., 1938b; Dietz, R. S., Emery, K. O., and Shepard, F. P., 1942; Dill, R. F., 1952; Durham, J. W., 1952; Emery, K. 0., 1941b, 1945a, 1946b, 1948, 1950d, 1952a, 1952b, 1954b; Emery, K. O., Butcher, w. S., Gould, H. R. and Shepard, F. P., 1952; Emery, K. O., and Dietz, R. S.; Emery,

K. O. and Rittenberg, S. C., 1952; Emery, K. 0. and Shepard, F. P., 1941; Emery, K. O. and Tschudy, R. H., 194I; Everest, F. A., Young, R. W. and Johnson, M. W., 1948; Fox, D. L., 1937, 1950; Fox, D. L. and Coe, W. R., 1943; Fox, D. L. Crane, S. C. and McConnaughey, B. H., 1948; Fraser, C. McL., 1943; Galliher, E. W., 1932b, 1933, 1935a, 1935c; Gaylord, E. G. and Hanna, G. D., 1925; Gislen, T., 1944; Goldberg, E. D., 1954; Gorgy, S., Rakestraw, N. W., and Fox, D. L., 1948; Graham, H. W., 1934; Grant, U. S. and Gale, H. R., 1931; Hanna, G. D., 1928, 1932, 1952; Helfand, S., 1927; Hertlein, L. G. and Emerson, W. K., 1953; Hertlein, L. G., and Strong, A. M., 1940; Holzman, J. E., 1950; Hubbs, C. L., 1948; Inman, D. L., 1950; James, E. L., 1950;

Johnson, M. W., 1939b; Johnson, M. W., Everest, F. A. and Young, R. W., 1947; Jordan, E. K., 1926; Keen, A. M., 1941; Keep, J., 1947; Kemnitzer, L. E., 1933; Kindle, E. M., 1934; Knudsen, V. O., Alford, R. S., and Emling, J. W., 1948; Light, S. F., et al, 1954; Louderback, G. D., 1920; Lowenstam, H. A., 1954; McConnaughey, B. H. and Fox, D. L., 1949; McEwen, G. F., 1950; McKee, E. D., 1939, 1953; MacGinitie, G. E., 1927, 1935, 1939; MacGinitie, G. E., and MacGinitie, N., 1949; Marks, G. W., 1938; Mason, H. L., 1931; Mears, E. G., 1943; Menard, H. W., 1952; Michael, E. L., 1919; Miller, R. C., Ramage, W. D. and Lazier, E. L., 1928; Morrison, R. L., 1930; Moyer, D. A., 1929b; Munk, W. H., 1950; Natland, M. L., Revelle, R. and Rittenberg, S. C., 194I; Newell, I. M., 1948; Norris, R. M., 1951; Oldroyd, I. S., 1924; Olsson-Seffer, P., 1910a; Packard, E. L., 1918; Page, G. B., 1950; Palmer, R. H., 1928; Pierce, W. D. and Pool, D., 1938; Piggot, C. S., 1932, 1944; Piggot, C. S. and Urry, W. D., 1942; Putnam, W. C., 1942; Revelle, R., 1935, 1937a; Revelle, R. and Emery, K. O., 1951; Revelle, R. and Shepard, F. P., 1939b; Richter, C. M. 1887; Ritter, W. E., 1901, 1902; Rothwell, W. T., Jr., 1944; Schenck, H. G., 1928, 1940;

Schenck, H. G. and Keen, A. M., 1935, 1936a, 1936b, 1937; Scofield, E. C., 1934; Scripps Institution of Oceanography, 1953e; Shaler, N. S., 1895; Shepard, F. P., 1936f, 1936g, 1940c, 1941a, 1949b, 1951a, 1952a; Shepard, F. P. and Emery, K. O., 1945; Shepard, F. P. and Wrath, W. F., 1937; Shumway, G. A., 1953; Smith, A. G. and MacKenzie, G., Jr., 1948; Stearns, R. E. C., 1875; Stevenson, R. E., 1954; Stevenson, R. E. and Emery, K. O., 1951; Stock, C., 1935, 1936, 1946; Stock, C. and Furlong, E. L., 1928, 1929; Sverdrup, H. U., 1938c, 194la, 1941c; Sverdrup, H. U. and Staff, 1948; Takahash1, J., 1928; Trask, B. 1907; Trask, P. D., 1932b, 1939; Uchupi, E., 1954; Vaughan, T. W., 1940; White, D., 1911;
Williams, W., 1948; Woodford, A. O., 1935; Woodring, W. P., 1938a; ZoBell, C. E., 1939, $1942 \mathrm{a}, 1942 \mathrm{c}, 1947 \mathrm{c}, 1947 \mathrm{~d} ; \mathrm{ZoBell}, \mathrm{C} . \mathrm{E}$. and Feltham, C. B., 1942

Ostracods (See also: Zooplankton): Allen, W. E., 1920; Butcher, W. S., 1951a; Carsola, A. J., 1947; Carsola, A. J. and Dietz, R. S., 1952; Crouch, R. W., 1954; Emery, K. O., Butcher, W. S., Gould, H. R. and Shepard, F. P., 1952; Revelle, R., 1935; Rothwell, W. T., Jr., 1944, 1946

Outcrop - see Bedrock

Oxidation---Reduction Potential - see Eh

oxidation of Organic Matter - see Organic Matter, Decomposition of

oxidizing or Aerobic Environment (See also: Aeration, Eh, Oxygen): Dietz, R. S., Emery, K. O. and Shepard, F. P., 1942; Dill, R. F., 1952; Emery, K. 0. and Rittenberg, S. C., 1952; Fox, D. L., 1944a; Fox, D. L., Updegraff, D. M. and Novelli, G. D., 1944; Louderback, G. D., 1940; Piggot, C. S., 1932, 1944; Revelle, R. and Shepard, F. P., 1939b; Scripps Institution of Oceanography, 1953e; Stevenson, R. E., 1954; ZoBell, C. E., 1936, 1946b; ZoBell, C. E., Grant, C. W. and Haas, H. F., 1943

Oxygen: Anonymous, $1944 \mathrm{~b}$ (in mud), 1950; Ahlstrom, E. H., 1950; Allen, W. E., 1933b, 1939, 194la, 1941b, 194lc, 1946a; Bandy, O. L., 1953a; Bigelow, H. B. and Leslie, M., 1930; Brongersma-Sanders, M. 1948; Bullock, F. W., 1933; California Academy of Sciences, California Division of Fish and Game, Scripps Institution of Oceanography of the University of California, and U. S. Fish and Wildlife Service, 1950, 195la; California Academy of Sciences, California Division of Fish and Game, Stanford University, Hopkins Marine Station, U. S. Fish and Wildlife Service, South Pacific Fishery Investigation, University of California, Scripps Institution of oceanography, 1952, 1953; California Bureau of Sanitary Engineering, 1952; California Department of Fish and Game, 1951; California Department of Public Health, 1951; Connell, C. H. and Cross, J. B., 1950; Couch, E. B., 1915; Crouch, R. W., 1951; Dapples, E. C., 1942; Dill, R. F., 1952; Dietz, R. S., Emery, K. O. and Shepard, F. P., 1942; Emery, K. O., 1946b, 1952b, 1953a, 1954d; Emery, K. O. and Dietz, R. S., 1950; Emery, K. O. and Rittenberg, S. C., 1952; Emilian1, C., 1954; Epstein, S. and Mayeda, T., 1953 (018); Evans, R. D., Kip, A. F. and Moberg, E. G., 1938; Fleming, J. A., 1930; Fleming, J. A., Sverdrup, H. U. Ennis, C. C., Seaton, S. L. and Hendrix, W. C. 1945; Fleming, R. H., 1939b, 1940b, 1942; Fleming, R. H., Moberg, E. G. and Revelle, R. 1937b; Fleming, R. H. and Revelle, R., 1939; Fox, D. L., 1937, 1944a, 1944b; Fox, D. L. and Anderson, L. J., 1941; Fox, D. L., Updegraff, D. M., Novelli, G. D., 1944; Galliher, E. W., 1933; Gilbert, J. Y. and Allen, W. E., 1943; Gislēn, T., 1943, 1944; Goldberg, E. D., 1954; Goldberg, E. D., Baker, M. and Fox, D. L., 1952; Graham, H. W., 1934, 194la; Graham, H. W. and Moberg, E. G., 1944; Hewatt, W. G., 1934; Holzman, J. E., 1950; Hoots, H. W., 1943; Hutton, W. E. and ZoBell, C. E., 1949; Krumbein, W. C., 1942; Leslie, M., 1928; Leslie, M. and Moberg, E. G., 1930; Lowenstam, H. A., $1954\left(0^{18} / 0^{16}\right)$; McEwen, G. F., 1915; MacGinitie, G. E., 1927; Mayor, A. G., 1922; Michael, E. L., 1921; Miller, H. E. and Nusbaum, I., 1952; Miller, R. C., Ramage, W. D. and Lazier, E. L., 1928; Moberg, E. G., 1930a, 1930b; Moberg, E. G. and Graham, H. W., 1930; Munk, W. H., 1940; Myers, E. H., 1943; Natland, M. L., Revelle, R. and Rittenberg, S. C., 1941; Osorio Thfall, B. F., 1943; Phelps, A., 1940; Piggot, C. S., 1944; Pratt, W. E., 1947; Rakestraw, N. W., Rudd, P. D. and Dole, M., 195l; Revelle, R., 1939b, 1950; Revelle, R. and Shepard, F. P., 1939b; San Diego Regional water Pollution Control Board, 1952; Sargent, M. S. and walker, T. J., 1948; Schneider, W. A., 1954; Scripps Institution of Oceanography, 1949a, 1949b, 1949c, 1949d, 1949e, 1950a, 1950b, 1950c, 1950d, $1950 \mathrm{e}, 1950 \mathrm{~g}, 1951 \mathrm{la}, 1951 \mathrm{~b}, 1951 \mathrm{c}, 1951 \mathrm{~d}, 1951 \mathrm{e}$, 
1951f, 195lh, 1951i, 1951 J, 1951k, 195ll, 1951m, $1952 \mathrm{a}, 1952 \mathrm{~b}, 1952 \mathrm{e}, 1952 \mathrm{f}, 1952 \mathrm{~g}$; Sormer, H. and Clark, F. N., 1946; Stevenson, R. E. and Emery, K. O., 1951; Sverdrup, H. U., 1937-1938, $1938 \mathrm{a}, 1938 \mathrm{c}, 1938 \mathrm{~d}, 1939 \mathrm{a}, 1939 \mathrm{~b}, 1939 \mathrm{c}, 1940 \mathrm{~b}$, $1940 \mathrm{e}, 1940 \mathrm{~g}, 1941 \mathrm{c}, 1944 \mathrm{~s}$; Sverdrup, H. U. and Allen, W. E., 1939; Sverdrup, H. U. and Fleming, J. A., 1944; Sverdrup, H. U. and Fleming, R. H., 1941; Sverdrup, H. U. and Staff, 1941, 1943b, 1944, 1947b; Thompson, T. G. and Robinson, R. J., 1932; Thompson, T. G., Thomas, B. G. and Barnes, C. A., 1934; Tibby, R. B., 1943, 1944; Tilden, C. A., 1925; Topp, E. P., 1929; Trask, P. D., 1934, 1939; Uchup1, E., 1954; Ufford, C. W., 1947a; Updegraff, D. M., 1948; Vaughan, T. W., 1930b, 1930d, 1932a, 1932c, 1933, 1934, 1935a, 1940; Wooster, W. S., 1950; Young, R. T., 1939; ZoBell, C. E., $1936,1938,1939,1942 \mathrm{a}, 1942 \mathrm{~b}, 1943,1946 \mathrm{~b}$, 1946-1947, 1947b, 1947c, 1947d, 1950; ZoBell, C. E. and Anderson, D. Q., 1936; ZoBell, C. E. and Feltham, C. B., 1942; ZoBell, C. E., Grant, C. W. and Haas, H. F., 1943

Paleoclimate - see Meteorology and Climate, Paleogeography Paleogeography (See also: Meteorology and Climate): Clark, B. L., 1921; Corey, W. H., 1951, 1952; Emery, K. O. and Shepard, F. P., 1945; Sanchez, P. C., $1934 c$

Pelagic Sediments (See also: Red Clay, various oozes): Dietz, R. S., Emery, K. O. and Shepard, F. P., 1942; Goldberg, E. D., 1954 (also pelagic oozes); Lawson, A. C., 1924; Rittenberg, S. C., 1940; Trask, P. D., 1932b (pelagic oozes); Vaughan, T. W., 1940

Permeability: Emery, K. O., 1945a, 1950e; Emery, K. O. and Foster, J. F., 1948; Emery, K. O. and Gale, J. F., 195l; Emery, K. O. and Rittenberg, S. C., 1951, 1952; Krumbein, w. C., 1942, 1947, 1950; Stevenson, R. E. , 1954

Petrofabric Diagrams - see Orientation of Pebbles

Petroleum, Asphaltum, Oil (See also: Bacteria C/N Ratio, Diatoms in Relation to origin of Petroleum, Hydrogen, Methane, Nitrogen, Organic Matter; Organic Matter, Decomposition of; Petroleum, Origin of; Source Beds for Petroleum, Tidelands): Anonymous, 1906a, 1932a, 1932b, 1938c, 1944b, 1946a, $1948,1949 \mathrm{a}, 1949 \mathrm{~b}, 1952 \mathrm{c}, 1952 \mathrm{~d}, 1952 \mathrm{~g}, 1952 \mathrm{f}$, $1952 \mathrm{k}, 1952 \mathrm{~L}, 1952 \mathrm{~m}, 1952 \mathrm{n}, 1952 \mathrm{o}, 1952 \mathrm{p}, 1952 \mathrm{q}$, $1953 \mathrm{a}, 1953 \mathrm{~b}, 1953 \mathrm{c}, 1953 \mathrm{e}, 1954 \mathrm{~b}, 1954 \mathrm{~d}, 1954 \mathrm{f}$, 19548, 1954i, 1954k; Alexander, A. H., 1936; Allen, W. E., 1941c; Anderson, F. M., 1926; Anderson, R., 1927; Armstrong, T. A., 1954; Balley, T. L., 1947; Barnes, K. B., 1945; Beach Erosion Board, 1948j; Bell, G. K., 1948; Blake, W. P., 1855; Blodget, R. M., 1949; Branner, J. C., 1913; Brongersma-Sanders, M., 1948; Bullington, J. P., 1940; California Legislature, 1931b, 1951b; Chase, J. L., 1948; Coe, W. R. and Fox, D. L., 1942; Collins, L. B., Gilbert, J. C. and Simon, J. H., 1933; Davidson, G., 1897; Emery, K. O., 1950b, 1951; Emery, K. 0. and Rittenberg, S. C., 1951, 1952; Ford, J. L. C., 1942; Fox, D. L., 1944a, 1944b; Fox, D. L. and Anderson, L. J., 1941; Fox, D. L., Updegraff, D. M. and Novelli, G. D., 1944; Friedman, S. L., 1949; Gale, H. S., 1933, 1934a, 1934b; Galliher, E. W., 1933; Gester, G. C., 1927; Gilbert, J. C. and Simon, J. H., 1933; Gilluly, J. and Grant, U. S., 1947; Goodyear, W. A., 1890; Grant, U. S. and Sheppard, W. E., 1939; Gross, H. E., 1945; Hanna, G. D., 1952; Hansen, H. A. and Pemberton, J. R., 1950; Harris, F. R. and Harlow, E. H., 1948; Hjelte, G., 1938; Hoots, H. W., 1943; Hoots, H. W., Blount, A. L. and Jones, P. H. , 1935; Hubbs, C. L. and Rechnizer, A. B., 1952; Hughes, R. V., 1932; Hutton, W. E. and ZoBell, C. E., 1949; Kemnitzer, W. J., 1937; Larsen, G. P., 1941; Leypoldt, H., 1947; McLaughlin, R. P., 1921; Menard, H. W., Dill, R. F., Hamilton, E. L., Moore, D. G., Shumway, G., Silvermen, M. and Stewart, H. B., 1954; Merrili, F. J. H., 1914; Miller, J. C., 1953; Mills, B., 1932a, 1932b, 1932c, 1932d, 1932e, 1932f, 1932g, 1936; Moberg, E. G., Fleming, R. H., Heusner, K. and Revelle, R., 1937; Morgan, F. A., 1930; Murray-Aaron, E.
R., 1947; National Petroleum Council, 1953; Nicholls, C. P. L., 1936a, 1936c; Pecham, S. F., 1897; Pollak, c. N., 1953; Pratt, W. E., 1947; Pyles, E. E., 1954; Rittenberg, S. C., 1940; Shepard, F. P., 1951b; Shepard, F. P. and MacDonald, G. A., 1938; Shumway, G. A., 1953; Smith, P. V.
Jr., 1954; Smith, J. S., 1936; Sheddon, R., 1948; Sosedko, A. F., 1950; Stockman, L. P., 1932, 1939, 1949a, 1949b, 1949c; Stormont, D. H., 1951b, 1951c, $1952 \mathrm{a}, 1952 \mathrm{~b}, 1952 \mathrm{c}, 1954 \mathrm{a}, 1954 \mathrm{~b}, 1954 \mathrm{c}$; Sweeney, J., 1930; Tanner, Z. L., 1892a, 1896; Takahask1, J., 1925, 1928; Thayer, L. A., 1935, 1937; Thom, W. T., Jr., 1938; Trask, P. D., 1927a, 1927b, 1928, 1930, 1931b, 1934, 1936, 1939; Trask, P. D., Hammar, H. E. and Wu, C. C., 1932; Trask, P. D. and Wu, C. C., 1930b; Vickery, F. P., 1927a; Weaver, C. E., 1945; Weaver, D. K., 1937; Weaver, D. K. and Wilhelm, V. H., 1943; Weber, B. V., 1946; Weeks, L. G., 1952; Welker, S. C., 1954; Wharton, M., 1948; White, D., 1911; Woodring, W., Bramlette, M. N. and Lohman, K. E., 1943; ZoBell, C. E., 1938, 1939, 1942a, 1942b, 1944 , $1946 \mathrm{~b}, 1946-1947$, 1947c, 1947d, 1949, 1950; ZoBell, C. E. and Anderson, D. Q., 1936; ZoBell, C. E., Grant, C. W. and Haas, H. F., 1943

Petroleum, Origin of (Also see: Bacteria, Diatoms in Relation to origin of Petroleum, Petroleum, Pigments, Source Beds for Petroleum): Anderson, F. M., 1926; Anderson, R., 1927; Bailey, T. L., 1947; Emery, K. O. and Rittenberg, S. C., 1952; Gester, G. C., 1927; Hughes, R. V., 1932; Pratt, W. E., 1947; Smith, P. V., Jr., 1954; Takahashi, J., 1925, 1928; Thayer, L. A., 1935, 1937; Trask, P. D., 1927a, $1927 b, 1928$, 1930, 1931b, 1934, 1936, 1939; Trask, P. D. and Wu, C. C., 1930b; Weeks, L. G., 1952

pH (hydrogen ion concentration): Allen, W. E., 1921a, 1923b; Andrews, H. L., 1945; California Department of Public Health, 1951; Crouch, R. W., 1951; Dapples, E. C., 1942; Di11, R. F., 1952; Emery, K. O., $1946 \mathrm{~b}, 1950 \mathrm{e}, 1953 \mathrm{a}, 1954 \mathrm{~d}$; Emery, K. O. and Rittenberg, R. S., 1951, 1952; Fleming, J. A., 1930; Fleming, J. A., Sverdrup, H. U., Ennis, C. C., Seaton, S. L. and Hendrix, W. C., 1945; Fox, D. L. and Coe, W. R., 1943; Fox, D. L., Updegraff, D. M., Novelli, G. D., 1944; Galliher, E. W., 1933, 1935a, 1935c; Gee, H., Greenberg, D. M. and Moberg, E. G., 1932; Gislén, T., 1943, 1944; Goldberg, E. D., 1954; Graham, H. W., 1934; Graham, H. W. and Moberg, E. G., 1944; Harding, H. W. and Moberg, E. G., 1934; Hinde, H. P., 1952; Horonjeff, R. and Patrick, D. A., 1952; Hutton, W. E. and ZoBell, C. E., 1949; Krumbein, W. C., 1942; Leslie, M., 1928; Lipman, C. B., 1929; McClendon, J. F., Gault, C. C. and Mulholland, S., 1917; McEwen, G. F., 1934a, 1940a; Meyor, A. G., 1922; Michaels, E. L., 1921; Miller, R. C., Ramage, W. D. and Lazier, E. L., 1928; Moberg, E. G., 1925, 1928a, 1928b, 1930c; Moberg, E. G. and Allen, W. E., 1927; Moberg, E. G. and Earding, H. W., 1933; Myers, E. H., 1943; Natland, M. L., Revelle, R. and Rittenber 8, S. C., 194l; Revelle, R., 1937b, 1950; Revelle, R. and Emery, K. O., 1951; Revelle, R. and Fleming, R. H., 1934; Revelle, R. and Shepard, F. P., 1939b; Sisler, F. D. and ZoBell, C. E., 1951a, 1951b; Smith, P. V., Jr., 1954; Stevenson, R. E., 1954; Stevenson, R. E. and Emery, K. O., 1951; Sverdmup, H. U., 1939a, 1940d, 1940e; Sverdrup, H. U. and Staff, 1943a; Thompson, T. G. and Robinson, R. J., 1932; Trask, P. D., 1927a; Vaughan, T. W., 1930b, 1930d, 1932a, 1932c, 1933; Wells, R. C., 1921; Williams, W., 1948; ZoBell, C. E., 1935, 1938, 1939, 1941, 1942a, 1942b, 1943 , $1944,1946 \mathrm{~b}, 1946-1947,1947 \mathrm{~b}, 1947 \mathrm{c}, 1947 \mathrm{~d}$; ZoBell, C. E. and Anderson, D. Q., 1936; ZoBell, e. E. and Feltham, C. B., 1942; ZoBell, C. E., Grant, C. W., and Haas, H. F., 1943; ZoBell, C. E. and Rittenberg, S. C., 1938

Phillipaite (See also: Clay): Carsola, A. J. and Dietz, R. S., 1952; Dietz, R. S., 1941; Grim, R. E., Dietz, R. S. and Bradley, W. F., 1949

Phosphorescence - see Luminescence

Phosphorite (See also: Flourine, Nodules, Phosphorous): Brongersma-Sanders, M., 1948; Butcher, W. S., 195la; Chesterman, C. W., 1952; Clements, T. and Emery, K. O., 1947; Dapples, E. C., 1942; Dietz, R. S.', 
1952a; Dietz, R. S. and Emery, K. O., 1936a, 1938b; Dietz, R. S., Emery, K. O. and Shepard, F. P., 1942; Dill, R. F., 1952; Emery, K. O., $1941 \mathrm{a}, 1947 \mathrm{a}, 1947 \mathrm{~b}, 1947 \mathrm{c}, 1948,1952 \mathrm{a}$; Emery, K. O., Butcher, W. S., Gould, H. R. and Shepard, F. P., 1952; Emery, K. O. and Dietz, R. S., 1950; Emery, K. O. and Rittenberg, S. C., 1952; Emery, K. O. and Shepard, F. P., 1945; Galliher, E. W., 1932b; Hanna, G. D., 1952; Holzman, J. E., 1950; Krumbein, W. C., 1942; Norris, R. M., 1951; Revelle, R. and Shepard, F. P., 1939b; Shepard, F. P., 194la; Shepard, F. P. and Emery, K. O., 1945; Shumway, G. A., 1953; Uchupi, E., 1954 Phosphorous (See also: Nutrients, Phosphorite): Ahlstrom, E. H., 1950; Allen, W. E., 1941a, 194lc, 1946b; Bigelow, H. B. and Leslie, M., 1930; BrongersmaSanders, M., 1948; Bullock, F. W., 1933; California Academy of Sciences, California Division of Fish and Game, Scripps Inst1tution of Oceanography of the University of California and U. S. Fish and Wildlife Service, 1950, 1951a; California Academy of Sciences, California Division of Fish and Game, Stanford University, Hopkins Marine Station, U. S. Fish and Wildife Service, South Pacific Fishery Investigation, University of California, Scripps Institution of oceanography, 1953; Dietz, R. S., 1954; Dietz, R. S., Emery, K. O. and Shepard, F. P., 1942; Dill, R. F., 1952; Emery, K. O., 1954a; Emery, K. O. and Dietz, R. S., 1950; Fleming, J. A., 1930; Fleming, J. A., Sverdrup, H. U., Ennis, C. C., Seaton, S. L. and Hendrix, W. C., 1945; Fleming, R. H., 1939a, 1939b, 1942; Ford, J. L. C., 1942; Fox, D. L., 1950; Fox, D. L., Isaacs, J. D. and Corcoran, E. F., 1952; Galliher, E. W., 1935a; Gislen, T., 1943, 1944; Goldberg, E. D., 1954; Goldber B, E. D., Walker, T. J. and Whisenand, A., 1952; Grabam, H.W., 1934, 1941a, 1941b; Graham, H. W. and Moberg, E. G., 1944; Hewatt, W. G., 1934; Hoots, H. W., Blount, A. L. and Jones, P. H., 1935; Inman, D. L., 1950; Leslie, M., 1928; Lipman, C. B., 1929; McEwen, G. F., 1934a; Moberg, E. G., 1925, 1928a, 1928c, 1930c; Moberg, E. G. and Fleming, R. H., 1934; Moberg, E. G. and Harding, H. W., 1933; Moberg, E. G., Seiwell, H. R., Graham, H. W. and Paul, J. H , 1930; Munk, W. H., 1950; Natland, M. L., Revelle, R. and Rittenberg, S. C., 1941; Phelps, A., 1940; Revelle, R., 1937a, 1937b, 1950; Scripps Inst1tution of Oceanography, 1949a, 1949b, 1949c, 1949d, $1949 \mathrm{e}, 1950 \mathrm{a}, 1950 \mathrm{~b}, 1950 \mathrm{c}, 1950 \mathrm{~d}, 1950 \mathrm{e}, 1950 \mathrm{~g}$, 1951a, 1951b, 1951c, 1951d, 1951e, 1951f, 1951h, 1951i, 1951L, 1952a, 1952b, 1953e; Skogsberg, T., 1936; Slegg8, G. F., 1927; Sverdrup, H. U., $1939 a$, $1940 \mathrm{e}, 1940 \mathrm{~g}, 1941 \mathrm{a}, 1944 \mathrm{a}$; Sverdrup, H. U. and Staff, 1941, 1942b, 1944; Thompson, T. G. and Robinson, R. J., 1932; Tibby, R. B., 1944; Trask, P. D., 1927a, 1934, 1939; Tilden, C. A., 1925; Updegraff, D. M., 1948; Vaughan, T. W., 1930a, 1930b, 1930d, 1931, 1932a; 1932c, 1940; Wooster, W. S., 1950, 1952; ZoBell, C. E., 1938, 1941, 1942a, 1942b, 1943, 1946-1947, 1947c, 1950; ZoBell, C. E. and Feltham, C. B. 1942

Photography: Beach Erosion Board, 1952b; California, University of, 1952b; Grant, U. S. and Shepard, F. P., 1937; Moffit, F. H., 19.53b; Munk, W. H. and Traylor, M. A., 1945; O'Brien, M. P., 1946a, 1947b; Scripps Institution of Oceanography, 19521; Shepard, F. P., 1949d, 1949e; Shepard, F. P. and Grant, U. S., 1947; Stump, R. S., 1946a; Stump, R. S. and Bascom, W. N., 1947; Wiegel, R. L., 1947c

Aerial Photography: Anonymous, 1945; Bascom, W. N., 1947d; California, University of, 1945; Congressional Documents, 1953b; Dunham, J. W., 1951; Isaacs, J. D., 1945 J; Johnson, J. W., 1944, 1945b; McAdam, D., 1947a; Menard, H. W. Dill, R. F., Hamilton, E. L., Moore, D. G., Shumway, G., S1lverman, M. and Stewart, H. B., 1954; Moff1t, F. H., 1953a; Morey, B. F., 1944, 1945; Norris, R. M., 1951; O'Brien, M. P. and Johnson, J. W., 1947; Scripps Institution of Oceanography, 1944 f 1944g; Shepard, F. P., 1950b; Shepard, F. P. and Emery, K. O., 1941; Snodgrass, F. E., 1951;
Stump, R. S., 1946a; Stump, R. S. and Bascom, W. N., 1947; Thompson, W. C., 1949; Van Dorn, W. G. 1953; Wanless, H. R., 1950; Wiegel, R. L., 1947a Bottom Photography: Buffington, E. C., 1951; Butcher, W. S., 1951a; Carsola, A., Dietz, R. S., 1952; Carsola, A., Dietz, R. S. and Russell, R. S., 1949; Dietz, R. S., 1954; Emery, K. O., $1947 \mathrm{~b}, 1952 \mathrm{~b}, 1953 \mathrm{~b}$; Emery, K. O., Butcher, W. S., Gould, H. R. and Shepard, F. P., 1952; Emery, K. O. and Dietz, R. S., 1941, 1950; Emery, K. O. and Rittenberg, S. C., 1952; Goldberg, E. D., 1954; Holzman, J. E., 1950; Menard, H. W., 1952; Menard, H. W., Dill, R. F., Bamilton, E. L., Moore, D. G., Shumway, G., Silverman, M. and Stewart, H. B., 1954; Norr1s, R. M., 1951; Scripps Institution of oceanography, 1947b; Shepard, F. P., 1947a, 1948d, 1949b, 1953; Shepard, F. P. and Emery, K. O., 1941, 1945; Uchupi, E., 1954

'Photosynthesis: Ahlstrom, E. H., 1950; Allen, W. E., $1939 \mathrm{~b}, 1940 \mathrm{a}, 1941 \mathrm{a}, 1941 \mathrm{~d} ; \mathrm{Bigelow}, \mathrm{H} . \mathrm{B}$. and Leslie, M., 1930; Brongersma-Sanders, M., 1948; California Academy of Sciences, California Division of Fish and Game, Scripps Institution of Oceanography, U. S. Fish and Wildlife Service, 1950; California Bureau of Sanitary Engineering, 1952; Dawson, E. Y., 1951; Dill, R. F., 1952; Emery, K. O.; 1946b; Emery, K. O. and Rittenberg, S. C., 1952; Fleming, R. H., 1939a (zone); Fox, D. L. 1937, 1950; Galliher, E. W., 1933; Goldberg, E. D., Baker, M. and Fox, D. L., 1952; Goldberg, E. D., Walker, T. J. and Whisenand, A., 1952; Graham, H. W., 1934 (zone); Graham, H. W. and Moberg, E. G., 1944; Holzman, J. E., 1950; Leslie, M., 1928; Leslle, M. and Moberg, E. G., 1930; McEwen, G. F., 1934a; Mayor, A. G., 1922; Michael, E. L., 1921; M1ller, H. E. and Nusbaum, I., 1952; Miller, R. C., Ramage, W. D. and Lazier, E. L., 1928; Moberg, E. G., 1928a, 1928b, 1930c; Moberg, E. G. and Allen, W. E., 1927; Natland, M. L., Revelle, R. and Rittenberg, S. C., 1941; Revelle, R., 1950; San Diego Regional Water Pollution Control Board, 1952; Stevenson, R. E. 1954; Sverdrup, H. U., 1940g, 1941a; Thompson, T. G. and Robinson, R. J., 1932; Trask, P. D., 1939; Vaughan, T. W., 1932c, 1934; Williams, W. 1948; ZoBell, C. E., 1942 (photosynthetic zone), 1947c; ZoBell, C. E. and Feltham, C. B., 1942

Phytoplankton (See also: Diatoms, Dinoflagellates, Plankton): Ablstrom, E. H., 1950; Allen, W. E., 1921b, 1921c, $1921 d, 1921 e, 1922 a, 1922 c, 1923 a, 1923 b, 1928 c$, $1928 \mathrm{~d}, 1929,1930 \mathrm{a}, 1934 \mathrm{~b}, 1938 \mathrm{a}, 1938 \mathrm{~b}, 1939 \mathrm{a}$, $1940 \mathrm{a}, 1940 \mathrm{c}, 1940 \mathrm{~d}$, 194lc, 1946a; Brongersma Sanders, M., 1948; Bullock, F. M., 1933; Cal1fornia Academy of Sciences, California Division of Fish and Game, Scripps Institution of oceanography of the University of California, and U. S. Fish and Wildlife Service, 1950, 1951a, 1951b; Callfornia Academy of Sclences, California Division of Fish and Game, Stanford University, Hopkins Marine Station, U. S. Fish and Wildlife Service, South Pacific Fishery Investigation; University of California, Scripps Institution of oceanography, 1953; California Bureau of Sanitary Engineering, 1952; Coe, W. R., 1945, 1948; Coe, W. R. and Fox, D. L., 1942, 1944; Dawson, E. Y., 1951; Dietz, R. S. and LaFond, E. C., 1950; Emery, K. O. and Rittenberg, S. 6., 195́; Esterly, C. O., 1923; Fleming, R. H., 1939a, 1939b; Fox, D. L., 1944b, 1950; Fox, D. L., Isares, J. D. and Corcoran, E. F., 1952; Fox, D. L., Updegraff, D. M. and Novell1, G. D., 1944; Gee, H., 1932; Gilbert, J. Y. and Allen, W. E., 1943; Graham, H. W., 1934, 1941b, 1943; Graham, H. W. and Moberg, E. G., 1944; Howard, L., 1937; Johnson, M. W., 1942; Mason, E. H., 1930; M1chael, E. L., 1921; Miller, H. E. and Nusbaum, I., 1952; Miller, R. C., Ramage, W. D. and Lazier, E. L., 1928; Moberg, E. G., 1928a, 1928c,; Myers, E. H., 1942, 1943; Natland, M. L., Revelle, R. and Rittenberg, S. C., 1941; Revelle, R., 1950; San Diego Regional Water Pollution Control Board, 1952; Scr1pps Institution of Oceanography, 1953e; Slegga, G. F., 1927; Smith, P. V., Jr., 1954; Sverdrup, H. U, $1938 \mathrm{c}, 1940 \mathrm{e}, 1940 \mathrm{e}, 1941 \mathrm{c}$; Sverdrup, H. U. and Allen, W. E., 1939; Sverdrup, H. U. and Staff, 1941; 
TIbby, R. B., 1939; Tilden, C. A., 1925; Trask, P. D., 1934, 1939; Vaughan, T. W., 1930b, 1932b, 1934, 1940; Whedon, W. F., 1939; ZoBell, C. E., $1942 \mathrm{a}, 1947 \mathrm{c}$

Piers - see Engineering

Plements, Carotenoids (See also: Chlorophyll, Petroleum): Anonymous, 1942, 1944b; Fox, D. L., 1937, 1944a, 1944b; Fox, D. L. and Anderson, L. J., 1941; Fox, D. L., Crane, S. C. and McConnaughey, B. H., 1948; Fox, D. L., Updegraff, D. M. and Novelli, G. D. , 1944; Pinckard, J. H., Kittredge, J. S., Fox, D. L., Haxo, F. T. and Zechmeister, L., 1953; Trask, P. D. and Wu, C. C., 1930b; Vaughan, T. W., 1933

Plankton (See also: Copepods, Diatoms, Dinoflagellates, Phytoplankton): Anonymous, 195la; Ahlstrom, E. H., 1950; Allen, W. E., 1920, 192la, 1921b, $1921 c, 1921 d, 1921 \mathrm{e}, 1922 \mathrm{a}, 1922 \mathrm{~b}, 1922 \mathrm{c}, 1923 \mathrm{a}$, $1923 b, 1923 c, 1923 d, 1923 e, 1923 f, 1924 a, 1924 b$, $1925,1926,1927 \mathrm{a}, 1927 \mathrm{~b}, 1927 \mathrm{c}, 1927 \mathrm{~d}, 1928 \mathrm{a}$, $1928 \mathrm{~b}, 1928 \mathrm{c}, 1928 \mathrm{~d}, 1929,1930 \mathrm{a}, 1930 \mathrm{~b}, 1933 \mathrm{a}$, $1933 b, 1934 a, 1934 b, 1935,1936,1937 a, 1937 b$, $1938 \mathrm{a}, 1938 \mathrm{~b}, 1938 \mathrm{c}, 1939 \mathrm{a}, 1939 \mathrm{~b}, 1939 \mathrm{c}, 1939 \mathrm{~d}$ $1940 \mathrm{a}, 1940 \mathrm{~b}, 1940 \mathrm{c}, 1940 \mathrm{~d}, 1941 \mathrm{a}, 1941 \mathrm{~b}, 1941 \mathrm{c}$, $1941 d, 1942 a, 1942 b, 1943,1945,1946 \mathrm{a}, 1946 \mathrm{~b}$; Allen, W. E. and Lewis, R., 1927; Anderson, R., 1927; Bartch, P., 1921b; Bigelow, H. B. and Leslie, M., 1930; Boden, B. P., 1950; Bonnot, P. and Phillips, J. B., 1938; Brongersma-Sanders, M., 1948; Bullock, F. W., 1933; California Academy of Sciences, California Division of Fish and Game, Scripps Institution of oceanography, U. S. Fish and Wildlife Service, 1950; California Academy of Sciences, California Division of Fish and Game, Scripps Institution of Oceanography of the University of California, U. S. Fish and Wildlife Service, and Hopkins Marine Station, Sianford University, 1951; California Academy of Sciences, California Division of Fish and Game, Stanford University, Hopkins Marine Station, U. S. Fish and Wildlife Service, South Pacific Fishery Investigation, University of California, Scripps Institution of Oceanography, 1952, 1953; California, University of, 1946a; Clark, A. H. 1914; Coe, W. R. and Fox, D. L., 1942; Couch, E. B., 1915; Cupp, E. E., 1930, 1934a, 1934b, 1938,' 1943; Cupp, E. E. and Allen, W. E., 1938; Daws on, E. Y., 1951; Dorman, H. P., 1927a, 1927b; Emery, K. 0., 1954a; Esterly, C. 0., 1923, 1928b; Ewing, G. C., 1950a; Fleming, R. H. and Revelle, R., 1939; Ford, J. L. C., 1942; Fox, D. B. 1929, 1930; Fox, D. L., 1937; Galliher, E. W., 1933; Goldberg, E. D., 1954; Goldberg, E. D., Baker, M. and Fox, D. L., 1952; Goldberg, E. D., Walker, T. J. and Whisenand, A., 1952; Grabsm, H. W., 1934, 1941a, 1941b, 1943; Harvey, D. R., 1928; Hewatt, W. G., 1934; Hinde, H. P., 1952; Hoots, H. W., 1943; Howard, L., 1937; Johnson, M. W., 1939a, 1939b, 1948; Kofo1d, C. A., 1911; Kofoid, C. A. and Swezy, 0., 1921; Leslle, M., 1928; Lesl1e, M. and Moberg, E. G., 1930; Lewis, R. C., 1927, 1929; McEwen, G. F., 1934a, 1950; McEwen, G. F. and Staff, 1948; Marshall, N. B., 1951; Mason, E. H., 1930; Michael, E. L., 1919; Michael, E. L. and McEwen, G. F., 1915, 1916; Moberg, E. G. , 1925, 1928b, 1928c, 1928d; Morrison, R. L., 1930; Murphy, H. E., 1924; Osorio Tafall, B. F., 1943; Phelps, A., 1937; Pinckard, J. H., Kittredge, J. S. , Fox, D. L. Haxo, F. T. and Zechmeister, L., 1953; Pratt, W. E. 1947; Rakestraw, N. W., Rudd, P. D. and Dole, M., 1951; Rankin, E. P., 1913; Revelle, R., 1939b, 1950; Ritter, W. E., 1924; Russell, F. S., 1934; Saur, J. T. F., Jr., 1950; Shepard, F. P., 1947a, 1949b; Skogsberg, T., 1936; Sommer, H. and Clark, F. N., 1946; Sommer, H., Whedon, W. F., Kofoid, C. A. and Stohler, R., 1937; Stevenson, R. E., 1954; Sumner, F. B., Louderback, G. D., Schmitt, W. L., and Johnston, E. C., 1914; Sverdrup, H. U., 1938c, 1939a, 1939b, 1940e, 1940f; Sverdrup, H. U. and Staff, 1941; Taylor, C. V. and Vaughan, T. W., 1934; Thompson, T. G. and Robinson, R. J., 1932; T1bby, R. B., 1939, 1944; Tilden, C. A., 1925; Topp, E. P., 1929; Torrey, H. B., 1902; Trask, P. D., 1928, 1930, 1939;
Vaughan, T. W., $1933,1934,1935 \mathrm{~b}, 1936,1940$ Walford, L. A., 1951; Walker, B. W., 1947;

Whedon, W. F., 1939; Whedon, W. F. and Kofoid, C. A., 1936; Young, R. T., Jr., 1939

Plant Nutrients - see Nutrients

Plastisity: Emery, K. O. and Dietz, R. S., 194l; Trask, P. D. and Rolston, J. W., $1950 \mathrm{~b}$

Plateau (See also: Terraces): Kemnitzer, L. E., 1933; Koczy, F. F., 1954; Smith, P. A., 1940

Platform - see Wave Cut Terraces

Pleistocene (See also: Tertiary): Anderson, C. A., 1941; Bagg, R. M., Jr., 1912; Bruff, S. C., 1940, 1946; Bucher, W. H., 1940; Butcher, W. S., 1951a; California, University of, 1953a, 1953b; Carsola, A. J. and Dietz, R. S., 1952; Clark, A., 1933; Cohee, G. V., 1938; Corey, W. H., 1951; Crouch, R. W., 1954; Crowell, J. C., 1950, 1952; Daly, R. A., 1934; Davis, W. M., 1932, 1933; Dietz, R. S., Emery, K. O. and Shepard, F. P., 1942; Emery, K. O., 1950c, 1950d, 1951, 1952a; Emery, K. O., Butcher, W. S., Gould, H. R. and Shepard, F. P., 1952; Emery, K. O. and Dietz, R. S., 1950; Emery, K. O. and Natland, M. L., 1952; Emiliani, C., 1954; Galliher, E. W., 1935a; Hill, R. T.,
1928a; Holsman, J. E., 1950; Hubbs, C. L., 1948; Inman, D. L., 1949, 1950; Ives, R. L., 1951; Jenkins, O. P., 1943b; Laws on, A. C., 1893b; Louderback, G. D., 1941; Mason, H. L., 1929 , 1931; Merriam, P. D., 1949; Moore, D. G., 1951; Norris, R. M., 1951; Piggot, C. S. and Urry, W. D., 1942; Poland, J. F., 1947; Putnam, W. C., 1938; Reed, R. D., 1933b; Revelle, R., 1950; Shepard, F. P., 1932, 1935a, 1935e, 1936c, 1936d, $1936 \mathrm{f}, 1936 \mathrm{~g}, 194 \mathrm{la}, 1948 \mathrm{c}, 1949 \mathrm{~b}, 1949 \mathrm{~d}, 1950 \mathrm{e}$ 1951b, 195le, 1952a; Shepard, F. P. and Emery, K. O., 1941; Shepard, F. P. and MacDonald, G. A. 1938; Shepard, F. P. and Stetson, H. C., 1939; Shumway, G. A., 1953; Smith, w. D., 1933c; Spencer J. W., 1890; Thompson, W. C., 1949; Trask, P. D. and Scott, T., 1954; Uchupi, E., 1954; Upson, J. E., 1949b; Vaughan, T. W., 1940; Weeks, L. G., 1952; Willis, B., 1900; Woodford, A. O., 1951

Pliocene (See also: Tertiary): Anonymous, 1952d; Anderson, C. A., 1941; Armstrong, T. A., 1954; Bagg, R M., Jr., 1912; Bucher, W. H., 1940; Butcher, W. S., 1951a; Cohee, G. V., 1938; Corey, W. H., 1951, 1952; Crouch, R. W., 1954; Dietz, R. S., Emery, K. O. and Shepard, F. P., 1942; Emery, K. 0., 1941a, 1950b, 1950d, 1951, 1952a; Emery, K. 0., Butcher, W. S., Gould, H. R. and Shepard, F. P., 1952; Emery, K. O. and Dietz, R. S., 1950; Emery, K. O. and Natland, M. L., 1952; Emery, K. O. and Shepard, F. P., 1941, 1945. Emiliani, C., 1954; Hanna, G. D., 1952; Holzman, J. E., 1950; James, E. L., 1950; Lawson, A. C., 1893b; LeConte, J., 189l; Moore, D. G., 195l; Norris, R. M., 1951; Revelle, R., 1950; Revelle, R. and Emery, K. O., 1951; Revelle, R. and Shepard, F. P., 1939b; Shepard, F. P., 1935e, 1936d, 1936f, 1948c, 1949b, 1950e, 1951b; Shepard, F. P. and Emery, K. O., 1941; Shepard, F. P. and MacDonald, G. A., 1938; Shepard, F. P. and Stetson, H. C., 1939; Sverdrup, H. U., 1938c; Sverdrup, H. U. and Staff, 1941; Vaughan, T. W., 1940; Willis, B., 1900; ZoBell, C. E., 1946-1947

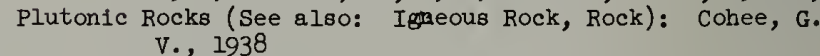

Plutonic Rocks (See also: Irseous Rock, Rock): Cohee, G
V., 1938 Pocket or Bayhead Beach (See also: Beach and Nearshore,
Cuspate Forelands): Beach Erosion Board, 1948h; Brant, I., 1925; California, University of, 1954b; Congressional Documents, 1953b; Davis, W. M., 1925; Handin, J. W., 1949; Inman, D. L., 1953a; Krumbein, W. C., 1947; Norris, R. M., 1951; Peel, K. P., 1951; Shepard, F. P., 1950g; Smith, W. D., 1933c; Stevenson, R. E., 1954

Pollution (See also: Bacteria, Eh, Hydrogen Sulfide, Reducing or Anaerobic Environment, Stagnant Water ): Anonymous, 1941b, 1950c, 1950f; Aldrich, L. and Smith, H. G., 1948; Alexander, A. H., 1936; Allen, W. E., 1928a; Beach Erosion Boord, 1948h, 1948i, 1953a; Blackman, J. W. B., 1936; Butler, M. M., 1936; California Bureau of Sanitary Engineering, 1943, 1952; California Department of Fish and Game, 1951; California Department of Public Works, 1951, 195la; California Legislature, 1949, 1951; 
California, University of, 1951a, 1951b, 1953b; California Water Pollution Control Board, 1952; Congressional Documents, 1936, 1953b; Connell, C. H. and Cross, J. B., 1950; Crooke, R. C., Elvitsky, A. W., et al, 1953; Dickey, L. K., 1936; Dill, R. F., 1949; Eddy, H. P., Hyde, C. G., Kennedy, C. C. and Reynolds, L. B., 1936; Emery, K. O. and Rittenberg, S. C., 1952; Fox, D. L., 1950; Fox, D. L., Isaacs, J. D. and Corcoran, E. F., 1952; Friedman, S. L., 1949; Gillespie, C. G., 1936; Griffin, D. F., 1944; Hall, T., 1943; Hjelte, G., 1938; Horonjeff, R. and Patrick, D. A., 1952; Hyde, C. G., Gray, H. F. and Rawn, A. M., 1941; Johnson, A. G., 1940c, 1951; Lamport, H. B., 1937; Larsen, G. P., 1944a, 1946; Los Angeles Regional Water Pollution Control Board, 1952; MacGinitie, G. E., 1927, 1935; Means, T. H., 1928; Metcalf and Eddy, 1944; Miller, H. E. and Nusbaum, I., 1952; Miller, R. C., Ramage, W. D. and Lazier, E. L., 1928; Mills, B., 1932a; Moberg, E. G., 1928c; Moffitt, J. and Orr, R. T., 1938; Moore, D. G., 1951; Morrison, R. L., 1930; Nicholla, C. P. L., 1936a, 1936c; Rawn, A. M. and Bowerman, F. R., 1951; Rice, E. K., 1951; San Diego Regional Water Pollution Control Board, 1952; Schne1der, W. A., 1954; Shaw; P. A. and Towers, C. L., 1937; Shuler, W. R., 1951; U. S. Navy, 1948; ZoBell, C. E., 1947c, 1947d; ZoBell, C. E. and Anderson, D. Q., 1936; ZoBell, C. E., and Feltham, C. B., 1942

Porosity: Anonymous, 1938a; Congressional Documents, 1938a, 1940a; Emery, K. O., 1945a; Emery, K. 0. and Foster, J. F., 1948; Emery, K. 0. and Rittenberg, S. C., 1952; Krumbein, W. C., 1942, 1947, 1950; Revelle, R. and Emery, K. 0., 1951; Shepard, F. P., 1949d; Stevenson, R. E., 1954; ZoBell, C. E., 1947d, 1950

Potassium: Evans, R. D., Kipp, A. F. and Moberg, E. G., 1938; Galliher, E. W., 1935a, 1935c; Kelley, W. P. and Liebig, G: F., Jr., 1934; Lipman, C. B., 1929; McEwen, G. F., 1934a; McKee, E. D., 1953; Revelle, R., 1941; Revelle, R. and Emery, K. O., 1951; Thompson, T. G. and Robinson, R. J., 1932; Trask, P. D., 1939; Vaughan, T. W., 1940; ZoBell, C. E., $1942 b$

Pot Holes - see Minor Features, Rocky Coasts

Precipitation of Sediments (See also: Colloids, various precipitated sediments): Butcher, W. S., 195la; Dietz, R. S., Emery, K. O. and Shepard, F. P., 1942; Evans, R. D., Kip, A. F. and Moberg, E. G., 1938; Fox, D. L., 1950; Gelliher, E. W., 1933; Gee, H., 1932; Goldberg, E. D., 1954; Krumbein, W. C., 1942; Lowenstam, H. A., 1954; McEwen, G. F., 1934a; Piggot, C. S., 1944; Revelle, R., 1935, 1937a, 19370, 1950; Revelle, R. and Emery, K. O., 1951; Revelle, R. and Fleming, R. H., 1934; Scripps Institution of Oceanography, 1953e; Sverdmu, H. U., 1938a, 1940d, 1940g; Trask, P. D., 1939; Vaughan, T. W., 1930a, 1931; ZoBell, C. E., 1938, 1947c; ZoBell, C. E. and Anderson, D. Q., 1936

Profile of Equilibrium - see Equilibrium

Prograding - see Accretion

Promitories - see Headlands

Pteropod Ooze - (See also: Pelagic Sediments): Emery, K. O. and Dietz, R. S., 1941; Michael, E. L., 1919; Shepard, F. P., 1932; Vaughan, T. W., 1940

Pumice (See also: Ash, Rock, Volcanic Rock): Goldberg, E. D., 1954; Shaler, N. S., 1896

Pyrite (See also: Iron, Iron Sulfides, "Sporbo", Sulfur): Beach Erosion Board, 1953c; Butcher, W. S., 1951a; Cohee, G. V., 1938; Dapples, E. C., 1942; Dill, R. F., 1952; Emery, K. O. and Rittenberg, S. C., 1952; Galliher, E. W., 1932b; Hoots, H. W., Blount, A. L. and Jonea, P. H., 1935 (pyritized Foraminfera); Krumbein, w. C., 1942 (pyritization); Revelle, R., 1950; Wright, R., 1937; ZoBell, C. E., 1939, $1946 \mathrm{~b}, 1947 \mathrm{c}, 1947 \mathrm{~d}$

Quartzite (See also: Metamorphic Rocks, Rocks): Butcher, W. S., 195la; Clements, T. and Dana, S. W., 1944; Emery, K. O., Butcher, W. S., Gould, H. R. and Shepard, F. P., 1952; Emery, K. O. and Shepard, F. P., 1945; Gorsline, D. S., 1954; Hanna, G. D.,
1952; Holzman, J. E., 1950; Shepard, F. P., 1938e; Shepard, F. P. and MacDonald, G. A., 1938; Shumway, G. A., 1953; Uchupi, E., 1954

Quarternary: Ashley, G. H., 1931; Cohee, G. V., 1938; Dietz, R. S., Emery, K. O. and Shepard, F. P., 1942; Emery, K. O. and Shepard, F. P., 1945; Hubbs, C. L., 1948; LeConte, J., 1891; Nelson, R. N. and Schenck, H. G., 1928; Shepard, F. P., 1938f, 1950e; Shepard, F. P., Emery, K. O. and LaFond, E. C., 1941; Shepard, F. P. and MacDonald, G. A., 1938; Trask, P. D., 1950

Radiation: Bigelow, H. B. and Leslie, M., 1930; Californio Academy of Sciences, California Division of Fish and Game, Scripps Institution of Oceanography, U. S. Fish and Wildlife Service, 1950; Coe, W. R., 1948; Cumings, N. W., 1950; Emery, K. O., Butcher, W. S., Gould, H. R. and Shepard, F. P., 1952; Fleming, R. H. and Revelle, R., 1939; Graham, H. W. and Moberg, E. G., 1944; LaFond, E. C., 1939a; Leipper, D. F., 1947; McEwen, G. F. , 1916, 1919a, 1929, 1930a, 1930c, 1933, 1934a, $1934 b, 1934 d, 1936,1937 b, 1937 c, 1937 d, 1937-1938$; Moberg, E. G., 1928a, 1930c; Neiburger, M., 1948; Richardson, B., 1930, 1935; Sverdrup, Н. U., 1938a, 1939c, 1944b; Tibby, R. B., 1941; Veughan, T. W., $1930 \mathrm{~b}, 1932 \mathrm{c}$

Radioactivity including Radioactive elements: Anonymous, 1950; Devaputra, D., Thompson, T. G. and Utterback, C. L., 1932; Evans, R. D., 1934; Evans, R. D., Kip, A. F. and Moberg, E. G., 1938; Goldberg, E. D., 1954; Goldberg, E. D., Baker, M. and Fox, D. L., 1952; Havemann, H., 1952; Karlik, B., Foyn, E., Petterson, H. and Rona, E., 1939; Lowenstam, H. A., 1954; McEwen, G. F., 1934a; Piggot, C. S., 1932, 1944; Piggot, C. S. and Urry, Wm. D., 1942; Revelle, R., 1935; Scripps Institution of Oceanography, 1953e; Sverdrup, H. U., 1940e; Thompson, T. G. and Robinson, R. J., 1932; Urry, W. D., 1940, 1948; Urry, W. D. and Piggot, C. S., 1942; Vaughan, T. W. , 1935a; Vaughan, T. W. and others, 1937; Woollard, G. P. (chairman), 1951; ZoBell, C. E., 1947d, 1950

Radiolarian Ooze and Radiolaria (Also see: Pelagic Sediments) Dietz, R. S., Emery, K. 0. and Shepard, F. P., 1942; Emery, K. O. and Dietz, R. S., 1950; Michael, E. L., 1919; Revelle, R., 1935; Shumway, G. A., 1953; Topp, E. P., 1929; Vaughan, T. W., 1940

Radium - see Radioactivity

Radon - see Radioactivity

Rafting (See also: Floating of Sediments): Brooks, C. W., 1875; Cockerell, T. D. A., 1938b; Davidson, 1873a, 1873b; Davis, H., 1872; Emery, K. O., 1941c, 1950d, 1952a; Emery, K. O., Butcher, W. S., Gould, H. R. and Shepard, F. P., 1952; Emery, K. O. and Shepard, F. P., 1945; Emery, K. O. and Tschudy, R. H., 1941; Ewing, G. C., 1950c; Fox, D. L., Isaacs, J. D. and Corcoran, E. F., 1952; Haase, L. G., 1926; Hanna, G. D., 1951, 1952; Ludwick, J. C., Jr., 1950; Shaler, N. S., 1896; Shepard, F. P., 1932, 1941a, 1948c, 1949b, 1949d, 1951b, 1951d; Shepard, F. P. and MacDonald, G. A., 1938; Shumway, G. A., 1953; Wooster, W. S., 1952

Raised Beaches (See also: Terraces): Griggs, A. B. and Wells, F. G., 1942; Trask, P. D., 1931b

Recreation: Anonymous, 1938a, 1938b, 1940b, 1941b, 1954b; Beach Erosion Board, 1948h, 1948i, 1954a, 1954c; Brown, E. I., 1939; Butler, M. M., 1936; California Legislature, 1931b; California Bureau of Sanitary Engineering, 1952; Chace, B. W., 1953; Congressional Documents, 1938a, 1940e, 1941 , 1949b, 1949d, 1949f, 1949-1950b, 1953b; Erickson, C. E., 1952, 1953; Friedman, S. L., 1949; Gillespie, C. G., 1936; Griffin, D. F., 1944; Hall, W. C., 1942; Hannum, G. W. T., 1944, 1947; Hjelte, G., 1938; Lamport, H. B., 1937; Larsen, G. P., 1941, 1942a, 1946; Leeds, C. T., 1946; Los Angeles County Regional Planning Commission, 1940, 1946; Nicholls, C. P. L., 1936b, 1936c, 1939, 1941; Nicholson, G. F., Grant, U. S., Shepard, F. P. and Crowell, J. C., 1946; O'Brien, M. P., 1939; Orange county Planning Commission, 1941; Place, J. L., 1952; Postel, A. C., 1939; Pyles, E. E., 1954; San Diego Regional Water Pollution 
Control Board, 1952; Shuler, W. R., 1951, 1952; Smith, J. S., 1937; Stapleton, C. R., 1952; Woodson, J. B., 1941

Recrystalization: Krumbein, W. C., 1942

Red Clay (See also: Clay, Color of Sediments, Limonite, Pelagic Sedimenta): Dietz, R. S., 1952a; Dill, R. F., 1952; Emery, K. O., 1954b; Emery, K. O. and Dietz, R. S., 1941; Goldberg, E. D., 1954; Grim, R. E., Dietz, R. S. and Bradley, W. F., 1949; Kuenen, Ph. H., 1946; Michael, E. L., 1919; Piggot, C. S., 1932, 1944; Piggot, C. S. and Urry, W. D., 1942; Revelle, R., 1935, 19370; Rittenberg, S. C., 1940; Shepard, F. P., 194la; Shepard, F. P., Revelle, R., Dietz, R. S. and Emery, K. O., 1938; Shepard, F. P. and Stetson, H. C., 1939; Shepherd, E. S., 1940, 1946; Shumway, G. A., 1953; Sverdrup, H. U., 1939a; Urry, W. D., 1948; Urry, W. D. and Piggot, C. S., 1942; Vaughan, T. W., 1940

Red Sand (See also: Color of Sediments, Limonite): Alden, J., 1856; Bache, A. D., 1852, 1856a; Crooke, R. C., Elvitaky, A. W. et al, 1953; Moore, D. G., 1951

Red Sediments (See also: Color of Sediments, Irox Oxides and Hydroxides, Limonite, Red Clay, Red Sand): Gorsline, D. S., 1954

Reducing or Anaerobic Environment (See also: Bacteria, Eb, Hydrogen Sulfide, Stagnant Conditions): Cartwright, L. D., Jr., 1928; Dill, R. F., 1952; Emery, K. O. and Rittenberg, S. C., 1952; Fox, D. L., 1944a; Fox, D. L., Updegraff, D. M. and Novelli, G. D., 1944; Galliber, E. W., 1933, 1935a, 1935c; Gee, H., 1932; Krumbein, W. C., 1942; Louderback, G. D., 1940; Marlette, J. W., 1954; Moberg, E. G., Fleming, R. H., Heusner, K. and Revelle, R., 1937; Piggot, C. S., 1932, 1944; Revelle, R. and Shepard, F. P., 1939b; Scripps Institution of Oceanography, 1953e; Stevenson, R. E., 1954; Trask, P. D., 1939; ZoBell, C. E., 1935, 1936, 1938, 1939, 1942b, 1943, $1944,1946 \mathrm{~b}, 1947 \mathrm{c}, 1950$; ZoBell, C. E. and Anderson, D. Q., 1936; ZoBell, C. E., Grant, C. W. and Haв, H. F., 1943

Reducing Capacity, Power or Intensity (See also: Eh): Trask, P., 1939; ZoBell, C. E., 1936, 1939, 1942b, 1944; ZoBell, C. E. and Anderson, D. Q., 1936

Red water, Yellow Water etc. (See also: Dinoflagellates, Mass Mortality, Turbid Water): Anonymous, 1943; Allen, W. E., 192lc, 1921d, 192le, 1927c, 1928b, $1928 \mathrm{c}, 1933 \mathrm{~b}, 1935,1937 \mathrm{a}, 1938 \mathrm{c}, 1940 \mathrm{~b}, 1940 \mathrm{~d}$, $1941 \mathrm{c}, 1943$, 1946a, 1946b; Bonnot, P. and Phillips, J. B., 1938; Brongersma-Senders, M., 1948; Connell, C. H. and Cross, J. B., 1950; Cupp, E. E., 1943; Dawson, E. Y., 1951; Ford, J. L. C., 1942; Kniffen, F. B., 1932; Kofoid, C. A., 1911; Michael, E. L., 1911; Natland, M. L., Revelle, R. and Rittenberg, S. C., 1941; Nightingale, H. W., 1937; Osorio Tafall, B. F., 1943; Pinckard, J. H., Kittredge, J. S., Fox, D. L., Haxo, F. T. and Zechmelater, L., 1953; Revelle, R., 1950; Ritter, W. E., 1902; Sommer, H. and Clark, F. N., 1946; Streets, T. H., 1878; Sverdrup, H. U. and Staff, 1941; Tanner, Z. L., 1896; Torrey, H. B., 1902; U. S. Hydrographic office, 1875; ZoBell, C. E., $1947 \mathrm{c}$

Reefs including Coral Reefs (See also: Corals): Atwill, E. R., 1942; Blake, W. P., 1856; Daly, R. A., 1934; Dietz, R. S., Menard, H. W., and Hamilton, E. L., 1954; Fewkes, J. W., 1889; Fox, L. S., 1930; Heck, N. H., 1926; Hertlein, L. G. and Emerson, w. K., 1953; Kindle, E. M., 1934; Krumbein, W. C., 1947; Pease, W. H., 1868; Shepard, F. P., 1932, 1936c, 1941a, 1948, 1949b, $1949 \mathrm{~d}, 1949 \mathrm{e}$ (atoll), 1950c, 1950g, 1952a (atoli); Shepard, F. P. and Emery, K. 0., 1941; Shepard, F. P. and Grant, U. S., 1947; Smith, P. A., 1940 (atoli); Smith, w. D., 1933c; Vaughan, T. W., 1931, 1940; White, D., 1911

Reflection (See also: Light Reflection off sea Water, Wave Refraction): Neiburger, M., 1948

Refraction - see Light, Wave Refraction

Regeneration (See also: Diagenesis, Nutrients, Solution and various diagenetic processes related to regeneration): California Academy of Sciences, California Division of Fish and Geme, Scripps Institution of Oceanography of the University of California, and U. S. Fish and Wildlife Service, 195la; Dietz,
R. S., Emery, K. O. and Shepard, F. P., 1942; Emery, K. O. and Rittenberg, S. C., 1952; Fleming, R. H., 1939a; Holzman, J. E., 1950 (resolution); Koczy, F. F., 1954 (resolution); Michael, E. L., 1921

Replacement (See also: Diagene日is): Krumbein, W. C., 1942 Realdual Sediments (See also: Gravel, i.e. lag gravel): Emery, K. O., 1947o, 1952a; Handin, J. W., 1951; Shepard, F. P., $1940 \mathrm{c}$

Retrograding, Retrogradation - вee Beach Erosion

Reworking of Sediments (See also: Nondeposition, Winnowing of Sediments): Crouch, R. W., 1954; Dietz, R. S., Emery, K. O. and Shepard, F. P., 1942; Holzman, J. B., 1950; Shepard, F. P., 1941a

Rhyolite (See also: IEneous Rock, Rock): Chesterman, C. W. 1952; Emery, K. 0., 1948; Emery, K. 0 . and Shepard, F. P., 1945; Norria, R. M., 1951; Shumway, G. A., 1953

Ridges (See also: Beach.Ridge): Allen, v. E., 1945; Bates, C. C. and Glenn, A. H., 1948; Blake, W. P., 1856; Bucher, W. H., 1939, 1940; Burt, W. V. and Saur, J. F. T., Jr., 1948; Buwalda, J. P., 1948; Colbert L. O., 1939; Crowell, J. C., 1952; Davidson, G., 1856, 1887, 1897; Davis, w. M., 1933; Dietz, R. S., Menard, H. W. and Hamilton, E. L., 1954; Dunkle, M. B., 1950; Eardley, A. J., 1954; Emery, K. O., 1950a, 1954a; Emery, K. O., Butcher, W. S., Gould, H. R. and Shepard, F. P., 1952; Emiliani C. and Epstein, S., 1953; Emonds, S. F. and Merrill, G. P., 1894; Galliher, E. W., 1933; Gorsline, D. S., 1954; Grant, U. S. and Shepard, F. P., 1940; Hanna, G. D., 1952; Hertlein, L. G. and Emerson, W. K., 1953; Hill, R. T., 1928b; Hinds, N. E. A., 1952; Holzman, J. E., 1950; Inman, D. L., 1950; Isaac日, J. D., Schorr, S. and Chinn, A. J., 1947; Krynine, P. D., 1937; Lawson, A. C., 1924; Ludwick, J. C., Jr., 1950; MacDonald, G. A., shepard, F. P. and Cox, D. C., 1947; Menard, H. W., 1952; Menard, H.W. and Dietz, R. S., 1951; Menard, H. W., Dill, R. F., Hamilton, E. L., Moore, D. G., Shumway, G., Silverman, M. and Stewart, H. B., 1954; Munk, W. H., 1948; Munk, W. H. and Traylor, M. A., 1947; Norris, R. M., 1951; Peel, K. P., 1951; Remondino, P. C., 1892 Revelle, R., 1938, 1939b, 1950; Revelle, R. and Shepard, F. P., 1939a, 1939b; Shepard, F. P., 1932, $1937 \mathrm{c}, 1937 \mathrm{e}, 1941 \mathrm{a}, 1948 \mathrm{c}$, 1950e, 1952a; Shepard, F. P. and Emery, K. 0., 1941, 1945; Shepard, F. P. and Inman, D. L., 1949, 1951a; Smith, W. S. T., 1900 (also origin of ridges); Sverdrup, H. U., 1939a, 1939b, 1940b, 1940g; Thompson, W. O., 1937; Trask, P. D., 1930, 1931a, 1932a, 1936, 1939; Trask, P. D. and Hammar, H. E., 1931; Uchupi, E., 1954; Vaughan, T. W., 1940; Veach, J. A., 1859; Woodring, W. P., 1938a

Beach and Nearshore: Dietz, R. S., 1947b; Hall, J. V., Jr., 1952; Hanna, M. A., 1926; Hertlein, L. G., and Grant, U. S., 1944; Hoots, H. W., 1943; Johnson, D. W., 1910, 1944; McKee, E. D., 1953; Munk, W. H. and Traylor, M. A., 1947; Norris, R. M., 1952; O'Brien, M. P., 1947b; Richardson, R. W., 1923; Schupp, R. D., 1953; Scripps Institution of Oceanography, 1944g; Shepard, F. P., 1942a, 1949a, 1950f, 1950g, 1952b; Smith, W. D., 1933c; Thompson, W. O., 1937 Coastal Sand Dunes: Blake, J., 1868a, 1868b (sand barrier); Gulliver, F. P., 1896; Merriam, P. D., 1949

Submarine Canyons: Dill, R. F., Dietz, R. S. and Stewart, H., 1954; Leipper, D. F., 1950; Menard, H. W. and Ludwick, J. C., 1951; Shepard, F. P., 1948b, 1950d; Shepard, F. P. and Emery, K. O., 1941

Rift Valley: Emery, K. O. and Shepard, F. P., 1945

Rill Marks or Rills: Bucher, W. H., 1940; Emery, K. O. and Foster, 1948; Emery, K. O. and Gale, J. F., 1951; Grant, U. S., 1946; Herold, C. L., 1934; McKee, E. D., 1953; Thompson, w. O., 1937

Rip Currents, Rip Tides, Undertow: Anonymous, 1916a, 1941a; Artbur, R. S., 1950; Brant, I., 1925; Congressional Documents, 1949f; Couch, E. B., 1915; Crowell, J. C., 1947, 1952; Davis, W. M., 1925; Deacon, G. E. R., 1949; Dietz, R. S., 1947b; Dietz, R. S. and Menard, H. W., 1951b; Dill, R. F., 1949; Diller, J. S., 1902; 
Eaton, R. O., 1951; Emery, K. O. and Gale, J. F., 1951; Grant, U. S., 1943; Grant, U. S. and Shepard, F. P., 1940; Handin, J. W., 1949; Handin, J. W. and Ludwick, J. C., 1949; Inman, D. L., 1950, 1953a, 1953b; Inman, D. L. and Quinn, W. H., 1952; Knudsen, V. O., Alford, R. S. and Emiling, J. W., 1948; LIvingston, A., Jr., 1939; Ludw1ck, J. C., Jr., 1950; Munk, W. H., 1949b; Munk, W. H. and Traylor, M. A., 1945,1947 ; Nicholls, C. P. L., 1936a, 1936b, 1939, 1941; N1cholson, G. F., Grant, U. S., Shepard, F. P. and Crowell, J. C., 1946; Norr1s, R. M., 1951; Putnam, J. A., Munk, W. H. and Traylor, M. A., 1949; Scripps Institution of Oceanography, 1945c, 19521; Shepard, F. P., $1936 \mathrm{a}, 1937 \mathrm{~b}, 1938 \mathrm{f}, 1943 \mathrm{~b}, 1947 \mathrm{a}, 1948 \mathrm{~b}, 1949 \mathrm{a}$, $1949 \mathrm{~b}, 1950 \mathrm{~b}, 1950 \mathrm{c}, 1950 \mathrm{f}, 1950 \mathrm{~g}, 1951 \mathrm{a}$;

Shepard, F. P., Emery, K. O. and LaFond, E. C., 1941; Shepard, F. P. and Inman, D. L., 1949, 195la; Shepard, F. P. and LaFond, E. C., 1939, 1942; Shepard, F. P. and Sayner, D. B., 1953; Skogsberg, T., 1936; Sverdrup, H. U. and Staff, 1940 , 1942a; Wlegel, R. L., 1947b Ripple Marks: Beach Erosion Board, 1952b; Buffington, E. C., 1951; Dletz, R. S., 1954; D1etz, R. S. and Menard, H. W., 1951b; Emery, K. O., 1947b, 1948, 1952b, 1953b; Emery, K. O. and Natland, M. L., 1952; Herold, C. L., 1934; Landes, K. K., 1952a, 1952b; Lesser, R. M., 1951; McKee, E. D., 1939; Menard, H. W., 1952; Scripps Institution of Oceanography, 19521; Shepard, F. P., 1948b, 1949b, 1949d, 1951a, 1951b; Shepard, F. P. and Emery, K. 0., 1945

Beach and Nearshore: Beach Erosion Board, 1948b, 1952a, 1954b; Cal1fornia, University of, 1952a, 1954a; Emery, K. 0., 1945a, 1945b, 1946b; Isaacs, J. D., 1947a; Isaacs, J. D. and Bascom, W. N., 1947; Johns on, D. W., 1910; Johns on, J. W., 1952; Lakes, A., 1903a; McKee, E. D., 1953; Munk, W. H. and Traylor, M. A., 1945; N1cholson, G. F., Grant, U. S., Shepard, F. P. and Crowell, J. C., 1946; Shepard, F. P., 1950b, 1950r;

Sverdrup, H. U. and Staff, 1942a; Thompson, W. 0., 1937; Woodford, A. 0., 1935

Cosstal Sand Dunes: 0lsson-Seffer, P., 1910a; Thompson, W. 0., 1937

\section{Rivers - see Streams}

Rock (See also varlous rock types): Allen, W. E., 1939

Andrews, H. L., 1945; Bache, A. D., $1856 \mathrm{c}, 1859$, 1864b; Bartlett, W. A., 1852; Bascom, W. N., 1950b; Belknap, G. E., 1874a; Blake, W. P., 1856; Bruff, S. C., 1946; Clark, A., 1933; Coe, W. R., 1945; Crooke, R. C., Elvitsky, A. W., et al, 1953; Dapples, E. C., 1942; Davidaon, G., 1856, 1875b; D1etz, R. S., 1952b; Dietz, R. S., Emery, K. O. and Shepard, F. P., 1942; Emery, K. O., 1941a, 1951, 1952b; Emery, K. O., Butcher, W. S., Gould, H. R. and Shepard, F. P., 1952; Emery, K. O. and Dietz, R. S., 1941; Emery, K. O. and Gould, H., 1948; Emery, K. O. and Shepard, F. P., 1941, 1945; Everest, F. A., Young, R. W. and Johnson, M. W., 1948; Fox, D. L., 1950; Fraser, C. MCL., 1943; Garrison, L. E. and Takesak1, K. L., 1950; G1slen, T., 1943, 1944; Hanna, G. D., 1951; Hansen, H. A. and Pemberton, J. R., 1950; Hoover-Young San Franclsco Bay Bridge Commission, 1930; Inman, D. L., 1949; Johnson, M. W., Everest, F. A. and Young, R. W., 1947; Lawson, J. S., 1862; Lawton, C. H., 1936; Leypoldt, H., 1941a; Louderback, G. D., 1924, 1940, 1951; Menard, H. W., 1952; Menard, H. W. and Ludw1ck, J. C., 1951; Michael, E. L. and McEwen, G. F., 1915; Morrison, R. L., 1930; Norr18, R. M., 1951; Purcell, G., 1914; Revelle, R., 1939a; Revelle, R. and Shepard, F. P., 1939a, 1939b; Rodgers, A. F. and Bache, A. D., 1864; Saur, J. T. F., Jr., 1950; Schupp, R. D., 1953; Shepard, F. P., 1938d, 1948c, 1950e; Shepard, F. P., Revelle, R. and Dietz, R. S., 1939; Smith, A. G. and Mackenz1e, G., Jr., 1948; Sverdrup, H. U., 1938c, 1940e; Tanner, Z. L., 1892a, 1894; Trask, P. D., 1931b; Varney, F. M. and Redwine, L. E., 1937; Weeks, L. G., 1952; Williamson, R. S. and Heuer, W. H., 1871

Banks and Seamounts: Beche, A. D., 1856b; Butcher, W. S., 1951a; Carsola, A. J. and Dietz, R. S., 1952; Clements, T. and Emery, K. 0., 1947;
Dietz, R. S. and Emery, K. O., 1938b; Emery, K. 0., 1947c, 1948; Emery, K. O., Butcher, W. S., Gould, H. R. and Shepard, F. P., 1952; Emery, K. O. and Dietz, R. S., 1950; Emery, K. O. and R1ttenberg, S. C., 1952; Emery, K. O. and Shepard, F. P., 1945; Garrison, L. E. and Takasaki, K. L., 1950; Hanna, G. D., 1952; Holzman, J. E., 1950; Lawson, A. C., 1924; Shepard, F. P., 1939d, 1940a, 1941a, 1947b; Shepard, F. P. and Emery, K. O., 1941, 1945; Shumway, G. A., 1953; Tanner, Z. L., 1892a; Uchup1, E., 1954

Bas1ns: Garrison, L. E. and Takasak1, K. L., 1950; Weeks, L. G., 1952

Beach and Nearshore: Anonymous, 1916a, 1938a, 1938b; Allen, W. E., 1941a; Bascom, W. N., 1946b, 1948a; Bruff, s. C., 1946; California, University of, 1954b; Congressional Documents, 1938a, 1940a, 1940c, 1949f; Davis, W. M., 1925; Emery, K. O., 1945b; Emery, K. O. and Stevenson, R. E., 1950 (beach rock); Emery, K. O. and Tschudy, R. H., 1941; Kniffen, F. B., 1932; Lawton, C. H., 1936; Norr18, R. M., 1951; Schupp, R. D., 1953; Shepard, F. P., 1950b; Trask, P. D., 1952b; Vaughan, T. W., 1940

ContInental and Insular Shelves: Butcher, W. S., 1951a; Crouch, R. W., 1954; Emery, K. O., 1952a; Emery, K. O., Butcher, W. S., Gould, H. R. and Shepard, F. P., 1952; Emery, K. O. and Shepard, F. P., 1941, 1945; Fairbanks, H. W., 1897; Gorsline, D. S., 1954; Handin, J. W., 1949; Inman, D. L., 1950; LaFond, E. C., Dietz, R. S. and Knauss, J. A., 1950; MacDonald, G. A., 1934; Menard, H. W., Dill, R. F., Hamilton, E. L., Moore, D. G., Shymway, G., S1lverman, M. and Stewart, H. B., 1954; Moore, D. G., 1951; Norr18, R. M., 1951; Pardee, J. T., 1934; Pratt, W. E., 1947; Putnam, W. C., 1937b; Revelle, R. and Shepard, F. P., 1939b; Shepard, F. P., 1932, 1935e, 1939b, $1940 \mathrm{a}, 1940 \mathrm{c}, 1940 \mathrm{e}, 1941 \mathrm{a}, 1949 \mathrm{~b}, 1949 \mathrm{~d}$; Shepard, F. P. and MacDonald, G. A., 1938; Shepard, F. P. and Wrath, W. F., 1937 (Insular shelf)

Continental Slope: Emery, K. O. and Shepard, F. P., 1945; Hanna, G. D., 1952; Shepard, F. P., $1940 \mathrm{c}, 1941 \mathrm{a}, 1941 \mathrm{c}$

Submartne Canyons: Anonymous, 1939; Beach Erosion Board, 1953c; Cohee, G. V., 1938; Crowell, J. C., 1952; Davideon, G., 1897; D1etz, R. S., Emery, K. O. and Shepard, F. P., 1942; Emery, K. O., 194la; . Emery, K. O., Butcher, w. S., Gould, H. R. and Shepard, F. P., 1952; Emery, K. O. and Shepard, F. P., 1941, 1945; Emery, K. 0 and Tschudy, R. H., 1941; Handin, J. W., 1949; Hinds, N. E. A., 1952; Inman, D. L., 1950; Kuenen, $\mathrm{Ph}$ H., 1947; Landes, K. K., 1952a; MacDonald, G. A., 1934; Menard, H. W. and Ludwick, J. C., 1951; Norr18, R. M., 1951; Revelle, R. and Shepard, F. P., 1939b; Shepard, F. P., 1934b, 1934c, 1935a, $1935 \mathrm{c}, 1936 \mathrm{~d}, 1936 \mathrm{f}, 1936 \mathrm{~g}, 1937 \mathrm{~b}, 1938 \mathrm{e}, 1938 \mathrm{f}$, $1939 \mathrm{~d}, 1940 \mathrm{~b}, 1940 \mathrm{~d}, 1941 \mathrm{a}, 1941 \mathrm{c}, 1943 \mathrm{a}, 1947 \mathrm{a}$, $1948 \mathrm{~b}, 1948 \mathrm{c}, 1949 \mathrm{~b}, 1949 \mathrm{c}, 1949 \mathrm{e}, 1951 \mathrm{a}, 1951 \mathrm{c}$, 1952a, 1953; Shepard, F. P. and Emery, K. O., 1941, 1945; Shepard, F. P. and Revelle, R. and Dietz, R. S., 1939; Smith, A. G. and MacKenzie, G., Jr., 1948; Toit, A. L. du, 1940; Vaughan, T. W., 1936; Woodford, A. 0., 1951

Rocky Cossts: Anonymous, 1882a, 1916a, 1932c, 1938a, 1940c, 1940d, 1949a; Alexander, C. S., 1950; Arnold, D. and Arnold, R., 1902; Arnold, R., 1900; Arnold, R. and Hannibal, H., 1913; Ashley, G. H., 1895, 1931; Balley, T. L., 1943; Barrows, A. L., 1913; Bartlett, W. A., 1852; Bascom, W. N , 1948a; Beach Erosion Board, 1942a, 1948a, 19́48h, $19481,1949 a, 1953 a, 1953 c, 1954 a$; Blake, W. P. 1856; Blankinsh1p, J. W. and Keeler, C. A., 1892; Bowers, S., 1878, 1890; Bremner, C. St. J., 1932; Brown, E. I. 1939; Bruff, S. C., 1940, 1946; Buwalda, J., 1936; California, Univera1ty of, 1954a; Carpenter, F. A., 1924; Cartwright, L. D., Jr., 1928; Chase, A. W., 1875; Cleland, H. F., 1910; Congressional Documents, 1938a, 1938c, 1940a, 1942b, 1949b, 1949f, 1953b; Couch, E. B., 1915; Crandall, H., 1915; Dav1dson, G., 1856, 1864, 1875a, 1897; Davis, W. M., 1931, 1932; Dav18, W. M., Putnam, W. C. and Richards, G. L., Jr., 1931; Dietz, R. S., 1947b; Dietz, R. S. and Menard, H. W., 1951b; Diller, J. S., 1896, 1902, 1903; Drury, N. B., 
1936, 1938; Dunkle, M. B., 1944, 1950; Eaton, R. O., 1951; Emery, K. O., 1941b, 1946b, $1954 \mathrm{a}$, 1954e; Emery, K. O. and Dietz, R. S., 1950; Emmonds, S. F. and Merr1ll, G. P., 1894; Erickson, C. E., 1952, 1953; Fairbanks, H. W., 1897, 1898, 1904; Fewkes, J. W., 1889; Friedman, S. L., 1949; Gllbert, G. K., 1917; Gislén, T., 1944; Goldberg, J., 1940; Gorsline, D. S., 1954; Grant, U. S. and Shepard, F. P., 1937, 1938b; Greenwell, W. E., 1858; Gull1ver, F. P., 1896; Haase, L. G., 1926; Hall, W. C., 1942; Handin, J. W., 1949, 1951; Hanna, G. D., 1951, 1952; Hannum, G. W. T., 1944, 1947; Harts, W. W., 1911; Hawgood, H., 1914; Henderson, J., 1932; Hertle1n, L. G. and Grant, U. S., 1939, 1944; Hewatt, W. G., 1934; H1nds, N. E. A., 1952; Hoover, J. W., 1932a; Horton, D. F., 1948; Inman, D. L., 1950, 1953a, 1953b; Isaacs, J. D., 1945d, 1947a; Ives, R. L., 1951; James, E. L., 1950; Johnson, A. G., 1935; Johnson, C. W., 1953; Johnson, W. M., 1858; Jones, E. L., 1918; Kemn1tzer, L. E., 1933; Kew, W. S. W., 1927; Krumbein, W. C., 1947; Krumbe1n, W. C. and Ohsiek, L. E., 1950; Kuenen, Ph. H., 1947; Lakes, A. 1903a, 1903b; Lange, A., 1954; Lawson, A. C., I893a, 1893b, 1894, 1895, 1914, 1924; Laws on, J. S., 1862; Leeds, C. T., 1936; Leonard, A. G., 1925; Leypoldt, H., 1941a, 1941b; Livingston, A., Jr., 1939; Louderback, G. D., 1940; MeArthur, W. P., 1850; McGee, W. J., 1900; McLellan, M. E., 1925; MacDonald, G. A., 1934; MacDonald, G. A., Shepard, F. P. and Cox, D. C., 1947; MacGinit1e, G. E., 1939; Masters, P. 1840; Moore, D. G., 1951; Morgan, F. A., 1930; Munk, W. H. and Traylor, M. A., 1947; N1cholson, G. F., Grant, U. S., Shepard, F. P. and Crowell, J. C., 1946; Norr18, R. M., 1949, 1951, 1952; O'Brien, M. P., 1936a, 1936b, 1939; Orr, P. C., 1952; Page, G. B., 1950; Pagulrigan, F., 1941; Pardee, J. T., 1934; Peel, K. P., 1951; Place, J. L., 1952; Ров8, E. G., 1937; Pr1ce, F., 1936; Putnam, W. C., 1937b, 1938, 1937c; Reed, R. D., 1930; Re1che, P., 1937; Remondino, P. C., 1892; Revelle, R. and Shepard, F. P., 1939b; R1chardson, R. W., 1923; Sanchez, P. C., 1934e; Schupp, R. D., 1953; Scripps Inst1tution of Oceanography, 19450; Shaler, N. S., 1895; Shepard, F. P., 1936e, 194la, 1943b, 1950b, 1950c, 1950e, 1950g; Shepard, F. P. and Emery, K. O., 1941; Shepard, F. P., Emery, K. O. and LaFond, E. C., 1941; Shepard, F. P. and Grant, U. S., 1947; Shepard, F. P., Grant, U. S. and Dietz, R. S., 1939; Sheperd, F. P. and Inman, D. L., 1949, 1951b; Shepard, F. P. and LaFond, E. C., 1942; Shepard, F. P. and MacDonald, G. A. 1938; Shepard, F. P. and Wrath, W. F., 1937; Shuler, W. R., 1951, 1952; Sm1th, W. D., 1930, 1933a, 1933b, 1933c; Smith, W. S. T., 1897, 1898 , 1900; Snavely, P. D., Jr., 1951; Spencer, J. W., 1897; Stevenson, R. E., 1954; Stock, C., 1936; Sw1nnerton, A. C., 1927; Symons, T. W., 1893; Thompson, W. O., 1937; Tower, M. L., 1910; Trask, P. D., 1952a, 1952b; Trowbr1dge, W. P., 1856b; Twenhofel, W. H., 1943; Upson, J. E., 1951; Vaughan, T. W., 1930a, 1930b, 1930c, 1931, 1932d; Walters, L., 1953; Wanless, H. R., 1950; Wheeler, G., 1936; Wh1tney, J. D., 1865; Williams, W., 1948; W11l1s, B., 1900; W1lson, M. E., 1907; Winsted, H. L., 1913; W1tt1ch, E., 1920; Yates, L. G. , 1890a, 1890b, 1902

Rocky Headlands - see Headlands

Roundness - see Shape and Roundness

Rub1d1um: Thompson, T. G. and Rob1nson, R. J., 1932

Saddles (See also: D1vides): Dietz, R. S., Menard, H. W. and Hamilton, E. L., 1954; Emery, K. O., 1952; Garrison, L. E. and Takasak1, K. L., 1950; Gorsline, D. G., 1954; Holzman, J. E., 1950; Revelle, R., 1938; Revelle, R. and Shepard, F. P., 1939b; Shepard, F. P., 194la; Shepard, F. P. and Emery, K. 0., 1941, 1945; Shepard, F. P. Revelle, R. and Dletz, R. S., 1939; Uchup1, E., 1954

Salinity (See also: Water Mksses, Water (1ypes): Anonymous, 1925, 1929b, 1933a, 1933b, 1951c; Ahlstrom, E. H., 1950; Allen, W. E., 1920, 1923a, 1927o, 1928a, $1928 \mathrm{~b}, 1928 \mathrm{c}, 1930 \mathrm{a}, 1930 \mathrm{~b}, 1946 \mathrm{a}$; Bandy, 0. L., 1953a; Barrows, A. L., 1917; Bartsch, 'P., 1921a, 1921b; B1gelow, H. B. and Leslie, M., 1930; Buley, H. M., 1929; Bullock, F. W., 1933; Cal1forn1a Acaderry of Sciences, California D1v1sion of F1sh and Game, Scripps Institution of Oceanography of the University of California, and U. S. F1sh and Wildlife Service, 1950, 195la, 1951b; Cal1fornia Academy of Sclences, California Division of Fish and Game, Stanford Unlversity, Hopk1ns Marine Station, U. S. Fish and Wildife Service, South Pac1fic Fishery Investigation, Un1versity of California, Scripps Institution of oceanography, 1952 , 1953; California Department of Public Works, 1951a; Callfornia, Un1versity of, 1929; Chambers, S. W., 1930; Clark, K. B., 1934; Coe, W. R., 1948; Connell, C. H. and Gross, J. B., 1950; Couch, R. W., 1951; Crooke, R. C., Elv1tski, A. W. et al, 1953; Dall, W. H., 1911; Dapples, E. C., 1942; Defant, A., 1950b; D1etz, R. S., 1953; Dietz, R. S., Emery, K. O. and Shepard, F. P., 1942; Dill, R. F., 1952; Dorman, H. P., 1927a, 1927b; Dyk, K. and Swainson, 0. W., 1953; Elliott, F. E., Tressler, W. L. and Myers, W. H., 1953 Emery, K. 0., 1953a (bottom), 1954d (bottom); Emery, K. O. and Rittenberg, S. C., 1952 (bottom); Emillani, C., 1954; Enn1s, c. C., 1934; Epste1n, S. and Mayeda, T., 1953; Esterly, C. O., 1928b; Evans, R. D., Kip, A. F. and Moberg, E. G., 1938; Fleming, J. A., Sverdrup, H. U., Enn1s, C. C., Seaton, S. L. and Hendr1x, W. C., 1945; Fleming, R. H., 1939b, 1940b, 1942; Fleming, R. H., Moberg, E. G. and Revelle, R., 1937 a, 1937b; Fox, D. B. 1929; Fraser, C., 1928; Gilbert, G. K., 1917; Gilbert, J. Y. and Allen, W. E., 1943; Gislén, T., 1943, 1944; Goldberg, E. D., 1954; Gorsline, D. S., 1954; Gorton, A. F., 1930a; Graham, H. W., 1934, 1941a, 1941b; Gutenberg, B., 1941b; Harvey, D. R., 1928; Heck, N. H. and Service, J., 1926; Hewatt, W. G., 1937; Hinde, H. P., 1952; Holway, R. S., 1905; Horanjeff, R. and Patr1ck, D. A., 1952; Horrer, P. L., 1948a; Jacobs, W. C., 1939, 1949; Jarv1s, C. S., 1921; Kempkey, A., 1935; Kindle, E. M., 1934; Kniffen, F. B., 1932; Krumbe1n, W: C., 1942; LaFond, E. C., 1939a; Lesl1e, M., 1928; Lesser, R. M., 1951; Louderback, G. D., 1924, 1940; Lowenstam, H. A., 1954; McClendon, J. F., Gault, C. C. and Mulholland, S., 1917; McDonald, J. A. and Dieker, P. L., 1930; McEwen, G. F., 1916, 1919a, 1919b, 1927, 1929, 1930a, $1930 \mathrm{c}, 1934 \mathrm{a}, 1937 \mathrm{~T}, 1940 \mathrm{a}, 1950$; MacGin1t1e, G. E., 1927, 1935; Maо, H., 1951; Mayor, A. G., 1922; Means, T. H., 1931; Mears, E. G., 1943; M1chael, E. L., 1919, 1921; M1chel, E. L. and McEwen, G. F., 1915, 1916; M1ller, R. C., Ramage, W. D., and Laz1er, E. L., 1928; Moberg, E. G., 1927, 1928a, 1928c, 1930a, 1930c; Moberg, E. G. and Revelle, R., 1937; Montgomery, R. B. and Wooster, W. S., 1954; Munk, W. H., 1940; Myers, E. H., 1943; Natland, M. L., Revelle, R. and Rittenberg, S. C., 1941; O'Brien, M. P., 1935 O'Brien, M. P. and Cherno, J., 1934; Olsson-Seffer, P., 1910b; Orsor1o Tafall, B. F., 1943; Packard, E. L., 1918; Patr1ck, D. A., 1950; Patton, R. S., 1930; P'e1, C., 1929; Phelps, A., 1940; Purer, E. A., 1942; Revelle, R., 1950; Revelle, R. and Shepard, F. P., 1939b; Richardson, B., 1932b; Robins, T. M., 1935; San Franc1sco Bay Mar1ne P1ling Committee, 1921, 1922; Sargent, M. S. and Walker, T. J., 1948; Saur, J. T. F., Jr., 1950; Schne1der, W. A., 1954; Schott, G., 1935; Shulz, B. 1914; Scripps Institution of Oceanography, 1949 a to $1949 \mathrm{e}, 1950 \mathrm{a}$ to $1950 \mathrm{e}, 1950 \mathrm{~g}, 1951 \mathrm{a}$ to $19511,1951 \mathrm{k}$ to $1951 \mathrm{r}$, 1952a to 1952g; Shepard, F. P., 1952a; Shepard, F. P. and LaFond, E. C. 1942; Simmons, H. B., 1952; Soule, F. M., 1934, 1944a; Stevenson, R. E., 1954; Stevenson, R. E. and Emery, K. O., 1951; Sumner, F. B., Louderbeck, G. D., Schm1tt, W. L. and Johnston, E. C., 1914; sverdrup, H. U., 1934, 1937-1938, 1938a, 1938c, 1939 $1939 \mathrm{~b}, 1939 \mathrm{c}, 1940 \mathrm{~b}, 1940 \mathrm{e}, 1940 \mathrm{e}, 1940 \mathrm{f}, 194 \mathrm{la}$, 1941c, 1944a, 1944b; Sverdrup, H. U. and Allen, W. E., 1939; Sverdrup, H. U. and Fleming, J. A., 1944; Sverdrup, H. U. and Fleming, R. H., 1941; Sverdrup, H. U. and Staff, 1941, 1942b, 1943a, 1943b, $1944,1945 \mathrm{a}, 1945 \mathrm{~b}, 1946,1947 \mathrm{~b}$; Thompson, T. G. and Rob1nson, R. J., 1932; T1bby, R. B., 1941, 1943 , 
1944; Tilden, C. A., 1925; Topp, E. P., 1929; Trask, P. D., 1932a, 1932b, 1937a; Uchupi, E., 1954; Ufford, C. W., I947a; U. S. Casst and Geodetic Survey, 1946, 1950; U. S. Hydrographic Office, 1934b; U. S. Navy, 1948; Vaughan, T. W., $1930 \mathrm{~b}, 1932 \mathrm{a}, 1932 \mathrm{~b}, 1932 \mathrm{c}, 1933,1934,1936,1940$; Vaughan, T. W. and Others, 1937; Weber, B. V., 1946; Wittich, E., 1916a; Wooster, W. S., 1952; Young, R. T., Jr., 1939; ZoBell, C. E., 1941, $1942 \mathrm{a}, 1946-1947,1947 \mathrm{~b}, 1947 \mathrm{c}$; ZoBell, C. E. and Feltham, C. B., 1934a, 1942; ZöBell, C. E., Grant, C. W. and Haas, H. F., 1943

Salt: Anderson, C. A., 1950; Blake, J., 1868a; Bose, A. J., 1938; Dawson, E. Y., 1951; Emery, K. O. and Footer, J. F., 1948; Emery, K. O. and Gale, J. F., 1951; Emery, K. O. and Rittenberg, S. C., 1952; Hanna, G. D., 1952; Merr1ll, F. J. H., 1915, 1917; ZoBell, C. E., 1938, 1947d, 1950 Saltation (See also: Transport of Sediment): Fmery, K. O. 1945b; Grant, U. S., 1943; Trask, P. D., 1952b Salt Marsh (See also: Bay, Estuary, Harbor, Lagoon, Marsh,
Swamp, Tide Flat): Anonymous, 19h0d; Anderson, C. A., 1950; Bowman, A., 1873; Clark, w. O., 1915; Cook, E. H., 1908; Hinde, Н. P., 1952; MacDonald, G. A., 1934; Mendenhall, w. C., 1905; Revelle, R., 1950; Trowbridge, W. P., 1856b; Weaver, C. E., 1949; White, D., 1911; Wittich, E., $1916 \mathrm{~b}$

Salt Water Intruaion, salt Water Encroachment: Anonymous, 1929b, 1933a, 1933b, 1936; Arnold, C. E., Hedger, H. E., Rawn, A. M., 1949; Banks, H. O., Bookman, M., 1951; Banks, H. O., Gleason, G. B. and Richter, R. C., 1950; Banks, H. O. and Lawrence, J. H., 1953; Banks, H. O. and Richter, R. C., 1953; Beardslee, C. G., 1942a, 1942b; California Legislature, 1931a, 1947; California Department of Public Work8, 1932a, 1932b, 1933, 1950, 1951, 1951d, 1952, 1952a, 1952b, 1952c, 1952d, 1952e; California, University of, 1951a, 1952b; Clark, W. O., 1915; Congressional Documents, 1929, 1934a, 1949c, 1950a, 1953a; Eldredge, Z. S. and Molera, E. J., 1909; Freeman, J. R., 1912; Garrett, A. A., 1948-1949, 1951; Gregor, H. F., 1952; Hyatt, E., 1933, 1934, 1935; Inman, D. L., 1949; Isaace, J. D. and Bascom, W. N., 1949; Jarvis, C. S., 1921, 1936; Kempkey, A., 1935; Laverty, F. B., 1952; Laverty, F. B., Jordan, L. W. and van der Goot, H. A., 1951; Lawson, A. C., 1914; Lee, C. H., 1941; Los Angeles County Flood Control District, 1950; Means, T. H., 1928, 1929, 1931; O'Brien, M. P., 1931, 1935; O'Brien, M. P. and Cherno, J., 1934; Patrick, D. A., 1950; Peel, K. P., 1951; Pentegoff, V. P., 1947; Pierce, J. W., 1948; Piper, A. M., Garrett, A. A. and Others, 1953; Piper, A. M. and Poland, J. F., 1945; Poland, J. F., 1943, 1947, 1950; Poland, J. F., Garnett, A. A. and Mann, J. F., 1948; Poland, J. F., Garnett, A. A. and Sinnott, A., 1948; Poland, J. F. and others, 1946; Revelile, R., 1941; Rhodes, A. D., 1951; Robertson, R. R., 1942; Robins, T. M., 1935; Shuler, W. R., 1951; Simons, H. B., 1952; Simpson, T. R., 1946; Streiff, A., 1936; Thomasson, H. G., Jr., 1951; Todd, D. K., 1952, 1953; Tolman, C. F. and Poland, J. F., 1940; Upson, J. E. and Others, 1951; Upson, J. E. and Thomasson, H. G., Jr., 1951; U. S. Army Corps of Engineers, 1931; U. S. Department of Interior, 1927; Wade, J. A. and Brown, K. W., 1934; Worts, G. F. and Others, 1951; Young, W. R., 1929; Zander, G. and Gleason, G. B., 1947

Sand (See also: Ccastal Sand Dunes, Graded Bedding, Sand Layers): Anonymous, 1906a; Agase1z, A., 1905; Alden, J., 1856 (Specks of red sand on bar at entrance to San Francisco Bay); Anderson, C. A., 1941; Andrews, H. L., 1945; Arnold, D. and Arnold, R., 1902; Arnold, J. L., 1928; Bache, A. D., 1852, 1856 a (see - Alden, J., 1856 above); Belknap, G. E., 1874a; Bruff, S. C., 1946; Buck, C. D., 1928; California Department of Fish and Game, 1951; California Department of Public Health, 1951; California, University of, 1946a, 1954a; Chace, B. W., 1953; Coe, W. R., 1945; Collins, L. B., 1931; Congressional Documents, 1880a; Crooke, R. C., Elvitsky, A. w., et al, 1953;
Dapples, E. C., 1942; Dietz, R. S. and Emery, K. O., 1938a; Dunham, J. W., 1951; Eldridge, Z. S. and Molera, E. J., 1909; Emery, K. 0., 1941b, 1950d, 1952b; Emery, K. O., Butcher, W. S., Gould, H. R. and Shepard, F. P., 1952; Emery, K. O. and Dietz, R. S., 1941; Emery, K. O. and Gould, Н., 1948; Fox, D. L., 1950; Fox, D. L., Crane, S. C. and McConnaughey, B. H., 1948; Fox, D. L., Irace, J. D. and Corcoran, E. F., 1952; Fox, L. S., 1930; Fraser, C. MCL., 1943; Galliher, E. W., 1935a, 1935c, 1939; Gislén, T., 1943; Gorsline, D. S., 1954; Grim, R. E., Dietz, R. S. and Bradley, W. F., 1949; Harding, C. R., 1929; Hoots, H. W., 1943; Hoover-Young San Franciaco Bay Bridge Commission, 1930; Inman, D. L., 1949, 1950; Johnson, M. W., 1948; Johnвon, M. W., Everest, F. A. and Young, R. W., 1947; Kindle, E. M., 1934; Kuenen, Ph. H. and Menard, H. W., 1952; Lesвer, R. M., 1951; Louderback, G. D., $1920,1924,1940,1951 ;$ McKee, E. D., 1939; MacGinitie, G. E., 1927, 1935; Martin, L. T., 1935; Menard, H. W., 1952; Michael, E. L. and McEwen, G. F., 1915; Moberg, E. G., Fleming, R. H., Heusner, K. and Revelle, R., 1937; MorriBon, R. L., 1930; Norr18, R. M., 1951; Packard, E. L., 1918; Pease, W. H., 1868; Revelle, R., 1938, 1939a, 1950; Revelle, R. and Emery, K. O., 1951; Revelle, R. and Shepard, F. P., 1939a, 1939b; San Diego Regional water Pollution Control Board, 1952; Saur, J. T. F., Jr., 1950; Scheffauer, F. C., 1927; Schupp, R. D., 1953; Scripps Institution of Oceanography, 19521; Shepard, F. P., 194la, 1950c; Shepard, F. P. and Emery, K. O., 1945; Shepard, F. P. and Inman, D. L., 1951b; Sherzer, W. F., 1910; Sisler, F. P. and ZoBell, C. E., 1950; Smith, A. G. and MacKenzie, G., Jr., 1948; Soper, E. K., 1938; Stevenson, R. E., 1954; Sumner, F. B., Louderback; G. D., Schmitt, W. L. and Johns on, E. C., 1914; Tanner, Z. L., 1892a; Trask, P. D., 1931a, 1931b, 1934, 1936, 1939, 1950, 1952a; Trask, P. D. and Rolston, J. W., 1950a, 1950b; Woodring, W. P., 1938a; ZoBell, C. E., 1938, 1943, 1946-1947, 1947b, 1947d; ZoBell, C. E. and Feltham, C. B., 1942; ZoBell, C. E., Grant, C. W. and Haas, H. F., 1943

Abysaal: Emery, K. O. and Natland, M. L., 1952; Revelle, R., 1935; Shepard, F. P., 1949d, 1950a; Tanner, z. L., 1892b; Urry, W. D. and Piggot, C. S., 1942

Bank and Seamount: Butcher, W. S., 195la; Carsola, A. J. and Dietz, R. S., 1952; Dietz, R. S. and Emery, K. O., 1938a, 1938b; Emery, K. O., 1947c, 1948; Emery, K. O., Butcher, W. S., Gould, Н. R. and Shepard, F. P., 1952; Emery, K. O. and Dietz, R. S., 1950; Emery, K. O. and Rittenberg, S. C., 1952; Emery, K. O. and Shepard, F. P., 1945; Garrison, L. E. and Takasaki, K. L., 1950 Hanne, G. D., 1952; Holzman, J. E., 1950; Shepard, F. P., 1938f, 194la; Shepard, F. P. and Emery, K. O., 1941, 1945; Uchupi, E., 1954

Basin: Emery, K. O. and Rittenberg, S. C., 1951, 1952; Emery, K. O. and Shepard, F. P., 1945; Garrison, L. E. and Takasaki, K. L., 1950; Grim, R. E., Dietz, R. S. and Bradley, W. F., 1949; Ludwick, J. C., Jr., 1950; Phleger, F. B., 1951; Revelle, R., 1939b; Revelle, R. and Shepard, F. B., 1939b; Shepard, F. P., 1939d, 1940a, 1948c, 1951b; Shepard, F. P., Revelle, R. and Dietz, R. S., 1939; Weeks, L. G., 1952

Beach and Nearshore: Anonymous, 1882c, 1894a, 1915, 1917 , $1935,1938 \mathrm{a}, 1938 \mathrm{~b}, 1940 \mathrm{~b}, 1940 \mathrm{~d}, 1941 \mathrm{~b}$, $1949 \mathrm{a}, 1949 \mathrm{c}, 1950 \mathrm{a}, 1950 \mathrm{~b}, 1950 \mathrm{~d}, 1950 \mathrm{e}, 1954 \mathrm{~m}$; Allen, W. E., 1935; Anderson, C. A., 1950; Anders on, F. M., 1896-1902; Anderson, G. E., 1926; Arnold, J. L., 1928; Averill, C. V., 1941; Averill, C. V. and others, 1946; Bartlett, W. A., 1852; Bascom, W. N., 1947c, 1947d, 1950c, 1951; Bascom, W. N., Wiegel, R. L., and Chinn, A. J., 1948; Beach Erosion Board, 1948a, 1948b, 1948h, $1948 \mathrm{j}, 1949 \mathrm{a}, 1951,1952 \mathrm{a}, 1952 \mathrm{~b}, 1953 \mathrm{a}, 1953 \mathrm{~b}$, 1953c, 1954b, 1954c; Blake, W. P., 1853, 1856; Boos, M. F., 1940; Bowman, A., 1873; Branner, J. C., 1900; Brown, E. I., 1939; Bruff, S. C., 1946; Bullard, F. M. and Mills, R. A., 1951; 
California, University of, 1945, 1952a, 1952b, 1952c, 1952d, 1953a, 1953b, 1954b; Corpenter, E. J. and Storie, R. E., 1929; Carpenter, F. A., 1924; Clark, A., 1933; Coe, W. R., 1945, 1947, 1948, 1953; Coe, W. R. and Fox, D. L., 1942; Congresslonal Documents, 1938a, 1940a, 1940c, 1941, 1949b, 1953b; Crowell, J. C., 1952; Dasher, J., Fraas, F. and Gabriel, A., 1942; Davidson, G., 1864, 1873c; Davis, W. M., 1932, 1933; Day, D. T., 1899; Day, D. T. and Richards, R. H., 1906; Diller, J. S., 1902; Drury, N. B., 1936; Edman, J. A., 1894; Einatein, Н. A., 1951; Emery, K. O., 1944, 1945a, $1945 \mathrm{~b}, 1946 \mathrm{~b}, 1950 \mathrm{~d}, 1952 \mathrm{a}, 1954 \mathrm{~b}$; Emery, K. 0 . and Foster, J. F., 1948; Emery, K. 0. and Rittenberg, S. C., 1952; Emery, K. 0. and Stevenson, R. E., 1950; Emery, K. O. and Tachudy, R. H., 1941; Fisher, R. L. and Mills, R., 1952; Fox, D. L., 1950; Fox, D. L., Isascs, J. D. and Corcoran, E. F., 1952; Fraser, C. MCL., 1943; Galliher, E. W., 1935b; Goodyear, W. A., 1873; Gorsline, D. S., 1954; Grant, U. S., 1943, 1948; Grant, U. S. and Shepard, F. P., 1937, 1938a, 1940, 1946; Grant, U. S. and Sheppard, W. E., 1939; Griggs, A. B. and Wells, F. G., 1942; Hall, J. V., Jr., 1952; Hall, W. C., 1938; Handin, J. W., 1949; Handin, J. W. and Ludwick, J. C., 1949; Hanna, M. A, 1926; Hannum, G. W. T., 1947; Hawgood, H., 1914; Inman, D. L., 1949, 1953a, 1953b; Irvine, C. D., 1908; Isaacs, J. D., 1945b, 1945c, 1945d, 19451, $1945 \mathrm{~J}, 1945 \mathrm{k}, 1945 \mathrm{~m}, 1947 \mathrm{a}$; Isaacs, J. D. and Bascom, W. N., 1947; Ives, R. L., 1951; Johnson, A. G., 1935; Johnson, D. W., 1910; Johnson, J. W., 1952; Johnson, M. W., 1939b; Johns on, W. M., 1856; Jones, E. L., 1918; Keller, W. D., 1945; Kindle, E. M., 1934; Kniffen, F. B., 1932; Krumbein, W. C., 1947; LaFond, E. C., 1938, 1939b; Lakes, A., 1899; Lapsley, W. W., 1937; Lawson, A. C., 1893a, 1894, 1895; Lawton, C. H., 1936; Leeds, C. T., 1936; Leypoldt, H., 1941a; Lindsay, D. R., 1952; Los Angeles County Regional Planning Commission, 1940; Louderback, G. D., 1940; Lowell, F. L. L., 1915a, 1915b; McAfee, C. M., Jr., 1939; McConnaughey, B. H. and Fox, D. L., 1949; McEwen, G. F., 1935b; MacDonald, G. A., 1934; MacDonald, G. A., Shepard, F. P. and Cox, D. C., 1947; MacGinitie, G. E., 1939; Marlette, J. W., 1954; Mason, E. H., 1930; Mason, M. A. 1942, 1950b; Messner, W. E., 1954; Nelson, J. W., Dean, W. C., Kocher, A. E., Watson, E. B., and Carpenter, E. J., 1920; Nelson, J. W., Zinn, C. J., Strahorn, A. T., Watson, E. B. and Dunn, J. E., 1919; Nicholson, G. F., Grant, U. S., Shepard, F. P. and Crowell, J. C., 1946; Norris, R. M., 1951, 1952; O'Brien; M. P., 1936b, 1939, 1945b; Olsson-Seffer, P., 1910a; Orange County Planning Commission, 1941; Page, G. B., 1950; Paguirigan, F., 1941; Palmer, R. H., 1928; Patrick, D. A., 1953; Purer, E. A., 1942; Putnam, J. A., Munk, W. H. and Traylor, M. A., 1949; Putnam, W. C., 1938; Paul, A. B., 1894; Rechnitzer, A. B., 1952; Reed, R. D., 1930b; Revelle, R. and Emery, K. O., 1951; Revelle, R. and Shepard, F. P., 1939b; Rolland, M. C., 1952; Sanford, J. J., 1908; Schaufele, H. J., 1951; Schupp, R. D., 1953; Scripps Institution of Oceanography, 1953c, 1953f; Sears, C. B., 1876; Shalevetz, S., 1952; Shepard, F. P., 1936a, 1938g, 194la, 1943b, 1949a, $1950 \mathrm{~b}, 1950 \mathrm{c}$, 1950 $, 1950 \mathrm{~g}, 1951 \mathrm{~b}, 1952 \mathrm{a}$; Shepard, F. P., Emery, K. O. and LaFond, E. C., 1941; Shepard, F. P. and Inman, D. L., 1949, 1951a, 1951b; Shepard, F. P., Inman, D. L. and Fisher, R. L., 1951; Shepard, F. P. and LaFond, E. C., 1940, 1942; Shepard, F. P. and MacDonald, G. A., 1938; Sherzer, W. H., 1910; Sinnott, A., 1941; Smith, A. G. and MacKenzie, G., Jr., 1948; Smith, W. D., 1933b, 1933c; Smith, W. S. T., 1897, 1898; Somers, P., 1952; Stevenson, R. E., 1954; Storie, R. E. and Carpenter, E. J., 1929, 1930; Sverdrup, H. U. 1936; Sverdrup, H. U. and Staff, 1941; Thompson, W. F. and Thompson, J. B., 1919; Thompson, W. O., 1933, 1934, 1937; Tower, M. L., 1910, 1913; Trask, P. D., 1924, 1952a, 1952b; Trask, P. D. and Scott, T., 1954; Twenhofel, W. H., 1943, 1946; Vaughan, T. W., 1940; Walker, B. W., 1947; Walters, L., 1953; Washburne, C. W., 1904; Whitney, J. D., 1865;
Whittemore, G. F., 1928; Wiegel, R. L., 19470; Woodford, A. O., 1935; ZoBell, C. E. and Rittenberg, S. C., 1938; Zodac, P., 1952

Continental and Insular shelves: Butcher, W. S., 1951a; Cohee, G. V., 1938; Crouch, R. W., 1954; Davidson, G., 1897; Dietz, R. S., Emery, K. 0. and Shepard, F. P., 1942; Dietz, H. W. and Menard, H. W., 1951b; Emery, K. 0., 1947c; Falrbanks, H. W., 1897; Fisher, R. L. and Mills, R., 1952; Garrison, L. E. and Takasaki, K. L., 1950; Gorsline, D. S., 1954; Grim, R. E., Dletz, R. S. and Bradley, W. F., 1949; Handin, J. W., 1949; Hanna, G. D., 1952; Inman, D. L., 1950; LaFond, E. C., Dietz, R. S. and Knauss, J. A., 1950; MacDonald, G. A., 1934; Marlette, J. W., 1954; Menard, H. W., Dill, R. F., Hamllton, E. L., Moore, D. G. , Shumway, G., Silverman, M., Stewart, H. B., 1954 (insular shelf); Moore, D. G., 1951; Norris, R. M., 1951; Pardee, J. T., 1934; Scripps Institution of Oceanography, 19521; Shepard, F. P., 1932, $1934 \mathrm{a}, 1939 \mathrm{~b}, 1949 \mathrm{~b}, 1949 \mathrm{~d}$; Shepard, F. P. and Emery, K. O., 1945; Shepard, F. P. and Inman, D. L., 1951b; Shepard, F. P. and MacDonald, G. A., 1938; Shepard, F. P. and Wrath, W. F., 1937 (Insular shelf); Thompson, W. C., 1949; Udden, J. A., 1914

Continental Slope: Udden, J. A., 1914 Submarine Canyons: Cohee, G. V., 1938; Congress Ional Documents, 1953b; Davidson, G., 1887, 1897 Davis, W. M., 1933; Dietz, R. S. and Emery, K. 0., 1938a; Dill, R. F., Dietz, R. S. and stewart, H., 1952, 1954; Emery, K. O., Butcher, W. S., Gould, H. R. and Shepard, F. P., 1952; Emery, K. O. and Tschudy, R. H., 1941; Fisher, R. L. and Mills, R., 1952; Grim, R. E., Dietz, R. S. and Bradley, W. F., 1949; Handin, J. W., 1949; Inman, D. L., 1950; Kuenen, Ph H., 1947; Ludwick, J. C., Jr., 1950; Marlette, J. W., 1954; Menard, H. W. and Ludwick, J. C., 1951; Phleger, F. B., 1951; Revelle, R. and Shepard, F. P., 1939b; Scripps Institution of Oceanography, 19521; Shepard, F. P., 1932, 1933c, 1934a, 1938a, 1939d, 1941a, 1948b, 1949e, 1950a, 1950d, 1950g, 1951a, 1953; Shepard, F. P. and Beard, C. N., 1938; Shepard, F. P. and Emery, K. 0., 1941; Shepard, F. P. and Iman, D. L., 1949; Shepard, F. P. and MacDonald, G. A., 1938; Shepard, F. P. and Revelle, R. and Dietz, R. S., 1939; Shepard, F. P., Revelle, R., Dietz, R. S. and Emery, K. O., 1938; Shepard, F. P. and Wrath, W. F., 1937; Woodford, A. 0., 1951

Sand Layers: 1.e., in basins and submarine canyons: Crouch, R. W., 1954; Dill, R. F., Dietz, R. S. and Stewart, H., 1954; Emery, K. O. and Rittenberg, S. C., 1951, 1952; Ludwick, J. C., Jr., 1950; Phleger, F. B., 1951; Revelle, R., 1939a; Shepard, F. P., 1950a, 1951a, 1951b; Shepard, F. P. and Emery, K. $0 ., 1941$

Sandstone (See also: Rock, Sedimentary Rocks): Blake, J., 1868b; Butcher, W. S., 1951a, 1952a; Chesterman, C. W., 1952; Cohee, G. V., 1938; Davidson, G. 1875a; Emery, K. 0., 1941b, 1941c, 1945a, 1946b, 1952a; Emery, K. O., Butcher, W. S., Gould, H. R. and Shepard, F. P., 1952; Emery, K. O. and Foster, J. F., 1948; Emery, K. 0. and Shepard, F. P., 1945; Emery, K. O. and Tschudy, R. H., 1941; Goodyear, W. A., 1873; Hinds, N. E. A., 1952; Holzman, J. E., 1950; Hoover-Young San Francisco Bay Bridge Commission, 1930; Inman, D. L., 1950; Landes, K. K., 1952a; Menard, H. W., Dill, R. F., Hamilton, E. L., Moore, D. G., Shumway, G., Silverman, M. and Stewart, H. B., 1954; Moore, D. G., 1951; Norris, R. M., 1951; Shepard, F. P., 1935c, 1936r, 1949b, 1949d, 1953; Shepard, F. P. and Emery, K. O., 1941; Shepard, F. P. and Grant, U. S., 1947; Shumway, G. A., 1953; Thompson, W. 0., 1937; Uchup1, E., 1954; ZoBell, C. E., 1946b

Sand Waves: Gibson, W. M., 1951; Knox, R. W., 1953; Smith, P. A., 1940; Studds, R. F. A., 1950

Sapropel: Fox, D. L., 1950; Fox, D. L., Isaace, I. D. and Corcoran, E. F., 1952; Fox, D. L., Updegraff, D. M. and Novelli, G. D. 1944; Trask, P. D., 1939; ZoBell, C. E., 1947 d

Scattering Layer: Anonymous, 1951a; Boden, B. P., 1950; 
California, University of, 1942, 1943, 1946a, 1946b, $1946 \mathrm{c}$; D1etz, R. S., 1948,; Emery, K. O., 1952b; Johnson, M. W., 1948; McEwen, G. F. and Staff, 1948; Marshall, N. B., 1951; Tucker, G. H., 1951; Walford, L. A., 1951

Scavengers, Mud Eaters (See also: Organ1sms): Coe, W. R., 1947; Dapples, E. C., 1942; Dietz, R. S., Emery, K. O. and Shepard, F. P., 1942; Dill, R. F., 1952; Emery, K. O., 1952b; Emery, K. O. and R1ttenberg, S. C., 1952; Fox, D. L., 1944b; Fox, D. L. Isaacs, J. D. and Corcoran, E. F., 1952; Fox, D. L., Updegraff, D. M. and Novell1, G. D., 1944; Galliher, E. W., 1935a; Goldberg, E. D., 1954; Gorsline, D. S., 1954; Hesse, R., Allee, W. C. and Schmidt, K. P., 1937; Hoots, H. W., 1943; McConnaughey, B. H. and Fox, D. L., 1949; MacGintt1e, G. E., 1939; Moberg, E. G., Fleming, R. H., Heusner, K. and Revelle, R., 1937; Natland, M. L., Revelle, R. and Rittenberg, S. C., 1941; Revelle, R. and Shepard, F. P., 1939b; Scr1pps Inst1tution of Oceanography, 19521; Vaughan, T. W. , 1940

Sch1st (See also: Metamorphic Rocks, Rock): Butcher, W. S., 1951a; Cohee, G. V., 1938; Emery, K. O., 19470, 1948; Emery, K. O. and Shepard, F. P., 1945; Emery, K. O. and Tschudy, R. H., 1941; Hanna, G. D., 1952

Scouring: Beach Erosion Board, 1952a; Blinn, F. S., 1928; California, University of, 1952a; Crooke, R. C., Elvitsky, A. W., et al, 1953; Crowell, J. C., 1952; Dietz, R. S., 1954; Emery, K. O., 1952; G1bson, N. M., 1951; Grant, U. S., 1940; Johnson, J. W., 1948b; LeConte, J., 1891; McOuat, H. W., 1951; Menard, H. W., 1952; Nicholls, C. P. L., 1936a; Nicholaon, G. F., Grant, U. S., Shepard, F. P. and Crowell, J. C., 1946; Rawn, A. M. and Bowermen, F. R., 1951; Sears, C. B., 1876; Stevenson, R. E., 1954; Tanner, Z. L., $1892 \mathrm{~b}$ (See also: Natural Bridge, Sea Caves): Anonymous, 1882a; Arnold, R. and Hannibal, H., 1913; Blake, W. P., 1856; Blankinship, J. W. and Keeler, C. A., 1892; Cleland, H. F., 1910; Hanna, G. D., 1951; Henderson, J., 1932; Hoover, J. W., 1932a; L1vingston, A., Jr., 1939; Leonard, A. G., 1925; McLellan, M. E., 1925; Paguirigan, F., 1941; Shepard, F. P. and Grant, U. S., 1947; Sm1th, W. D., 1933c; Witt1ch, E., 1920; Yates, L. G., $1890 \mathrm{a}, 1902$

Sea Caves (See also: Natural Bridge, Sea Arch): Blake, W. P., 1856; Blankinsh1p, J. W. and Keeler, C. A., 1892; Bowers, S., 1878; Chase, A. W., 1875; Cleland, H. F., 1910; Crandall, H., 1915; Davis, W. M., 1932; Emery, K. O., 1954e; Fairbanks, H. W., 1904; Fewkes, J. W., 1889; Hanna, G. D., 1951; Hanna, M. A., 1926; Henderson, J., 1932; Hertle 1n, L. G. and Grant, U. S., 1937; Hinds, N. E. A., 1952; Hoover, J. W., 1932a; Kemn1tzer, L. E., 1933; Lakes, A., 1903a; Lange, A., 1954; Lawson, A. C., 1893b; Leonard, A. G., 1925; McLellan, M. E., 1925; Orr, P. C., 1952; Pease, W. H., 1868; Remondino, P. C., 1892; Richardson, R. W., 1923; Shaler, N. S., 1895; Shepard, F. P. and Grant, U. S., 1947; Smith, W. D., 1933c; Spencer, J. W., 1897; W1lson, M. E., 1907; Winsted, H. L., 1913; Yates, L. G., 1890a, $1890 \mathrm{~b}, 1902$

Cliff (See also: Elevated Sea Cliff, Rocky Costs): Anonymous, 1940d, 1949a; Alexander, C. S., 1950; Anderson, C. A., 1950; Arnold, D. and Arnold, R. 1902; Arnold, R., 1900; Ashley, G. H., 1895; Balley, T. L., 1943; Bartlett, W. A., 1852; Beach Erosion Board, 1942a, 1953a, 1954a; Blake, W. P., 1856; Bowers, S., 1878; Bremner, C. St., J., 1932; Bruff, S. C., 1940, 1946; Buwalda, J. 1936; Chase, A. W., 1875; Cleland, H. F., 1910; Congressional Documents, 1940a, 1949f, 1953b; Cotton, C. A., 1942; Couch, E. B., 1915; Crandell, H., 1915; Deridson, G., 1856, 1875a, 1897; Dav1s, W. M., 1932; Dav1s, W. M., Putnam, W. C. and RIchards, G. L., Jr., 1931; Dietz, R. S. and Menard, H. W., 1951b; D1ller, J. S., 1902, 1903; Drury, N. B., 1938; Dunkle, M. B., 1944, 1950; Fmery, K. O., 1946b, 1950d, 1952a, 1954e; Emery, K. O. and Dietz, R. S., 1950; Erickson, C. E., 1952, 1953; Fairbanks, H. W., 1897, 1898, 1904; Fewkes, J. W., 1889; G1lbert, G. K., 1917;
Goldberg, J., 1940; Gorsline, D. S., 1954; Grant, U. S. and Shepard, F. P., 1937; Grlesbach, J. O., 1947; Gulliver, F. P., 1896; Hall, W. C., 1942; Hand1n, J. W., 1949, 1951; Hanna, G D., 1951, 1952; Hanna, M. A., 1926; H1nds, N. E. A., 1952; Horton, D. F., 1948; Inman, D. L., 1953a, 1953b; James, E. L., 1950; Johnson, A. G., 1935; Johnson, C. W., 1953; Kemnitzer, L. E., 1933; Kew, W. S. W., 1927; Krumbe1n, W. C., 1947; Lange, A., 1954; Lawson, A. C., 18932 , 1893b, 1894; Lawson, J. S., 1862; Livingston, A., Jr., 1939; Leonard, A., 1925; McGee, W. J., 1900; MacDonald, G. A., 1934; MacDonald, G. A., Shepard, F. P. and Cox, D. C., 1947; Masters, P., 1840; Moore, D. G., 1951; Nicholson, G. F., Grant, U. S., Shepard, F. P. and Crowell, J. C., 1946; Norr1s, R. M., 1949, 1951; O'Brien, M. P., 1939; Paguirigan, F., 1941; Pardee, J. T., 1934; Place, J. L., 1952; Poss, E. G., 1937; Putnam, W. C., 1937o, 1937c, 1938; Reed, R. D., 1930a; Relche, P., 1937; Shaler, N. S., 1895; Shepard, F. P., 1943b, 1949b, 1950c, 1950e; Shepard, F. P. and Emery, K. O., 1941; Shepard, F. P., Grant, U. S. and Dietz, R. S., 1939; Shepard, F. P. and Inman, D. L., 1949; Shepard, F. P. and MacDonald, G. A., 1938; Shepard, F. P. and Wrath, W. F., 1937; Smith, W. D., 1933a, 1933b, 1933c; Smith, W. S. T., 1898, 1900; Spencer, J. w., 1897; Stock, C., 1936; Swinnerton, A. C., 1927; Trask, P. D., 1952b; Trowbridge, W. P., 1856b; Twenhofel, W. H., 1943; Upson, J. E., 1951; Will1s, B., 1900; Wheeler, G., 1936; Whitney, J. D., 1865

Sea Level (See also: Sea Level Changes; Sea Level Changes, Glac1al): Disney, L. P. and Oversbiner, W. H., 1925; Grant, U. S., 1943; Hoover-Young San Franc1sco Bay Bridge Commission, 1930; LaFond, E. C., 1939a; Leypoldt, H., 194la; Marmer, H. A., 1928; Meaney, C., 1949; Nicholson, G. F., Grant, U. S., Shepard, F. P. and Crowell, J. C., 1946; Shalowitz, A. L., 1951; Shepard, F. P. and LaFond, E. C., 1942; Sverdrup, H. U., 1939 a

Sea Level Changes (See also: Sea Level; Sea Level Changes, Glacial): Alexander, C. S., 1950; Anderson, W., 1939; Avers, H. G., 1927; Beach Erosion Board, 1953c; Bowie, W., 1936; Bucher, W. H., 1940; Butcher, W. S., 1951a; California, University of, 1952a; Carsola, A. J. and Dietz, R. S., 1952; Carter, G. F., 1948; Clements, T. and Dana, S. W., 1944; ' Cockerell, T. D. A., 1938b; Cohee, G. V., 1938; Cotton, C. A., 1942, 1944; Crooke, R. C., Elvitsky, A. W., et al, 1953; Davidson, G., 1875a; Davis, W. M. , 1932, 1933; Dav1s, W. M., Putnam, W. C., and Richards, G. L., Jr., 1931; Dietz, R. S., 1947a, 1952a; Dietz, R. S. and Menard, H. W., 1951b; Dill, R. F., 1952; Emery, K. O., 1950c, 1952a, 1952b, 1954e; Emery, K. O. Butcher, W. S., Gould, H. R. and Shepard, F. P., 1952; Emery, K. O. and Natland, M. L., 1952; Galliher, E. W., 1935c; Gilluly, J. and Grant, U. S., 1947; Gislên, T., 1943, 1944; Goldberg, J., 1940; Goodyear, W. A., 1873; Grant, U. S. and Shepard, F. P., 1938a; Gutenberg, B., 1933, 1941b; Hall, J. V., Jr., 1952; Handin, J. W., 1949; Hess, H. H. and Macclintock, P., 1936; Holzman, J. E., 1950; Ives, R. L., 1951; Jacobs, W. C., 1939; Johnson, D. W., 1944; Kuenen, Ph. H., 1947; LaFond, E. C., 1938, 1939a, 1940; Landes, K. K, 1952b; Lawson, A. C., 1948; LeConte, J., 1891; Louderback, G. D., 1941, 1951; Lucke, J. B., 1938; Leypoldt, H., 1934, 1937a, 1941c, 1947; Leypoldt, H., and McHenry, J. R., 1942; MacDonald, G. A., 1934; Marmer, H. A., 1949, 1952; Meaney, C. D., 1949; Merriam, P. D., 1949; Munk, W. H. and Traylor, M. A., 1947; Norr1s, R. M., 1951; Pratt, W. E., 1947; Putnam, W. C., 1938, 1940; Schureman, P., 1936; Shaler, N. S., 1895; Shepard, F. P., 1931, 1932 $1933 \mathrm{c}, 1936 \mathrm{c}, 1936 \mathrm{~g}, 1937 \mathrm{~b}, 1938 \mathrm{a}, 1938 \mathrm{f}, 1938 \mathrm{~h}$, $1940 \mathrm{~b}, 1949 \mathrm{~b}, 1949 \mathrm{c}, 1949 \mathrm{~d}, 1950 \mathrm{~g}, 1951 \mathrm{e}, 1952 \mathrm{a}$, 1953; Shepard, F. P. and Emery, K. 0., 1941; Shepard, F. P. and Grant, U. S., 1947; Shepard, F. P. and Inman, D. L., 1949; Shepard, F. P. and LaFond, E. C., 1940; Shepard, F. P. and MacDonald, G. A., 1938; Shepard, F. P. and Stetson, H. C., 1939; Shepard, F. P. and Wrath, 
W. F., 1937; Shepard, F. P., Revelle, R., Dietz, R. S. and Emery, K. O., 1938; Studds, R. F. A., 1951; Thompson, W. O., 1937; Treasher, R. C., 1937; Twenhofel, w. H., 1943, 1946; Uchupi, E., 1954; Upson, J. E., 1949a; Wheeler, G., 1936

Sea Level Changes, Glacial (See also: Sea Level, Sea Level Changes): Alexander, C. S., 1950; Anderson, W., 1939; Bucher, W. H., 1940; Butcher, W. S., 1951a; Carsola, A. J. and Dietz, R. S., 1952; Cohee, G. V., 1938; Cotton, C. A., 1942, 1944; Davis, W. M., 1932, 1933; Emery, K. O., 1950c, 1952a, 1952b; Emery, K. O., Butcher, w. S., Gould, H. R. and Shepard, F. P., 1952; Gutenberg, B., 1933; Lawson, A. C., 1948; Louderback, G. D., 1941; MacDonald, G. A., 1934; Norris, R. M., 1951; Shaler, N. S., 1895; Shepard, F. P., 1936g, 19370, 1938a, 1938f; Shepard, F. P. and Emery, K. O., 1941; Shepard, F. P. and MacDonald, G. A., 1938; Shepard, F. P. and Stetson, H. C., 1939; Shepard, F. P. and Wrath, W. F., 1937; Uchupi, E., 1954; Upson, J. E., 1949 a

Seamounts (See also: Banks, Submarine Mountains): Carsola, A. J., Dietz, R. S. and Russell, R. D., 1949; Carsola, A. J. and Dietz, R. S., 1952; Dietz, R. S., 1947a, 1952a, 1954; Dietz, R. S., Emery, K. O. and Shepard, F. P., 1942; Dietz, R. S., Menard, H. W. and Hamilton, E. L., 1952, 1954; Dill, R. F., 1952; Eardley, A. J., 1954; Emery, K. O. and Dietz, R. S., 1950; Emery, K. O. and Natland, M. L., 1948; Emery, K. O. and Shepard, F. P., 1945; Goldberg, E. D., 1954; Handin, J. W., 1949; Hanna, G. D., 1952; Hinds, N. E. A. 1952; Koczy, F. F., 1954; LaFond, E. C., 1949; Landes, K. K., 1952a, 1952b; Lawson, A. C., 1950; Ma, T. Y. H., 1952; Menard, H. W., 1952; Menard, H. W. and Dietz, R. S., 195l; Murray, H. W. 1939; Scripps Institution of Oceanography, 1953e; Shepard, F. P., 1941a, 1947b, 1948c, 1949b, 1949d, 1949 e, 1950e, 195le, 1952a; Shepard, F. P. and Emery, K. O., 1941, 1945; Wooster, W. S., 1951, 1952

Sea or Wave Ripples: Ewing, G. C., 1950b, 1950c

Sea Slicks: Aldrich, L. and Smith, H. G., 1948; Allen, W. E., 1935, 1940b; Alliott, H., 1917 (floating oil); Bates, C. C. and Glenn, A. H., 1948 (damping action); Beach Erosion Board, 1948h; Belcher, E., 1843; Blake, w. P., 1853, 1855, 1856; California Department Public Health, 1951; Davidson, G., 1856, 1859, 1864; Dietz, R. S. and LaFond, E. C., 1950; Dill, R. F., 1949; Ewing, G. C., 1950a, 1950b, 1950c; Fox, D. L., Isaacs, J. D. and Corcoran, E. F., 1952; Hubbs, C. L. and Rechnizer, A. B., 1952; Imray, J. F., 1870; McEwen, G. F., 1918 (streaks); Nicholls, C. P. L., 1936c; San Diego Regional Water Pollution Control Board, 1952; Scripps Institution of Oceanography, 1952i; Tanner, $\mathrm{z}$. L., 1892a; Van Dorn, W. G., 1953

Sea Stacks: Blake, W. P., 1856; Carpenter, F. A., 1924; Hinds, N. E. A., 1952; Hoover, J. W., 1932a; Lawson, A. C., 1893a, 1893b, 1894, 1924; MacDonald, G. A., 1934; Paguirigan, F., 1941; Reiche, P., 1937; Richardson, R. W., 1923; Shepard, F. P., 1941a; Shepard, F. P. and Grant, U. S., 1947; Smith, W. D., 1933c; Wanless, H. R., 1950; Wilson, M. E., 1907; Yates, L. G., 1902

Sea Surface Roughness: Scripps Institution of Oceanography, $1952 i$

Sea Valley - see Rift Valley, Submarine Canyons

Sea Walls - see Engineering

Sea Weed - see Algae

Sedimentary Rocks (See also: Rocks, various types of sedimentary rock): Chesterman, C. W., 1952; Clements, T. and Emery, K. 0., 1947; Dietz, R. S., Emery, K. O. and Shepard, F. P., 1942; Emery, K. O., 1947b, 1951; Emery, K. O. and Dietz, R. S., 1950; Emery, K. O. and Shepard, F. P., 1941, 1945; Gorsline, D. S., 1954; Hanna, G. D., 1952; Holzman, J. E., 1950; Shepard, F. P. and Emery, K. O., 1941; Shumway, G. A., 1953; Uchupi, E., 1954

Sedimentation (See also: Accretion, Artificial Beach Nourishment; Continental Shelf, origin; Continental Slope, origin; Interstitial sedimentation; Submarine Canyons, Loss of Sediment into): Anonymous, 1951b; Allen, W. E., 1941d; Ashauer, H., Hollister, J. S. and Reed, R. D., 1936; Atwill, E. R., 1942; Bache, A. D., 1852; Blake, W. P., 1856; Bruff, S. C., 1946; Buffington, E. C., 1951; Butcher, W. S., 195la; Caldwell, J. M., 1950; California Department of Fish and Game, 1951; Carpenter, E. J. and Storie, R. E., 1929; Congressional Documents, 1880a, 1940e, 1941, 1942a, 1949-1950a, 1953a; Crowell, J. C., 1952; Dapples, E. C., 1942; Davis, W. M., 1932; Darrow, W. E., 1942; Dawson, E. Y., 1951; Dietz, R. S. and Emery, K. O., 1938a; Dietz, R. S. and Menard, H. W., 1951b; Dietz, R. S., Menard, H. W. and Hamilton, E. L., 1954; Dill, R. F., 1952; Diller, J. S., 1901; Elliott, F. E., Tressler, N. L. and Myers, W. H., 1953; Emery, K. O. and Dietz, R. S., 1939; Emery, K. O. and Shepard, F. P., 1945; Evans, R. D., Kip, A. F. and Moberg, E. G., 1938; Fox, C. K., 1936; Fox, D. L., 1950; Fox, J. L C., 1942; Friedman, S. L., 1949; Golliher, E. W., 1935a, 1935b, 1935c; Gilbert, G. K., 1917; Gillette, C. E., 1905; Goldberg, E. D., 1954; Gross, H. E., 1945; Harts, W. W., 1901; Hinde, H. P., 1952; Inman, D. L., 1949, 1950; Johnson, J. W., 1948d; Kenyon, E. C., Jr., 1951; Koczy, F. F., 1954; 'Kuenen, Ph. H. and Menard, H. W., 1952; Landes, K. K., 1952b; Lawson, A. C., 1894; Laws on, L. M., 1950; Lawton, C. H., 1936; LeConte, J., 1891; Leeds, C. T., 1915, 1936; Leeds, C. T., Vanoni, V. A. and Knapp, R. T., 1934; Louderback, G. D., 1920, 1940, 1951; McEwen, G. F., 1935b, 1940b; McKee, E. D., 1939; Means, T. H., 1928; Miller, R. L., 1954; Morrison, R. L., 1930; Munk, W. H., 1941; Nelson, N. C., 1909, 1910; Page, G. B., 1950; Reagan, J. W., 1915; Revelle, R., 1938, 1939a, 1939b; San Diego Regional Water Pollution Control Board, 1952; Shaler, N. S., 1896; Shepard, F. P., 1939a, 1940a, 194la, 19́49a, 195le; Shepard, F. P., Revelle, R. and Dietz, R. S., 1939; Shepard, F. P. and Stetson, H. C., 1939; Smith, W. D., 1933c; Smith, W. S. T., 1900; Spencer, J. W., 1890; Stevenson, R. E., 1954; Sumner, F. B., Louderback, G. D., Schmitt, W. L. and Johnston, E. C., 1914; Sverdrup, H. U., 1938c, $1940 \mathrm{~g}$; Sykes, G., 1938; Trask, P. D., 1927a, 1931b, 1932b, 1939; Twenhofel, W. H., 1943; Udden J. A., 1914; U. S. Army Corps of Engineers, 1931; U. S. Waterways Experiment Station, Vicksburg, Mississippi, 1950; Vaughan, T. W., 1932b; White, D., 1911; Wood, H. O., 1915; ZoBell, C. E., 1938 , 1944

Abyssal: Carsola, A. J. and Dietz, R. S., 1952; Piggot, C. S., 1944; Piggot, C. S. and Urry, W. D., 1942; Revelle, R., 1935; Shepard, F. P., 1937f; Shepard, F. P., Revelle, R., Dietz, R. S. and Emery, K. O., 1938

Bank: Carsole, A. J. and Dietz, R. S., 1952; Clements, T. and Dana, S. W., 1944; Emery, K. O., 1947b; Emery, K. O. and Dietz, R. S., 1950; Holzman, J. E., 1950; Shepard, F. P., 1940a; Basin: Dietz, R. S., 1938; Emery, K. O., 1950e; Emery, K. O. and Rittenberg, S. C., 1952; Emery, K. O. and Shepard, F. P., 1945; Pratt, W. E., 1947; Shepard, F. P., 1937f; Shepard, F. P., Revelle, R., Dietz, R. S. and Emery, K. 0., 1938; Weeks, Z. G., 1952

Beach and Nearshore: Anonymous, 1950d; Bascom, W: N., 1946b; Beach Erosion Board, 1949a, 1953c; Congressional Documents, 1940e, 1953a, 1953b; Darrow, W. E., 1942; Eaton, R. O., 1951; Emery, K. O., 1945a; Emery, K. O. and Stevenson, R. E., 1954; Grant, U. S., 1940, 1943, 1944, 1948; Grant, U. S. and Shepard, F. P., 1938a, 1940; Gulliver, F. P., 1896; Hawgood', H., 1914; Inman, D. L., 1949, 1953a, 1953b; Johnson, J. W., 1952; Kerr, A. R., 1938; Krumbein, W. C., 1947; Lakes, A., 1899, 1903; Lapsley, w. W., 1937; Leeds, C. T., Vanoni, V. A. and Knapp, R. T., 1934; Marlette, J. W., 1954; Pardee, J. T., 1934; Scripps Institution of oceanography, $1953 \mathrm{c}$ (depositional environments); Shepard, F. P., 1941a, 1949a, 1950c, 1950f, 1951d; Shepard, F. P., Emery, K. O. and LaFond, E. C., 1941; Shepard, F. P. and Inman, D. L., 1949, 1951b; Thompson, W. 0., 1933, 1937; Tower, M. L., 1910; Trask, P. D. and scott, T., 1954; 
Troster, J. G., 1949; Verrill, G. E., 1930; Wiege 1, R. L., Patrick, D. A. and Kimberley, H. L., 1953

Continental and Insular Shelves: Anderson, $F$. M., 1896-1902; Bucher, W. H., 1940; Butcher, W. S., 195la; Clark, B. L., 1932; Dietz, R. S., 1951, 1952b; Dietz, R. S. and Menard, H. W., 1951b; Emery, K. O., 1952a; Galliher, E. W., 1935b; Gorsline, D. S., 1954; Jeffreys, H., 1934; MacDonald, G. A., 1934; Miller, R. L., 1954; Moore, D. G., 1951; Pardee, J. T., 1934; Shepard, F. P., 1932, 1940c, 1949b, 1949d, 195la; Shepard, F. P., Emery, K. O. and LaFond, E. C., 1941; Shepard, F. P. and Inman, D. L., 1951b; Shepard, F. P. and Wrath, W. F., 1937 (Insular shelf); Smith, W. S. T., 1900; Wrath, W. F., 1936 (insular shelf)

Continental Slope: Dietz, R. S., 1952b; Dietz, R. S. and Menard, H. W., 1951b; Dill, R. F., 1952

Submarine Canyons: Davis, W. M., 1933; Dill,

R. F., Dietz, R. S. and Stewart, H., 1954; Fairbanka, H. W., 1897; Norr18, R. M., 1951;

Phleger, F. P., 1951; Ritter, W. E., 1902;

Shepard, F. P., 1933c, 1934b, 1935a, 1936f

$1937 b, 1938 \mathrm{a}, 1938 \mathrm{c}, 1938 \mathrm{f}, 1939 \mathrm{c}, 1941 \mathrm{a}$,

$1948 \mathrm{~b}, 1948 \mathrm{c}, 1949 \mathrm{~b}, 1950 \mathrm{a}, 1950 \mathrm{~g}, 1951 \mathrm{a}, 1951 \mathrm{~d}$,

1952a; Shepard, F. P. and Emery, K. O., 1941;

Shepard, F. P., Revelle, R., Dietz, R. S. and

Emery, K. O., 1938; Smith, W. S. T., 1902;

Woodford, A. 0., 1951

Sedimentation, Rate of: Dietz, R. S., Emery, K. O. and

Shepard, F. P., 1942; Dill, R. F., 1952; Dill,

R. F., Dietz, R. S. and Stewart, H., 1954; Emery,

K. O., 1947a, 1947c; Emery, K. 0. and Dietz,

R. S., 1939; Emery, K. O. and Rittenberg, S. C.,

1952; Ford, J. L. C., 1942; Fox, D. L., 1944b;

Fox, D. L. and Anderson, L. J., 1941; Fox, D.

L., Updegraff, D. M. and Novelli, G. D., 1944;

Galliher, E. W., 1935c; Goldberg, E. D., 1954;

Inman, D. L., 1950; Krumbein, W. C., 1947;

Kuenen, Ph. H., 1946; McKee, E. D., 1953;

Natland, M. L., Revelle, R. and Rittenberg, S.

C., 1941; Piggot, C. S. and Urry, W. D., 1942; Revelle, R., 1935, 1938, 1950; Revelle, R. and Shepard, F. P., 1939b; Scripps Institution of Oceanography, 1953e; Shepard, F. P., 1948c;

Stevenson, R. E., 1954; Sverdrup, H. U. and Staff, 1941; Trask, P. D., 1931a, 1939; Uchupi, E., 1954; Urry, W. D., 1940, 1948; Urry, W. D. and Piggot, C. S., 1942; ZoBell, C. E., 1942b Sediment By-Passing - see By-Passing of Sediment'

Sediment Color - see Color of Sediment and various colors of sediments

Sediment Masking - aee Masking of Sediment

Sediment Reworking - see Reworking of Sediment

Sediment Thickness - see Thickness of Sediment

Sediments: Agassis, A. and Murray, J., 1902 (description of bottom materials and bottom sediment chartz); Allen, W. E., 194lc; Anderson, C. A., 1950; Andrews, H. L., 1945; Arnold, D. and Arnold, R., 1902; Arnold, J. L., 1928; Bache, A. D., 1856a; Belknap, G. E., 1874 (tables of bottom sediments); Buck, C. D., 1928; Buffington, E. C., 1951; Calffornia Department of Public Health, 1951; California Department of Public Works, 1947; Carsola, A. J., 1947; Coe, W. R., 1947; Crooke, R. C., Elvitaky, A. W., et al, 1953; Dana, s. W., 1942; Davis, W. M., 1932; Dietz, R. S., Emery, K. O. and Shepard, Fv P., 1942; Emery, K. O., 194lc, 1946a; Emery, K. O. and Gould, H., 1948; Emery, K. O. and Tschudy, R. H., 1941; Evana, R. D., Kip, A. F. and Moberg, E. G., 1938; Fleming, J. A., Sverdrup, H. U., Ennis, C. C., Seaton, S. L. and Hendrix, W. C., 1945; Ford, J. L. C., 1942; Fox, D. L., 1944a, 1944b, 1950; Fox, D. L., Crane, S. C. and McConnaughey, B. H., 1948; Fox, D. L., Updegraff, D. M. and Novell1, G. D., 1949; Fraser, C. McL., 1943 (tables of sediments and rocks); Galliher, E. W., 1933, 1935a, 1935c, 1939; Gilbert, G. K., 1917; Gilbert, J. Y. and Allen, W. E., 1943; Gislen, T., 1943; Grant, U. S. and Shepard, F. P., 1937; Handin, J. W., 1951; Hansen, H. A. and Pemberton, J. R., 1950; Helfand, S., 1927 (bottom sample notations);
Hutton, W. E. and ZoBell, C. E., 1949; Kindle, E M., 1934; Krumbein, W. C., 1942; Lawson, A. C., 1894; Lesser, R. M., 1951; Louderback, G. D., 1921, 1924, 1951; MacGinitie, G. E., 1927, 1935; Mann, A., 1907 (bottom notations); Means, T. H., 1928; Menard, H. W. and Ludwick, J. C., 1951; Michael, E. I. and MCEwen, G. F., 1915; Miller, R. L., 1954; Moberg, E. G. and Allen, W. E. 1927; Moberg, E. G., Fleming, R. H., Heusner, K. and Revelle, R., 1937; Munk, W. H., 1941; Natland, M. L., Revelle, R. and Rittenberg, S. C., 1941; Nelson, J. W., Dean, W. C., Kocher, A. E., Watson, E. B. and Carpenter, E. J., 1920; Norris, R. M., 1951; Osorio Tafall, B. F., 1943; Pierce, J. W., 1948; Raitt, R. W., 1949; Revelle, R., 1941; Revelle, R. and Shepard, F. P., 1939a, 1939b; Rittenberg, S. C., 1940; Rosenfeld, W. D., 1948; San Diego Regional water Pollution Control Board, 1952; Saur, J. T. F., Jr., 1950; Scheffauer, F. C., 1927; Shepard, F. P., 1938b, 1941a, 1950e; Sherzer, w. H., 1910; Smith, P. V., Jr., 1954; Smith, ․ D., 1933c; Soper, E. K., 1938; Storie, R. E. and Carpenter, E. J., 1929; Studds, R. F. A., 1951; Sumner, F. B., Louderback, G. D., Schmitt, W. L. and Johnson, E. C., 1914; Sverdrup, H. U., 1939a, 1940e, 1940f, 1940g; Sverdrup, H. U. and Staff, 1941; Tanner, Z. L., $1892 a$ (tables listing sediments), 1893 (tables listing sediments), 1894; Thayer, L. A., 1937; Townsend, C. H., 1901 (tables listing dredging); Trask, P. D. , 1927a, 1927b, 1931a, 1932a, 1932b, 1934, 1937a, 1939, 1950; Trask, P. D. and Hanmar, H. E., 1931; Trask, P. D. and Rolaton, J. W., 1950b; Trask, P. D. and Wu, C. C., 1930a; Udden, J. A., 1914; Updegraff, D. M., 1948; Urry, W. D., 1940; U. S. Commission of Fish and Fisheries, 1898 (tables listing sediments); U. S. Bureau of Fisheries, 1906 (tables liating dredging, 1921 (tables listing dredging; U. S. Hydrographic office, 1934b, 1947b; Vaughan, T. W., 1932b, 1933; Vaughan, T. W. and Others, 1937; ZoBel1, C. E., 1936, 1939, 1944, 1946b, 1946-1947, $1947 \mathrm{~b}, 1947 \mathrm{c}, 1947 \mathrm{~d}, 1949$, 1950; ZoBell, C. E. and Anderson, D. Q., 1936; ZoBell, C. E. snd Feltham, C. B., 1934b; ZoBell, C. E. and Grant, C. W. and Haas, H. F., 1943

Abyssal: Davidson, G., 1875b, 1897; Dietz, R. S., 1952a; Dill, R. F., 1952; Emery, K. O., 1954b; Emery, K. O. and Dietz, R. S., 1941; Emery, K. 0. and Natland, M. L , 1952; Evans, R. D., Kip, A. F. and Moberg, E. G., 1938; Fleming, J. A., Sverdrup, H. U., Ennis, C. C., Seaton, S. L. and Hendrix, W. C., 1945; Fox, D. L., Updegraff, D. M. and Novelli, G. D., 1944; Galliher, E. W., 1935a; Göes, A., 1896; Graham, H. W. and Moberg, E. G., 1944; Grim, R. E., Dietz, R. S. and Bradley, W. F., 1949; Kuenen, Ph. H., 1946; Michael, E. L., 1919; Murray, J. and Lee, G. V., 1909; Piggot, C. S., 1932; Piggot, C. S. and Urry, W. D., 1942; Revelłe, R., 1935, 1937a, 1937b; Rittenberg, S. C., 1940; Scripps Institution of Oceanography, 1953e; Shepard, F. P., 1941a, 1949d, 1951b; Shepard, F. P., Revelle, R., Dietz, R. S. and Emery, K. O., 1938; Shepard, F. P. and Stetson, H. C., 1939; Shepherd, E. S., 1940, 1946; Shumway, G. A., 1953; Sverdrup, H. U., 1939a; Tanner, Z. L., 1892b, 1894; Takahash1, J., 1925; Urry, W. D., 1948; Urry, W. D. and Piggot, C. S., 1942; Vaughan, T. W., 1933, 1940; White, D., 1911

Bank: Dietz, R. S., Emery, K. O. and Shepard, F. P., 1942; Emery, K. 0., 1947b,.1948; Emery, K. O., Butcher, W. S., Gould, H. R. and Shepard, F. P., 1952; Emery, K. O. and Dietz, R. S., 1950; Emery, K. $O$ and Rittenberg, S. C., 1952; Holzman, J. E., 1950 Kuenen, Ph. H., 1947; Lawson, A. C., 1924; Shepard, F. P., 1939d, 1941a, 1947b; Shepard, F. P. and Emery, K. O., 1941; Uchupi, E., 1954

Basin: Clements, T. and Emery, K. 0., 1947; Congressional Documents, 1953b; Emery, K. O., Butcher, W. S., Gould, H. R. and Shepard, F. P., 1952; Emery, K. O. and Rittenberg, S. C., 1951, 1952; Emery, K. O. and Shepard, F. P., 1945; Fleming, R. H. and Revelle, R., 1939; Garrison, 
L. E. and Takasaki, K. L., 1950; Ludw1ck, J. C. J., 1950; Moberg, E. G., Fleming, R. H., Heusner, $\mathrm{K}$ and Revelle, R., 1937; Phleger, F. B., 1951; Raltt, R. W., 1949; Revelle, R., 1939b; Revelle, R. and Shepard, F. P., 1939b; Shepard, F. P., 1940a, $1941 \mathrm{a}, 1947 \mathrm{~b}, 1948 \mathrm{c}, 1951 \mathrm{~b}, 1951 \mathrm{~d}$; Shepard, F. P., Revelle, R. and Dietz, R. S., 1939; Trask, P. D., 193la, 1931b; Weeks, L. G., 1952; ZoBell, C. E., 1944

Beach and Nearshore: Bascom, W. N., 1950c; Beach Erosion Board, 1953b; Brown, C. B., 1942; Callfornia, University of, 1953a, 1953b; Coe, W. R. and Fox, D. L., 1942; Eaton, R. O., 1951; Grant, U. S., 1938, 1946; Grant, U. S. and Shepard, F. P., 1938b; Inman, D. L., 1953b; Lombard1, L. V., 1949; Masters, P., 1940; N1cholson, G. F., Grant, U. S., Shepard, F. P. and Crowell, J. C., 1946; Putnam, J. A., Munk, W. E. and Traylor, M. A., 1949; Scripps Institution of Oceanography, 1953\%; Thompson, W. O., 1934; Updegraff, D. M., 1948; ZoBell, C. E. and Rittenberg, S. C., 1938

Continental and Insular Shelves: Congressional Documents, 1953b; D1etz, R. S., 1952b; D1etz, R. S., Emery, K. O. and Shepard, F. P., 1942; Emery, K. O., 1952a; Emery, K.O. and Gould, H., 1948; Handin, J. W., 1949; Inman, D. L., 1950, 1953b; LaFond, E. C., Dletz, R. S. and Knauss, J. A., 1950; M1ller, R. L., 1954; Moore, D. G., 1951; Norr1s, R. M., 1951; Pratt, W. E., 1947; Revelle, R., 1950; Revelle, R. and Shepard, F. P., 1939b;

Scripps Institution of Oceanography, 19521; Shepard, F. P., 1932, 1935a, 1937f, 1939b, 1940c, 194la, 1947b, 1949b, 1951e; Shepard, F. P. and MacDonald, G. A., 1934, 1938; Shepard, F. P. and Wrath, W. F., 1937 (insular shelf); Thompson, W. C., 1949; Udden, J. A., 1914; Updegraff, D. M., 1948; Wrath, W. F., 1936 (insular shelf)

Continental slope: Dietz, R. S., 1952b; D1ll, R. F., 1952; Emery, K. O., 1950c; Emery, K. O. and Rittenberg, S. C., 1952; Shepard, F. P., 1932, 1933c, 1949d; Udden, J. A., 1914 Submarine Canyons: Anonymous, 1939; Congressionel Documents 1953b; crowell, J. C., 1950, 1952; Dav1dson, G., 1887, 1897; Dav1s, W. M., 1933; D11l, R. F., Dletz, R. S. and Stewart, B., 1954; Emery, K. O., Butcher, W. S., Gould, H. R. and Shepard, F. P., 1952; Handin, J. W., 1949; Inman, D. L., 1950, 1953b; Kuenen, Ph. H., 1947; Laws on, A. C., 1950; Ludw1ck, J. C., Jr., 1950; MacDonald, G. A., 1934; Marlette, J. W., 1954; Norr18, R. M., 1951; Phleger, F. B., 1951; Revelle, R. and Shepard, F. P., 1939b; Scripps Institution of Oceanography, 19521; Shepard, F. P., 1932, 1933b, 1934a, 1934b, 1935a, 1935c, $1936 \mathrm{~g}, 1939 \mathrm{~d}, 1940 \mathrm{~d}, 1941 \mathrm{a}, 1946,1947 \mathrm{a}, 1949 \mathrm{e}$, 1950a, 195la, 1951d, 1951e, 1953; Shepard, F. P. and Emery, K. 0., 1941; Shepard, F. P. and Inman, D. L., 1951b; Shepard, F. P. and MacDonald, G. A., 1938; Shepard, F. P., Revelle, R. and Dietz, R. S., 1939

Sediment Transport - see Transport of Sediment

Sediment Trap (See alвo: Submarine Canyons, Loss of Sediment 1nto): Beach Erosion Board, 1952b; Lapsley, W. W., 1937; McEwen, G. F. and Staff, 1948; Shepard, F. P., 1938b, 1949b, 1949d, 1951a; Shepard, F. P. and Emery, K. O., 1941

Selcher (See also: Surf Beat, Surge): Bates, C. C. and Glenn, A. H., 1948; Beach Erosion Board, 1953c; Broshous, C. R., 1938; Chose, J. L., 1948; crooke, R. C., Elvitsky, A. W., et al, 1953; Gallard, D. D., 1904; Green, C. K., 1946; Knapp, R. T. and Vanon1; V. A., 1945; Leypoldt, 世., 1937b; McEwen, G. F., 1935a; N1cholson, G. F., Grant, U. S., Shepard, F. P. and Crowell, J. C., 1946; Patton, R. S. and Marmer, H. A., 1932; Shepard, F. P. and Emery, K. 0., 1941; Van Dorn, W. G., 1953

Selsmology (See also: Escarpments, Faulting, Microse1sms): Anonymous, 1927, 1928, 1946c, 1952a, 1952c, 1952e; Bascom, W. N., 1946a; Bath, M., 1952; Beach Erosion Boord, 1952b; Belcher, E., 1843; Bentoff, H., 1938; Blttinger, C., 1933; Blake, J., 1868b; Bodle, R. R., 1941, 1944, 1945, 1946b; Bodle, R. R. and Murphy, L. M., 1947; Bucher, W. H., 1940; Buwalda, J. P., 1933; Byerly, P.,
$1927,1930,1931,1937,1938 \mathrm{a}, 1938 \mathrm{~b}, 1940 \mathrm{a}$, 1940b, 1952; Byerly, P. and Evernden, J. F., 1950b, 1950d; Byerly, P. and Wllson, J. T., 1936, 1937, 1938; Carder, D. S., 1934; Clements, T., 1946; Clements, T. and Emery, K. 0., 1947; Crooke, R. C., Elviteky, A. W., et al, 1953; Daly, R. A., 1934; Davidson, G., 1873b, 1897; Dav1son, C., 1937; D111, R. F., 1952; Disney, L. P. and Overshiner, W. B., 1925; Eardley, A. J., 1942; Eaton, J. E., 1933; Emery, K. O., 1941a, $1947 \mathrm{c}$, 1950c; Gulluly, J. and Grant, U. S., 1947; Gislén, T., 1944; Green, C. K., 1946; Gutenberg, B., 1934, 1936b, 1939, 1941a, 1941b, 1943, 1950, 1953; Gutenberg, B. and R1chter, C. F., 1937 , $1938,1939,1940,1941,1945,1949$; Gutenberg, В., R1chter, C. F. and wood, в. О., 1932; Earding, C. R., 1929; Harris, F. R. and Harlow, E. H. 1948; Havemann, H., 1952; Heck, N. H., 1924 , 1926, 1934, 1938; Heck, N. H. and Bodle, R. R., 1930, 1931; Heck, N. H. and Neumann, F., 1942; Hill, R. T., 1928b; Bobbs, W. E., 1921, 1944; Hodge, E. T., 1934; Holden, E. S., 1895, 1898 ; Hinds, N. E. A., 1952; Hoover-Young San Franc1sco Bay Bridge Commission, 1930; Inman, D. L., 1953b; Jeffreys, E., 1934; Koczy, F. F., 1954; KonIng, L. P. G., 1952; Landes, K. K., 1952a; Lawson, A. C. and Others, 1908; Leypoldt, H., 1938; Louderback, G. D., 1919, 1944; McAdle, A. G., 1907; McComb, E. E., 1934; McEwen, G. F., 193 McHenry, J. R., 1942; MacDonald, G. A., Shepard, F. P. and Cox, D. C., 1947; Macelwane, J. B., 1923, 1934; Matte1, A. C., 1917; Menard, H. W. and Dietz, R. S., 1951; Mitchell, G. D., 1928; Munk, W. H. and Traylor, M. A., 1947; Murphy, L. M., 1950; Murphy, L. M. and Cloud, W. K., 1953; Murphy, L. M. Ulrtch, F. P., 1951a, 1951b, 1952; Murray, H. W., 1939; Neumann, F., 1929, $1932,1934,1935,1936,1937,1938$, 1940a, 1940b, 1942 , 1943, 1952; Neumann, F. and Bodle, R. R., 1932; Nicholls, C. P. L., 1936c; Nicholson, G. F., 1929; Norr1s, R. M., 1951; O'Brien, M. P., 1946b; Parkin, E. J., 1948; R1chter, C. F., 1940; Roop, F. C., 1946; Sanchez, P. C., 1934e; Scripps Institution of Oceanography, 19521, 1953c; Shepard, F. P., 1933c, 1936e, 1936f, 1937d, 1941a, 1950e, 195la, 1951d; Shepard, F. P. and Emery, K. 0., 1941; Schuck, 0. T., 1869; Sm1th, W. D. , 1919, 1933b; Sparks, N. R., 1936; Stockman, L. P., 1949c; Swainson, O. W., 1944; Taber, S., 1920; Tanner, Z. L., 1896; Townley, S. D. and Allen, M. W., 1939; Trask, J. B., 1856, 1857; Uchup1, E., 1954; Vaughen, T. W. and Others, 1937; W1ll1s, B., 1925; W1lson, R. M., 1928b; Wood, H. O., 1915, 1933a, 1933b, 1947; Wood, E. O. and Heck, N. H., 1951; Woollard, G. P. 1951

Selective Transportation - see By-Passing of Sediment, NonDeposition, Winnowing

Serpintine (See also: Igneous Rock, Rock): Cohee, G. V., 1938; Emery, K. O., 1948; Emery, K. O. Butcher, W. S., Gould, H. R. and Shepard, F. P., 1952

Sewage - see Pollution

Shale (See also: Rock, Sedimentary Rock): Anonymous, 1950d; Butcher, W. S., 1951a; Callfornia, University of, 1953a, 1953b; Cohee, G. V., 1938; Congress1onal Documents, 1940e; Coxe, L. C., 1949; Emery, K. 0., 194la, 1941c, 1946b, 1950d, 1952a, 1952b, 1953b; Emery, K. O., Butcher, W. S., Gould, H. R. and Shepard, F. P., 1952; Emery, K. O. and Natland, M. L., 1952; Emery, K. O. and Shepard, F. P., 1945; Emery, K. O. and Tschudy, R. H., 1941; Fox, L. S., 1930; Fraser, C. MCL., 1943; Goreline, D. S., 1954; Hanna, G. D., 1952; Hoover-Young San Francisco Bay Bridge Commission, 1930; Johnson, M. W., 1948; Johnson, M. W., Everest, F. A. and Young, R. W., 1947; MacDonald, G. A., 1934; M1118, B., 1932c; Moore, D. G., 1951; Norr1s, R. M., 1951; Revelle, R. 1939; Schupp, R. D., 1953; Shepard, F. P., 1936p, 1949b, 1949d; Shepard, F. P. and Emery, K. 0., 1941, 1945; Shepard, F. P. and MacDonald, G. A., 1938; Shumway, G. A., 1953; Trask, P. D., 193la, 1931b, 1939; Uchup1, E., 1954; Vaughan, T. W., 1936; White, Di, 19ll; Woodford, A. O., 1951; ZoBell, C. E., 
$1946 \mathrm{~b}, 1946-1947,1947 \mathrm{~b}$

Shape and Roundness of Gravel, Rock, and Sand (See also: Abrasion of Sediments and Rocks): Anonymous, 1950d; Anderson, G. E., 1926; Beach Erosion Board, 1952a; Во0в, M. F., 1940; Butcher, W. S., 195la; Carsola, A. J. and Dietz, R. S., 1952; Clements, T. and Dane, S. W., 1944; Cohee, G. V., 1938; Dana, S. W., 1942; Dietz, R. S., Emery, K. O. and Shepard, F. P., 1942; Dill, R. F., Dietz, R. S. and Stewart, Н., 1954; Eaton, R., 1951; Emery, K. 0., 1941a, 1946b, 1947b, 1948, 1952; Emery, K. O., Butcher, W. S., Gould, H. R. and Shepard, F. P., 1952; Emery, K. O. and Dietz, R. S., 1941; Emery, K. O. and Gale, J. F., 1951; Emery, K. O. and Gould, H., 1948; Emery, K. O. and Rittenberg, S. C., 1952; Emery, K. O. and Shepard, F. P., 1941, 1945; Emery, K. O. and Tschudy, R. H., 1941; Enmonds, S. F. and Merrill, G. P., 1894; Gorsline, D. S., 1954; Griggs, A. B. and Wells, F. G., 1942; Gulliver, F. P., 1896; Hanna, G. D., 1952; Holzman, J. E., 1950; Inman, D. L., 1949, 1950, 1953b; Krumbein, W. C., 1942, 1947; Ludwick, J. C., Jr., 1950; MacDonald, G. A., 1934; Martens, J. H. C., 1939; Mason, M. A., 1942, 1949a; Merriam, P. D., 1949; Moore, D. G., 1951; Norria, R. M., 1951; Revelle, R., 1950; Revelle, R. and Shepard, F. P., 1939b; Schupp, R. D., 1953; Shaler, N. S., 18'95; Shepard, F. P., 1940b, 1949b, 1949d, 1949e, 1952a; Shepard, F. P. and Emery, K. O., 1941, 1945; Shepard, F. P. and MacDonald, G. A., 1938; Shepard, F. P. and Wrath, W. F., 1937; Sherzer, W. H., 1910; Shumway, G. A., 1953; Sinnott, A., 1941; Smith, W. S. T., 1897; Thompson, W. O., 1934; Twenhofel, W. H, 1946; Uchupi, E., 1954; Wiegel, R. L., Patrick, D. A. and Kimberley, H. L., 1953

Shells, Shell Sand etc. (See also: Carbonates, Coquina, Limestone, Marl, organic Sediments): Anonymous, 1906a; Andrews, H. L., 1945; Arnold, D., 1896; Blake, J., 1868b; California Department of Fish and Game, 1951; California Department of Public Health, 1951; Cohee, G. V., 1938; Crooke, R. C., Elvitsky, A. W., et al, 1953; Dana, S. W., 1942; Dietz, R. S., Emery, K. O. and Shepard, F. P., 1942; Emery, K. O., 1952a, 1952b; Emery, K. O., Butcher, W. S., Gould, H. R. and Shepard, F. P., 1952; Emery, K. O. and Dietz, R. S., 1941; Emery, K. O. and Gould, H., 1948; Emery, K. O. and Tschudy, R. H., 1941; Everest, F. A., Young, R. W. and Johnson, M. W., 1948; Fox, D. L., 1950; Fraser, C. McL., 1943; Galliher, E. W., 1933, 1935a, 1935c, 1937; Grim, R. E., Dietz, R. S. and Bradley, W. F., 1949; HooverYoung San Francisco Bay Bridge Cormission, 1930; Johnson, M. W., 1948; Lawson, A. C., 1894; Louderback, G. D., 1924, 1940; Lowenstam, H. A., 1954; McKee, E. D. 1953; Norris, R. M., 1951; Packard, E. L., 1918; Putnam, J. A., Bermel, K. J. and Johnson, J. W., 1947; Revelle, R., 1950; Revelle, R. and Emery, K. O., 1951; Revelle, R. and Shepard, F. P., 1939b; San Diego Regional Water Pollution Control Board, 1952; Scheffauer, F. C., 1927; Schupp, R. D., 1953; Sears, C. B., 1876; Shepard, F. P., 1940d; Shepard, F. P. and Emery, K. O., 1941; Stevenson, R. E., 1954; Sumner, F. B., Louderback, G. D., Schmitt, W. L. and Johnston, E. C., 1914; Trask, P. D., 1931b; Trask, P. D. and Rolston, J. W., 1950a; Vaughan, T. W., 1933

Banks: Butcher, W. S., 195la; Dietz, R. S., Emery, K. O. and Shepard, F. P., 1942; Emery, K. O., 1948; Emery, K. O., Butcher, W. S., Gould, H. R. and Shepard, F. P., 1952; Emery, K. O. and Dietz, R. S., 1950; Shepard, F. P. and Emery, K. O., 1945; Uchupi, E., 1954

Basins: Emery, K. O. and Rittenberg, S. C., 1952 Beach and Nearshore: Anonymous, 1950d; Barrows, A. L. $\overline{1913 ;}$ Bruff, S. C., 1946; Butcher, W. S., 1951a; Coe, W. R., 1945, 1947; Coe, W. R. and Fox, D. L., 1942; Davis, W. M., 1932; Emery, K. O., 1945a, 1945b, 1946b; Emery, K. O. and Gale, J. F., 1951; Emery, K. O. and Stevenson, R. E., 1950; Hanna, G. D., 1952; Lakes, A., 1903a; McKee, E. D., 1953; Martens, J. H. C., 1939;
Norris, R. M., 1951, 1952; Putnam, W. C., 1938; Shepard, F. P., Inman, D. L. and Fisher, R. L., 1951; Thompson, W. O., 1937

Coastal Sand Dunes: Merriam, P. D., 1949; OlssonSeffer, $\overline{\text { P., }} 1910 \mathrm{a}$

Continental and Insular Shelves: crooke, R. C., Elvitsky, A. W., et al, 1953; Davidson, G., 1897; Emery, K. O., 1952a; Emery, K. O., Butcher, W. S., Gould, H. R. and Shepard, F. P., 1952; Gorsline, D. S., 1954; Inman, D. L., 1950; Moore, D. G., 1951; Norri8, R. M., 1951; Pardee, J. T., 1934; Shepard, F. P., 1932, 194la, 1949b; Shepard, F. P. and Wrath, W. F., 1937

Continental Slope: Hanna, G. D., 1952; Udden, J. A., 1914

Submarine Canyons: Crowell, J. C., 1952; Davidson, G., 1887, 1897; Dietz, R. S., Emery, K. O. and Shepard, F. P., 1942; Norris, R. M., 1951;

Phleger, F. B., 1951; Revelle, R. and Shepard, F. P., 19390; Shepard, F. P., 1932, 1951d

Shells, Siliceous (See also: Diatoms and other Siliceous Organisms): Goldberg, E. D., 1954

Shingle Beach - see Cobble Beach

Shoreline: Anonymous, 1932c, 1938a, 1940b, 1940d; Anderson, F. M., 1896-1902; Bartlett, W. A., 1852; Beach Erosion Board, 1939, 1948a, 1948h, 1948i; Berghaus, H., 1891; Blake, W. P., 1856; Bowers, S., 1890; Brown, E. I., 1939; Bruff, S. C., 1946; Burt, W. V. and Saur, J.'F. T., Jr., 1948; Buwalda, J., 1936, 1948; Congressional Documents, 1953b; Cotton, C. A., 1942; Davidson, G., 1856, 1897; Davis, W. M., 1931, 1932; Diller, J. S., 1915; Emonds, S. F. and Merrill, G. P., 1894; Fairbanks, H. W., 1904; Goldberg, J., 1940; Greenwell, W. E., 1858; Harts, W. W., 1911; Hinds, N. E. A., 1952; Hoover, J. W., 1932a; Inman, D. L., 1953a; Johnson, A. G., 1935; Jones, E. L., 1918; LaFond, E. C., 1939 a (ahoreline changes); Lawson, A. C., 1914, 1924; Leeds, C. T., 1936; Leypoldt, H., 1941b, 1942; Livingston, A., Jr., 1939; Louderback, G. D., 1919; Lucke, J. B., 1938; Mclaughlin, R. P., 1921; MacDonald, G. A., Shepard, F. P. and Cox, D. C., 1947; Marlette, J. W., 1954; Maxson, J. H., 1931, 1932; Morgan, F. A., 1930; Nicholson, G. F., Grant, U. S., Shepard, F. P. and Crowell, J. C., 1946; O'Brien, M. P., 1936a, 1939, 1941; Putnam, W. C., 1937c, 1938 (shoreline changes); Richardson, R. W., 1923; Sanchez, P. C., 1934a; Sanford, J.. J., 1908; Shaler, N. S., 1892;

Shalowitz, A. L., 1953; Shepard, F. P., 1938h (classification of shorelines); Shepard, F. P. and Emery, K. O., 1941; Shepard, F. P. and Inman, D. L., 1949; Smith, P. A., 1938 (also classification of shorelines); Smith, W. D., 1930, 1933a (also classification of shorelines), 1940 (classification of shorelines); Smith, W. S. T., 1900; Thompson, W. O., 1937; Twenhofel, W. H., 1943; Upson, J. E., 1949a, 1951; U. S. Cosst and Geodetic Survey, 1915; Vickery, F. P., 1927a; Walters, L., 1953; Willis, B., 1900; Wittich, E., 1910

Silicates, Silica (See also: Nutrients): Anonymous, $1954 \mathrm{~m}$; Ahlstrom, E. H., 1950; Atwill, E. R., 1941b, 1942; Bigelow, H. B. and Leslie, M., 1930; BrongersmaSander8, M., 1948; Bullock, F. W., 1933; Chesterman, C. W., 1952; Dietz, R. S., Emery, K. O. and Shepard, F. P., 1942; Emery, K. O. and Dietz, R. S., 1950; Emery, K. O. and Rittenberg, S. C., 1951, 1952; Fleming, J. A., Sverdrup, H. U., Ennis, C. C., Seaton, S. L. and Hendrix, W. C., 1945; Fleming, R. H., 1939a; Ford, J. L. C., 1942; Gislén, T., 1943, 1944; Goldberg, E. D., 1954; Grahsm, H. W., 1934; Grahsm, H. W. and Moberg, E. G., 1944; Hewatt, W. G., 1934; Leslie, M., 1928; L1pman, C. B., 1929; McEwen, G. F., 1934a; Michael, E. L., 1921; Moberg, E. G., 1925, 1930c; Moberg, E. G. and Fleming, R. H., 1934; Moberg, E. G. and Harding, H. W., 1933; Natland, M. L., Revelle, R. and Rittenberg, S. C., 1941; Phelps, A., 1937, 1940; Piggot, C. S., 1932, 1944; Revelle, R., 1935, 1937a, 1937b, 1950; Revelle, R. and Emery, K. O., 1951; Scripps Institution of Oceanography, 1953e; Skogsberg, T., 1936; Skogsberg, T. and Phelps, A., 1946; Smith, P. V., Jr., 1954; Stanton, T. E., Jr., 1938; Sverdrup, H. U., 1940g; Sverdrup, H. U. and Staff, 1941; 
Thompson, T. G. and Robinson, R. J., 1932; Trask, P. D., 1939; Vaughan, T. W., 1930b, 1930d, 1932a, 1932c, 1933, 1940; ZoBell, C. E., 1941; ZoBell, C. E., Grant, C. W. and Haas, H. F., 1943 Siliceous Doze - see Doze, General Siliceous Shells - see Shells, Siliceous

Sill of Basins, Banks, Canyons etc.: Atwill, E. R., 1942 (in bay and lagoon): Congressional Documents, 1953b; Crouch, R. W., 1951; Dapples, E. C., 1943; Dawson, E. Y., 1952 (lagoon); Dietz, R. S., 1938; Emery, K. O., 1953a, 1954d; Emery, K. O. and Butcher, W. S., Gould, H. R. and Shepard, F. P., 1952; Emery, K. O. and Shepard, F. P., 1945; Emery, K. O. and Rittenberg, S. C., 1952; Garrison, L. E. and Takasaki, K. L., 1950; Handin, J. W., 1949; Hoots, H. W., 1943; Kuenen, Ph. H., 1947; Lawson, A. C., 1924; Natland, M. L., Revelle, R. and Rittenberg, S. C., 1941; Revelle, R., 1939a, 1950; Revelle, R. and Shepard, F. P., 1939b; Shepard, F. P., 1948c, 1950d, 1950e, 1952a; Shepard, F. P. and Beard, C. N., 1938; Shepard, F. P. and Emery, K. O., 194l; Sverdrup, H. U., 1940d; Vaughan, T. W., 1940; Woodford, A. O., 1951

Silt: Atwill, E. R., 1942 (s1lting in bay and lagoon); Beach Erosion Board, 1952b; Butcher, W. S., 1951a; Crooke, R. C., Elvitsky, A. W., et al, 1953; Congressional Documents, 1940e, 1942; Dietz, R. S., Emery, K. O. and Shepard, F. P., 1942; Elliott, F. E., Tressler, W. L. and Myers, W. H., 1953; Emery, K. O., 1950d; Emery, K. O. and Gould, H., 1948; Emery, K. O. and Natland, M. L., 1952; Ford, J. L. C., 1942; Fox, D. L., I8aac8, J. D. and Corcoran, E. F., 1952; Fries, A. A., 1912; Galliher, E. W., 1935a, 1935c; Grim, R. E., Dietz, R. S. and Bradley, W. F., 1949; Hanna, M. A., 1926; Inman, D. I., 1949, 1950; Lawson, A. C., 1914; Leeds, C. T., 1915; Louderback, G. D., 1940; McEwen, G. F., 1940b; McKee, E. D., 1953; Martin, L. T., 1935; Nelson, J. W., Dean, W. C., Kocher, A. E., Watson, E. B. and Carpenter, E. J., 1920; P1ggot, C. S. and Urry, W. D., 1942; Revelle, R., 1938, 1939a, 1950; Revelle, R. and Emery, K. O., 1951; Revelle, R. and Shepard, F. P., 1939b; Schupp, R. D., 1953; Shepard, F. P., 1949d; Shepard, F. P., Revelle, R. and Dietz, R. S., 1939; Stevenson, R. E., 1954; Sverdrup, H. U., 1939a; Trask, P. D., 1928, 1931a, 1931b, 1934, 1939, 1950; Trask, P. D. and Rolston, J. W., 1950a, 1950b; Udden, J. A., 1914; U. S. Waterways Exper1ment Station, V1cksburg, Miss1ssipp1, 1950; Varney, F. M. and Redwine, L. E., 1937; White, D., 1911; ZoBell, C. E., 1938, 1943, 1947c; ZoBell, C. E. and Feltham, C. B., 1942; ZoBell, C. E., Grant, C. W. and Haas, H. F., 1943

Abyssal: Revelle, R., 1935; Shepard, F. P., 1950a; Urry, W. D. and P1ggot, C. S., 1942 Bank: Butcher, W. S., 1951a; Emery, K.. 0., 1948; Emery, K. O., Butcher, W. S., Gould, H. R. and Shepard, F. P., 1952; Shepard, F. P. and Emery, K. O., 1945; Uchup1, E., 1954

Basin: Dietz, R. S., Emery, K. O. and Shepard, F. P., 1942; Emery, K. O. and Rittenberg, S. C., 1951, 1952; Garr1son, L. E. and Takasak1, K. L., 1950; Grim, R. E., Dletz, R. S. and Bradley, W. F., 1949; Ludw1ck, J. C., Jr., 1950; Revelle, R., 1939b; Revelle, R. and Shepard, F. P., 1939b; Shepard, F. P., 1939d, 1940a, 1941a, 1951d; Shepard, F. P., Revelle, R. and Dietz, R. S., 1939; Trask, P. D., 1931b

Beach and Nearshore: Emery, K. O. and Foster, J. F., 1948; Grant, U. S. and Shepard, F. P., 1940; Purer, E. A., 1942; Shepard, F. P., 1950c; Stevenson, R. E., 1954; Thompson, W. O., 1937; Vaughan, T. W., 1940

Coastal Sand Dunes: Congressional Documents, $1953 \mathrm{~b}$

Continental Shelf: Cohee, G. V., 1938; Dietz, R. S., Emery, K. O. and Shepard, F. P., 1942; Emery, K. O. and Gould, H., 1948; Galliher, E. W., 1935b; Garrison, L. E. and Takasak1, K. L., 1950; Gorsline, D. S., 1954; Grim, R. E., Dietz, R. S. and Bradley, W. F., 1949; Handin, J. W., 1949; Imman, D. L., 1950; MacDonald, G. A., 1934; Moore, D. G., 1951; Pardee, J. T., 1934;
Revelle, R. and Shepard, F. P., 1939b; Shepard, F. P., 1932, 1939b, 1949b, 1949d; Shepard, F. P. and MacDonald, G. A., 1938; Shepard, F. P. and Wrath, W. F., 1937

Continental Slope: Shepard, F. P., 1932

Submarine Canyons: Cohee, G. V., 1938; Congress ional Documents, 1953b; Dill, R. F., Dietz, R. S. and Stewart, H., 1954; Emery, K. 0., Butcher, W. S., Gould, H. R. and Shepard, F. P., 1952; Handin, J. W., 1949; Inman, D. L., 1950; Ludwick, J. C., Jr., 1950; Revelle, R. and Shepard, F. P., 1939b; Shepard, F. P., 1932, 1933c, 1948b, 1950a, 1950d, 195la; Shepard, F. P. and Emery, K. O., 1941; Shepard, F. P. and Inman, D. L., 1949; Shepard, F. P., Revelle, R. and Dietz, R. S., 1939; Shepard, F. P. and Wrath, W. F., 1937; Toit, A. L. du, 1940

Siltstone (See also: Rock, Sedimentary Rock): Chesterman, C. W., 1952; Cohee, G. V., 1938; Gorsline, D. S., 1954; Hanna, G. D., 1951, 1952; Moore, D. G., 1951; Shumway, G. A., 1953; Uchup1, E., 1954

S1lver: P1ggot, C. S., 1932, 1944; Thompson, T. G. and Robinson, R. J., 1932; Tresk, P. D., 1939; Vaughan, T. W., 1933

Skewness: Dapples, E. C., 1942; Emery, K. O. and Gould, H. R., 1948; Garrison, L. E. and Takasak1, K. L., 1950; Inman, D. L., 1950; Scripps Institution of Oceanography, 1953c; Trask, P. D., 1932a Abyssal: Emery, K. O., 1954b

Bank: Emery, K. O., 1954b; Holzman, J. E., 1950 Basin: Emery, K. 0., 1954b; Ludwick, J. C., Jr., $\overline{1950}$ (sorting vs. skewness; medium diameter vs. skewness)

Beach and Nearshore: Beach Eros1on Board, 1953c, 1954b; Emery, K. O., 1954b; Inman, D. L., 1949 , 1950, 1953b; Keller, W. D., 1941; Sinnott, A., 1941; Trask, P. D., 1952a; Trask, P. D. and Scott, T., 1954; Twenhofel, W. H., 1946 Coastal Sand Dunes: Emery, K. 0., 1954b; Keller,

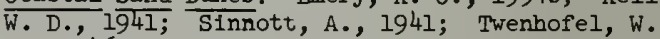
H., 1946

Conținental Shelf: Dill, R. F., 1952; Emery, K. O., 1954b; Inman, D. L., 1950; MacDonald, G. A., 1934; Miller, R. L., 1954; Moore, D. G., 1951 Continental Slope: D111, R. F., 1952; Emery, K. $0 ., 1954 \mathrm{~b}$

Submarine Canyons: Cohee, G. V., 1938

Slack Water - see Pollution, Reducing or Anaerob1c Environment, Stagnant Water

Slate (See also: Metamorphic Rock, Rock): Cohee, G. V., 1938; Emery, K. O. and Shepard, F. P., 1945; Shepard, F. P. and MacDonald, G. A., 1938

Slope - see Beach and Nearshore, Continental Shelf, Continental Slope, Submarine Canyons

Slopes - see Escarpment

Slough - see Swamp

Slumping - see Submarine Canyons, origin of; Submarine Slumping

Snapper Samples (See also: Cores and Coring, Dredging): Butcher, W. S., 195la; Carsola, A. J., Dletz, R. S., 1952; Carsola, A. J., Dletz, R. S. and Russell, R. D., 1949; Crouch, R. W., 1954; Dietz, R. S., 1954; Dietz, R. S., Emery, K. O. and Shepard, F. P., 1942; Emery, K. 0., 19470, 1948; Emery, K. O. and Dietz, R. S., 1950; Emery, K. O. and Gould, H., 1948; Emery, K. O. and Shepard, F. P., 1945; Garrison, L. E. and Takasak1, K. L., 1950; Holzman, J. E., 1950; Moore, D. G., 1951; Revelle, R., 1950; Revelle, R. and Shepard, F. P., 1939b; Shepard, F. P., 1950e; Shepard, F. P. and Emery, K. O., 1941; Sverdrup, H. U. and Staff, 1941; Trask, P. D., 1931b; Uchup1, E., 1954

Sodium: Galliher, E. W., 1935a; Kelley, W. P. and Lieblg, G. F., Jr., 1934; L1pman, C. B., 1929; McEwen, G. F., 1934a; McKee, E. D., 1953; Revelle, R., 1935, 1941; Revelle, R. and Emery, K. O., 1951; Stanton, T. E., Jr., 1938; Sverdrup, H. U. and Staff, 1942a ( $\left.\mathrm{Na}_{2} \mathrm{CO}_{3}\right)$; Thompson, T. G. and Robingon, R. J., 1932; Vaughan, T..W., 1940; Veach, J. A., 1859

Solution, Resolution, Desolving of Rocks, Sediments etc. (Also see: Regeneration): Allen, W. E., 194la (solution and decomposition of dinoflagellates); 
Emery, K. O., 1941b, 1946b; Emery, K. 0.

and Rittenberg, S. C., 1952; Sverdrup, H. U., 1940g; Williams, W., 1948

ollution Basins (See also: Minor Features, Rocky Cossts; Tide Pools): Emery, K. O., 1946b; Williams, W., 1948

Sorting (See also: Skewness): California, university of, 1954b; Dana, S. W., 1942; Emery, K. O., 1950d, 1954b; Emery, K. O. and Dietz, R. S., 1941; Emery, K. O. and Gould, H. R., 1948; Emery, K. O., Tschudy, R. H., 1941; Galliher, E. W., 1935c; Garrison, L. E. and Takasaki, K. L., 1950; Inman, D. L., 1950; Kuenen, Ph. H. and Menard, H. W., 1952; Lesser, R. M., 1951; Louderback, G. D., 1920, 1940; McKee, E. D., 1953; Menard, H. W., 1952; Norris, R. M., 1951; Revelle, R., 1935, 1939; Revelle, R. and Shepard, F. P., 1939b; Scripps Institution of Oceanography, 1953c; Stevenson, R. E., 1954; Trask, P. D., 1931b, 1932a; Ud̊den, J. A., 1914; ZoBell, C. E., 1938 Abysвal: Emery, K. O., 1954b; Revelle, R., 1935; Bank: Emery, K. O., 1954b; Bmery, K. O., Butcher, W. S., Gould, H. R. and Shepard, F. P., 1952; Holzman, J. E., 1950; Uchupi, E., 1954

Basin: Emery, K. O., 1954b; Emery, K. O. and Rittenberg, S. C., 1952; Grim, R. E., Dietz, R. S. and Bradley, W. F., 1949; Ludwick, J. C., Jr., 1950 (sorting vs. skewness) (sorting vs. medium diameter); Shepard, F. P., 1951d; Trask, P. D., $1931 \mathrm{~b}$

Beach and Nearshore: Bascom, W. N., 1950c; Beach Erosion Board, 1948i, 1953c, 1954b; Bullard, F. M. and Mills, R. A., 1951; California, University of, 1952a; Dietz, R. S., 1947b; Emery, K. 0., $1946 \mathrm{~b}, 1954 \mathrm{~b}, 1954 \mathrm{c}$ (gravel); Emery, K. O. and Foster, J. F., 1948; Emery, K. O. and Stevenson, R. E., 1950; Hall, J. V., Jr., 1952; Handin, J. W., 1949; Handin, J. W. and Ludwick, J. C., 1949; Inman, D. L., 1949, 1950, 1953a, 1953b; Isaac8, J. D. and Bascom, W. N., 1947; Keller, W. D., 1941; Krumbein, W. C., 1947, 1950; Lang, H., 1916; McKee, E. D., 1953; Marlette, J. W., 1954; Martens, J. H. C., 1939; Mason, M. A., 1942; Nicholson, G. F., Grant, U. S., Shepard, F. P. and Crowell, J. C., 1946; Norris, R. M. 1951; Olsson-Seffer, P.., 1910a; Pardee, J. T., 1934; Schupp, R. D., 1953; Shepard, F. P., 1936a; Shepard, F. P., Inman, D. I. and Fisher, R. L., 1951; Sherzer, W. H., 1910; Shuler, W. R., 1951; Sinnott, A., 1941; Thompson, W. O., 1937; Trask, P. D., 1924, 1952a; Trask, P. D. and Scott, T., 1954 (also sorting vs. medium diameter); Twenhofel, W. H., 1946; Wiegel, R. L., Patrick, D. A. and Kimberley, H. L., 1953; Woodford, A. O., 1935

Coastal Sand Dunes: Emery, K. O., 1954b;

Gorsline, D. S., 1954; Handin, J. W., 1949;

Keller, W. D., 1941; Merr1am, P. D., 1949;

0lsson-Seffer, P., 1910a; Sinnott, A., 1941; Thompson, W. O., 1937; Twenhofel, w. H., 1946 Continental and Insular Shelves: D11l, R. F., 1952; Emery, K. 0., 1954b; Gorsline, D. S., 1954; Inman, D. L., 1950; MacDonald, G. A., 1934; Marlette, J. W., 1954; Moore, D. G., 1951; Norr18, R. M., 1951; Shepard, F. P., $1940 \mathrm{c}, 1941 \mathrm{a}$, (Insular), 1941b; Shepard, F. P. and MacDonald, G. A., 1938; Shepard, F. P. and Wrath, W. F., 1937 (Insular); Udden, J. A., 1914 Continental Slope: Dill, R. F., 1952; Emery, K. $0 ., 1954 \mathrm{~b}$

Submarine Canyons: Cohee, G. V., 1938; Dill, R. F., Dletz, R. S. and Stewart, H., 1954; Inman, D. L., 1950; Ludwlck, J. C., 1950; Marlette, J. W., 1954; Phleger, F. B., 1951; Shepard, F. P., $1948 \mathrm{~b}, 1951 \mathrm{~d}$

Sound (See aløo: Geophysics and Geophyaical Surveys): Anderson, E. R., 1950; Boden, B. P., 1950; Cal1fornia Academy of Sciences, California Division of Fish and Game, Scripps Institution of Oceanography of the University of Califoruia, and U. S. Fish and Wildlife Service, 195la; California, University of, 1942, 1943, 1946a, 1946b, 1946c; Crooke, R. C., Elvitsky, A. W. et al, 1953; Dletz, R. S., 1948, 1952a; Dyk, K. and Swainson, W. O., 1953; Ennis, C. C., 1934; Everest, F. A., Young, R. W. and Johnson, M. W., 1948; Fish, M. P., 1949; Fleming, J. A. and Sverdrup, H. U., Ennis, C. C., Seaton, S. L. and Hendrix, W. C., 1945; Heck, N. H. and Service, J., 1926; Holtsmark, B. E., 1949; Johnson, M. W., 1948; Johnson, M. W., Everest, F. A. and Young, R. W., 1947; Knox, R. W., 1930; Knudsen, V. O., Alford, R. S. and Emling, J. W., 1948; LaFond, E. C., 1949; Marshall, N. B., 1951; Menard, H. W. and Dietz, R. S., 1951; Munk, W. H., 1947a; Patton, R. S., 1930; Raitt, R. W., 1948, 1954; Revelle, R., 1943; Rude, G. T., 1933, 1934; Seur, J. T. F., Jr., 1950; Scripps Institution of Oceanography, 1952h, 1953b, 1953g; Shepard, F. P., 1950e; Soule, F. M., 1934, 1944a; Swainson, 0. W., 1936; Swainson, O. W., McIlwraith, C. G. and Dyk, K. 1934; Tucker, G. H., 1951; Walford, L. A., 1951 Source Beds for Petroleum (See also: Petroleum, origin of); Anderson, R., 1927; Branner, J. C., 1913; Gester, G. C., 1927; Trask, P. D., 1930, 1931b, 1934, 1936; Trask, P. D., Hammar, H. E. and Wu, C. C., 1932; Trask, P. D. and Patnode, H.W., 1942; ZoBell, C. E., 1943, 1944

Source Rocks (See also: Bedrock, Transport of Rock): Uchupi, E., 1954

Source Sediments: Butcher, W. S., 195la; Buwalda, J. P., 1948; Crowell, J. C., 1952; Emery, K. O., Butcher, W. S., Gould, H. R. and Shepard, F. P., 1952; Emery, K. O. and Rittenberg, S. C., 1952; Gilbert, G. K., 1917; Ludwick, J. C., Jr., 1950; Morrison, R. L., 1930; Phleger, F. B., 1951; Revelle, R., 1937a; Revelle, R. and Shepard, F. P., 1939b; Scripps Institution of Oceanography, 1953e; Shepard, F. P., 1937f, 1951d; Stevenson, R. E., 1954; U. S. Waterways Experiment Station, V1cksburg, Miss18sippi, 1950

Abysaal: Goldberg, E. D., 1954; Revelle, R., 1936,1944

Beach and Nearshore: Anonymous, 1938a, 1940d; Beach Erosion Board, 1939, 1948a, 1948h, 1948i, 1949a, 1952a, 1952b, 1953c, 1954a; Blackman, J. W. B., 1936; Brown, C. B., 1942; Brown, E. I., 1939; Buwalda, J., 1936; Callfornia, University of, 1952a, 1952b, 1952c, 1952d, 1953a, 1953b; Congressional Documents, 1938a, 1940a, 1942b, 1949f, 1953b; Crowell, J. C., 1952; Darrow, W. E., 1942; Eaton, R. O., 1951; Einstein, H. A., 1951; Goldberg, J., 1940; Gorsline, D. S., 1954; Grant, U. S. and Shepard, F. P., 1937, 1938b; Griffin, D. F., 1944; Gr1gge, A. B. and Wells, F. G., 1942; Hall, W. C., 1942; Handin, J. W., 1949, 1951; Handin, J. W. and Ludwick, J. C., 1949; Hannum, W. T., 1947; Harts, W. W., 1911; Hornor, R. R., 1918; Horton, D. F., 1948; Inman, D. L., 1949, 1953a, 1953b; Johnson, A. G., 1940c; Krumbein, W. C., 1947, 1950; Krumbein, W. C. and Ohsiek, L. E., 1950; Lang, H., 1916; Leeds, C. T., 1916, 1936; Leypoldt, H., 1941a; Lindsay, D. R., 1952; Livingston, A., Jr., 1939; Los Angeles County Regional Planning Commission, 1940; McAfee, C. M., Jr., 1939; Mason, M. A., 1942, 1949a, 1950a; Nicholson, G. F., Grant, U. S., Shepard, F. P. and Crowell, J. C., 1946; Norris, R. M., 1951; O'Brien, M. P., 1936a, 1936b, 1939; Page, G. B., 1950; Pardee, J. T., 1934; Schupp, R. D., 1953; Shepard, F. P., 1947b, 1950c, 1950g; Shepard, F. P. and Inman, D. L., 1951b; Shepard, F. P., Inman, D. L. and Fisher, R. L., 1951; Schuler, W. R., 1951, 1952; Sinnott, A., 1941; Symons, T. W., 1893; Thompson, W. O., 1937; Tower, M. L., 1910; Trask, P. D., 1952b; Twenhofel, W. H., 1943, 1946; Wiegel, R. L., Patr1ck, D. A. and Kimberley, H. L., 1953

Coastal Sand Dunes: Blake, W. P., 1853; Diller, J. S., 1898 ; Gor8line, D. S., 1954; L1vingston, A., Jr., 1939; 0188on-Seffer, P., 1910a

Source Water of Basins: Emery, K. 0., 1954 a

Specific Gravity (water except where noted): Anonymous, 1938a and 1940d (sediment); Allen, W. E., 1923b; Beach Erosion Board, 1942a (sediment); Congressional Documents, 1938a and 1940a (sediment); Lipman, C. B., 1929; McEwen, G. F., 1919a; M1chael, E L. and McEwen, G. F., 1915, 1916; Revelle, R. and Emery, K. O., 1951 (sediment); Schulz, B., 1914; 
Sumner, F. B., Louderbeck, G. D., Schmitt, w. L. and Johnston, E. C., 1914; Tanner, Z. L., 1892a

1893; U. S. Commise1on of F1sh and F1sheries, 1898

Specific Volume: Montgomery, R. B. and wooster, W. S., 1954 Spherlcity - see Shape and Roundness

Splculite (See also: Rock): Emery, K. O. and Shepard, F. P., 1945

Sp1t: Arnold, J. J., 1928; Atw111, E. R., 1942; Bruff, S. C., 1946; Buwalda, J., 1936; Congresesional Documents, 1908e, 1938c, 1941, 1949d; Davidson, G., 1873c; Davis, W. M., 1932; D1etz, R. S., 1947b; Grant, U. S., 1938, 1940, 1944; Grant, U. S. and Shepard, W. E., 1939; Gull1ver, F. P., 1896; Handin, J. W., 1949, 1951; Hanna, M. A., 1926; Harria, F. R. and Harlow, E. H., 1948; Harts, W. W., 1901, 1911; Hawgood, H., 1914; Hinds, N. E. A., 1952; Inmen, D. L., 1949; Iraacs, J. D., 1945d; Isaacs, J. D. and Bascom, W. N., 1947; Johnson, A. G., 1940c; Kemnitzer, L. E., 1933; Kniffen, F. B., 1932; Krumbe1n, W. C. and Ohs1ek, L. E., 1950; Leeds, C. T., 1936; Leeds, C. T., Vanon1, V. A. and Knapp, R. T., 1934; Leypoldt, H., 1941b; Livingaton, A., Jr., 1939; Mendenhail, W. C., 1905; N1cholson, G. F., Grant, U. S., Shepard, F. P. and Crowell, J. C., 1946; Norr18, R. M., 1951, 1952; Olsson-Seffer, P., 1910a; Orange County Planning Commisa1on, 1941; Pardee, J. T., 1934; Pease, W. H., 1868; Purer E. A., 1942; R1chardson, R. W., 1923; Shepard, F. P., 1950c, 1952b; Shepard, F. P. and Emery, K. O., 1941; Shepard, F. P. and Inman, D. L. 1951a; Sm1th, W. D., 1933b, 1933c; Stevenson, R. E., 1954; Storie, R. E. and Carpenter, E. J., 1930; Thompson, W. O., 1937; Tower, M. L., 1910, 1913; Wh1ttemore, G. F., 1916, 1917, 1926

"Sporbo" (Also see: Iron Sulfides, Pyrite): Galliher, E. W., $1932 b$

Spout Holes - see Minor Features, Rocky Cossts Springs - see Submarine 011 and Gas Seeps, Submarine Springe Stability - see Equilibrium

Stagnant Water, Stagnant or Toxic Conditions, Slack water (See also: Eh, Hydrogen Sulfide, Pollution, Reducing or Anaerobic Environment, various factors bringing about atagnant conditions, 1.e. bacteria etc.): Allen, W. E., 1945; Bullock, F. W., 1933; Callfornla Department of Public Bealth, 1951; Dall, W. H., 1911; Dapples, E. C., 19k2; D1etz, R. S., 1952a; Dletz, R. S., Emery, K. O. and Shepard, F. P., 1942; Emery, K. O., 1952b, 1953a, 1954d; Emery, K. O. and Rittenberg, S. C., 1952; Evans, R. D., Kip, A. F. and Moberg, E. G., 1938; Fox, D. L., Updegraff, D. M. and Novell1, G. D., 1944; Hall, J. V., Jr., 1952; Hoots, H. W., 1943; Krumbe1n, W. C., 1942; McEwen, G. F., 1950; Moberg, E. G. and Allen, W. E., 1927; Moore, D. G., 1951; Morr1son, R. L., 1930; Revelle, R. and Shepard, F. P., 1939b; San Diego Regional Water Pollution Control Board, 1952; Sverdrup, H. U., 1940g; Thompson, T. G. and Robinson, R J., 1932; Trask, P. D., 1939; Weber, B. V., 1946; Weeks, L. G., 1952; White, D., 1911; ZoBell, C. E., 1936, 1937, 1938, 1939, 1941, 1942b, 1943, 1944, 1947c, 1947d, 1950; ZOBell, C. E. and Anderson, D. Q., 1936; ZoBell, C. E., Grant, C. W. and Haas, H. F., 1943

Standard Deviation (See also: Skewness): Scripps Institution of Oceanography, $1953 \mathrm{c}$

Stone Lace - see Minor Features, Rocky Coasts

Storms (see also: Meteorology and Climate): Anonymous, 1894a, 1915 , 1916a, 1916b, 1916a, 1925b, 1938a, 1940b, 1940c, 1940d, 1941b, 1951d, 1952f; Ahlstrom, E. H., 1950; Allen, w. B., 1932; All18on, J. M., 1940; Andrews, H. L., 1945; Army A1r Forces, weather Information Branch, 1943; Bache, A. D., 1856e, 1862; Bascom, W. N., 1946b, 1947c, 1950b, 1950c; Batea, C. C. and Glenn, A. H., 1948; Beach Erosion Board, 1942a, $1948 \mathrm{~b}, 1948 \mathrm{~h}, 1951,1952 \mathrm{~b}, 1953 \mathrm{a}, 1953 \mathrm{c}$; Beals, E. A., 1919; . Bell, w. E., Baseler, F. F., Buck, F. E., Murphy, D. E., Writt, J. J. and Beauchamp, E. E., 1944; Blake, D., 1935; Blinn, F. S., 1928; Bond, A. H., 1927; Brown, E. I., 1939; Brown, S. C., 1946; Bucher, W. H., 1940; California, University of, 1952a, 1952b, 1952c; Campbell, M. R., 1915; Chase, J. L., 1948; Congress1onal Documents, $1880 \mathrm{c}, 1908 \mathrm{e}, 1938 \mathrm{a}, 1940 \mathrm{e}, 1940 \mathrm{~b}, 1940 \mathrm{c}$,
$1941,1942 b, 1943,1949 b, 1949 c, 1949 d, 1949-1950 b$, 1949f, 1953a, 1953b; Cram, C. M., 1931; Crooke, R. C., Elvitaky, A. W., et al, 1959; Darrow, W. E., 1942; Datz, M. and Others, 1953; Dav1 8, W. M., 1932, 1933, 1934; Deacon, G. E. R., 1949; Donn, W. L., 1954; Dunkle, M. B., 1944; Eaton, R. O., 1951; Emery, K. 0., 1948, 1953b; Emery, K. O. and Foster, J. F., 1948; Emery, K. 0. and Techudy, R. H., 1941; F1sher, R. L. and Mills, R., 1952; Frledman, S. L., 1949; Fries, A. A., 1912; Galllard, D. D., 1904; Gilbert, G. K., 1917; Goldberg, J., 1940; Gorton, A. F., 1930a, 1930b; Grant, U. S., 1938; Grant, U. S. and Sheperd, F. P., 1937, 1938a, 1938b, 1940; Gull1ver, F. P., 1896; Gutenberg, B., 1933, 1953; Haase, L. G. 1926; Hall, J. V., Jr., 1952; Hall, W. C., 1941,

1942; Handin, J. W., 1949; Harts, W..W., 1901,

1911; Hickson, R. E. and Rodolf, F. W., 1951;

Hoover-Young San Francisco Bay Bridge Commission,

1930; Horrer, P. L., 1948b, 1950; Hughes, R. T.,

1947; Hurd, W. E., 1942; Inman, D. L., 1949,

1953a, 1953b; Iraace, J. D. and Bascom, W. N.,

1947; Iraacs, J. D. and Saville, T., Jr., 1948; Johnson, A. G., 1935, 1940c, 1951; Johnson, D. W., 1910; Johnson, J. W., 1948b, 1949; Johnson, J. W. and Iraacs, J. D., 1948; Jonea, E. L., 1918; Kaplan, K. and Pape, H. E., Jr., 1951; Kemnitzer, L. E., 1933; Kniffen, F. B., 1932 (1n Gulf of California); Krumbein, w. C., 1947, 1950; Kuenen, Ph. H., 1947; Kuenen, Ph. H. and Menard, H. W., 1952; Lang, H., 1916; Lawton, C. H., 1936; Leeds, С. T., 1915, 1916, 1936; Leypoldt, H., 1937b, 194la; Lleber, A. C., Jr., 1940; Los Angeles County Regional Planning Commiasion, 1940; Livingaton, A., Jr., 1939; Lowell, F. L L L., 1915a; McEwen, G. F., 1935a, 1935b; McEwen, G. F. and Staff, 1948; McGee, w. J., 1900; McGowan, W. C., 1916; McKee, E. D., 1953; McOuat, H. W., 1951; MacDonald, G. A., 1934; Marlette, J. W., 1954; Mason, M. A., 1942 , 1949b, 1950a, 1950b; Means, T. H., 1929; Moffitt, J. and orr, R. T., 1938; Morrieon, R. L., 1930 (estuary); Munk, W. H., 1952; Munk, W. H. and Arthur, R. S., 1952; N1cholson, G. F., Grant, U. S., Shepard, F. P. and Crowell, J. C., 1946; O'Brien, M. P., 1936a, 1936b, 1939, 1941, 1947b; Olsson-Seffer, P., 1910a; Orange county Planning Commiseion, 1941; Page, G. B., 1950; Palmer, A. H., 1917; Pardee, J. T., 1934; $\mathrm{P}^{\prime}$ e1 C., 1929; Purer, E. A., 1942; Putnam, J. A., 1947; Putnam, w. C., 1940; Rawn, A. M. and Bowerman, F. R., 1951; Revelle, R. and Shepard, F. P., 1939b; Richardson, R. W., 1923; Rollend, M. C., 1952; Rosвer, W. H., 1870; Sanchez, P. C., 1934e; Senford, J. J., 1908; Schupp, R. D. 1953; Scr1ppe Institution of Oceanography, 1944c, 1944h, 1945b, 19521; Sears, C. B., 1876; Shepard, F. P., 1935d, 1936r, 1938b, 1938c, 1938f, 1940c, 1941a, 1947b, 1950c, 1950g; Shepard, F. P. and Emery, K. 0., 1941, 1945; Shepard, F. P. and Grant, U. S., 1947; Shepard, F. P. and Inman, D. L., 1951b; Shepard, F. P. and LaFond, E. C., 1940; Shepard, F. P. and Sayner, D. B., 1953; Shepard, F. P. and wrath, W. F., 1937; Shipmasters and others, 1879; Shuler, W. R., 1951, 1952; Sinnott, A., 1941; Skeats, E. M., 1923; Smith, C. D., Jr., 1950; Smith, W. D., 19338; Stevenвon, R. E., 1954; Stump, R. S., 1946a, 1946c; Stump, R. S. and Hermaneon, R. T., 1945b; Sverdrup, H. U. and Staff, 1941, 1942a; Swinnerton, A. C., 1927; Symons, T. W., 1893; Sweeney, J., 1930; Tanner, Z. L., 1892b; Thompson, w. O., 1937; T1lden, C. A., 1925; Todd, D. K. and Wiegel, R. L., 1951, 1952; Tower, M. L., 1910; Trask, P. D., 1952a; Troxell, H. C. and Others, 1942; U. S. Hydrograph1c off1ce, 1875; Vaughan, T. W., 1940; Verrill, G. E., 1940; Wh1tney, P. C., 1935; Wh1ttemore, G. F., 1916, 1928; W1egel, R. L. and Kimberley, H. L., 1950; wlegel, R. L., Patrick, D. A. and Kimberley, H. L., 1953; Wlegel, R. L., Todd, D. K. and Kimberley, H. L., 1950; Yale, C. G., 1879; Yate日, L. G., $1890 \mathrm{c}$

Stratification - see Lamination

Stratification, water: California, University of, 1946a; Leipper, D. F., 1950; Menard, H. W. and Ludwick, 
J. C., 1951 (density stratification); Natland,

M. L., Revelle, R. and Rittenberg, S. C., 1949

(density stratification); Revelle, R. and Shepard, F. P., 1939b; Shepard, F. P. and Emery, K. O. 1941; Sverdrup, H. U., 1934; Sverdrup, H. U. and Staff, 1941 (density stratification); Young, R. T., Jr., 1939 (density stratification)

Streams, Rivers: Anonymous, 1933a, 1933b, 1938a, 1940b, 1940d, 1951b; Allen, W. E., 1920, 194la; Anderson, C. A., 1950; Arnold, J. L., 1928; Ashley, G. H., 1931; Bache, A. D., 1852, 1862; Barrows, A. L., 1917; Beach Erosion Board, 1939, 1948b, 1948h, 1948i, $1949 \mathrm{a}, 1952 \mathrm{~b}, 1953 \mathrm{a}, 1953 \mathrm{c}, 1954 \mathrm{a}, 1954 \mathrm{c}$; Benest, H., 1899; Blackman, J. W. B., 1936; Blake, J., $1868 \mathrm{~b}$; Blinn, F. S., 1928; Boos, M. F., 1940; Bruff, S. C., 1940, 1946; Bullard, F. M. and Mills, R. A., 1951; Butcher, W. S., 195la; Buwalda, J., 1936; California Department of Public Works, 1932a, 1932b; California, University of, 1952b, 1952c; Carpenter, E. J. and Storie, R. E., 1929; Cartwright, L. D., Jr., 1928; Clements, T. and Dana, S. W., 1944; Cohee, G. V., 1938; Congressional Documents, $1908 \mathrm{f}, 1934 \mathrm{a}, 1936,1938 \mathrm{a}, 1938 \mathrm{c}, 1940 \mathrm{a}, 1940 \mathrm{~b}$, $1940 \mathrm{e}, 1942 \mathrm{a}, 1942 \mathrm{c}, 1949 \mathrm{a}, 1949 \mathrm{e}, 1950 \mathrm{a}, 1953$; Copeland, C. A., 1933; Crandall, H., 1915; Crooke, R. C., Elvitaky, A. W., et al, 1953; Crowell, J. C., 1950, 1952; Dall, W. H., 1911; Darrow, W. E., 1942; Davidson, G., 1856, 18́73c, 1897; Davis, W. M., 1932, 1933; Dietz, R. S., Emery, K. 0. and Shepard, F. P., 1942; Dill, R. F., 1952; Diller, J. S., 1903; Eaton, R. O., 1951; Einstein, H. A., 1951; Elliott, F. E., Tressler, W. L. and Myers, W. H., 1953; Emery, K. O., 1950d, 1952a, 1954b, 1954c; Emery, K. O., Butcher, W. S., Gould, H. R. and Shepard, F. P., 1952; Emery, K. O. and Shepard, F. P., 1945; Ewlng, G. C., 1950c; Falrbanks, H. W., 1904; Fox, C. K., 1936; Fox, D. L., 1950; Fox, D. L., Isaacs, J. D. and Corcoran, E. F. 1952; Galliher, E. W., 1935a; Gllbert, G. K., 1917; Goldberg, J., 1940; Gordon, J. H., 1923; Grant, U. S., 1940, 1944, 1946; Grant, U. S. and Shepard, F. P., 1937, 1938a, 1938b; Grant, U. S. and Sheppard, W. E., 1939 (stream erosion); Grunsky, C. E., 1907; Gulliver, F. P., 1896; Gutenberg, B., 1941b; Hall, W. C., 1942; Hall, W. H., 1886; Handin, J. W., 1949; Handin, J. W. and Ludwick, J. C., 1949; Hinde, H. P., 1952; Hinds, N. E. A. 1952; Hobbs, W. H., 1921; Holway, R. S., 1914; Horton, D. F., 1948; Hyatt, E., 1935; Inman, D. L., 1949, 1950, 1953a; Isaacs, J. D. and Bascom, W. N., 1947; Ives, R. L., 1951; Jarvis, C. S., 1921; Johnson, A. G., 1940; Johnson, D., 1944; Johnson, W. M., 1855; Kenyon, E. C., Jr., 1951; Kindle, E. M., 1934; Kniffen, F. B., 1929, 1931, 1932; Krumbein, W. C., 1947; Lawson, A. C., $1893 \mathrm{a}, 1893 \mathrm{~b}, 1894,1914,1950$; Lawson, L. M. 1950; LeConte, J., 1891; Leeds, C. T., 1915, 1936; Leeds, C. T., Vanon1, V. A. and Knapp, R. T., 1934; Livingston, A, Jr., 1939; Louderback, G. D., 1940, 1941; Ludwick, J. C., Jr., 1950; McArthur, W. P., 1850; McEwen, G. F., 1940b; McKee, E. D., 1939; MacGinit1e, G. E., 1935; Marlette, J. W., 1954; Maxson, J. H., 1931, 1932; Means, T. H., 1928, 1931; Menard, H. W. and Ludwick, J. C., 1951; Moore, D. G., 1951; Morrison, R. L., 1930; Nelson, J. W., Dean, W. C., Kocher, A. E., Watson, E. B. and Carpenter, E. J., 1920; Nelson, J. W., Zinn, C. J., Strahorn, A. T., Watson, E. B. and Dunn, J. E., 1919; N1cholson, G. F., Grant, U. S., Shepard, F. P. and Crowell, J. C., 1946; Norris, R. M., 1951; O*Brien, M. P., 1936a, 1939; Orange County Planning Commission, 1941; Page, G. B., 1950; Palmer, R. H., 1928; Place, J. L., 1952; Purer, E. A., 1942; Putnam, W. C., 1937c, 1938; Reagan, J. W., 1915; Revelle, R., 1938, 1950; Revelle, R. and Shepard, F. P., 1939b; Richardson, R. W., 1923; Robertson, R. R., 1942; Sanchez, P. C., 1934b, 1934c; San Franc1sco Bay Marine Plling Committee, 1921; Schupp, R. D., 1953; Sears, C. B., 1876; Shaler, N. S., 1895; Shepard, F. P., 1932, 1937b, 1937f, 1941a, 1949d, 1950b, 1950c, 1950e, 1950f, 1952a; Shepard, F. P. and Beard, C. N., 1938; Shepard, F. P. and Emery, K. 0., 1941; Shepard, F. P. and Inman, D. L., 1951b; Shepard, F. P., Inman, D. L. and Fisher, R. L., 1951;
Shepard, F. P. and MacDonald, G. A., 1938; Shepard, F. P. and Stetson, H. C., 1939; Shuler, W. R., 1951; Smith, W. S. T., 1897, 1902; Spencer, J. W., 1890; Stevenson, R. E., 1954; Storie, R. E. and Carpenter, E. J., 1929; Sumner, F. B., Louderback, G. D., Schmitt, W. L and Johnston, E. C. 1914; Sverdrup, H. U., 1938c; Swain, F. E., 1951; Thompson, W. O., 1937; Toit, A. L. du, 1940; Trask, P. D., 1939, 1952b; Trask, P. D. and Rolston, J. W., 1950a; Troxell, H. C. and Others, 1942; Twenhofel, W. H., 1943, 1946; Udden, J. A., 1914; Upham, W., 1899; Upson, J. E., 1949a; U. S. Waterways Experiment Station, Vicksburg, M1ssissipp1, 1935, 1950; Vickery, F. P., 1927a, 1927b; White, D., 1911; Whiting, W. D. and Others, 1858; Whittemore, G. F., 1928; Wiegel, R. L., Patrick, D. A. and Kimberley, H. L., 1953; Wilson, M. E., 1907; Wood, H. O., 1915; Woodford, A. O., 1951; Wright, R., 1937; Yale, C. G., 1879; ZoBell, C. E., 1947 d

Strike and Dip: Fox, L. S., 1930; Menard, H. W., D11l, R. F. et al, 1954

Stront1um: Lowenstam, H. A., 1954 (also Sr/Ca); McEwen, G. F., 1934a; Revelle, R. and Emery, K. 0., 1951; Thompson, T. G. and Robinson, R. J., 1932; Vaughan, T. W., 1933

Submarine Cables - see Engineering

Submarine Pipelines - see Engineering

Submarine Slopes - see Escarpments

Submarlne Canyon, Sea Valley, Drowned Valley, Mock Valley (See also: Rift Valley): Anonymous, 1927, 1939, 1940d, 194la; Allen, W. E., 194la; Aver1li, C. V. and Others, 1946; Beach Erosion Board, 1948h, $19481,1948 \mathrm{j}, 1949 \mathrm{c}, 1952 \mathrm{~b}, 1953 \mathrm{c}, 1954 \mathrm{a}, 1954 \mathrm{~b}$; Bell, Н. S., 1942; Benest, Н., 1899; Bigelow, Н. B. and Leslie, M., 1930; Bruff, S. C., 1946; Bucher, W. H., 1940; Buffington, E. C., 1951, 1952; Bullard, E. C., 1940; Burt, W. V. and Saur, J. F. T., Jr., 1948; Butcher, W. S., 1951 a (sea valley); Carsola, A. J. and Dietz, R. S., 1952; Carter, G. F., 1948; Clements, T. and Emery, K. 0., 1947; Cohee, G. V., 1938; Colbert, L. O., 1939; Congressional Documents, 1940a, 19491950b, 1953b; Crandall, H., 1915; Crowell, J. C., 1950, 1952; Darrow, W. E., 1942; Dav1d, L., 1947; Dev1dson, G., 1887, 1897; Dev1s, W. M., 1932, 1933; Dietz, R. S., 1947b, 1952a, 1952b, 1953, 1954; Dietz, R. S. and Emery, K. O., 1938a; Dietz, R. S., Emery, K. O. and Shepard, F. P., 1942; Dietz, R. S. and Menard, H. W., 1951b; D1ll, R. F., 1952; Dill, R. F., Dietz, R. S. and Stewart, H., 1952, 1954; Dunham, J. W., 1951; Eaton, J. E., 1932, 1939; Emery, K. O., 194la, 1950c, 1952a, 1952b; Emery, K. O., Butcher, W. S., Gould, H. R., and Shepard, F. P., 1952 (sea valley); Emery, K. O. and Natland, M. L., 1952; Emery, K. O. and Shepard, F. P., 1941, 1945; Emery, K. O. and Tschudy, R. H., 194l; Ewing, G. C., 1950b; Fairbanks, H. W., 1897, 1904; Fewkes, J. W. 1889; Fisher, R. L. and Milis, R., 1952; Ford, J. L. C., 1942; Friedman, S. L., 1949; Galliher, E. W., 1935b, 1935c; Garrison, L. E. and Takasak1 K. L., 1950; Goldberg, J., 1940; Grant, U. S. and Sheppard, W. E., 1939; Griffin, D. F., 1944; Grim, R. E., Dietz, R. S. and Bradley, W. F., 1949; Handin, J. W., 1949, 1951; Hanna, G. D., 1952; Hershey, О. H., 1903; Hess, H. H. and Macclintock, P., 1936; H1Il, R. T., 1928b; Hinds, N. E. A., 1952; Holway, R. S., 1905, 1914; Holzman, J. E., 1950; Horrer, P. L., 1950; Hubbs, C. L. and Rechnizer, A. B., 1952; Inman, D. L., 1949, 1950, 1953a, 1953b; Isaacs, J. D., Schorr, S. and Chinn, A. J., 1947; Jenkins, O. P., 1943a, 1943b; Jone日, E. L., 1918; Kuenen, Ph. H., 1947; Landes, K. K., 1952a, 1952b; Lawson, A. C., 1893a, 1924, 1948, 1950; Leconte, J., 1891; Leeds, C. T., 1936; Le1pper, D. F., 1950; L1ttlehalea, G. W., 1932a; Livingston, A., Jr., 1939; Louderback, G. D., 1919; Ludw1ck, J. C., Jr., 1950; McEwen, G. F., 1916, 1927; MacDonald, G. A., 1934; MacDonald, G. A., Shepard, F. P. and Cox, D. C., 1947; Ma, T. Y. H., 1952; Marlette, J. W., 1954; Maxson, J. H., 1932; Menard, H. W. and Dietz, R. S., 1951; Menard, H. W. and Ludwick, J. C., 1951; Milner, F., 1941; Moore, D. G., 1951; Munk, W. 
H., 1948; Munk, W. H. and Traylor, M. A., 1947; Murray, H. W., 1939; Nicholson, G. F., Grant, U. S., Shepard, F. P. and Crowell, J. C., 1946; Norris, R. M., 1951; O'Brien, M. P., 1936a; Page, G. B., 1950; Peel, K. P., 1951; Phleger, F. B., 1951; Putnam, W. C., 1938; Reed, R. D., 1933a, 1934; Revelle, R. and Shepard, F. P., 1939a, 1939b, 1943; Richter, C. M., 1887; Richardson, R. W., 1923; Ritter, W. E., 1902; Rude, G. T., 1933; Schaffer, F. X., 1940?; Schupp, R. D., 1953; Scripps Institution of oceanography, 1945a, 1945b, 19521, 1953d, 1953f; Shepard, F. P., 1931, 1932, 1933a, 1933b, 1933c, 1934a, 1934b, $1934 \mathrm{c}, 1935 \mathrm{a}, 1935 \mathrm{~b}, 1935 \mathrm{c}, 1935 \mathrm{e}, 1936 \mathrm{a}, 1936 \mathrm{~b}$, $1936 \mathrm{c}, 1936 \mathrm{~d}, 1936 \mathrm{e}, 1936 \mathrm{f}, 1936 \mathrm{~g}, 1936 \mathrm{~h}, 1937 \mathrm{a}$, $1937 \mathrm{~b}, 1937 \mathrm{~d}, 1937 \mathrm{e}, 1937 \mathrm{~g}, 1938 \mathrm{a}, 1938 \mathrm{~b}, 1938 \mathrm{c}$, $1938 \mathrm{~d}, 1938 \mathrm{e}, 1940 \mathrm{e}, 1941 \mathrm{~b}, 1941 \mathrm{c}, 1942 \mathrm{~b}, 1942 \mathrm{c}$, $1943 \mathrm{a}, 1946,1947 \mathrm{a}, 1947 \mathrm{~b}, 1948 \mathrm{a}, 1948 \mathrm{~b}, 1948 \mathrm{c}$, $1948 \mathrm{~d}, 1949 \mathrm{a}, 1949 \mathrm{~b}, 1949 \mathrm{c}, 1949 \mathrm{~d}, 1949 \mathrm{e}, 1950 \mathrm{a}$, $1950 \mathrm{~b}, 1950 \mathrm{c}, 1950 \mathrm{~d}, 1950 \mathrm{e}, 1950 \mathrm{~g}, 1951 \mathrm{a}, 1951 \mathrm{~b}$, 1951c, 1951d, 1951e, 1952a, 1953; Shepard, F. P. and Beard, C. N.', 1938; Shepard, F. P. and Emery, K. O., 1937, 1941, 1945; Shepard, F. P., Emery, K. O. and LaFond, E. C., 1941; Shepard, F. P. and Inman, D. L., 1949, 1951a, 1951b; Shepard, F. P. and MacDonald, G. A., 1934, 1938; Shepard, F. P., Revelle, R. and Dietz, R. S., 1939; Shepard, F. P., Revelle, R., Dietz, R. S. and Emery, K. 0., 1938; Shepard, F. P. and Saymer, D. B., 1953; Shepard, F. P. and Stetson, H. C., 1939; Shepard, F. P. and Wrath, W. F., 1937; Shuler, W. R., 1952; Shumway, G. A., 1953; Skogrberg, T., 1936; Smith, A. G. and MacKenzie, G., Jr., 1948; Smith, J. P., 1910; Smith, P. A., 1940; Smith, W. D., 1933a; Smith, W. S. T., 1900, 1902; Spencer, J. W. 1890; Stelzenmuller, W. B., 1949; Stevenвon, R. E., 1954; Sverdrup, H. U., 1938c, 1940e, 1944b; Sverdrup, H. U. and Staff, 1941 , 1942, 1943b; Tanner, Z. L., 1892b, 1894; Toit, A. L. du, 1940; Trask, P. D., 1931b; Treasher, R. C., 1937; Uchupi, E., 1954; Upham, W., 1890, 1899; Upson, J. E., 1949b; Vaughan, T. W., 1936; Weeks, L. G., 1952; Whitcroft, H. T., 1944; Williams, E. A. and Iaacs, J. D., 1952; Wittich, E., 1920; Wood, Н. O., 1915; Woodford, A. O., 1951

Submarine Canyons, Age of: Crowell, J. C., 1952; Emery, K. 0., 194la; Emery, K. O. and Shepard, F. P., 1945; Handin, J. W., 1949; Hess, H. H. and Macclintock, P., 1936; Jenkins, O. P., 1943b; Shepard, F. P., $1935 \mathrm{a}, 1935 \mathrm{e}, 1936 \mathrm{~B}, 1938 \mathrm{f}, 1948 \mathrm{~d}, 1949 \mathrm{~d}$; Shepard, F. P. and Emery, K. O., 1941; Shepard, F. P. and Stetron, H. C., 1939; Woodford, A. O., 1951

Submarine Canyons, Changes in, Depth Changes, Cut and Fill, Submarine Slumping, Turbidity Currents. Generally applied to head of submarine canyons. (See also: Submarine Canyons, Head of): Anonymous, 1939; Beach Erosion Board, 1952b; Buffington, E. C. 1952; Crowell, J. C., 1952; Emery, K. O., Butcher, W. S., Gould, H. R. and Shepard, F. P., 1952; Inman, D. L., 1949, 1950; Kuenen, Ph. H., 1947; Ludw1ck, J. C., Jr., 1950; Marlette, J. W., 1954; Norr1s, R. M., 1951; Scripps Institution of Oceanography, 19521, 1953d, 1953f; Shepard, F. P., 1934a, 1935a, 1936d, 1936f, 1937a, 1938b, 1938c, 1939c, 1941a, $1946,1948 \mathrm{~b}, 1948 \mathrm{c}, 1948 \mathrm{~d}, 1949 \mathrm{~b}, 1949 \mathrm{c}, 1949 \mathrm{e}$, 1950d, 1950g, 195la, 1951d, 1952a, 1953; Shepard, F. P. and Emery, K. O., 1941; Shepard, F. P. and Inman, D. L., 1951b; Sverdrup, H. U., $1938 c$

Submarine Canyons, Characteristics: Bucher, W. H., 1940; Cohee, G. V., 1938; Crowell, J. C., 1950, 1952; Davis, W. M., 1933; Dill, R. F., Dietz, R. S. and Stewart, H., 1952, 1954; Emery, K. O., Butcher, W. S., Gould, H. R. and Shepard, F. P., 1952; Hess, H. H. and MacClintock, P., 1936; Inman, D. L., 1950; Kuenen, Ph. H., 1947; Landes, K. K., 1952a; Marlette, J. W., 1954; Maxson, J. H., 1932; Menard, H. W. and Ludwick, J. C., 1951; Norris, R. M., 1951; Revelle, R. and Shepard, F. P., 1939b; Richerdeon, R. W., 1923; Schupp, R. D., 1953; Shepard, F. P., 1931, 1933a, 1933b, 1934a, $1934 \mathrm{~b}, 1935 \mathrm{a}, 1935 \mathrm{~b}, 1935 \mathrm{c}, 1936 \mathrm{~g}, 1937 \mathrm{~b}, 1937 \mathrm{e}$, 1938a, 1938f, (comparison with land valleys), 1940b, $1940 \mathrm{e}, 1941 \mathrm{c}, 1943 \mathrm{a}, 1946,1947 \mathrm{a}, 1948 \mathrm{~b}, 1949 \mathrm{~b}, 1949 \mathrm{e}$ 1950d, 1950e, 1951c, 195le; Shepard, F. P. and
Beard, C. N., 1938; Shepard, F. P. and Emery, K. $0 ., 1941$ (comparison with land valleys); Smith, W. S. T., 1902; Toit, A. L. du, 1940; Upham, W., 1899; Woodford, A. 0., 1951

Submarine Canyons, Currents in: Crowell, J. C., 1952; Dill, R. F., Dietz, R. S. and Stewart, H., 1954; Handin, J. W., 1949; Leipper, D. F., 1950; Revelle, R. and Shepard, F. P., 1939a, 1939b; Ritter, W. E. 1902; Shepard, F. P., 1933c, 1936g, 1940e, 194la, $1947 \mathrm{~b}, 1948 \mathrm{~b}$, 195le; Shepard, F. P. and Emery, K. O., 1941; Smith, W. S. T., 1902; Sverdrup, H. U. and Staff, 1943b; Toit, A. L. du, 1940

Submarine Canyons, Distribution of: Crowell, J. C., 1952; Davidson, G., 1887; Hess, H. H. and Macclintock, P., 1936; Hinds, N. E. A., 1952; Lawson, A. C., 1950; Leconte, J., 1891; MacDonald, G. A., 1934; Norris, R. M., 1951; O'Brien, M. P., 19368; Richardson, R. W., 1923; Shepard, F. P., 1931, $1933 \mathrm{~b}, 1933 \mathrm{c}, 1934 \mathrm{~b}, 1935 \mathrm{a}, 1935 \mathrm{~b}, 1935 \mathrm{e}, 1936 \mathrm{c}$, $1936 \mathrm{~h}, 1937 \mathrm{~d}, 1937 \mathrm{~g}, 1938 \mathrm{a}, 1941 \mathrm{~b}, 1943 \mathrm{a}, 1949 \mathrm{e}$, 1953; Shepard, F. P. and Beard, C. N., 1938; Shepard, F. P. and Emery, K. 0., 1937, 1941; Smith, W. S. T., 1900; Spencer, J. W., 1890; Sverdrup, H. U. and Staff, 1941; Woodford, A. 0., 1951

Submarine Canyons, Floor of: Anonymous, 1939; Beach Erosion Board, 1954b; Cohee, G. V., 1938; Congressional Documents, 1953b; Davidson, G., 1887, 1897; Davis, W. M., 1933; Dill, R. F., Dietz, R. S. and Stewart, H., 1954; Emery, K. O., Butcher, W. S., Gould, H. R. and Shepard, F. P., 1952; Garrison, L. E. and Takasaki, K. L., 1950; Hinds, N. E. A., 1952; Inman, D. L., 1950; Kuenen, $\mathrm{Ph}$. H., 1947; Landes, K. K., 1952a; MacDonald, G. A., 1934; Marlette, J. W., 1954; Menard, H. W. and Ludwick, J. C., 195l; Revelle, R. and Shepard, F. P., 1939b; Ritter, W. E., 1902; Schupp, R. D., 1952; Scripps Institution of Oceanography, 1952i; Shepard, F. P., 1932, 1933b, $1933 \mathrm{c}, 1934 \mathrm{~b}, 1935 \mathrm{a}, 1935 \mathrm{e}, 1936 \mathrm{~d}, 1936 \mathrm{f}, 1937 \mathrm{~b}$, $1937 \mathrm{e}, 1938 \mathrm{a}, 1939 \mathrm{~d}, 1940 \mathrm{a}, 1940 \mathrm{~b}, 1941 \mathrm{a}, 194 \mathrm{tb}$, $1948 \mathrm{~b}, 1948 \mathrm{c}, 1948 \mathrm{~d}, 1949 \mathrm{~b}, 1949 \mathrm{~d}, 1949 \mathrm{e}, 1950 \mathrm{a}$, 1950d, 1951a, 1951b, 1951d, 1951e, 1952a, 1953; Shepard, F. P. and Beard, C. N., 1938; Shepard, F. P. and Emery, K. O., 1941; Shepard, F. P. and Inman, D. L., 1949; Shepard, F. P. and MacDonald, G. A., 1938; Shepard, F. P., Revelle, R. and Dietz, R. S., 1939; Smith, W. S. T., 1902; Tanner, Z. L., 1892b; Toit, A. L. du, 1940; Weeks, L. G., 1952; Woodford, A. O., 1951

Submarine Canyons, Gradient of: Cohee, G. V., 1938; Congressional Documents, 1953b; Crowell, J. C., 1952; Dill, R. F., Dietz, R. S. and Stewart, H., 1954; Emery, K. O., Butcher, W. S., Gould, H. R. and Shepard, F. P., 1952; Handin, J. W., 1949; Hinds, N. E. A., 1952; Inman, D. L., 1950; Kuenen, Pb. H., 1947; Ma, T. Y. H., 1952 , Marlette, J. W., 1954; Moore, D. G., 1951; Murray, H. W., 1939; Rude, G. T., 1933; Schupp, R. D., 1953; Shepard, F. P., 1934a, 1934c, 1935a, $1937 \mathrm{a}, 1937 \mathrm{~b}, 1937 \mathrm{e}, 1938 \mathrm{f}, 1948 \mathrm{~b}, 1950 \mathrm{~d}, 1950 \mathrm{e}$, 1951d; Shepard, F. P. and Beard, C. N., 1938; Sheperd, F. P. and Emery, K. O., 1941; Smith, W. S. T., 1902; Spencer, J. W., 1890; Toit, A. L. du, 1940; Upham, W., 1899; Woodford, A. O., 1951

Submarine Canyons, Head of: Anonymous, 1939; Beach Erosion Board, 1949c, 1952b; Cohee, G. V., 1938; Congressional Documents, 1953b; Crowell, J. C., 1950, 1952; Davidson, G., 1897; Dunham, J. W., 1951; Emery, K. O., Butcher, W. S., Gould, H. R. and Shepard, F. P., 1952; Fisher, R. L. and Mille, R., 1952; Garrison, L. E. and Takasaki, K. L., 1950; Handin, J. W., 1949; Inman, D. L., 1949, 1950; Kuenen, Ph. H., 1947; Lawson, A. C., 1950; Ludwick, J. C., Jr., 1950; MacDonald, G. A., 1934; Marlette, J. W., 1954; Norria, R. M., 1951; Scripps Institution of Oceanography, 19521, 1953d, 1953f; Shepard, F. P., 1933b, 1933c, 1935a, 1936d, 1936e, $1936 \mathrm{f}, 1937 \mathrm{a}, 1938 \mathrm{e}, 1940 \mathrm{a}, 1941 \mathrm{a}, 1946,1947 \mathrm{a}$, $1948 \mathrm{~b}, 1948 \mathrm{c}, 1949 \mathrm{~b}, 1949 \mathrm{c}, 1949 \mathrm{~d}, 1950 \mathrm{a}, 1950 \mathrm{~d}$, $1950 \mathrm{~g}, 1951 \mathrm{a}, 1951 \mathrm{~b}, 1951 \mathrm{~d}, 1951 \mathrm{e}, 1952 \mathrm{a}, 1953$; Shepard, F. P. and Beard, C. N., 1938; Shepard,
F. P. and Emery, K. O., 1941; Shepard, F. P. and Inman, D. L., 1951a, 1951b; Sverdrup, H. U., 1938c; 
Woodford, A. O., 1951

Submarine Canyons, Loss of Sediment into (See also: Sedimentation, Sediment Trap): Congressional Documents, 1953b; Goldberg, J., 1940; Griffin, D. F., 1944; Handin, J. W., 1951; Marlette, J., 1954; Nicholson, G. F., Grant, U. S., Shepard, F. P. and Crowell, J. C., 1946; Page, G. B., 1950; Phleger, F. B., 195l; Shepard, F. P., 1933b; Shepard, F. P. and Emery, K. O., 194l; Shepard, F. P. and MacDonald, G. A., 1938 (influence of canyons on sediment distribution)

Submarine Canyons, origin of:

Currents: Bucher, W. H., 1940; Crowell, J. C., 1950, 1952; Davis, W. M., 1933; Kuenen, Ph. H. 1947; Lawson, A. C., 1924; Reed, R. D., 1933a; Shepard, F. P., 1933a, 1933c, 1934b, 1935a, 1935b, 1936f, 1936g, 1938e, 1938f, 1940b, 1948b; Shepard, F. P. and Emery, K. O., 194l; Smith, W. S. T., 1902; Toit, A. L. du, 1940; Upson, J. E., 1949b Density or Turbidity Currents, Mudflows, Submarine Landslides, Slumping: Bell, H. S., 1942; Bucher, W. H., 1940; Butcher, W. S., 195la; Crowell, J. C., 1950; Davis, W. M., 1932, 1933; Emery, K. O., Butcher, W. S., Gould, H. R. and Shepard, F. P., 1952; Hess, Н. Н. and MacClintock, Р., 1936; Hinds, N. E. A., 1952; Kuenen, Ph. H., 1947; Landes, K. K., 1952a; Shepard, F. P., 1933a, 1936r, $1936 \mathrm{~g}, 193 \mathrm{~Tb}, 1938 \mathrm{a}, 1938 \mathrm{c}, 1938 \mathrm{f}, 1943 \mathrm{a}, 1948 \mathrm{~b}$, $1948 \mathrm{c}, 1949 \mathrm{~b}, 1949 \mathrm{e}, 1951 \mathrm{c}, 1951 \mathrm{~d}, 1951 \mathrm{e}, 1952 \mathrm{a}$, 1953; Shepard, F. P. and Beard, C. N., 1938; Shepard, F. P. and Emery, K. 0., 1941, 1945; Shepard, F. P., Emery, K. O. and LaFond, E. C., 1941; To1t, A. L. du, 1940; Weeks, L. G., 1952; Woodford, A. O., 1951

Subaerial: Benest, H., 1899; Bucher, W. H., 1940; Bullard, E. C., 1940; Butcher, W. S., 1951a; Cohee, G. V., 1938; Crowell, J. C., 1950, 1952; Davis, W. M., 1932; Emery, K. O., 1950c; Emery, K. O., Butcher, W. S., Gould, H. R. and Shepard, F. P., 1952; Emery, K. O. and Shepard, F. P., 1945; Fa1rbanks, H. W., 1897; Fewkes, J. W., 1889; Ford, J. L. C., 1942; Grant, U. S. and Sheppard, W. E., 1939; Hershey, О. H., 1903; Hess, Н. H. and Macclintock, P., 1936; Hinds, N. E. A., 1952; Kuenen, Ph. H., 1947; Landes, K. K., 1952a; Lawson, A. C., 1893a, 1924; Leconte, J., 1891; Livingaton, A., Jr., 1937; Louderback, G. D., 1919; Maxson, J. H., 1932; Reed, R. D., 1933a; Shepard, F. P., 1931, 1933a, 1933b, 1933c, 1934b, 1935a, $1935 \mathrm{~b}, 1935 \mathrm{c}, 1935 \mathrm{e}, 1936 \mathrm{c}, 1936 \mathrm{~g}, 1936 \mathrm{~h}, 1937 \mathrm{~b}$, $1938 \mathrm{a}, 1938 \mathrm{f}, 1940 \mathrm{~b}, 1940 \mathrm{e}, 1941 \mathrm{~b}, 194 \mathrm{c}, 1943 \mathrm{a}$, $1948 \mathrm{~b}, 1948 \mathrm{c}, 1949 \mathrm{~b}, 1949 \mathrm{~d}, 1949 \mathrm{e}, 1951 \mathrm{c}, 1951 \mathrm{e}$, 1952a, 1953; Shepard, F. P. and Beard, C. N. 1938; Shepard, F. P. and Emery, K. 0., 1941; Shepard, F. P. and Stetвon, H. C., 1939; Smith, W. S. T., 1900, 1902; Spencer, J. W., 1890; To1t, A. L. du, 1940; Uchup1, E., 1954; Upham, W., 1890, 1899; Upson, J. E., 1949b; Woodford, A. $0 ., 1951$

Submarine Spring Sapping: Benest, H., 1899; Bucher, W. H., 1940; Hinds, N. E. A., 1952; Kuenen, Ph. H., 1947; Shepard, F. P., 1933a, 1933c, 1943a, 1948c, 1949b, 1949e; Shepard, F. P. and Emery, K. o., 1941; Toit, A. L. du, 1940

Structural, Diastrophism including Faulting: Fa1rbanks, H. W., 1897; Hinds, N. E. A., 1952; Kuenen, Ph. H., 1947; Lawron, A. C., 1893, 1924; Livingston, A., Jr., 1939; Reed, R. D., 1933a; Richardson, R. W., 1923; Shepard, F. P., 1931, $1933 \mathrm{a}, 1933 \mathrm{c}, 1934 \mathrm{~b}, 1935 \mathrm{a}, 1935 \mathrm{~b}, 1938 \mathrm{e}, 1948 \mathrm{c}$, 1949b, 1949e, 1951c; Shepard, F. P. and Emery, K. O., 1941; Smith, W. S. T., 1900, 1902; Toit, A. L. du, 1940; Woodford, A. 0., 1951

Tunamis: Bucher, W. H., 1940; Kuenen, Ph. H. 1947; Shepard, F. P., 1948c, 1949b, 1949e; Shepard, F. P. and Emery, K. O., 1941

Other: Davis, W. M., 1932, 1933; Eaton, J. E., 1939; Emery, K. O., Butcher, W. S., Gould, H. R. and Shepard, F. P., 1952; Kuenen, Ph. H. 1947; Landes, K. K., 1952a; Putnam, W. C. 1938; Shepard, F. P., 1931, 1933a, 1940d, 1941c, $1946,1949 \mathrm{~b}, 1950 \mathrm{~d}, 1951 \mathrm{c}$, 195le, 1952a; Shepard, F. P. and Emery, K. O., 1941, 1945; Spencer, J. W. , 1890

Submarine Canyons, Profiles of: Crowell, J. C., 1950, 1952;
Inman, D. L., 1950; Kuenen, Ph. H., 1947; Ludwick, J. C., Jr., 1950; Revelle, R. and Shepard, F. P., 1939b; Scripps Institution of Oceanography, 1953d; Shepard, F. P., 1937a, 19381, $1939 \mathrm{c}, 1948 \mathrm{~b}, 1948 \mathrm{~d}, 1949 \mathrm{e}, 1950 \mathrm{a}, 1950 \mathrm{~g}, 1951 \mathrm{a}$,

1951d; Shepard, F. P. and Beard, C. N., 1938; Shepard, F. P. and Emery, K. O., 1941; Smith, W. S. T., 1902; Woodford, A. O., 1951

Submarine Canyons, Terminal End including Delta at the Terminal end of Canyons: Crowell, J. C., 1950; Davis, W. M., 1933; Dill, R. F., Dietz, R. S. and Stewart, H., 1952 and 1954 (delta origin); Emery, K. O., Butcher, W. S., Gould, H. R. and Shepard, F. P., 1952; Ford, J. L. C., 1942; Kuenen, Ph. H., 1947; Landes, K. K., 1952a; Ludwick, J. C., Jr., 1950; Menard, H. W. and Ludwick, J. C., 195l; Shepard, F. P., 1933b, 1934b, $1938 \mathrm{e}, 1940 \mathrm{~b}, 1941 \mathrm{a}, 1948 \mathrm{~b}, 1948 \mathrm{c}, 1950 \mathrm{~d}, 1951 \mathrm{a}$, 1951b, 1951d, 195le, 1952a, 1953; Shepard, F. P. and Emery, K. O., 1941; To1t, A. L. du, 1940

Submarine Canyons, Walls of: Beach Erosion Board, 1949c (slope), 1954b; Cohee, G. V., 1938; Congressional Document8, 1953b; Crowell, J. C., 1952; Davis, W. M., 1933; Dietz, R. S., Emery, K. O. and Shepard, F. P., 1942; Emery, K. O., 1941a; Emery, K. O., Butcher, W. S., Gould H. R. and Shepard, F. P., 1952; Emery, K. O. and Shepard, F. P., 1941, 1945; Handin, J. W., 1949; Hinds, N. E. A., 1952; Inman, D. L., 1950; Kuenen, Ph. H., 1947; MacDonald, G. A., 1934; Menard, H. W. and Ludwick, J. C., 1951; Murray, H. W., 1939; Norris, R. M., 1951; Revelle, R. and Shepard, F. P., 1939b; Richarda on, R. W., 1923; Shepard, F. P., 1933b, 1934a, 1934c, 1935a, 1935b, 1935c, $1935 \mathrm{e}, 1936 \mathrm{f}, 1936 \mathrm{~g}, 1937 \mathrm{~b}, 1937 \mathrm{e}, 1938 \mathrm{c}, 1938 \mathrm{e}$, $1938 \mathrm{r}, 1939 \mathrm{~d}, 1940 \mathrm{a}, 1940 \mathrm{~b}, 1941 \mathrm{a}, 1943 \mathrm{a}, 1946$, $1947 \mathrm{a}, 194 \mathrm{7b}, 1948 \mathrm{~b}, 1948 \mathrm{c}, 1948 \mathrm{~d}, 1949 \mathrm{~b}, 1949 \mathrm{~d}$ 1949e, 1950e, 1951a, 1951e, 1952a, 1953; Shepard, F. P. and Beard, C. N., 1938; Shepard, F. P. and Emery, K. O., 1941, 1945; Smith, A. G. and MacKenzie, G., Jr., 1948; Smith, W. S. T., 1902; To1t, A. L. du, 1940; Vaughan, T. W., 1936; Woodford, A. $0 ., 1951$

Submarine Mountains (See also: Banks, Seamounts): Anonymous, 1951a; Belknap, G. E., 1874b; Blake, W. P., 1856; Clements, T. and Emery, K. O., 1947; Colbert, L. 0., 1940; Davideon, G., 1875b; Emery, K. O., 1947a, 1947c; Emery, K. O., Butcher, W. S., Gould, H. R. and Shepard, F. P., 1952; Emery, K. O. and Shepard, F. P., 1941; Hill, R. T., 1928a; Littlehales, G. W., 1890, 1932a; Pagenhart, E. H., 1931; Shepard, F. P., 1937g, 1940a; Smith, P. A., 1940 (also submarine mountain range) Tanner, Z. L., 1892b, 1894

Submarine 011 and Gas Seeps (See also: Submarine Springs): Alliott, H., 1917; Armstrong, T. A., 1954; Beach Erosion Board, 1948h; Blackman, J. W. B., 1936; Blake, W. P., 1853, 1856; Congressional Documents, 1954b; Dietz, R. S. and LaFond, E. C., 1950; Dill, 筷. F., 1949; Eldridge, G. H., 1901; Emery, K. O. and Rittenberg, S. C., 1952; Fewkes, J. W., 1889; Fox, L. S., 1930; Hanвen, H. A. and Pemberton, J. R., 1950; Heizer, R. F., 1943; Heizer, R. F. and Treganza, A. E., 1944; Kemnitzer, W. J., 1937; Livingeton, A., Jr., 1939; MacDonald, G. A., 1934; Merrill, F. J. H., 1914; Nicholls, C. P. L., 1936c; Purcell, G., 1914; Reed, R. D., 1938; Skeats, E. M., 1923; Taber, S., 1920

Submarine Slumping, Landslides, Mudflows (See also: Cut and/or Fill; Submarine Canyons, origin of; Turbidity Currents): Beach Erosion Board, 1952b, 1954b; Brown, E. I., 1939; Bucher, W. H., 1940; Buffington, E. C., 1952; Butcher, W. S., 1951a; Crowell, J. C., 1952; Davis, W. M., 1933; Dietz, R. S. 1952a, 1952b; Dietz, R. S. and Menard, H. W. 1951b; Dill, R. F., Dietz, R. S. and Stewart, H., 1954; Emery, K. O., 1953b, 1954b; Emery, K. O., Butcher, W. S., Gould, H. R. and Shepard, F. P., 1952; Emery, K. O. and Dietz, R. S., 1941; Emiliani, C., 1954; Galliher, E. W., 1935b, 1935c; Garrison, L. E. and Takasaki, K. L., 1950; Handin, J. W., 1949; Inman, D. L., 1949, 1953b; Krumbein, W. C., 1942; Kuenen, Ph. H., 1947; Kuenen, Ph. H. and Menard, H. W., 1952; Lawson, A. C., 1950; Ludwick, J. C., Jr., 1950; Menard, H. W., and 
Ludwick, J. C., 1951; Paguirigan, F., 1941; Plggot, C. S. and Urry, W. D., 1942; Revelle, R. and Shepard, F. P., 1939b; Sanchez, P. C. 1934c; Scripps Institution of Oceanography, 1953d, 1953f; Shepard, F. P., 1933b, 1933c, $1934 \mathrm{~b}, 1935 \mathrm{a}, 1935 \mathrm{~b}, 1936 \mathrm{f}, 1937 \mathrm{a}, 1938 \mathrm{a}, 1938 \mathrm{c}$, $1938 \mathrm{e}, 1939 \mathrm{c}, 1939 \mathrm{~d}, 1940 \mathrm{a}, 1940 \mathrm{~d}, 1940 \mathrm{e}, 1941 \mathrm{a}$ $1947 \mathrm{a}, 1947 \mathrm{~b}, 1948 \mathrm{~b}, 1948 \mathrm{c}, 1949 \mathrm{~b}, 1949 \mathrm{c}, 1949 \mathrm{~d}$ $1949 \mathrm{e}, 1950 \mathrm{a}, 1950 \mathrm{~d}, 1950 \mathrm{~g}, 1951 \mathrm{a}, 1951 \mathrm{~b}, 1951 \mathrm{c}$, 1951d, 1952a, 1953; Smith, W. D., 1933b, 1933c; Sverdrup, H. U., 1938c; Walters, L., 1953

Submarine Springs (See also: Submerine Canyons, Origin of; Submarine 011 and Gas Seeps): Benest, H., 1899; Blake, W. P., 1855; Dill, R. F., 1949; Smith, W. S. T., 1902 (subterranean streams)

Submarine Structures. (See also: Submarine Topography, various submarine topographic structures): Fox, L. S., 1930; Weaver, C. E., 1944

Submarine Terraces - see Terraces, Submarine

Submarine Topography (See also various submarine topographic structure ): Anonymous, 1940d, 1941a; Arthur, R. S., 1950; Bartsch, P., 1921a; Beach Erosion Board, 1939, 19481; Belknap, G. E., 1874a, 1874b; Berghaus, H., 1891; Bigelow, H. B. and Leslie, M., 1930; Blake, W. P., 1856; Brown, E. I., 1939; Bruff, S. C., 1946; Buffington, E. C., 1951; Burt, W. V. and Saur, J. F. T., 1948; Butcher, W. S., 1951a; Buwalda, J., 1936; Carsola, A. J. and Dietz, R. S., 1952; Clements, T. and Emery, K. 0., 1947; Colbert, L. 0., 1939; Congressional Documents, 1953b; Crooke, R. C., Elvitaky, A. W., et al, 1953; Crosley, W. S., 1927; Crouch, R. W., 1951; Daly, R. A., 1934; Davidson, G., 1887, 1897; Davis, W. M., 1932; Dietz, R. S., 1938, 1954; Dletz, R. S. and Menard, H. W., 1951b; Dietz, R. S., Menard, H. W. and Hamilton, E. L., 1954; Dill, R. F., 1952; Dunham, J. W., 1951; Dyk, K. and Swainson, O. W., 1953; Eardley, A. J., 1954; Emery, K. 0., 1941a, 1947a, 1947c, $1948,1950 b, 1951,1952 a$, 1953a; Emery, K. 0., Butcher, W. S., Gould, H. R. and Shepard, F. P., 1952; Emery, K. O. and Shepard, F. P., 1945; Ewing, G. C., 1950b, 1950c; Fleming, J. A., Sverdrup, H. U., Ennis, C. C., Seaton, S. L. and Hendrix, W. C., 1945; Fleming, R. H , 1937-1938, 1939b; Ford, J. L. C., 1942; Gerrison, L. E. and Takasaki, K. L., 1950; Gilbert, J. Y. and Allen, W. E., 1943; Gorsline, D. S., 1954; Gutenberg, B., Richter, C. F. and Wood, H. 0., 1932; Hanna, G. D., 1952; Handin, J. W., 1951; Handin, J. W. and Ludwick, J. C., 1949; H111, R. T., 1928b; Hinds, N. E. A., 1952; Holway, R. S., 1905; Hoots, H. W., 1943; Horrer, P. L., 1949, 1950; Inman, D. L., 1949, 1950, 1953a; Johnson, A. G., 1935; Johnson, C. W., 1953; Kemnitzer, L. E., 1933, 1936; Knox, R. W., 1953; Koczy, F. F., 1954; Kossins, E., 1921; LaFond, E. C., Dietz, R. S. and Knaus8, J. A., 1950; Landes, K. K., 1952a; Lawson, A. C., 1924; Leeds, C. T., Vanoni, V. A. and Knapp, R. T., 1934; Le1pper, D. F., 1950; Lesser, R. M., 1951; Littlehales, G. W., 1890, 1932a, 1932b; Longwell, C. R., 1942; Louderback, G. D., 1951; Ludwick, J. C., Jr., 1950; McEwen, G. F., 1916, 1927; McManus, A. B. and Collins, E. B., 1934; MacDonald, G. A., 1934; Marlette, J. W., 1954; Menard, H. W. and Dietz, R. S., 1951; Menard, H. W., D11l, R. F., Hamilton, E. L., Moore, D. G., Shumway, G., Silverman, M. and Stewart, H. B., 1954; Menard, H. W. and Ludwick, J. C., 1951; Moore, D. G., 1951; Morey, B. F., 1944; Morrison, R. L., 1930; Moberg, E. G. and Allen, W. E., 1927; Munk, W. H., 1940, 1948; Munk, W. H. and Traylor, M. A., 1947; Murray, H. W., 1939; Nicholson, G. F., Grant, U. S., Shepard, F. P. and Crowell, J. C., 1946; Norris, R. M, 1951; O'Brien, M. P., 1936a; O'Brien, M. P. and Johnson, J.W., 1947; osorio-Tafall, B. F., 1943; Putnam, J. A., Munk, W. H. and Traylor, M. A., 1949; Raitt, R. W., 1950, 1954; Remondino, P. C., 1892; Revelle, R., 1938, 1939b, 1943, 1950; Revelle, R. and Shepard, F. P., 1939a, 1939b, 1943; Richter, C. M., 1887; Rude, G. T., 1933; Sanchez, P. C., 1934c; Saur, J. T. F., Jr., 1950; Sav1lle, T., Jr., and Caldwell, J. M., 1953; Schnelder, W. A.,
1954; Schupp, R. D., 1953; Scripps Inetitution of Oceanography, 1945o, 1949a, 1951 J, 1951l, 1952e 19521, 1953e; Shepard, F. P., 1932, 1933b, 1938b, $1938 \mathrm{f}, 19381,1939 \mathrm{e}, 1940 \mathrm{c}, 1941 \mathrm{a}, 1941 \mathrm{~b}, 1948 \mathrm{~b}$, $1949 \mathrm{a}, 1949 \mathrm{~b}, 1949 \mathrm{e}, 1950 \mathrm{c}, 1950 \mathrm{~d}, 1950 \mathrm{e}, 1950 \mathrm{f}$, 1951a, 1953; Shepard, F. P. and Emery, K. 0., 1941; Shepard, F. P. and Inman, D. L., 1949, 195la, 1951b; Shepard, F. P. and Saymer, D. B., 1953; Shepard, F. P. and Wrath, W. F., 1937; Shuck, O. T., 1869; Shuler, W. R., 1952; Skogsberg, T., 1936; Smith, P. A., 1940; Smith, W. D., 1933b, 1933c; Sm1th, W. S. T., 1897; Stevenson, R. E., 1954; Stock, C., 1935; Sverdrup, H. U., 1939a, 1939b, 1939c, $1940 \mathrm{~b}, 1940 \mathrm{e}$; Sverdrup, H. U. and Staff, 1943b, 1947a; Tanner, Z. L., 1894; Thom, W. T., Jr., 1938; Thompson, W. C., 1949; Tibby, R. B., 1939; Tower M. L., 1910; Trask, P. D., 1927b, 1931a, 1931b, 1932a, 1939; Trask, P. D. and Hammar, H. E., 1931; Trowbridge, W. P., 1856b; Twenhofel, W. H., 1943; Uchup1, E., 1954; Vaughan, T. W., 1940; Ward, H. A., 1952; Warner, S. E., 1946a, 1946b; Wharton, M., 1948; Whiteroft, Н. T., 1944; W11liams, E. A. and Isaacs, J. D., 1952; W1sser, E., 1954; ZoBell, C. E., 1938

Submarine Vulcanism - see Vulcanism

Submarine Weathering: Goldberg, E. D., 1954; Holzman, J. E., 1950; Scripps Institution of Oceanography, 1953e; Shepard, F. P., 1949b, 1952a; Shepard, F. P., and Emery, K. 0., 1941

Submergence (See also: Diastrophism, Warping): Anonymous, 1925a; Anderson, C. A., 1950; Arnold, D. and Arnold, R., 1902; Ashley, G. H., 1931; Aver111, C. F. and others, 1946; Barrows, A. L., 1913; Beach Erosion Board, 1948j; Blake, J., 1868b; Buwalda, J. P., 1927, 1936; clements, T., 1946; Cockerell, T. D. A., 1938b; Corey, W. H., 1951, 1952; Cotton, C. A., 1942; Davidson, G., 1884; Davis, W. M., 1931, 1932, 1933; Dietz, R. S. 1947b; Diller, J.S., 1901; Dunkle, M. B., 1944; Eardley, A. J., 1954; Eaton, J. E., 1943; Emery, K. O., 1947b; Emery, K. 0., Butcher, W. S., Gould H. R. and Shepard, F. P., 1952; Emiliani, C. and Epstein, S., 1953; Emmonds, S. F. and Merrill, G. P., 1894; Fairbanks, H. W., 1897; Galliher, E. W., 1935c; Gilluly, J., 1949; Goldberg, J., 1940; Hanna, G. D., 1952; Hanna, M. A., 1926; Hershey, O. H., 1903; H1Il, R. T., 1928b; Hinde, H. P., 1952; Hinds, N. E. A., 1952; Howard, A. D., 1951; Holway, R. S., 1914; Jeffreys, H., 1934; Jenkins, o. P., 1943b; Kemnitzer, L. E., 1933; Krumbein, W. C., 1947; Lawson, A. C., 1893b, 1894; Leconte, J., 1891; L1vingston, A., Jr., 1939; Louderback, G. D., 1930; Lucke, J. B., 1938; Ludwick, J. C., Jr., 1950; MacDonald, G. A., 1934; Maxson, J. H., 1932; Menard, H. W., Dill, R. F., Hamilton, E. L., Moore, D. G., Shumway, G., Silverman, M. and Stewart, H. B., 1954; Merrill, F. J. H., 1915; Norris, R. M., 1951; Osmont, V. C., 190k; Pratt, W. E., 1947; Putnam, W. C., 1930, 1937c; Richardon, R. W., 1923; Sanchez, P. C., 1934a, 1934e; Shaler, N. S., 1892, 1895; Shepard, F. P., 1933a, $1933 \mathrm{~b}, 1933 \mathrm{c}, 1934 \mathrm{~b}, 1935 \mathrm{a}, 1935 \mathrm{~b}, 1936 \mathrm{c}, 1938 \mathrm{f}$, $1938 \mathrm{~b}, 1941 \mathrm{a}, 1941 \mathrm{~b}, 1943 \mathrm{a}, 1948 \mathrm{c}, 1948 \mathrm{~d}, 1949 \mathrm{~b}$, 1949e, 1950e, 1951c, 1951e, 1952a, 1953; Shepard, F. P. and Emery, K. 0., 1941; Smith, J. P., 1910; Smith, W. D., 1930, 1933a, 1933b, 1933c; Smith, W. S. T., 1900; Spencer, J. W., 1890; Stevenson, R. E., 1954; Thayer, W. N., 1916; Thompson, W. 0., 1937; To1t, A. L. du, 1940; Twenhofel, W. H., 1943; Upham, W., 1899; Weaver, D. K., 1937; Weeks, L. G., 1952; Whitney, J. D., 1865; W11118, B., 1900; Woodring, W. P. and Kew, W. S. W., 1932

Subsidence (See also: Diastophism, Warping): Anonymous, 1949b, 19521; Anderson, C. A., 1941; Ashley, G. H., 1895, 1896; Bandy, O. L., 1953b; Beach Erosion Board, 19481, 1948j; Blake, W. P., 1898; Bowlus, F. D., 1943; Bucher, W. H., 1940; Carsola, A. J. and Dietz, R. S., 1952; Clements, T. and Dana, S. W., 1944; Clement 8, T. and Emery, K. 0., 1947; Congressional Documents, 1953a; Crowell, J. C., 1952; Dickerson, R. E., 1922; Dietz, R. S., Menard, H. W. and Hamiltion, E. L., 1954; Diller, J. S., 1902; Dunkle, M. B., 1950; Emilian1, C., 1954; Fairbanks, H. W., 1904; Fewkes, J. W. , .1889; Gllbert, G. K., 1917; G1lluly, J. and Grant, 
U. S., 1947; Grant, U. S., 1941, 1944; Grant, U. S. and Sheppard, W.: E., 1939; Handin, J. W., 1949; Harris, F. R. ahd Harlow, E. H., 1947; Hertlein, L. G. and Emerson, W. K., 1953; Kuenen, Ph. H., 1947; Landes, K. K., 1952a, 1952b;

Lawson, A. C., 1914, 1950; Leonerd, A. G., 1925; Leypoldt, H., 1934, 1938, 1947; Leypoldt, H. and McHenry, J. R., 1942; Louderback, G. D., 1951; McHenry, J. R., 1942; Ma, T. Y. H., 1952; Merriam, P. D., 1949; Nelson, N. C., 1909, 1910; Page, G. B., 1950, Parkin, E. J., 1948; Rappleye, H. S., 1933; Reagan, J. W., 1915; Revelle, R., 1950; Ritter, W. E., 1901; Sanchez, P. C., 1934c; Scripps Institution of Oceanography, 1953e;

Shepard, F. P., 1933b, 1936g, 1940b, 1949d; Shepard, F. P. and Emery, K. O., 1941; Shuler, W. R., 1951, 1952; ShumwEy, G. A., 1953; Sosedko, A. F., 1950; Stevenson, R. E., 1954; Stock, C. and Furlong, E. L., 1928; Stockman, L. P., 1949a, 1949b, 1949c; Stormont, D. H., 1954b; Taylor, A. E. and Grant, U. S., 1947; Thom, W. T., Jr., 1938; Tower, M. L., 1913; Upham, W., 1890; Whittemore, G. F., 1926; Whitworth, G. W., 1932; Weaver, C. E., 1949; Wilson, M. E., 1907; Wood, H. O., 1915

Subsurface of Beach: Anonymous, 1938a

Subterranean Streams - вee Submarine Springs

Sulfate - see sulfate/Chloride Ratio ( $\left.\mathrm{SO}_{4} / \mathrm{Cl}\right)$, sulfur

Sulfate/Chloride Ratio ( $\mathrm{SO}_{4} / \mathrm{Cl}$ ). (See also: Chlorinity, Sulfur): Emery, K. O., 1954d; Emery, K. O. and Rittenberg, S. C., 1952; McEwen, G. F., 1934a; Smith, P. V., Jr., 1954

Sulfur including Sulfates ('See also: Hydrogen Sulfide, Iron Sulfides, Pyrite, Sulfate/Chloride Ratio):

Ahlstrom, E. H., 1950; California Department of Public Health, 1951; Dill, R. F., 1952; Emery, K. O., 1946b, 1954d; Emery, K. 0 . and Rittenberg, S. C., 1951, 1952; Evans, R. D., Kip, A. F. and Moberg, E. G., 1938; Fox, D. L., 1950; Fox, D. L., Isaacs, J. D. and Corcoran, E. F., 1952; Galliher, E. W., 1933, 1935a, 1935c; Gee, H., 1932; Koe, K. B., Fox, D. L. and Zechmeister, L., 1950; Lipman, C. B., 1929; McEwen, G. F., 1934a; McKee, E. D., 1953; Miller, R. C., Ramage, W. D. and Lazier, E. L., 1928; Moulton, G. F., 1928; Natland, M. L., Revelle, R. and Rittenberg, S. C., 1941; Nicholls, C. P. L., 1936c; Revelle, R., 1941, 1950; Revelle, R. and Emery, K. O., 1951; Rittenberg, S. C., 1941; Rosenfeld, W. D., 1948; Sialer, F. D. and ZoBell, C. E., 1950, 1951a, 1951b; Smith, P. V., Jr., 1954; Stanton, T. E., Jr., 1938; Stevenson, R. E., 1954; Sverdrup, H. U. and Staff, 1941; Thayer, L. A., 1937; Thompson, T. G. and Robinson, R. J., 1932; Trask, P. D., 1934, 1936, 1939; Trask, P. D. and Wu, C. C., 1930a, 1930b; Updegraff, D. M., 1948; Vaughan, T. W., 1935a, 1940; White, D., 1911; Wright, R., 1937; ZoBell, C. E., 1935, $1936,1938,1939,1941,1942 \mathrm{a}, 1942 \mathrm{~b}, 1942 \mathrm{c}$, 1943, 1944, 1946b, 1946-1947, 1947b, 1947c, 1947d, 1949, 1950; ZoBell, C. E. and Feltham, C. B., 1942; ZoBell, C. E., Grant, C. W. and Heas, H. F., $19 \dot{4}$

Sulphuretum (See also: Sulfur): Galliher, E. W., 1933 Surf Beat (See also: Seiches, Surge): Dietr, R. S. and Menard, H. W., 1951b; Inman, D. L., 1950, 1953b; Mason, M. A., 1951; Munk, W. H., 1949a; Scripps Institution of Oceanography, 1953c; Shepard, P. P. and Inman, D. L., 1949; Vanoni, V. A. and Carr, J. H , 1951; Williams, E. A. and Iraacs, J. D., 1952

Surge (See also: Channels, Seiches, Surf Beat): Bascom, W. N., 1946b, 1950b; Broshous, C. R., 1938; Chase, J. L., 1948; Congressional Documents, 1940c; Gerhardt, J. R. and Jehn, K. H., 1954; Hanna, G. D., 1952; Hughes, R. T., 1947; Johnson, J. W., 1947b, 1948a; Knapp, R. T., 1951, 1952; Knapp, R. T. and Vanoni, V. A., 1945; Mason, M. A., 1949b; Peel, K. P., 1951; Scrippa Institution of Oceanography, 19521, 1953c; Shepard, F. P., 1949b (bottom surge); Swain, F. E., 1951; U. S. Waterways Experiment Station, Vicksburg, Mississippi, 1947a, 1947b, 1949; Vanoni, V. A. and Carr, J. H., 1951; Williams, E. A. and Ireacs, J. D., 1952
Suspended Sediment, Detritus etc. (See also: Concentration of Sediment in the Surf zone, Creep, Littoral Drift, Rip Currents, Transport of Sediment): Anonymous, 1938a, 1944b, 1952f; Allen, W. E., 1941 (suspended datoms); Beach Erosion Board, 1948a, 1948b, 1948h, 1953c; Bullard, F. M. and Mills, R. A., 1951; California Department of Public Health, 1951; California, University of, 1952a, 1954b; Congressional Documents, 1908a, 1938a, 1949f; Crooke, R. C., Elvitsky, A. W., et al, 1953; Dietz, R. S., 1952a, 1953; Eaton, R. O., 1951; Elliott, F. E., Tressler, W. L. and Myers, W. H., 1953; Emery, K. O., $1954 \mathrm{~b}$ (also saltation), 1954a; Emery, K. O., Butcher, W. S., Gould, H. R. and Shepard, F. P., 1952; Emery, K. O. and Gale, J. F., 1951; Emery, K. O. and Tschudy, R. H., 1941; Fox, D. L., 1937; Fox, D. L., Isaac8, J. D. and Corcoran, E. F., 1952; Fox, D. L., Updegraff, D. M. and Novelli, G. D., 1944; Fox, L. S., 1930; Gillette, C. E., 1905; Goldberg, E. D., Baker, M. and Fox, D. L., 1952; Gorsline, D. S., 1954; Grant, U. S., 1947; Grant, U. S. and Shepard, F. P., 1940, 1946; Hall, W. C., 1942; Handin, J. W., 1949; Holzman, J. E., 1950; Inman, D. L., 1953a, 1953b; Johnson, J. W., 1952; LaFond, E. C., 1938; Leypoldt, В., 1941b; Livingston, A., Jr., 1939; McAfee, C. M., Jr., 1939; McKee, E. D., 1939; Marlette, J. W., 1954; Mason, M. A., 1942, 1950b; Menard, H. W. and Ludwick, J. C., 1951; Moore, D. G., 1951; Munk, W. H., 1949b; Munk, W. H. and Traylor, M. A., 1947; Nicholson, G. F., Grant, U. S., Shepard, F. P. and Crowell, J. C., 1946; O'Brien, M. P., 1939, 1941; Pardee, J. T., 1934; Putnam, J. A., Bermel, K. J. and Johnson, J. W., 1947; Revelle, R., 1938; Revelle, R. and Shepard, F. P., 1939b; Richardaon, R. W., 1923; Rothwell, W. T., Jr., 1944; Scripps Institution of oceanography, 1951g, 19521, 1953f; Shepard, F. P., 1932, 1936a, 1941a, 1948c, 1949b, 1950c, 1950e; Shepard, F. P. and Emery, K. O., 1941; Shepard, F. P., Emery, K. O. and LaFond, E. C., 1941; Shepard, F. P. and LaFond, E. C., 1940; Sinnott, A., 1941; Somers, P., 1952; Stelzenmuller, W. B., 1949; Sverdrup, H. U., 1939a, 1940d; Sverdrup, H. U. and Staff, 1941; Symons, T. W., 1893; Tower, M. L., 1910; Trask, P. D., 1952b; Twenhofel, W. H., 1946; Uchupi, E., 1954; U. S. Waterways Experiment Station, Vicksburg, Míriseippi; 1950; Vaughan, T. W., 1940

Swamp, Slough, Bog (See also: Bay, Embayment, Estuary, Lagoon, Marsh, Salt Marsh, Tide Flat): Arnold, J. L., 1928; Bascom, W. N., 1947c; Beach Eroaion Board, 1948j; Blake, W. P. , 1856; Buck, C. D., 1928; Congressional Documents, 1949c; Diller, J. C., 1901, 1903; Fenton, M. A. and Fenton, C. L., 1934; Fox, D. B., 1930; Gee, H., 1932; Goodyear, W. A., 1873; Handhausen, R. J., 1947; Johnson, W. M., 1855; Leeds, C. T., 1915; MacGinitie, G. E., 1927; Morrison, R. L., 1930; Nelson, J. W., Dean, W. C., Kocher, A. E., watson, E. B. and Carpenter, E. J., 1920; Nelson, J. W., Zinn, C. J., Strahorn, A. T., Watron, E. B. and Dunn, J. E., 1919; Pardee, J. T., 1934; Scripps Institution of Oceanography, 1953c; Shepard, F. P. and Emery, K. O., 194l; Storie, R. E. and Carpenter, E. J., 1929; Trask, P. D., 1934, 1939; Wright, R., 1937; ZoBell, C. E., 1939, 1947d

Swash and Backswash: Bascom, W. N., 1950c; Beach Erosion Board, 1948b, 1953c; Emery, K. O., 1944, 1945a, 1945b; Emery, K. O. and Gale, J. F., 1951; Grant, U. S., 1943, 1948; Grant, U. S. and Shepard, F. P., 1940; Handin, J. W., 1949; Herold, C. L., 1934; Inman, D. L., 1953a; Isaac8, J. D., 1947a; Iraace, J. D. and Bascom, W. N., 1947, 1949; Johnson, J. W., 1952; McKee, E. D., 1953; Marlette, J. W., 1954; Mason, M. A., 1942; O'Brien, M. P., 1941; O'Brien, M. P. and Johneon, J. W., 1947; Patrick, D. A., 1953; Schupp, R. D., 1953; Shepard, F. P., 1950; Shepard, F. P., Emery, K. O. and LaFond, E. C., 1941; Sinnott, A., 1941; Thompson, w. O., 1937; Wiegel, R. L., 19470; Wiegel, R. L., Patrick, D. A. and Kimberley, H. L., 1953; Woodford, A. O., 1935

Swash Marka: Emery, K. 0., 1944; Emery, K. O. and Gale, 
J. F., 1951; Johnson, D. W., 1910: McKee, E. D., 1953; Thompson, W. O., 1937

Syncline (See also: Geosyncline, Submarine Topography, Trench): Bucher, W. H., 1940; Gorsline, D. S., 1954; Shepard, F. P. and Emery, K. O., 1941

Talus, i.e. on Rocky Coasts and in Submarine Canyons: Shaler, N. S., 1895; Shepard, F. P., 1941a, $1948 \mathrm{c}$; Vaughan, T. W., 1940

Tectonics: Smith, P. A., 1940

Temperature (See also: Meteorology, Thermocline, Water Type): Agassiz, A., 1905; Ahlstrom, E. H. 1950; Allen, W. E., 1920, 192le, 1923b, 1923c, $1925,1926,1927 \mathrm{a}, 1927 \mathrm{~b}, 1928 \mathrm{a}, 1928 \mathrm{~b}, 1928 \mathrm{c}$, $1930 \mathrm{a}, 1930 \mathrm{~b}, 1933 \mathrm{a}, 1937 \mathrm{~b}, 1940 \mathrm{~d}, 1941 \mathrm{a}, 194 \mathrm{c}$, 1946a; Anderson, J. B., 1931; Armstrong, T. A., 1954; Arnold, J. L., 1928; Bandy, O. L., 1953a; Barrows, A. L., 1917; Bartholomew, J. W. and Rittenberg, S. C., 1939 (temperature in sediments); Bartach, P., 192la, 1921b; Beach Erosion Board, 1953c; Bigelow, H. B. and Leslie, M., 1930 (temperature profiles); Bishop, S. E., 1904; Blake, W. P., 1856; Brongersma-Sanders, M., 1948; Bruff, S. C., 1946; Buley, н. М., 1929; Bullock, F. W., 1933; Burt, W. V., and Bush, V., 1949; Byers, H. R., 1930, 1931; California Academy of Sciences, California Division of Fish and Game, Scripps Institution of Oceanography of the University of California, and U. S. Fish and Wildlife Service, 1950, 195la, 1951b; California Academy of Sciences, California Division of Fish and Game, Scripps Institution of oceanography of the University of California, U. S. Fish and wildlife Service, and Hopkina Marine Station, Stanford University, 1951; California Academy of Sciences, California Division of Fish and Game, Stanford Univeraity, Hopkins Marine Station, South Pacific Fishery Invertigation, University of California, Scripps Institution of Oceanography, 1952, 1953; California Department of Fish and Game, 1951; California Department of Public Worke, 1951, 195la; Carsola, A. J. and Dietz, R. S., 1952; Chambers, S. W., 1930; Clarke, K. B., 1934; Coe, W. R., 1945, 1948; Coe, W. R. and Fox, D. L., 1942; CongressIonal Documents, 1949b; Copeland, 'C. A., 1933; Couch, E. 1., 1915; Crooke, R. C., Elvitsky, A. W., et al, 1953, 1954; Crouch, R. B., 1951 (also bottom temperature); Curmings, N. W., 1921, 1950; Cupp, E. E., 1930, 1934a, 1934b; Dall, W. H., 1904, 1911; David, L., 1947; Davideon, G., 1875b, 1886; Dawson, E. Y., 1946, 1950, 1951, 1952; Defant, A., 1950b; Dietch, S., 1937; Devaputra, D., Thompaon, T. G. and Utterback, C. L., 1932; Dietz, R. S., 1953; Dietz, R. S., Emery, K. O. and Shepard, F. P., 1942; Dill, R. F., 1952; Dorman, H. P., 1927a, 1927b; Durham, J. W., 1942, 1949, 1950b (paleotemperature); Dyk, K. and Swainson, O. W., 1953; Emery, K. 0., 1946b, 1947c, 1948, 1952b, 1953a (bottom temperature), 1954a, 1954 d (also bottom temperature); Emery, K. O., Butcher, W. S., Gould, H. R. and Shepard, F. P., 1952; Emery, K. O. and Rittenberg, S. C., 1952; Emilian1, C., 1954 (paleotemperature); Emiliani, C. and Epatein, S., 1953; Ennis, C. C., 1934; Esterly, C. O., 1911, 1928b; Evans, R. D., Kip, A. F. and Moberg, E. G., 1938; Fleming, J. A., 1930; Fleming, J. A. and Sverdrup, H. U., Ennis, C. C., Seaton, S. L. and Hendrix, W. C., 1945; Fleming, R. H., 1939a, 1939b, 1940b, 1942; Fleming, R. H., Moberg, E. G. and Revelle, R., 1937a, 1937b; Fleming, R. H. and Revelle, R., 1939; Fox, D. B., 1929; Fox, D. L., 1937, 1950; Galliher, E. W., 1933, 1935c; Gee, H., 1932; Gilbert, J. Y. and Allen, W. E., 1943; Gislén, T., 1943, 1944; Gorkline, D. S., 1954; Gorton, A. F., 1930a, 1930b, 1930c, 1931a, 1931b, 1932, 1933, 1934; Gorton, A. F. and Partridge, A. G., 1930; Graham, H. W., 1934, 1941a, 1941b; Graham, H. W. and Gay, H., 1945; Grant, U. S., 1943; Great Britain Meteorological office, 1950; Gutenberg, B., 1941b; Harvey, D. R., 1928; Hewatt, W. G., 1937, 1946; Hinde, H. P., 1952; Holway, R. S., 1905; Holzman, J. E., 1950; Horonjeff, R. and Patrick, D. A., 1952; Horrer, P. L., 1948a;
Howard, L., 1937; Hubbs, C. L., 1948; Hutchins, L. W. and Scharff, M., 1947; Hutton, W. E. and ZoBell, C. E., 1949; Hyde, C. G., Gray, H. F. and Rawn, A. M., 1941; Isaacs, J. D. and Bascom, W. N., 1949; Jacobs, W. C., 1939, 1942; Jacobr, W. C. and Clarke, K. B., 1943; Johnson, M. W., 1939a, 1948; Johnson, M. W., Everest, F. A. and Young, R. W., 1947; Kindle, E. M., 1934; Krumbein, W. C., 1942 (also temperature in sediments); LaFond, E. C., 1939a, 1940; Louderback, G. D., 1924; Leipper, D. F., 1947, 1948a, 1948b, 1950; Leslie, M., 1928; Lesilie, M. and Moberg, E. G., 1930; Lesser, R. M., 1951; Lewis, R. C., 1927, 1929; McAdie, A. G., 1914; McEwen, G. F., 1910, 1912, 1914 , 1915, 1916, 1918, 1919a, 1919b, 1925, 1926, 1927, 1928a, 1928b, 1929, 1930a, 1930b, 1930c, $1933,1934 \mathrm{a}, 1934 \mathrm{~b}, 1934 \mathrm{c}, 1936,1937 \mathrm{a}, 1937 \mathrm{~b}$, 1937d, 1937-1938, 1940a, 1950; McEwen, G. F. and Gorton, A. F., 1930; McEwen, G. F. and Staff, 1948; McManus, A. B., 1934; MacGinitie, G. E., 1927, 1935; Martin, L. T., 1935; Mason, E. H., 1930; Mear8, E. G., 1943; Menard, H. W., Dill, R. F., Hamilton, E. L., Moore, D. G., Shumway, G. Silverman, M. and Stewart, H. B., 1954; Michael, E. L., 1919, 1921; Michael, E. L. and McEwen, G. F., 1915, 1916; Miller, R. C., Ramage, W. D. and Lazier, F. L., 1928; Moberg, E. G., 1928a, $1928 \mathrm{~b}, 1928 \mathrm{c}, 1930 \mathrm{a}, 1930 \mathrm{~b}, 1930 \mathrm{c}$; Moberg, E. G. and Allen, W. E., 1927; Montgomery, R. B. and Wooster, W. S., 1954; Morrison, R. L., 1930; Moser, J. F., 1898 (bottom); Munk, W. H., 1940, 1947b; Munk, W. H. and Anderson, E. R., 1948; Myers, E. H., 1942, 1943; Natland, M. L., 1933b (bottom temperature); Natland, M. L., Revelle, R. and Rittenberg, S. C., 1941; OlssonSeffer, P., 1910b; Orsorio Tafall, B. F., 1943, 1944, 1948; Packard, E. L., 1918; Patton, C. P., 1953; Patton, R. S., 1930; Pease, W. H., 1868; P'e1, C., 1929; Pettersaen, S., 1938; Phelps, A., 1937, 1940; Purer, E. A., 1936, 1942; Reed, W. G., 1914; Remondino, P. C., 1892; Revelle, R., 1950; Revelle, R. and Shepard, F. P., 1939b; Richardson, B., 1935; Richter, C. M., 1887 (1sothermal profile); Robinson, M. K., 1951; Rude, G. T., 1933, 1934; Rudnick, P. and Cochrane, J. D., 1951; Russell, F. S., 1934; Sanchez, P. C., 1934c; San Diego Regional Water Pollution Control Board, 1952; Sargent, M. S. and Walker, T. J., 1948; Saur, J. T. F., Jr., 1950; Schenck, H. G., 1928; Schenck, H. G. and Keen, A. M., 1937; Schneider, W. A., 1954; Schulz, B., 1914; Scofield, E. C., 1934; Scripps Institution of Oceanography, 1949a, 1949b, 1949c, $1949 \mathrm{~d}, 1949 \mathrm{e}, 1950 \mathrm{a}, 1950 \mathrm{~b}, 1950 \mathrm{c}, 1950 \mathrm{~d}, 1950 \mathrm{e}$, $1950 \mathrm{f}, 1950 \mathrm{~g}, 1951 \mathrm{a}, 1951 \mathrm{~b}, 1951 \mathrm{c}, 1951 \mathrm{~d}, 1951 \mathrm{e}$, 1951f, 1951g, 1951h, 19511, 1951j, 1951k, 195lL, $1951 \mathrm{~m}, 1951 \mathrm{n}, 19510,1951 \mathrm{p}, 1951 \mathrm{q}, 1951 \mathrm{r}, 1952 \mathrm{a}$, $1952 b$, 1952c, 1952d, 1952e, 1952f, 1952g, 19521 (bottom temperature), 1953c, 1953e; Shepard, F. P., 1950c; Skogaberg, T., 1933, 1934, 1936 , Skogaberg, T. and Phelps, A., 1946; Slegge, G. F., 1927 (seasonal temperature changes); Slocum, G., 1931; Smith, J. P., 1904; Soule, F. M., 1934, 1944a; Stephenson, E. B., 1932; Stevenson, R. E., 1954; Sumner, F. B., Louderback, G. D., Schmitt, W. L. and Johnaton, E. C., 1914; Sverdrup, H. U., 1934, 1937-1938, 1938a, 1938c, $1938 \mathrm{~d}, 1939 \mathrm{a}, 1939 \mathrm{~b}, 1939 \mathrm{c}, 1940 \mathrm{a}, 1940 \mathrm{c}, 1940 \mathrm{~d}$, $1940 \mathrm{e}, 1940 \mathrm{f}, 1940 \mathrm{~g}, 1941 \mathrm{a}, 194 \mathrm{c}, 1944 \mathrm{a}, 1944 \mathrm{~b}$; Sverdrup, H. U. and Allen, W. E., 1939; Sverdrup, H. U. and Fleming, J. A., 1944 (also bottom temperature); Sverdrup, H. U. and Fleming, R. H. 1941; Sverdmup, H. U. and Staff, 1940, 1941, 1942b, $1943 \mathrm{a}, 1943 \mathrm{~b}, 1944,1945 \mathrm{a}, 1945 \mathrm{~b}, 1946,1947$; Swalneon, O. W., McIlwraith, C. G., and Dyk, K., 1934; Tanner, Z. L., 1892a (also bottom temperature), $1892 b, 1893$ (al:o bottom temperature), 1894; Thompson, W. F. and Thompson, J. B., 1919; Thorade, H., 1909; Tibby, R. B., 1937o, 1941, 1943; Tilden, C. A., 1925; Townsend, C. H., 1901; Trask, P. D., 1932b; Uchupi, E., 19.54; Ufford, C. W., 1947a, 1947b; Updegraff, D. M., 1948; U. S. Commisaion of Fish and Fisheries, 1898 (also bottom temperature); U. S. Bureau of Fisheriea, 1921; U. S. Coast and Geodetic 
Survey, 1948, 1950, 1952; U. S. Hydrographic Office, 1934b, 1943b, 1944a, 1944b, 1947a; Van Dorn, W. G., 1953; Vaughan, T. W., 1930b, 1930d, $1932 a, 1932 b, 1932 c, 1933,1934,1936,1940$; Vaughan, T. W. and Others, 1937; Wells, R. C., 1921; Whedon, W. F., 1939; Whedon, W. F. and Kolo1d, C. A., 1936; W1lstam, A., 1926; Wyman, R. H., 1878; ZoBell, C. E., 1938, 1939, 1942a, $1942 \mathrm{~b}, 1943,1946 \mathrm{~b}, 1946-1947$; 1947b, 1947c, $1947 \mathrm{~d}$, 1950; ZoBell, C. E. and Feltham, C. B., 1942; ZoBell, C. E., Grant, C. W. and Haas, H. F., 1943; ZoBell, C. E. and Rittenberg, S. C., 1938

Temperature of Hydration and Dehydration: Revelle, R., $1937 \mathrm{~b}$

Terraces (See also: Plateau, Wave Cut Terraces): Anonymous, 1932c, 1932e; Alexander, C. S., 1950; Anderson, C. A., 1941, 1950; Anderson, F. M., 1896-1902; Anderson, F. M. and Hanna, G. D., 1935; Anderson, R. E., Redwine, L. E. and McGovney, P. E., 1949; Anderson, W., 1939; Arnestad, K. H., 1950; Arnold, D., 1896; Arnold, D. and Arnold, R., 1902; Arnold, R., 1900, 1903; Arnold, R. and Hannibal, H., 1913; Ashley, G. H., 1895, 1896 , 1931; Bailey, T. L., 1943; Baldw1n, E. M., 1945; Bauer, F. H., 1952; Beach Erosion Board, 19481; Beal, C. H., 1915; Beard, C. N., 1941; Becker, G. F., 1888; Black, G. L., 1954; Blake, W. P., 1856; Blankinship, J. W., 1892; Böse, E. and Witt1ch, E., 1913; Bowman, A., 1873; Bremner, C. St. J., 1932, 1933; Bruff, S. C., 1940, 1946; Buwalda, J., 1927, 1936; California Department of Public Works, 1933; Carpenter, E. J. and Storie, R. E., 1929; Carsola, A. J. and Dietz, R. S., 1952; Chace, E. P. and Chace, E. M., 1919;

Clark, B. I., 1930, 1933?; Cleland, H. F., 1910; Clements, T., 1948; Clements, T. and Emery, K. 0., 1947; Cockerell, T. D. A., 1938b; Comstock, T. B., 1902; Congressional Documents, 1940a, 1953b; Cotton, C. A., 1942, 1944; Coulter, J. W., 1922; Crandall, H., 1915; Crowell, J. C., 1952; Darton, N. H., 1921; Dasher, J., Fraas, F. and Gabriel, A., 1942; Davidson, G., 1873d, 1875a, 1897; Dav1s, W. M. , 1931, 1932; Dickerson, R. E., 1910, 1922; Dietz, R. S., 1947b; Dietz, R. S., Emery, K. O. and Shepard, F. P., 1942; Dietz, R. S. and Menard, H. W., 1951b; Diller, J. S., 1896, 1901, 1902, 1903, 1915; Drake, W. F., 1897; Driver, H. L., 1948; Dunkle, M. B., 1944, 1950; Durst, F. M., 1915; Eaton, J. D., 1928, 1932, 1939, 1943; Eck1s, R., 1934; Eldridge, G. H., 1901; Ellis, A. J. and Lee, E. H., 1919; Emery, K. O., 1941a, 1947c, 1950a, 1954e; Emery, K. O., Butcher, W. S., Gould, H. R. and Shepard, F. P., 1952; Emery, K. O. and Shepard, F. P., 1945; Emiliani, C. and Epstein, S., 1953; Emmonds, S. F. and Merrill, G. P., 1894; Fairbanks, H. W. , 1893, 1896-1902, 1897, 1898, 1904; Fewkes, J. W., 1889; Ford, J. L. C., 1942; Gale, H. S. and Others, 1932; Gilbert, G. K., 1917; Goldberg, J., 1940; Goodyear, W. A., 1889; Gorsline, D. S., 1954; Grant, U. S., 1944; Grant, U. S. and Gale, H. R., 1931; Greene, E. L., 1886; Grlesbach, J. 0., 1947; Griggs, A. B., 1945; Griggs, A. B. and Wells, F. G., 1942; Haase, I. G., 1926; Ha.l, F. R., 1952; Hammond, E. H., 1951( ?); Handin, J. W., 1949, 1951; Hanna, G. D., 1951, 1952; Hanna, M. A., 1926; Hershey, O. H., 1902, 1903; Hertle1n, L. G. and Grant, U. S., 1939, 1944; Hess, H. H. and MacClintock, P., 1936; Hewatt, W. G., 1946; H111, M. L., 1928; H1ll, R. T., 1929; Hinds, N. E. A., 1952; Hobbs, W. H., 1921, 1944; Hoover, J. W., 1932a, 1932b; Howard, A. D., 1951; Howe, H. V., 1926; Hundhausen, R. J., 1947; Inman, D. L., 1950; Ives, R. L., 1951; Jenkins, O. P. and Others, 1933; Johnson, D., 1944; Johnson, W. M., 1858; Kelley, V. C., 1932 (?); Kemnitzer, L. E., 1933, 1936; Kew, W. S. W., 1927; Krumbe1n, W. c., 1947; Lakes, A., 1899, 1903a; Landes, K. K., 1952a, 1952b; Lawson, A. C., 1893a, 1893b, 1894, 1895 , 1914, 1924; Leonard, A. G., 1925; Lean, H. M., 1952; Lindgren, W., 1888; Lindgren, W. and Knowlton, F. H., 1896; Lindsay, D. R., 1952; Livingston, A., Jr., 1939; Louderback, G. D. 1930, 1940; McGee, w. J., 1900; MacDonald,
G. A., 1934; Ma, T. Y. H., 1952; Martens, J. H. C., 1939; Merriam, P. D., 1949; Merr11l, F. J. H., 1914, 1915; Miller, W. J., 1935; Moore, D. G., 1951; Nelson, N. C., 1909, 1910; Nicholson, G. F., 1929; Nicholson, G. F., Grant, U. S., Shepard, F. P. and Crowell, J. C., 1946; Norris, R. M., 1949, 1951; Oakeshott, G. B., 1951; O'Brien, M. P., 1936a; Osmont, V. C., 1904; Osorio Tapall, B. F., 1943; Page, G. B., 1950; Pardee, J. T., 1934; Pelline, J. E., 1952; Place, J. L., 1952; Putnan, W. C., 1930, 1937a, 1937b, 1938, 1940; Reed, R. D., 1933a, 1933b,

1934; Reed, R. D. and Holisster, J. S., 1936; Reiche, P., 1937; Revelle, R., 1950; Richardson, R. W., 1923; Ritter, W. E., 1901; Robertson, G. K., 1932; Rode, K., 1930; Shaler, N. S., 1895; Shepara, F. P., 1933c, 1934c, 1935b, 1938b, 1940c, 1941a, 1948c, 1949b, 1950e, 1950e, 1951e, 1953; Shepard, F. P. and Emery, K. O., 1941; Shepard, F. P., Emery, K. O. and LaFond, E. C., 1941; Shepard, F. P. and Grant, U. S., 1947; Shepard, F. P., Grant, U. S. and Dietz, R. S., 1939; Shepard, F. P. and MacDonald, G. A., 1938; Shepard, F. P. and Wrath, W. F., 1937; Sm1th, J. P., 1910; Smith, P. A., 1938; Sm1th, W. D., 1933b, 1933c; Smith, W. S. T., 1897, 1898, 1900, 1933; Snavely, P. P., Jr., 1951; Soper, E. K., 1938; Spencer, J. W., 1897; Stephenson, E. L., 1945; Stevenson, R. E., 1954; Stille, B., 1936; Stock, C., 1935; Stock, C. and Furlong, E. L., 1928; Storle, R. E. and Carpenter, E. J., 1929, 1930; Swinnerton, A. C., 1927; Taber, S., 1920; Taliaferro, N. L., 1943; Thomasson, H. G., Jr., 1951; Thompson, W. O., 1933, 1934, 1937; Trask, J. B., 1854; Trask, P. D., 1926a, 1926b, 1931b; Troxell, H. C. and others, 1942; Twenhofel, W. H., 1943; Uchupi, E., 1954; Udden, J. A., 1914; Upson, J. E., 1949a, 1949b; Upson, J. E. and Others, 1951; Upson, J. E. and Thomasson, H. G., Jr., 1951; Vickery, F. P., 1927a; Wanless, H. R., 1950; Warne, A., 1936; Weaver, C. C., 1944, 1945, 1949; Webb, R. W., 1936; Wheeler, G., 1936; Whitney, J. D., 1865; Wilcox, G. A., 1911; Willis, B. 1900; Wilson, M. E., 1907; Wittich, E., 1910, 1913 (?), 1920; Wood, H. 0., 1915; Woodford, A. 0., 1925, 1951; Woodring, w. P., 1935, 1938a, 1947, 1952; Woodring, W. P., Bramlette, M. N. and Kew, W. S. W., 1946; Woodring, W. P., Bramlette, M. N. and Kleinpell, R. M., 1936; Woodring, W. P., Bramlette, M. N. and Lohman, K. E., 1943; Woodring, W. P. and Kew, W. S. W., 1932; Worts, G. F., Jr., Others, 1951; Yates, L. G., 1902

Terraces, Submarine (See also: Wave Cut Terraces): Butcher, W. S., 1951a; Eaton, J. E., 1932; Emery, K. O. and Shepard, F. P., 1945; Gorsline, D. S., 1954; Holzman, J. E., 1949; Landes, K. K. 1952a; McGee, W. J., 1900; Norr1s, R. M., 1951; Shepard, F. P., 1941b, 1949e; Shepard, F. P. and Emery, K. O., 1941; Sverdrup, H. U. and Staff, 1941; Uchup1, E., 1954

Terrigenous Sediments (See also various types of terrigenous sediments): Lawson, A. C., 1924; P1ggot, C. S. 1932; Rittenberg, S. C., 1940; Shepherd, E. S., 1946; White, D., 1911

Tertiary (See also the geological Periods of the Tertiary): Anderson, C. A., 1941; Butcher, W. S., 1951a; Carsola, A. J. and Dietz, R. S., 1952; Clark, B. L., 1921; Crouch, R. W., 1954; Emery, K. O. and Natland, M. L., 1952; Emery, K. O. and Shepard, F. P., 1945; Emlliani, C., 1954; Hanna, G. D., 1952; Hill, R. T., 1928a; Hinds, N. E. A., 1952; Kuenen, Pb. H., 1947; LeConte, J., 1891; Shepard, F. P., 1935a, 1935c, 1936c, 1936g, $1941 \mathrm{a}, 1949 \mathrm{~b}, 1949 \mathrm{~d}, 1950 \mathrm{e}, 1952 \mathrm{a}$; Shepard, F. P. and Emery, K. O., 1941; Shepard, F. P. and MacDonald, G. A., 1938; Shepard, F. P. and Stetson, H. C., 1939; Spencer, J. W., 1890 Thermocline (See also: Bathythermography, Temperature): California Academy of Sclences, California Division of Fish and Game, Scripps Institution of Oceanography, U. S. Fish and Wildilfe Service, 1950; California Academy of Sciences, California Division of Fish and Game, Stanford University, Hopkins Marine Station, U. S. Fiah and Wildlife 
Service, Soutb Pacific Fishery Investigation, University of California, Scripps Institution of Oceanography, 1953; Carsola, A. J., 1947; Defant, A., 1950a; Dietz, R. S. and LaFond, E. C., 1950; Emery, K. O., Butcher, W. S., Gould, H. R. and Shepard, F. P., 1952; Ewing, G. C., $1950 \mathrm{~b}, 1950 \mathrm{c}$; Graham, H. W., 1934; Graham, H. W. and Moberg, E. G., 1944; McEwen, G. F., 1916; Moberg, E. G., 1928a, 1930b; Moberg, E. G. and Fleming, R. H., 1934; Munk, W. H. and Anderson, E. R., 1948; Pattullo, J., 1952; Rudnick, P. and Cochrane, J. D., 1951; Sargent, M. S. and Walker, T. J., 1948; Scripps Institution of Oceanography, 1951j, 1951L; Sverdrup, H. U. and Allen, W. E., 1939; Ufford, C. W., 1947a, 1947c; Vaughan, T. W., $1932 \mathrm{c}$

Thickness of Sediment: Emery, K. 0 . and Rittenberg, S. C., 1952; Raitt, R. W., 1949; Scripps Institution of Oceanography, 1953e; Shepard, F. P., 1940e; Thompson, W. C., 1949; Trask, P. D. and Scott, T., 1954

Thixotrophy: Emery, K. 0 and Rittenberg, S. C., 1952 Thorium - see Radioactivity

Tidal Bore: Emery, K. O. and Gale, J. F., 1951; Gordon, J. H., 1923; Kniffen, F. B., 1932; Swain, F. E., 1951

Tidal Currents (See also: Sediment Transport): Beach Erosion Board, 1948b, 1951; Berghaus, H., 1891; Brown, E. I., 1939; Bucher, W. H., 1940; Butcher, W. S., 195la; California Bureau of Sanitary Engineering; 1952; California Department of Fish and Game, 1951; Chase, J. L., 1948; Coe, W. R., 1953; Crooke, R. C., Elvitsky, A. W., et al, 1953; Crowell, J. C., 1947; Davideon, G., 1884; Defant, A., 1950b; Dietz, R. S., 1953; Dietz, R. S. and Menard, H. W., 1951b; Emery, K. O., 1950d; Emery, K. O., Butcher, W. S., Gould, H. R. and Shepard, F. P., 1952; Evans, O. F., 1941; Fleming, R. H., 1937-1938; Gibson, W. M., 1951; Goldberg, E. D., 1954; Gorsline, D. S., 1954; Goldberg, J., 1940; Gulliver, F. P., 1896; Handin, J. W., 1949; Hoover-Young, San Francisco Bay Bridge Commission, 1930; Horton, D. F., 1948; Inman, D. L., 1949; Jarv1s, C. S., 1921; Lapsley, W. W., 1937; Lawson, A. C., 1894; Lawson, J. S., 1862; LeConte, J., 1891; Louderback, G. D., 1940; Lelpper, D. F., 1950; Leypoldt, H., 1941b; McAfee, C. M., 1939; McGee, W. J., 1900; Marmer, H. A., 1926, 1932; Menard, H. W., 1952; Menard, H. W. and Ludwick, J. C., 1951; Miller, R. C., Ramage, W. D. and Lazier, E. L., 1928; Nicholson, G. F., Grant, U. S., Shepard, F. P. and Crowell, J. C., 1946; O'Brien, M. P., 1936b, 1941; Rawn, A. M. and Bowerman, F. R., 195l; Revelle, R., 1939b; Revelle, R. and Shepard, F. P., 1939a, 1939b; Rolland, M. C., 1952; San Diego Regional Water Pollution Control Board, 1952; Sear8, C. B., 1876; Shaler, N. S., 1895; Shepard, F. P., 1933a, 1938g, $1941 \mathrm{a}, 1948 \mathrm{~b}, 1949 \mathrm{a}, 1950 \mathrm{c}$; Shepard, F. P. and Emery, K. 0., 1941, 1945; Shepard, F. P. and Inman, D. L., 1949, 1951a; Simmons, H. B., 1952; Skogsberg, T., 1936; Stevenson, R. E., 1954; Studds, F. A., 1951; Sumner, F. B., Louderback, G. D., Schmitt, W. L. and Johnston, E. C., 1914; Sverdrup, H. U., 1936, 1939a, 1939c; Sverdrup, H. U. and Staff, 1947a; Tower, M. L., 1910, 1913; Trask, P. D., 1952b; Udden, J. A., 1914; U. S. Army Corps of Engineers 1931; U. S. Cosst and Geodetic Survey, 1947; Whitney, P. C., 1935

Tidal Flushing - see Flushing of Estuary

Tidal Prism: Blinn, F. S., 1928; Congressional Documents, 1953; Crooke, R. C., Elvitsky, A. W., et al, 1953; Kenyon, E. C., Jr., 1951; Leeds, C. T., Vanon1, V. A. and Knapp, R. T., 1934; Nicholson, G. F., Grant, U. S., Shepard, F. P. and Crowell, J. C., 1946; O'Brien, M. P., 1931

Tide (See also: Flushing of Estuary, Tidal Bore, Tidal Currents, Tidal Prism, Tide Flat): Anonymous, 1915, 1916a, $1929 \mathrm{~b}, 1933 \mathrm{e}, 1940 \mathrm{c}, 1940 \mathrm{~d}, 1951 \mathrm{~b}$; Allen, W. B., 1932; Allen, W. E., 1920, 1923b, 1941a; Anderson, C. A., 1950; Averill, C. V., 1941; Bache, A. D., 1852, 1854a, 1854b, 1856a, 1856d, 1856e; Bascom, W. N., 1946a, 1947a, 1947c, 1947a, 1950b, 1950c; Bates, C. C. and Glenn, A. H., 1948; Beach Erosion Board, 1948b, 1948i, 1952b, 1953a, 1953c;
Bigelow, H. B. and Leslie, M., 1930; Blake, E. W., Jr., 1887; Blake, J., 1868b; Bowie, W., 1936; Brown, E. I., 1939; Bucher, W. H., 1940; Bullock, F. W., 1933; Byerly, P., 1927, 1930; Caldwell, J. M., 1950; California Academy of Sciences, California Division of Fish and Game, Scripps Institution of oceanography of the University of California, and U. S. Fish and Wildlife Service, 1951b; California Academy of Sclences, California Division of Fish and Game, Scripps Institution of Oceanography of the University of California, U. S. Fish and Wildlife service, and Hopkins Marine Station, Stanford University, 1951; California Department of Public Health, 1951; California, University of, 1945, 1952a, 1952b, 1954b; Carpenter, E. J. and storie, R. E., 1929; Carpenter, F. A., 1924; Clark, F. N., 1938; Congressional Documents, 1908e, 1938a, $1940 \mathrm{a}, 1940 \mathrm{c}, 1941,1942 \mathrm{c}, 1943,1949-1950 \mathrm{~b}$, 1953; Couch, E. B., 1915; Cram, C. M., 1931; Crooke, R. C., Elvitsky, A. W., et al, 1953; Dall, W. H., 1904, 1911; Dapples, E. C., 1942; Davidson, G., 1856, 1859, 1864, 1873b; Davis, W. M., 1925, 1932; Dawson, E. Y., 1952; Defant, A., 1950a, 1950b; DeGroot, H., 1890; Dietz, R. S., 1947b; Diller, J. S., 1902; D1sney, L. P. and overshiner, W. H., 1925; Eaton, R. O., 1951; Eldredge, Z. S. and Molera, E. J., 1909; Elliott, F. E., Tressler, W. L. and Myers, W. N., 1953; Emery, K. 0., 1944, 1945a, 1945b, 1946b; Emery, K. O. and Foster, J. F., 1948; Emery, K. O. and Gale, J. F., 1951; Emery, K. O. and Tschudy, R. H., 1941; Evans, R. D., Kip, A. F. and Moberg, E. G., 1938; Fleming, R. H., 1937-1938; Folsom, R. G., 1945c; Fraser, C. MCL., 1943; Gilbert, G. K., 1917; Gillette, C. E., 1905; Gislen, T., 1943, 1944; Gorsline, D. S., 1954; Grant, U. S., 1938, 1943, 1944, 1948; Grant, U. s. and Shepard, F. P., 1938a, 1940; Green, C. K., 1946; Green, J. L. and Smyser, R. E. , Jr., 1932; Gulliver, F. P. 1896; Gutenberg, B., 1933, 1941b; Hall, W. C., 1938, 1942; Harts, W. W., 1911; Harvey, D. R., 1928; Hawgood, H., 1914; Hewatt, W. G., 1937, 1946; Hickson, R. E. and Rodolf, F. W., 1951; Hinde, H. P., 1952; Holway, R. S., 1914; Hoover-Young San Francisco Bay Bridge Commission, 1930; Inman, D. L., 1949, 1950, 1953a; Isaacs, J. D., 1948; Isaacs, J. D. and Bascom, W. N., 1947, 1949; Johnson, A. G., 1940c, 1951; Johnson, D. W., 1910; Johnson, J. W., 1948b, 1948d, 1952; Johnson, M. W., 1939b, 1948; Kenyon, E. C., 1951; Kniffen, F. B., 1932; Krumbein, W. C., 1947; Krumbein, W. C. and Ohsiek, L. E., 1950; LaFond, E. C., 1938, 1939a, 1939b; Lawson, J. S., 1862; Lawson, L. M., 1950; Leeds, C. T., 1916; Leeds, c. T., Vanoni, A. and Knapp, R. T., 1934; Leipper, D. F., 1950; Leypoldt, H., 1934, 1938, 1941a, 1941c, 1947; Leypoldt, H. and McHenry, J. R., 1942; Lieber, A. C., Jr., 1940; Louderback, G. D. 1940; McEwen, G. F., 1935a; McGee, W. J., 1900; McKee, E. D., 1939, 1953; McManus, A. B., 1934; McOuat, H. W., 1951; MacDonald, G. A., 1934; MacGinit1e, G. E., 1927, 1935; Marlette, J. W., 1954; Marmer, H. A., 1926, 1927, 1928, 1932, 1952; Mason, E. H., 1930, 1950a, 1950b; Meaney, C. D., 1949; Means, T. H., 1928, 1929, 1931; Menard, H. W., 1952; Miller, H. E. and Nusbaum, I., 1952; Miller, R. C., Ramage, W. D. and Lazier, E. L., 1928; Moberg, E. G. and Allen, W. E., 1927; Morey, B. F., 1945; Morrison, R. L., 1930; Munk, W. H., 1940, 1949a, 1951, 1953; Munk, W. H. and Traylor, M. A., 1947; Murphy, L. M. and Ulrich, F. P., 1952; Nelson, J. W., Dean, W. C., Kocher, A. E., Watson, E. B. and Carpenter, E. J., 1920; Nelson, N. C., 1909; Nicholson, G. F., 1929; Norris, R. M., 1951; O'Brien, M. P., $1931,1936 \mathrm{a}, 1939$, 1945b; O'Brien, M. P. and Johnson, J. W., 1947; 0lsson-Seffer, P., 1910a; orange County Planning Commission, 1941; Palmer, R. H., 1928; Patrtek, D. A., 1953; Patton, R. S., 1941; Paul, A. B., 1894; Pratt, W. E., 1947; Price, F., 1936; Purer, E. A., 1942; Putnam, J. A., Bermel, K. J. and Johnson, J. W., 1947; Putnam, J. A., Munk, W. H. and Traylor, M. A., 1949; Remondino, P. C., 1892; Revelle, R., 1950; 
Revelle, R. and Shepard, F. P., 1939b, 1943; Richardson, R. W., 1923; Roop, F. C., 1946; Rudnick, P. and Cochrane, J. P., 1951; San Francisco Bay Marine Piling Comnittee, 1921; Saur, J. T. F., Jr., 1950; Scanlon, T. S., Jr., and Osborn, P., 1950; Schneider, w. A., 1954; Scripps Institution of Oceanography, 1944c, 1945c, 1945d, 1950g, 19521; Shepard, F. P., 1932, $1935 \mathrm{~d}, 1938 \mathrm{~g}, 1943 \mathrm{~b}, 1949 \mathrm{~b}, 1950 \mathrm{~b}, 1950 \mathrm{f}, 1950 \mathrm{~g}$, 195la; Shepard, F. P. and Emery, K. O., 1941; Shepard, F. P. and Inman, D. L., 1951, 1951b; Shepara, F. P. and LaFond, E. C., 1940; Shepard, F. P. and MacDonald, G. A., 1938; Shepard, F. P., Revelle, R. and Dietz, R. S., 1939; Shepard, F. P. and Sayner, D. B., 1953; Shuler, W. R. 1951, 1952; Skogsberg, T., 1936; Smith, W. D., 1933b; Somers, P., 1952; Stevenson, R. E., 1954; Stevenson, R. E. and Emery, K. O., 1951; Storie, R. E. and Carpenter, E. J., 1929, 1930; Studds, F. A., 1951; Stump, R. S., 1944b, $1944 \mathrm{c}$, 1945k; Stump, R. S. and Hermanson, R. T., 1945c; Stump, R. S., and Johnson, J. W., 1944; Sumner, F. B., Louderback, G. D., Schmitt, W. L. and Johnston, E. C., 1914; Sverdrup, H. U., 1939c; Sverdrup, H. U. and Staff, 1943b; Swain, F. E., 1951; Symons, T. W., 1893; Thompson, W. O. 1933, 1937; Thompson, W. F. and Thompson, J. B., 1919; Topp, E. P., 1929; Trask, P. D., 1931b, 1952a; Trowbridge, w. P., 1855, 1856b; Ufford, C. W., 1947b; U. S. Coast and Geodetic Survey, 1953; U. S. Coast Survey, 1864, 1867; U. S. Hydrographic office, 1875; U. S. Waterways Experiment Station, Vicksburg, Mississippi, 1935, 1950; Vanoni, V. A. and Carr, J. H., 1951; Vaughan, T. W., 1933; Walker, B. W., 1947; Walters, L., 1953; Watts, G. M. and Others, 1953; Whiting, W. D. and Others, 1858; Whitney, P. C. 1935; Woodford, A. O., 1935; Wright, R., 1937; Yale, C. G., 1879; ZoBell, C. E. and Feltham, C. B., 1942

Tide Flat or Mud Flat (See also: Bay, Estuary, Harbor, Lagoon, Marsh, Salt Marsh, Swamp): Congressional Documents, 1949a; Cook, E. H., 1908; Crandall, H., 1915; Dapples, E. C., 1942; Emery, K. O. and Dietz, R. S., 1941; Hanna, M. A., 1926; Leeds, C. T., 1915; Louderback, G. D., 1940; McKee, E. D., 1953; MacGinit1e, G. E., 1939; Scripps Institution of Oceanography, 1953c; Stevenson, R. E., 1951; Tolman, C. F. and Poland, J. F., 1940; Trask, P. D., 1928; ZoBell, C. E. and Feltham, C. B., 1942

Tidelands (See also: Legal, Petroleum): Anonymous, 1932a, $1932 b, 1938 \mathrm{c}, 1946 \mathrm{a}, 1948,1952 \mathrm{~b}, 1952 \mathrm{c}, 1952 \mathrm{~h}$, $1952 \mathrm{j}, 1952 \mathrm{k}, 1952 \mathrm{~L}, 1952 \mathrm{~m}, 1952 \mathrm{n}, 19520,1952 \mathrm{p}$, $1952 \mathrm{q}, 1953 \mathrm{a}$, to $1953 \mathrm{f}, 1954 \mathrm{a}$ to $1954 \mathrm{~d}, 1954 \mathrm{f}$ to 1954i, 1954k; Alexander, A. H., 1936; Armstrong, T. A., 1954; Barnes, K. B., 1945; Beach Erosion Board, 1948j; Bell, G. K., 1948; Blodget, R. M., 1949; Bullington, J. P., 1940; California Legislature, 1931b, 1951b; Chase, J. L., 1948; Clary, W. W., 1949; Collins, L. B., Gilbert, J. C. and Simon, J. H., 1933; Congressional Documents, 1953b; Fitzgerald, J. N. J., 1952; Fox, L. S., 1930; Friedman, S. L., 1949; Gale, H. S., 1933, 1934a, 1934b; Gilbert, J. C. and Simon, J. H., 1933; Grant, U. S., 1939; Gross, H. E., 1945; Hansen, H. A. and Pemberton, J. R., 1950; Hjelte, G., 1938; Horrer, P. L., 1949; Hoots, H. W., Blount, A. L. and Jones, P. H., 1935; Hubbs, C. L. and Rechnizer, A. B., 1952; Kemnitzer, W. J., 1937; King, C., 1953a, 1953b, 1953c; Larsen, G. P., 1941; Leeds, C. T., 1951; Menard, H. W., Dill, R. F., Hamilton, E. L., Moore, D. G., Shurway, G., Silverman, M. and Stewart, H. B., 1954; Mills, B., 1932d, 1932e, 1932f, 1936; Morgan, F. A., 1930; Murray-Aaron, E. R., 1947; National Petroleum Counc1l, 1953; Nicholls, C P. L., 1936c; Pollak, C. N., 1953; Pratt, W. E., 1947; Pyles, E. E., 1954; Shalow1tz, A. L., 1951, 1953; Smith, J. S., 1936; Stockman, I. P., 1932, 1939, 1949a, 1949b, 1949c; stormont, D. H., 1951b, 1951c, 1952a, 1952b, 1952c, 1954a, 1954b, 1954c; Sweeney, J., 1930; Weaver, D. K., 1937; Weaver, D. K. and willbelm, V. H., 1943; Welker, S. C., 1954; Wharton, M., 1948
Tide Pool (See also: Minor Features, Rocky Coasts; Solution Basins): Allen, W. E., 194la; Bruff, S. C., 1946; Cartwright, L. D., Jr., 1928; Couch, E. B., 1915; Drury, N. B., 1938; Emery, K. O., 1945b, 1946b; Fox, D. L., Isaacs, J. D. and Corcoran, E. F., 1952; Fraser, C. McL., 1943; Haase, L. G., 1926; Hewatt, W. G., 1934; Lakes, A., 1903a; McKee, E. D., 1953; Michael, E. L., 1921; Morr1son, R. L., 1930; Sanchez, P. C., 1934e; Stevenson, R. E., 1954; Thompson, W. O., 1937; Vaughan, T. W., 1940; Williams, W., 1948

Tilting (See also: Diasorphism, Warping): Alexander, $C$. S., 1950; Buwalda, J. P., 1927; Gutenberg, B., 1933; McHenry, J. R., 1942; Shepard, F. P. and Wrath, W. F., 1937; Troxell, H. C. and Others, 1942

Tin: Revelle, R., 1935; Thompson, T. G. and Robinson, R. J., 1932; Trask, P. D., 1939; Vaughan, T. W., 1933

Titanium: Goldberg, E. D., 1954; Lowenstam, H. A., 1954; Revelle, R.' and Emery, K. O., 1951; Scripps Institution of Oceanography, $1953 \mathrm{e}$

Tombolo: Dietz, R. S., 1947b; Grant, U. S. and Shepard, F. P., 1940; Gulliver, F. P., 1896; Handin, J. W. and Ludwick, J. C., 1949; Leypoldt, H., 1941b; Shepard, F. P., 1950c; Wanless, H. R., 1950

Tonalite (See also: Rock): Shumway, G. A., 1953 Topography - see Submarine Topography

Topography, Rocky Coasts: Isaacs, J. D., 1945f, 1945b

Total Solids (See also: Non-volatile Solids, Volatile Solids): Lipman, C. B., 1929

Toxic Conditions - see Pollution, Reducing or Anaerobic Environment, Stagnant Water

Traction (See also: Creep, Transport of Sediment): Emery, K. O. and Gale, J. F., 1951; Trask, P. D., 1952b; Twenhofel, W. H., 1946

Transparency (See also: Light, Red Water, Turbid water): Anonymous, 1941b; Boden, B. P., 1950; California Academy of Sciences, California Division of Fish and Game, Scripps Institution of Oceanography, $U$. S. Fish and wildlife Service, 1950; California Bureau of Sanftary Engineering, 1952; California Department of Fish and Game, 1951; Crooke, R. C., Elvitsky, A. W., et al, 1953; Dietz, R. S., 1947b; Emery, K. 0., 1954; Gislen, T., 1943, 1944; Gorsline, D. S., 1954; Hyde, C. G., Gray, H. F. and Rawn, A. M., 1941; Miller, H. E. and Nusbaum, I., 1952; Munk, W. H., 1950; Natland, M. L., Revelle, R. and Rittenberg, S. C., 1941; Richardson, B., 1934; San Diego Regional water Pollution Control Board, 1952; Shepard, F. P., $1938 \mathrm{~b}, 1949 \mathrm{~b}, 1950 \mathrm{~b}$; Sverdrup, H. U., 1939a; Sverdrup, H. U. and Staff, 1941; U. S. Navy, 1948; Young, R. T., 1939, 1943; Young, R. T. and Gordon, R. D., 1939

Transported Rock (See also: Source Rock): Butcher, W. S., 195la; Dietz, R. S., Emery, K. O. and Shepard, F. P., 1942; Emery, K. O., Butcher, W. S., Gould, H. R. and Shepard, F. P., 1952; Hanna, G. D., 1951; McEwen, G. F., 1935a

Transport of Sediment (See also: Concentration of sediments in the Surf Zone, Creep, Littoral Drift, Rip Currents, Suspended Sediment, Traction): Anonymous, 1938a; Bascom, W. N., 1946b, $1950 \mathrm{a}$, 1951; Beach Erosion Board, 1948a, 1952b, 1952c, 1953c; Burt, W. V. and Saur, J. F. T., Jr., 1948; California, University of, 1951c, 1952c, 1954a, 1954b; Crowell, J. C., 1950; Darrow, W. E., 1942; Davis, W. M., 1932; Dietz, R. S., 1947b; Dietz, R. S., Emery, K. O. and Shepard, F. P., 1942; Dietz, R. S. and Menard, H. W., 1951b; Dietz, R. S., Menard, H. W. and Hamilton, E. L., 1954; Eaton, R. O., 1951; Emery, K. O., 1950c; Emery, K. O. and Gale, J. F., 1951; Emery, K. O. and Shepard, F. P., 1945; F1sher, R. L. and Mills, R., 1952; Fries, A. A., 1912; Gillette, C. E., 1905; Gislęn, T., 1943; Goldberg, J., 1940; Hall, W. C., 1942a; Handin, J. W., 1949; Handin, J. W. and Ludwick, J. C., 1949; Hanna, G. D., 1952; Inman, D. L., 1949, 1953b; Isaacs, J. D., I947a; Johnson, A. G., 1940c; Johnson, J. W., 1948d, 1952; Koczy, F. F., 1954; Krumbein, W. C. and Ohsiek, L. E. 1950; Kuenen, Ph. H. and Menard, H. W., 1952; Laws on, A. C., 1894; Lesser, R. M., 1951; 
McEwen, G. F., 1935a; Mason, M. A., 1942, 1950b; Menard, H. W., 1952; Moore, D. G., 1951; Munk, W. H., 1949b; Munk, W. H. and Traylor, M. A., 1947; Page, G. B., 1950; Pardee, J. T., 1934; Revelle, R., 1939a; Scripps Institution of Oceanography, 1953e, 1953f; Shaler, N. S., 1895; Shepard, F. P., 1936a, 1941a, 1949e, 1950c, 1950f; Shepard, F. P. and Inman, D. L., 1949, 1951b; Shepard, F. P. and MacDonald, G. A., 1938; Shepard, F. P. and Revelle, R. and Dietz, R. S., 1939; Shepard, F. P. and Wrath, W. F., 1937; Somers, P., 1952; Stelzenmuller, W. B., 1949; Sverdrup, H. U., 1936, 1939a; Sverdrup, H. U. and Staff, 1946; Toit, A. L. du, 1940; Trask, P. D., 1924 (sorting by waves), $1952 b$

currents: Bucher, W. H., 1940; Crowell, J. C., 1947; Dapples, E. C., 1942; Emery, K. O., Butcher, W. S., Gould, H. R. and Shepard, F. P., 1952; Grant, U. S. and Shepard, F. P., 1940; Gulliver, F. P., 1896; Hough, J. L., 1942; Louderback, G. D., 1920; Revelle, R. and Shepard, F. P., 1939b; Shepard, F. P.,' 1940c, 1950f, 1951b; Twenhofel, W. H., 1946 Tidal Currents: Emery, K. O., 1950d; Lawson, A. C., 1894; Revelle, R. and Shepard, F. P., $1939 \mathrm{~b}$

Waves: Anonymous, 1950e; Boos, M. F., 1940; Dietz, R. S., Emery, K. O. and Shepard, F. P. 1942; Emery, K. O. and Stevenson, R. E., 1950; Fox, L. S., 1930; Grant, U. S., 1943; Grant, U. S. and Shepard, F. P., 1940, 1946; Gulliver, F. P., 1896; Handin, J. W. and Ludwick, J. C., 1950; Krumbein, W. C., 1947; Revelle, R. and Shepard, F. P., 1939b; Shepard, F. P., 194la; Shepard, F. P. and Inman, D. L., 1949, 1951b; Shepard, F. P. and Wrath, W. F., 1937; Thompson, W. O., 1937; Twenhofel, W. H., 1946

Trench, Deeps (See also: Geosyncline, Grabens, Submarine Topography, Syncline, Trough): Anonymous, 1927; Cochrane, J. D. and Arthur, R. S., 1948; Daly, R. A., 1939 (foredeep); Davidson, G., 1875b; Eardley, A. J., 1954; Emery, K. O., 1950c; Emery, K. O. and Natland, M. L., 1952; Gunn, R., 1947; Gutenberg, B., 1950; Heck, N. H., 1924, 1926; Hertlein, L. G. and Emerson, W. K., 1953; Littlehales, G. W., 1932b; Raitt, R. W., 1954; Revelle, R., 1943; Richter, C. F., 1940; Scripps Institution of Oceanography, 1953e; Shepard, F. P., 1952a; Smith, W. D., 1933c; Sverdrup, H. U.., 1939b; Trask, P. D., 1931b; Whiteroft, H. T., 1944

Triassic: Cohee, G. V., 1938; Emery, K. O., 194lc; Emery, K. O. and Shepard, F. P., 1941, 1945

Trough (see also: Grabens, Submarine Topography, Trench): Anderson, C. A., 1950; Boden, B. P., 1950; Bucher, W. H., 1939; Buffington, E. C., 1952; Butcher, W. S., 195la; California, University of, 1946a; Clark, B. L., 1931; Crowell, J. C., 1952; Dietz, R. S., 1952a; Dietz, R. S., Menard, H. W. and Hamilton, E. L., 1954; Emery, K. O., 1941a, 1948, 1951, 1952a; Emery, K. 0., Butcher, W. S., Gould, H. R. and Shepard, F. P., 1952; Emery, K. O. and Rittenberg, S. C., 1952; Fox, D. L., 1937; Garrison, L. E. and Takasaki, K. L., 1950; Gilbert, J. Y. and Allen, W. E., 1943; Grim, R. E., Dietz, R. S, and Bradley, W. F., 1949; Heck, N. H., 1924, 1934, 1938; Hill, R. T., 1928b; Hinds, N. E. A., 1952; Hobbs, W. H., 1944; Kuenen, $\mathrm{Ph}$. H. and Menard, H. W., 1952; Landes, K. K., 1952a; Menard, H. W. and Dietz, R. S., 1951; Menard, H. W. and Ludwick, J. C., 1951; Phleger, F. B., 1951; P1ggot, C. S. and Urry, W. D., 1942; Reed, R. D., 1938; Revelle, R., 1938, 1939b; Revelle, R. and Shepard, F. P., 1939b; Scripps Institution of Oceanography, 1953e; Shepard, F. P., 1932, 1935b, 1937c, 1937e, $1939 \mathrm{~d}, 1940 \mathrm{a}, 1940 \mathrm{c}, 1940 \mathrm{~d}, 1940 \mathrm{e}, 1941 \mathrm{a}, 1942 \mathrm{~b}$, $1949 \mathrm{~b}, 1950 \mathrm{a}, 1950 \mathrm{~d}, 1950 \mathrm{e}, 1951 \mathrm{a}, 1951 \mathrm{~b}, 1951 \mathrm{~d}$; Shepard, F. P., and Emery, K. O., 1941; Shepard, F. P., Emery, K. O. and LaFond, E. C., 1941; Shepard, F. P., Revelle, R., Dietz, R. S. and Emery, K. 0., 1938; Shepard, F. P. and Wrath, W. F., 1937; Shumway, G. A., 1953; Smith, P. A., 1940; Sverdrup, H. U., 1938c, 1939a; Sverdrup, H. U. and Staff, 1941; Swainson, 0.
W., 1944; Sykes, G., 1938; Whiteroft, H. T., 1944

Nearshore, including Longshore and offshore Troughs, Low and Ball: Anonymous, 1916a, 1917; Brant, I., 1925; Congressional Documents, 1953b; Inman, D. L., 1953b; Lawson, A. C., 1894; Leeds, C. T., 1916; McKee, E. D., 1953; Norris, R. M., 1952; Scripps Institution of Oceanography, 1944c, 1944g; Shepard, F. P., 1942a (low and ball), 1950b, 1950f, 1950g; Shepard, F. P., Emery, K. O. and LaFond, E. C., 1941; Shepard, F. P. and Inman, D. L., 1951b; Shuler, w. R., 1952

T-S Curves (See also: Salinity, Temperature, Thermocline, Water Mass, Water Type): California Academy of Science, California Division of Fish and Game, Scripps Institution of Oceanography of the University of California, and U. S. Fish and Wildlife Șervice, 195la; California Academy of Sciences, California Division of Fish and Game, Stanford University, Hopkins Marine Station, U. S. Fish and Wildife Service, South Pacific Fishery Investigation, University of California, Scripps Institution of oceanography, 1953; Fleming, R. H., 1940a; Horrer, P. L., 1948a; Robinson, M. K., 1951; Sverdrup, H. U., 1939c, 1944a, 1944b; Sverdrup, H. U. and Fleming, J. A., 1944; Sverdrup, H. U. and Staff, 1943b; Tibby, R. B., 1943

Tsunamis (See also: Submarine Canyons, origin of): Anonymous, 1883, 1946b, 1946c; Bache, A. D., 1856e; Bascom, W. N., 1946a; Bates, C. C. and Glenn, A. H., 1948; Beach Erosion Board, 1952b; Belcher, G., 1843; Bodle, R. R., 1946a, 1946b; Bodle, R. R. and Murphy, L. M., 1948; Boutelle, C. O., 1884; Bucher, W. H., 1940; Byerly, P., 1930; Carpenter, F. A., 1924; Clark, J. T., 1944; Clements, T. and Emery, K. 0., 1947; Cochrane, J. D. and Arthur, R. S., 1948; Congressional Documents, 1953; Davidson, G., 1873b; Davison, C., 1900, 1933; DeBallore, M., 1912a, 1912b; Dietz, R. S., 1947b; Evans, F. J. and Wharton, W. L., 1888; Fonck, F., 1871; Galllard, D. D., 1904; Green, C. K., 1946; Gutenberg, B., 1939; Haley, S., 1886; Heck, N. H., 1934, 1947; Heck, N. H. and Bodle, R. R., 1930; Hochstetter, F., 1868; Holden, E. S., 1898; Honda, K., 1906; Kuenen, Pb. H., 1947; Louderback, G. D., 1944; McKay, E. C., 1946; Mallet, R., 1858; Mason, M. A., 1950a; Menard, H. W., 1952; Menard, H. W. and Ludwick, J. C., 1951; Mi yabe, N., 1934; Munk, W. H., 1947a, 1949a, 1953; Murphy, L. M. and Ulrick, F. P., 1951b, 1952; Neumann, F. 1932, 1935, 1940b, 1943; O'Brien, M. P., 1946b; Omori, F., 1907; Patton, R. S. and Marmer, H. A., 1932; Reid, H. F., 1918; Roop, F. C., 1946; Scanlon, T. S., Jr. and osborn, P., 1950; Scripps Institution of oceanography, 19521, 1953c; Shepard, F. P., 1941a, 1943a, 1949d, 1950b. Shepard, F. P. and Emery, K. O., 1941; Shuck, 0. T., 1869; Smith, W. D., 1933b; Swainson, O. W., 1944; Thornton, D. L., 1946; Townley, S. D. and Allen, M. W., 1939; Trask, J. B., 1856, 1857; U. S. Coast and Geodetic Survey, 1953a; Vanoni, V. A. and Carr, J. H., 1951; Verbeek, R. D. M., 1885-1886; Wilson, R. M., 1928a, 1928b

Tuff (See also: Rock, Volcanic Rock): Chesterman, c. W., 1952; Clements, T. and Dana, S. W., 1944; Cohee, G. V., 1938; Emery, K. O. and Shepard, F. P., 1945; Shepard, F. P. and Wrath, W. F., 1937; Shumway, G. A., 1953

Turbidity or Density Currents (See also: Submarine Canyons, origin of): Bell, H. S., 1942; Buffington, E. C., 1951, 1952; Crouch, R. W., 1954; Crowell, J. C., 1952; Dietz, R. S., 1952a, 1952b, 1954; Dietz, R. S. and Menard, H. W., 1951b; Dill, R. F., Dietz, R. S. and stewart, H., 1952, 1954; Emery, K. 0., 1952b; Emery, K. O., Butcher, W. S., Gould, H. R. and Shepard, F. P., 1952; Emery, K. O. and Natland, M. L., 1952; Emery, K. O. and Rittenberg, S. C., 1952; Garrison, L. E. and Takasaki, K. L., 1950; Handin, J. W., 1949; Koczy, F. F., 1954; Kuenen, Ph. H. and Menard, H. W., 1952; Landes, K. K., 1952a, 1952b; Ludwick, J. C., Jr., 1950; Menard, H. W. and Ludwick, J. C., 1951; Natland, M. L. and Kuenen, 
Ph. H., 1951; Phleger, F. P., 1951; Scripps Institution of Oceanography, 1953e; Shepard, F. P., 1947a, 1949b, 1949d, 1950a, 1950d, 1951a, 1951b, 1951d; Shepard, F. P. and Emery, K. O., 1941; Shumway, G. A., 1953; Sverdrup, H. U., 1947; Toit, A. L. du, 1940; Woodford, A. O., 1951

Turbid Water, Discolored Water, Water Color (See also: Absorption, Extinction Coefficient, Light, Red Water, Transparency): Allen, W. E., 1940b, 194lc; Beach Erosion Board, 1948h; Bell, H. S., 1942; Bullard, F. M. and Mills, R. A., 1951; Burt, W., 1952; California Department of Public Health, 1951; Congressional Documents, 1938a, 1949f; Crooke, R. C., Elvitsky, A. W., et al, 1953; Dietz, R. S., 1947b; Emery, K. O., 1954a; Emery, K. O. and Tschudy, R. H., 1941; Gilbert, G. K., 1917; Gilbert, J. Y. and Allen, W. E., 1943; Gillette, C. E., 1905; Goldberg, E. D., 1954; Hawgood, H., 1914; Hinde, H. Р., 1952; Hyde, C. G., Gray, H. F. and Rawn, A. M., 1941; Inman, D. L., 1950; Menard, H. W., 1952; Miller, R. C., Ramage, W. D. and Lazier, E. L., 1928; Moberg, E. G., 1928a, 1930c; Myers, E. H., 1943; Natland, M. L. and Kuenen, Ph. H., 1951; Page, G. B., 1950; Schenider, W. A., 1954; Schulz, B., 1.914; Shepard, F. P., 1941a, 1951d; Shepard, F. P. and Emery, K. O., 1941, 1945; Thompson, W. O., 1937; U. S. Navy, 1948; Yale, C. G., 1879

Turbulence: Allen, W. E., 194la, 1941b, 194lc, 1941d; Beach Erosion Board, 1948b, 1948h; Bronger smaSander 8, M., 1948; California, University of, 1952a; Crowell, J. C., 1947, 1952; Eaton, R. O., 1951; Emery, K. 0., 1948; Emery, K. 0., Butcher, W. S., Gould, H. R. and Shepard, F. P., 1952; Emery, K. O. and Foster, J. F., 1948; Emery, K. O. and Gale, J. F., 1951; Fox, L. S., 1930; Goldberg, E. D., 1954; Grant, U. S., 1943, 1948; Grant, U. S. and Shepard, F. P., 1940; Handin, J. W. and Ludwick, J. C., 1949; Hidaka, K., 1953; Holzman, J. E., 1950; Koczy, F. F., 1954; Krumbein, W. C., 1942; Kuenen, Ph. H. and Menard, H. W. , 1952; Leipper, D. F., 1950; Lesser, R. M., 1951; McEwen, G. F., 1934a, 1934c, 1934d, 1937b, $1940 \mathrm{a}, 1940 \mathrm{~b}, 1950$; Mao, H., 1951; Marlette, J. W., 1954; Mason, M. A., 1942, 1950b; Moberg, E. G., 1928a, 1930c; Moberg, E. G. and Fleming, R. H., 1934; Moore, D. G., 1951; Myers, E. H. 1943; Nicholson, G. F., Grant, U. S., Shepard, F. P. and Crowell, J. C., 1946; Phleger, F. B., 1951; Revelle, R., 1939a; Revelle, R. and Shepard, F. P., 1939a, 1939b; Rice, E. K., 1951; Scrippe Institution of oceanography, 19521; Shepard, F. P., 1932, 1939c, 1949a; Shepard, F. P. and LaFond, E. C., 1940; Sinnott, A., 1941; Sverdrup, H. U., 1938a, 1939a, 1939c; Sverdrup, H. U. and Staff, 194l; Trask, P. D., 1952b; Uchupi, E., 1954; VanDorn, W. G., 1953; Watts, C. M. and Others, 1953

Unconformity: Barrows, A. L., 1913; Emery, K. O. and Shepard, F. P., 1945; Shepard, F. P., 1941 a Uplift (See also: Diastrophism, Emergence, Warping): Anonymous, 1932e; Alexander, C. S., 1950; Arnold, D. and Arnold, R., 1902; Arnold, R., 1903, 1909; Ashley, G. H., 1895, 1896, 1931; Bandy, O. L., 1953b; Beach Erosion Board, 1948i; Black, G. L., 1954; Blake, W. P., 1898; Blankinship, J. W. and Keeler, C. A., 1892; Bremner, C. St. J. 1932; Bullard, E. C., 1940; Buwalda, J. P., 1927, 1936, 1948; Chamberlin, R. T., 1944; Chase, J. L., 1948; Clark, B. L., 1931; Cockerell, T. D. A., 1938b; Comstrock, T. B., 1902; Congressional Documents, 1940a, 1953b; Cotton, C. A., 1942; Crowell, J. C., 1952; Dall, W. H., 1878; Dickerson, R. E., 1922; Dietz, R. S., 1947b; Dietz, R. S., Emery, K. O. and Shepard, F. P., 1942; Dietz, R. S. and Menard, H. W., 1951b; Diller, J. S., 1901, 1902; Dunkle, M. B., 1944, 1950; Eardley, A. J., 1954; Eaton, J. E., 1932; Emery, K. O., 1954e; Emiliani, C. and Epstein, S., 1953; Fairbanks, H. W., 1897, 1904; Fewkes, J. W., 1889; Galliher, E. W., 1935c; Gilbert, G. K. 1917; Gilluly, J., 1949; Gislen, T., 1943, 1944; Goodyear, W. A., 1890; Gorsline, D. S., 1954; Grant, U. S., 1944; Grant, U. S. and Sheppard,
W. E., 1939; Gutenberg, B., 1933, 1941b; Handin, J. W., 1949; Hershey, O. H., 1903; Hertlein, L. G. and Emerson, W. K., 1953; Hewatt, W. G., 1946; Hill, R. T., 1928b, 1929; Hinde, H. P., 1952; Hinds, N. E. A., 1952; Hоbbs, W. H , 1921 Holway, R. S., 1914; Howard, A. D., 1951; Johnson, D. W., 1944; Kemnitzer, L. E., 1933, 1936; Kew, W. S. W., 1927; Kniffen; F. B., 1932 Krumbein, W. C., 1947; Lakes, A., 1899, 1903a; Landes, K. K., 1952a; Laws on, A. C., 1914, 1950; Leeds, C. T., 1915; Leonard, A. G., 1925; Leypoldt, H., 1934; Livingston, A., Jr., 1939; Louderback, G. D., 1930; Ma, T. Y. H., 1952; Marshall, W. C., 1934; Merriam, P. D., 1949; Merrill, F. J. H., 1914; Moore, D. G., 1951; Morrison, R. L., 1930; Nicholson, G. F., 1929; Norris, R. M., 1951; O'Brien, M. P., 1936a; Parkin, E. J., 1948; Pratt, W. E., 1947; Putnam, W. C., 1930, 1937b; Reed, R. D., 1933a, 1943a; Richarason, R. W., 1923; Ritter, W. E., 1901; Salisbury, R. D., 1909; Sanchez, P. C., 1934e; Sears, C. B., 1876; Shepard, F. P., 1933a, 1933b, 1933c, $1935 \mathrm{a}, 1935 \mathrm{~b}, 1936 \mathrm{~g}, 1938 \mathrm{a}, 1938 \mathrm{f}, 1948 \mathrm{c}$; Shepard, F. P. and Emery, K. O., 1941; Shuck, O. T. 1869; Shuler, W. R., 1952; Sm1th, P. A., 1938; Smith, W. D., 1930, 1933a, 1933b, 1933c; Smith, W. S. T., 1900, 1933; Stevenson, R. E., 1954; Stille, H., 1936; Stock, C. and Furlong, E. L., 1928; Taliaferro, N. L., 1943; Thayer, W. N., 1916; Troxell, H. C. and Others, 1942; Twenhofel, W. H., 1943; Upham, W., 1890, 1899; Upson, J. E., 1951; Vickery, F. P., 1927a, 1927b; Weaver, C. E., 1945, 1949; Whitney, J. D., 1865; Wilson, M. E., 1907; Wisser, E., 1954; Wittich, E., 1913, 1920; Wood, H. O., 1915; Woodring, w. P. and Kew, W. S. W., 1932; Yates, L. G., $1890 \mathrm{~b}$

Upwelling (See also: Downwelling): Ahlstrom, E. H., 1950; Allen, W. E., 1921a, 1922c, 1927c, 1940b, 1940c, 1941c, 1945; Bartsch, P., 1921b; Bigelow, н. B. and Leslie, M., 1930; Brongersma-Sanders, M., 1948; Bullock, F. W., 1933; Byers, H. R. 1930; California Academy of Sciences, California Division of Fish and Game, Scripps Institution of oceanography of the University of California, and U. S. Fish and Wildlife Service, 1950, 1951a; Calffornia Academy of Sciences, California Division of Fish and Game, Scripps Institution of oceanography of the University of California, U. S. Fish and Wildlife Service, and Hopkins Marine station, Stanford University, 1951; California Academy of Sciences, California Division of Fish and Game, Stanford University, Hopkins Marine Station, U. S. Fish and Wildlife Service, South Pacific Fishery Investigation, University of California, Scripps Institution of Oceanography, 1952, 1953; Carsola, A. J., 1947; Dall, W. H., 1911; Dawson, E. Y., 1946, 1950, 1952; Defant, A., 1950a, 1950b; Dill, R. F., 1952; Dunkle, M. B., 1950; Emery, K. O., 1954a; Emery, K. O. and Dietz, R. S., 1950; Emiliani, C. and Epstein, S., 1953; Fleming, R. H., 1939a, 1939b, 1940b, 1942; Fleming, R. H., Moberg, E. G. and Revelle, R., 1937a; Fleming, R. H. and Revelle, R., 1939; Galliher, E. W., 1935c; Gilbert, J. Y. and Allen, W. E., 1943; Gislên, T., 1943, 1944; Gorton, A. F., 1930a, 1930b, 1932, 1934; Gorsline, D. S., 1954; Graham, H. W., 1941b; Graham, H. W. and Moberg, E. G., 1944; Hanna, G. D., 1952; Hidaka, K., 1953; Holway, R. S., 1905; Hocver, J. W., 1932a, 1932b; Horrer, P. L., 1948a; Hubbs, C. L., 1948; Krumbein, W. C., 1947; LaFond, E. C., 1939a; Leipper, D. F., 1950; Leslie, M., 1928; Leslie, M. and Moberg, E. G., 1930; Leypoldt, H., 1941a; McAdie, A. G., 1914; McEwen, G. F. $1910,1912,1914,1915,1916,1918$, 1919a, 1919b, 1927, 1934a, 1934e; Mason, E. H., 1930; Mayor, A. G., 1922; Michael, E. L., 1919, 1921; Miller, R. C., Ramage, W. D. and Lazier, E. L., 1928; Moberg, E. G., 1925, 1928a, 1930b, 1930c; Moberg, E. G. and Fleming, R. H., 1934; Moberg, E. G., Selwell, H. R., Graham, H. W. and Paul, J. H., 1930; Munk, W. H., 1947b; Murphy, H. E., 1924; Myers, E. H., 1943; Natland, M. L., Revelle, R. and Rittenberg, S. C., 1941; Nicholson, G. F. Grant, U. S., Shepard, F. P., Crowell, J. C., 1946; 
O'Brien, M. P., 1936a; Palmer, A. H., 1917;

Patton, C. P., 1953; P'e1, C., 1929; Petterssen, S., 1938; Phelps, A., 1937; Pratt, W. E., 1947; Revelle, R., 1950; Revelle, R. and Shepard, F. P., 1939b; Ritter, W. E., 1924; Russell, F. S., 1934; Saito, Y., 1951; Sargent, M. S. and Walker, T. J., 1948; Schenck, H. G., 1928; Schott, G., 1934, 1935; Scripps Institution of Oceanography, 1950g; Shepard, F. P. and Emery, K. 0., 1941; Skogsberg, T., 1933, 1934, 1936; Skogsberg, T. and Phelps, A., 1946; Sleggs, G. F., 1927; Stockmann, W. B., 1946; Sverdrup, H. U., 1934, $1937-1938,1938 \mathrm{a}, 1938 \mathrm{~b}, 1938 \mathrm{c}, 1939 \mathrm{a}, 1939 \mathrm{~b}$ $1939 \mathrm{c}, 1940 \mathrm{a}, 1940 \mathrm{~b}, 1940 \mathrm{~d}, 1940 \mathrm{e}, 1940 \mathrm{f}, 1941 \mathrm{a}$, 1941c, 1942, 1944a, 1944b; Sverdrup, H. U. and Allen, W. E., 1939; Sverdrup, H. U. and Fleming, R. H., 194l; Sverdrup, H. U. and Fleming, R. H., Johnson, M. W., 1942; Sverdrup, H. U. and Staff, 1941, 1942b, 1943b; Thompson, T. G. and Robinson, R. J., 1932; Tibby, R. B., 1939, 1943; Tilden, C. A., 1925; Topp, E. P., 1929; Trask, P. D., 1932a, 1934, 1939; Vaughan, T. W., 1930b, 1930d, $1932 b, 1932 \mathrm{c}, 1933,1934$, 1940; Woodring, W. P., 1938a; Wooster, W. S., 1952; Yoshida, K. and MaO, H. L., 1954

Upwelling, Rate: Ahlstrom, E. H., 1950; H1daka, K., 1953; Salto, Y., 1951

Uranium - see Radioactivity

Vanadium: Goldberg, E. D., 1954; Lowenstam, H. A., 1954; Revelle, R. and Emery, K. 0., 1951; Thompson, T. G. and Robinson, R. J., 1932

Varved Clay (See also: Clay): Emery, K. O. and Dietz, R. S., 1941

Vegetation, Coastal Sand Dunes: Beach Erosion Board, 1953c; Blake, J., 1868a; Bremner, C. St. J., 1933; Cambell, M. R., 1915; Cockerell, T. D. A., 1938a; Cooper, W. S., 1927, 1934; Gibbs, R. E., 1900; Gorsline, D. S., 1954; Inman, D. L., 1949; McKee, R. and Schoth, H. A., 1941; McLaughlin, W. T. and Brown, R. L., 1943; Merriam, P. D., 1949; Olsson-Seffer, P., 1908; Page, G. B., 1950; Plerce, W. D. and Pool, D., 1938; Purer, E. A., 1936; R1chardson, R. W., 1923; Smith, W. D., 1933c; V1ckery, F. P., 1927a; White, D., 1911; Wiggins, I. L., 1929; Woodring, W. P., Bramlette, M. N. and Kew, W. S. W., 1946

Viscosity: Allen, w. E., 1941d; Goldberg, E. D., 1954; Moberg, E. G., 1928a, 1930c; Revelle, R., 1936, 1944

Volatile Solids (See also: Non-volatile Solida, Total Sol1ds): Lipman, 'C. B., 1929

Volcanic Debris (See also: Ash, Purmice, Rock, Volcanic Rock): Goldberg, E. D., 1954 (volcanic glass); P1ggot, C. S., 1932; Revelle, R., 1935, 19370; Scripps Institution of oceanography, 1953e; Shepard, F. P., Revelle, R., Dletz, R. S. and Emery, K. O., 1938

Volcanic Mud (See also: Terrigenous Sediments): Revelle, R., 1935

Volcanic Rock (See a loo various types of volcanic rock): Anderson, C. A., 1941; Butcher, W. S., 195la; Chesterman, C. W., 1952; Clements, T. and Emery, K. O., 1947; Dietz, R. S., Emery, K. O. and Shepard, F. P., 1942; Dill, R. F., Dietz, R. S. and Stewart, H., 1954; Eardley, A. J., 1954; Emery, K. 0., 194lc, 1946b, 1947b, 1948; Emery, K. O., Butcher, W. S., Gould, H. R. and Shepard, F. P., 1952; Emery, K. O. and Shepard, F. P., 1945; Emery, K. O. and Tschudy, R. H., 1941; Gorsline, D. S., 1954; Hanna, G. D., 1952; Hansen, H. A. and Pemberton, J. R., 1950; Holzman, J. E., 1950; Norr18, R. M., 1951; Pease, W. H., 1868; Revelle, R. and Shepard, F. P., 1939b; Shepard, F. P., 1948c; Shepard, F. P. and Emery, K. O., 194l; Shepard, F. P. and MacDonald, G. A., 1938; Shepard, F. P. and Wrath, w. F., 1937; Sherzer, W. F., 1910; Trask, P. D., 1931b

Vulcan1sm, Submarine: Anonymous, 1927; Blake, w. P., 1856; Bucher, W. H., 1940; Daly, R. A., 1934; Dietz, R. S., Emery, K. O. and Shepard, F. P., 1942; Eardley, A. J., 1954; Emery, K. O., 1952a; Goldberg, E. D., 1954; Harding, M. W. and Moberg, E. G., 1934; Havemann, H., 1952; Hobbs, W. H., 1944; Hodge, E. T., 1934; Koczy, F. F., 1954;
Ludwick, J. C., Jr., 1950; Menard, H. W. and Dietz, R. S., 1951; Menard, H. W. and Ludwick, J. C., 1951; Norr18, R. M., 1951; Piggot, C. S., 1944; Piggot, C. S. and Urry, W. D., 1942; Revelle, R., 1950; Scripps Institution of Oceanography, 1952h, 1953b; Shaler, N. S., 1895, 1896; Shepard, F. P., 19381, 1941b, 1950e; Shepard, F. P. and Emery, K. O., 1937, 1941; Shuck, O. T., 1869; Smith, P. A., 1940; Swainson, O. W., 1944; Veach, J. A., 1859

Warping, Deformation (See also: Continental shelf, origin; Continental Slope, Origin; Dlastrophism, Emergence, Uplift): Alexander, c. S., 1950; Buwalda, J. P., 1927; Cotton, C. A., 1942, 1944; Crowell, J. C., 1952; Dav18, W. M., 1933; Emery, K. O., 1950c; Goldberg, J., 1940; Handin, J. W., 1949; Kemnitzer, L. E., 1936; Krumbein, W. C., 1947; Landes, K. K., 1952a; Livingston, A., Jr., 1939; Putnam, W. C., 1930, 1937b; Rode, K., 1930; Shepard, F. P., 1950e; Sm1th, W. D., 1933b; Smith, W. S. T., 1902; Taliaferro, N. L., 1943; Tolt, A. L. du, 1940; Upson, J. E., 1951; Vickery, F. P., 1927a; W1sser, E., 1954; Wood, H. O., 1915

Water Color - see Red Water, Turbid water

Water Content of Sediments - see Interstitial water Water Masses (See also: Salinity, Temperature, T-S Curves, Water Type): Allen, W. E., 1941a, 1941c, 1946a, 1946b; California Academy of Sclences, California Department of Fish and Game, Scripps Institution of Oceanography of the University of California, U. S. Fish and Wildlife Service, and Hopkins Marine Station, Stanford University, 1951; Defant, A., 1950a; Dietz, R. S., Emery, K. O. and Shepard, F. P., 1942; Dill, R. F., 1952; Emery, K. O., 1954d; Emilian1, C., 1954; Fleming, R. H., 1939a, 1940a; Fleming, R. H., Moberg, E. G. and Revelle, R., 1937a, 1937b; Fleming, R. H. and Revelle, R., 1939; Goldberg, E. D., 1954; Horrer, P. L., 1948a; Johnson, M. W., 1939b; McEwen, G. F., 1937b, 1950; Robinson, M. K., 1951; shepard, F. P., 1950c; Sverdrup, H. U., 1934, 1937-1938, $1938 \mathrm{c}, 1938 \mathrm{~d}, 1939 \mathrm{~b}, 1939 \mathrm{c}, 1940 \mathrm{~d}, 1940 \mathrm{~g}, 1941 \mathrm{a}$, 1944a; Sverdrup, H. U. and Allen, W. E., 1939; Sverdrup, H. U., Johnson, M. W. and Fleming, R. H., 1942; Sverdrup, H. U. and Staff, 1941, 1943b; Tibby, R. B., 1941, 1944; Vaughan, T. W., 1934 Water Table, beach unless otherwise noted: Bascom, w. N.,
1946b, 1947d; Emery, K. O., 1945a; Emery, K. O and Foster, J. F., 1948; Emery, K. O. and Gele, J. F., 1951; Grant, U. S., 1946, 1948; Inman, D. L., 1953a; Isaacs, J. D., 1947; Isaacs, J. D. and Bascom, W. N., 1949; McKee, E. D., 1953; Nicholson, G. F., Grant, U. S., Shepard, F. P. and Crowell, J. C., 1946; Nelson, J. W., Z1nn, C. J., Strahorn, A. T., Watson, E. B. and Dunn, J. E., 1919 (marsh, slough, lagoon); Patrick, D. A., 1950; Stevenson, R. E., 1954 (marsh, lagoon, estuary)

Water Type (See also: Salinity, Temperature, T-S Curves, Water Masses): Sverdrup, H. U. and Allen, W. E., 1939

Waves (See also: Internal Waves, Sediment Transport, Wave Forecasting, wave Refraction): Anonymous, $1894 \mathrm{a}$ $1916 \mathrm{a}, 1916 \mathrm{~d}, 1933 \mathrm{e}, 1935,1938 \mathrm{a}, 1940 \mathrm{c}, 1940 \mathrm{~d}$, 194la, 1950b, 1950d, 1951d, 1952f, 1954j; Allen, W. E., 1941d; Andrews, H. L., 1945; Arthur, R. S., 1948, 1949, 1950, 1951; Bache, A. D., 1856e, 1862; Bascom, w. N., 1946b, 1947a, 1947b, 1947d, $1947 \mathrm{e}, 1948 \mathrm{a}, 1948 \mathrm{~b}, 1948 \mathrm{~h}, 19481$, 1950c; Bascom, W. N., Wiegel, R. L., and Chinn, A. J., 1948; Bates, C. C. and Glenn, A. H., 1948; Baucher, J. W., 1947; Beach Erosion Board, 1942a, 1948b, 19481, $1951,1952 b, 1953 \mathrm{a}, 1953 \mathrm{~b}, 1953 \mathrm{c}, 1954 \mathrm{~b}$; Blinn, F. S., 1928; Bond, A. H., 1927; Branner, J. C. 1900; Brown, E. I., 1939; Bruff, S. C., 1946; Bucher, W. H., 1940; Burt, W. V. and Saur, J. F. T., Jr., 1948; Butcher, W. S., 1951a; Byerly, P., 1942; California, University of, 1945, 1949 , 1951c, 1952a, 1954a, 1954b; Carpenter, F. A., 1924: Chase, J. L., 1948; Chinn, A. J., 1949; Cleland, H. F., 1910; Cochrane, J. D. and Arthur, R. S., 1948; Congressional Documents, 1908a, 1908e, 1938a, $1940 \mathrm{a}, 1940 \mathrm{~b}, 1940 \mathrm{e}, 1942 \mathrm{~b}, 1949 \mathrm{~b}, 1949 \mathrm{c}, 1949 \mathrm{f}$, 
1949-1950b, 1953; Connell, C. H. and Cross, J. B., 1950; Cotton, C. A., 1942; Crooke, R. C., Elvitsky, A. W., et al, 1953; Crowell, J. C., 1947, 1952; Datz, M. and Others, 1953; Davis, W. M., 1925, 1932; Deacon, G. E. R., 1949; Defant, A., 1950b; Dietz, R. S., 1947b, 1952b; Dunham, J. W., 1951; Eaton, R. O., 1951; Emery, K. O., 1944, 1945a, 1945b, 1947b, 1948, 1952a, 1953b, 1954e; Emery, K. O., Butcher, W. S., Gould, H. R. and Shepard, F. P., 1952; Emery, K. O. and Foster, J. F., 1948; Emery, K. O. and Gale, J. F., 1951; Emery, K. O. and Shepard, F. P., 1945; Emery, K. O. and Stevenson, R. E., 1950; Emery, K. O. and Tschudy, R. H., 1941; Ewing, G. C., 1950a, 1950b; Fisher, R. L. and Mills, R., 1952; Folsom, R. G., 1944a, 1944b, $1944 \mathrm{c}, 1944 \mathrm{~d}, 1945 \mathrm{a}, 1945 \mathrm{~b}, 1945 \mathrm{c}, 1948 \mathrm{a}, 1948 \mathrm{~b}$; Forrest, D. R., 1950, 1951a, 1951b; Fox, L. S., 1930; Fries, A. A., 1912; Galllard, D. D., 1904; Galliher, E. W., 1933; Gerhardt, J. R. and Jehn, K. H., 1954; Gilbert, G. K., 1917; Gillette, C. E., 1905; Gislén, T., 1943, 1944; Goldberg, J., 1940; Gorsline, D. S., 1954; Grant, U. S., 1938, 1943, 1946, 1948; Grant, U. S. and Shepard, F. P., 1937, 1938a, 1940, 1946; Granthem, K. N., 1952, 1953; Griggs, A. B. and Wells, F. G., 1942; Gulliver, F. P., 1896; Gutenberg, B., 1936a 1953; Hall, J. V., Jr., 1952; Hall, w. C., 1938, 1941, 1942; Handin, J. W., 1949, 1951; Handin, J. W. and Ludwick, J. C., 1949; Harney, L. A., Saur, J. F. T., Jr. and Robinson, A. R., 1949; Harts, W. W., 1911; Hawgood, H., 1914; Herold, C. L., 1934; Hickson, R. E. and Rodolf, F. W., 1951; Hinds, N. E. A., 1952; Horrer, P. L., $1948 \mathrm{~b}, 1949$, 1950; Horton, D. F., 1948; Hovick, J., 1945; Hudson, R. Y. and Moore, L. F., 1951; Hughes, R. T., 1946, 1947; Inman, D. L., 1949, 1950, 1953a, 1953b; Inman, D. L. and Quinn, W. H., 1952; Isaacs, J. D., 1945a, 1945c, 1945d, $19451,1945 \mathrm{k}, 1945 \mathrm{~m}, 1947 \mathrm{a}, 1947 \mathrm{~b}, 1948$; Isaacs, J. D. and Bascom, W. N., 1947; Isaacs, J. D. and Saville, T., Jr., 1948; Isaacs, J. D. and Schorr, S. and Chinn, A. J., 1947; Isaacs, J. D. and Wiegel, R. L., 1950; Iversen, H. W., 1945; Iversen, H. W. and Morrison, J. R., 1951; Johnson, A. G., 1940c; Johnsun, D. W., 1910, 1944; Johnson, J. W., 1944, 1945a, 1945c, 1945c, 1947a, $1947 \mathrm{~b}, 1948 \mathrm{a}, 1948 \mathrm{~b}, 1948 \mathrm{~d}, 1949,1949 \mathrm{a}, 1949 \mathrm{~b}$, 1950; Johnson, J. W. and Isaacs, J. D., 1948; Johnson, J. W. and Wiegel, R. L., 1953; Jones, J. W., 1948; Kaplan, K. and Pape, H. E., Jr., 1951; Killory, M. F., 1945a, 1945b; Knapp, R. T., 1951, 1952; Knapp, R. T. and Vanoni, V. A., 1945; Knudsen, V. O., Alford, R. S. and Emling, J. W., 1948; Krumbein, W. C., 1947 (also cross waves), 1950; Krumbein, W. C. and ohsiek, L. E., 1950; Kuenen, Ph. H. and Menard, H. W., 1952; LaFond, E. C., 1939a; Lakes, A., 1899; Lansley, W. W., 1937; Lauer, E., 1948; Leeds, C. T., 1916, 1936; Leedi, C. T., Vanoni, V. A., and Knapp, R. T., 1934; Livingston, A., Jr., 1939; Lieber, A. C., Jr., 1940; McAdam, D., 1947a; McAfee, C. M., Jr., 1939; McEwen, G. F., 1935a; McEwen, G. F. and Staff, 1948; McGowan, W. C., 1916; McKee, E. D., 1953; McLellan, M. E., 1925; Mcouat, H. W., 1951; Maccamy, R. C., 1952; MacDonald, G. A. and Shepard, F. P., 1947; Marlette, J. W., 1954; Mason, M. A., 1942, 1948, 1949a, 1949b, 1950a, 1950b, 1951; Meek, R. T., 1945; Menard, H. W., 1952; Meyer, R. D., 1936; Moffit, F. Н., 1953a, 1953b; Moore, D. G., 1951; Morey, B. F.' 1945; Morrison, R. L., 1930; Munch, J. F., 1945; Munk, w. H., $1947 \mathrm{a}, 1947 \mathrm{~b}, 1948,1949 \mathrm{a}, 1949 \mathrm{~b}$, 1951, 1952, 1953; Munk, W. H. and Arthur, R. S. , 1952; Munk, W. H. and Traylor, M. A., 1945, 1947; Nicholls, C. P. L., 1936a, 1936c, 1939; Nicholson, G. F., Grant, U. S., Shepard, F. P. and Crowell, J. C., 1946; Norris, R. M., 1951; O'Brien, M. P., 1936a, 1936b, 1939, 1941, 1945a, 1945b, $1946 \mathrm{a}, 1947 \mathrm{a}, 194 \mathrm{7b}$; O'Brien, M. P. and Johnson, J. W., 1947; O'Brien, M. P. and Nilmeler, H. P., 1945; Olsson-Seffer, P., 1910a; Page, G. B., 1950; Palmer, R. H., 1928; Patrick, D. A., 1953; Patton, R. S. and Marmer, H. A., 1932; Peel, K. P., 1951; Postel, A. C., 1937; Pratt, W. E.,
1947; Putnam, J. A., 1947; Putnam, J. A. and Arthur, R. S., 1948; Putnam, J. A. and Bermel, K. J., 1946; Putnam, J. A., Munk, W. H. and Traylor, M. A., 1948, 1949; Putnam, V. C., 1938; Putz, R. R., 1950a, 1950b, 1953; Revelle, R. and Shepard, F. P., 1939b; Richardson, R. W., 1923; Rode, K., 1930; Roop, F. C., 1946; Rudnick, P., 1951; Sanchez, P. C., 1934b; Saur, J. T. F., Jr., 1950; Saville, T., Jr., 1947, 1948; Schaufele, H. J., 1951; Schupp, R. D. 1953; Scripps Institution of Oceanography, 1944a, $1944 \mathrm{~b}, 1944 \mathrm{c}, 1944 \mathrm{~d}, 1944 \mathrm{e}, 1944 \mathrm{~g}, 1944 \mathrm{~h}, 1945 \mathrm{a}$, $1945 b, 1945 d, 1947,1951,1952 i, 1953 c, 1953 d$, 19531; Selwell, H. R., 1950; Shaler, N. S., 1895; Shepard, F. P., 1932, 1933b, 1935d, 1936a, $1936 \mathrm{f}, 1937 \mathrm{~b}, 1937 \mathrm{f}, 1938 \mathrm{c}, 1938 \mathrm{~g}, 1940 \mathrm{c}, 1941 \mathrm{a}$, $1942 a, 1943 b, 1947 b, 1948 b, 1949 a, 1949 b, 1949 d$, 1950b, 1950f, 1950g, 1951a; Shepard, F. P. and Emery, K. 0., 1941; Shepard, F. P., Emery, K. 0. and LaFond, E. C., 1941; Shepard, F. P. and Grant, U. S., 1947; Shepard, F. P. and Inman, D. L., 1949, 195la; 1951b; Shepard, F. P., Inman, D. L., and Fisher, R. L., 1951; Shepard, F. P. and LaFond, E. C., 1939, 1940, 1942; Shepard, F. P. and MacDonald, G. A., 1938; Shepard, F. P. and Sayner, D. B., 1953; Shepard, F. P. and Wrath, W. F., 1937; Sherzer, W. H., 1910; Shuler, W. R., 1951, 1952; Sinnott, A., 1941; Smith, W. D., 1933b; Smith, W. S. T., 1897; Snodgrass, F. E., 1951, 1952, 1954; Snodgrass, F. E., Morison, J. R., Hall, M. A., Granthem, K. N. and Wiegel, R. L., 1952; Snodgrass, F. E., Rice, E. K. and Hall, M. A., 1951; Snodgrass, F. E. and Stiling, D. E., 1951; Somers, P., 1952; Stanford, University of, 1951; Stelzenmuller, Wm. B., 1949; Stevenson, R. E., 1954; Stockman, L. P., 1932; Stump, R. S., 1944a; Sverdrup, H. U., 1936; Sverdrup, H. U. and Munk, W. H., 1947; Sverdrup, H. U. and Staff, 1942a, 1946; Swinnerton, A. C., 1927; Swa1n, F. E., 1951; Thompson, W. 0., 1933, 1937; Thompson, W. F. and Thompson, J. B., 1919; Todd, D. K. and Wiegel, R. L., 1951, 1952; Tower, M. L., 1910, 1913; Trask, P. D., $1924,1931 b, 1952 a, 1952 b$; Twenhofel, W. H., 1943; U. S. Hydrographic office, 1943a, 1944c; U. S. Waterways Experiment Station, Vicksburg, Mississippi, 1935, 1947a, 1947b, 1949, 1950; VanDorn, W. G:, 1953; Vanon1, V. A., and Carr, J. H., 1951; Vaughan, T. W., 1931; Verrill, G. E., 1930; Ward, H. A., 1952; Warner, S. E., 1947; Walker, B. W., 1947; Watts, G. M. and Others, 1953; White, A. B., 1945; White, D. 1911; Whittemore, G. F., 1916, 1928; Wiegel, R. L., 1947a, 1947b,.1947c, 1948, 1949; Wlegel, R. L. and Kimberley, H. L., 1950; Wiegel, R. L., Patrick, D. A. and Kimberley, H. L., 1953; Wiegel, R. L., Todd, D. K. and Kimberley, H. L., 1950; Williams, E. A., and Isaacs, J. D., 1952; Woodford, A. 0., 1935

Wave and Marine Erosion, including erosion by Currents (See also: Continental Shelf, origin; Continental Slope, Erosion; Submarine Canyons, origin): Anonymous, 1882a; Beach Erosion Board, 1948j; Bowman, A., 1873; Buffington, E. C., 1951; Carsola, A. J. and Dietz, R. S., 1952; Carsola, A. J., Dietz, R. S, and Russell, R. D., 1949; Carter, G. F., 1948; Clark, B. L., 1931; Cleland, H. F., 1910; Davis, W. M., 1932; Davidson, G., 1875; Dietz, R. S., 1947a; Dietz, R. S., Emery, K. O. and shepard, F. P., 1942; Dietz, R. S. and Menard, H. W., 1951a, 1951b; Dill, R. F., Dietz, R. S. and Stewart, H., 1954; Diller, J. S., 1902; Dunkle, M. P., 1950; Emery, K. O., $1941 b, 1947 \mathrm{~b}, 1947 \mathrm{c}, 1950 \mathrm{~d}, 1952 \mathrm{~b}$; Emery, K. 0. and Dletz, R. S., 1950; Emery, K. O. and Shepard, F. P., 1945; Emmonds, S. F. and Merrill, G. P., 1894; Goldberg, J., 1940; Grant, U. S., 1940, 1946; Grant, U. S. and Shepard, F. P., 1938a, 1938b; Gulliver, F. P., 1896; Hanna, M. A., 1926; Handin, J. W. and Ludwick, J. C., 1949; Holzman, J. E., 1950; Herold, C. L., 1934; Ives, R. 'L., 1951; Landes, K. K., 1952b; Laws on, A. C., 1883a, 1894; LeConte, J., 1891; Louderback, G. D., 1940; McDonald, G. A., 1934; 
McGee, W. J., 1900; McLellan, M. E., 1925; Menard, H. W. and Ludwick, J. C., 1951; Norris, R. M., 1951; Pease, W. H., 1868; Reiche, P., 1937; Revelle, R. and Shepard, F. P., 1939b; Shaler, N. S., 1896; Shepard, F. P., 1932, 1935a, 1936f, 1938h, 194la, 1949e; Shepard, F. P. and Emery, K. 0., 1937; Shepard, F. P. and Grant, U. S., 1947; Shepard, F. P., Grant, U. S. and Dietz, R. S., 1939; Shepard, F. P. and MacDonald, G. A., 1938; Shepard, F. P. and Wrath, W. F., 1937; Smith, W. D., 1933c; Smith, W. S. T., 1900; Toit, A. L., du, 1940; Trask, P. D., 1952b; Willis, B., 1900; Wilson, M. E., 1907

Wave Base - see Equilibrium

Wave Convergence - see Convergence, Waves

Wave Cut Terraces, Platform, Bench (See also: Terraces): Davis, W. M, 1932; Griggs, A. B. and Wells, F. G., 1942; Handin, J. N., 1949, 1951; Lawson, A. C., 1893a (time to cut wave cut bench); Leonard, A. G., 1925; Putnam, W. C., 1938, 1940; Shaler, N. S., 1895; Shepard, F. P., 1938h, 1941a, 1948c, 1950g; Shepard, F. P. and Grant, U. S., 1947; Shepard, F. P. and MacDonald, G. A., 1938; Shepard, F. P. and Wrath, W. F., 1937; Thompson, W. O., 1933; Trask, P. D., 1952a; Twenhofel, W. H., 1943; Upson, J. E., 1949a, 1951; Willis, B., 1900

Wave Diffraction - see Diffraction of Waves

Wave Divergence - see Divergence of Waves

Wave Forecasting: Arthur, R. S., 1948, 1951; Datz, M. and Others, 1953; Folsom, R. G., 1944d; Forrest, D. R., 1951b; Horrer, P. L , 1949; Isaacs, J. D. and Saville, T., Jr., 1948; Isaacs, J. D., Schorr, S. and Chinn, A. J., 1947; Johnson, J. W., 1945a; Killory, M. F!, 1945a, 1945b; Munk, W. H. and Arthur, R. S., 1952; Scripps Institution of Oceanography, 1944h, 1945b; Stump, R. S., 1945a, $1945 \mathrm{~b}, 1945 \mathrm{e}, 1945 \mathrm{f}, 1945 \mathrm{~g}, 1945 \mathrm{~h}, 19451,1945 \mathrm{j}$, $1945 \mathrm{k}, 1946 \mathrm{~b}, 1946 \mathrm{c}, 1948 \mathrm{a}, 1948 \mathrm{~b}$; Stump, R. S. and Bascom, W. N., 1947; Stump, R. S. and Hermanson, R. T., 1945a, 1945b, 1945c, 1945a, 1945e; Sverdrup, H. U. and Munk, W. H., 1947; U. S. Hydrographic office, $1943 \mathrm{a}, 1944 \mathrm{c}$

Wave Refraction (See also: Diffraction of Waves, Divergence of Waves): Anonymous, 1940c, 1940d; Arthur, R. S., 1950; Bates, C. C. and Glenn, A. H., 1948; Beach Erosion Board, 1948a, 1948h, 1948i, 1953c; Branner, J. C., 1900; Burt, W. V. and Saur, J. F. T., Jr., 1948; California, University of, 1945 , 1952a; Carpenter, F. A., 1924; Congressional Documents, 1938a, 1940a, 1949f, 1949-1950b, 1953; Crooke, R. C., Elvitsky, A. W., et al, 1953; Crowell, J. C., 1950; Dietz, R. S., 19470; Dunham, J. W., 1951; Eaton, R. O., 1951; Emery, K. O., Butcher, W. S., Gould, H. R. and Shepard, F. P., 1952; Folsom, R. G., 1944a; Forrest, D. R., 195la; Gee, H. C., 1938; Goldberg, J., 1940; Gorsline, D. S., 1954; Grant, U. S. and Shepard, F. P., 1940; Hall, J. V., Jr., 1952; Hall, W. C., 1938; Handin, J. W., 1949, 1951; Handin, J. W. and Ludwick, J. C., 1949; Horrer, P. L., 1949, 1950; Inman, D. L., 1949, 1953a, 1953b; Isaacs, J. D., 19470, 1948; Isaacs, J. D., Schorr, S. and Chinn, A. J., 1947; Johnson, J. W., $1945 \mathrm{~b}, 1945 \mathrm{c}, 1945 \mathrm{~d}, 1947 \mathrm{c}, 1948 \mathrm{~b}, 1948 \mathrm{c}$, 1952; Johnson, J. W. and Isaacs, J. P., 1948; Johnson, J. W. and O'Brien, M. P., 1946; Johnson, J. W. , O'Brien, M. P. and Isaacs, J. D., 1948; Kaplan, K., 1952; Krumbein, W. C., 1947, 1950; Krumbein, W. C. and Ohsiek, L. E., 1950; Lapsley, W. W., 1937; Livingston, A., Jr., 1939; MacCamy, R. C., 1952; Marlette, J. W., 1954; Mason, M. A., 1949a, 1951; Miller, F., 1941; Milner, F., 1941; Moffitt, F. H., 1953b; Moore, D. G., 1951; Munk, W. H., 1948, 1953; Munk, W. H. and Traylor, M. A., 1947; Nicholson, G. F., Grant, U. S., Shepard, F. P. and Crowell, J. C., 1946; O'Brien, M. P., 1939, 1944, 1946a, 19470; O'Brien, M. P. and Johnson, J. W., 1947; Osborn, P., (undated); Page, G. B., 1950; Peel, K. P., 1951; Putnam, J. A. and Arthur, R. S., 1948; Richardoon, R. W., 1923; Saville, T., Jr., 1951; Scripps Institution of Oceanography, 1944c, 1944e, 1944e, 1945a, 1945b, 19521, 1953c; Shepard, F. P., 1948b, 1950c, 1950g; Shepard, F. P. and Inman, D. L., 1949, 1951a, 1951b;
Shuler, W. R., 1951; Stump, R. S., 1944a, 1944b, 194: $1945 \mathrm{a}, 1945 \mathrm{~b}, 1945 \mathrm{c}, 1945 \mathrm{~d}, 1945 \mathrm{e}, 1945 \mathrm{f}, 1945 \mathrm{~g}$, $1945 \mathrm{~h}, 1945 \mathrm{i}, 1945 \mathrm{j}, 1945 \mathrm{k}, 1946 \mathrm{a}, 1946 \mathrm{~b}, 1946 \mathrm{c}$, $1946 \mathrm{~d}, 1946 \mathrm{e}, 1948 \mathrm{a}, 1948 \mathrm{~b} ;$ Stump, R. S. and Bascom, W. N., 1947; Stump, R. S. and Hermanson, R. F., 1945a, 1945b, 1945c, 1945d, 1945e; Sverdrup, H. U. and Staff, 1946; Trask, P. D., 1931b, 1952b; U. S. Hydrographic office, 1944c; U. S. Waterways Experiment Station, Vicksburg, Mississippi, 1947a; Vanoni, V. A. and Carr, J. H., 1951; Wanless, H. R., 1950; Ward, H. A., 1952; Wiegel, R. L., Patrick, D. A. and Kimberley, H. L., 1953; Williams, E. A. and Isaacs, J. D., 1952

Wave Ripples - see Sea or Wave Ripples

Wave Shadow: Grant, U. S., 1938; Handin, J. W. and Ludwick, J. C., 1949

Width - see Beaches, Continental shelf

Wind (See also: Meteorology and Climate): Anonymous, 1916a, 1917, 1938a, 1940d, 1951d, 1952f; Ahlstrom, E. H., 1950; Anderson, J. B., 1931; Andrews, H. L., 1945; Arthur, R. S., 1949, 1951; Atwill, E. R., 1942; Bache, A. D., 1858; Bascom, W. N., 1946b; Bates, C. C. and Glenn, A. H., 1948; Beals, E. A., 1919; Beer, C. G. P. and Leopold, L. B., 1947; Beach Erosion Board, 1939, 1942a, 1948b, B. and Leslie, M., 1930; Blake, W. P., 1856; Blankinship, J. W., 1892; Bond, A. H., 1927; Branner, J. C., 1913; Brant, I., 1925; Brooks, C. W. , 1875; Brown, E. I., 1939; Bullock, F. W., 1933; Calif. Acad. of Sci., Calif. Div. Fish and Game, Scripps Inst. Oceanography et al, 1950; Calif. Academy of Science, Calif. Div. Fish and Game, Stanford Univ., Hopkins Mar. Sta., et al, 1952 1953; California Department of Public Works, 1952f; California, University of, 1952a, 1954a; Carpenter, F. A., 1924; Chase, J. L., 1948; Clarke, K. B., 1934; Congressional Documents, $1908 \mathrm{a}, 1938 \mathrm{a}, 1940 \mathrm{a}, 1942 \mathrm{~b}, 1943,1949 \mathrm{~b}, 1949-$ 1950b, 1953a, 1953b; Connell, C. H. and Cross, J. B., 1950; Crooke, R. C., Elvitsky, A. W., et al, 1953; Cummings, N. W., 1950; Dall, W. H., 1904, 1911; Datz, M. and others, 1953; Davidson, G., 1859, 1864, 1873c; Davis, W. M., 1925, 1932; Dewson, E. Y., 1951; Dietz, R. S.' and LaFond, E. C., 1950; Dietz, R. S. and Menard, H. W., 1951b; Dill, R. F., 1949, 1952; Disney, L. P. and Overshiner, W. H., 1925; Dunkle, M. B., 1944, 1950; Eddy, H. P., Hyde, C. G. , Kennedy, C. C. and Reynolds, L. B., 1936; Eldridge, Z. S. and Molera, E. J., 1909; Elliott, F. E., Tressler, W. L. and Myers, W. H., 1953; Emery, K. O., Butcher, W. S., Gould, H. R. and Shepard, F. P., 1952; Emery, K. O. and Tschudy, R. H., 1941; Evans, O. F., 1941; Ewing, G. C., 1950a, 1950b, 1950c; Findlay, A. G., 1851; Folsom, R. G., 1944d, 1945b; Ford, J. L. C., 1942; Gaillard, D. D., 1904; Gisién, T., 19́43, 1944; Goldberg, J., 1940; Gorsline, D. S., 1954; Gorton, A. F., 1930b, 1934; Grant, U. S., 1938; Great Britain Hydrographic office, 1866 ; Great Britain Meteorological Office, 1950; Gulliver, F. P., 1896; Gutenberg, B., 1941b, 1953; Hall, W. C., 1942; Hall, W. H., 1886; Handin, J. W., 1949; Handin, J. W. and Ludwick, J. C., 1949; Hanna, M. A., 1926; Harts, W. W., 1911; Hawgood, H., 1914; Hidaka, K., 1953; Hinds, N. E. A., 1952; Holway, R. S., 1905; Hoover-Young San Francisco Bay Bridge Commission, 1930; Horrer, P. L., 1949, 1950; Horton, D. F., 1948; Hyde, C. G., Gray, H. F. and Rawn, A. M., 194l; Inman, D. L., 1949; Inman, D. L. and Quinn, W. H., 1952; Ives, R. L., 1951; Jacobs, W. C., 1939, 1943; Jacobs, W. C. and Clarke, K. B., 1943; Johnson, A. G. , 1935; Johnson, D. W., 1910; Johnson, J. W. , 1949a, 1952, 1953b; Jones, E. L., 1918; Kniffen, F. B., 1932; Krumbein, W. C. , 1947; LeFond, E. C. , 1938, 1939a; Lawton, C. H., 1936; Leeds, с. T., 1916, 1936; Leeds, C. T., Vanon1, V. A. and Knapp, R. T., 1934; Leypoldt, H., 1941a, 1942; Leipper, D. F., 1950; Lieber, A. C., Jr., 1940; Livingston, A. , Jr., 1939; McAdie, A. G., 1914; McAPee, C. M., Jr., 1939; MCEwen, G. F., 1912, 1914, 1915, 1916, 1918, $1919 a, 1919 b, 1927,1928 b$, 1930c, 1934a, $1934 c$, 
1935a; McEwen, G. F., and Staff, 1948; McLellan, M. E., 1925; McManus, A. B., 1934; Mcouat, H. W., 1951; MacGinitie, G. E., 1934; Marlette, J. W., 1954; Marmer, H. A., 1926, 1928, 1952; Mason, M. A., 1942, 1950b; Masters, P., 1840 ; Mayor, A. G., 1922; Menard, H. W. and Ludwick, J. C., 1951; Michael, E. L., 1921; Miller, R. C., Ramage, W. D. and Lazier, E. L., 1928; Moberg, E. G., 1928a, 1930c; Moberg, E. G. and Fleming, R. H., 1934; Moore, D. G., 1951; Morrison, R. L., 1930; Moser, J. F., 1898; Munk, W. H., 1947b, 1950; Natland, M. L., Revelle, R. and Rittenberg, S. C., 1941; Nicholls, C. P. L., 1939; Nicholson, G. F., Grant, U. S., Shepard, F. P. and Crowell, J. C., 1946; Norr1s, R. M., 1951, 1952; O'Brien, M. P., 1936a, 1936b, 1939, 1941 1946a, 1947b; O'Brien, M. P. and Johnson, J. W., 1947; Olsson-Seffer, P., 1910a; Page, G. B., 1950; Palmer, A. H., 1917; Patton, C. P., 1953; Patton, R. S. and Marmer, H. A., 1932; Postel, A. C., 1937; Purer, E. A., 1936; Putnam, J. A., 1947; Putnam, J. A., Munk, W. H. and Traylor, M. A., 1949; Putnam, W. C., 1938; Raitt, R. W., 1954; Re1d, R. O., 1948a; Remondino, P. C., 1892; Rice, E. K., 1951; Richardson, R. W., 1923, 1943; Richter, C. M., 1887; Rolland, M. C., 1952; Rossby, C.-G., 1951; Rosser, W. H., 1870; Rude, G. T., 1933; San Diego Regional Water Pollution Control Board, 1952; Sanford, J. J., 1908; Saur, J. T. F., 1950; schne1der, W. A., 1954; Schott, G., 1934, 1935; Schupp, R. D., 1953; Scripps Institution of Oceanography, $1944 \mathrm{c}, 1945 \mathrm{c}, 1949 \mathrm{a}, 1949 \mathrm{~b}$ to $1949 \mathrm{e}, 1950 \mathrm{a}$ to $1950 \mathrm{e}, 1950 \mathrm{~g}$, 1951a to $1951 \mathrm{f}, 195 \mathrm{lh}$ to $1951 \mathrm{~J}$, $1951 \mathrm{~L}, 1951 \mathrm{~m}, 1952 \mathrm{a}, 1952 \mathrm{~b}, 1952 \mathrm{e}$ to $1952 \mathrm{~g}, 1953 \mathrm{c}$; Sears, C. B., 1876; Shaler, C. B., 1895; Shepard, F. P., 1932, 1935d, 1949d, 1950b, 1950c, 1950f; Shepard, F. P. and Emery, K. 0., 1941; Shepard, F. P. and Inman, D. L., 1949, 1951b; Shepard, F. P. and LaFond, E. C., 1940; Shepard, F. P. and MacDonald, G. A., 1938; Shepard, F. P. and Sayner, D. B., 1953; Shepard, F. P. and Wrath, W. F., 1937; Shipmesters and Others, 1879; Shuler, W. R., 1951; Sinnott, A., 1941; Skogsberg, T., 1936; Smith, W. S. T., 1897; Somers, P., 1952; Stelzenmuller, Wm. B., 1949; Stevenson, R. E., 1954; Stockman, L. P., 1932; Stockmann, W. B., 1946; Stump, R. S., 1944b, 1944c; Sverdrup, H. U., 1937-1938, 1938a, 1938c, 1939b, 1939c, 1940b, 1944a, 1947; Sverdrup, H. U. and Munk, W. H. 1947; Sverdrup, Н. U. and Staff, 1941, 1942b, 19446, 1946; Tanner, Z. L., 1892a, 1893, 1894 ; Thomson, A., 1934; Thompson, W. O., 1937; Thorade, H., 1909, 1914; Tibby, R. B., 1939, 1943; Tilden, C. A., 1925; Todd, D. K. and Wiegel, R. L., 1951, 1952; To1t, A. L., du, 1940; Topp, E. P., 1929; Tower, M. L., 1910; Trask, P. D., 1924, 1931b, 1934, 1939, 1952b; Twenhofel, W. H., 1943; Udden, J. A., 1914; Ufford, C. W., 1947a; U. S. Army Air Weather Service, 1945; U. S. Commission of Fish and Fisheries, 1898; U. S. Hydrographic office, 1875, 1934b; Van Dorn, W. G., 1953; Vaughan, T. W., 1932c, 1934, 1940; Whittemore, G. F., 1928; Wiegel, R. L. and Kimberley, H. L. 1950; Wyman, R. H., 1878; Yale, C. G., 1879; Yates, L. G., $1890 \mathrm{c}$

Wind Erosion - see Wind Transport

Wind Transport, Erosion, Deflation (See also: Coastal Sand Dune Movement): Beach Erosion Board, 1953c; Blake, J., 1868a; Bowers, S., 1878; Bremner, C. St. J., 1933; Cambell, M. R., 1915; Congresslonsl Documents, 1953b; Dawson, E. Y., 1951; Eaton, R. O., 1951; Emery, K. 0., 1951; Emery, K. O. and Foster, J. F., 1943; Gilbert, G. K., 1917; Gorsline, D. S., 1954; Grant, U. S. and Shepard, F. P., 1938b; Gulliver, F. P., 1896; Handin, J. w. and Ludwick, J. C., 1949; Harts, W. W., 1901; Inman, D. L., 1949; Kuenen, Ph. H. and Menard, H. W., 1952; Lawson, J. S., 1862; Ludwick, J. C., Jr., 1950; Mason; M. A., 1950b; Merriam, P. D., 1949; N1cholson, G. F., Grant, U. S., Shepard, F. P. and Crowell, J. C., 1946; Norris, R. M., 1952; O'Brien, M. P., 1936a; Olason-Seffer, P., 1908; Page, G. B., 1950; Purer, E. A., 1942; Revelle, R. and Shepard, F. P., 1939b; Richardson, R. W., 1923; Shepard, F. P., 1937f, 1951b; Shepard, F. P. and Emery, K. O., 1941; Shuler, W. R., 1952; Smith, W. D., 1933b, 1933c; Somers, P., 1952; Thompson, W. O., 1937; Trask, P. D., 1924, 1950; Twenhofel, W. H., 1946; Vaughan, T. W., 1940; Vickery, F. P., 1927a; White, D., 1911; Yates, L. G., 1892

Winnowing of Sediment, Selective Transportation (See also: By-passing of Sediment, Non-deposition): Emery, K. O., 1948; Gorsline, D. S., 1954; Holzman, J. E., 1950; Krumbein, W. C., 1947, 1950; Ludwick, J. C., Jr., 1950; 01sson-Seffer, P., 1910a; Shepard, F. P., 1949b; Stevenson, R. E., 1954; Trask, P. D., 1952b; Uchupi, E., 1954; Udden, J. A., 1914

X-Ray of sediments etc.: Dietz, R. S., 1938; Dietz, R. S., Emery, K. O. and Shepard, F. P., 1942; Fmery, K. O. and Dietz, R. S., 1950; Galliher, E. W., 1937; Grim, R. E., Dietz, R. S. and Bradley, W. F., 1949; Lowenstam, H. A., 1954; Revelle, R., 1935, 1937b; Vaughan, T. W., 1933

Yellow Mud (See also: Terrigenous Sediments): Belknap, G. E., 1874a; Crooke, R. C., Elvitsky, A. W., et al, 1953 (yellow sand); Davidson, G., 1897; Fox, D. L., Updegraff, D. M. and Novell1, G. D., 1944; Hoover-Young San Franciaco Bay Bridge Commission, 1930; Richardson, R. W., 1923

Yellow water - see Red Water

Zinc: Revelle, R., 1935; Severy, H. W., 1923; Thompson, T. G. and Robinson, R. J., 1932; Trask, P. D., 1939; Vaughan, T. W., 1933; ZoBell, C. E., $1939,1941,1942 b$

Zirconium (See also: Beach Placers, Black Sands, Mineralogy): Goldberg, E. D., 1954; Lowenstam, H. A., 1954; Revelle, R. and Emery, K. O., 1951

Zooplankton (See also: Copepods, Plankton): Ahlstrom, E. H., 1950; California Academy of Sciences, California Division of Fish and Game, Scripps Institution of oceanography, U. S. Fish and Wildilfe Service, 1950; Coe, W. R., 1945, 1947, 1948; Dawson, E. Y., 1951; Dietz, R. S., 1948; Esterly, C. O., 1928a; Ewing, G. C., 1950c; Fleming, R. H., 1939a, 1939b; Harvey, D. R., 1928; Johnson, M. W., 1942, 1948; Mason, E. H., 1930; Myers, E. H., 1942; Russell, F. S., 1934; Sverdrup, H. U., 1938c, 1939a, 1940e, 1940f; Tibby, R. B., 1939; T1lden, C. A., 1925; Trask, P. D., 1939; Tucker, G. H., 1951; Vaughan, T. W., 1935b, 1936; ZoBell, C. E., $1947 \mathrm{c}$. 



\section{OTHER BIBLIOGRAPHIES AND SOURCE MATERIAL}

\section{A. IMPORTANT BOOKS ON MARINE GEOLOGY AND OCEANOGRAPHY}

A few of the most important books on marine geology and oceanography are listed below. Additional books can be found by checking Hedgpeth's bibliography (c1ted below) where more than 500 books on all phases of marine geology, oceanography, and marine biology are listed.

The books by Shepard; Sverdrup; and Sverdrup, Johnson, and Fleming, are very important for those who are particularly interested in the California region.

Bigelow, H. B., and Edmondson, W. T., 1947, Wind waves at sea, breakers and surf: U. S. Hydrographic office, Pub. 602, xi1, 177 p., 57 figs., 24 pls.

Cornish, V., 1934, Ocean waves and kindred geophysical phenomena. Additional notes by Harold Jeffreys: Cambridge, Univ. Press, xv, 164 p., 26 pls.

Harvey, H. W., 1945, Recent advances in the chemistry and biology of sea water: Cambridge, Univ. Press, 164 p., vi1, 29 figs.

Kuenen, Ph. H., 1950, Marine geology: New York, John Wiley and Sons, $x, 568$ p., 246 figs., 2 charts.

National Research Council, 1932, Physics of the earth - V. Oceanography. Prepared under the auspices of the subsldiary committee on oceanography: Wash., Natl. Research Council Bull. 85, v, 581 p., 1llus.

Proudman, A. J., 1953, Dynamical oceanography: New York, John Wiley and Sons, to9 p.

Revelle, R., 1944, I. Marine bottom samples collected in the Pacific ocean by the Carnegie on its Seventh Cruise, in Scientific results of Cruise VII of the Carnegie during 1928-1929 under command of Captain J. P. Ault, Oceanography - II, Carnegie Inst. Wash. pub. 556, 180 p. incl. 13 pls., 10 charts, 45 figs.

Shepard, F. P., 1948, Submarine geology: New York, Harper and Bros., xvi, 348 p., 100 figs., 1 chart.

Sverdrup, H. U., 1942, oceanography for meteorologists: New York, Prentice-Hall, Inc., $246 \mathrm{p}$.

vierdrup, H. U., Johnson, M. W., and Fleming, R. H., 1942, The oceans. Their physics, chemistry and general biology: New York, Prentice-Hall, Inc., x, 1087 p., 265 figs., 7 charts.

\section{B. OTHER BIBLIOGRAPHIES AND GENERAL REFERENCES}

The following section lists: a) other bibliographies, b) references of general interest, c) references on the early history of discovery and exploration along the Pacific cosst of the United States, and d) periodicals having a large number of references on oceanography and related subjects.

The purpose of this section is to aid the user in locating additional references on oceanography, marine geology and related topics.

Adams, K. T., 1946, Hydrographic manual: U. S. Coast and Geod. Survey, special pub. 143, Revised 1942, 940 p., corrected and reprinted 1946. Very good reference on methods of making hydrographic surveys, currents, tides, soundings, submarine topography, instrumentation, nevigation, sound etc.

Allen, J. E., 1947, Bibliography of the geology and mineral resources of oregon (supplement), July 1,1936 to December 31, 1945: Compiled by J. E. Allen, geologist with contributions by $\mathrm{E}$. Kinsley, H. Quasdorf, and R. C. Treasher: Oregon Dept. Geology and Min. Indus. Bull. $33,108, \mathrm{p}$.

Allen, R. H., and Ifft, J. D., 1943, Early naturalists in the far west: Calif. Acad. Sci., Occ. Paper 20, $59 \mathrm{p}$. Selected bibliography on early exploration up to about 1850. Concerns primarily botany and zoology.
American Geophysical Union Transactions. This, and the following two journals, contain numerous references on oceanography and marine geology.

Annalen der Hydrographie und Maritimen Meteorology Archiv für Hydrobiologie.

Ayers, J. C., 1951, A preliminary report upon the state of our knowledge of the waters in and around New York Harbor: Cornell Univ. prog. rept., June 1, 8 p., diagrams. Bibliography of 750 references including references on: Geology, botany and oceanography of the area.

Baughman, J. L., 1948, An annotated bibliography of oysters with pertinent material on mussels and other shellfish and an appendix on pollution: Texas Agr. and Mechanical Research Foundation, $794 \mathrm{p}$.

Brooks, C. E. P., 1950, selected annotated bibliography on climatic changes: Meteorol. Abstracts and Bibllography, Am. Meteorol. Soc., v. 1, no. 7, p. 446-475.

Brown, R. E., 1942, Some manganese deposits in the southern Oregon coastal region: Oregon Dept. Geol. and Mineral Indus. G. M. I. Short Paper 9, 6 p., 2 figs., map. *

California Department of Public Works, 1952, Ground water basins in California: Calif. Div. Water Res., Water Quality Inv. Rept. no. 3, 44 p., 3 pls. Includes selected bibliography of published and unpublished material.

California Division of Mines, 1945, Consolidated index of publications of the Division of Mines and predecessor State Mining Bureau, 1880-1943 inclusive: Calif. Div. Mines Bull. 131, 872 p., xxi.

California Institute of Technology, Seismological Laboratory, 1950, Bibliography on microseism: Quarterly progress rept. no. 9, TIP U16976, Nov. 8, 3 p., 12 references.

California Water Pollution Control Board, 1952, Water quality criteria: Sacramento, SWPCB no. 3, 512 p., incl. app., tables, figs. Extensive bibliography on pollution.

Canada Dominion Observatory, Bibliography of seismology: Canada Dominion Observatory Pub., Ottawa, Canada. This is a current bibliography containing references on earthquakes throughout the world. The first few hundred references were printed in the Seismol. Soc. America Bull., in volumes 17-19 (1927-1929), these and all subsequent references are listed in the canadian bibliography. Epicenters for the United States can be found in the United States Coast and Geod. Survey publications. Other epicenters can be found in "Seismological Notes" in Seismol. Soc. America Bull., and in, a few of the more recent issues of the Am. Geophys. Union Trans.

Centre de recherches et d'etudes oceanographiques, Paris. Circulalres, ser. B., Renseignements techniques et bibliographiques, 1, 1949-.

Chapin, E. L., Jr., 1950, A selected cartobibliography of southern California: M. A. thesis, Univ. Calif., LOB Angeles, 2 volumes, 451 p., pls.

Chapin, E. L., Jr., 1953, Selected bibliography of southern California maps: Berkeley and Los Angeles, Univ. Calif. Press., 136 p.

Cobb, G. C., 1943, Bibliography of the interpretation of aerial photographs and recent bibliographies on aerial photography and related subjects: Geol. Soc. America Bull., v. 54, p. 1195-1210.

Collins, Elizabeth, Subject Guide, an annotated bibliography on geology and mineral resources kept current in typed form. This reference service began in 1947, includes many entries on marine geology and tidelands petroleum development, and 18 avallable for consultation in offices of the California Division of Mines. 
Crooke, R. C., et al., 1953, Inshore survey, San Francisco Bay: Literature survey: Univ. Calif., Berkeley, Inst. eng. research, waves research lab.; tech. rept. ser. 57, 1ssue 1, approx. 370 p., Incl. 1llus. B1bllography and resume of each of the general topics covered in marine geology and oceanography.

Cuellar, M. P., 1953, Annotated blbllography on tounamis: U. S. Army, Corps of Englneers, Beach Erosion Board, Tech. Memo. 30, 69 p.

Cushman, J. A., 1932, A bibllography of American Foraminifera: Cushman Foram. Lab. Research, speclal pub. 3, 40 p.

Davidson, G., 1887, An examination of some of the early voyages of discovery and exploration on the northwest cosst of America from 1539 to 1603: Rept. U. S. Coast Survey 1886, app. 7, p. 155-253. Th1s and the following references of Davidson concern early history and discovery of Pacific Cosst.

Davidson, G., 1891, The discovery of Humboldt Bay: Geog. Soc. Pacte1c Trans. and Proc., v. 2, no. 1, p. 1-16, 5 pla. (charta).

Davidson, G., 1892, The discovery of San Dlego Bay: Geog. Soc. Pacific Trang. and Proc., v. 3, p. 37-47. Also see U. S. Coast Survey Rept. 1886 (1887), p. 155-253.

Davidson, G., 1907, The discovery of San Franclisco Bay, the rediscovery of the port of Monterey, the establishment of the Presidio, and the founding of the Mission of san Francisco: Geog. Soc. Pactfic Trans. and Proc., v. 4, ser. 2, p. 1-153.

Devidson, G., 1908, Franc1s Drake on the northwest cosst of America in the year 1579. The Golden Hinde did not anchor in the Bay of San Francisco: Geag. Soc. Pactific Trans. and Proc., v. 5, ser. 2, p. 1-114.

Davidson, G., 1910, The origin and meaning of the name california: Geog. Soc. Pacific Trans. and Proc., ser. 2, v. 6 , pt. 1, p. 1-50.

Dawson, E. Y., 1945, An annotated list of the marine algae and marine grasses of San Diego County, California: Sen Diego Soc. Nat. History, occ. paper 7.

DeGolyer, E., and Vance, H., 1944, B1bliography on the petroleum Industry: Texas Agr and Mechanical College Bull. $83,729 \mathrm{p}$.

D1xon, D. E., 1926, B1bllography of the geology of oregon: Or,egon Un1v. College Pub., v. 1, p. 1-125.

Doyle, J. T., 1889, The bay of San Franc1sco: Am. Ant1quarium Soc. Proc., new. ser., v. 6, p. 78-83, 1 pl. Early history.

Edmondson, C. H., 1946, Ecology of marine invertebrate fauna of the Pacific: Natl. Research Council, Div. Geology and Geography, Rept. Corm. on Marine Ecology as Related to Paleontology, 1945-1946, no. 6, p. 49-64. Excellent annotated bibliography on invertebrates.

Emery, K. O., 1950, An international directory of oceanographers: Pub. by the Allan Hancock Foundation, Univ. of Southern Calif., Los Angeles, Callf., Iv, 54 p. Lists name, address and major field of interest of oceanographers of the world (Revision in preas).

Falrbridge, R. W., 1947, Coarse sediments on the edge of the continentel shelf: Am. Jour. S1c., v. 245, p. 146-153. See bibllography at the end of paper for references on the subject.

Geyer, R. A., 1948, Annotated b1bllography of marine geophyafcal and geological surveys: Geol. Soc. America Bull., v. 59 , p. 671-696.

Geyer, R. A., 1950, A blbllography on the Gulf of Mexico: Texas Jour. Sc1., v. 2, no. 1, p. 44-93.

Geyer, R. A., undated, Bibliography of oceanography, marine biology, geology, geophysics and meteorology of the Gulf of Mexico: Humble 011 and Refining Co., 1v, 54 p.

Goldberg, E. D., undated, Bibliography and chemical methods of analysis of the trace elements in sea water: Scripps Inst. Oceanography, unpdg. Conslats of mimeographed sheets on wh1ch each trace element is given geograph1cally, bundance, chemlcal methods of analysis, and a list of pertinent references. The following elements are included in the bibliography: L1, B, F, Al, Sm, T1,
$\mathrm{V}, \mathrm{Cr}, \mathrm{Mn}, \mathrm{Fe}, \mathrm{Co}, \mathrm{N1}, \mathrm{Cu}, \mathrm{Zn}, \mathrm{Gs}, \mathrm{Ge}, \mathrm{As}, \mathrm{Se}, \mathrm{Pb}, \mathrm{Rb}$, $\mathrm{Sr}, \mathrm{Y}, \mathrm{Mo}, \mathrm{Sn}, \mathrm{Sb}, \mathrm{Ca}, \mathrm{Ba}, \mathrm{La}, \mathrm{Ce}, \mathrm{Hg}, \mathrm{B} 1, \mathrm{Rn}, \mathrm{Ra}, \mathrm{Th}, \mathrm{U}$.

Gould, H. R., undated, An annotated bibliography on the geoloby of phosphates: Unpub. rept. on f1le at the Sedimentation Lab., Allan Hancock Foundation, Univ. Southern Calif., 43 p., 133 reference, many on marine phosphates.

Great Britain Hydrograph1c office, 1926, 1927, Catalogue of Admiralty charts and other hydrographic pubs., London, 2 v., maps. May be later simflar lists.

Grier, M. C., 1941, Oceanography of the North Pacific Ocear, Bering Sea and Bering Strait; a contribution toward a bibllography: Univ. Wash. Pub. L1brary Ser., Univ. Wesh. Press, v. 2, 290 p.

Grier, M, C., 1952, References on the physical oceanography of the western Pacific Ocean: U. S. Navy Hydrog. Office Pub. 238, 174 p.

Haferkorn, H. E., 1929, Sand movement, beaches, and kindered subjects, a bibllography: Englneering School Library, office of Chlef of Engineers, U. S. Army, Fort Humphreys, Va., 114 p. 1101 references. Includes references on general works, sand movement, beaches, bars, bays, casst changes, currents, erosion, estuaries, shorelines, t1des and waves.

Haferkorn, H..E., 1932, Breakwaters. A bibliography of books, papers of societies and articles in periodicals on the subject, together with an index to subjects, topics, persons, and places: Eng. School Library, Army War College, wash., 86 p., xiv. 503 references.

Harlow, N., 1950, Maps of San Franclsco Bay from the Spantsh discovery in 1769 to the American occupation: San Franc1sco, The Book Club of California, xi1, 140 p., Grabborn Press. Extensive bibliography and historical account.

Hedgpeth, J. W., 1953, A prellminary bibllography of booke on the seashore, oceanography and related subjects: Scripps Inst. Oceanography, SIO ref. 53-13, 69 p., 550 references.

Hodge, E. T., 1932, Progress in oregon geology since 1925: Northwest Sc1., v. 6 , no. 2, 44-53 (b1bllography).

Hodge, E. T., 1936, B1bllography of oregon geology: Geol. Soc. oregon Country News Letter, $v, 2$, no. 6 , p. 1-2l.

Howell, J. V., and Levorsen, A. I , 1946, Directory of geological material in North America: Am. Assoc. Petroleum Geologists Bull., v. 30, pt. II, 112 p. Lists name and addresses of sources of information needed by geologists: maps, well data, aerial photographs, geologic publication books, reports, descriptions, special services, basic data.

International Counc1l for the Study of the Sea. Each 18sue of this journal carries a current bibllography.

International Geodetic and Geophysical Union, 1929-1939, Bibliograph1es on tides: Assoc. d'océanographie de L'Union Géodésique et Géophysique Internat. The bibliographies were published as follows: Proudman, J., 1929, B1bllographie des Marees (1910-1927), Bull. no. 12, 27 p.; 1931, T1dal b1bllography, Bull. no. 17, 14 p. $\{1932$, T1dal bibliography (third installment): sc1. pub. 2; 1936, B1bllography on tides and certain kindered matters (fourth installment): sc1. pub. 3; 1939, Bibllography on tides and certain kindered matters (fifth installment), aci. pub. 6 .

Isaecs, J. D., and Isel1n, C. O'D., editors, 1954, Oceanographi instrumentation. A conference held at Rancho Sante $\mathrm{Fe}$ California, 21-23 June, 1952 under the sponsorship of the office of Naval Research: Pub. 309, Natl. Acad. Sc1ences - Natl. Research Counc1l, 233 p., 1llus. Sumposiur of 12 articles and discussions on oceanographic instrumentation.

Jepson, W. L., 1893, Early scientific expeditions to California Erythea, v. 1, no. 9, p. $185-190$; v. 7 (1899), no. 11, p. 129-134.

Keen, A. M., 1937, An abridged check 11st and bibliography of west North American marine Molusca: Stanford Univ. Press $87 \mathrm{p}$. 
Kemler, E. N., undated, Bibliography on: Offshore petroleum developments: Houston Southwest Research Inst., Div. oceanography and Meteorol., pub. 1.

Kindle, E. M., and Edwards, E. M., 1924, Literature of ripple marks: Pan Am. Geologist, v. 41, p. 191-203.

Kohl, J. G., 1885, History of discovery and exploration on the coasts of the United States: Rept. U. S. Coast Survey 1884, app. 19, p. 493-617.

Kramer, H. P., 1950, Selected annotated bibliography on evaporation: Meterol. Abstracts and Bibllography, Am. Meteorol. Soc., v. 1, no. 11, p. 733-762. Also lists several other bibliographies on evaporation.

Laclavère, G. and Tard1, P., 1954, International bibliography of geodesy (Bibliographie Géodésique Internationale): London, Butterworths Sc1. Pubs., v. 6, covering the years 1946-1948, xx1v, 293 p. Other bibliographies by this group have been published starting with volume 1 (1928-1930), tc volume 7 (1949-1951) which will be published in 1954.

Ladd, H. S., and Others, Report of the committee on a treatise on marine ecology and paleontology, for various years published by the Div. Geology and Geography of the Natl. Research Council. Contains excellent bibliographies on marine flora and fauna.

Lee, C. C., 1937, Salinity: A bibllography of books, periodicals, and society publications appearing from 1845 to date: U. S. Waterwa ys Experiment Station, Vicksburg, M1ss., March, 12 p., 70 references, supplement 1942, 4 p. 26 references.

Lee, C. C., 1946, Waves and wave action: P. O. Box 80, V1cksburg, Miss., Nov. 23, privately printed, supplement no. 1, 33 p. Bibliography on the subject.

Lohman, K. E., 1941, Ecology of diatoms: Natl. Research Council, Div. Geology and Geography, Rept. Subcomm. on the Ecology of Marine Organisms, no. 1, p. 27-31. Reprinted July 1944. Annotated bibliography of papers that contain ecological data.

London Science Museum, 1937, Cosstal erosion protection, drainage and allied topics, 1931 to date: South Kenington, London, England, Sc1. Mus., Sc1. Library Bibliographic ser. no. 336, 7 p., mimeo. Bibliography on the above mentioned subjects.

Lorens, P. J., and R1chter, R. C., 1954, B1bllography and map index of unpublished geologic mapping and reports in California. January, 1937 to January 1954: Calif. Dept. Public Works, Div. Water Res., 11, 51 p. + map. Mimeo. rept., limit distribution, references on geology ground water, paleontology and stratigraphy, and sediment studies.

MacDonald, R. M. E., 1921, An alalytical subject bibllography of the publications of the Bureav of Fisheries, 1871-1920. App. v, Rept. 1920, 306 p., Bur. F1sher1es Doc. 899.

Michigan University, Lake Hydraulics Laboratory, 1950, B1bliography on beach erosion and related subjects: Research pub. 1, 86 p., March 1. Contains approximately 700 references on beach erosion, ripple marks, sand and sand movement, shore protection, and engineering aspects of beach problems. Annotations are given for about 150 references.

Moats, R. W., 19413, Wind erosion and sand dune control - A selected list of references: Soll Conservation of the U. S. Dept. Agriculture, Soll Conservation Bibliography no. 1, 66 p., mimeo. Summaries and indexes of 443 domestic and foreign publications and articles on the subject, many of them dealing exclusively with shore protection aspects of the problem.

Notom1, R. S., 1947, Glossary of Japanese terms used in hydrography and physical oceanography: Woods Hole Oceanographic Inst., tech. rept. no. 1, 132 p.

Rühl, A., 1906, Beltrage zür kenntnis der morphologoschen Wirksamke1t der Meereströmungen: Berlin, Univ. Inst. fur Merresionde, Veroff., H. 8, 44 p., paper no. 5 in v. 16, 1870-1912 of papers on hydrography. Has many references on oceanography.

Russell, R. D., and Taylor, R. E., 1937, B1bliography on roundness and shape of sedimentary particles: Natl. Research Counc1l Ann. Rept. 1936-37, app. I., Rept. Comm. Sedimentation, p. 65-79, app. by F. P. Pettijohn, 1b1d, 1937, p. 80.

Shedd, S., 1933, B1bliography of the geology and mineral resources of California to December 31, 1930: Calif. D1v. Mines Bull. 104, xil, p. 25-376.

Shedd, S., 1937, Bbiliography of the geology and mineral resources of California for the years 1931-1936 inclusive (Supplementing the master bibliography, Bull. 104): Calif. Div. Mines Bull. 115, xiv, $125 \mathrm{p}$.

Shedd, S., 1939, Bibliography of the geology and mineral resources-of California for the year 1937 (Supplementing Bull. 104 and 115): Calif. D1v. Mines, Jour. Mines and Geology, v. 35 , no. 3 , p. 275-307.

Spencer, W. W., 1905, Bibliography of submarine valleys off North America: Am. Jour. Sci., 4th ser., v. 19, p. $341-344$.

Stanford, California, School of Mineral Science, Stanford Grotto, Nati. Speleological Soc. Bibliography and reports haye numerous references on sea caves, especially off the California coast.

Stetson, H. C., 1938, Report of the committee on sedimentation, 1937-38; exhibit $c$, papers dealing with sedimentation since 1933: Natl. Research Council Ann. Rept. 1937-38, p. $31-36$.

Stuntz, S. C., and Free, E. E., 1911, Bibliography of eolian geology: U. S. Dept. Agriculture, Bur. Snils, Bull. 68 , p. $174-263$.

Todd, D. K., 1952, An abstract of literature pertaining to sea water intrusion and 1ts control: Univ. Calif., Richmond, Calif., Sanitary eng. research project, 72 p. Divided into five parts as follows: I. Reduction of aquafer permeability, II. Sea water intrusion, III. Injection and recharge aquafers, IV. Laboratory and model studies, V. Ground water flow.

Trask, P. D. and Others, 1933-1939, Report of the committee on sedimentation 1935-36: Natl. Research Counc1l Ann. Rept. 1935-36, app. 1, 47 p. (1936; 1936-37, app. 1, 128 p. (1937); 1937-38, app. A., 114 p., with exhibits A to F, (1938), reprinted 1939; Exhib1t D, Bibliography relating to organic content of sediments, p. $37-43$ (1938); Exhibit $\mathrm{E}$, unpub. theses in American colleges and universities on sedimentation, p. 44-105 (1938); 1938-39, app. B., 102 p. (1939).

Treasher, R. C., and Hodge, E. T., 1936, Bibllography of the geology and mineral resources of oregon with digests and Index to July 1, 1936: Portland, Oregon, Oregon State Planning Board, 224 p.

U. S. Coast and Geodetic Survey, Current tables Pacific Corst of North America etc. The U. S. Cosit and Geodetic Survey perlodically publishes a guide to the currents along this and other coast lines.

U. S. Corst and Geodetic Survey, U. S. Cosst Pilot, Pacific Cosst, California, Oregon and Washington: These reports give a considerable amount of information on oceanographic and submarine geological data. The various coasts and 1slands are also described. Some of the very early coast Pilots contain all the information known about our cosst lines at that time.

U. S. Coast and Geodetic Survey, Key map and index diagrams showing the limits of hydrographic surveys along the Pacific Coast, prepared by the U. S. Cosst and Geodetic Survey, Wash., D. C. Index sheets show location of the surveys made along the Pacific Coast of the U. S. from 1851 to date. Each loose leaf, generally covering a span of years, show the survey course, date- of survey, field sheet number, and the scale used.

U. S. Department of Agriculture, 1950, Annotated bibllography on sedimentation, complled under the auspices of the subcommittee of sedimentation, federal inter-agency River 
Basin Committee, and prepared under the supervision of the Soll Conservation Service, U. S. Dept. Agriculture, Sedimentation Bull. 2, 351 p.

U. S. Department of Defense, 1953, Arctic bibliography: Prepared for and in cooperation with the Department of Defense, under direction of North America Arctic Inst., Gov't. Printing office, Wash., D. C., 4 v.

U. S. Hydrographic office, Index-catalogue of nautical charts and publications: U.S. Navy Hydrog. Office Pub. 1-N.

U. S. Hydrographic office, 1949, Preliminary bibliography of the North Atlantic ocean, including the Mediteranean Sea: U. S. Navy Hydrog. Office, Z. 0. 15, 180, 15 p.

U. S. Naval Photographic Interpretation Center, 1951, Antarctic bibllography: U. S. Navy, Bur. Aeronautica, Gov't. Printing office, Wa.h., D. C., NAVAER 10-35-591, 147 p., charts. Includes approx. 5,500 references on: Biological sciences, geophysical sciences (geology paleontology, floating ice, meteorology), geographic sciences (geography, oceanography, hydrography, charta etc.), geographic exploration and many other oubjects.

U. S. Waterways Experiment Station, Vicksburg, Misoisoippi, 1954, Bibliography on tidal hydraulics, Comittee on Tidsil Hydraulica: $201 \mathrm{p}$.

Wagner, H. R., 1926, Sir Francis Drake's voyage arround the world: Ita aims and achlevementa: San Franciaco, John Howell, 543 p., 1llus. Early history of the Pacific Coast.

Wagner, H. R., 1929, Spanish voyages to the northwest coast of America in the oixteenth century: San Francisco, Hiatorical Soc. apecial pub. 4. Early history of the Pacific coast.

Wagner, H. R., 1937, The cartography of the northwest coast of America to the year 1880: Berkeley, Univ. Calif. Press, 2 v., 543 p., 11lus. A complete history of exploration of the west cosat of America. Lista hundreds of references and maps.

Ward, H. A., 1948, The use of historical surveys in beach erosion studies: U. S. Army, Corps of Engineers, Beach Erosion Board Bull., v. 2, no. 3, p. 13-16.

Washington, University of, Department of Oceanography, 1953-54, Puget Sound and approaches, a literature survey: v. 1, geography, climatology, hydrology, 130 p. + figs.; v. 2, geology, geomagnetism, geodesy, hydrography, volcanology, seismology, $118 \mathrm{p}$. + figs.: v. 3 , physical oceanography, marine blology, and general summary, 175 p. + figs.

Wexler, H., and Tepper, M., 1951, Results of the wartime historical and normal map program: First Conf. on Coestal Eng. Proc., Berkeley, p. 98-101. Gives sources of historical weather maps.

Wlegel, R. L., 1953, Waves, t1des, currents and beaches: Gloseary of terms and list of standard symbols: Council on Wave Research, Berkeley, $113 \mathrm{p}$.

Williams, L., 1937, Classiflcation and selected bibliography of the surface textures of sedimentary fragments: Nat1. Research Counc11, Ann. Rept. 1936-37, app. I., Rept. Comm. Sedimentation, p. 114-128.

Woodring, W. P., 1948, Annotated bibliography of paleontology of California Tertiary marine mollusks: Natl. Research Council, Div. Geology and Geography, Rept. comm. of a Treatise on Marine Ecology and Paleontology, no. 7 , p. 54-57.

Yoshimura, S., 1934, Bibliography of oceanographic geology in Japan. I. (1927-1937): Jour. Oceanography, Imperial Marine Observatory, Kobe. (In Japaneae).

Yoshimurs, S., 1938, Classified list of papers and reports bearing on oceanic geology published in Japan during 1927-1937: Geologie der Meere und Binnengewasser, band 2 , p. $451-476$.

Young, P., 1926, Blbliographic notes on ports and harbors including lista by the Library of Congress: Am. Assoc. Port Authorieles, New orleans, vili, $188 \mathrm{p}$.
ZoBell, C. E., 1950, Annotated bibllography on ecology of marine bacteria: Natl. Regearch Council, Div. Geology and Geography, Rept. Comm. on a Treatise of Marine Ecology and Paleontslogy, no. 10, p. 31-54.

C. OUTLINE OF ORGANIZATIONS THAT MAY HAVE UNPUBLISHED DATA, INCLUDTNG A LIST OF POSSIBLE SUBJECTS

The following section is a suggested outline of possible sources of information, especially unpublished report and data, and includes a liat of topics on which there may be information.

Harbor Departments, City Councils, C1ty and County Engineering offices

Historica]

Engineering aspects of: harbor, beach erosion and its control, pollution, otream discharge including quantity and sometimes texture of sediment discharged into har. bors or ocean front; sometimes deep boring and probes have been made in connection with engineering projects. Meteorological data including: water and air temperatures, waves, swell, currents, storms, winds etc. Salt water intrusion.

\section{U. S. Weather Bureau}

Meteorological data including: a Ir and sea temperatures, winds, storms, currents, upwelling, fog etc.

Charts

\section{U. S. Coast and Geodetic Survey}

Phyolcal and chemical oceanography including: currents, waves, underwater sound, density of sea water, temperature, salinity, tidal data including selomology and selomic sea waves, variations in sea level, tide tables.

Hydrographic data including: soundinga, submarine topography, bottom character (i.e. type of bottom material).

U. S. Cosst Pilot Guides frequently contain pertinent data. In the early hiatory of exploration on the Weat coast of the U. S., this was about the only source of oceanographic information.

\section{U. S. Army, Corps of Engineers}

Beach erosion, its control and prevention.

oceanographic data expecially owell, waves and currents. Stream discharge, amount and sometimes nature of sediments deposited in harbors and on the sea floor or beaches. Harbor and coatal engineering.

Military oceanography.

Charts

\section{U. S. Navy Eydrographic office}

Sailing Directions

Soundinge and submarine topography

Bottom sediment charts

Oceanographic data including: waves, currents, swell, density, temperature, salinity, underwater sound etc.

Meteorological data including: winds, storms, if and sea temperature.

\section{California Division of Mines}

Most reports on the California Division of Mines concern the geology and mineral resources of the state, however, there are a few scattered reports on beaches, lolands, petroleum, physiography of the coastal area, including terraces.

\section{California Division of Water Resources}

Geology

Salt water intrusion

Pollution

California Water Pollution Control Board Pollution primarily in harbors and in streams. Physical and chemical oceanography (mostly in harbors).

California Division of Beaches and Parke

Beaches, especially legal and recreation

\section{City and County Sewage Disposal Plants}

(Department of Sanitary Engineering)

Pollution

Engineering

Physical and chemical oceanography including waves, currents, turbidity etc. 
California Department of F1sh and Game

The Sardine Research Program belng carrled out by the Callfornia Department of F1sh and Game and others have made many detalled oceanographlc crulses off the coast of California and Baja California. Their reports include blology, physical and chemlcal oceanography. In addition, they have made studies of the influence of seismic surveys on flsh mortality.

\section{Local Libraries}

Local librarles generally contain more reports and books of the area than will more distant ones. They frequently have copies of local reports and reports of limited distribution on harbors, and other cosstal projects. Historical books, documents, and letters are often a source of information which are frequently overlooked by most scientists. Books and documents often give an insight into early conditions, characteristics of the shoreline, stream dralnage including former location of streams, great storms, floods, tsunamis, earthquakes, old maps, charts, oll seeps etc. Shlp logs and expedition reports likewise contain information of interest. Newspaper clippinge sometimes have interesting information.

Marine Engineering Consultants and companied Consultants and private companies carrying out marine work may have useful information including borings, beach and harbor englneering.

\section{Companies}

Many of the California oll companies undoubtedly bave a host of information of the offshore region of California, primarily as a result of the recent tideland decision. Unfortunately, most of their data are restricted to company personnel and as a result generally are not avallable to research workers. Under certain circumstances, however, the oll companies have been known to release some data to outside personnel.

\section{Universities and colleges}

Universities and colleges frequently have financial support by the government or other organizations and as a result have a considerable amount of data. They also have a large amount of unpublished reports, or papers in preparation for publication by the faculty and students. For example, the Sedimentation Iaboratory of the Allan Hancock Foundation of the University of Southern Callfornia has several hundred research and seminar reports on marine geology, oceanography, sedimentation, and ground water.

Five universities carrying out marine research on the Pacific Coast are:

Allan Hancock Foundation of the University of Southern California

Hopkins Marine Station of Stanford University Scripps Institution of Oceanography of the University of California

University of California, Berkeley

Univeraity of Waghington 

EXPLANATION

(1)

+

年

19.

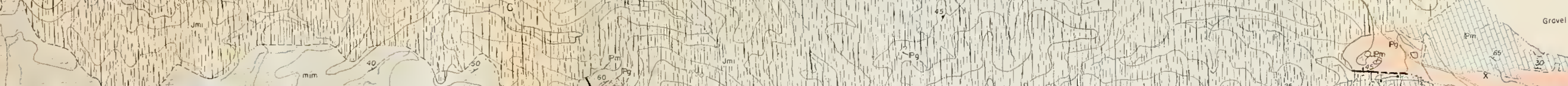

1.
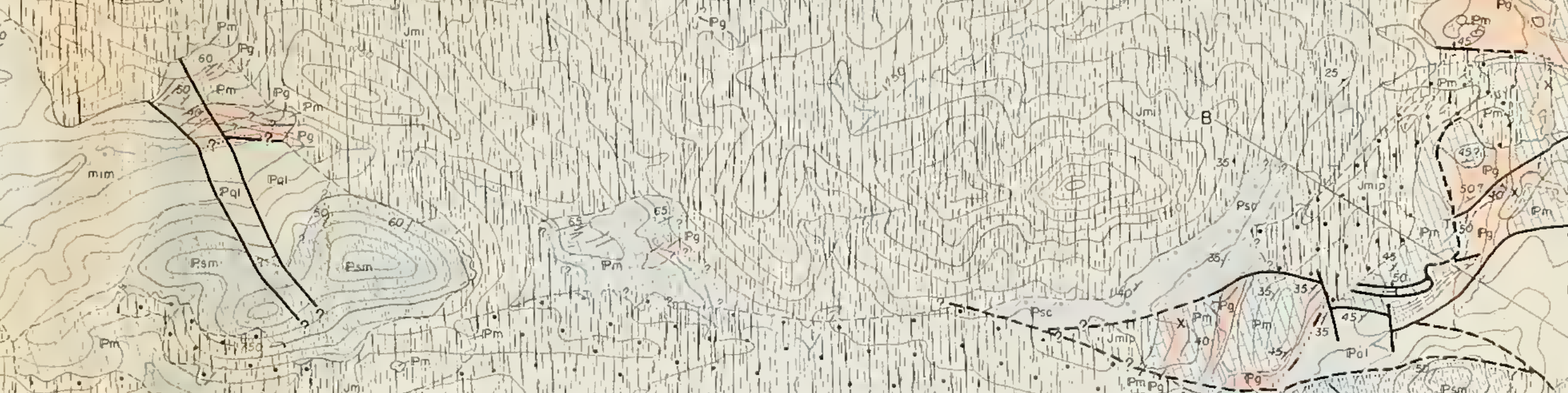

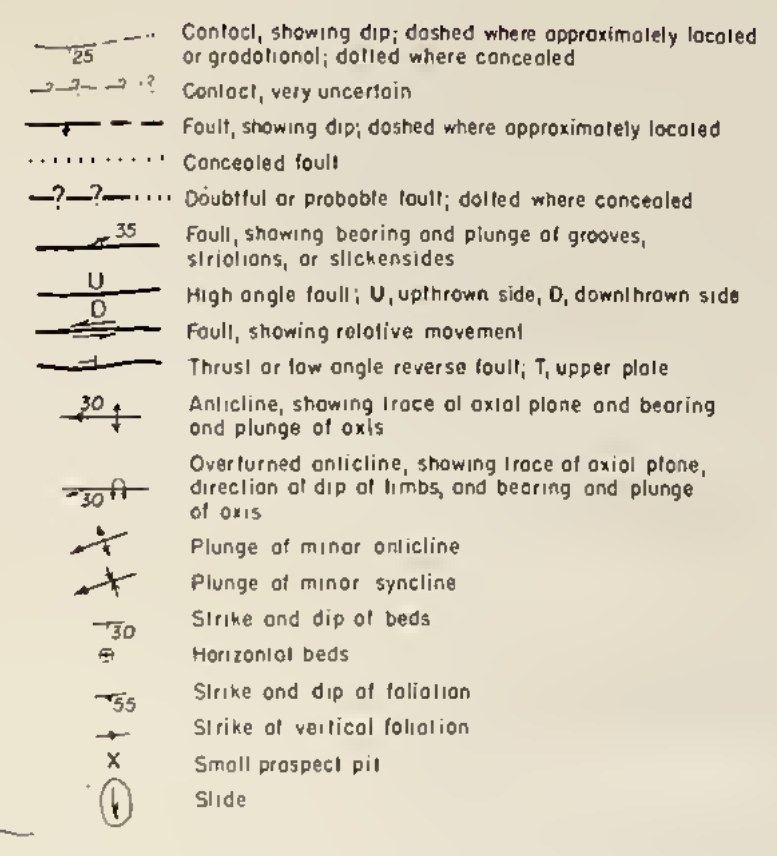

(n)

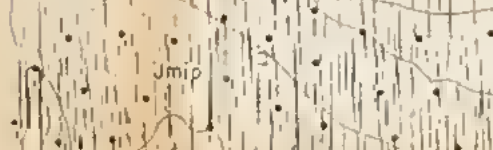

min

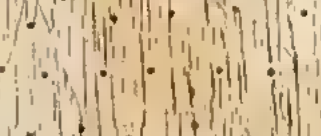

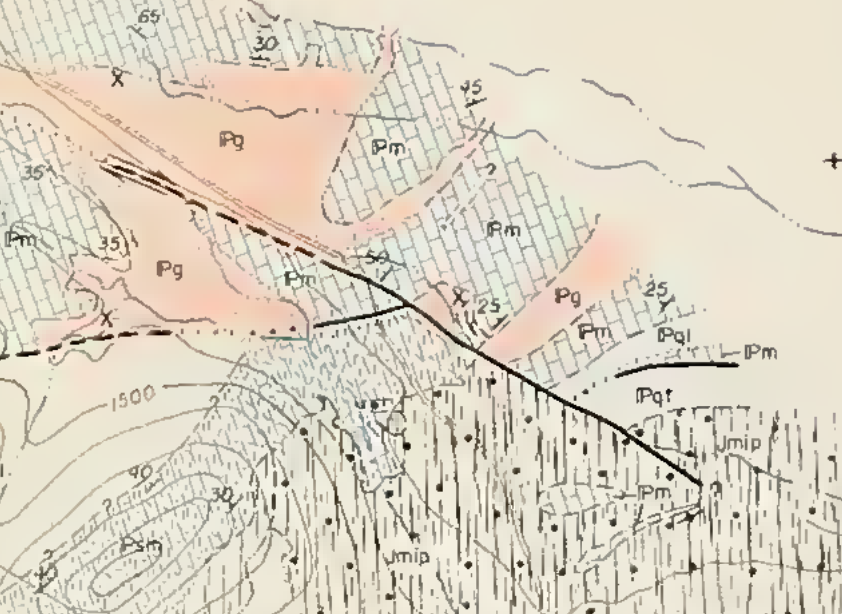

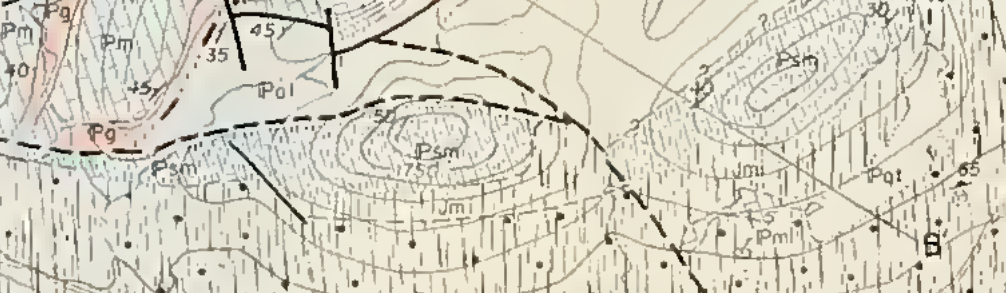
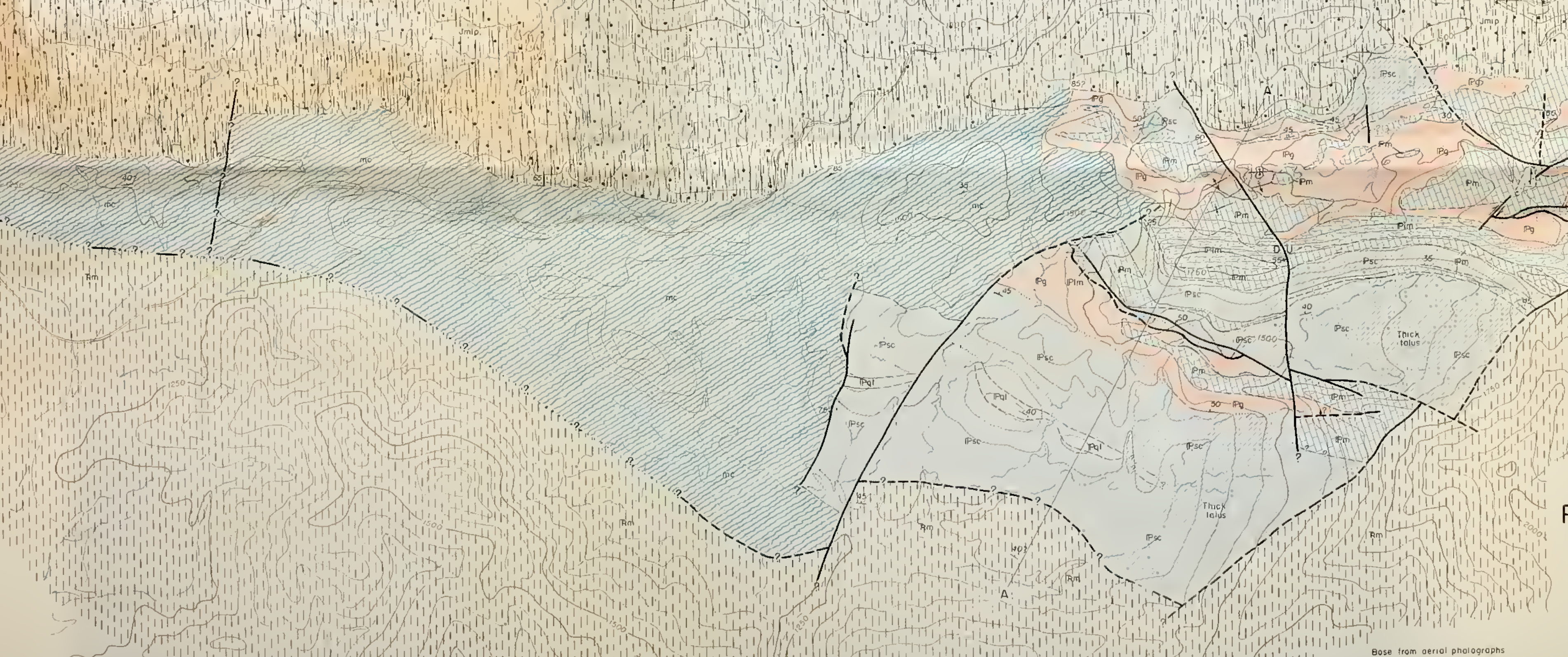




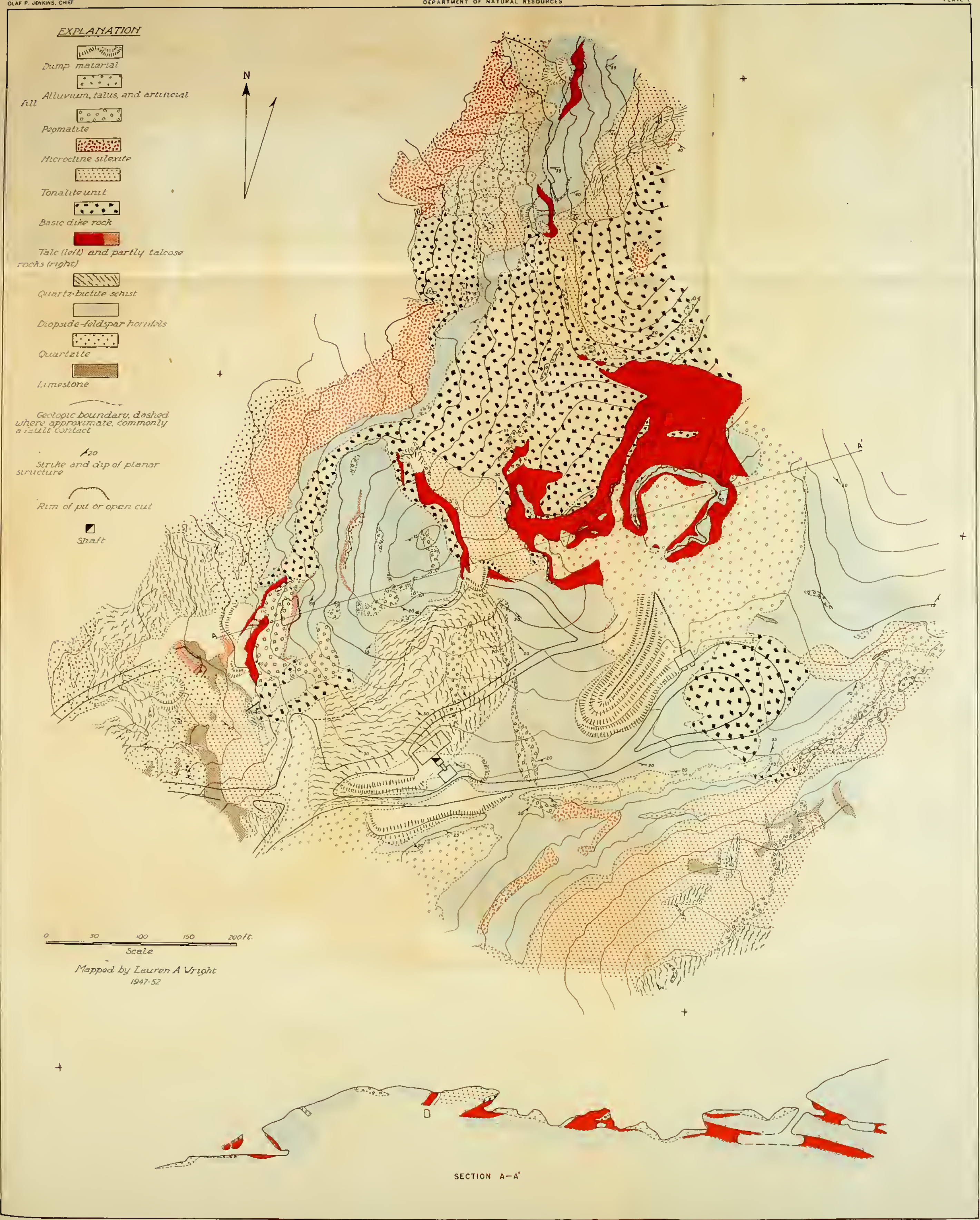






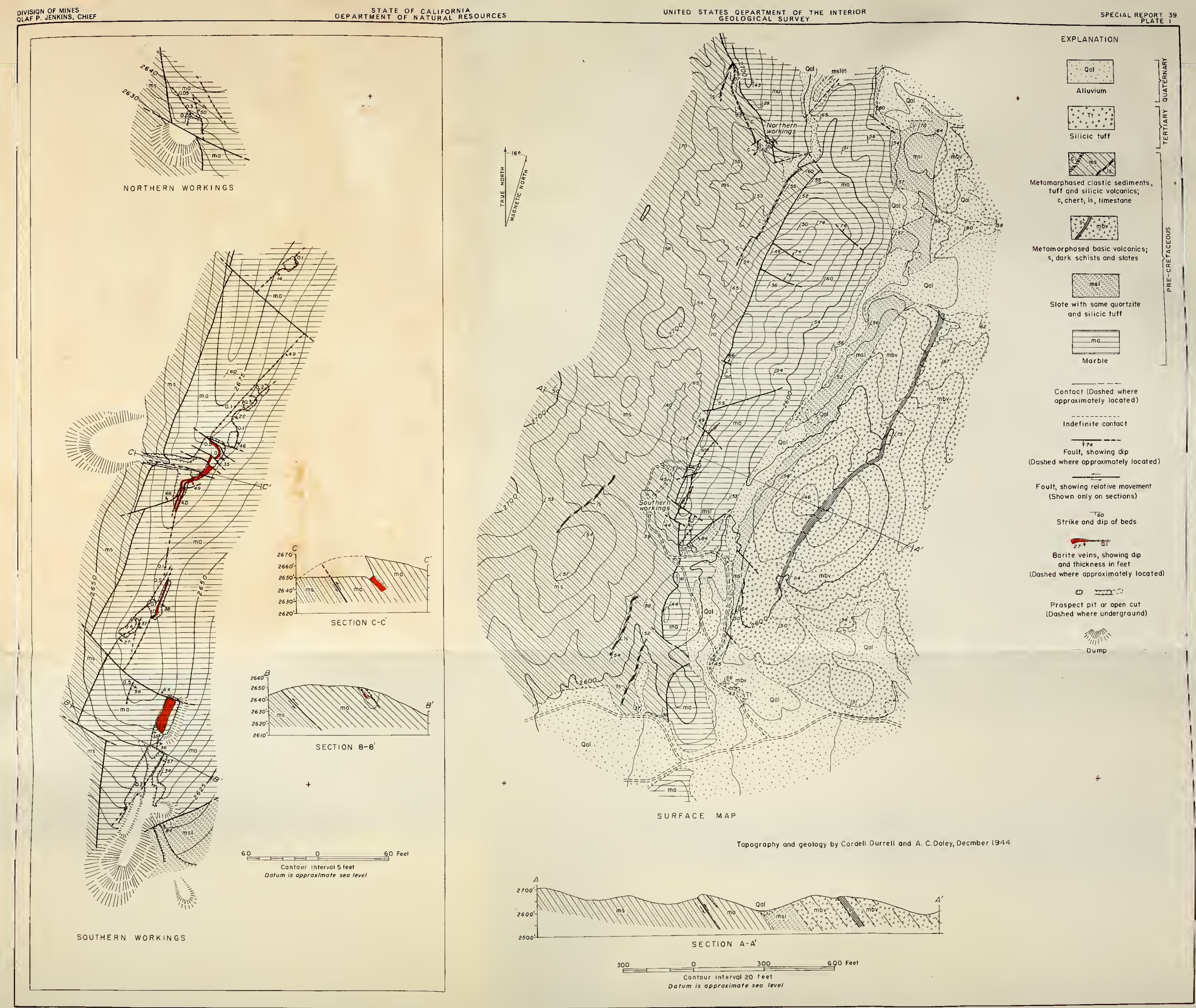

BALL BARITE DEPOSIT, SAN BERNARDINO COUNTY, CALIFORNIA 



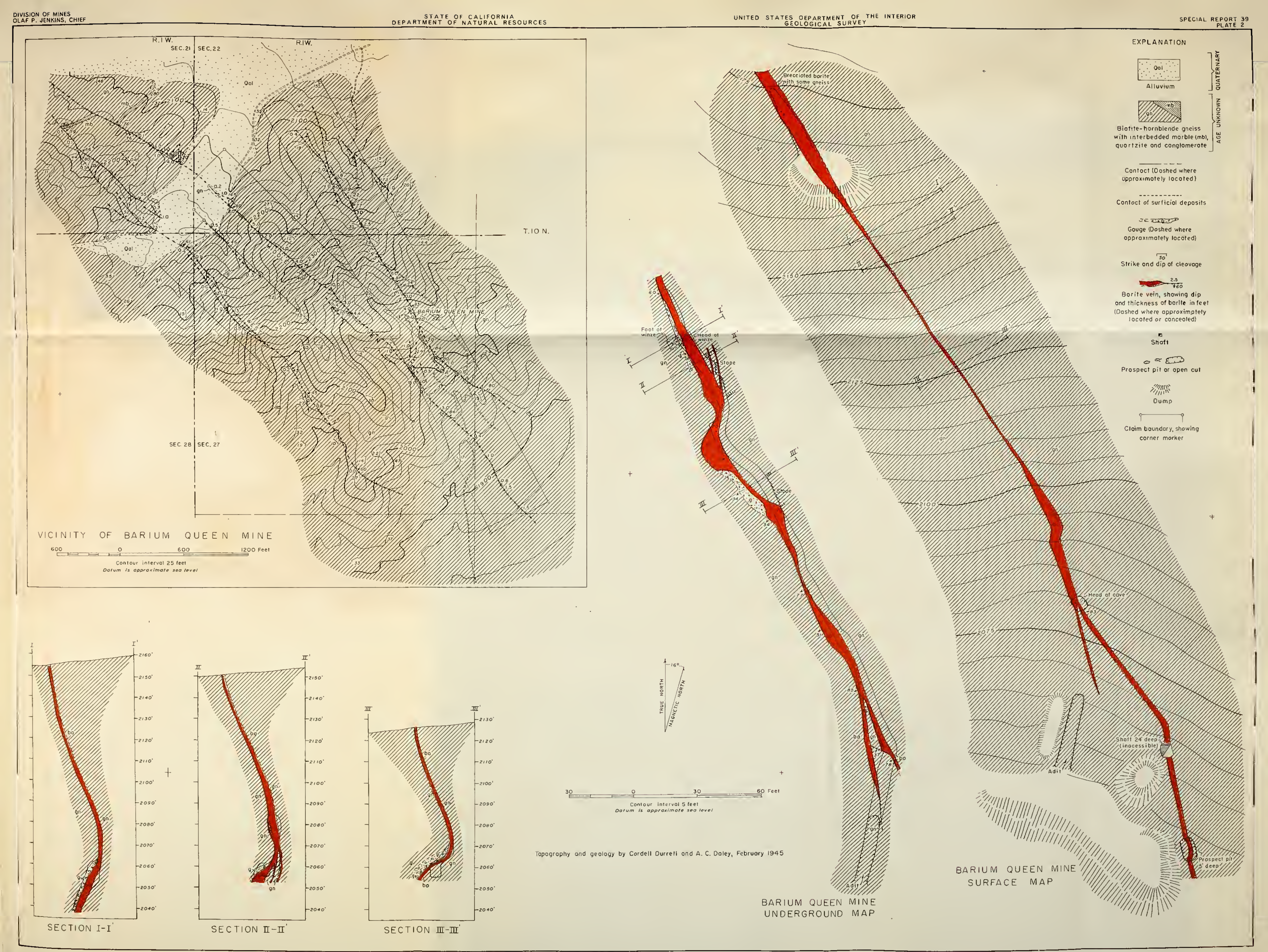

BARIUM QUEEN MINE AND VICINITY, SAN BERNARDINO COUNTY, CALIFORNIA 



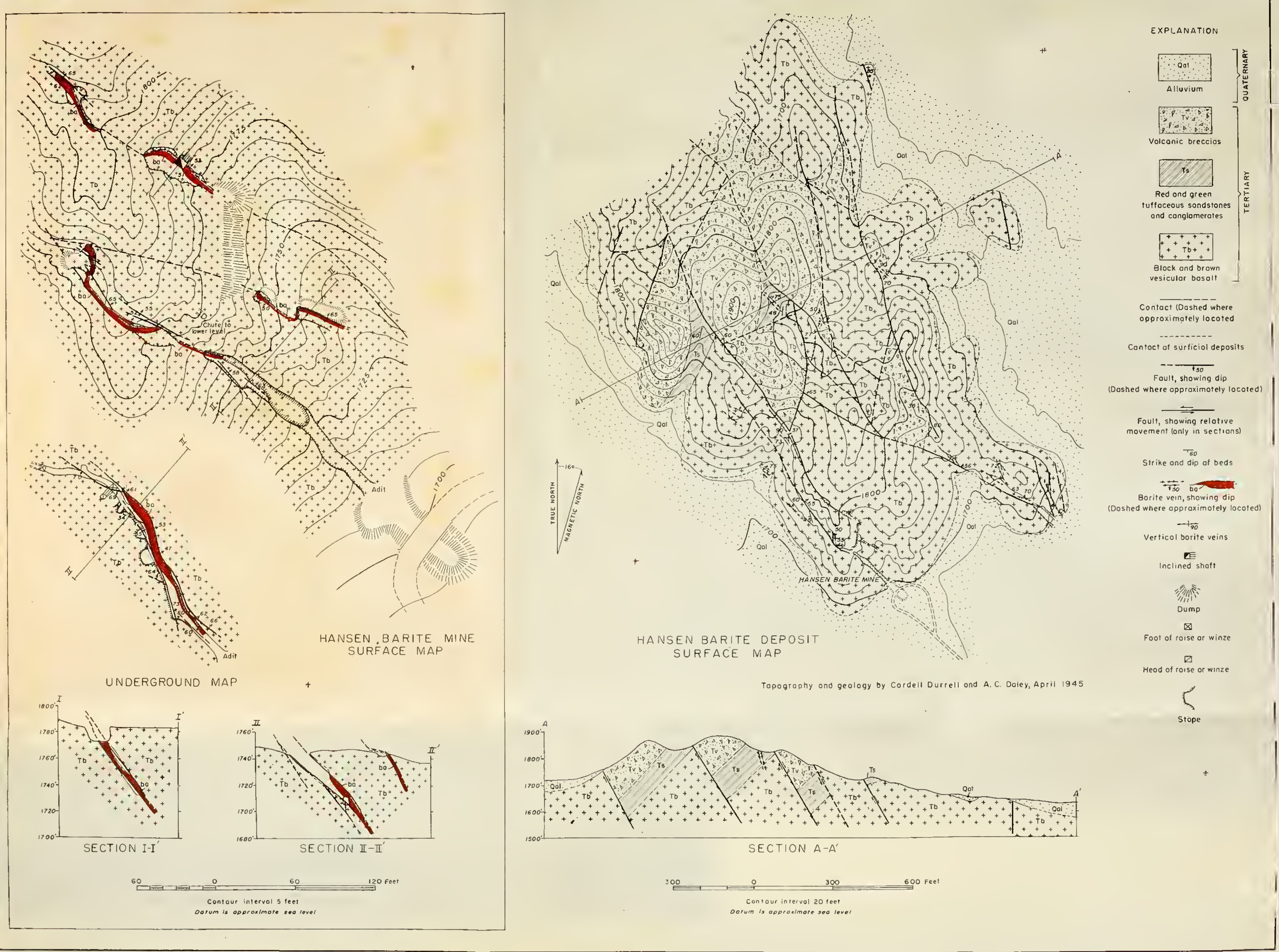

HANSEN BARITE DEPOSIT, SAN BERNARDINO COUNTY, CALIFORNIA 


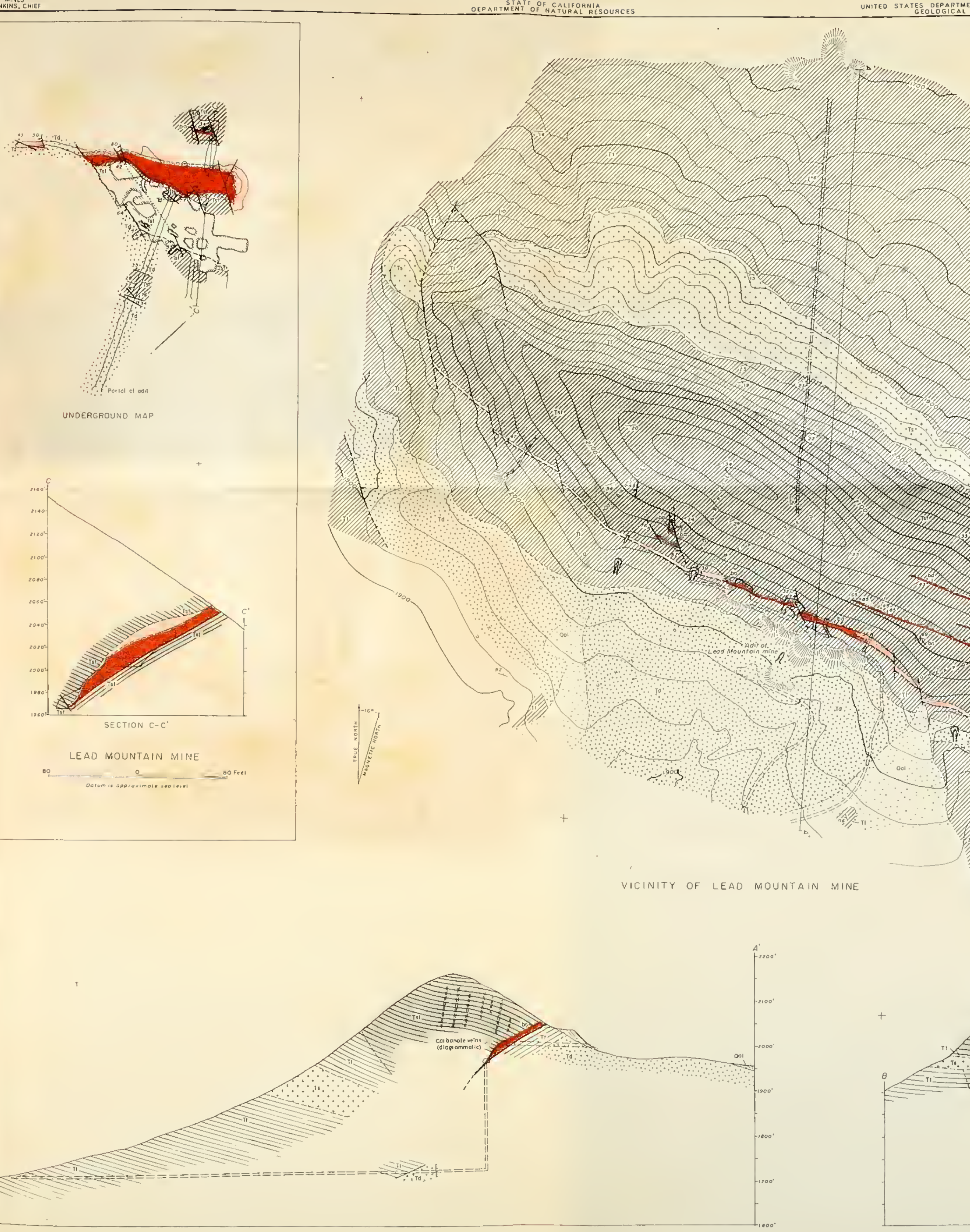

LEAD MOUNTAIN MINE
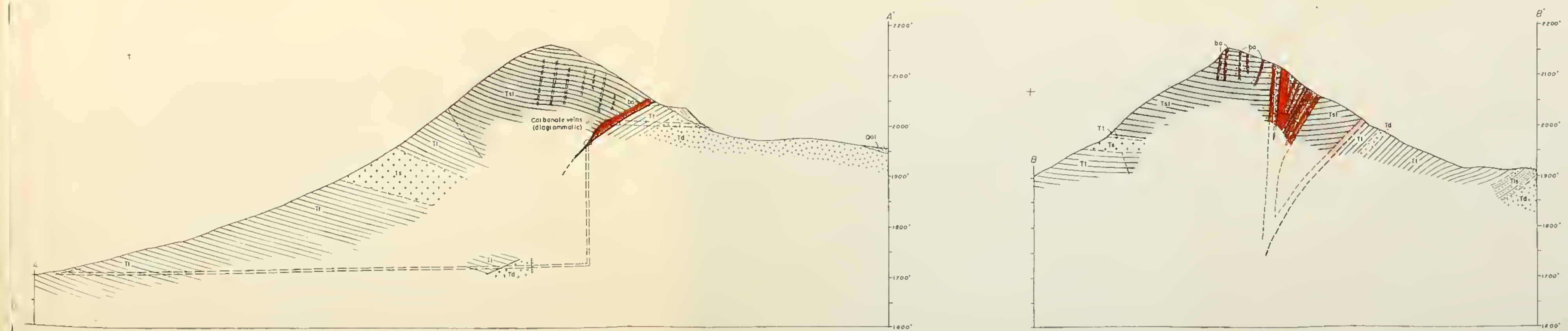



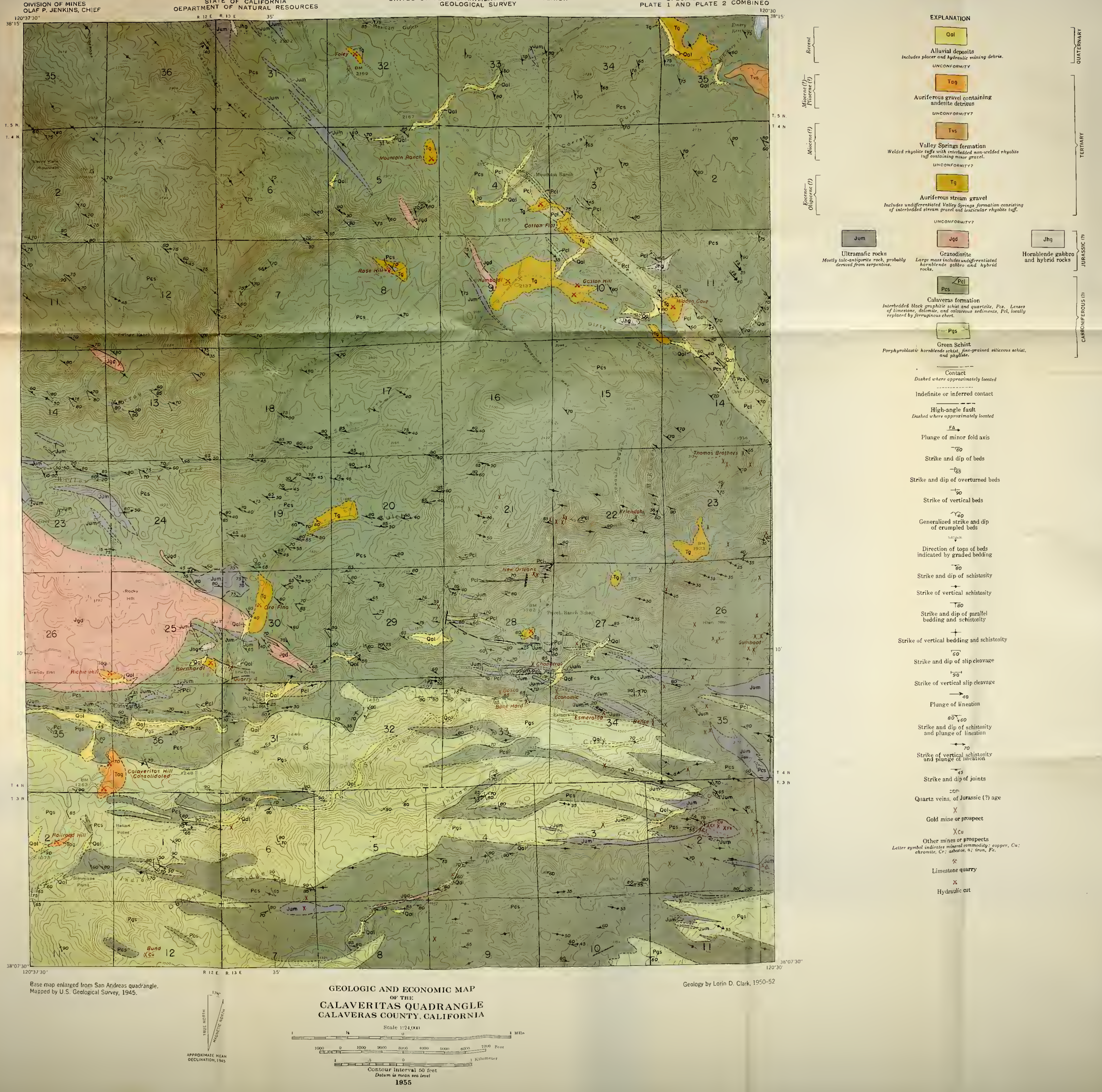





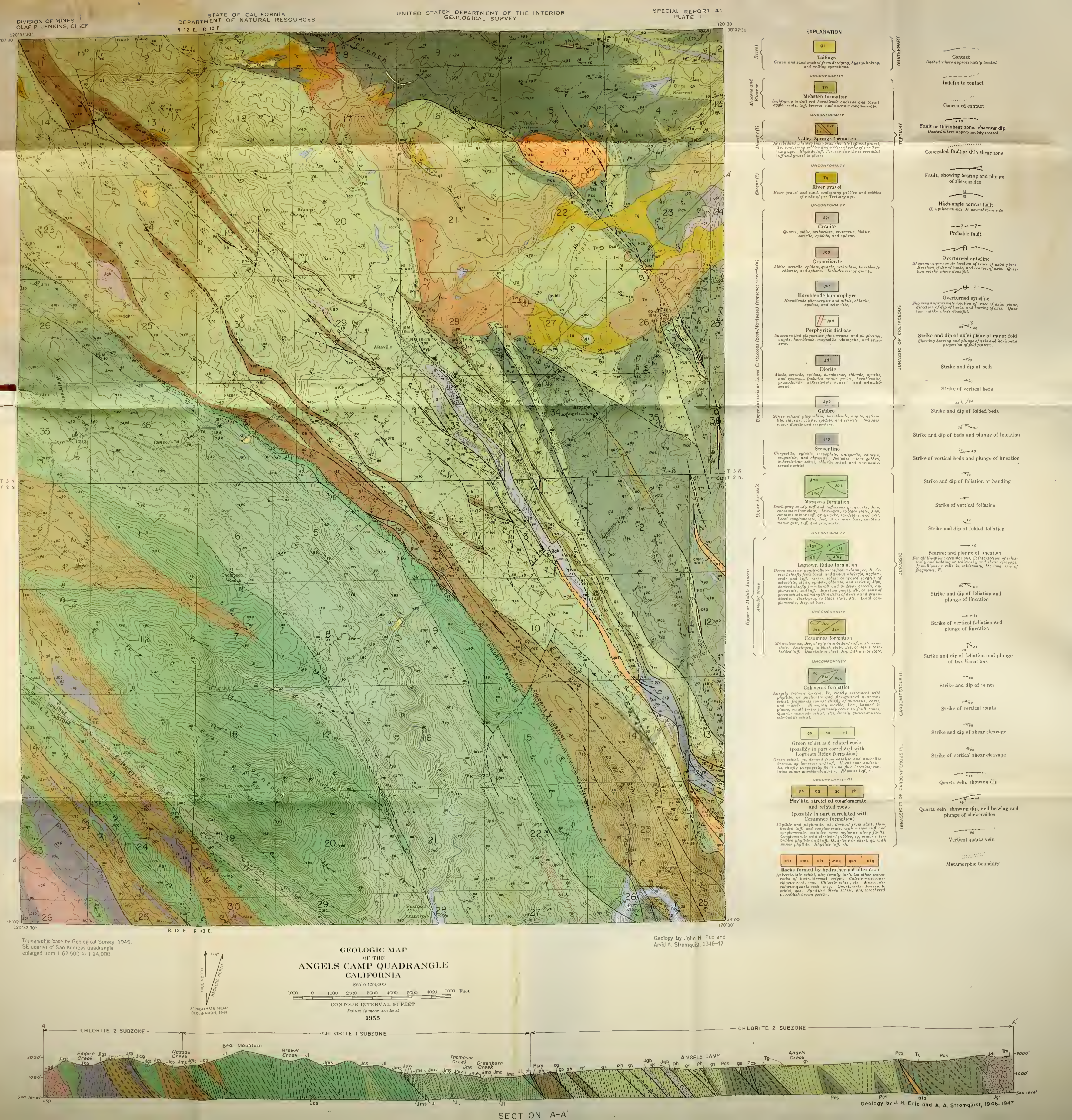





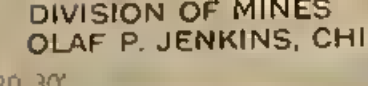

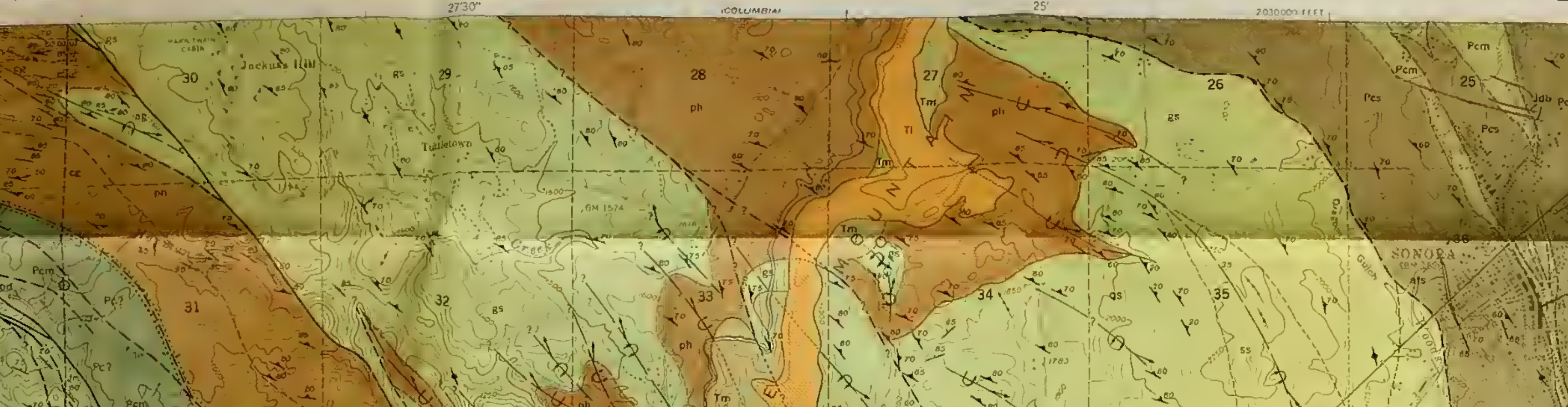

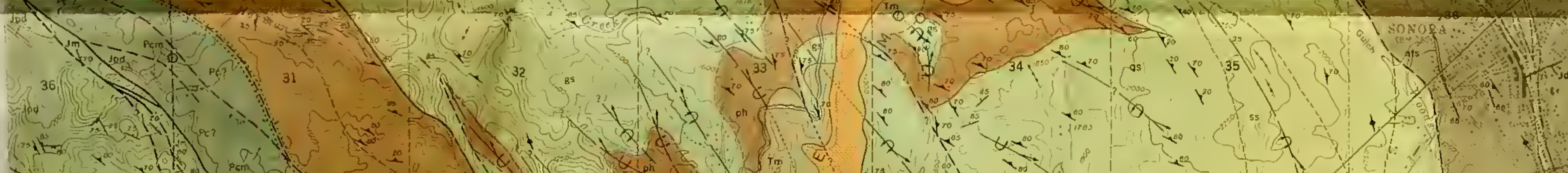

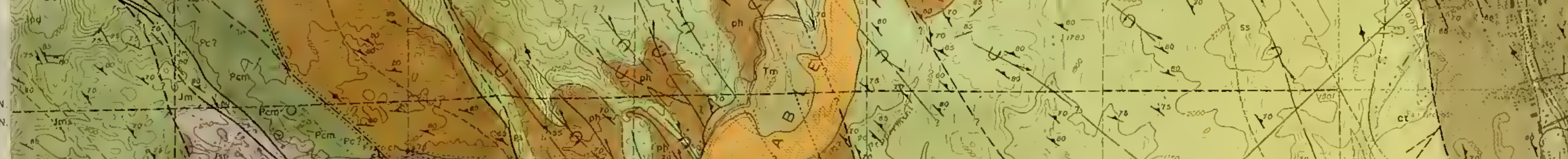

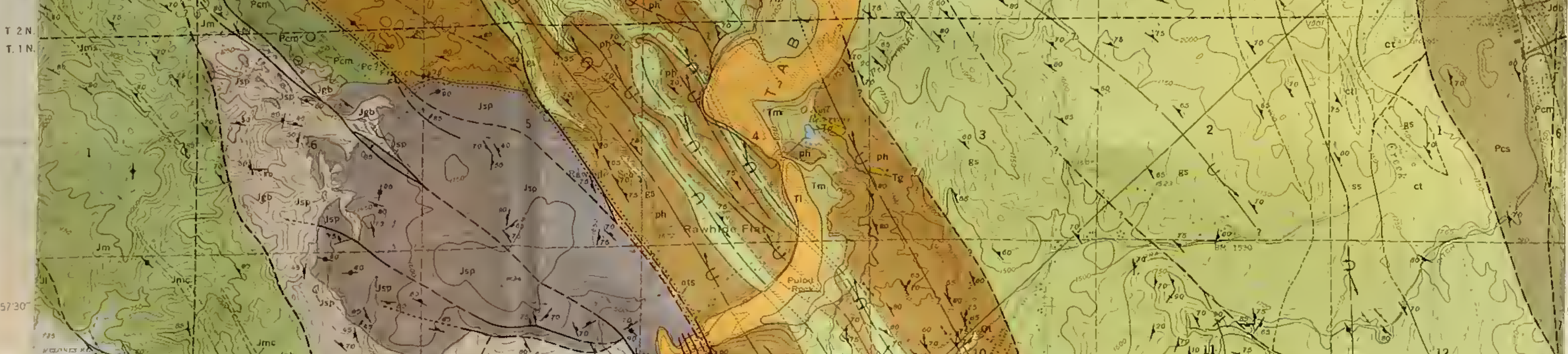

$+3 y^{2}$
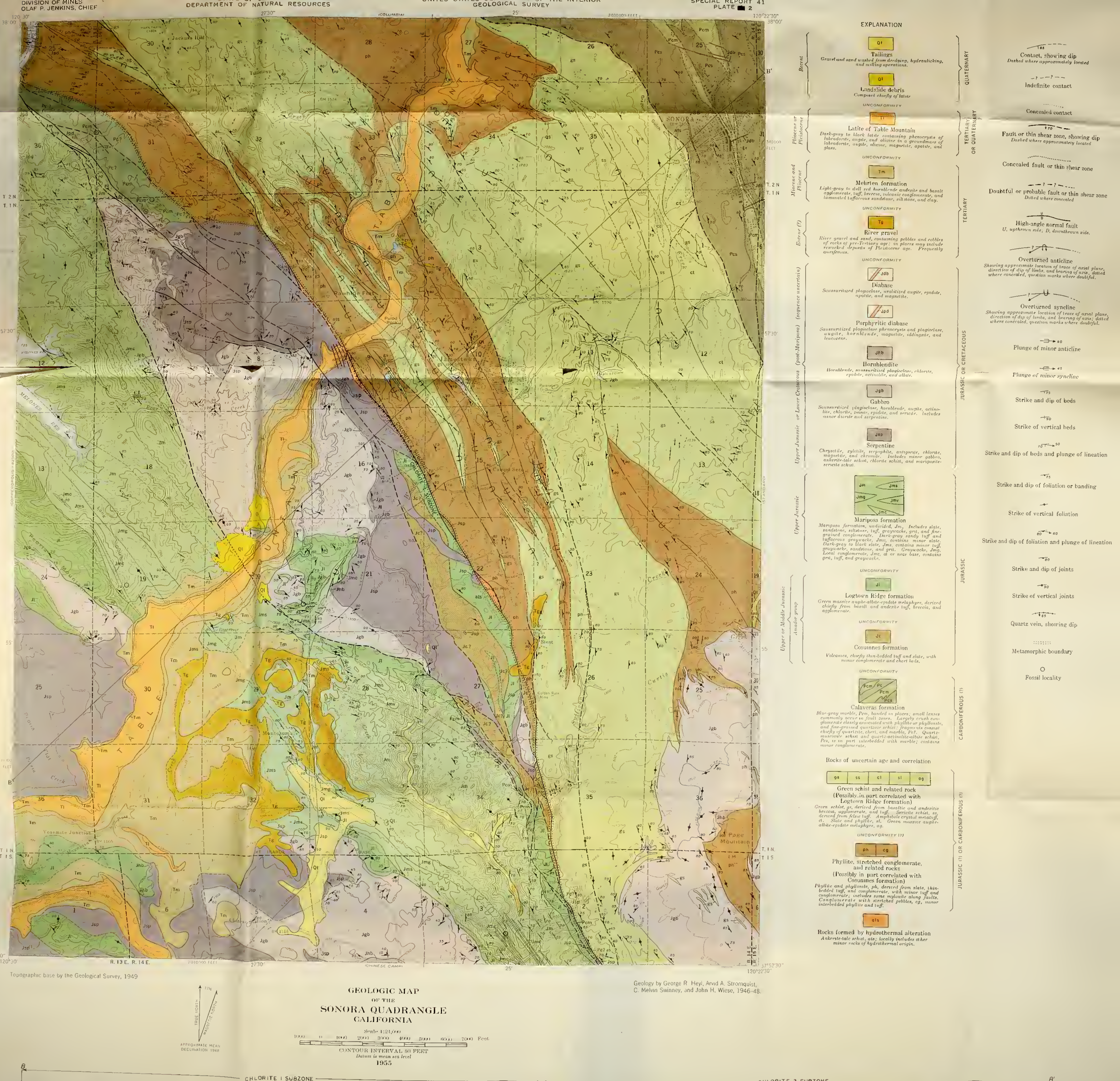

. 



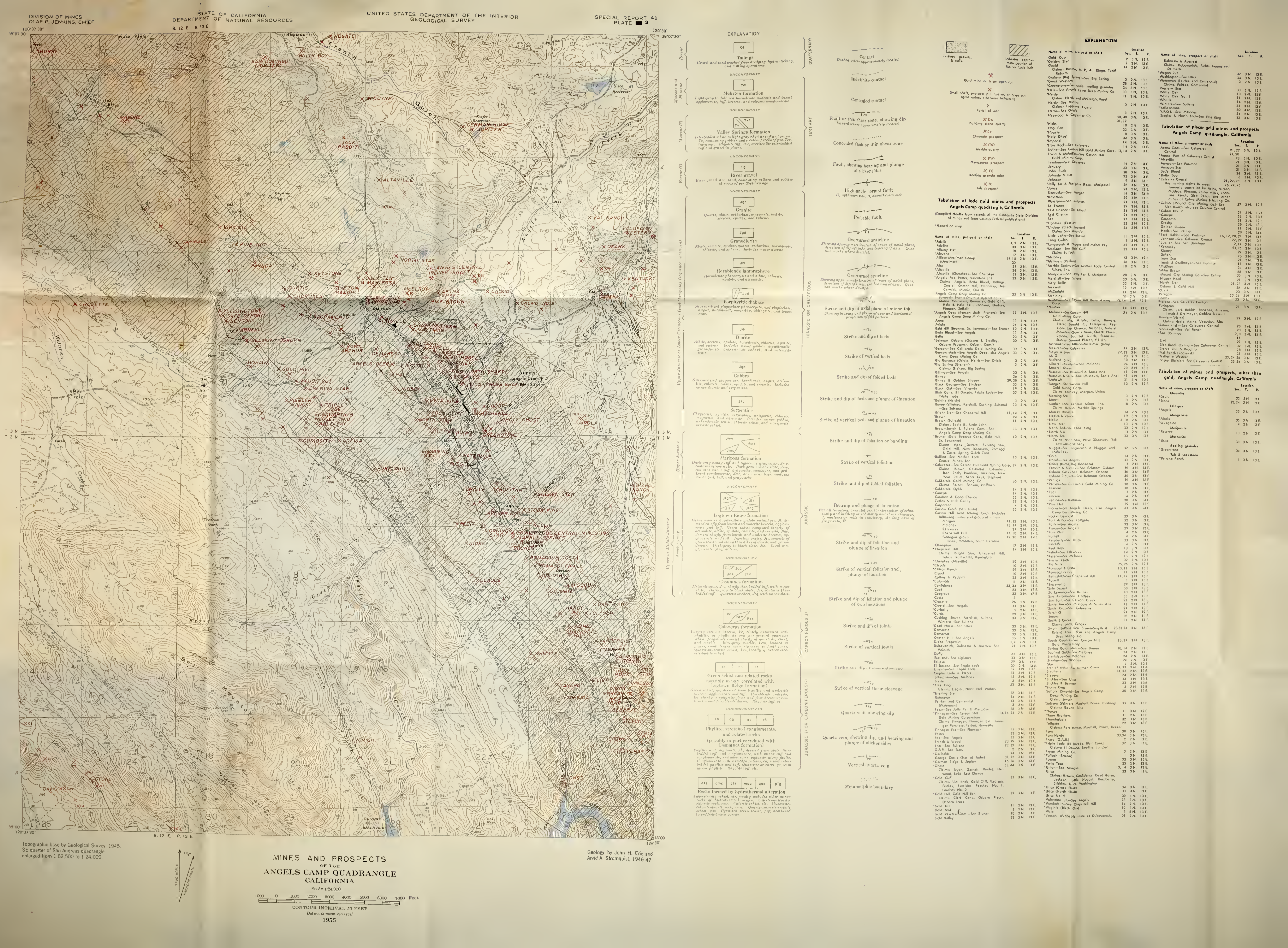





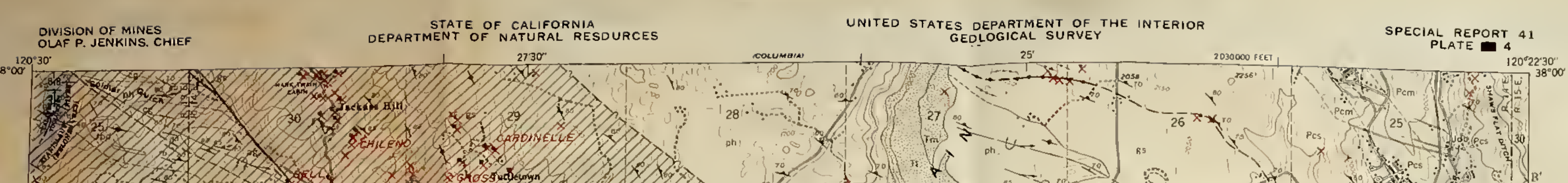

1.1.

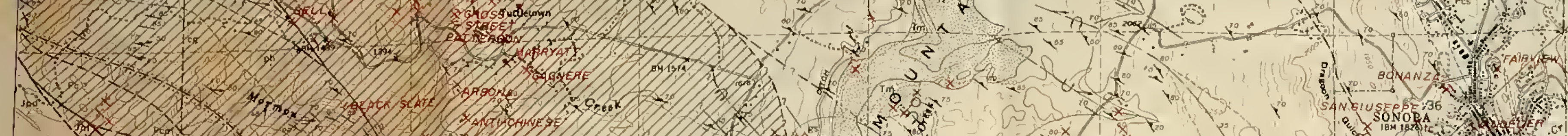

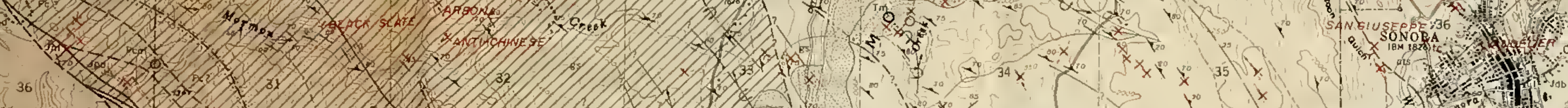

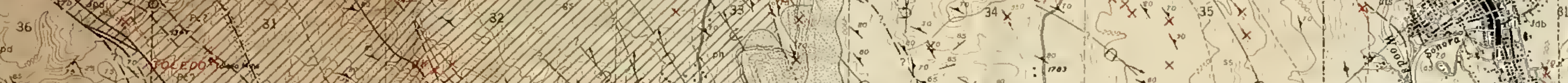

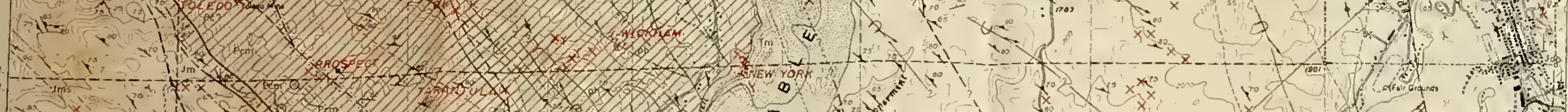
L.

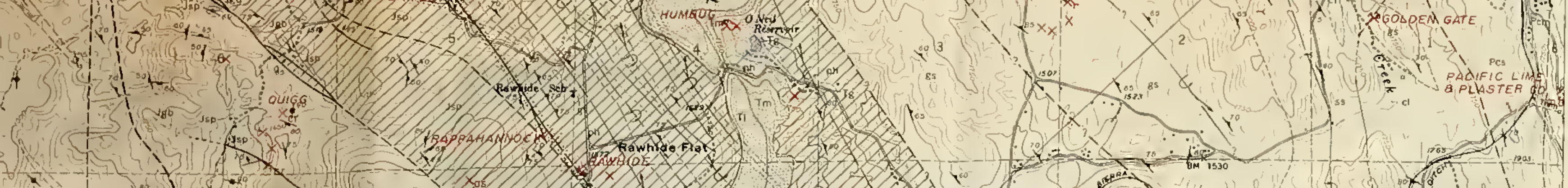

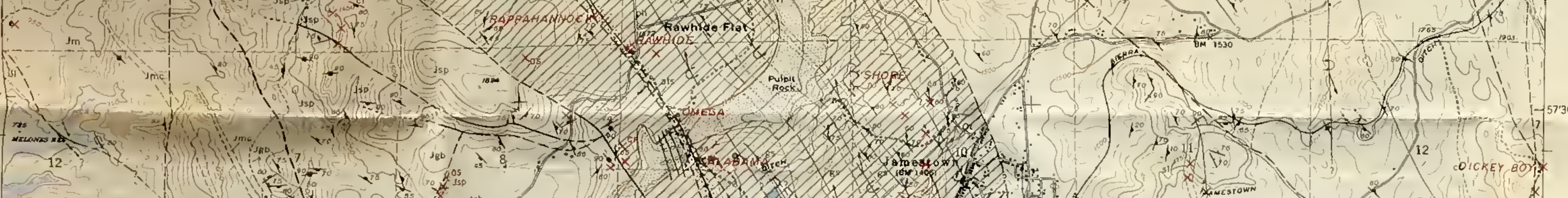
ton

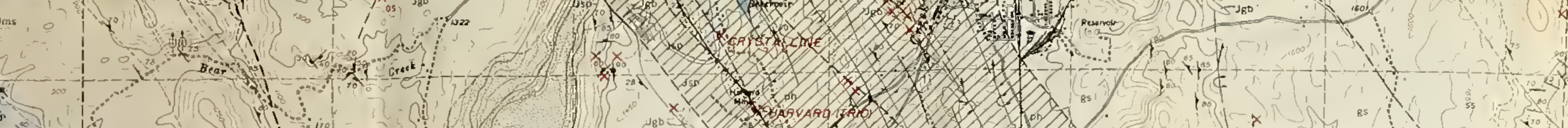

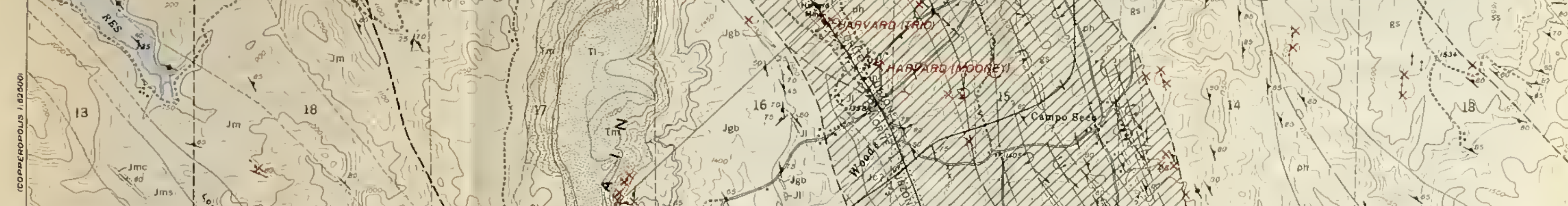

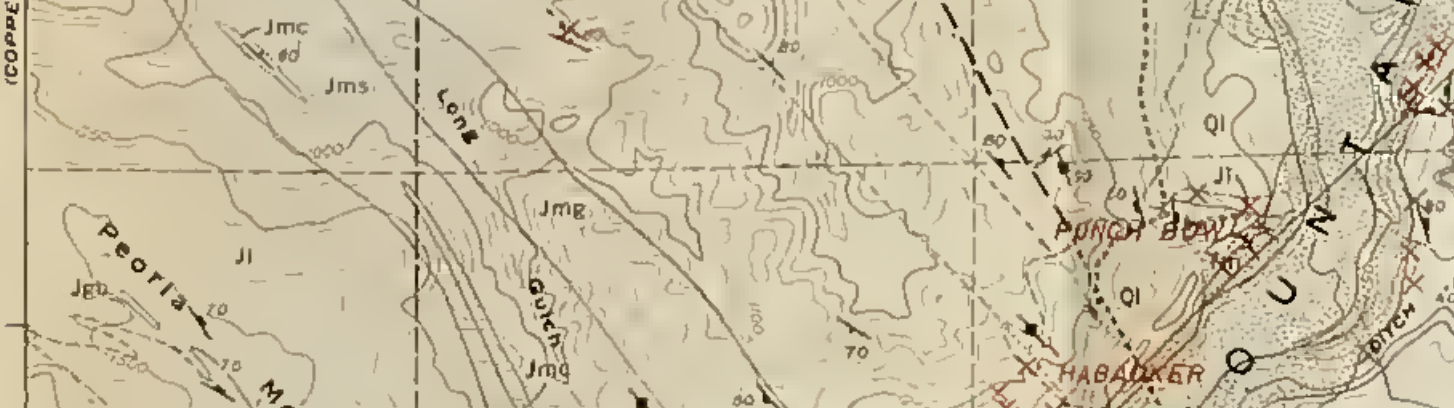
1240

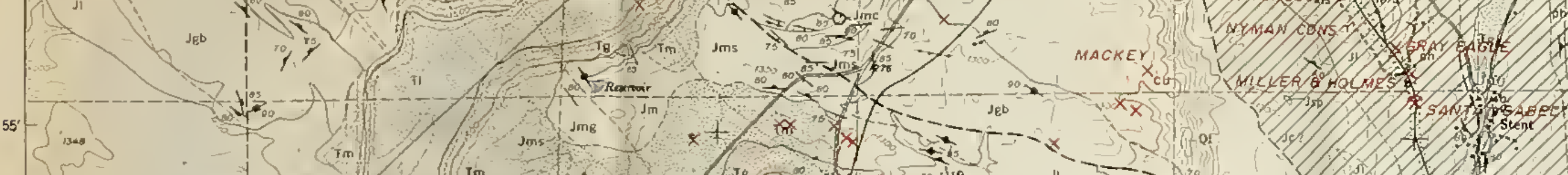

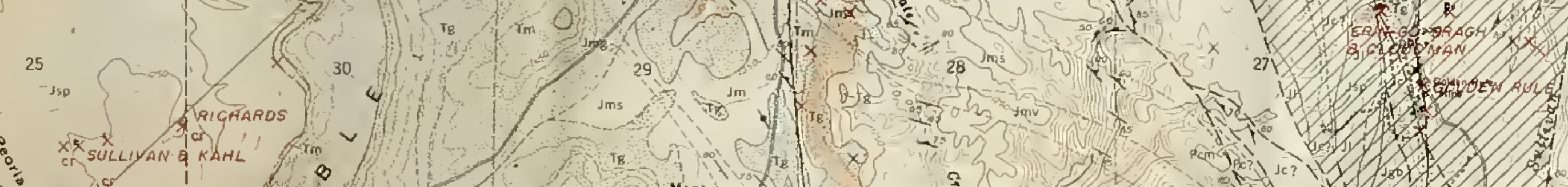
\& (1) = (n) renctions (n) $\frac{1}{2} \sqrt{1}$

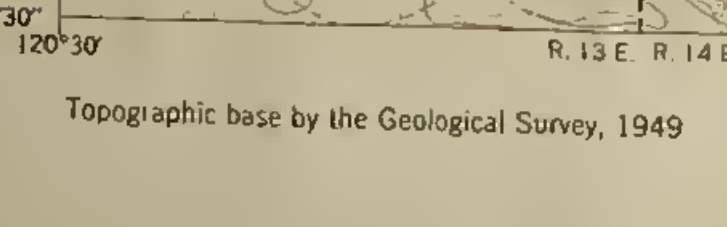

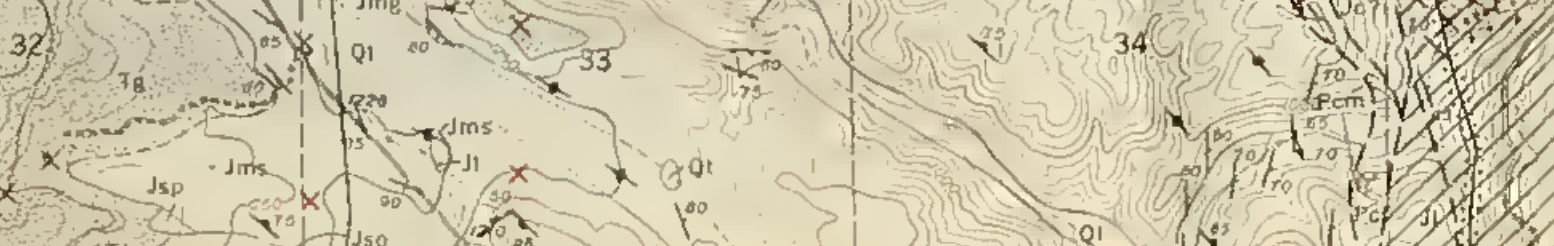

tring

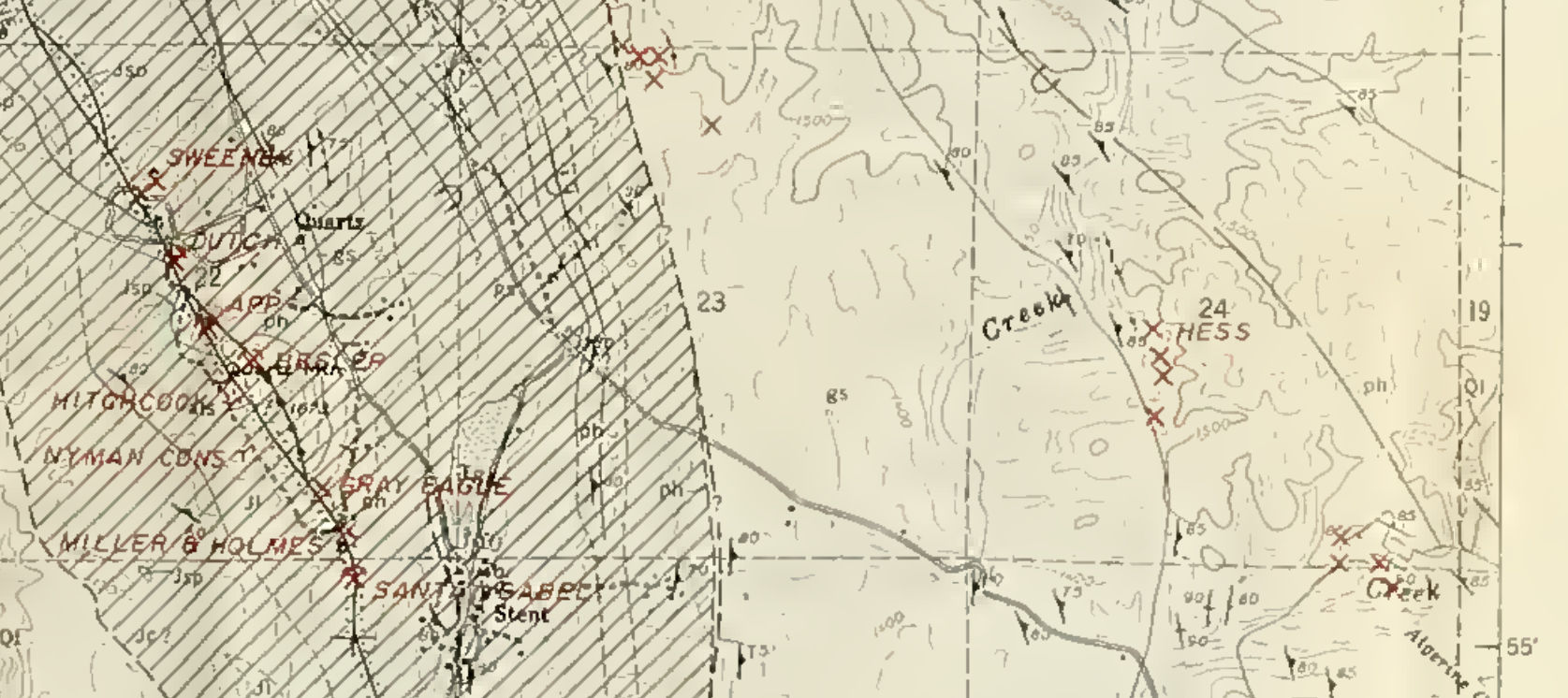

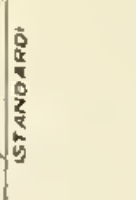

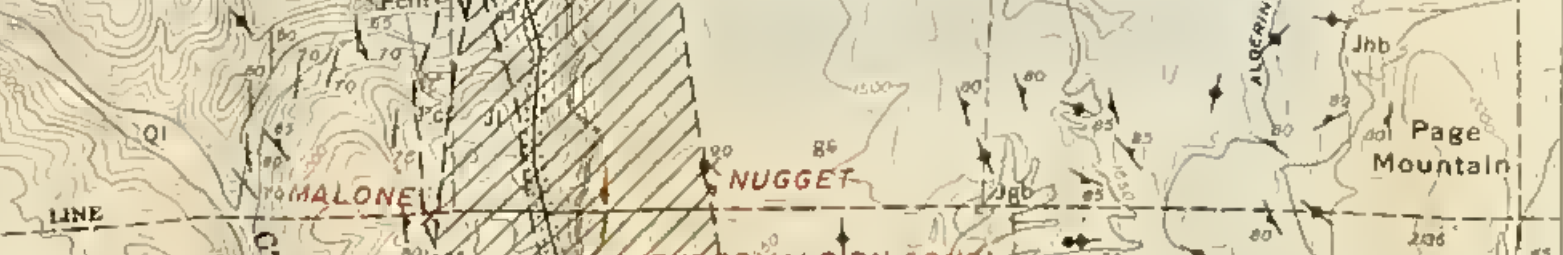

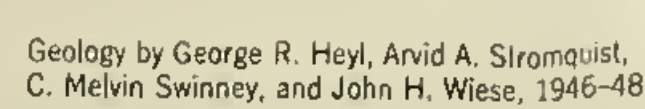

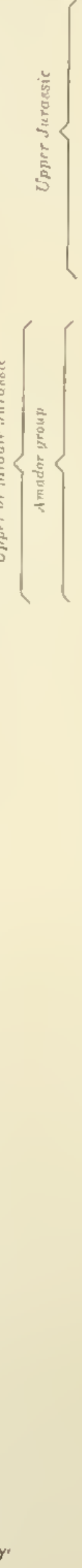

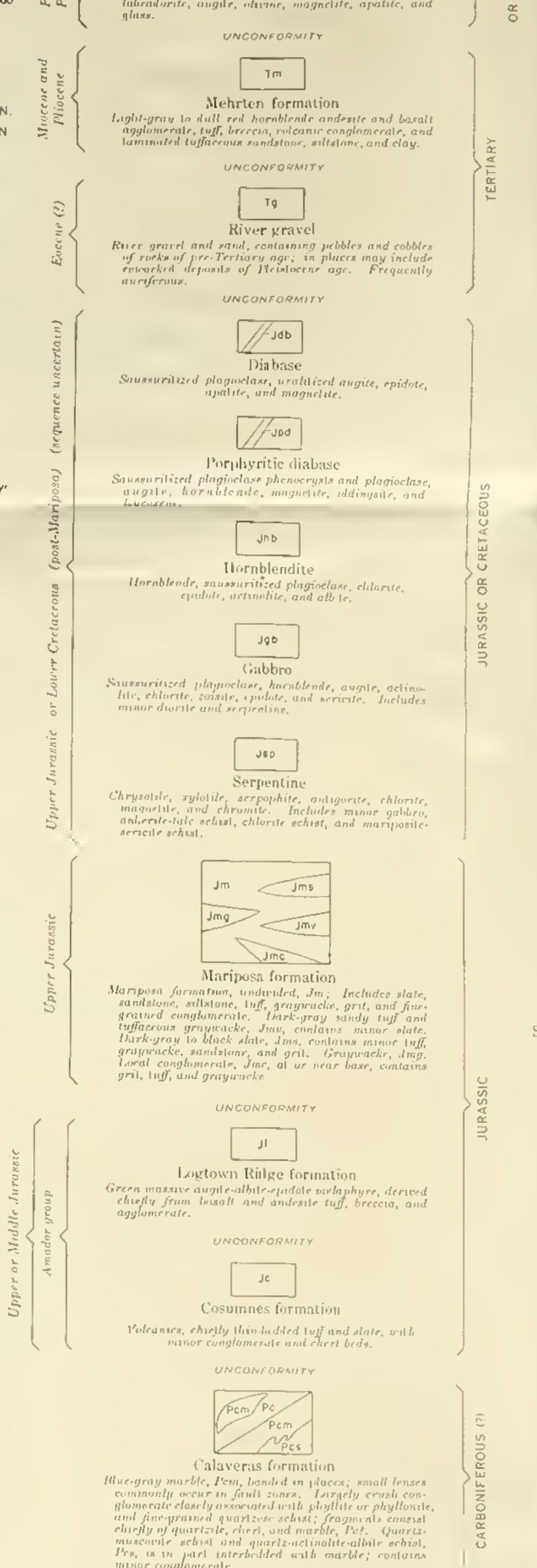

(1)

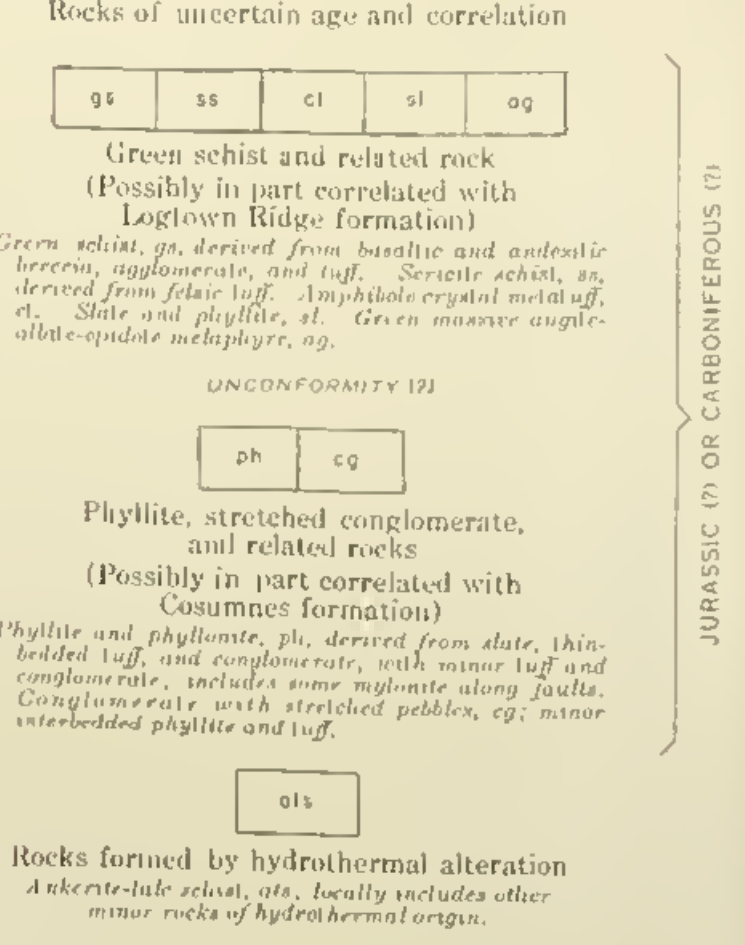

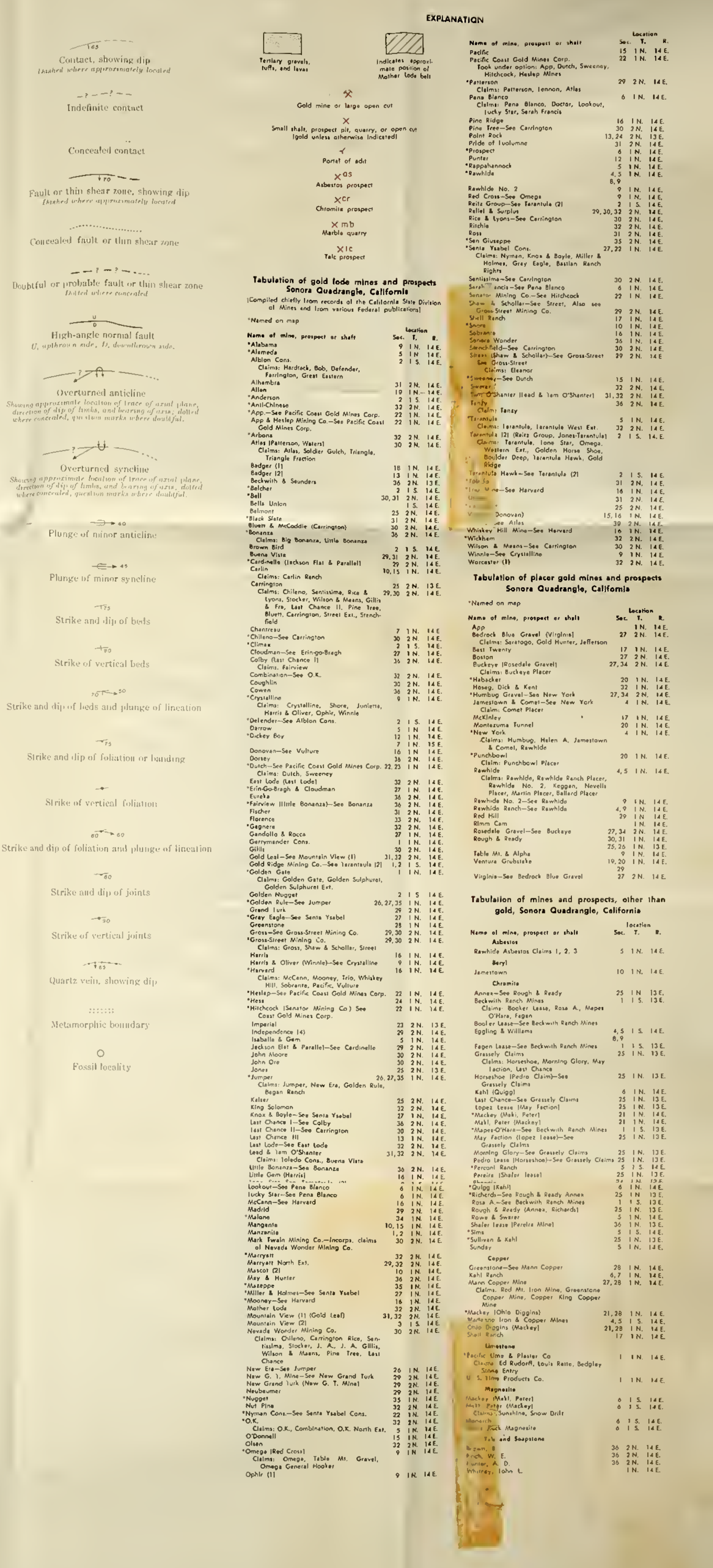

MINES AND PROSPECTS

CLFORNIA

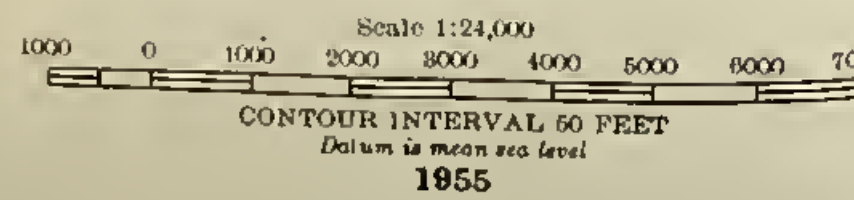





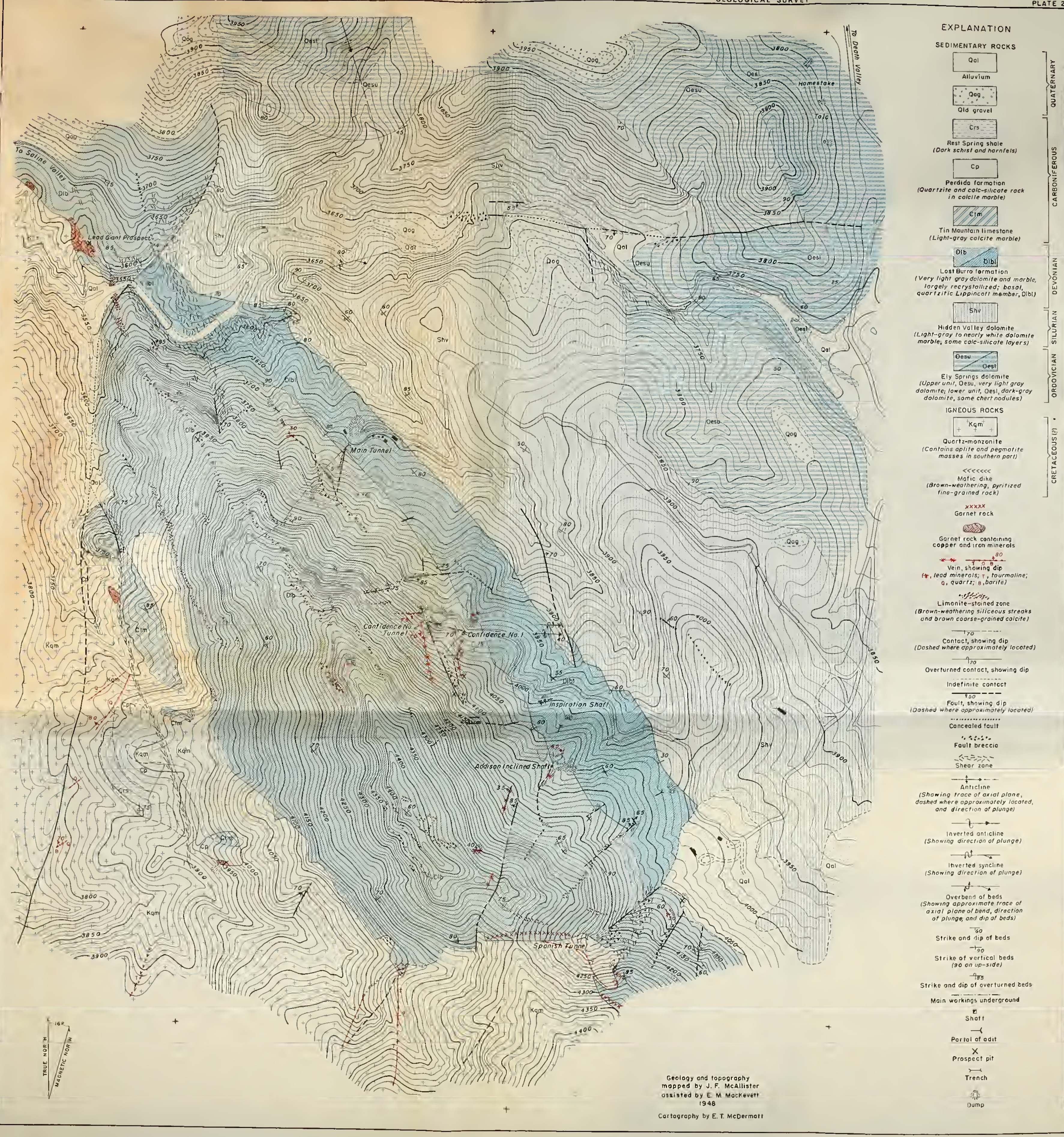

GEOLOGIC AND TOPOGRAPHIC MAP OF THE LIPPINCOTT MINE AREA, INYO COUNTY, CALIFORNIA

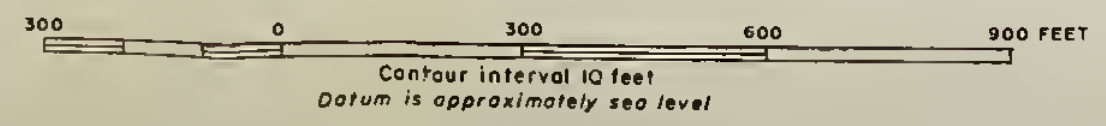





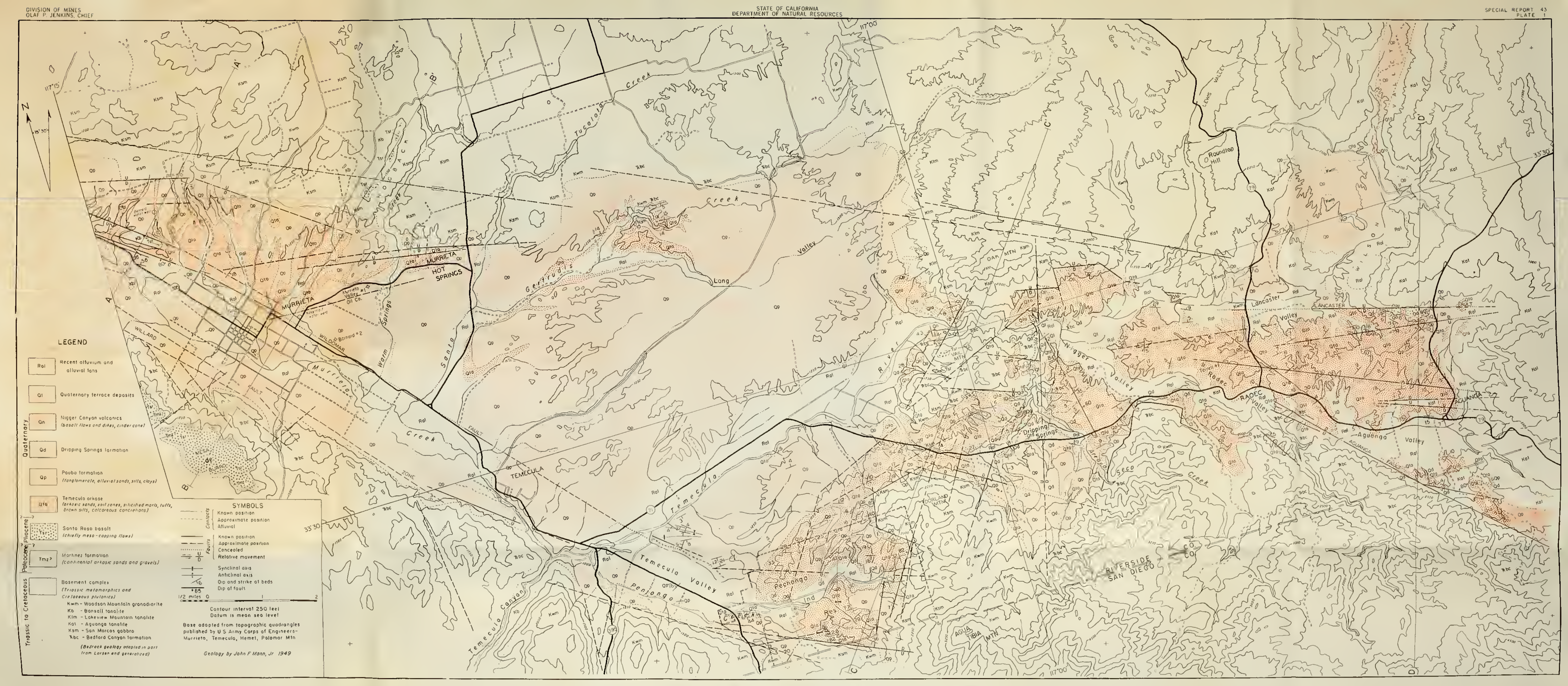



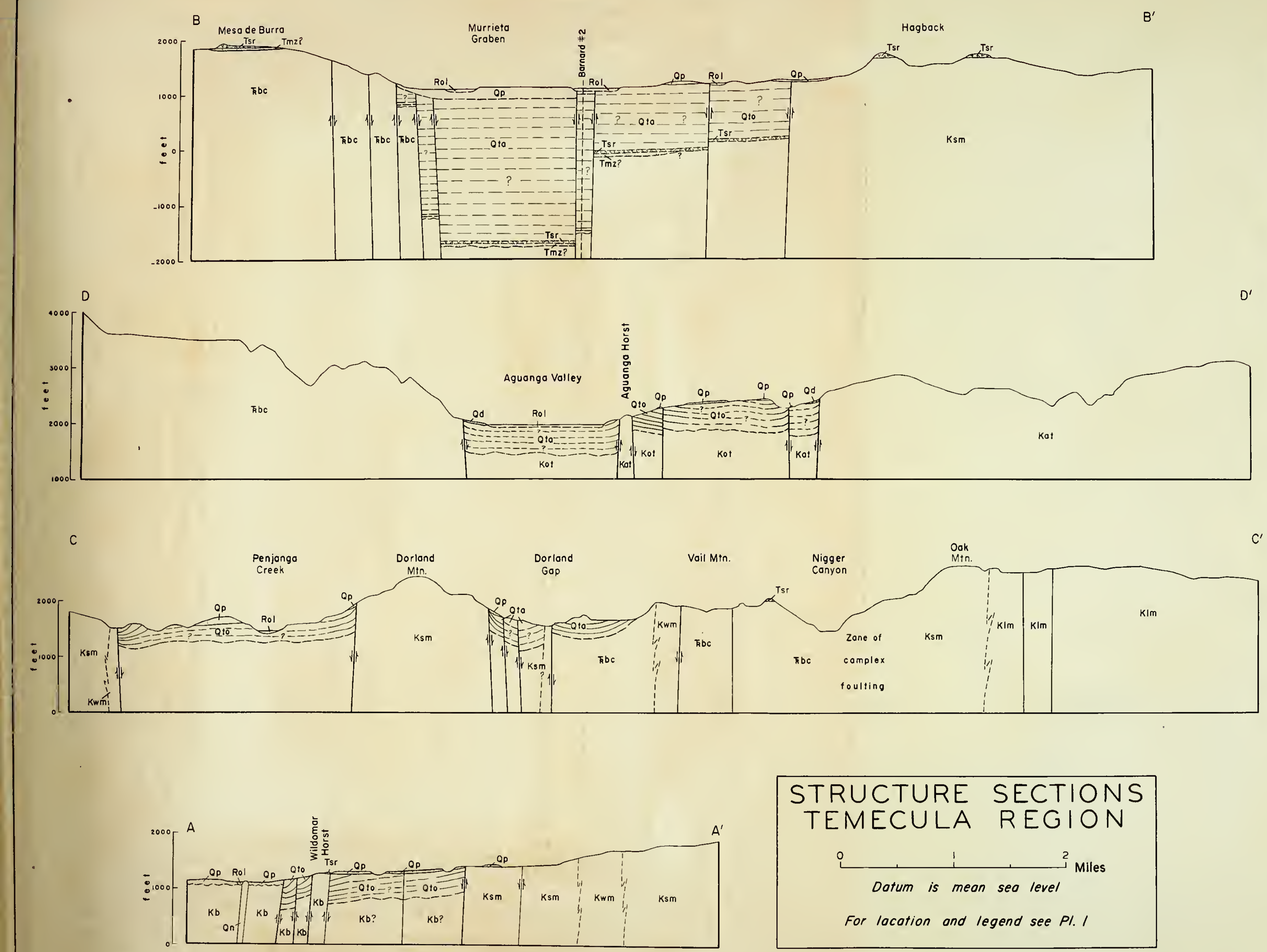

\section{STRUCTURE SECTIONS TEMECULA REGION} 운 Dotum is mean seo level For lacation and legend see PI. I 
203796 

THIS BOOK IS DUE ON THE LAST DATE

STAMPED BELOW

BOOKS REQUESTED BY ANOTHER BORROWER

ARE SUBJECT TO RECALL AFTER ONE WEEK.

RENEWED BOOKS ARE SUBJECT TO IMMEDIATE RECALL

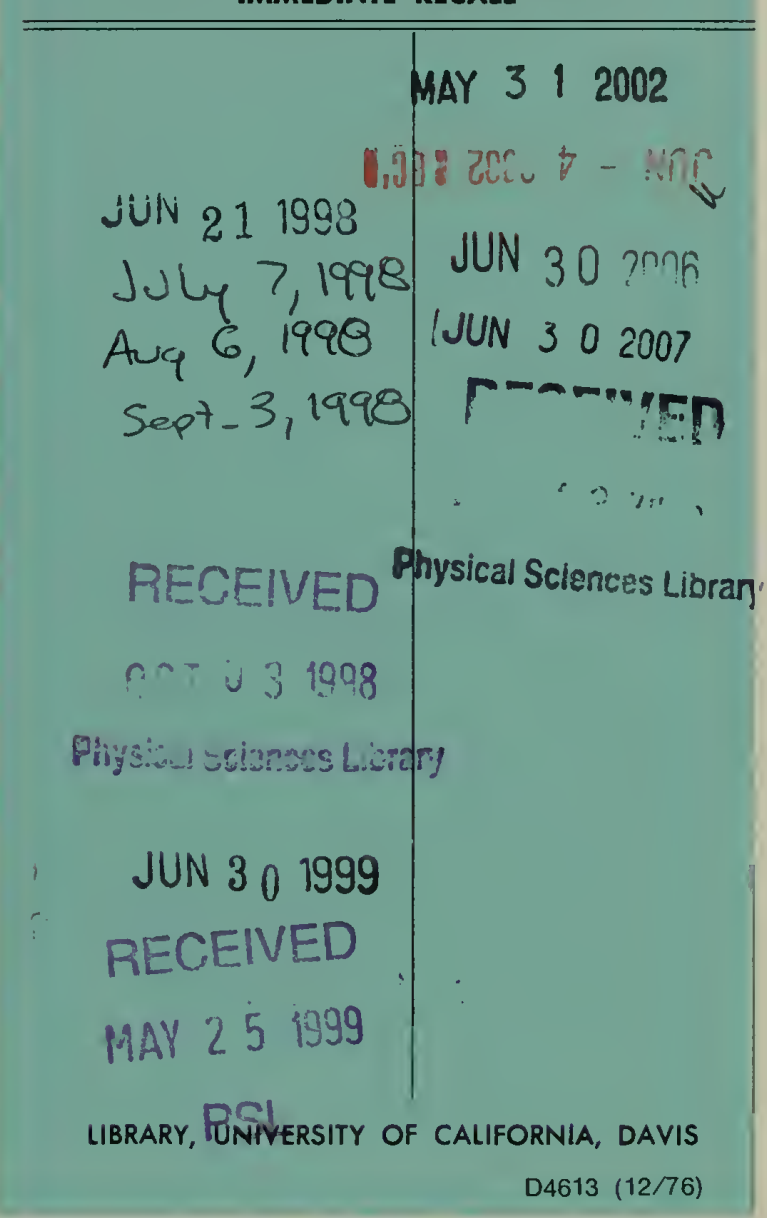


\rfloor

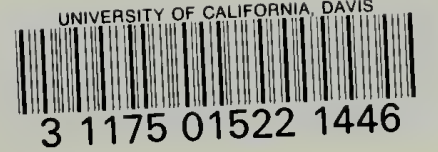


